US Army Corps

of Engineers \&

Prepared for the U.S. Army Corps of Engineers, Portland District,

under an Interagency Agreement with the U.S. Department of Energy

Contract DE-AC05-76RL01830

\title{
Acoustic Telemetry Evaluation of Juvenile Salmonid Passage and Survival at John Day Dam, 2011
}

FINAL REPORT

Pacific Northwest National Laboratory

University of Washington

Pacific States Marine Fisheries Commission

June 2013

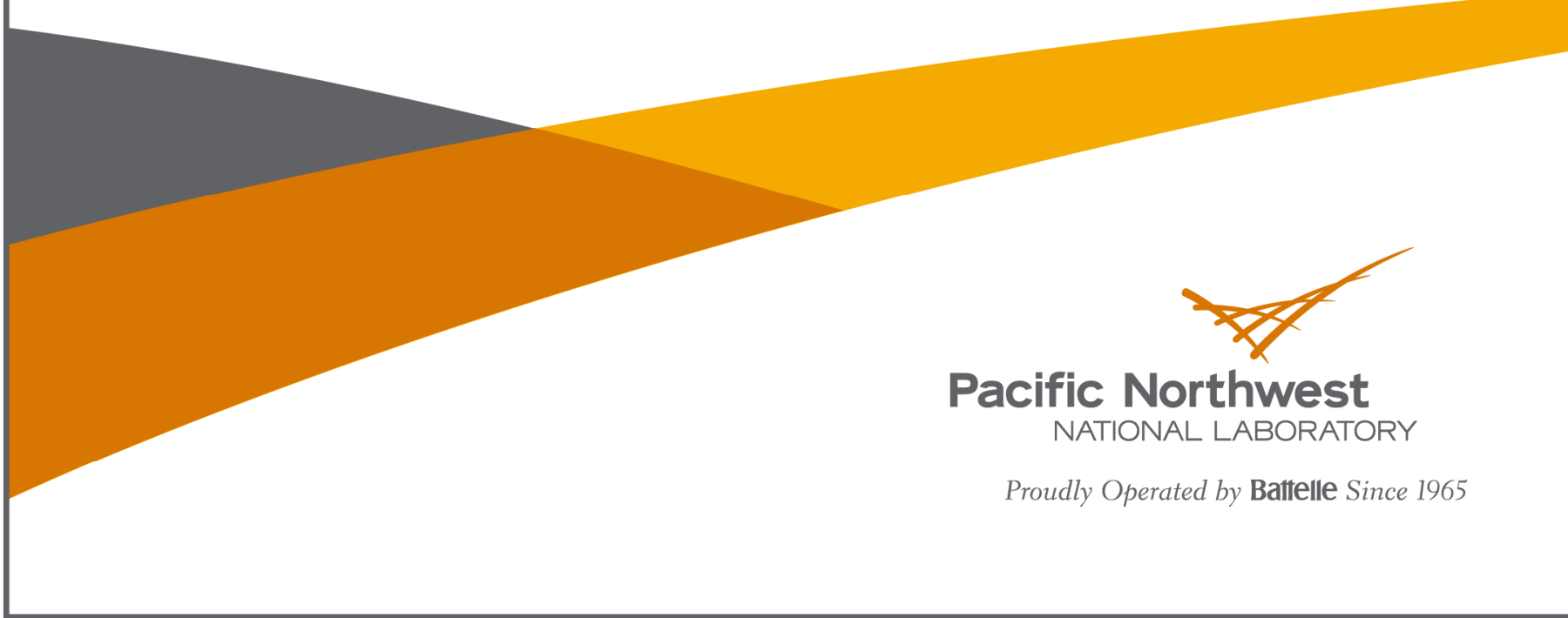




\title{
DISCLAIMER
}

This report was prepared as an account of work sponsored by an agency of the United States Government. Neither the United States Government nor any agency thereof, nor Battelle Memorial Institute, nor any of their employees, makes any warranty, express or implied, or assumes any legal liability or responsibility for the accuracy, completeness, or usefulness of any information, apparatus, product, or process disclosed, or represents that its use would not infringe privately owned rights. Reference herein to any specific commercial product, process, or service by trade name, trademark, manufacturer, or otherwise does not necessarily constitute or imply its endorsement, recommendation, or favoring by the United States Government or any agency thereof, or Battelle Memorial Institute. The views and opinions of authors expressed herein do not necessarily state or reflect those of the United States Government or any agency thereof.

\author{
PACIFIC NORTHWEST NATIONAL LABORATORY \\ operated by \\ BATTELLE \\ for the \\ UNITED STATES DEPARTMENT OF ENERGY \\ under Contract DE-AC05-76RL01830
}

Printed in the United States of America
Available to DOE and DOE contractors from the Office of Scientific and Technical Information,
P.O. Box 62, Oak Ridge, TN 37831-0062;
ph: (865) 576-8401
fax: $(865)$ 576-5728
email: reports@adonis.osti.gov

\begin{abstract}
Available to the public from the National Technical Information Service, U.S. Department of Commerce, 5285 Port Royal Rd., Springfield, VA 22161 ph: (800) 553-6847 fax: $(703) 605-6900$ email: orders@ntis.fedworld.gov online ordering: http://www.ntis.gov/ordering.htm
\end{abstract}

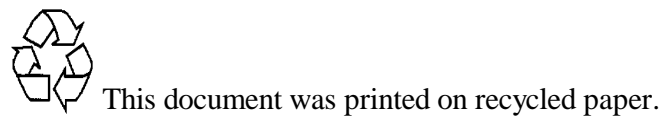




\section{Acoustic Telemetry Evaluation of Juvenile Salmonid Passage and Survival at John Day Dam, 2011}

FINAL REPORT

$\begin{array}{llll}\text { MA Weiland } & \text { SA Zimmerman } & \text { TJ Carlson } & \text { AL Miracle }^{1} \\ \text { CM Woodley } & \text { GR Ploskey } & \text { SM Carpenter }^{1} & \text { TD Mitchell }^{1} \\ \text { JS Hughes } & \text { Z Deng } & \text { AW Cushing } & \text { K Prather }^{1} \\ \text { J Kim } & \text { T Fu } & \text { T Elder }^{1} & \text { B Rayamajhi }^{1} \\ \text { MJ Hennen }^{1} & \text { JR Skalski }^{2} & \text { DJ Etherington }^{1} & \text { IM Royer }^{1} \\ \text { ES Fischer } & \text { RL Townsend }^{2} & \text { MJ Greiner } & \\ \text { JP Duncan } & \text { AG Seaburg }^{2} & \text { F Khan } & \\ \text { KA Wagner } & \text { GW Batten }^{1} & \text { JJ Martinez } & \end{array}$

June 2013

Prepared for U.S. Army Corps of Engineers, Portland District under an Interagency Agreement with the U.S. Department of Energy Contract DE-AC05-76RL01830

Pacific Northwest National Laboratory Richland, Washington 99352

\footnotetext{
${ }^{1}$ Pacific State Marine Fisheries Commission, Portland, Oregon.

${ }^{2}$ Columbia Basin Research, University of Washington, Seattle, Washington.
} 
This report should be cited as follows:

Weiland, MA, CM Woodley, JS Hughes, J Kim, MJ Hennen, ES Fischer, JP Duncan, KA Wagner, SA Zimmerman, GR Ploskey, Z Deng, T Fu, JR Skalski, RL Townsend, AG Seaburg, GW Batten III, TJ Carlson, SM Carpenter, AW Cushing, T Elder, DJ Etherington, MJ Greiner, F Khan, JJ Martinez, AL Miracle, TD Mitchell, K Prather, B Rayamajhi, and IM Royer. 2013. Acoustic Telemetry Evaluation of Juvenile Salmonid Passage and Survival at John Day Dam, 2011. PNNL-22266. Final report submitted to the U.S. Army Corps of Engineers, Portland District, Portland, Oregon, by the Pacific Northwest National Laboratory, Richland, Washington. 


\section{Preface}

This study was conducted by the Pacific Northwest National Laboratory (PNNL), the University of Washington (UW), and Pacific States Marine Fisheries Commission (PSMFC) for the U.S. Army Corps of Engineers (USACE), Portland District (CENWP). The CENWP technical lead was Mr. Brad Eppard. This report presents survival, behavioral, and fish passage results for tagged yearling Chinook salmon and juvenile steelhead as part of a survival study conducted at John Day Dam during spring 2011.

This study was designed to evaluate the passage and survival of yearling Chinook salmon and juvenile steelhead to assist managers in identifying dam operations for compliance testing as stipulated by the 2008 Federal Columbia River Power System Biological Opinion and the 2008 Columbia Basin Fish Accords. Survival estimates were based on a paired-release survival model. 


\section{Executive Summary}

Improving the survival rate of juvenile salmonids migrating downstream through the Federal Columbia River Power System (FCRPS) continues to be a high priority for the U.S. Army Corps of Engineers (USACE) and the region. Many of these fish are from populations listed as threatened or endangered under the Endangered Species Act of 1973. Increasing survival rates is necessary to ensure healthy salmon populations in the future and meet performance standards set forth in the 2008 Biological Opinion (BiOp) on configuration and operation of the FCRPS. The BiOp mandates that a 96\% and 93\% survival rate be achieved for spring and summer downstream migrating juvenile salmonids, respectively. At John Day Dam (JDA), the USACE Portland District (CENWP) is evaluating surface-flow outlets (SFOs) as a means to increase fish passage efficiency and in turn increase fish passage survival rates by reducing turbine passage of juvenile salmonids. The goal of this study was to provide fish passage and survival data necessary to evaluate the performance of the JDA prototype SFO, a top-spill weir (TSW), and the dam as a whole relative to the performance standards outlined in the BiOp and additional performance measures as stipulated in the Columbia Basin Fish Accords for yearling Chinook salmon (Oncorhynchus tshawytscha) and juvenile steelhead (O. mykiss). This study was conducted to provide the CENWP and regional fisheries managers with information necessary to assist with decision making for adaptively managing the configuration and operation of JDA to maximize the survival rates for juvenile salmonids.

Researchers at the Pacific Northwest National Laboratory collaborated with the Pacific States Marine Fisheries Commission, CENWP, and the University of Washington to estimate survival rates and other performance measures for yearling Chinook salmon and juvenile steelhead passing through JDA during spring 2011. The original study design included evaluation of subyearling Chinook salmon in summer but river discharge far exceeded the 10-yr average halfway through the spring season and well into the summer, so the summer portion of this study was cancelled. The spring study was also divided into early season (April 27-May 16), where treatment discharge levels could be maintained and late season (May 16-May 29), when treatment discharge levels could not be managed.

The objectives of this acoustic telemetry (AT) study of survival and passage at JDA were to estimate the following performance measures for yearling Chinook salmon and juvenile steelhead:

- Survival: forebay to tailrace (BRZ-to-BRZ [boat-restricted zone]; 5 river kilometers [rkm], JDA forebay array to JDA dam face (2 rkm) and JDA dam face to JDA tailrace array (3 rkm)), dam passage to the JDA tailrace array $(3 \mathrm{rkm})$, and dam passage by route to the JDA tailrace.

- Travel times: forebay residence, tailrace egress, and project passage.

- Passage metrics: fish passage efficiency, spill passage efficiency, and TSW passage efficiency.

- Distributions: forebay horizontal approach distribution, forebay vertical distribution, and horizontal distribution by route and subroute.

The current study was an official compliance test as outlined in the 2008 FCRPS BiOp. This study relied on releases of live juvenile salmonids double tagged with Juvenile Salmon Acoustic Telemetry System (JSATS) acoustic micro-transmitters (AMTs) and passive integrated transponders (PITs) in the Columbia River and used AT to evaluate the approach, passage, and survival of passing juvenile salmonids. Additional passage performance measures were also estimated, most of which were stipulated 
in the Columbia Basin Fish Accords. Two spill discharge levels were also tested, $30 \%$ and $40 \%$, to determine the effects of each independently on passage and survival metrics. A similar study conducted in 2010 at JDA verified that the dam face array performance was suitable for a full-scale compliance study in 2011, because detection probabilities were essentially $100 \%$ for both yearling Chinook salmon and steelhead and survival model assumptions were met.

In the spring, 2,510 Yearling Chinook salmon and 2,587 juvenile steelhead surgically implanted with JSATS AMTs and PITs were released in the Columbia River upstream of JDA (rkm 390 near Roosevelt, Washington) and regrouped at the JDA face to form virtual releases. These releases were followed by downstream releases at two sites below JDA of 1,992 yearling Chinook salmon and 1,993 steelhead, which allowed for estimation of paired-release survival at JDA. Paired-release passage survival was estimated for fish passing through two river reaches: 1) the dam and $3 \mathrm{~km}$ of the tailrace and 2) the forebay $(2 \mathrm{~km})$, dam, and $3 \mathrm{~km}$ of the tailrace. The JSATS AMT model number SS130 weighing $0.438 \mathrm{~g}$ in air manufactured by Advanced Telemetry Systems and the Biomark HPT12 PIT were used in this investigation.

This report provides a comprehensive summary of 2011 results, including route-specific passage survival estimates, travel times, and passage distributions. The study methods and results are summarized below (Table ES.1-Table ES.6).

Table ES.1. Summary of methods and conditions at John Day Dam during 2011.

Objectives of Study: Estimate paired-release dam passage survival and other performance measures for yearling and subyearling Chinook salmon and steelhead for $30 \%$ and $40 \%$ spill tests.

Unique Study Characteristics: Top-spill weirs were installed in spill bays 18 and 19. In 2010, the deflector at spill bay 20 was modified to improve egress conditions and survival for downstream migrating juvenile salmon. Also, a new avian array was installed across the tailrace in 2010 and was further expanded in 2011.

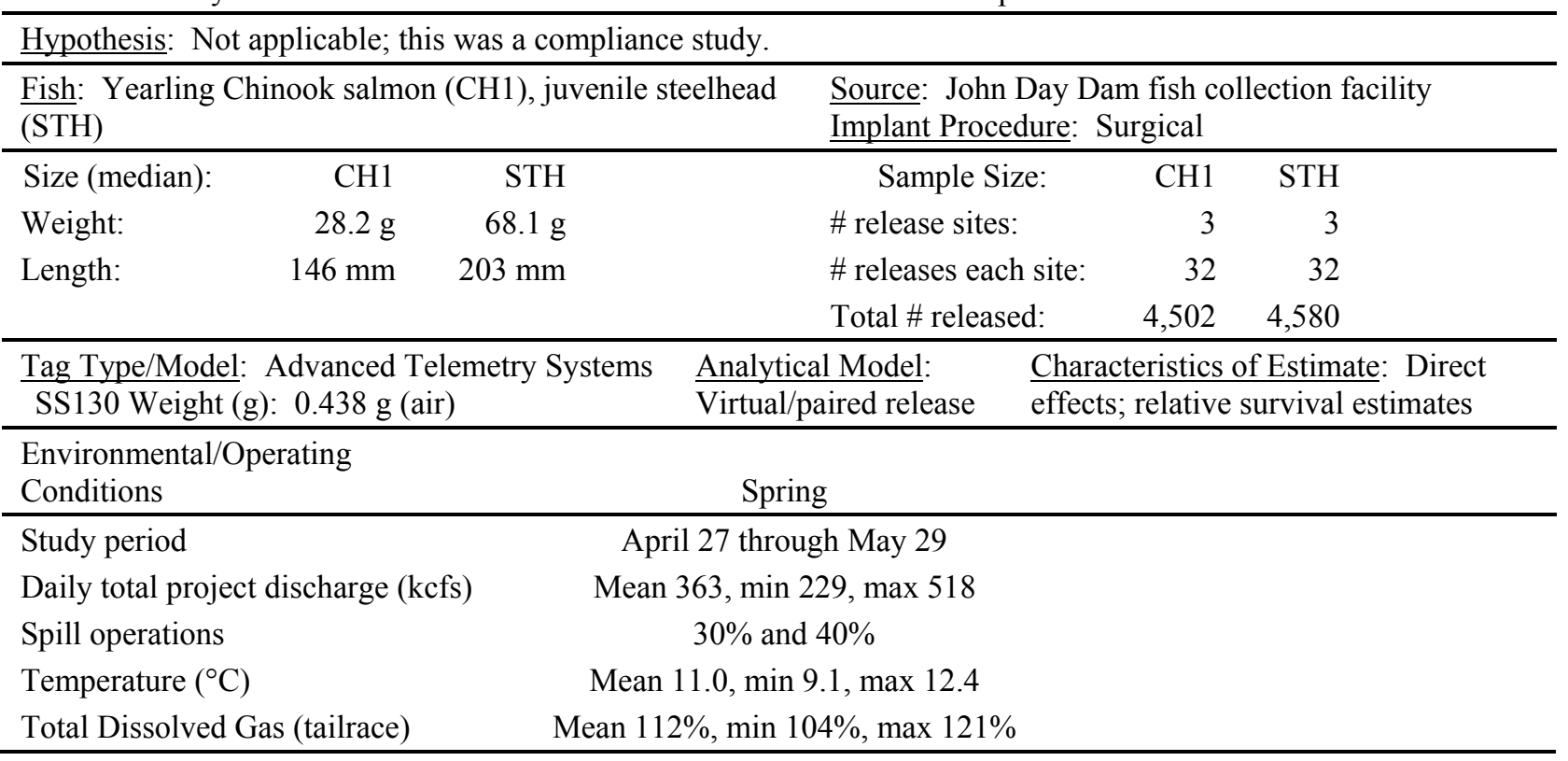


Table ES.2. Summary of survival and other performance metrics at John Day Dam during 2011, seasonwide (April 27-May 29) and early season for 30\% and 40\% spill treatments (April 27-May 16). Travel times (median and mean) are provided in hours.

\begin{tabular}{|c|c|c|}
\hline Metric & $\mathrm{CH} 1$ & STH \\
\hline Survival: Dam passage & $0.968(\mathrm{SE}=0.007)$ & $0.987(\mathrm{SE}=0.006)$ \\
\hline Early Season $30 \%$ spill & $0.967(\mathrm{SE}=0.010)$ & $0.984(\mathrm{SE}=0.009)$ \\
\hline Early Season $40 \%$ spill & $0.978(\mathrm{SE}=0.011)$ & $0.990(\mathrm{SE}=0.010)$ \\
\hline Survival: Forebay to tailrace (BRZ-to-BRZ) & $0.965(\mathrm{SE}=0.007)$ & $0.980(\mathrm{SE}=0.006)$ \\
\hline Early Season $30 \%$ spill & $0.966(\mathrm{SE}=0.010)$ & $0.972(\mathrm{SE}=0.010)$ \\
\hline Early Season $40 \%$ spill & $0.973(\mathrm{SE}=0.011)$ & $0.982(\mathrm{SE}=0.010)$ \\
\hline Forebay Residence Time (hours) (median; mean) & $1.42 ; 2.93$ & $2.91 ; 6.89$ \\
\hline Early Season $30 \%$ spill & $2.01 ; 3.61$ & $4.34 ; 8.85$ \\
\hline Early Season $40 \%$ spill & $2.03 ; 3.40$ & $4.71 ; 9.49$ \\
\hline Tailrace Egress Time (hours) (median; mean) & $0.57 ; 3.98$ & $0.58 ; 9.09$ \\
\hline Early Season $30 \%$ spill & $0.60 ; 4.66$ & $0.60 ; 11.27$ \\
\hline Early Season $40 \%$ spill & $0.59 ; 4.21$ & $0.57 ; 9.87$ \\
\hline Project Passage Time (median; mean) & $2.53 ; 7.01$ & $5.42 ; 16.35$ \\
\hline Early Season $30 \%$ spill & $3.18 ; 8.38$ & $7.38 ; 20.27$ \\
\hline Early Season $40 \%$ spill & $2.97 ; 7.57$ & $7.22 ; 19.48$ \\
\hline Fish Passage Efficiency & $0.885(\mathrm{SE}=0.007)$ & $0.960(\mathrm{SE}=0.004)$ \\
\hline Early Season $30 \%$ spill & $0.893(\mathrm{SE}=0.010)$ & $0.950(\mathrm{SE}=0.007)$ \\
\hline Early Season $40 \%$ spill & $0.893(\mathrm{SE}=0.012)$ & $0.973(\mathrm{SE}=0.007)$ \\
\hline Spill Passage Efficiency & $0.637(\mathrm{SE}=0.010)$ & $0.628(\mathrm{SE}=0.010)$ \\
\hline Early Season $30 \%$ spill & $0.613(\mathrm{SE}=0.016)$ & $0.609(\mathrm{SE}=0.016)$ \\
\hline Early Season $40 \%$ spill & $0.680(\mathrm{SE}=0.019)$ & $0.715(\mathrm{SE}=0.018)$ \\
\hline TSW Efficiency ||Dam & $0.238(\mathrm{SE}=0.009)$ & $0.323(\mathrm{SE}=0.009)$ \\
\hline Early Season $30 \%$ spill & $0.327(\mathrm{SE}=0.015)$ & $0.398(\mathrm{SE}=0.016)$ \\
\hline Early Season $40 \%$ spill & $0.273(\mathrm{SE}=0.018)$ & $0.450(\mathrm{SE}=0.020)$ \\
\hline TSW Efficiency\|Spillway & $0.373(\mathrm{SE}=0.012)$ & $0.514(\mathrm{SE}=0.013)$ \\
\hline Early Season $30 \%$ spill & $0.533(\mathrm{SE}=0.021)$ & $0.654(\mathrm{SE}=0.020)$ \\
\hline Early Season $40 \%$ spill & $0.402(\mathrm{SE}=0.024)$ & $0.629(\mathrm{SE}=0.023)$ \\
\hline Fish Guidance Efficiency & $0.683(\mathrm{SE}=0.016)$ & $0.893(\mathrm{SE}=0.010)$ \\
\hline Early Season $30 \%$ spill & $0.725(\mathrm{SE}=0.023)$ & $0.871(\mathrm{SE}=0.018)$ \\
\hline Early Season $40 \%$ spill & $0.667(\mathrm{SE}=0.033)$ & $0.906(\mathrm{SE}=0.022)$ \\
\hline JBS Efficiency & $0.248(\mathrm{SE}=0.009)$ & $0.332(\mathrm{SE}=0.009)$ \\
\hline Early Season $30 \%$ spill & $0.281(\mathrm{SE}=0.015)$ & $0.340(\mathrm{SE}=0.016)$ \\
\hline Early Season $40 \%$ spill & $0.213(\mathrm{SE}=0.016)$ & $0.258(\mathrm{SE}=0.018)$ \\
\hline
\end{tabular}


Table ES.3. Route-specific paired-release survival estimates at John Day Dam in 2011.

\begin{tabular}{ccc}
\hline Route & CH1 & STH \\
\hline Spillway & $0.968(\mathrm{SE}=0.008)$ & $0.990(\mathrm{SE}=0.006)$ \\
TSW & $0.958(\mathrm{SE}=0.011)$ & $0.989(\mathrm{SE}=0.007)$ \\
Non-TSW & $0.974(\mathrm{SE}=0.008)$ & $0.990(\mathrm{SE}=0.007)$ \\
JBS & $0.993(\mathrm{SE}=0.008)$ & $1.003(\mathrm{SE}=0.006)$ \\
Turbine & $0.910(\mathrm{SE}=0.018)$ & $0.797(\mathrm{SE}=0.042)$ \\
\hline
\end{tabular}

Table ES.4. Summary of combined and day and night paired-release survival estimates and other performance metrics.

\begin{tabular}{ccc}
\hline Route & $\mathrm{CH} 1$ & $\mathrm{STH}$ \\
\hline Survival: Dam passage to JDA & $0.968(\mathrm{SE}=0.007)$ & $0.987(\mathrm{SE}=0.006)$ \\
Day & $0.965(\mathrm{SE}=0.008)$ & $0.987(\mathrm{SE}=0.007)$ \\
Night & $0.972(\mathrm{SE}=0.008)$ & $0.987(\mathrm{SE}=0.007)$ \\
Fish Passage Efficiency $\|$ Dam & $0.885(\mathrm{SE}=0.006)$ & $0.960(\mathrm{SE}=0.004)$ \\
Day & $0.943(\mathrm{SE}=0.006)$ & $0.978(\mathrm{SE}=0.004)$ \\
Night & $0.807(\mathrm{SE}=0.012)$ & $0.946(\mathrm{SE}=0.006)$ \\
Spill Passage Efficiency $\|$ Dam & $0.637(\mathrm{SE}=0.010)$ & $0.628(\mathrm{SE}=0.010)$ \\
Day & $0.784(\mathrm{SE}=0.011)$ & $0.853(\mathrm{SE}=0.011)$ \\
Night & $0.441(\mathrm{SE}=0.015)$ & $0.448(\mathrm{SE}=0.013)$ \\
TSW Efficiency $\|$ Dam & $0.238(\mathrm{SE}=0.009)$ & $0.323(\mathrm{SE}=0.009)$ \\
Day & $0.304(\mathrm{SE}=0.012)$ & $0.560(\mathrm{SE}=0.015)$ \\
Night & $0.149(\mathrm{SE}=0.011)$ & $0.134(\mathrm{SE}=0.009)$ \\
TSW Efficiency $\|$ Spillway & $0.373(\mathrm{SE}=0.012)$ & $0.514(\mathrm{SE}=0.013)$ \\
Day & $0.388(\mathrm{SE}=0.015)$ & $0.656(\mathrm{SE}=0.016)$ \\
Night & $0.338(\mathrm{SE}=0.022)$ & $0.298(\mathrm{SE}=0.018)$ \\
Fish Guidance Efficiency & $0.683(\mathrm{SE}=0.016)$ & $0.893(\mathrm{SE}=0.010)$ \\
Day & $0.736(\mathrm{SE}=0.025)$ & $0.852(\mathrm{SE}=0.028)$ \\
Night & $0.655(\mathrm{SE}=0.020)$ & $0.901(\mathrm{SE}=0.011)$ \\
Day & $0.248(\mathrm{SE}=0.009)$ & $0.332(\mathrm{SE}=0.009)$ \\
Night & $0.159(\mathrm{SE}=0.010)$ & $0.126(\mathrm{SE}=0.010)$ \\
& $0.366(\mathrm{SE}=0.015)$ & $0.497(\mathrm{SE}=0.013)$ \\
\hline
\end{tabular}


Table ES.5. Summary of horizontal distributions at John Day Dam in spring 2011.

\begin{tabular}{ccr}
\hline Metric & CH1 & STH \\
\hline Percent that passed at the powerhouse & 36.3 & 37.2 \\
Percent that passed through the JBS & 24.8 & 33.2 \\
Percent that passed through the turbine & 11.5 & 4.0 \\
Percent that passed at the spillway & 63.7 & 62.8 \\
Percent that passed through non-TSW bays & 39.9 & 30.5 \\
Percent that passed through TSW bays & 23.8 & 32.3 \\
\hline
\end{tabular}

Table ES.6. Summary of survival and other performance metrics for the entire field season and early and late season at John Day Dam during 2011. Travel times (median and mean) are provided in hours (early season: April 27-May 16, 2011 and late season: May 16-May 29, 2011).

\begin{tabular}{ccc}
\hline \multicolumn{1}{c}{ Metric } & CH1 & STH \\
\hline Survival: Dam passage to JDA & $0.968(\mathrm{SE}=0.007)$ & $0.987(\mathrm{SE}=0.006)$ \\
Early Season & $0.971(\mathrm{SE}=0.009)$ & $0.986(\mathrm{SE}=0.008)$ \\
Late Season & $0.970(\mathrm{SE}=0.006)$ & $0.990(\mathrm{SE}=0.009)$ \\
Forebay Residence Time (hours) (median; mean) & $1.42 ; 2.93$ & $2.91 ; 6.89$ \\
Early Season & $2.01 ; 3.72$ & $4.60 ; 9.16$ \\
Late Season & $0.83 ; 1.46$ & $1.26 ; 3.17$ \\
Tailrace Egress Time (hours) (median; mean) & $0.57 ; 3.98$ & $0.58 ; 9.09$ \\
Early Season & $0.60 ; 4.77$ & $0.58 ; 10.65$ \\
Late Season & $0.48 ; 1.95$ & $0.56 ; 5.94$ \\
Project Passage Time (CR351 to CR346) (median; mean) & $2.53 ; 7.01$ & $5.42 ; 16.35$ \\
Early Season & $3.03 ; 8.38$ & $7.38 ; 19.86$ \\
Late Season & $1.48 ; 3.43$ & $2.72 ; 9.04$ \\
\hline
\end{tabular}




\section{Acknowledgments}

Many people from Pacific Northwest National Laboratory (PNNL), Pacific States Marine Fisheries Commission (PSMFC), the U.S. Army Corps of Engineers, Portland District (CENWP), and the University of Washington (UW) made valuable contributions to this study and deserve acknowledgment.

- PNNL: T Able, C Brandt, A Bryson, K Carter, E Choi, K Deters, G Dirkes, A Flory, D Geist, K Hall, M Halvorsen, K Ham, K Hand, JL Hughes, R Karls, B LaMarche, K Larson, K Lavender, B Miller, A Phillips, H Ren, G Roesijadi, I Royer, D Saunders, J Smith, G Squeochs, S Southard, N Tavin, A Thronas, S Titzler, N Trimble, D Trott, J Vavrinec, Y Yuan.

- PSMFC: R Martinson, G Kolvachuk and D Ballenger along with the helpful staff at John Day and Bonneville Dam Smolt Monitoring Facility. In addition, B Babcock, R Blanchard, A Collins, L Cushing, T Elder, M Gay, G George, A Halston, C Holzer, M Jenkins, K Knox, D Lock, D Marvin, T Monter, M Neumann, T Royal, K Schaedel, N Tancreto, R Wall.

- CENWP: B Eppard, M Langeslay, and electricians, mechanics, riggers, operators, and biologists at John Day (M Zyndol, T Hurd), The Dalles (B Cordie) and Bonneville dams (J Rerecich, B Hausmann, A Traylor).

We also acknowledge the following manufacturers of the tags, hydrophones, and hardware required to accomplish testing:

- Advanced Telemetry Systems (ATS), Inc. manufactured the JSATS AMT.

- Sonic Concepts, Seattle, Washington produced the autonomous and dam-mounted hydrophones.

- The Dalles Ironworks, The Dalles, Oregon provided the anchors for autonomous nodes and various components required for successful completion of this project. 


\section{Acronyms and Abbreviations}

\begin{tabular}{|c|c|}
\hline${ }^{\circ} \mathrm{C}$ & degrees Celsius \\
\hline $3 \mathrm{D}$ & three-dimensional \\
\hline AMT & acoustic micro-transmitter \\
\hline ANOVA & analysis of variance \\
\hline AT & acoustic telemetry \\
\hline ATLAS & Active Tag-Life Adjusted Survival \\
\hline ATS & Advanced Telemetry Systems, Inc. \\
\hline $\mathrm{BiOp}$ & Biological Opinion \\
\hline $\mathrm{BON}$ & Bonneville Dam \\
\hline BRZ & boat-restricted zone \\
\hline cDNA & complementary DNA \\
\hline CENWP & Corps of Engineers, Northwest, Portland \\
\hline $\mathrm{cfs}$ & cubic feet per second \\
\hline $\mathrm{CH} 1$ & yearling Chinook salmon \\
\hline $\mathrm{cm}$ & centimeter(s) \\
\hline DART & Data Access in Real Time \\
\hline DNA & deoxyribonucleic acid \\
\hline DSP & digital signal-processing card \\
\hline DSP+FPGA & digital signal-processing cards with field-programmable logic gate array \\
\hline FCRPS & Federal Columbia River Power System \\
\hline FPE & fish passage efficiency \\
\hline FGE & fish guidance efficiency (in-turbine screens) \\
\hline $\mathrm{ft}$ & foot(feet) \\
\hline$\mu \mathrm{g}$ & milligram(s) \\
\hline$g$ & acceleration $\left(\mathrm{m} / \mathrm{s}^{2}\right)$ \\
\hline g & $\operatorname{gram}(\mathrm{s})$ \\
\hline $\mathrm{g} / \mathrm{L}$ & $\operatorname{gram}(\mathrm{s})$ per liter \\
\hline gal & gallon(s) \\
\hline
\end{tabular}




$\begin{array}{ll}\text { h } & \text { hour(s) } \\ \text { HA } & \text { hydroacoustic } \\ \text { HSD } & \text { honestly significant difference } \\ \text { IgM } & \text { immunoglobulin } \mathrm{M} \\ \text { IL1- } \beta & \text { interleukin-1 beta } \\ \text { JBS } & \text { juvenile bypass system } \\ \text { JBSE } & \text { juvenile bypass system passage efficiency } \\ \text { JDA } & \text { John Day Dam } \\ \text { JSATS } & \text { Juvenile Salmon Acoustic Telemetry System } \\ \text { kcfs } & \text { thousand cubic feet per second } \\ \text { kg } & \text { kilogram(s) } \\ \text { km } & \text { kilometer(s) } \\ \text { PRI } & \text { pulse repetition interval } \\ \text { pre-tagged } \\ \text { PIT }\end{array}$




\begin{tabular}{|c|c|}
\hline psi & pounds per square inch \\
\hline PSMFC & Pacific States Marine Fisheries Commission \\
\hline PTAGIS & Passive Integrated Transponder (PIT) Tag Information System \\
\hline qPCR & quantitative polymerase chain reaction \\
\hline $\mathrm{rkm}$ & river kilometer \\
\hline RME & research, monitoring, and evaluation \\
\hline RNA & ribonucleic acid \\
\hline ROR & run-of-river \\
\hline $\mathrm{rpm}$ & rotations per minute \\
\hline RT & radio telemetry \\
\hline$\mu \mathrm{s}$ & microsecond(s) \\
\hline $\mathrm{s}$ & second(s) \\
\hline SBDP & spectrin breakdown product \\
\hline SByC & sort by code \\
\hline SD & standard deviation \\
\hline SE & standard error \\
\hline SEF & spill passage effectiveness \\
\hline SFO & surface-flow outlet \\
\hline SMF & Smolt Monitoring Facility \\
\hline SMP & Smolt Monitoring Program \\
\hline SPE & spill passage efficiency \\
\hline STH & steelhead \\
\hline SW & spillway or spillway block \\
\hline TDA & The Dalles Dam \\
\hline TDG & total dissolved gas \\
\hline TOAD & time-of-arrival difference \\
\hline TSW & top-spill weir \\
\hline TSWE & top-spill weir passage efficiency \\
\hline USACE & U.S. Army Corps of Engineers \\
\hline UW & University of Washington \\
\hline
\end{tabular}


wk

WW

$\chi^{2}$

yr week(s)

wet weight

Chi Squared Test

year(s) 


\section{Contents}

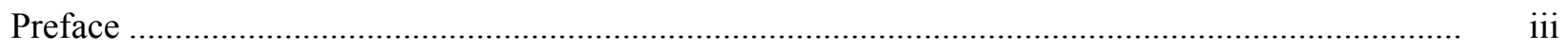

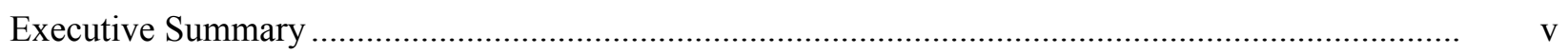

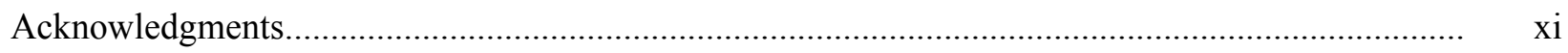

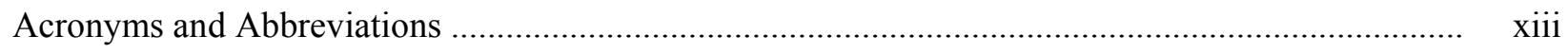

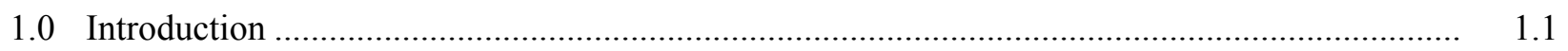

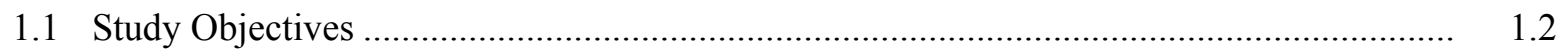

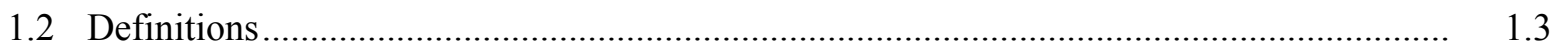

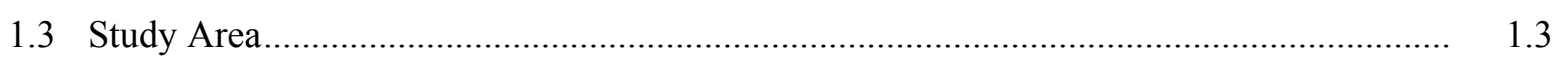

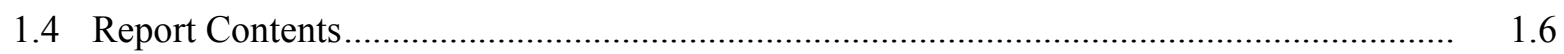

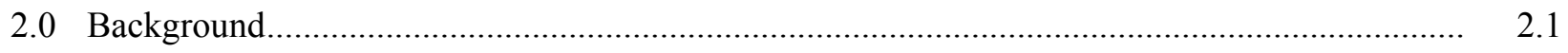

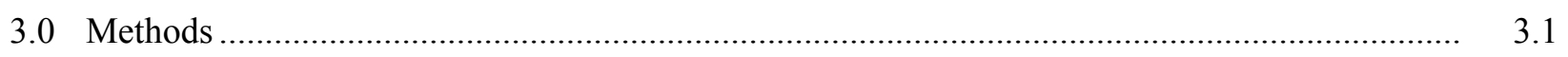

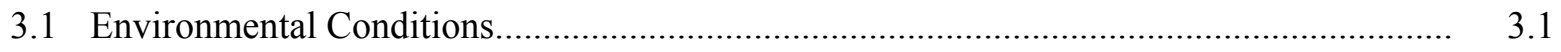

3.1.1 Water Discharge and Temperature .............................................................. 3.1

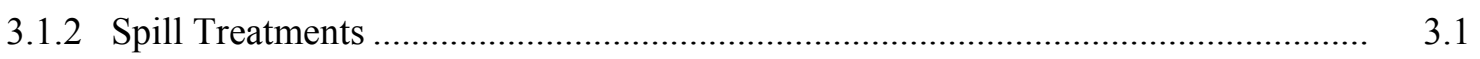

3.2 Release-Recapture Design and Sample Sizes ............................................................. 3.2

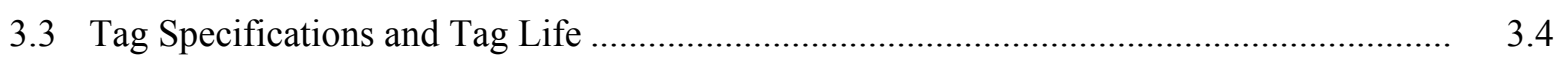

3.4 Handling, Tagging, and Release Procedures .............................................................. 3.5

3.4.1 Fish Source and Collection Methods................................................................ 3.5

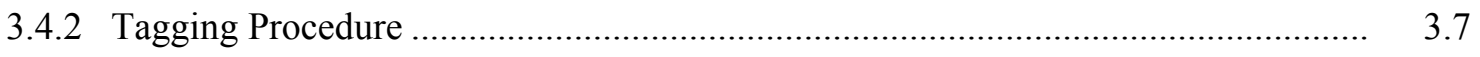

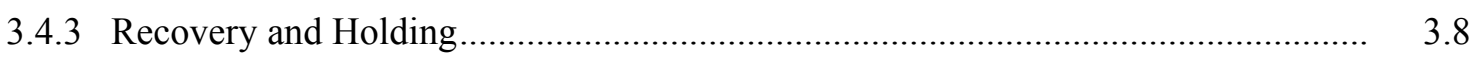

3.4.4 Fish Transportation and Release ................................................................. 3.9

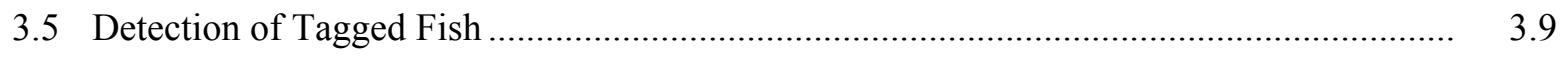

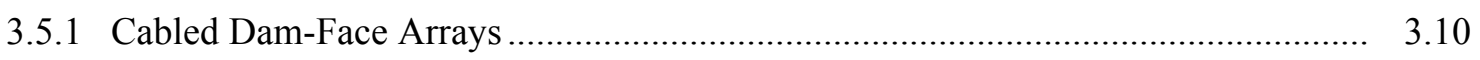

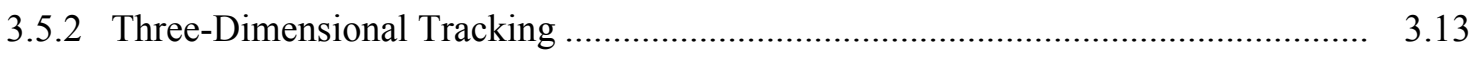

3.5.3 Autonomous Receiver Arrays ........................................................................ 3.13

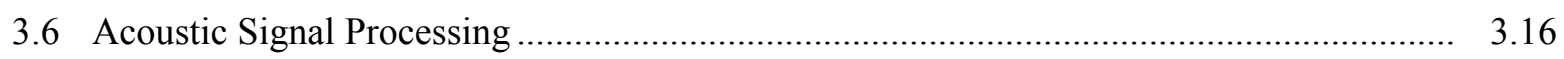

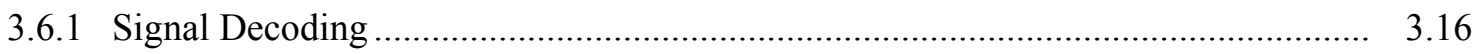

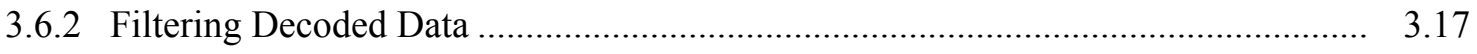

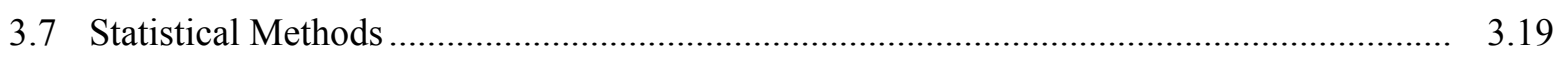

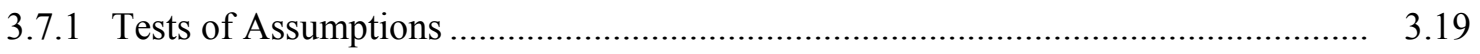

3.7.2 Estimation of Dam Passage and Route-Specific Survivals ................................... 3.20

3.7.3 Estimation of Forebay-to-Tailrace Survival ........................................................ 3.22

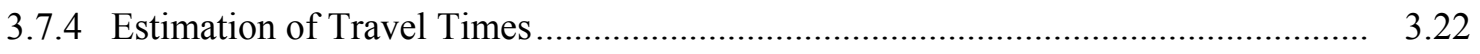

3.7.5 Estimation of Passage Efficiencies................................................................. 3.23

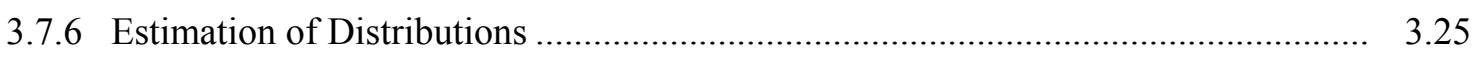


4.0 Results - Environmental Conditions .................................................................... 4.1

4.1 River Discharge and Water Temperature ................................................................. 4.1

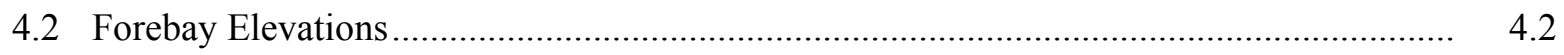

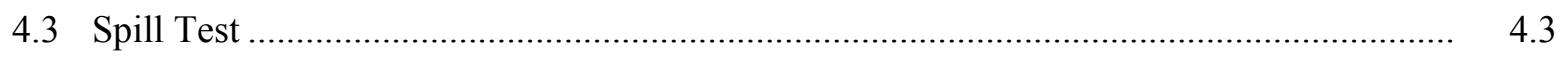

5.0 Results - Fish Collection and Tagging ......................................................................... 5.1

6.0 Results - Yearling Chinook Salmon............................................................................. 6.1

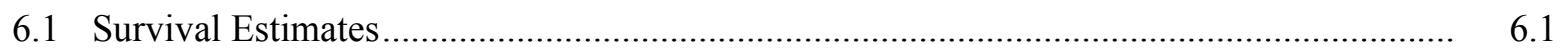

6.2 Estimates of Passage Efficiency .................................................................................... 6.2

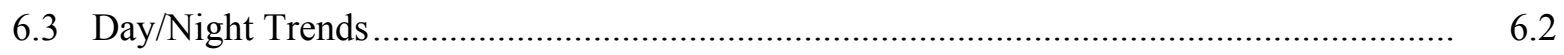

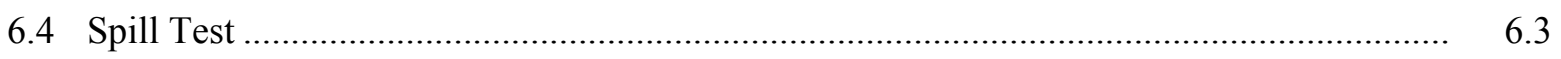

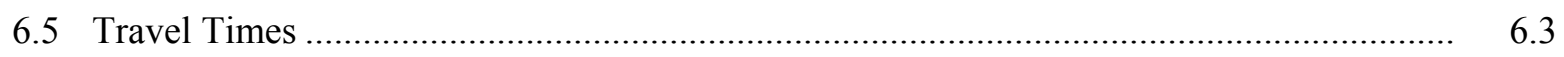

6.6 Fish Passage Distributions and Passage Times ............................................................... 6.4

6.6.1 Horizontal Distributions ................................................................................ 6.4

6.6.2 Forebay Approach Distribution and Route Specific Passage Times ....................... 6.5

6.6.3 Forebay Vertical Distribution........................................................................... 6.8

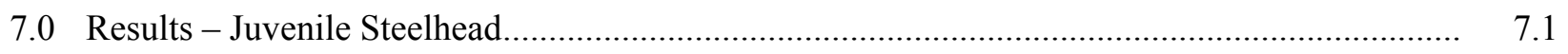

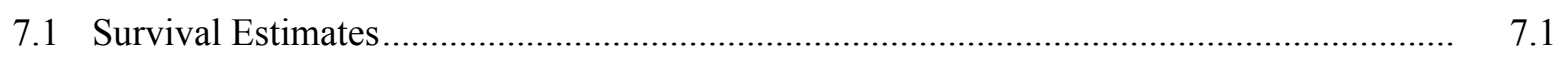

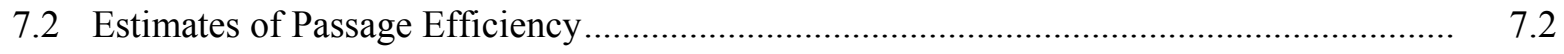

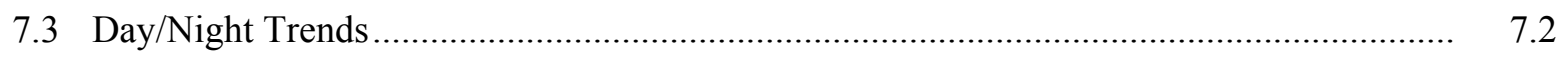

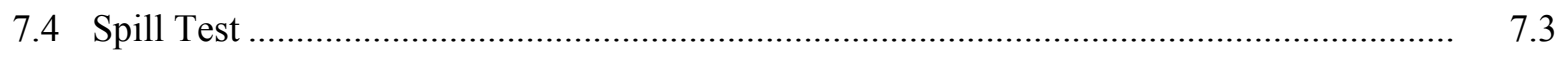

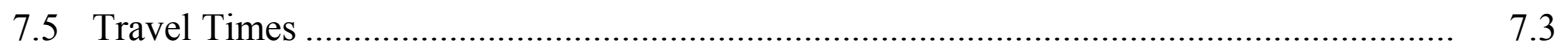

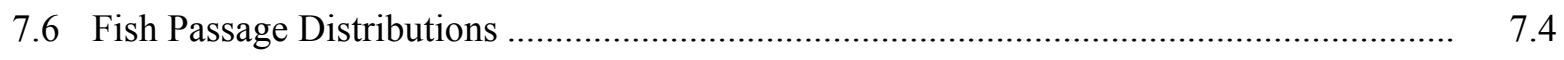

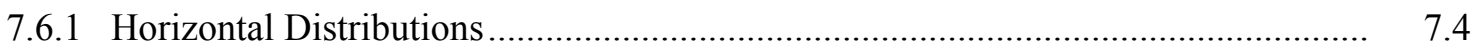

7.6.2 Forebay Approach Distribution and Route Specific Passage Times ....................... 7.5

7.6.3 Forebay Vertical Distribution...................................................................... 7.7

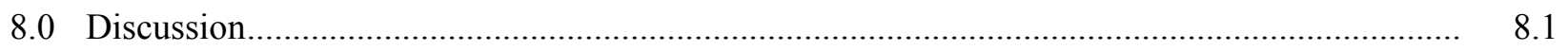

8.1 Statistical Performance and Survival Model Assumptions ............................................... 8.1

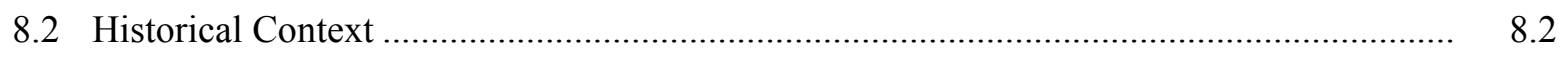

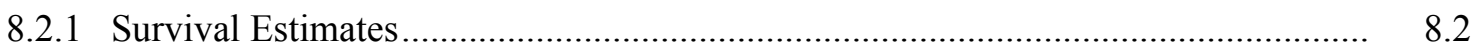

8.2.2 Passage Efficiency Estimates ..................................................................... 8.4

8.2.3 Top-Spill Weir Performance ....................................................................... 8.4

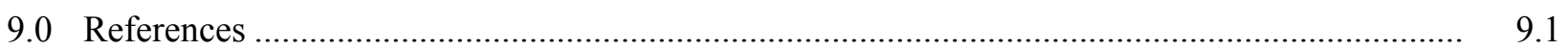

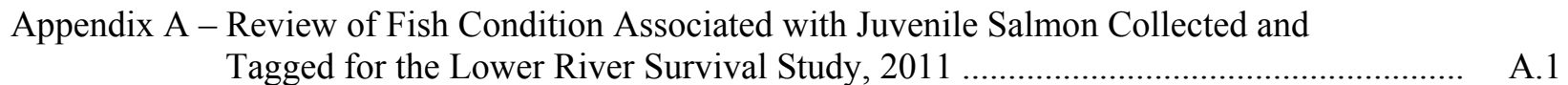

Appendix B - Surgeon Assessment and Feedback for the Lower Columbia River Acoustic-

Tag Investigations of Dam Passage Survival and Associated Metrics, 2011 f............. B. B

Appendix C - Fish-Tagging Tables .................................................................................. C. 1

Appendix D - Hydrophone and Autonomous Node Deployment Tables........................................ D. D.1

Appendix E - Capture Histories …..................................................................................... E. 
Appendix F - Detection and Survival Probabilities................................................................. F.1

Appendix G - Juvenile Salmon Acoustic Telemetry System Hydrophone Array Performance........... G.1

Appendix H - Assessment of Survival Model Assumptions ......................................................... H.1

\section{Figures}

1.1 John Day Dam on the Columbia River......................................................................... 1.1

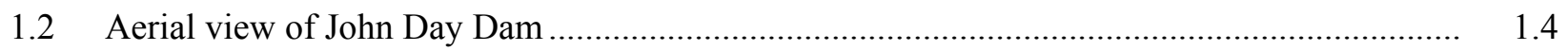

1.3 Top-spill weirs at John Day Dam showing the location of the stoplog weirs upstream

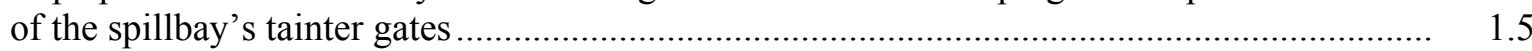

1.42011 study area on the lower Columbia River from Roosevelt, Washington, to

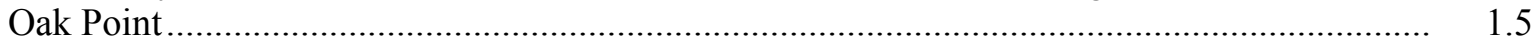

3.1 Spill test schedule at JDA from April 27 through May 29, 2011 .......................................... 3.2

3.2 Schematic of the virtual/paired-release design used to estimate dam passage survival at John Day Dam

3.3 JSATS Model SS130 acoustic micro-transmitter and Biomark HPT12 passive integrated transponder that were surgically implanted in CH1 and STH at John Day Dam in spring 2011

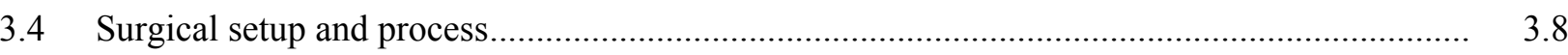

3.5 Post-surgery holding tank with tagged fish in recovery buckets ......................................... 3.8

3.6 Schematic of dam-face modular receiver system showing the main components and direction of signal acquisition and processing

3.7 Trolley pipe mounted on a main pier of the John Day Dam powerhouse showing a cone used as a guide for trolley insertion ........................................................................... 3.12

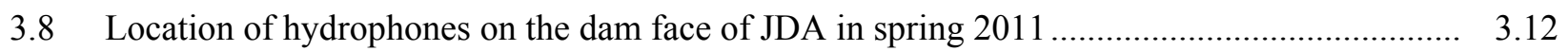

3.9 Trolleys used to deploy hydrophones at the John Day powerhouse and spillway, 2011 ........... 3.13

3.10 Outer and internal views of an autonomous node top .................................................... 3.14

3.11 Location of the three fish release transects, dam-face cabled arrays, and four autonomous node arrays deployed to detect fish tagged with acoustic microtransmitters migrating downstream

3.12. Autonomous node deployment rigging and teledyne acoustic release.....

3.13 Example of time-domain waveforms and corresponding cross-correlations acquired at the John Day Dam spillway.....

4.1 Average daily water discharge from John Day Dam during the 2011 study and for the preceding 10 -yr period

4.2 Average daily water temperature from John Day Dam during the spring 2011 study and for the preceding 10-yr period

4.3 Mean forebay elevation from John Day Dam during the spring 2011 study and for the preceding 10 -yr period

4.4 Spring spill test at John Day Dam, April 29 through May 29, 2011. 
6.1 Spill bay route of passage and associated percent discharge ................................................ 6.5

6.2 Passage distribution by percent discharge for turbine- and JBS-passed $\mathrm{CH} 1$ at

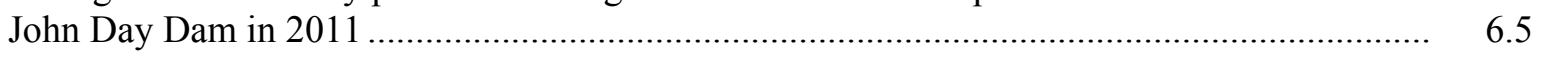

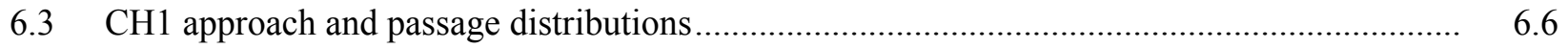

6.4 Approach and route of passage for $\mathrm{CH} 1$ passing during high spill and low spill.................... 6.6

6.5 CH1 approach and passage distributions during day and night........................................ 6.7

6.6 Median depth at last detection of tagged CH1 at John Day Dam........................................... 6.8

6.7 Median depth at last detection of tagged CH1 at John Day dam during the day..................... 6.8

6.8 Median depth at last detection of tagged CH1 at John Day Dam at night............................. 6.9

7.1 Percent discharge and passage proportions of STH by spill bay ........................................... 7.5

7.2 Passage distribution and percent discharge for turbine and JBS-passed STH at

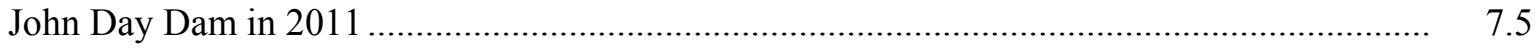

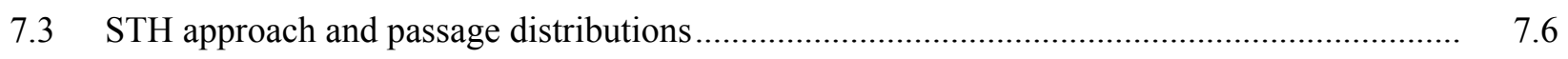

7.4 Approach and route of passage for STH passing during high spill and low spill.................... 7.6

7.5 STH approach and passage distributions during day and night............................................ 7.7

7.6 Median depth at last detection of tagged STH at John Day Dam......................................... 7.8

7.7 Median depth at last detection of tagged STH at John Day Dam during the day..................... 7.8

7.8 Median depth at last detection of tagged STH at John Day Dam at night............................... 7.9

8.1 Route-specific survival for CH1 from the dam-face virtual release at John Day Dam to The Dalles Dam tailrace, 2008-2011 ........................................................................ 8.3

8.2 Route-specific survival for STH salmon from the dam-face virtual release at John Day Dam to The Dalles Dam tailrace, 2008-2011 ...................................................... 8.4

8.3 Summary of passage efficiency metrics for CH1 at John Day Dam, 2008 through $2011 \ldots \ldots . . . \quad 8.5$

8.4 Summary of passage efficiency metrics for STH at John Day Dam, 2008 through 2011 ......... 8.6

\section{Tables}

ES.1 Summary of methods and conditions at John Day Dam during 2011.

ES.2 Summary of survival and other performance metrics at John Day Dam during 2011, season-wide and early season for $30 \%$ and $40 \%$ spill treatments

vii

ES.3 Route-specific paired-release survival estimates at John Day Dam in 2011

viii

ES.4 Summary of combined and day and night paired-release survival estimates and other performance metrics......

viii

ES.5 Summary of horizontal distributions at John Day Dam in spring 2011.

ix

ES.6 Summary of survival and other performance metrics for the entire field season and early and late season at John Day Dam during 2011

ix

1.1 Definitions of performance measures in this study ........................................................... 1.3

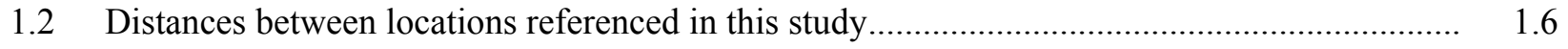


2.1 Estimates of survival rates for two salmonid stocks passing routes at John Day Dam using radio telemetry during 2000, 2002, and 2003, and acoustic telemetry during 2008 to 2010

2.2 Radio-telemetry, acoustic telemetry, and hydroacoustic estimates of fish passage efficiency and spill efficiency for John Day Dam....

3.1 Numbers of fish tagged with acoustic micro-transmitters used in the spring 2011 survival study at John Day Dam.

3.2 Release time of fish tagged with JSATS acoustic micro-transmitters released at three sites in spring 2011 ....

3.3 Description, location, name, and survival model function of arrays deployed in 2011

5.1 Summary of the number and percentage of fish rejected, excluded, tagged and released alive, tagged and released dead, and that exceeded collection needs

5.2 Number of observed malady types that warranted rejection and percent rejected by malady type in 2011

5.3 Number of juvenile salmonids excluded from tagging for other reasons and percent excluded by reason in 2011

6.1 CH1 virtual/paired-release survival estimates from the John Day Dam forebay entrance and dam face to the John Day Dam tailrace for early spring and season-wide

6.2 CH1 season-wide route-specific virtual/paired-release survival estimates from the John Day Dam face to the tailrace

6.3 Season-wide estimates of major passage metrics for CH1 at John Day Dam, spring 2011 .......

6.4 Comparison of day/night season-wide paired-release estimates of survival for $\mathrm{CH} 1$ for dam passage and forebay to tailrace survival

6.5 Comparison of season-wide day and night passage efficiencies for CH1 at John Day Dam in spring 2011

6.6 Early spring estimates of survival and fish passage metrics for $\mathrm{CH} 1$ during $30 \%$ and $40 \%$ spill tests.

6.7 Travel times for CH1 at John Day Dam in spring 2011

6.8 Percent of total passage by subroute for CH1 at John Day Dam in spring 2011.

6.9 CH1 forebay median residence time by approach and passage routes during day, night, low spill, and high spill

7.1 STH virtual/paired-release survival estimates from the John Day Dam forebay entrance and dam face to the John Day Dam tailrace

7.2 STH season-wide route-specific virtual/paired-release survival estimates from the dam face virtual release at John Day Dam to the JDA tailrace

7.3 Season-wide estimates of major fish passage metrics for STH at John Day Dam in 2011 ........

7.4 Comparison of day/night season-wide paired-release estimates of survival for STH for dam passage and forebay to tailrace survival

7.5 Comparison of season-wide day and night passage efficiencies for STH at John Day Dam in spring 2011

7.6 Early spring estimates of major fish passage metrics and survival of STH during 30\% and $40 \%$ spill tests

7.7 Travel times for STH at John Day Dam in spring 2011. 
7.8 Percent of total passage by route for STH at John Day Dam in spring 2011

7.9 STH median residence time by approach and passage distributions during day, night, low spill, and high spill

8.1 Survival from the John Day Dam forebay entrance and dam face to the John Day Dam tailrace in spring 2011 


\subsection{Introduction}

In a continual effort to improve conditions for juvenile anadromous fish passing through Columbia River dams, the U.S. Army Corps of Engineers (USACE), Portland District (CENWP), has funded numerous evaluations of fish passage and survival through various structural configurations and operations at dams within the Federal Columbia River Power System (FCRPS) (Anglea et al. 2001; Weiland et al. 2009; Weiland et al. 2011a). Examining passage behavior and survival of juvenile salmonids is necessary to ensure healthy salmon populations in the future and meet performance standards set forth in the 2008 FCRPS Biological Opinion (BiOp) (National Oceanic and Atmospheric Administration [NOAA] Fisheries 2008) and the Columbia Basin Fish Accords (Fish Accords) (3 Treaty Tribes-Action Agencies 2008). The BiOp mandates that a $96 \%$ and $93 \%$ survival rate with an associated standard error of $\leq 0.015$ be achieved for spring and summer downstream migrating juvenile salmonids, respectively. The ultimate goal is to improve passage conditions for various populations, some of which are listed as threatened or endangered under the Endangered Species Act of 1973.

This report describes research conducted using acoustic telemetry (AT) to evaluate juvenile salmonid passage and survival during spring 2011 at John Day Dam (JDA) (Figure 1.1). Researchers at the Pacific Northwest National Laboratory (PNNL) in collaboration with the Pacific States Marine Fisheries Commission (PSMFC), CENWP, and the University of Washington (UW), conducted this juvenile fish passage and survival study.

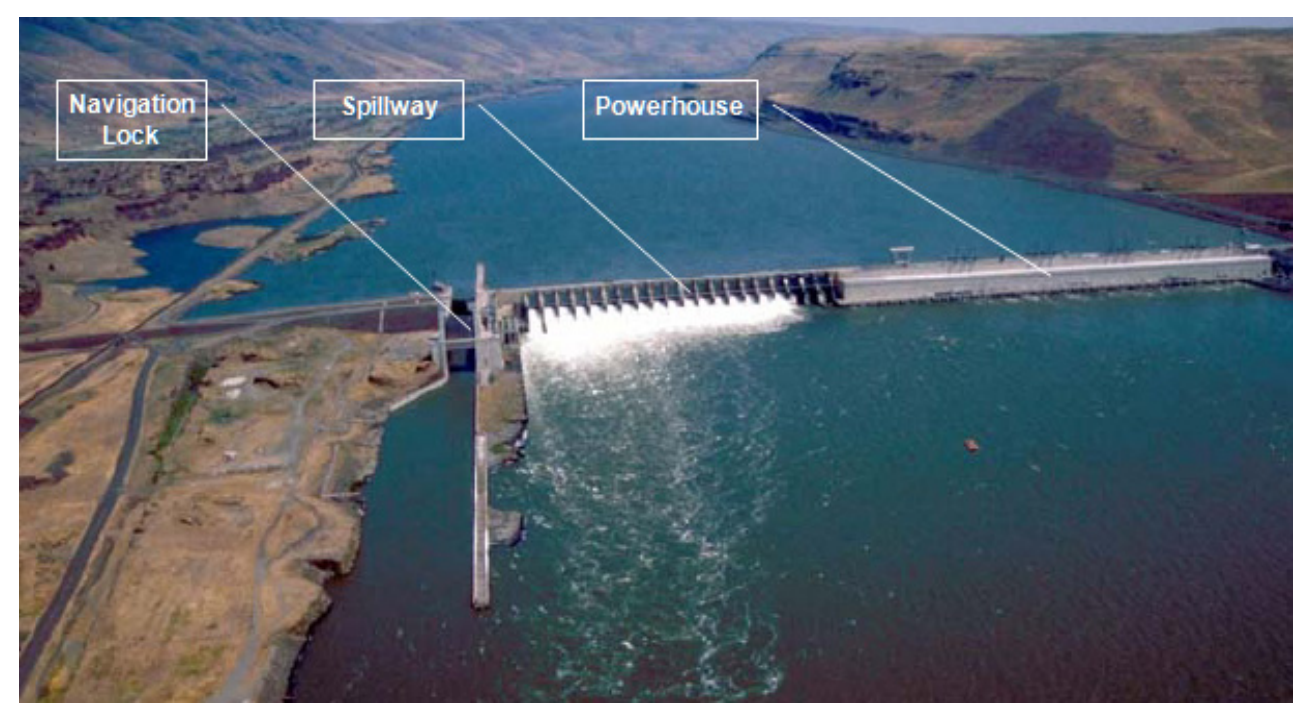

Figure 1.1. John Day Dam on the Columbia River.

The 2011 study was an official compliance test as described by the 2008 FCRPS BiOp (NOAA Fisheries 2008). The primary goal of the current study was to estimate the survival of yearling Chinook salmon (CH1) and juvenile steelhead (STH) passing through JDA and $3 \mathrm{~km}$ of tailwater using a pairedrelease survival model. Also, the effects of two spill discharge levels (30\% and $40 \%$ spill) on survival rates were independently tested and the performance of the JDA surface-flow outlets (SFOs) and passage performance measures were evaluated. Due to an above-normal snow pack and high flows, the summer portion of the study was cancelled and no subyearling Chinook were tagged. This study was conducted to 
provide the CENWP and regional fisheries managers with the information necessary to make decisions for adaptive management of the configuration and operation of JDA to maximize the survival of juvenile salmonids past the dam.

\subsection{Study Objectives}

The overall purpose of the AT study at JDA during 2011 was to estimate fish survival rates and passage efficiencies under $30 \%$ and $40 \%$ spill-discharge test levels and to evaluate the performance of the prototype SFOs, called top-spill weirs (TSWs) installed in spill bays 18 and 19. For studies occurring during 2008 and 2009, the TSWs were installed at spill bays 15 and 16; in 2010 they were moved to spill bays 18 and 19. This study was the second year passage metrics were examined at the new locations closer to the powerhouse. In addition, the effects of $30 \%$ and $40 \%$ spill discharge levels on fish survival and passage rates were independently evaluated using a uniform block study design with one 2-d test randomly selected to be $30 \%$ or $40 \%$ spill discharge followed by the alternate discharge level. The field study period began with fish releases on April 26, 2011 continuing through May 29, 2011; data collection concluded on June 22, 2011, with the detection of the last spring migrant at JDA. In this report for fish detected at JDA data were truncated on May 29, 2011, after the final tailwater reference fish were released below JDA.

The study objectives and sub-objectives outlined below were applied separately to $\mathrm{CH} 1$ and STH surgically implanted with JSATS acoustic micro-transmitters (AMTs) and passive integrated transponders (PIT) at JDA during 2011:

1. Estimate survival rates ${ }^{1}$ :
a. Dam passage for the total project
b. JDA forebay-to-tailrace survival
c. Dam passage by route (turbines, TSW, non-TSW, spillway and JBS).

2. Estimate passage efficiency metrics:
a. Fish passage efficiency (FPE)
b. Spill passage efficiency (SPE; with and without the TSW)
c. TSW passage efficiency (TSWE) relative to the total project
d. TSWE relative to the spillway.

3. Estimate passage distributions:
a. Horizontal
b. Vertical
c. Diel.

\footnotetext{
${ }^{1}$ See Section 1.2 for definitions.
} 
4. Compute travel times:
a. Forebay residence time
b. Tailrace egress
c. Project passage.

5. Observe the forebay approach paths of tagged fish and relate them to passage distribution:

a. Compare forebay approach paths of turbine- vs. bypass- vs. spill- vs. TSW-passed fish.

6. Subsample juvenile salmonids during tagging to assess population-level fitness:

a. Characterize the fitness of in-river fish and those selected to be tagged

b. Compare the fitness of in-river fish and those selected to be tagged.

\subsection{Definitions}

For this report, we define virtual paired-release survival, travel time, and passage efficiency metrics (Table 1.1).

Table 1.1. Definitions of performance measures in this study.

\begin{tabular}{|c|c|}
\hline Measure & Definition \\
\hline $\begin{array}{l}\text { Dam passage } \\
\text { survival }\end{array}$ & $\begin{array}{l}\text { Survival from the upstream face of the dam to the primary survival detection array located at } \\
\text { TDA dam face } 40 \mathrm{~km} \text { downstream from JDA }\end{array}$ \\
\hline $\begin{array}{l}\text { Forebay to } \\
\text { tailwater } \\
\text { survival }\end{array}$ & $\begin{array}{l}\text { Survival from a forebay array } 2 \mathrm{~km} \text { upstream of the dam to the primary survival detection array } \\
\text { located at TDA dam face } 40 \mathrm{~km} \text { downstream from JDA }\end{array}$ \\
\hline $\begin{array}{l}\text { Forebay } \\
\text { residence time }\end{array}$ & $\begin{array}{l}\text { Median and average times required for juvenile salmonids to travel from the time of first } \\
\text { detection on the forebay entrance array } 2 \mathrm{~km} \text { upstream of the dam until the time of last detection } \\
\text { on the dam-face array }\end{array}$ \\
\hline $\begin{array}{l}100-\mathrm{m} \text { forebay } \\
\text { residence time }\end{array}$ & $\begin{array}{l}\text { Median and average times required for juvenile salmonids to travel the last } 100 \mathrm{~m} \text { of forebay } \\
\text { until they pass through the dam }\end{array}$ \\
\hline $\begin{array}{l}\text { Tailrace egress } \\
\text { time }\end{array}$ & $\begin{array}{l}\text { Median and average time required for juvenile salmonids to pass through the tailrace after they } \\
\text { pass through the dam, i.e., from time of last detection on the dam-face array until the time of last } \\
\text { detection on the tailrace egress array } 3 \mathrm{~km} \text { downstream of JDA }\end{array}$ \\
\hline $\begin{array}{l}\text { Project passage } \\
\text { time }\end{array}$ & $\begin{array}{l}\text { Median and average time juvenile salmonids take to travel from first detection on the array } 2 \mathrm{~km} \\
\text { upstream of the dam until the last detection on the tailrace exit array } 3 \mathrm{~km} \text { downstream of the } \\
\text { dam }\end{array}$ \\
\hline $\begin{array}{l}\text { Spill passage } \\
\text { efficiency }\end{array}$ & Proportion of fish passing through the dam via the spillway and TSW bays \\
\hline $\begin{array}{l}\text { Fish passage } \\
\text { efficiency }\end{array}$ & Proportion of fish passing through the dam via the spillway, TSWs, and JBS \\
\hline
\end{tabular}

\subsection{Study Area}

John Day Dam, located at rkm 349, is the third dam upstream from the mouth of the Columbia River. The dam consists of a powerhouse with 16 turbine units and 4 skeleton bays (bays where turbines were 
never installed) on the Oregon side of the river and a 20-bay spillway on the Washington side (Figure 1.2). The skeleton bays are located between the powerhouse turbine intakes and the spillway. In 2008 and 2009, the TSWs were located at spill bays 15 and 16; in 2010 they were moved to spill bays 18 and 19 (their current location) to optimize the diversion of fish away from the powerhouse thus minimizing turbine passage. The TSWs create a flow field in the forebay that is designed to attract juvenile salmonids migrating downstream and encourage passage through the dam via the surface route in preference to sounding and passing through turbines. The TSW consists of a stop log assembly placed on top of the spillway crest, and when the spill gate is raised, water flows over the weir (Figure 1.3). The TSW discharge per bay is approximately 10,000 cfs. Spill from adjacent bays guides the TSW outfall discharge in the tailrace to aid in rapid movement of fish through the spillway tailrace. In addition, a new avian line array was installed in the air above the JDA tailrace in 2010 and was further expanded in 2011. The purpose of this line array was to reduce avian predation in the tailrace.

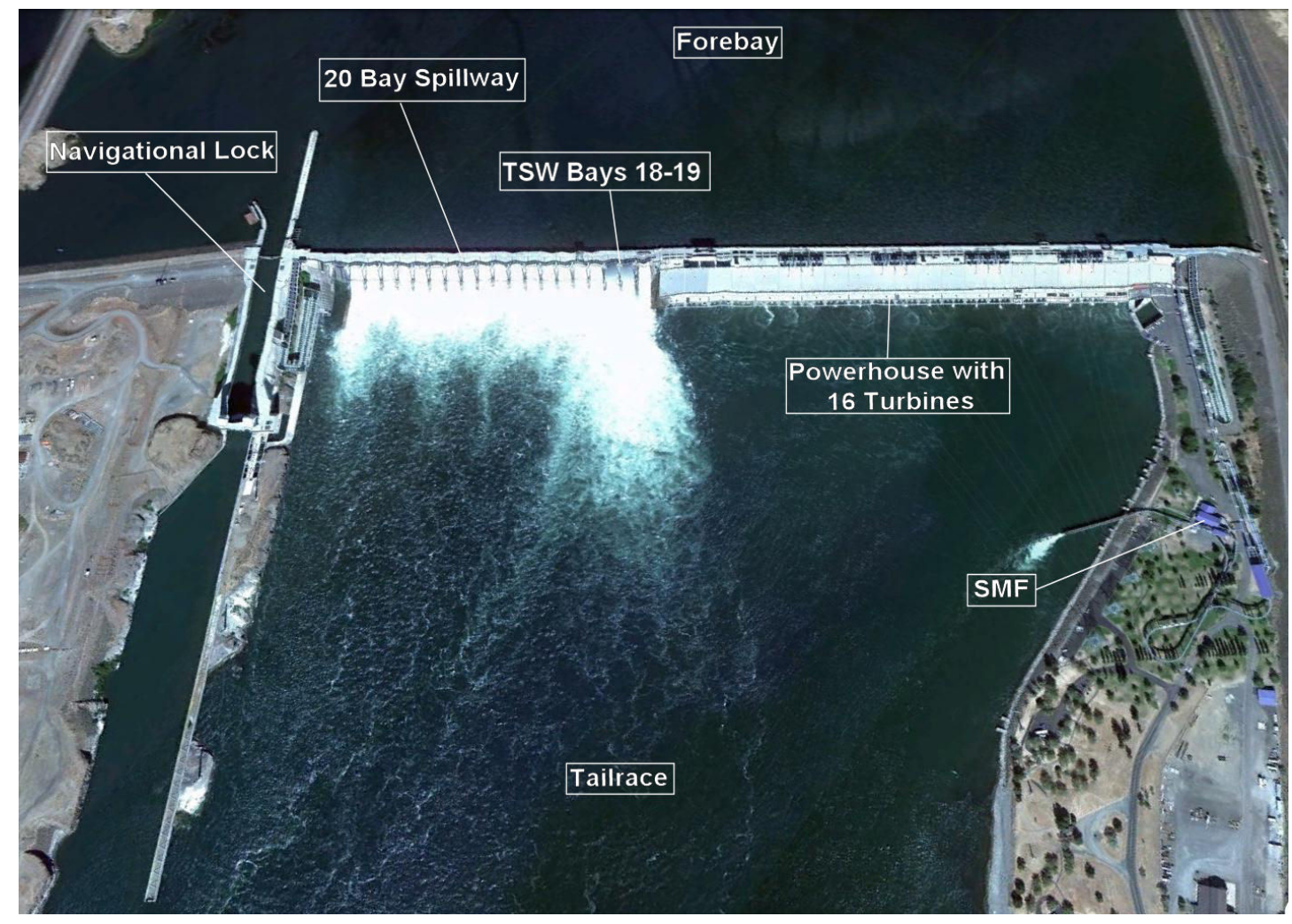

Figure 1.2. Aerial view of John Day Dam (Google Earth image). 


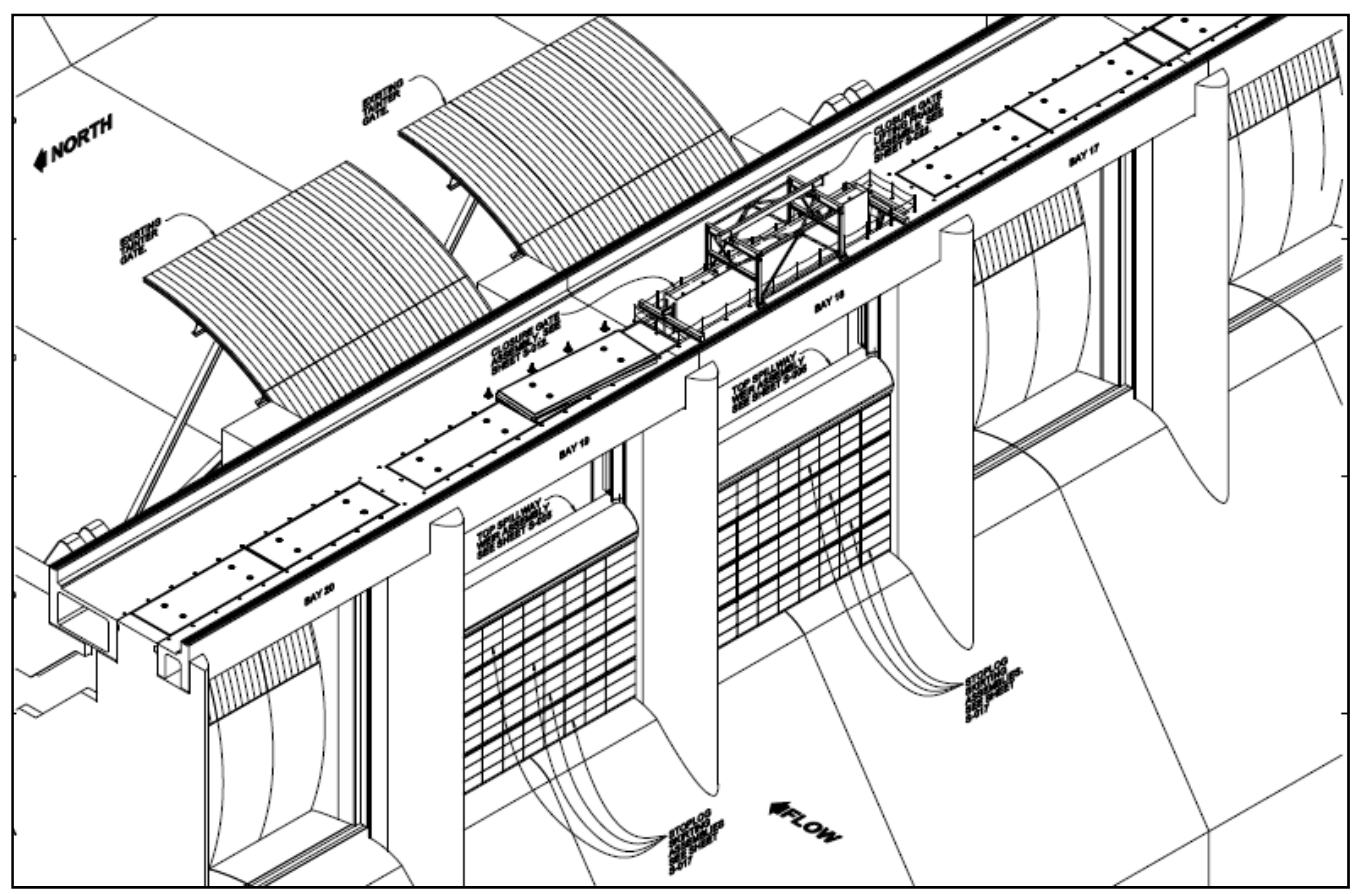

Figure 1.3. Top-spill weirs at John Day Dam showing the location of the stoplog weirs upstream of the spillbay's tainter gates (provided by $\mathrm{S}$ Askelson, CENWP).

The study area for the AT evaluation of survival and passage at JDA during 2011 covered approximately $304 \mathrm{rkm}$ of the lower Columbia River from Roosevelt, Washington (fish release point; rkm 390), to Oak Point (rkm 86) (Figure 1.4). John Day Dam is located $41.4 \mathrm{~km}$ downstream of the fish release transect at Roosevelt, Washington. Throughout this report, we refer to locations on the river that are varying distances apart; so a quick reference table below provides the distances between river locations referred to in this report (Table 1.2).

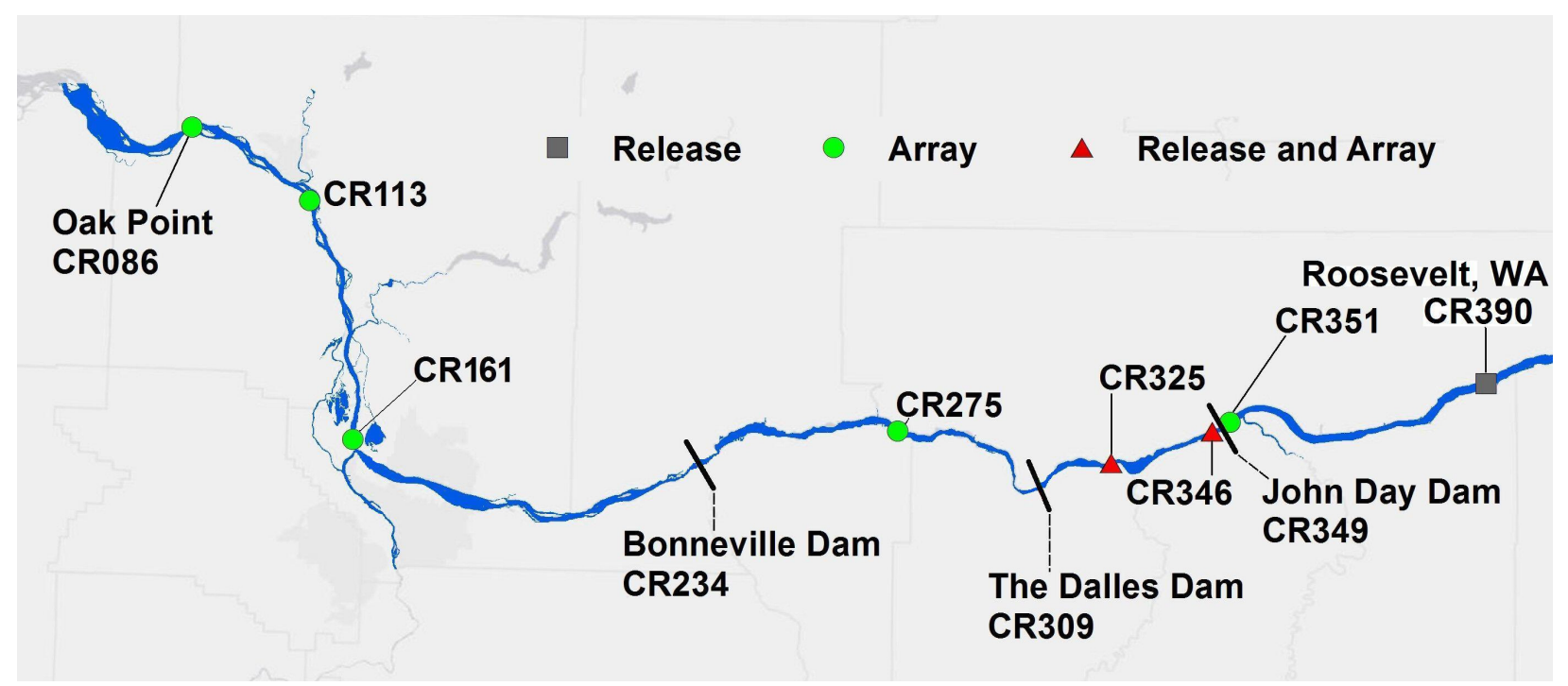

Figure 1.4. 2011 study area on the lower Columbia River from Roosevelt, Washington, to Oak Point. 
Table 1.2. Distances (rkm) between locations referenced in this study.

\begin{tabular}{|c|c|c|c|c|c|c|c|c|c|c|c|c|}
\hline & $\begin{array}{l}\text { Distance } \\
\text { Upstream of } \\
\text { Columbia }\end{array}$ & 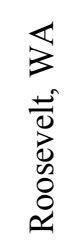 & 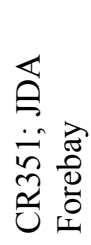 & 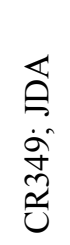 & 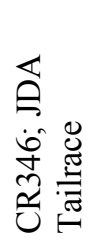 & $\begin{array}{l}\frac{0}{\overline{0}} \\
\ddot{0} \\
\ddot{n} \\
\tilde{己}\end{array}$ & $\begin{array}{l}\overleftrightarrow{O} \\
\ddot{\theta} \\
\ddot{0} \\
\stackrel{\theta}{0}\end{array}$ & 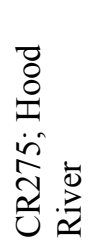 & 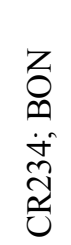 & 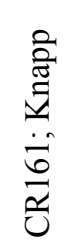 & 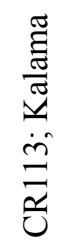 & 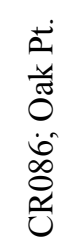 \\
\hline Location & $(\mathrm{rkm})$ & 390 & 351 & 349 & 346 & 325 & 309 & 275 & 234 & 161 & 113 & 86 \\
\hline Roosevelt, WA & 390 & 0 & 39 & 41 & 44 & 65 & 81 & 115 & 156 & 229 & 277 & 304 \\
\hline $\begin{array}{l}\text { CR351; JDA } \\
\text { Forebay }\end{array}$ & 351 & & 0 & 2 & 5 & 26 & 42 & 76 & 117 & 190 & 238 & 265 \\
\hline CR349; JDA & 349 & & & 0 & 3 & 24 & 40 & 74 & 115 & 188 & 236 & 263 \\
\hline $\begin{array}{l}\text { CR346; JDA } \\
\text { Tailrace }\end{array}$ & 346 & & & & 0 & 21 & 37 & 71 & 112 & 185 & 233 & 260 \\
\hline CR325; Celilo & 325 & & & & & 0 & 16 & 50 & 91 & 164 & 212 & 239 \\
\hline CR309; TDA & 309 & & & & & & 0 & 34 & 75 & 148 & 196 & 223 \\
\hline $\begin{array}{l}\text { CR275; Hood } \\
\text { River }\end{array}$ & 275 & & & & & & & 0 & 41 & 114 & 162 & 189 \\
\hline CR234; BON & 234 & & & & & & & & 0 & 73 & 121 & 148 \\
\hline CR161; Knapp & 161 & & & & & & & & & 0 & 48 & 75 \\
\hline CR113; Kalama & 113 & & & & & & & & & & 0 & 27 \\
\hline CR086; Oak Pt. & 86 & & & & & & & & & & & 0 \\
\hline
\end{tabular}

John Day Dam has a JBS that uses intake screens to divert fish out of turbine intakes and convey them through a series of gates, chutes, and flumes to the tailrace. Fish are diverted by submerged traveling screens from the upper part of the powerhouse turbine intake flow into turbine gatewell slots. The diverted fish volitionally move from the gatewells through orifices in the gatewells into a bypass channel that runs the length of the powerhouse. The volume of flow through the bypass channel is reduced by dewatering to a volume small enough to pass through pipes to the Smolt Monitoring Facility (SMF) or to an outfall pipe discharging into the tailrace (Figure 1.2). At the SMF, diverted fish are sampled as part of the regional Smolt Monitoring Program and some were used for the 2011 JDA AT study.

\subsection{Report Contents}

Additional project background is provided in Chapter 2.0. The ensuing chapters of this report then describe the methods used to estimate the survival, and observe the behavior, of juvenile salmonids passing JDA (Chapter 3.0), followed by a description of the environmental conditions during the study period (Chapter 4.0). Results for survival, travel time, passage efficiency, and distributions for $\mathrm{CH} 1$ and STH are found in Chapters 5.0 and 6.0, respectively. Discussion and conclusion of study results (Chapter 7.0), and references (Chapter 8.0) complete the main body of the report. In the appendices we provide the fish condition report (Appendix A); Surgeon Training (Appendix B); Tagging and Release Data (Appendix C); Hydrophone and Autonomous Node Deployment Locations (Appendix D); Capture Histories (Appendix E); Detection and Survival Probabilities (Appendix F); JSATS Hydrophone Array Performance (Appendix G); and Assessment of Survival Model Assumptions (Appendix H). 


\subsection{Background}

Researchers first used radio telemetry (RT) and hydroacoustics at JDA in the early 1980s to examine the behavior of juvenile salmon as they approached and passed the dam (Giorgi and Stevenson 1995; Anglea et al. 2001). Baseline biological data on fish movement, distribution, and behavior at JDA using RT and hydroacoustics were summarized for the years of 1980 through 2000 by Anglea et al. (2001). Subsequent technological advances in RT allowed for estimates of passage proportions for turbine, screen bypass, and spillway routes through JDA (Hansel et al. 2000; Beeman et al. 2003), as well as estimates of $\mathrm{CH}$ and STH survival rates (Counihan et al. 2000). In the mid-2000s, juvenile salmon dam passage and survival studies on the lower Columbia River transitioned from the use of RT to the use of AT with the development of the Juvenile Salmon Acoustic Telemetry System (JSATS) (Ploskey et al. 2007; McMichael et al. 2010).

Data from previous studies indicated that some of the BiOp performance standards would not be met under previous dam operating conditions (Table 2.1). Passage survival estimates through JDA as a whole from previous studies using AT and RT ranged from $92.2 \%$ to $95.7 \%$ for $\mathrm{CH} 1$ and from $90.5 \%$ to $98.6 \%$ for STH. Survival estimates for spring salmonid stocks (CH1 and STH), tended to be higher for fish passing at the spillway rather than at the powerhouse. RT study results indicated differences between the powerhouse and spillway survival rates were greater for $\mathrm{CH} 1$ than for STH. However, results from AT studies performed in 2008, 2009, and 2010 displayed greater differences in survival rates for STH than for $\mathrm{CH} 1$ when comparing spillway and powerhouse passage. Nevertheless, evaluating these differences and altering dam operations and structural configurations may be required to meet $\mathrm{BiOp}$ standards.

At least eight previous studies have estimated $\mathrm{FPE}^{1}$ and $\mathrm{SPE}^{2}$ at JDA (Table 2.2). Radio-telemetry studies indicated that FPE ranged from $82 \%$ to $92 \%$ for $\mathrm{CH} 1$ and $88 \%$ to $94 \%$ for STH. More recent AT studies estimated FPE ranging from $91 \%$ to $97 \%$ for $\mathrm{CH} 1$ and $97 \%$ to $99 \%$ for $\mathrm{STH}$, and a hydroacoustic study in 2002 estimated a similar FPE range for spring stocks. Estimates of SPE for the two fish stocks were highly variable among years. Most recently, AT studies estimated SPE from $76 \%$ to $92 \%$ for $\mathrm{CH} 1$ and $72 \%$ to $90 \%$ for $\mathrm{STH}$.

The USACE (Portland and Walla Districts) and regional fisheries managers began evaluating SFOs in the mid-1990s as structural modifications to provide safer passage routes for juvenile salmonids in the FCRPS (Sweeney et al. 2007). Engineering and model studies examining skeleton bays as potential SFO sites at JDA were conducted in the late 1990s (CH2M Hill/Montgomery Watson Joint Venture 1998; CH2M Hill/Montgomery Watson Joint Venture et al. 2001). These studies, conducted in a physical hydraulic model of JDA at the U.S. Army Engineer Research and Development Center, showed that a 20,000-cfs SFO in a skeleton bay exhibited strong forebay flow nets, suggesting a potential for fish to discover the SFO flow (CH2M Hill/Montgomery Watson Joint Venture 1998; CH2M Hill/Montgomery Watson Joint Venture et al. 2001; Sweeney et al. 2007). However, this effort was discontinued because of cost concerns and prolonged tailrace egress caused by a large eddy in the spillway stilling basin adjacent to the SFO outfall plume (Sweeney et al. 2007). Additional studies at JDA examined specific spill bays as potential sites for SFO development (BioSonics, Inc. 1999; Hensleigh 1999). Hydroacoustic

\footnotetext{
${ }^{1}$ Fish passage efficiency is defined as total passage through non-turbine routes divided by total dam passage.

${ }^{2}$ Spill passage efficiency is defined as total spill passage divided by total dam passage.
} 
and radiotelemetry studies of prototype spillway SFOs were conducted at JDA in 1997 when overflow weirs were placed at spill bays 18 and 19 (BioSonics, Inc. 1999; Hensleigh 1999). However, the weirs allowed both overflow and underflow and thus were not true surface spill SFOs (Sweeney et al. 2007).

Table 2.1. Estimates of survival rates for two salmonid stocks passing routes at John Day Dam using radio telemetry during 2000, 2002, and 2003, and acoustic telemetry during 2008 to 2010. The ranges are for point estimates under different treatments. Standard errors were provided for 2008 to 2010.

\begin{tabular}{|c|c|c|c|}
\hline Study Year (Passage Route) & $\mathrm{CH} 1$ & STH & Reference \\
\hline \multicolumn{4}{|c|}{ Radio Telemetry } \\
\hline 2000 (Dam) & 93.7 to $98.6 \%$ & 90.5 to $98.8 \%$ & Counihan et al. (2002) \\
\hline 2002 (Spillway) & 99.3 to $100 \%$ & 93.2 to $95.8 \%$ & Counihan et al. (2006a) \\
\hline 2002 (Powerhouse) & 77.8 to $83.2 \%$ & 89.9 to $93.0 \%$ & Ibid \\
\hline 2002 (Dam) & 92.9 to $96.3 \%$ & 91.5 to $94.0 \%$ & Ibid \\
\hline 2003 (Spillway) & 93.4 to $93.9 \%$ & --- & Counihan et al. (2006b) \\
\hline 2003 (Powerhouse) & 76.4 to $82.0 \%$ & --- & Ibid \\
\hline 2003 (Dam) & 92.2 to $94.0 \%$ & --- & Ibid \\
\hline \multicolumn{4}{|c|}{ Acoustic Telemetry } \\
\hline 2008 (Dam) & $95.7 \pm 1.3 \%$ & $98.6 \pm 1.7 \%$ & Weiland et al. (2009) \\
\hline 2008 (Non-TSW Spillbays) & $96.6 \pm 1.1 \%$ & $98.5 \pm 2.3 \%$ & Ibid \\
\hline 2008 (TSW Spillbays) & $96.1 \pm 2.0 \%$ & $99.2 \pm 2.3 \%$ & Ibid \\
\hline 2008 (Turbine) & $85.5 \pm 3.4 \%$ & $74.9 \pm 6.2 \%$ & Ibid \\
\hline 2008 (JBS) & $97.6 \pm 4.5 \%$ & $100.2 \pm 1.9 \%$ & Ibid \\
\hline 2009 (Dam) & $92.7 \pm 1.0 \%$ & $95.3 \pm 0.8 \%$ & Weiland et al. (2011a) \\
\hline 2009 (Non-TSW Spillbays) & $91.3 \pm 1.4 \%$ & $93.6 \pm 1.6 \%$ & Ibid \\
\hline 2009 (TSW Spillbays) & $95.1 \pm 1.4 \%$ & $96.3 \pm 1.0 \%$ & Ibid \\
\hline 2009 (Turbine) & $85.1 \pm 4.7 \%$ & $82.4 \pm 8.0 \%$ & Ibid \\
\hline 2009 (JBS) & $97.5 \pm 1.6 \%$ & $96.6 \pm 1.4 \%$ & Ibid \\
\hline 2010 (Dam) & $93.7 \pm 0.50 \%$ & $95.0 \pm 0.50 \%$ & Weiland et al. (2013) \\
\hline 2010 (Non-TSW Spillbays) & $95.0 \pm 0.80 \%$ & $94.4 \pm 1.2 \%$ & Ibid \\
\hline 2010 (TSW Spillbays) & $95.2 \pm 0.60 \%$ & $97.2 \pm 0.40 \%$ & Ibid \\
\hline 2010 (Turbine) & $77.6 \pm 4.7 \%$ & $69.4 \pm 7.4 \%$ & Ibid \\
\hline 2010 (JBS) & $90.1 \pm 2.6 \%$ & $94.3 \pm 1.7 \%$ & Ibid \\
\hline
\end{tabular}

The CENWP identified SFO development as a priority in the John Day Lock and Dam Configuration and Operation Plan (USACE 2007). Accordingly, new model investigations and engineering design work were undertaken to develop a prototype SFO for JDA. In the winter of 2007/2008, the CENWP installed prototype SFOs, called TSWs, at spill bays 15 and 16. A bulkhead on top of the weir provided hydraulic control, creating a critical entrance flow condition. The weir, discharging approximately $10,000 \mathrm{cfs}$ per bay, was designed to minimize the angle of SFO jet impact on the spill bay ogee. The intent was to increase the FPE and passage survival rates of downstream-migrating juvenile salmonids at JDA. Beginning in 2010, the TSWs were moved to spill bays 18 and 19 to optimize flow conditions and diversion of fish away from the powerhouse. 
Table 2.2. Radio-telemetry (RT), acoustic telemetry (AT), and hydroacoustic (HA) estimates of fish passage efficiency and spill efficiency for John Day Dam. See Section 3.7.5 for definitions of metrics.

\begin{tabular}{|c|c|c|c|}
\hline Study Year/Type & $\mathrm{CH} 1$ & STH & Reference \\
\hline \multicolumn{4}{|c|}{ Fish Passage Efficiency } \\
\hline 1999 (RT) & 82 to $88 \%$ & 90 to $94 \%$ & Hansel et al. (2000) \\
\hline $2000(\mathrm{RT})$ & 90 to $92 \%$ & 91 to $93 \%$ & Beeman et al. (2003) \\
\hline $2002(\mathrm{RT})$ & 84 to $85 \%$ & 88 to $91 \%$ & Beeman et al. (2006) \\
\hline $2002(\mathrm{HA})^{(\mathrm{a})}$ & \multicolumn{2}{|c|}{89 to $94 \%$} & Moursund et al. (2003) \\
\hline 2003 (RT) & 84 to $86 \%$ & -- & Hansel et al. (2004) \\
\hline 2008 (AT) & 91 to $93 \%$ & $97 \%$ & Weiland et al. (2009) \\
\hline 2009 (AT) & 93 to $94 \%$ & 97 to $98 \%$ & Weiland et al. (2011a) \\
\hline $2010(\mathrm{AT})$ & 96 to $97 \%$ & 98 to $99 \%$ & Weiland et al. (2013) \\
\hline \multicolumn{4}{|c|}{ Spill Passage Efficiency } \\
\hline 1999 (RT) & 53 to $66 \%$ & 45 to $53 \%$ & Hansel et al. (2000) \\
\hline 2000 (RT) & 75 to $86 \%$ & 61 to $83 \%$ & Beeman et al. (2003) \\
\hline $2002(\mathrm{RT})$ & 48 to $57 \%$ & 54 to $64 \%$ & Beeman et al. (2006) \\
\hline $2002(\mathrm{HA})^{(\mathrm{a})}$ & \multicolumn{2}{|c|}{72 to $78 \%$} & Moursund et al. (2003) \\
\hline 2003 (RT) & 47 to $57 \%$ & --- & Hansel et al. (2004) \\
\hline 2008 (AT) & 76 to $77 \%$ & 72 to $76 \%$ & Weiland et al. (2009) \\
\hline 2009 (AT) & 76 to $85 \%$ & 72 to $81 \%$ & Weiland et al. (2011a) \\
\hline 2010 (AT) & 89 to $92 \%$ & 87 to $90 \%$ & Weiland et al. (2013) \\
\hline
\end{tabular}

(a) Hydroacoustic study - does not allow species differentiation.

Acoustic telemetry studies conducted in 2008 and 2009 (Weiland et al. 2009; Weiland et al. 2011a) showed the survival rates of juvenile CH1 (>95\%) and STH (>96\%) were high through the TSWs, second only to rates for juvenile salmonids passing through the JBS during both years. The 2010 study showed survival rates through the TSWs being higher for juvenile $\mathrm{CH} 1(>95 \%)$ and STH (>97\%) than fish passing through the JBS (Weiland et al. 2013). It was assumed that a loose steel plate in the JBS channel was causing increased mortalities for fish passing through the JBS; however, no significant difference in survival for both $\mathrm{CH} 1$ and STH was noted before and after the repair of the steel plate in the JBS channel in 2010 . 


\subsection{Methods}

Study methods include information regarding environmental conditions during the study period; tagged fish release-recapture experimental design; tag-life evaluation; fish collection, tagging, and release procedures; tagged fish detection; acoustic signal processing; and the statistical approach to data analysis. The primary research tool was the JSATS (McMichael et al. 2010).

\subsection{Environmental Conditions}

Environmental conditions monitored in this study include water discharge (spillway and turbine), spill test (30\% and $40 \%$ spill out of total water discharge through JDA), temperature, forebay elevation, and tailrace elevation data.

\subsubsection{Water Discharge and Temperature}

Water discharge data by spill bay and turbine unit and elevation data for the forebay and tailrace were acquired by the CENWP in 5-min increments by an automated data-acquisition system at JDA. Weekly updates were provided by CENWP personnel. To provide historical context for 2011 observations of discharge and temperature, data were pooled by day and plotted with diel averages for the previous 10-yr period. Average water discharge and forebay water temperature data from 2001 through 2010 were downloaded from the UW's Data Access in Real Time website (DART; http://www.cbr.washington.edu/dart).

\subsubsection{Spill Treatments}

The effects of $30 \%$ and $40 \%$ spill discharge levels on fish survival and passage rates were independently evaluated using a uniform block study design (Figure 3.1). Spill testing started at the $40 \%$ discharge level and continued for $2 \mathrm{~d}$, alternating with $2 \mathrm{~d}$ of spill at the $30 \%$ level. This 2 -d pattern was scheduled throughout the spring spill test period starting on April 27 and concluding on May 29 with the release of the last reference fish. 


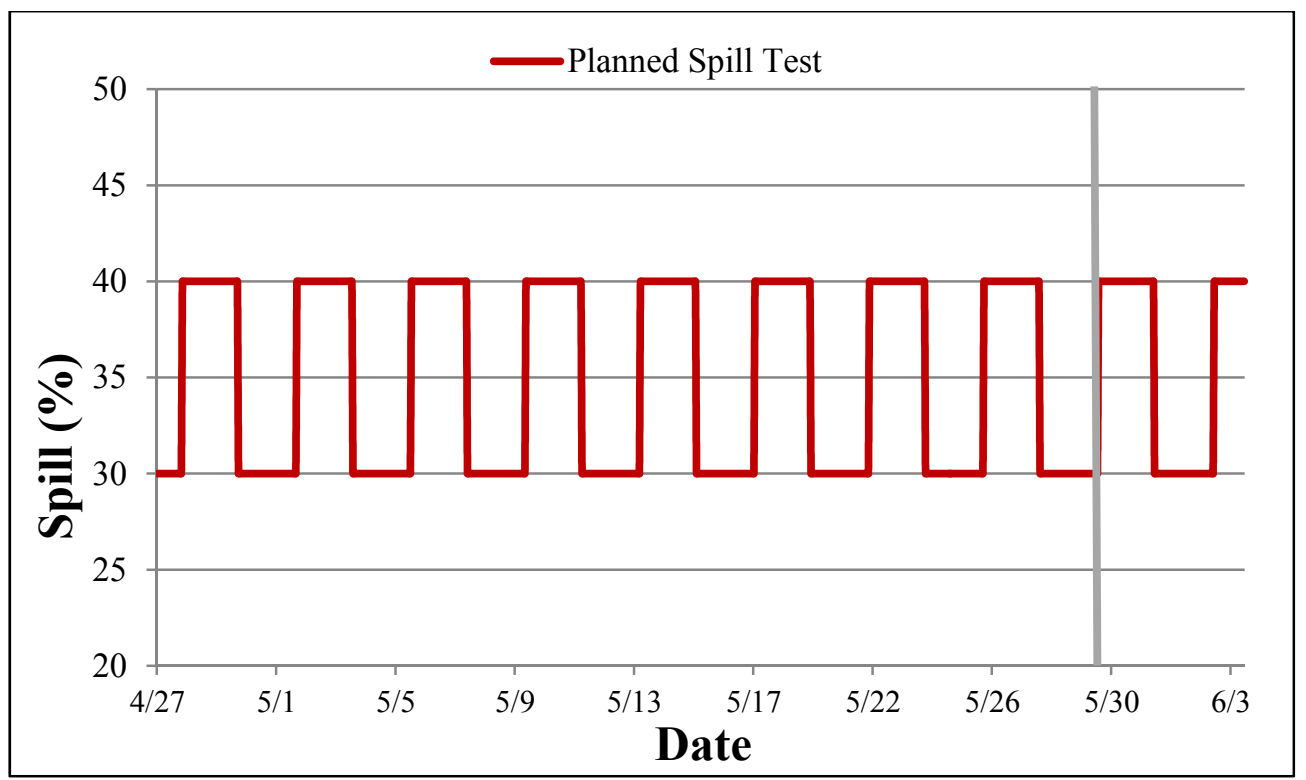

Figure 3.1. Spill test schedule at JDA from April 27 through May 29, 2011. The experimental design called for spill for $2 \mathrm{~d}$ at each spill discharge level until the end of the testing on May 29.

\subsection{Release-Recapture Design and Sample Sizes}

The release-recapture design used to estimate dam passage survival at JDA consisted of a virtual release $\left(V_{2}\right)$ of tagged fish at the face of the dam and a paired release $\left(R_{2}\right.$ and $\left.R_{3}\right)$ below the dam (Figure 3.2) (Skalski et al. 2009, 2010). Tagged fish released above JDA $\left(R_{1}\right)$ provided a source of fish known to have arrived alive at the face of the dam or forebay entrance array. Tagged fish were released far enough upstream, at rkm 390, so that they should arrive at the dam (rkm 349) in a nominal spatial pattern typical of run-of-river (ROR) fish. Virtual-release groups were then used to estimate survival through the dam and to the tailrace exit at rkm 346. To account and adjust for cumulative reach mortality, a paired release below JDA (i.e., $R_{2}$ and $R_{3}$ ) was used to estimate survival in that segment of reservoir below the dam. Dam passage survival was estimated as the quotient of the survival estimates for the virtual release to that of the paired release. The cumulative numbers of fish tagged with AMTs used in estimating survivals are summarized by release locale and species in Table 3.1.

The same release-recapture design was used to estimate forebay-to-tailrace survival, with the exception that the virtual-release group was composed only of fish known to have arrived at the forebay array $\left(V_{1} ; \mathrm{rkm} 351\right)$. The same below-dam paired release used to estimate dam passage survival was used to account and adjust for the extra release mortality below the dam. The cabled arrays at the face of the dam were analyzed as two independent arrays to allow estimation of detection probabilities. Subsequently, the arrays were combined to assign route of passage from the location of last detection. These passage route data were used to calculate SPE and FPE at JDA. The fish used in the virtual release at the face of the dam were used to estimate tailrace egress time. 


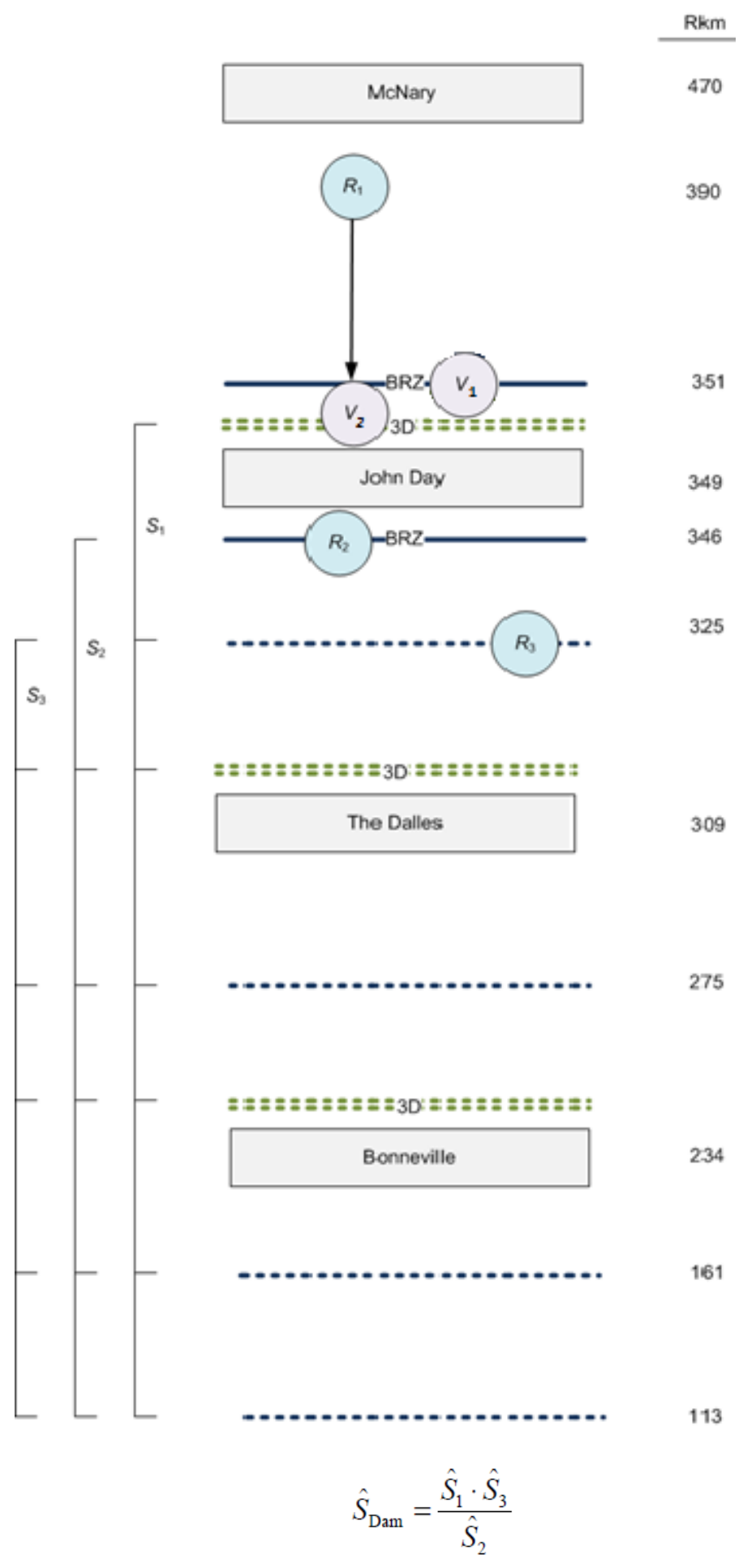

Figure 3.2. Schematic of the virtual/paired-release design used to estimate dam passage survival at John Day Dam. The virtual release for various dam passage metrics was composed of fish that arrived at the JDA face $\left(V_{2}\right)$ from the release at CR390. The below-dam release pair was composed of releases $R_{2}$ and $R_{3}$ with detection arrays used in the survival analysis denoted by dashed lines. A similar design was implemented for forebay-to-tailrace survival (boatrestricted-zone [BRZ]-to-BRZ) with upstream released fish regrouped at the forebay BRZ line $\left(V_{1}\right)$. 
Table 3.1. Numbers of fish tagged with acoustic micro-transmitters used in the spring 2011 survival study at John Day Dam.

\begin{tabular}{lrr}
\hline \multicolumn{1}{c}{ Release Location } & CH1 & STH \\
\hline Roosevelt, Washington $\left(R_{1}\right)$ & 2,510 & 2,587 \\
JDA forebay $\left(V_{1}\right)$ & 2,450 & 2,489 \\
JDA dam face $\left(V_{2}\right)$ & 2,441 & 2,469 \\
JDA tailrace $\left(R_{2}\right)$ & 1,193 & 1,196 \\
Celilo, Oregon $\left(R_{3}\right)$ & 799 & 797 \\
\hline
\end{tabular}

\subsection{Tag Specifications and Tag Life}

The AMTs used in the 2011 study (Figure 3.3) were manufactured by Advanced Telemetry Systems (ATS). Each tag, model number SS130, measured $12.02 \mathrm{~mm}$ long, $5.21 \mathrm{~mm}$ wide, $3.72 \mathrm{~mm}$ thick, and weighed $0.438 \mathrm{~g}$ in air. The tags had a nominal transmission rate of 1 pulse every $3 \mathrm{~s}$. Nominal tag life was expected to be about $25 \mathrm{~d}$. The PIT used in the study was the Biomark HPT12 that is $12.5 \mathrm{~mm}$ long.

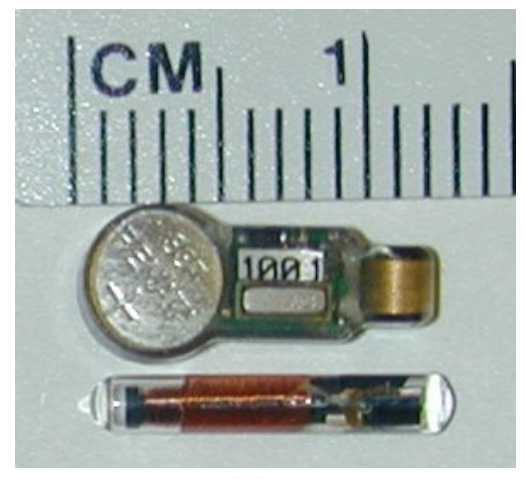

Figure 3.3. JSATS Model SS130 acoustic micro-transmitter (top) and Biomark HPT12 passive integrated transponder (bottom) that were surgically implanted in CH1 and STH at John Day Dam in spring 2011.

A total of 159 AMTs were randomly sampled from the tags used in the spring season for an assessment of tag life. The tags were activated, held in river water, and monitored continuously until they failed. All AMTs were enclosed in water-filled plastic bags and suspended from a rotating foam ring within a 2-m-diameter fiberglass tank. Two $90^{\circ} \times 180^{\circ}$ hydrophones were positioned $90^{\circ}$ apart in the bottom of the tank and angled upward at approximately $60^{\circ}$ to maximize coverage for detecting acoustic signals. Hydrophones were cabled to a quad-channel receiver that amplified all acoustic signals. All acoustic signals were saved, decoded, and processed. Post-processing software calculated the number of hourly decodes for each AMT, allowing tag failure times to be determined within $\pm 1 \mathrm{~h}$. The tag-failure times were fit to the four-parameter vitality model of Li and Anderson (2009), which takes into account 
both early onset random failures due to manufacturing and systematic battery failures. The probability density function for the vitality model can be rewritten as

$$
f(t)=1-\left(\Phi\left(\frac{1-r t}{\sqrt{u^{2}+s^{2} t}}\right)-e^{\left(\frac{2 u^{2} r^{2}}{s^{4}}+\frac{2 r}{s^{2}}\right)} \Phi\left(\frac{2 u^{2} r+r t+1}{\sqrt{u^{2}+s^{2} t}}\right)\right)^{e^{-k t}}
$$

where: $\Phi=$ cumulative normal distribution,

$r=$ average wear rate of components,

$S=$ standard deviation in wear rate,

$k=$ rate of accidental failure,

$u=$ standard deviation in quality of original components.

The random failure component, in addition to battery discharge, gives the vitality model additional latitude to fit tag-life data not found in other failure-time distributions such as the Weibull or Gompertz (Lady et al. 2012). Parameter estimation was based on maximum likelihood estimation. Tag-life adjustment for virtual-release group $\left(V_{1}\right)$ was based on fish known to have arrived at the forebay entrance array with active tags and the conditional probability of tag activation, given the tag was active at the detection array at rkm 351 (JDA forebay entrance array). The conditional probability of tag activation at time $t_{1}$, given it was active at time $t_{0}$, was computed by the quotient

$$
P\left(t_{1} \mid t_{0}\right)=\frac{S\left(t_{1}\right)}{S\left(t_{0}\right)}
$$

\subsection{Handling, Tagging, and Release Procedures}

Procedures for the handling, tagging, and releasing of fish to be used in this study followed USACE protocols set forth by Brown et al. 2010 and Axel et al. (2011). Fish obtained from the JDA JBS were surgically implanted with JSATS tags, held for 18 to $30 \mathrm{~h}$, and then transported to three different release locations on the Columbia River, as described in the following sections. A total of 4,502 $\mathrm{CH} 1$ and 4,580 STH were tagged and released for use in estimating survival and various passage metrics at JDA. Tagging and release data are presented in Appendix C.

\subsubsection{Fish Source and Collection Methods}

The $\mathrm{CH} 1$ and STH used in the study were obtained at the SMF at JDA. The SMF is situated on the Oregon shore at the downriver edge of the JBS where juvenile salmonids and other fishes diverted from turbine intakes are routed through a series of gates, chutes, flumes, and dewatering structures. Juvenile salmonids in the JBS can be diverted into the SMF as part of routine juvenile salmonid monitoring or directed into the tailrace through an outfall pipe located downstream of the facility. Pacific States Marine Fisheries Commission employees systematically diverted fish from the JBS into holding tanks and then to an examination trough in the SMF, as described by Martinson et al. (2010). Juvenile salmonids sampled in the SMF were examined, enumerated, and either selected for tagging as part of this study or released into the tailrace outfall. 
Juvenile salmonids were diverted from the JBS and routed into a 6,795-L holding tank in the SMF. About 150 to 200 juvenile salmonids and other fishes were crowded with a panel net into a 51.2- by 6.14-cm pre-anesthetic chamber. Water levels in the chamber were lowered to about $20.5 \mathrm{~cm}$ at which point fish were anesthetized with $60 \mathrm{ml}$ of a stock tricaine methanesulfonate (MS-222) solution prepared at a concentration of $50 \mathrm{~g} / \mathrm{L}$. Once anesthetized, fish were routed into the examination trough for identification and enumeration. Technicians added MS-222 as needed to maintain sedation and 5 to $10 \mathrm{ml}$ of PolyAqua ${ }^{\mathrm{TM}}$ to limit handling damage and reduce fish stress. Water temperatures were monitored in the main holding tank and examination trough to assure temperatures in the trough were maintained within $2^{\circ} \mathrm{C}$ of the main holding tank.

Once fish were in the examination trough, juvenile salmonids targeted for surgical procedures were evaluated in accordance with the following criteria:

- Qualifying (Acceptable) Conditions

- Fork length 95-299 mm

- Elastomer or coded wire tag(s) present or absent

- Adipose fin intact or clipped

- Nutritional cataracts

- Healed (moderate) injuries (e.g., bird strikes)

- Minor fin hematomas and hemorrhages

- Partial descaling $(<20 \%)$ on any one side

- Fin damage (e.g., tattering and erosion)

- $\quad<5 \%$ fungus on any one side.

- Disqualifying Conditions

- $\quad \geq 20 \%$ descaling on any one side

- $\quad>5 \%$ fungus on any one side or any fungus on gills

- Significant physical injuries

- Open lacerations or lesions

○ Opercular damage ( $>75 \%$ missing or folded over)

- Severe hemorrhages or any eye hemorrhages

- Exophthalmia (popeye)

- Inhibitory malformations (e.g., skeletal deformities)

- Parasites (found on gills or eyes)

- Moribund from existing disease (e.g., bacterial kidney disease, gas bubble trauma) or emaciated

- Fish that are too small ( $<95$-mm fork length) or to large ( $\geq 300$-mm fork length)

- Previously tagged (PIT, radio, acoustic). 
Juvenile salmonids that were representative of fish within the river were tagged, so the collection process was adaptive. If a specific malady/physical anomaly was observed in more than $5 \%$ of the sample on a specific day, the next day's fish with similar conditions were accepted in the collection.

\subsubsection{Tagging Procedure}

The surgical team followed the latest guidelines for surgical implantation of AMTs in juvenile salmonids (Brown et al. 2010; Axel et al. 2011). Numerous measures were taken to minimize the impacts of collection, handling, and surgical procedures on study fish. The majority of juvenile salmonids used for tagging were a portion of Smolt Monitoring Program (SMP) routine fish collection; for the most part, additional fish were not needed to meet daily tagging quotas.

The tagging process required a team of 11 or more people to conduct daily operations. Individuals were assigned to specific tasks within the tagging process which included anesthetizing fish, delivering fish to and from the various stations, assigning tagging information, recording data, taking photographs with a high-resolution digital camera, implanting tags (four surgeons), ensuring post-surgical transport buckets contain the correct fish, and moving tagged fish in transport buckets to post-surgery holding tanks.

Fish were netted in small groups from 302.8-L holding tanks and placed in a 24.6-L bucket containing an 80-mg/L concentration of MS-222 anesthetic and river water. Once a fish lost equilibrium, it was transferred to a data collection/processing table in a small container of river water and anesthetic. Species type, surgeon, release location, adipose fin (intact or clipped), fork length $( \pm 1 \mathrm{~mm})$, and fish condition comments (e.g., $<20 \%$ descaling) for each fish were recorded on a GTCO CalComp Drawing Board ${ }^{\circledR} \mathrm{VI}^{\mathrm{TM}}$ digitizer board. Fish were weighed $( \pm 0.1 \mathrm{~g})$ using a $2000 \mathrm{~g}$ Ohaus ${ }^{\circledR}$ Scout Pro scale and returned to the small transfer container along with assigned PITs and AMTs. PIT Tag Information System (PTAGIS) P3 software transferred all the information collected for a given fish automatically to the tagging database, thereby minimizing human error. The container, fish, and tags were then transferred to the photography table where photographs of each side of the fish were taken for documentation prior to being conveyed to the assigned surgeon for tag implantation.

During surgery (Figure 3.4), each fish was placed ventral side up and a gravity-fed "maintenance" anesthesia (40 mg/L) and fresh river water supply line was placed into its mouth. Using a surgical or stab blade, a 5- to 7-mm incision was made along the linea alba 3 to $5 \mathrm{~mm}$ anterior to the pelvic girdle. A PIT was inserted followed by an AMT with the acoustic element pointing toward the posterior. Both tags were inserted at an angle toward the anterior end of the fish to minimize internal damage. The incision was closed with two interrupted stitches using Ethicon 5-0 Monocryl sutures with a taper point needle. After closing the incision, fish were placed in a dark 24.6-L transport bucket filled with aerated river water and monitored until equilibrium was regained.

An established protocol was used to help minimize negative impacts that may occur as a result of surgical procedures and handling. PolyAqua ${ }^{\circledR}$ was used to protect damaged areas of the fish's mucus membrane, reduce the possibility of infection, and aid in healing. Water in anesthesia and recovery buckets was refreshed repeatedly to maintain temperatures within $2{ }^{\circ} \mathrm{C}$ of river water temperatures, and sodium bicarbonate was added to anesthesia buckets to act as a $\mathrm{pH}$ buffer. Six complete sets of instruments were used by each surgeon on a rotational basis during each day's tagging. After use, each set was soaked in a 70\% ethanol solution for approximately $10 \mathrm{~min}$ before being transferred to a distilled 
water bath for $10 \mathrm{~min}$ to remove residual ethanol and any remaining contaminants. Each evening, all surgical instruments were sterilized in an autoclave.

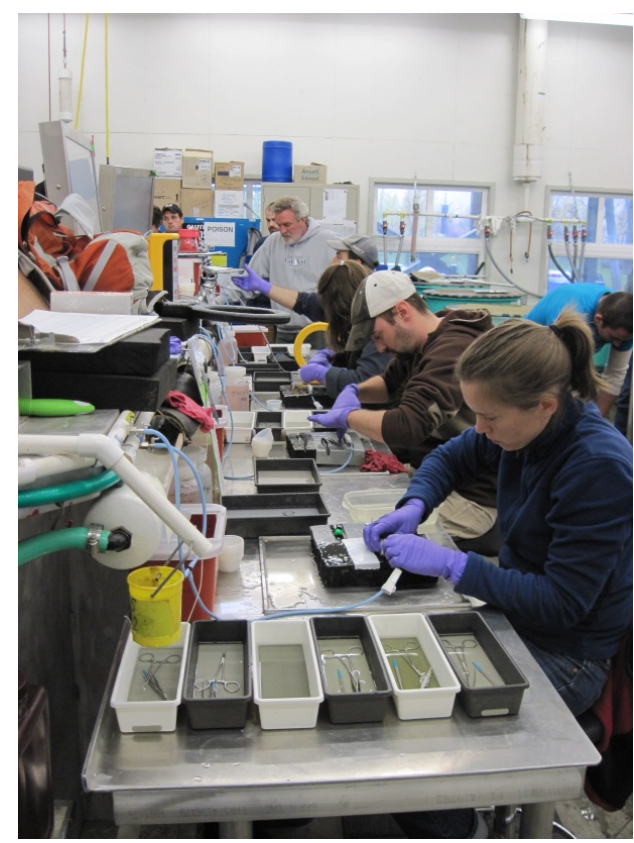

Figure 3.4. Surgical setup and process.

\subsubsection{Recovery and Holding}

After surgery, a maximum of five tagged fish were placed in 24.6-L aerated transport buckets and closely monitored until fish had reestablished equilibrium. Each bucket held one to five fish depending on the number to be released at each release site. The buckets were then transferred to an outdoor postsurgery holding tank continuously supplied with fresh river water (Figure 3.5). Dissolved oxygen and water temperature were closely monitored in the insulated holding tanks to ensure they were within acceptable limits. Fish were held for 18 to $30 \mathrm{~h}$ in the holding tanks prior to being transported for release into the river.

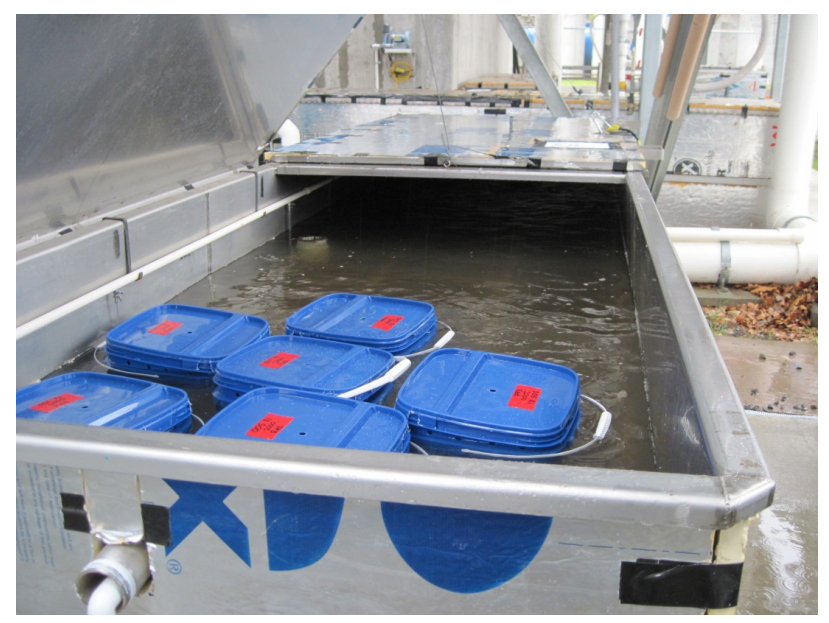

Figure 3.5. Post-surgery holding tank with tagged fish in recovery buckets. 


\subsubsection{Fish Transportation and Release}

Buckets with tagged fish were transported from JDA to the release locations using a $3 / 4$-ton truck outfitted with one 681-L Bonar insulated tote and one 265-L Bonar insulated tote. The Bonar totes were filled with fresh river water prior to buckets from the post-surgery holding tanks being placed in them. A YSI meter was used to monitor the dissolved oxygen and temperature of water in the totes to ensure they stayed within $80 \%-110 \%$ saturation and within $2{ }^{\circ} \mathrm{C}$ of the ambient river temperature, respectively, during transit. If dissolved oxygen or temperature were outside acceptable limits during transport, a network of valves and plastic tubing could deliver oxygen to the totes from a 2,200-psi oxygen tank and ice could be added to reduce water temperatures.

Upon arrival at the release site, the buckets containing tagged fish were transferred to a boat for transport to the in-river release locations. Generally, equal numbers of fish were released at each of the five equidistant locations along the river cross section throughout the spring season. During spring, releases occurred from April 26 to May 29, 2011 (37 consecutive days). Releases alternated between day and night, every other day, over the course of the study. The timing of the releases was staggered to help facilitate downstream mixing (Table 3.2).

Prior to fish release in the river, the buckets were opened and examined for dead fish. If found, dead fish were scanned with a BioMark portable transceiver PIT scanner to identify the implanted PIT code so that the associated acoustic tag code could be identified later from tagging data and removed from the list of released fish.

Table 3.2. Release time of fish tagged with JSATS acoustic micro-transmitters released at three sites in spring 2011.

\begin{tabular}{ccc}
\hline & \multicolumn{2}{c}{ Release Time } \\
\cline { 2 - 3 } Release Location & Daytime Start & Nighttime Start \\
\hline$R_{1}(\mathrm{rkm} 390)$ & Day 1: $2000 \mathrm{~h}$ & Day 2: 0800 h \\
$R_{2}(\mathrm{rkm} \mathrm{346)}$ & Day 3: $1100 \mathrm{~h}$ & Day 3: $2300 \mathrm{~h}$ \\
$R_{3}(\mathrm{rkm} \mathrm{325)}$ & Day 3: $2000 \mathrm{~h}$ & Day 4: $0800 \mathrm{~h}$ \\
\hline
\end{tabular}

\subsection{Detection of Tagged Fish}

Two types of JSATS receivers, cabled and autonomous, were deployed to detect fish bearing JSATS AMTs as they moved downstream through the study reach between Roosevelt, Washington, at rkm 390, and Bonneville Dam (BON) at rkm 234 (Table 3.3). Cabled arrays were deployed at the dams and autonomous node arrays were deployed in the open river. The JDA forebay array (rkm 351) was used to create virtual release groups of fish known to have survived since release into the river and to have entered the forebay $2 \mathrm{~km}$ upstream of JDA. These forebay virtual release groups were used to estimate forebay-to-tailrace survival (BRZ-to-BRZ) and forebay residence time. The dam-face array at JDA (rkm 349) was used to create virtual-release groups of fish known to have arrived alive at the dam face. These release groups were used to estimate dam passage and route-specific survival rates based on threedimensional (3D) tracking combined with observations of the location of last-detection of tagged fish prior to dam passage. Time of last detection on the dam-face array minus the time of first detection on 
the forebay entrance array at JDA was used to estimate forebay residence time. The time of last detection by the JDA tailwater egress array minus the time of last detection on the dam-face array provided an estimate of egress time. The time of last detection on the tailwater egress array minus the time of first detection on the forebay entrance array was used to estimate total project passage times. The Celilo, Oregon, autonomous node array (CR325) was the primary array for estimating the survival rates for tagged juvenile salmonids passing through JDA. The Dalles Dam (TDA) dam-face array (CR309) was used as the secondary array for estimating survival rates at JDA. The Hood River, Oregon array (CR275) was used as the tertiary array for estimating survival of juvenile salmonids passing through JDA. Detections on arrays downstream of the Hood River array were also used in the survival calculations (Table 3.3).

Table 3.3. Description, location, name, and survival model function of arrays deployed in 2011.

\begin{tabular}{|c|c|c|c|}
\hline Array Description & Location & Array Name & Array Function \\
\hline JDA Forebay & $2 \mathrm{~km}$ upstream of JDA & CR351 & $\begin{array}{l}\text { Virtual-release array; forebay residence } \\
\text { and project passage time; forebay-to- } \\
\text { tailrace survival estimates }\left(V_{1}\right)\end{array}$ \\
\hline JDA Dam Face & JDA & CR349 & $\begin{array}{l}\text { Regroup fish for route-specific virtual } \\
\text { releases; dam passage survival estimate } \\
\left(V_{2}\right) \text {; tailrace egress and forebay residence } \\
\text { times }\end{array}$ \\
\hline JDA Tailrace Egress & JDA tailrace & CR346 & $\begin{array}{l}\text { Paired fish release site; tailrace egress } \\
\text { and project passage time estimates }\end{array}$ \\
\hline JDA Tailwater & Celilo, OR & CR325 & $\begin{array}{l}\text { Primary survival array for virtual releases } \\
\text { of fish at JDA (forebay entrance or dam } \\
\text { face), paired fish release site }\end{array}$ \\
\hline TDA Dam Face & TDA & CR309 & $\begin{array}{l}\text { Secondary survival array for JDA virtual } \\
\text { releases }\end{array}$ \\
\hline Hood River & Hood River & CR275 & $\begin{array}{l}\text { Tertiary survival array for JDA virtual } \\
\text { releases }\end{array}$ \\
\hline BON Dam Face & BON & CR234 & Joint probability of survival and detection \\
\hline Knapp & Knapp, WA & CR161 & Joint probability of survival and detection \\
\hline Kalama & Kalama, WA & CR113 & Joint probability of survival and detection \\
\hline Oak Point & Oak Point, WA & CR86 & Joint probability of survival and detection \\
\hline
\end{tabular}

\subsubsection{Cabled Dam-Face Arrays}

The cabled dam-face receivers were designed by PNNL for the CENWP using an off-the-shelf userbuild system design. Each cabled receiver system includes a computer, data-acquisition software, digital signal-processing cards with field-programmable logic gate array (DSP+FPGA), global positioning system card, a four-channel signal-conditioning receiver with gain control, hydrophones, and cables (Figure 3.6).

A modular, time-synchronized JSATS cabled array was deployed along the upstream face of JDA to detect JSATS-tagged juvenile salmonids approaching the dam. The dam-face cabled array consisted of 23 cabled receivers each supporting up to four hydrophones. The receivers were housed in trailers on the 
forebay deck. The four possible hydrophones per cabled receiver were deployed on trolleys in pipes attached to the main piers at the powerhouse and spillway (Figure 3.7) in a known fixed geometry. Trolley pipes at the powerhouse were 4 in. in diameter and made of powder-coated schedule 40 , 4-in.-internal-diameter steel pipes that were slotted down one side for deployment of the trolley. A cone was attached to the top of the pipe to assist with trolley insertion. Pipes at the powerhouse were $120 \mathrm{ft}$ long and extended from deck level at elevation $281 \mathrm{ft}$ above mean sea level (MSL) down to a mid-intake depth at elevation $164 \mathrm{ft}$ above MSL. One hydrophone on each pier was deployed at a shallow elevation ( $\sim 251 \mathrm{ft}$ above MSL) and another was deployed at a deep elevation ( $\sim 165 \mathrm{ft}$ above MSL) to provide acceptable geometries for tracking AMT-tagged fish in three dimensions and then assigning it a route of passage through the dam (Figure 3.8).

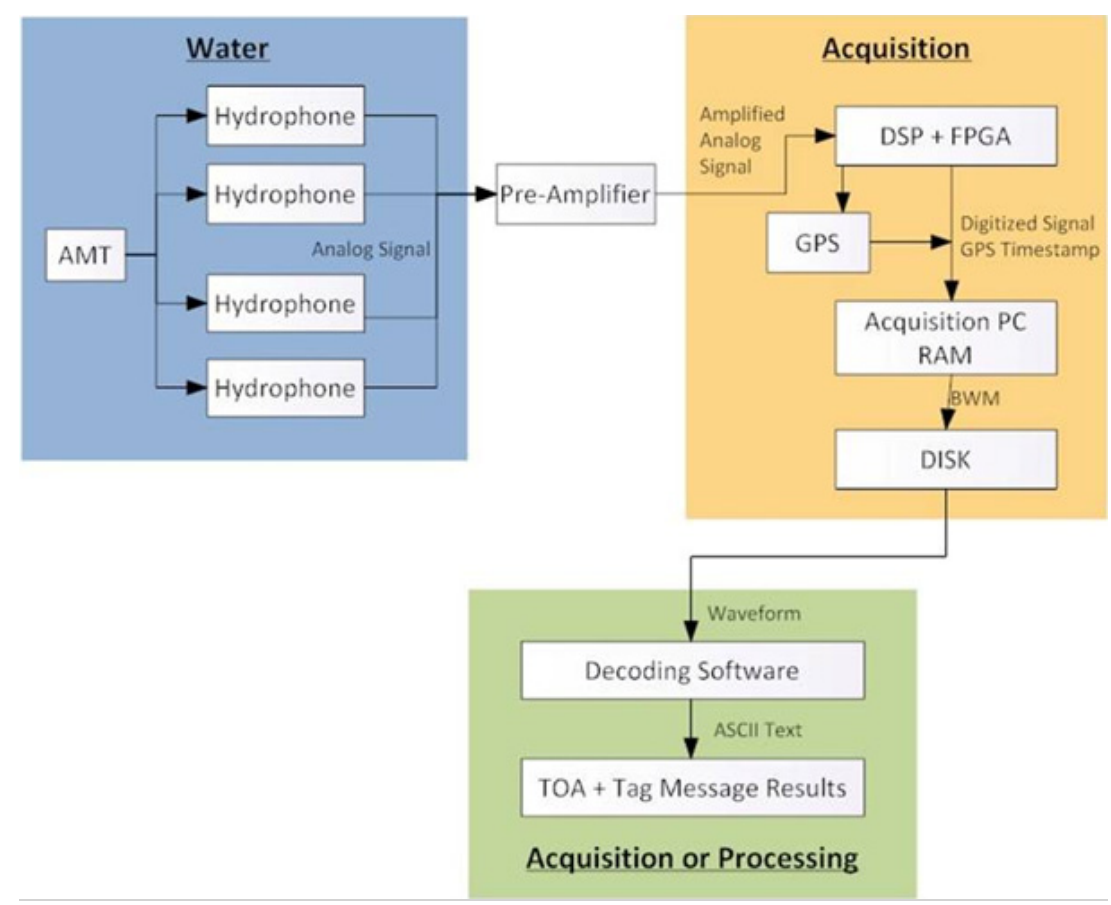

Figure 3.6. Schematic of dam-face modular receiver system showing the main components and direction of signal acquisition and processing. AMT = acoustic micro-transmitter implanted in fish; $\mathrm{DSP}=$ digital signal processing card; FPGA = field programmable logic gate array; GPS = global positioning system; $\mathrm{PC}=$ personal computer; $\mathrm{RAM}=$ random access memory; $\mathrm{BWM}=$ binary waveform; TOA $=$ time of arrival. 


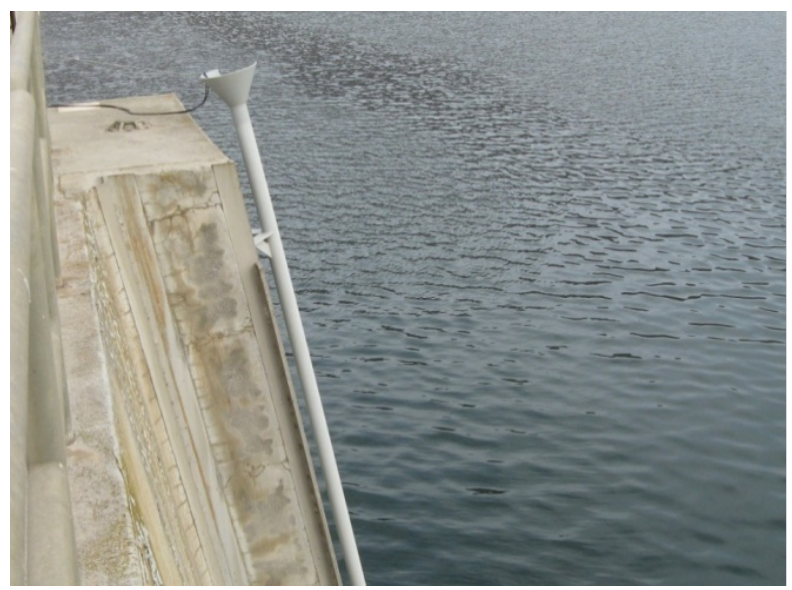

Figure 3.7. Trolley pipe mounted on a main pier of the John Day Dam powerhouse showing a cone used as a guide for trolley insertion.

- Dam Mounted Hydrophone

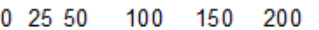
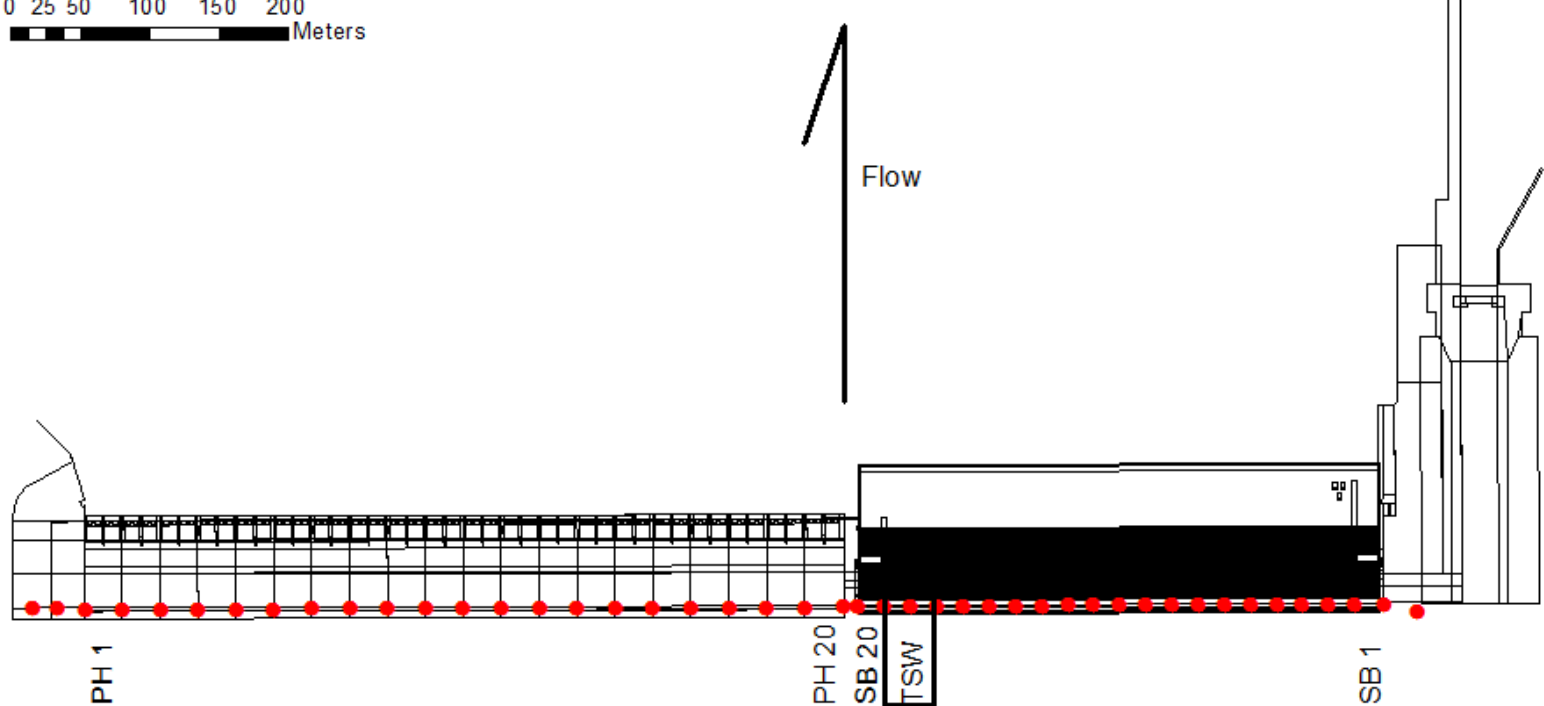

Figure 3.8. Location of hydrophones on the dam face of JDA in spring 2011.

At the spillway, hydrophones were mounted on trolleys that were deployed in 40-ft-long 8-in.-diameter slotted pipes installed previously for radio-telemetry studies. At each spillway pier, one hydrophone was deployed at a shallow elevation ( $256 \mathrm{ft}$ above MSL) and the other at a deep elevation ( $\sim 229 \mathrm{ft}$ above MSL). Each steel trolley slid down inside the pipe and was guided by an extension arm that protruded from the slot. The arm positioned the anechoic baffled hydrophone perpendicular to the face of the dam (Figure 3.9). 


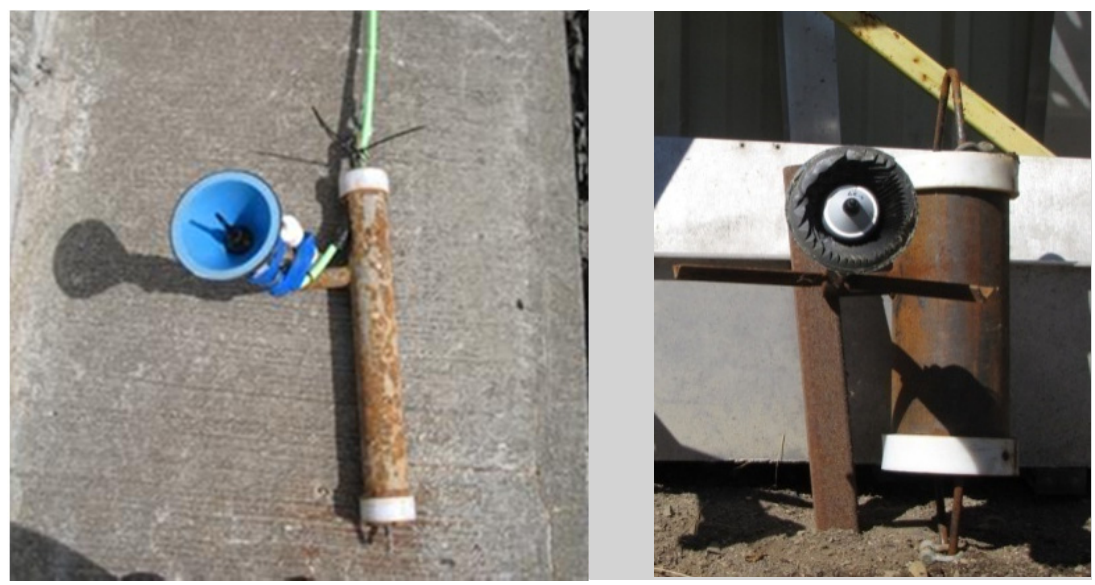

Figure 3.9. Trolleys used to deploy hydrophones at the John Day powerhouse and spillway, 2011. A 4-in.-diameter trolley with hydrophone (left) for slotted pipes on powerhouse piers and an 8-in.-diameter trolley with hydrophone (right) for slotted pipes on spillway piers. Each trolley had a steel arm to support a hydrophone that was surrounded by a plastic cone lined with anechoic material to prevent sound reception from a downstream direction.

\subsubsection{Three-Dimensional Tracking}

The cabled dam-face array deployed at JDA allowed fish behavior and route of passage through the dam to be assessed via 3D tracking of JSATS-tagged fish. Assigning spatial locations using acoustic tracking is a common technique in bioacoustics based on time-of-arrival differences (TOADs) among different hydrophones. Usually, the process requires a three-hydrophone array for two-dimensional tracking and a four-hydrophone array for 3D tracking. For this study, only 3D tracking was performed. The detailed 3D tracking system is described by Deng at al. (2011).

\subsubsection{Autonomous Receiver Arrays}

The autonomous AT receiver, hereafter referred to as an autonomous node or simply node, was designed and developed by Sonic Concepts and PNNL for the USACE to detect JSATS AMTs in a riverine environment. Each node is an independent, self-contained data-acquisition instrument that consists of a node top that houses the hydrophone, a pair of processing circuit boards, a compact flash card for data storage, and battery and serial cable connectors (Figure 3.10). The node top threads into another sealed section of polyvinyl chloride pipe that houses an internal battery pack and traps air to provide buoyancy. The outside of the bottom housing supports an external beacon tag and stabilizing fin to help keep the detecting hydrophone tip upright in the water column. A computer installed with custom software may be directly connected to a node for configuring and assessing its operation, in addition to viewing data collection in real time. All autonomous node tops were tested for acceptable detection performance in a specialized anechoic testing tank prior to deployment (Deng et al. 2010). 

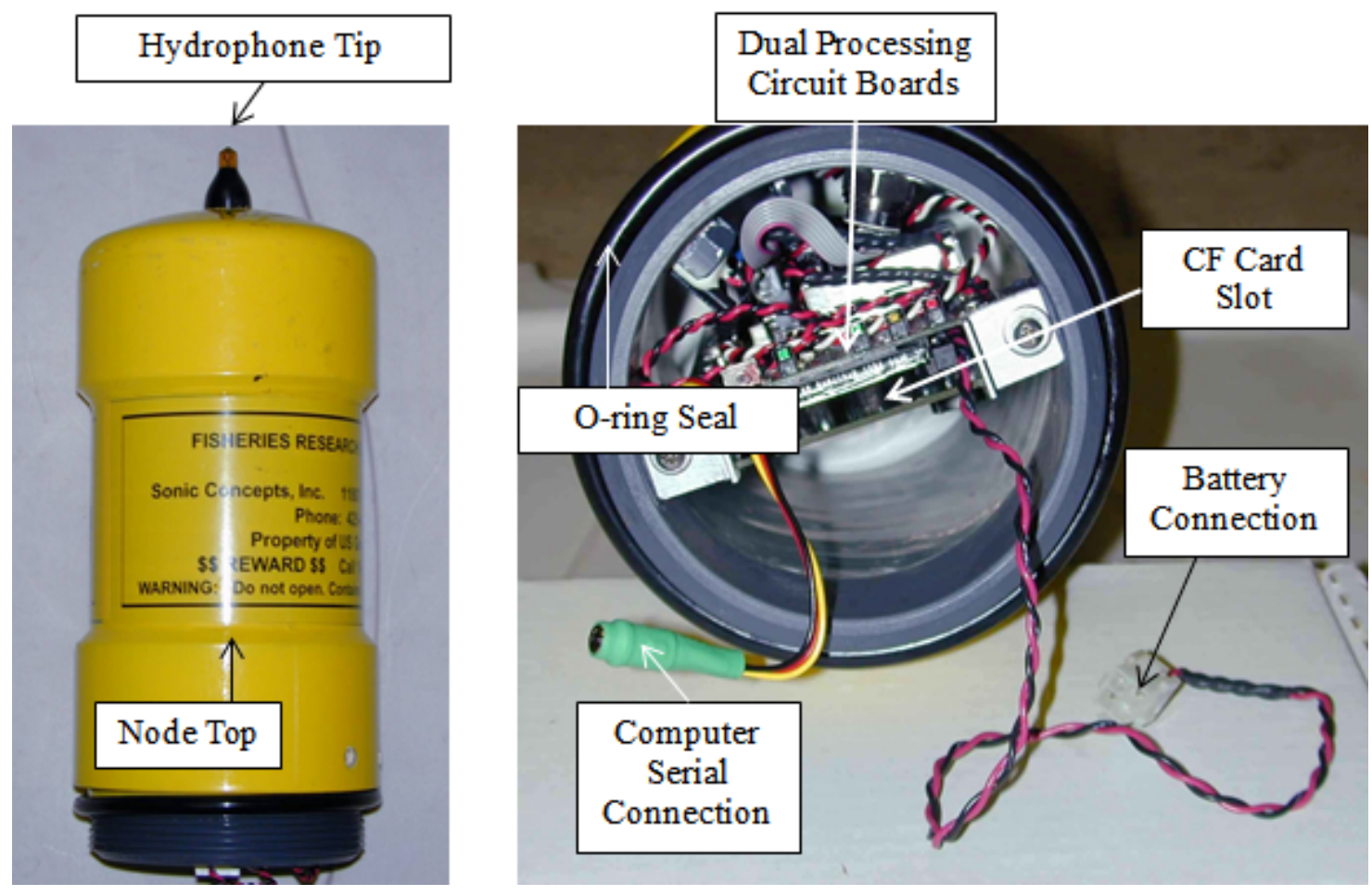

Figure 3.10. Outer (left image) and internal (right) views of an autonomous node top.

Autonomous nodes were deployed in arrays located at specific sites for the lower Columbia River study. An autonomous node array is defined as a line of autonomous nodes anchored on the riverbed, across the entire width of a river cross section, perpendicular to the river flow. Each array acts as a "passage gate" and detects passing fish that had JSATS tags surgically implanted. Autonomous nodes in most of the arrays were deployed within $150 \mathrm{~m}$ of each adjacent node and less than about $75 \mathrm{~m}$ from shore.

Four separate autonomous node arrays were deployed for the JDA 2011 survival study (Figure 3.11). Each array was named by concatenating CR (for Columbia River) with the nearest whole rkm upstream from the mouth of the river. The first and farthest upriver node array was in the JDA forebay near rkm 351 and was named CR351. The JDA tailrace egress array (CR346), which was also the second fish release site $\left(R_{2}\right)$, was located at rkm 346 about $3 \mathrm{~km}$ downstream of the downstream deck of the JDA powerhouse. A third array (CR325) was located at the third release site ( $R_{3}$ at rkm 325), between Celilo Village, Oregon, and Wishram, Washington. A fourth array (CR275) was located approximately $2.1 \mathrm{~km}$ upriver of the Hood River Bridge.

Autonomous nodes were deployed with the configuration shown in Figure 3.12. Nodes were attached to a $1.5-\mathrm{m}$ section of rope with three $2.7-\mathrm{kg}$ buoyancy floats, using a compression strap around the node's housing at its balance point. An acoustic release device (Inter-Ocean Model 111 or Teledyne Benthos Model 875-T) was attached to the lower end of the $1.5-\mathrm{m}$ line. Lengths of wire rope measuring $0.3,1.0$, or $2.0 \mathrm{~m}$, depending on water depth, were connected to the mechanism of the acoustic release and then to a 34-kg steel anchor. The shorter $0.3-\mathrm{m}$ lengths of wire rope were used in water less than about $7.0 \mathrm{~m}$ deep; the 1.0-m lengths were used in water less than $20.0 \mathrm{~m}$ deep; $2.0-\mathrm{m}$ lengths were used in deeper locations. 

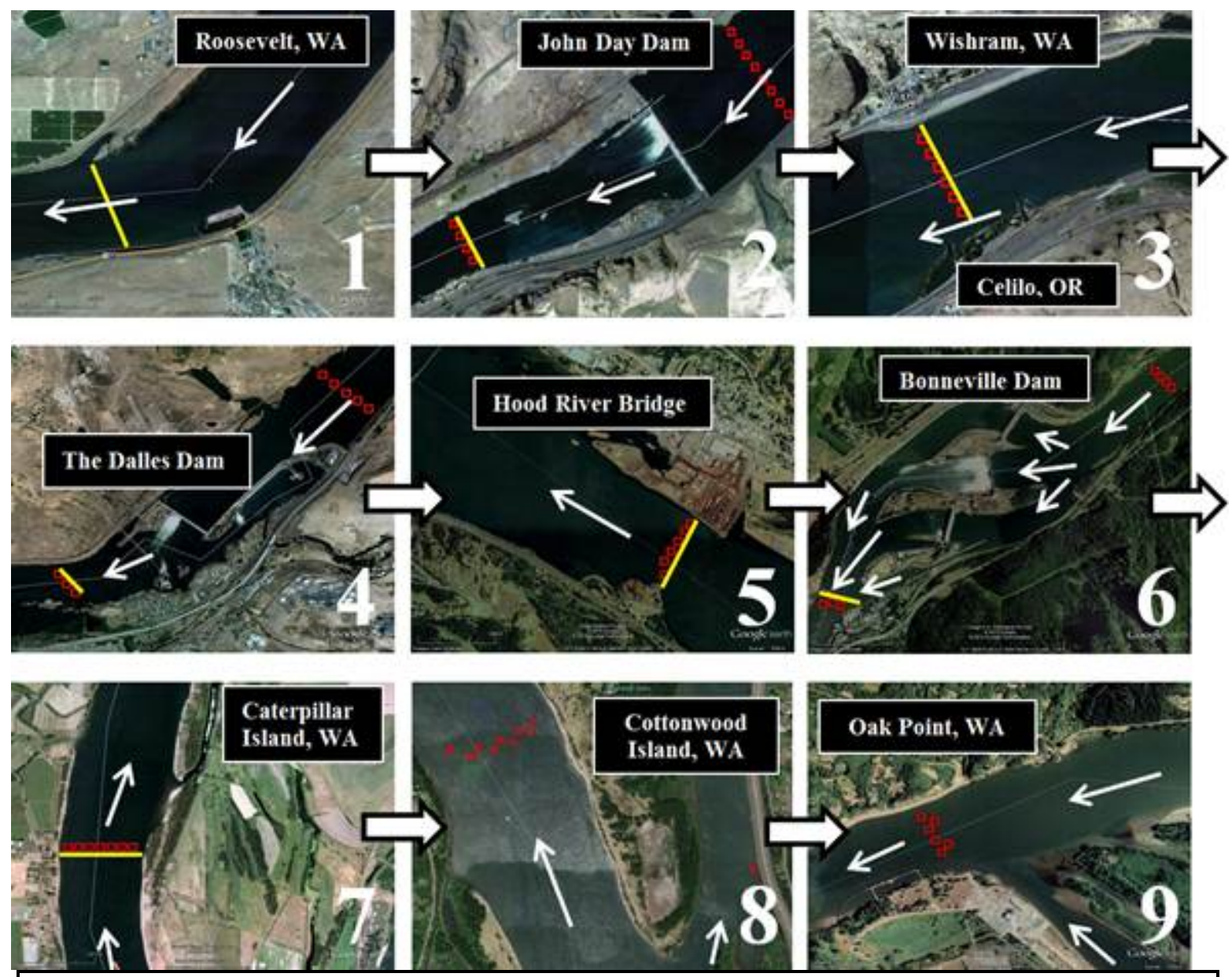

Image 1: Fish release location $R_{1}$, near Roosevelt, Washington (CR390). Image 2: John Day Forebay Array (right; $\left.V_{1}, \mathrm{CR} 351\right)$, Dam-Face Array (middle; $V_{2}, \mathrm{CR} 349$ ), and Tailrace Array (left; $R_{2}$, CR346). Image 3: JDA Tailwater Array (CR325) with fish release location $R_{3}$, and autonomous node array near Celilo, Oregon (CR325). Image 4: The Dalles Dam-face array (CR309). Image 5: Hood River autonomous node array (CR275). Image 6: Bonneville DamFace Array (CR234). Image 7: Caterpillar Island autonomous node array (CR161). Image 8: Cottonwood Island autonomous node array (CR113). Image 9: Oak Point autonomous node array (CR86). Array names are presented in parentheses, and the three-digit number at the end of each name is the river kilometer distance, upstream from the mouth of the Columbia River.

Figure 3.11. Location of the three fish release transects (yellow lines), dam-face cabled arrays (red lines), and four autonomous node arrays (red squares) deployed to detect fish tagged with acoustic micro-transmitters migrating downstream. Black bordered arrows, between Google Earth images, indicate the order of images from upstream to downstream, and the direction of water flow within each image is indicated by white arrows.

Autonomous nodes were recovered, serviced, and redeployed individually by boat, once every 2 wk. Batteries were changed out once every $4 \mathrm{wk}$. Node recovery began with communicating with the attached acoustic release by sending a release-specific acoustic code into the river through a transducer connected to a mobile command module. Upon successful receipt of this coded signal, the release's latch mechanism opened, freeing the node and acoustic release device to rise to the water surface for retrieval. Each node servicing included recording the node's internal clock time drift for the deployment period, downloading collected data, syncing the node clock back to the correct satellite time, and confirming each node's proper functionality before redeployment. Data files were also checked to verify that data were 
collected during the entire deployment, records were continuous, and records included time stamps and beacon tag detections. If any operational issues or data corruption were noticed, the node top was replaced and the suspect node top was assessed using a set of performance standards before being sent to Sonic Concepts for repair.

For the 2011 survival studies, all autonomous node arrays were deployed and collecting data by April 25, and serviced through the end of June, to ensure data acquisition for the entire period that implanted AMTs would still be transmitting.

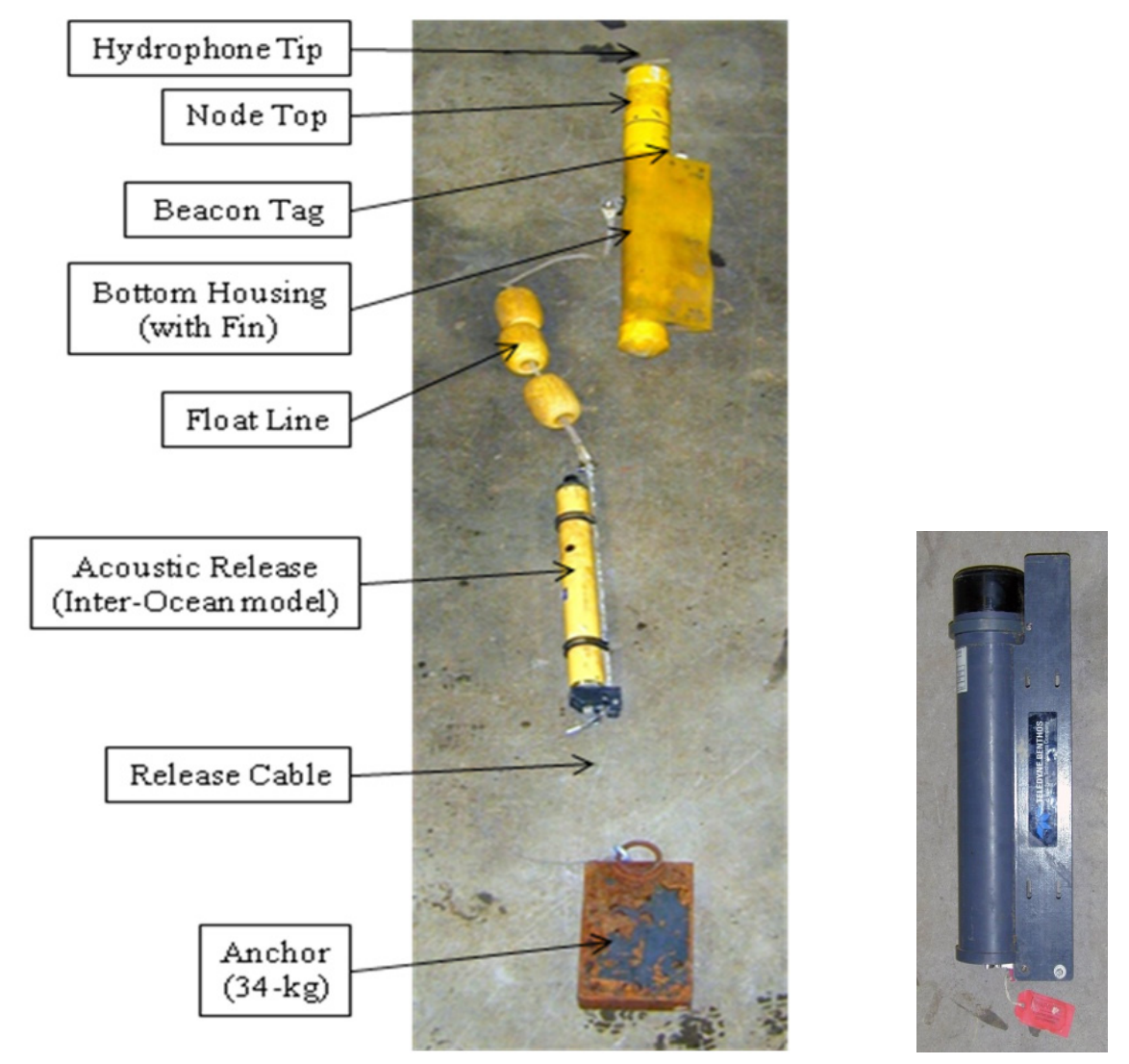

Figure 3.12. Autonomous node deployment rigging (left) and teledyne acoustic release (right).

\subsection{Acoustic Signal Processing}

Acoustic signal processing included decoding binary waveform data files, filtering the decoded signals, and tracking fish movements using the decoded data.

\subsubsection{Signal Decoding}

Data collected by the JSATS-cabled hydrophones were encoded candidate messages saved in binary time-domain waveform files (Figure 3.13). Binary waveform files were processed by a decoding utility (JSATS Decoder developed by the CENWP and PNNL) that identifies valid tag signals and computes the tag code and time of arrival using binary phase-shift keying. Binary phase-shift keying is a digitalmodulation technique that transmits messages by altering the phase of the carrier wave (Weiland 
et al. 2011b). Several filtering algorithms were then applied to the raw results from the decoding utilities to exclude spurious data and false positives.

JSATS tag-code transmissions received on cabled and autonomous hydrophones were recorded in raw data files and processed using standardized methods by two independent groups of PNNL staff located at North Bonneville and Richland, Washington.
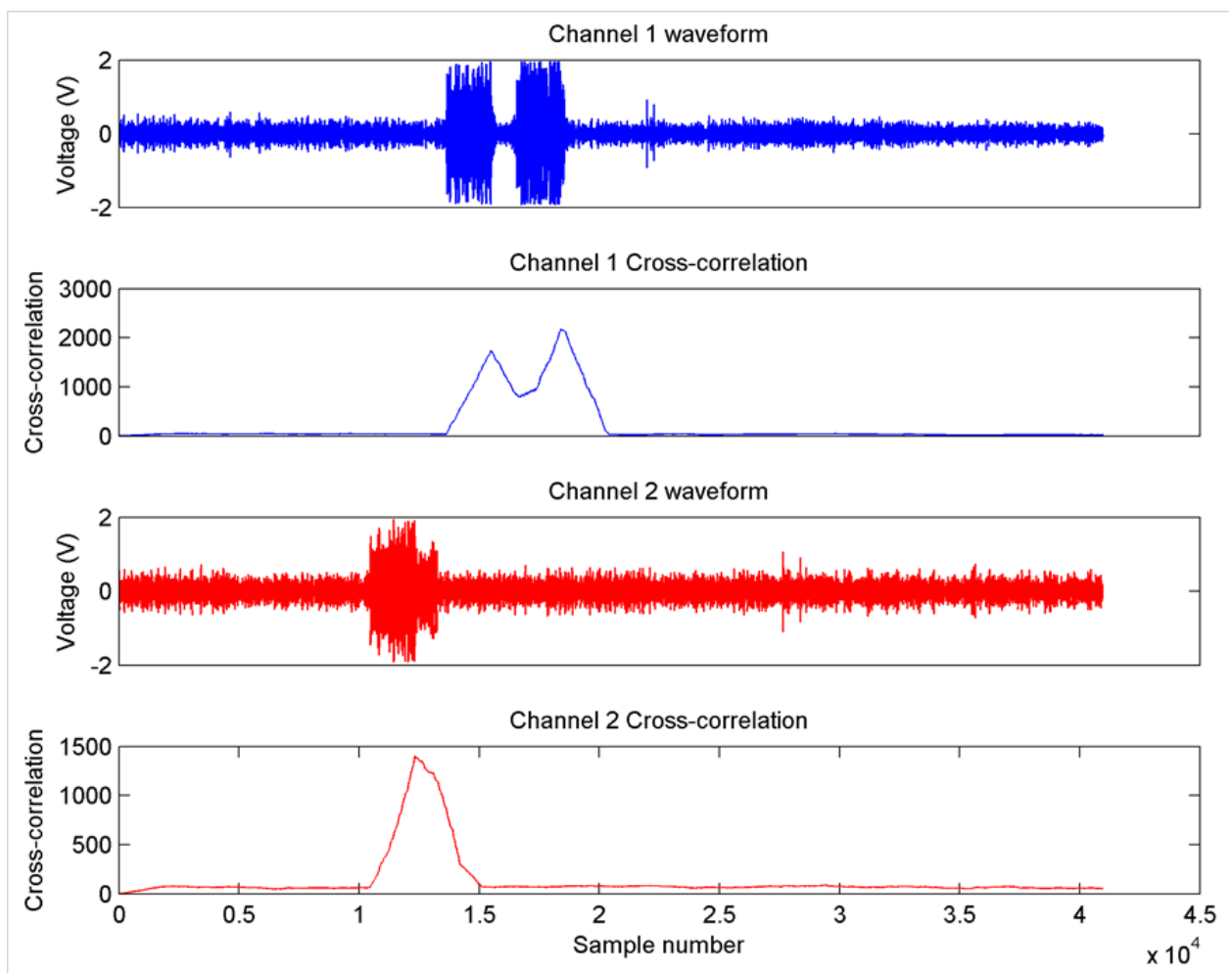

Figure 3.13. Example of time-domain waveforms and corresponding cross-correlations acquired at the John Day Dam spillway. The message portion was 1,860 samples (744 $\mu$ s long). Note that multipath components were present in both channels. Decodes from the multipath components were filtered out in post-processing.

\subsubsection{Filtering Decoded Data}

Receptions of tag codes within raw data files were processed to produce a data set of accepted tagdetection events. For cabled arrays, detections from all hydrophones at a dam were combined for processing. The following three filters were used for cabled array data:

- Multipath filter: For data from each individual cabled hydrophone, all tag-code receptions that occur within $0.156 \mathrm{~s}$ after an initial identical tag code reception were deleted under the assumption that closely lagging signals are multipath. Initial code receptions were retained. The delay of $0.156 \mathrm{~s}$ was the maximum acceptance window width for evaluating a pulse repetition interval (PRI) and was computed as 2(PRI_Window+12×PRI_Increment). Both PRI_Window and PRI_Increment were set at $0.006 \mathrm{~s}$, which was chosen to be slightly larger than the potential rounding error in estimating PRI to two decimal places. 
- Multi-detection filter: Receptions were retained only if the same tag code was received at another hydrophone in the same array within $0.3 \mathrm{~s}$ because receptions on separate hydrophones within $0.3 \mathrm{~s}$ (about $450 \mathrm{~m}$ of range) were likely from a single tag transmission.

- PRI filter: Only those series of tag-code receptions (or "messages") consistent with the pattern of transmissions from a properly functioning JSATS AMT were retained. Filtering rules were evaluated for each tag code individually, with the assumption that only a single tag would be transmitting that code at any given time. For the cabled system, the PRI filter operated on a message, which included all receptions of the same transmission on multiple hydrophones within $0.3 \mathrm{~s}$. Message time was defined as the earliest reception time across all hydrophones for that message. Detection required that at least six messages were received with an appropriate time interval between the leading edges of successive messages.

Like cabled-array data, receptions of JSATS tag codes within raw autonomous node data files are processed to produce a data set of accepted tag detection events. One single file is processed at a time, and no information about receptions at other nodes is used. The following two filters are used during processing of autonomous node data:

- Multipath filter: Same as for the cabled-array data.

- PRI filter: Only the series of receptions of a tag code (or "hits") that were consistent with the pattern of transmissions from a properly functioning JSATS AMT were retained. Each tag code was processed individually, and it was assumed that only a single tag will be transmitting that code at any given time. At least four messages passing the PRI filter were required for an acceptable tagdetection event.

The output of the filtering processes for both cabled and autonomous hydrophones was a data set of events that summarized accepted tag detections for all times and locations where hydrophones were operating. Each unique event record included a basic set of fields that provided the unique identification number of the fish, the first and last detection time for the event, the detection location, and the number of messages detected within the event. This list was combined with accepted tag detections from the autonomous arrays and PIT detections for additional quality assurance/quality control analysis prior to survival analysis. Additional fields capture specialized information, where available. One such example was route of passage, which was assigned a value for the events that immediately preceded passage at a dam based on spatial tracking of tagged fish movements to a location of last detection. Multiple receptions of messages within an event can be used to triangulate successive tag positions relative to hydrophone locations.

An important quality control step was to examine the chronology of detections of every tagged fish on all arrays above and below the dam-face array to identify any detection sequences that deviated from the expected upstream to downstream progression through arrays in the river. Apparent upstream movements of tagged fish between arrays that were greater than $5 \mathrm{~km}$ apart or separated by one or more dams were very rare $(<0.015 \%)$ and probably represented false positive detections on the upstream array. False positive detections usually will have close to the minimum number of messages and were deleted from the event data set before survival analysis. 


\subsection{Statistical Methods}

The statistical methods include tests of analysis model assumptions and estimation of dam passage survival, forebay and dam passage survival, travel times, passage efficiencies, and distributions. Capture histories and assessments of the survival model assumptions are contained in Appendices $\mathrm{E}$ and $\mathrm{H}$, respectively.

\subsubsection{Tests of Assumptions}

\subsubsection{Burnham et al. (1987) Tests}

Tests 2 and 3 of Burnham et al. (1987) have been used to assess whether upstream detection history has an effect on downstream survival. Such tests are most appropriate when fish are physically recaptured or segregated during capture as in the case with PIT-tagged fish going through the JBS. However, AMT studies do not use physical recaptures to detect fish. Consequently, there is little or no relevance of these tests in AMT studies. Furthermore, the very high detection probabilities present in AMT studies frequently preclude calculation of these tests. For these reasons, these tests were not performed.

\subsubsection{Detection of Dead Fish on Downstream Arrays}

Dead fish with active AMTs were released throughout the spring season from the JDA spillway to ensure the detection arrays were far enough downstream to not detect fish that either were released dead or died during passage through JDA.

\subsubsection{Tests of Mixing}

Evaluation of homogeneous arrival of release groups at downriver detection sites was based on graphs of arrival distributions. The graphs were used to identify any systematic and meaningful departures from mixing. Ideally, the arrival distributions should overlap one another with similarly timed modes.

\subsubsection{Tagger Effects}

Subtle differences in handling and tagging techniques can have an effect on the survival of juvenile salmonids tagged with AMTs used in the estimation of dam passage survival. For this reason, tagger effects were evaluated using the $F$-test. The single release-recapture model was used to estimate reach survivals for fish tagged by different individuals. The analysis evaluated whether any consistent pattern of reduced reach survivals existed for fish tagged by any of the tagging staff. 
For $k$ independent reach survival estimates, a test of equal survival was performed using the $F$-test

$$
F_{k-1, \infty}=\frac{s_{\hat{S}}^{2}}{\left(\frac{\left.\sum_{i=1}^{k} \widehat{\operatorname{Var}}\left(\hat{S}_{i} \mid S_{i}\right)\right)}{k}\right)}
$$

where

$$
s_{\hat{S}}^{2}=\frac{\sum_{i=1}^{k}\left(\hat{S}_{i}-\hat{\bar{S}}\right)^{2}}{k-1}
$$

and

$$
\hat{\bar{S}}=\frac{\sum_{i=1}^{k} \hat{S}_{i}}{k}
$$

\subsubsection{Estimation of Dam Passage and Route-Specific Survivals}

Maximum likelihood estimation was used to estimate dam passage survival at John Day Dam based on the virtual/paired-release design (Skalski et al. 2009, 2010). The capture histories from all the replicate releases, both daytime and nighttime, were pooled to produce the estimate of dam passage survival. A joint likelihood model was constructed of a product multinomial with separate multinomial distributions describing the capture histories of the separate release groups (i.e., $V_{1}, R_{2}$, and $R_{3}$ ) and differentiated by tag lot. The major manufacturing lots (i.e., 1, 2, 3-5) had separately estimated tag-life corrections, but, it was assumed, common reach survival parameters across tag lots for fish from a release location.

The joint likelihood model used for the three release groups was initially fully parameterized. Each of the three releases was allowed to have unique survival and detection parameters. If precision was adequate with the fully parameterized model (i.e., $S E \leq 0.015$ ), no further modeling was performed. If initial precision was inadequate, then likelihood ratio tests were used to assess the homogeneity of parameters across release groups to identify the best parsimonious model to describe the capture-history data. This approach was used to help preserve both precision and robustness of the survival results. All calculations were performed using Program ATLAS (Active Tag-Life Adjusted Survival; http://www.cbr.washington.edu/paramest/atlas/).

Dam passage survival was estimated by the function

$$
\hat{S}_{\text {Dam }}=\frac{\hat{S}_{1}}{\left(\frac{\hat{S}_{2}}{\hat{S}_{3}}\right)}=\frac{\hat{S}_{1} \cdot \hat{S}_{3}}{\hat{S}_{2}}
$$


where $\hat{S}_{i}$ is the tag-life-corrected survival estimate for the $i$ th release group $(i=1, \ldots, 3)$. The variance of $\hat{S}_{\text {Dam }}$ was estimated in a two-step process that incorporated both the uncertainty in the tag-life corrections and the release-recapture processes.

In 2011, compliance tests at JDA were planned for dam operation conditions that included either 30\% or $40 \%$ spill. High flow conditions in spring 2011 interrupted the alternating 2-d spill events. Consequently, a post-facto approach to examining dam passage survival during spring 2011 was necessary. Four alternative estimates of dam passage survival were computed as follows:

- Survival during 30\% spill - early season (27 April-16 May 2011)

- Survival during 40\% spill - early season (27 April-16 May 2011)

- Survival during the late season (16 May-29 May 2011)

- Season-wide survival (27 April-29 May 2011).

During the planned spill study, spill conditions were changed at 8 p.m. on transition days. Fish used in forming the virtual-release groups $\left(V_{2}\right)$ at the face of the dam excluded all detections occurring between 7-9 p.m. to make a clean distinction between $30 \%$ and $40 \%$ spill conditions.

In estimating dam passage survival during a particular segment of the study, all fish in releases $R_{2}$ and $R_{3}$ (see Figure 3.2) during the period regardless of spill conditions were used in the analyses. The location of this paired release procedure was based on the premise that the tailrace BRZ demarks the point below which tailrace conditions have no influence on fish survival or travel times. At JDA, the tailrace BRZ is located approximately $2 \mathrm{rkm}$ upstream of $R_{2}$, even though throughout this report we refer to BRZto-BRZ survival as forebay to tailrace $\left(R_{2}\right)$.

The 3D hydrophone array in the JDA forebay was used to identify fish known to have passed through the spillway, powerhouse, and TSWs (spill bays 18-19). Juvenile salmonids known to have passed through the various routes at JDA were detected by JSATS receivers on downstream arrays to obtain their capture histories. To estimate survival, you first must quantify the number of juvenile salmonids passing by various routes, as follows:

- $R_{\mathrm{PH}}=$ number of juvenile salmonids known to have passed through the powerhouse

- $n_{\mathrm{PH}}=$ number of juvenile salmonids among $R_{\mathrm{PH}}$ detected downriver

- $R_{\mathrm{SP}}=$ number of juvenile salmonids known to have passed through the spillway

- $n_{\mathrm{SP}}=$ number of juvenile salmonids among $R_{\mathrm{SP}}$ detected downriver

- $R_{\mathrm{TSW}}=$ number of juvenile salmonids known to have passed through the TSW

- $n_{\mathrm{TSW}}=$ number of juvenile salmonids among $R_{\mathrm{TSW}}$ detected downriver

- $R_{\mathrm{JBS}}=$ number of juvenile salmonids known to have passed through the JBS

- $n_{\mathrm{JBS}}=$ number of juvenile salmonids among $R_{\mathrm{JBS}}$ detected downriver. 
Using the relative recoveries of juvenile salmonids through the various routes compared to the powerhouse, the relative route-specific survival probabilities can be estimated, e.g., for the spill bay,

$$
R S_{\mathrm{SP} / \mathrm{PH}}=\frac{\left(\frac{n_{\mathrm{SP}}}{R_{\mathrm{SP}}}\right)}{\left(\frac{n_{\mathrm{PH}}}{R_{\mathrm{PH}}}\right)} .
$$

The variance of $R S_{\mathrm{SP} / \mathrm{PH}}$ is estimated by

$$
\widehat{\operatorname{Var}}\left(\widehat{R S}_{\mathrm{SP} / \mathrm{PH}}\right)=\widehat{R S}_{\mathrm{SP} / \mathrm{PH}}^{2}\left[\frac{1}{n_{\mathrm{PH}}}-\frac{1}{R_{\mathrm{PH}}}+\frac{1}{n_{\mathrm{SP}}}-\frac{1}{R_{\mathrm{SP}}}\right] .
$$

The estimators of relative survival rates for the other three routes are analogous to Equation (3.7) and their variances analogous to Equation (3.8).

Using the juvenile salmonids known to have passed through a specific route at the dam, absolute survival rates from the dam entrance to the tailrace release location were estimated using a paired releaserecapture model. Route-specific survival rates and associated standard errors for the fish passed through the powerhouse, spillway, TSW, JBS, and turbines were estimated using the paired-release CormackJolly-Seber algorithms in program ATLAS (Lady et al. 2012).

\subsubsection{Estimation of Forebay-to-Tailrace Survival}

The same virtual/paired-release methods used to estimate dam passage were also used to estimate forebay-to-tailrace survival. The only distinction was the virtual-release group $\left(V_{1}\right)$ was composed of fish known to have arrived alive at the forebay array ( $\mathrm{rkm} 351)$ at JDA instead of at the dam-face array.

\subsubsection{Estimation of Travel Times}

Travel times associated with forebay residence time and tailrace egress were estimated using arithmetic averages as specified in the Fish Accords, i.e.,

$$
\bar{t}=\frac{\sum_{i=1}^{n} t_{i}}{n}
$$

with the variance of $\bar{t}$ estimated by

$$
\widehat{\operatorname{Var}}(\bar{t})=\frac{\sum_{i=1}^{n}\left(t_{i}-\bar{t}\right)^{2}}{n(n-1)}
$$


and where $t_{i}$ was the travel time of the $i^{\text {th }}$ fish $(i=1, \ldots, n)$. Median and mean travel times were also computed and reported.

The estimated tailrace egress time was based on the time from last detection of a fish at the cabled array at the dam face at JDA to the last detection at the tailrace array $3 \mathrm{~km}$ downstream of the dam (rkm 346). The estimated forebay residence times were based on the time from the first detection at the forebay BRZ array $2 \mathrm{~km}$ above the dam to the last detection at the cabled array on the dam face of JDA. Project passage time was estimated as the difference from the time of first detection on the forebay entrance array to the time of last detection on the tailrace egress array at rkm 346.

\subsubsection{Estimation of Passage Efficiencies}

Spill passage efficiency was estimated by the fraction

$$
\widehat{\mathrm{SPE}}=\frac{\hat{N}_{N T S W}+\hat{N}_{T S W}}{\hat{N}_{N T S W}+\hat{N}_{T S W}+\hat{N}_{T U R}+\hat{N}_{J B S}}
$$

where $\hat{N}_{i}$ is the estimated abundance of fish tagged with AMTs through the $i^{\text {th }}$ route $(i=$ non-TSW [NTSW], temporary spill weir [TSW], turbines [TUR], and juvenile bypass system [JBS]). The cabled array was used to estimate absolute abundance $(N)$ through a route using the single mark-recapture model (Seber 1982) independently at each route. Calculating the variance in stages, the variance of $\widehat{\mathrm{SPE}}$ was estimated as

$$
\begin{aligned}
\operatorname{Var}(\widehat{\mathrm{SPE}})= & \frac{\widehat{\mathrm{SPE}}(1-\widehat{\mathrm{SPE}})}{\sum_{i=1}^{4} \hat{N}_{i}}+\widehat{\mathrm{SPE}}^{2}(1-\widehat{\mathrm{SPE}})^{2} \\
& \cdot\left[\frac{\operatorname{Var}\left(\hat{N}_{N T S W}\right)+\operatorname{Var}\left(\hat{N}_{T S W}\right)}{\left(\hat{N}_{N T S W}+\hat{N}_{T S W}\right)^{2}}+\frac{\widehat{\operatorname{Var}}\left(\hat{N}_{T U R}\right)+\operatorname{Var}\left(\hat{N}_{J B S}\right)}{\left(\hat{N}_{T U R}+\hat{N}_{J B S}\right)^{2}}\right] .
\end{aligned}
$$

Fish passage efficiency ${ }^{1}$ was estimated by the fraction

$$
\widehat{\mathrm{FPE}}=\frac{\hat{N}_{N T S W}+\hat{N}_{T S W}+\hat{N}_{J B S}}{\hat{N}_{N T S W}+\hat{N}_{T S W}+\hat{N}_{J B S}+\hat{N}_{T U R}}
$$

\footnotetext{
${ }^{1}$ Fish passage efficiency was called spill passage efficiency in the Columbia Basin Fish Accords.
} 
Calculating the variance in stages, the variance of $\widehat{\mathrm{FPE}}$ was estimated as

$$
\begin{aligned}
\operatorname{Var}(\widehat{\mathrm{FPE}})= & \frac{\widehat{\mathrm{FPE}}(1-\widehat{\mathrm{FPE}})}{\sum_{i=1}^{4} \hat{N}_{i}}+\widehat{\mathrm{FPE}}^{2}(1-\widehat{\mathrm{FPE}})^{2} \\
& \cdot\left[\frac{\operatorname{Var}\left(\hat{N}_{N T S W}\right)+\operatorname{Var}\left(\hat{N}_{T S W}\right)+\operatorname{Var}\left(\hat{N}_{J B S}\right)}{\left(\hat{N}_{N T S W}+\hat{N}_{T S W}+\hat{N}_{J B S}\right)^{2}}+\frac{\widehat{\operatorname{Var}}\left(\hat{N}_{T U R}\right)}{\hat{N}_{T U R}^{2}}\right] .
\end{aligned}
$$

Fish guidance efficiency (FGE) is the proportion of juvenile salmonids entering turbines that were subsequently guided by in-turbine screens to the JBS. It was estimated by the proportion

$$
\widehat{\mathrm{FGE}}=\frac{\hat{P}_{\mathrm{JBS}}}{\hat{P}_{\mathrm{TUR}}+\hat{P}_{\mathrm{JBS}}}
$$

with the associated variance estimator

$$
\begin{aligned}
\widehat{\operatorname{Var}}(\widehat{\mathrm{FGE}})= & \frac{\widehat{\mathrm{FGE}}(1-\widehat{\mathrm{FGE}})}{\hat{N}}+\widehat{\mathrm{FGE}}^{2}(1-\widehat{\mathrm{FGE}})^{2} \\
& \cdot\left[\frac{\widehat{\operatorname{Var}}\left(\hat{N}_{\mathrm{JBS}}\right)}{\hat{N}_{\mathrm{JBS}}^{2}}+\frac{\widehat{\operatorname{Var}}\left(\hat{N}_{\mathrm{SP}}\right)+\widehat{\operatorname{Var}}\left(\hat{N}_{\mathrm{PH}}\right)+\widehat{\operatorname{Var}}\left(\hat{N}_{\mathrm{TSW}}\right)}{\left(\hat{N}_{\mathrm{SP}}+\hat{N}_{\mathrm{PH}}+\hat{N}_{\mathrm{TSW}}\right)^{2}}\right] .
\end{aligned}
$$

Top-spill weir passage efficiency is defined as the proportion of juvenile salmonids passing the dam through the TSW spill bays. For this study, the TSWE was expressed by

$$
\widehat{\mathrm{TSWE}}=\hat{P}_{\mathrm{TSW}}
$$

with associated variance estimator

$$
\begin{aligned}
\widehat{\operatorname{Var}}(\widehat{\mathrm{TSWE}})= & \frac{\hat{P}_{\mathrm{TSW}}\left(1-\hat{P}_{\mathrm{TSW}}\right)}{\hat{N}}+\hat{P}_{\mathrm{TSW}}{ }^{2}\left(1-\hat{P}_{\mathrm{TSW}}\right)^{2} \\
& \cdot\left[\frac{\widehat{\operatorname{Var}}\left(\hat{N}_{\mathrm{TSW}}\right)}{\hat{N}_{\mathrm{TSW}}^{2}}+\frac{\widehat{\operatorname{Var}}\left(\hat{N}_{\mathrm{SP}}\right)+\widehat{\operatorname{Var}}\left(\hat{N}_{\mathrm{PH}}\right)+\widehat{\operatorname{Var}}\left(\hat{N}_{\mathrm{JBS}}\right)}{\left(\hat{N}_{S P}+\hat{N}_{\mathrm{PH}}+\hat{N}_{\mathrm{JBS}}\right)^{2}}\right] .
\end{aligned}
$$

The JBS passage efficiency (JBSE) is the proportion of fish passing the dam through the JBS:

$$
\mathrm{JBSE}=\frac{\hat{P}_{\mathrm{JBS}}}{\hat{P}_{\mathrm{JBS}}+\hat{P}_{\mathrm{TUR}}+\hat{P}_{\mathrm{NTSW}}+\hat{P}_{\mathrm{TSW}}}
$$


with the associated variance estimator

$$
\begin{aligned}
\widehat{\operatorname{Var}}(\widehat{\mathrm{JBSE}})= & \frac{\widehat{P}_{\mathrm{JBS}}\left(1-\widehat{P}_{\mathrm{JBS}}\right)}{\hat{N}}+\hat{P}_{\mathrm{JBS}}^{2}\left(1-\widehat{P}_{\mathrm{JBS}}\right)^{2} \\
& \cdot\left[\frac{\widehat{\operatorname{Var}}\left(\hat{N}_{\mathrm{JBS}}\right)}{\hat{N}_{\mathrm{JBS}}^{2}}+\frac{\left.\widehat{\operatorname{Var}}\left(\hat{N}_{\mathrm{PH}}\right)+\widehat{\operatorname{Var}}\left(\hat{N}_{\mathrm{SP}}\right)+\widehat{\operatorname{Var}}\left(\hat{N}_{\mathrm{TSW}}\right)\right]}{\left(\hat{N}_{\mathrm{PH}}+\hat{N}_{\mathrm{SP}}+\hat{N}_{\mathrm{TSW}}\right)^{2}}\right] .
\end{aligned}
$$

\subsubsection{Estimation of Distributions}

Based on detections on the dam-face array and 3D tracking results, the horizontal distribution of passage of each stock of fish at JDA was estimated according to the individual turbine and spill bay of passage. The same 3D tracking data set allowed evaluation of the vertical distribution of juvenile salmonids within $75 \mathrm{~m}$ of the dam.

For a broader picture of fish behavior in the forebay, the distribution of juvenile salmonids detected on the forebay entrance array $2 \mathrm{~km}$ upstream of JDA was compared to the distribution of juvenile salmonid passage at the dam. Juvenile salmonid detections on the forebay array were assigned to horizontal blocks corresponding to locations upstream of dam structures, from south to north: PH1-16= powerhouse units 1 to 16; skeleton bays; SW20 = spill bay 20; SW18-19= spill bays 18 and 19 (each with a TSW); and SW1-17 = spill bays 1 to 17 . Passage locations also were grouped into blocks of routes with the same names used to describe juvenile salmonid arrivals, except that skeleton bays were dropped because they could not pass fish. This approach allowed for examination of juvenile salmonid behavioral response to the dam by their avoidance or selection of passage route blocks. Similar arrival and passage distributions would suggest that juvenile salmonid responses to forebay conditions and operations were limited, whereas substantial shifts in those distributions would indicate that juvenile salmonids were responding to forebay conditions or operations by selecting preferred blocks of routes.

Vertical distributions of $\mathrm{CH} 1$ and STH as they approach JDA can be useful in determining the effectiveness of a SFO for entraining juvenile salmonids in its flow field. Assigning a depth of forebay travel from approximately $100 \mathrm{~m}$ upstream of the dam face to the near field of the dam face at JDA $(<5 \mathrm{~m})$ is accomplished using $3 \mathrm{D}$ tracking. All references in this report to vertical distributions are related to the depth of the hydrophone located on the southern-most pier-nose on the powerhouse (P00_P01S). This hydrophone is used as a reference point for a vertical forebay movement with a baseline elevation of $251.39 \mathrm{ft}$ above MSL. Normal pool elevation of the JDA pool is approximately $261 \mathrm{ft}$ above MSL. 


\subsection{Results - Environmental Conditions}

This section describes environmental conditions during the 2011 study, including river discharge and temperature relative to the 10 -yr average, JDA forebay elevation, and realized spill discharges for the $30 \%$ and $40 \%$ spill test levels.

\subsection{River Discharge and Water Temperature}

Throughout the duration of the study (April 27 to May 29, 2011), discharge remained above the 10-yr average (2001 to 2010) ranging from 229 to $518 \mathrm{kcfs}$, and averaging $363 \mathrm{kcfs}$ (Figure 4.1). Discharge began to rise sharply on May 12 and remained high throughout the remainder of the study period, ultimately increasing to almost 2.5 times the 10 -yr average.

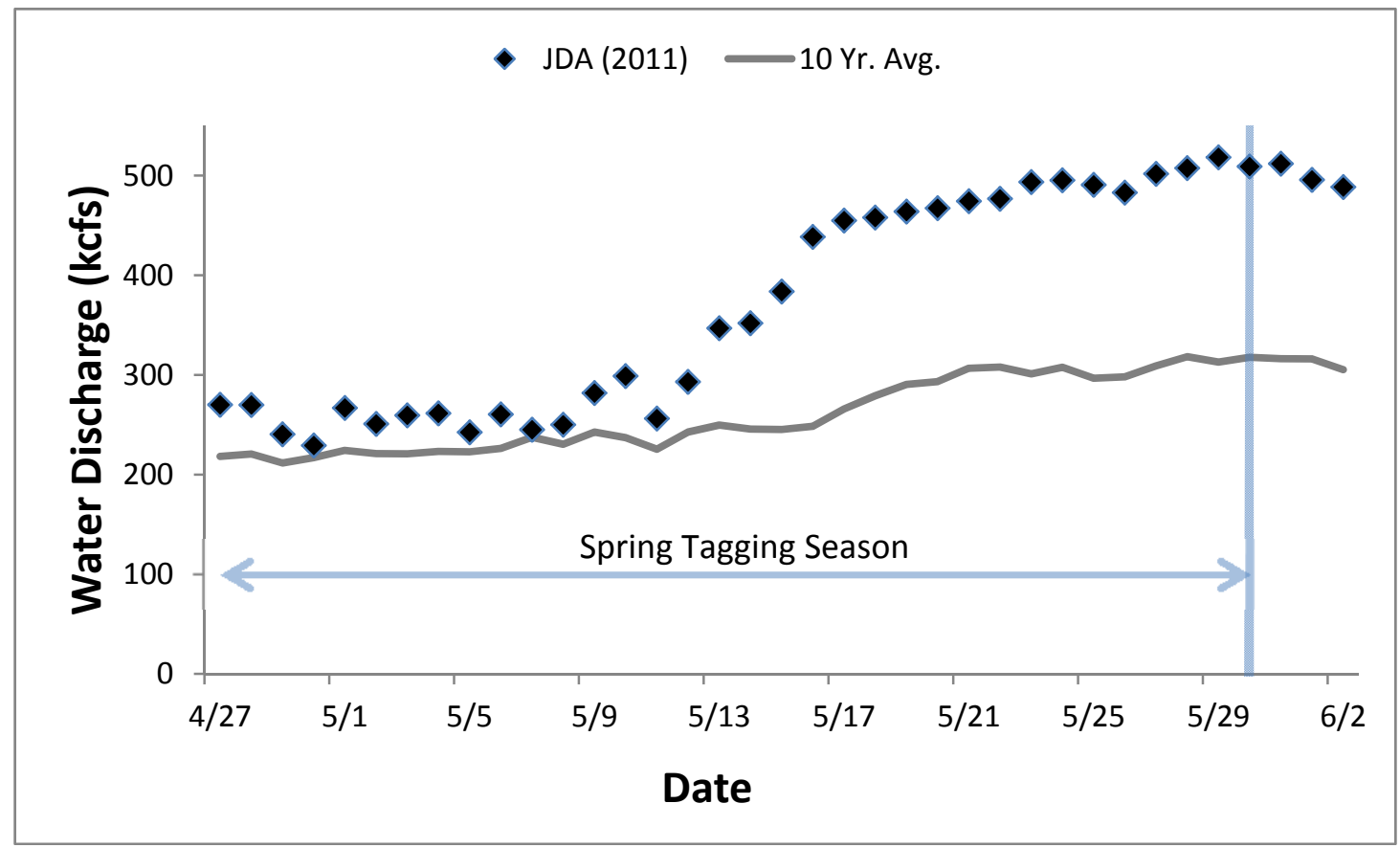

Figure 4.1. Average daily water discharge (kcfs) from John Day Dam during the 2011 study and for the preceding 10-yr (2001 to 2010) period.

Daily forebay water temperatures ranged from 9.1 to $12.4^{\circ} \mathrm{C}$ and were, on average, one degree cooler than the previous 10-yr average during the 2011 tagging season (Figure 4.2). This pattern was likely due to the increase in discharge which continued throughout the study. 


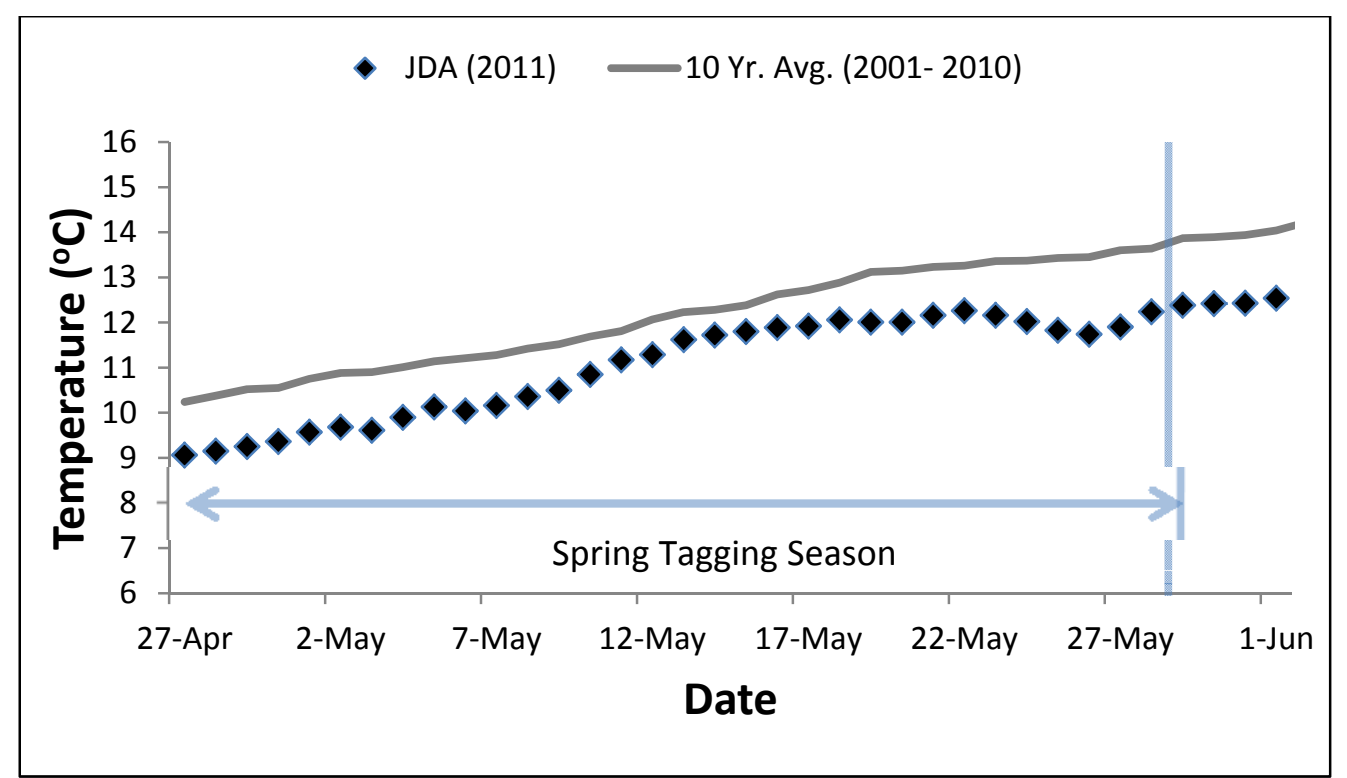

Figure 4.2. Average daily water temperature $\left({ }^{\circ} \mathrm{C}\right)$ from John Day Dam during the spring 2011 study and for the preceding 10-yr (2001 to 2010) period.

\subsection{Forebay Elevations}

During the 2011 study period, both mean and median forebay elevation averaged $263.3 \mathrm{ft}$ above MSL, ranging from $\sim 262$ to $\sim 265 \mathrm{ft}$ (Figure 4.3).

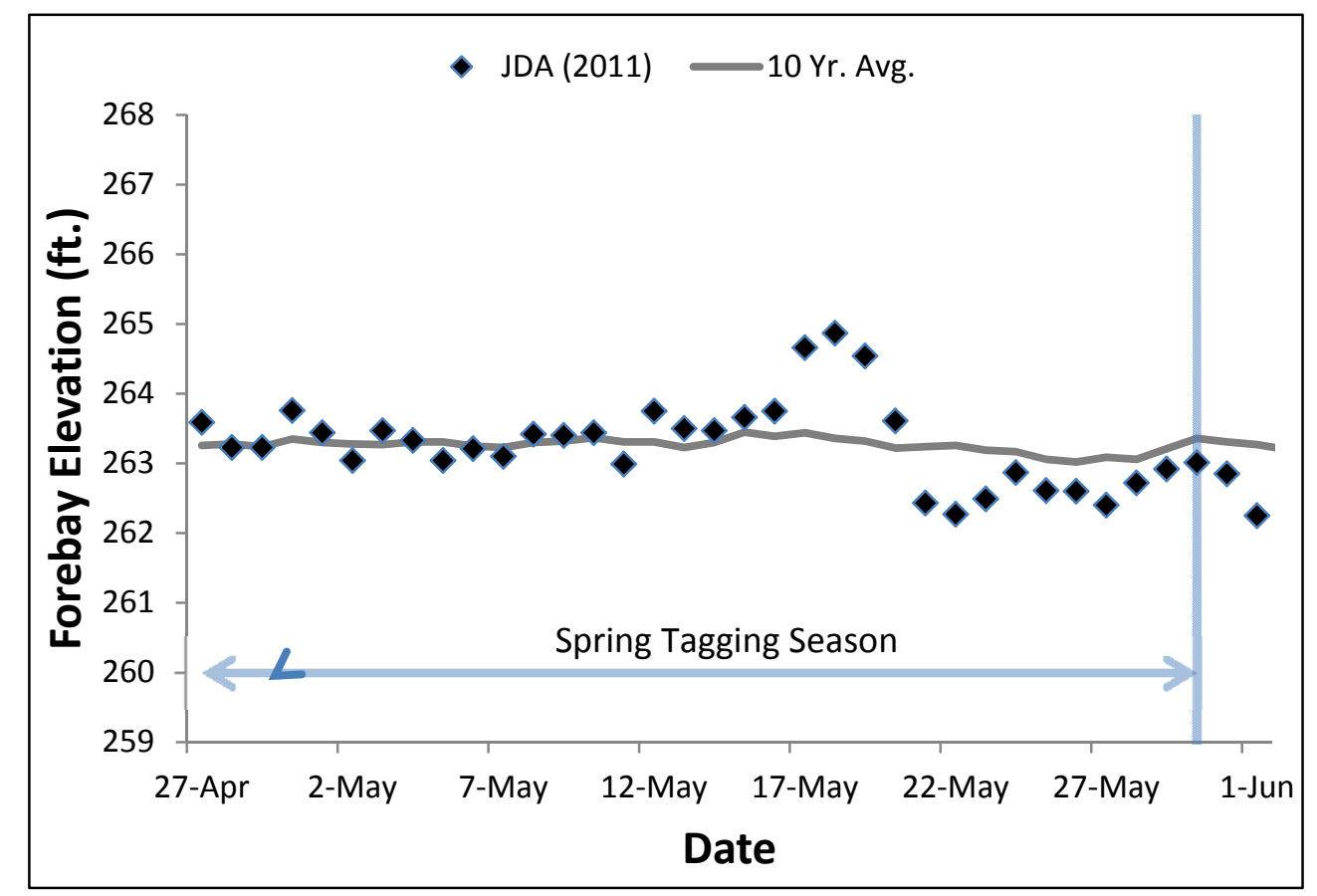

Figure 4.3. Mean forebay elevation (ft) from John Day Dam during the spring 2011 study and for the preceding 10-yr (2001 to 2010) period. 


\subsection{Spill Test}

The effects of $30 \%$ and $40 \%$ spill discharge levels on fish survival and passage rates were independently evaluated using a uniform block study design (Figure 3.1). The spill test study design was adhered to for the first half of the spring season (April 27-May 16), at which time spill exceeded $40 \%$ and was maintained well above that level for the remainder of the spring study period. Thus, the spring season was separated into an early (spill test levels maintained) and late season (Figure 4.4).

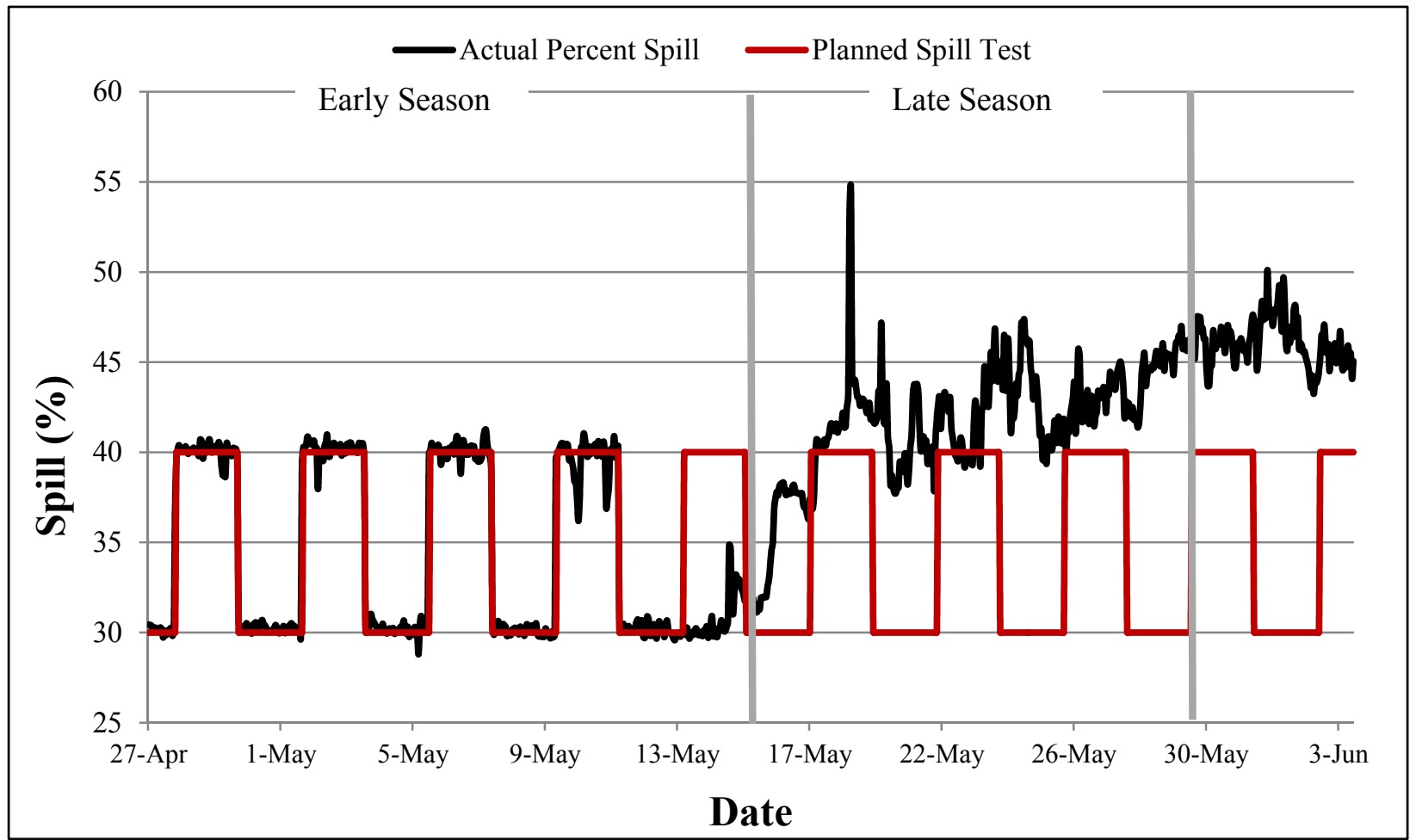

Figure 4.4. Spring spill test at John Day Dam, April 29 through May 29, 2011. There were eight spill test blocks planned with two 2-d tests per block; high discharge rates after April 16 prevented this spill block design from being obtainable. 


\subsection{Results - Fish Collection and Tagging}

The number and percent of fish collected for the tagging study according to their fate are summarized in Table 5.1. Rejected and excluded fish were released to the river through the SMF holding system after a period of recovery from anesthesia. Accepted fish were counted and transferred into twelve 302.8-L pre-surgery holding tanks, where they were held for 18 to $30 \mathrm{~h}$ before surgery. The pre-surgery holding duration depended on the time of collection and the time of tagging on the next day. The majority of fish collected for the study were tagged and released alive. Small percentages of fish were tagged and released dead to test detection assumptions. In addition, fish were tagged for a concurrent study of fish condition. The extra fish collected but not used for tagging, due to daily tagging quotas being met, were released to the river through the JDA juvenile bypass outfall. Table 5.2 summarizes rejections due to maladies and Table 5.3 summarizes other fish rejections. Post-tagging mortalities were minimal for each run of fish studied in 2011 (CH1 0.31\%; STH 0.08\%) compared to the total number tagged and released for the survival study. These fish were used for the dead fish released to test detection assumptions.

Table 5.1. Summary of the number and percentage of fish rejected, excluded, tagged and released alive, tagged and released dead, and that exceeded collection needs. Totals represent the number and percent collected in 2011 .

\begin{tabular}{|c|c|c|c|c|c|c|}
\hline \multirow{2}{*}{$\begin{array}{c}\text { Fate } \\
\text { Statistics }\end{array}$} & \multicolumn{2}{|c|}{$\mathrm{CH} 1$} & \multicolumn{2}{|c|}{ STH } & \multicolumn{2}{|c|}{ Total } \\
\hline & $\mathrm{n}$ & $\%$ & $\mathrm{n}$ & $\%$ & $\mathbf{n}$ & $\%$ \\
\hline Rejected $^{(a)}$ & 1,060 & 10.5 & 1,561 & 15.0 & 2,621 & 12.8 \\
\hline Excluded $^{(b)}$ & 495 & 4.9 & 358 & 3.4 & 853 & 4.2 \\
\hline Tagged and Released Live & 7,692 & 76.4 & 7,766 & 74.8 & 15,458 & 75.6 \\
\hline Tagged and Released Dead ${ }^{(\mathrm{c})}$ & 56 & 0.6 & 44 & 0.4 & 100 & 0.5 \\
\hline Tagged for Fish Condition Study & 180 & 1.8 & 179 & 1.7 & 359 & 1.8 \\
\hline Extra Fish $^{(\mathrm{d})}$ & 584 & 5.8 & 479 & 4.6 & 1,063 & 5.2 \\
\hline Collected & 10,067 & 100 & 10,387 & 100 & 20,454 & 100 \\
\hline
\end{tabular}

(a) Due to maladies.

(b) Did not meet length criteria, previously tagged, dead, non-target species, mishandled.

(c) Used specifically to meet detection assumptions.

(d) Collected but not tagged due to the daily tagging quota being met. 
Table 5.2. Number of observed malady types that warranted rejection and percent rejected by malady type in 2011.

\begin{tabular}{lrrrrrr}
\hline \multirow{2}{*}{\multicolumn{1}{c}{ Malady Description }} & \multicolumn{2}{c}{$\mathrm{CH} 1$} & \multicolumn{2}{c}{$\mathrm{STH}$} & \multicolumn{2}{c}{ Total } \\
\cline { 2 - 7 } & \multicolumn{1}{c}{$\mathrm{n}$} & \multicolumn{1}{c}{$\%$} & \multicolumn{1}{c}{$\mathrm{n}$} & \multicolumn{1}{c}{ n } & \multicolumn{1}{c}{$\mathbf{0}$} \\
\hline Bacterial kidney disease & 28 & 2.6 & 4 & 0.3 & $\mathbf{3 2}$ & $\mathbf{1 . 2}$ \\
Descaling $(\geq 20 \%)$ & 437 & 41.2 & 659 & 42.2 & $\mathbf{1 , 0 9 6}$ & $\mathbf{4 1 . 8}$ \\
Exophthalmia & 12 & 1.1 & 4 & 0.3 & $\mathbf{1 6}$ & $\mathbf{0 . 6}$ \\
Fungus & 101 & 9.5 & 200 & 12.8 & $\mathbf{3 0 1}$ & $\mathbf{1 1 . 5}$ \\
Hemorrhaging & 88 & 8.3 & 62 & 4.0 & $\mathbf{1 5 0}$ & $\mathbf{5 . 7}$ \\
Lacerations (including lesions) & 233 & 22.0 & 359 & 23.0 & $\mathbf{5 9 2}$ & $\mathbf{2 2 . 6}$ \\
Operculum damage & 77 & 7.3 & 163 & 10.4 & $\mathbf{2 4 0}$ & $\mathbf{9 . 2}$ \\
Other & 3 & 0.3 & 17 & 1.1 & $\mathbf{2 0}$ & $\mathbf{0 . 8}$ \\
Parasites & 77 & 7.3 & 79 & 5.1 & $\mathbf{1 5 6}$ & $\mathbf{6 . 0}$ \\
Skeletal deformities & 4 & 0.4 & 14 & 0.9 & $\mathbf{1 8}$ & $\mathbf{0 . 7}$ \\
\hline Total & $\mathbf{1 , 0 6 0}$ & $\mathbf{1 0 0}$ & $\mathbf{1 , 5 6 1}$ & $\mathbf{1 0 0}$ & $\mathbf{2 , 6 2 1}$ & $\mathbf{1 0 0}$ \\
\hline
\end{tabular}

Table 5.3. Number of juvenile salmonids excluded from tagging for other reasons and percent excluded by reason in 2011 .

\begin{tabular}{lrrrrrr}
\hline \multirow{2}{*}{ Reason for Exclusion } & \multicolumn{2}{c}{ CH1 } & \multicolumn{2}{c}{ STH } & \multicolumn{2}{c}{ Total } \\
\cline { 2 - 7 } \multicolumn{1}{c}{$\mathrm{n}$} & \multicolumn{1}{c}{$\%$} & \multicolumn{1}{c}{$\mathrm{n}$} & \multicolumn{1}{c}{$\%$} & \multicolumn{1}{c}{ n } & \multicolumn{1}{c}{} \\
\hline Moribund/emaciated & 10 & 2.0 & 8 & 2.2 & $\mathbf{1 8}$ & $\mathbf{2 . 1}$ \\
Pre-tagging holding mortality & 14 & 2.8 & 3 & 0.8 & $\mathbf{1 7}$ & $\mathbf{2 . 0}$ \\
Previously tagged & 449 & 90.7 & 326 & 91.1 & $\mathbf{7 7 5}$ & $\mathbf{9 0 . 9}$ \\
$<95$ or $>299 \mathrm{~mm}$ & 1 & 0.2 & 9 & 2.5 & $\mathbf{1 0}$ & $\mathbf{1 . 2}$ \\
Wrong species & 5 & 1.0 & 0 & 0.0 & $\mathbf{5}$ & $\mathbf{0 . 6}$ \\
Mishandled & 16 & 3.2 & 12 & 3.4 & $\mathbf{2 8}$ & $\mathbf{3 . 3}$ \\
\hline Total & $\mathbf{4 9 5}$ & $\mathbf{1 0 0}$ & $\mathbf{3 5 8}$ & $\mathbf{1 0 0}$ & $\mathbf{8 5 3}$ & $\mathbf{1 0 0}$ \\
\hline
\end{tabular}




\subsection{Results - Yearling Chinook Salmon}

This section contains survival estimates, spill test effects, travel times, estimates of passage efficiency, and fish passage distributions for CH1 at JDA during the spring of 2011. Tagging and release data, capture-history data, detection and survival probabilities, and the performance of JSATS equipment are presented in Appendices C, E, F, and G, respectively. The assessment of model assumptions showed that the assumptions were met, thereby allowing estimation of survival rates for $\mathrm{CH} 1$ (Appendix $\mathrm{H}$ ).

\subsection{Survival Estimates}

Dam passage survival estimates $[\hat{\mathrm{S}}( \pm \mathrm{SE})]$ were determined by using a virtual/paired-release model for 2,510 CH1 tagged with AMTs released at CR390 and regrouped at the dam-face array at JDA to form a virtual release $\left(V_{2} ; \mathrm{n}=2,441\right)$. Survival was estimated from the dam face at JDA to CR346 at the most downstream edge of the tailrace hydraulic influence. Paired releases of CH1 at CR346 $\left(R_{2} ; \mathrm{n}=1,193\right)$ and CR325 $\left(R_{3} ; \mathrm{n}=799\right)$ were used to estimate delayed mortality associated with dam passage and account for mortality associated with migration through various reaches downstream of JDA. Season-wide dam passage survival for $\mathrm{CH} 1$ was $96.8 \pm 0.007$ and forebay-to-tailrace survival (BRZ-to-BRZ) was $96.5 \pm$ 0.007 (Table 6.1); both exceeded the BiOp criterion with $>96 \%$ survival and standard error estimates of $\leq 1.5$. Early season estimates met BiOp criterion as well.

Route-specific survival for $\mathrm{CH} 1$ is provided in Table 6.2. The highest survival rates were observed for fish passing through non-TSW spill bays $(97.4 \pm 0.008)$ and the JBS $(99.3 \pm 0.008)$. The lowest survival rate was for $\mathrm{CH} 1$ passing through the turbines $(0.910 \pm 0.019)$.

Table 6.1. CH1 virtual/paired-release survival estimates from the John Day Dam forebay entrance and dam face to the John Day Dam tailrace for early spring and season-wide.

\begin{tabular}{lcccc}
\hline \multicolumn{1}{c}{ Reach } & Early Spring & SE & Season Wide & SE \\
\hline JDA dam passage survival (CR349 to CR346) & 0.971 & 0.009 & 0.968 & 0.007 \\
JDA forebay entrance to tailrace (CR351 to CR346) & 0.970 & 0.009 & 0.965 & 0.007 \\
\hline
\end{tabular}

Table 6.2. CH1 season-wide route-specific virtual/paired-release survival estimates from the John Day Dam face to the tailrace (CR349 to CR346).

\begin{tabular}{lccc}
\hline Route & Estimate & SE & $\mathrm{n}$ \\
\hline Spillway & 0.968 & 0.008 & 1,560 \\
TSW & 0.958 & 0.011 & 582 \\
Non-TSW & 0.974 & 0.008 & 977 \\
JBS & 0.993 & 0.008 & 599 \\
Turbines & 0.910 & 0.019 & 282 \\
\hline
\end{tabular}




\subsection{Estimates of Passage Efficiency}

During spring 2011, FPE for CH1 was $88.5 \%$ and SPE was $63.7 \%$ (Table 6.3). The TSWE relative to the dam and spillway was $23.8 \%$ and $37.3 \%$, respectively. Fish guidance efficiency was $68.3 \%$ and was $24.8 \%$.

Table 6.3. Season-wide estimates of major passage metrics for CH1 at John Day Dam, spring 2011.

\begin{tabular}{|c|c|c|}
\hline \multirow[b]{2}{*}{ Metric } & \multicolumn{2}{|c|}{ Season } \\
\hline & Estimate & SE \\
\hline FPE $\|$ Dam $^{(a)}$ & 0.885 & 0.006 \\
\hline SPE $\| \operatorname{Dam}^{(a)}$ & 0.637 & 0.010 \\
\hline TSWE $\| \operatorname{Dam}^{(\mathrm{a})}$ & 0.238 & 0.009 \\
\hline TSWE || Spillway & 0.373 & 0.012 \\
\hline FGE (powerhouse screen efficiency) & 0.683 & 0.016 \\
\hline JBSE $\| \operatorname{Dam}^{(a)}$ & 0.248 & 0.009 \\
\hline
\end{tabular}

(a) If dam route is included, proportions will not add up to 1 .

\subsection{Day/Night Trends}

During the spring season, fish passage data were divided into daytime (0600 to $2159 \mathrm{~h}$ ) and nighttime ( 2200 to $0559 \mathrm{~h}$ ) periods. Differences in dam passage and forebay-to- tailrace (BRZ-to-BRZ) survival estimates between day and night appear to not be significantly different, as indicated by the overlapping of $95 \%$ confidence intervals for the point estimates (Table 6.4).

The FPE, SPE, and TSWE estimates relative to the dam were significantly higher during the day than at night as indicated by $95 \%$ confidence intervals (Table 6.5). In contrast, JBSE estimates were significantly lower during the day than at night. There also appeared to be no significant difference for TSWE relative to the spillway or FGE for day versus night.

Table 6.4. Comparison of day/night season-wide paired-release estimates of survival for $\mathrm{CH} 1$ for dam passage (CR349 to CR346) and forebay to tailrace (CR351 to CR346) survival. Estimates were not corrected for tag life.

\begin{tabular}{lcccccc}
\hline & \multicolumn{3}{c}{ Day } & \multicolumn{3}{c}{ Night } \\
\cline { 2 - 7 } \multicolumn{1}{c}{ Survival Reach } & Estimate & SE & $\mathrm{n}$ & Estimate & SE & $\mathrm{n}$ \\
\hline Dam Passage & 0.965 & 0.008 & 1,477 & 0.972 & 0.008 & 964 \\
Forebay Array to Tailrace & 0.966 & 0.008 & 1,500 & 0.963 & 0.009 & 950 \\
\hline
\end{tabular}


Table 6.5. Comparison of season-wide day and night passage efficiencies for CH1 at John Day Dam in spring 2011. Significant difference $(*)$ is related to the $95 \%$ confidence intervals.

\begin{tabular}{lccccc}
\hline & \multirow{2}{*}{ Metric } & \multicolumn{3}{c}{ Day } & \multicolumn{3}{c}{ Night } & \\
\cline { 2 - 5 } & Estimate & SE & Estimate & SE & Sig Diff \\
\hline FPE $\|$ Dam $^{(a)}$ & 0.943 & 0.006 & 0.807 & 0.012 & $*$ \\
SPE $\|$ Dam $^{(a)}$ & 0.784 & 0.011 & 0.441 & 0.015 & $*$ \\
TSWE $\|$ Dam $^{(a)}$ & 0.304 & 0.012 & 0.149 & 0.011 & $*$ \\
TSWE $\|$ Spillway & 0.388 & 0.015 & 0.338 & 0.022 & \\
FGE $($ powerhouse screen efficiency) & 0.736 & 0.025 & 0.655 & 0.020 & \\
JBSE $\|$ Dam $^{(\text {a) }}$ & 0.159 & 0.010 & 0.366 & 0.015 & $*$ \\
\hline
\end{tabular}

(a) If dam route is included, proportions will not add up to 1.

\subsection{Spill Test}

Two spill tests levels were independently tested during the early season of the 2011 survival study. From April 27 until May 16 (early season) river water levels permitted alternating spill regimes of 30\% and 40\%; however, after May 16 (late season) high river flows necessitated $>40 \%$ spill and $30 \%$ and $40 \%$ discharge levels could not be maintained. Table 6.6 shows survival and fish passage metrics at the $30 \%$ and $40 \%$ spill test levels for the early spring season.

Table 6.6. Early spring (April 27-May 16, 2011) estimates of survival and fish passage metrics for CH1 during $30 \%$ and $40 \%$ spill tests.

\begin{tabular}{lcccc}
\hline & \multicolumn{2}{c}{$30 \%$ Spill } & \multicolumn{2}{c}{$40 \%$ Spill } \\
\cline { 2 - 5 } \multicolumn{1}{c}{ Metric } & Estimate & SE & Estimate & SE \\
\hline Survival - Dam Passage (CR349 to CR346) & 0.967 & 0.010 & 0.978 & 0.011 \\
Survival - Forebay entrance to Tailrace (CR351 to CR346) & 0.966 & 0.010 & 0.973 & 0.011 \\
\hline FPE $\|$ Dam $^{(a)}$ & 0.893 & 0.010 & 0.893 & 0.012 \\
SPE $\|$ Dam $^{(a)}$ & 0.613 & 0.016 & 0.680 & 0.019 \\
TSWE $\|$ Dam $^{\text {(a) }}$ & 0.327 & 0.015 & 0.273 & 0.018 \\
TSWE $\|$ Spillway $_{\text {FGE }(\text { powerhouse screen efficiency) }}$ & 0.533 & 0.021 & 0.402 & 0.024 \\
JBSE $\|$ Dam $^{\text {(a) }}$ & 0.725 & 0.023 & 0.667 & 0.033 \\
\hline
\end{tabular}

(a) If dam route is included, proportions will not add up to 1.

\subsection{Travel Times}

There were 2,448 tagged $\mathrm{CH} 1$ detected on the forebay array for which residence time could be estimated; they had a median residence time of $1.42 \mathrm{~h}$ in the forebay (CR351 to CR349; Table 6.7). Median travel time from the JDA dam face to the tailrace egress array was $0.57 \mathrm{~h}$ (CR349 to CR346). Median project passage time from the JDA forebay entrance to the JDA egress array was $2.53 \mathrm{~h}$ (CR351 to CR346). 
Table 6.7. Travel times (h) for CH1 at John Day Dam in spring 2011. Standard errors are in parentheses.

\begin{tabular}{lccc}
\hline \multicolumn{1}{c}{ Route } & $\mathrm{n}$ & Median & Mean \\
\hline Forebay residence (CR351 to CR349) & 2,448 & 1.42 & $2.93(0.13)$ \\
Tailrace egress (CR349 to CR346) & 2,002 & 0.57 & $3.98(0.49)$ \\
Project passage (CR351 to CR346) & 2,002 & 2.53 & $7.01(0.50)$ \\
\hline
\end{tabular}

\subsection{Fish Passage Distributions and Passage Times}

Horizontal distributions, forebay approach, and forebay vertical distributions for CH1 at JDA in spring 2011 are summarized in the following sections.

\subsubsection{Horizontal Distributions}

A total of $63.7 \%$ of the $\mathrm{CH} 1$ passing through JDA during spring 2011 passed by way of the spillway, including both the TSW and non-TSW (NTSW) routes (Table 6.8). The TSW bays (18 and 19), discharging similar water volumes to that of spill bays $4-17$, passed $23.8 \%$ of all $\mathrm{CH} 1$ passing JDA (Figure 6.1 ), while the standard spill bays passed $39.9 \%$ of the $\mathrm{CH} 1$. The powerhouse, including both the JBS and turbine routes, passed $36.3 \%$ of all $\mathrm{CH} 1$. JBS-passed $\mathrm{CH} 1$ composed $24.8 \%$ of all $\mathrm{CH} 1$ passing through JDA. Main units 2 and 3 (JBS and turbine) passed a higher proportion of $\mathrm{CH} 1$ than any other powerhouse route even though discharge was similar to that of other units (Figure 6.2), and 11.5\% of CH1 passed JDA through the turbines.

Table 6.8. Percent of total passage by subroute for CH1 at John Day Dam in spring 2011.

\begin{tabular}{lc}
\hline \multicolumn{1}{c}{ Parameter } & CH1 \\
\hline Percentage of total TSW passage & $23.8 \%$ \\
Percentage of total NTSW passage & $39.9 \%$ \\
Percentage of total JBS passage & $24.8 \%$ \\
Percentage of total turbine passage & $11.5 \%$ \\
\hline JBS = Juvenile bypass system. & \\
NTSW = Non-top-spill weir. & \\
TSW = Top-spill weir. & \\
\hline
\end{tabular}




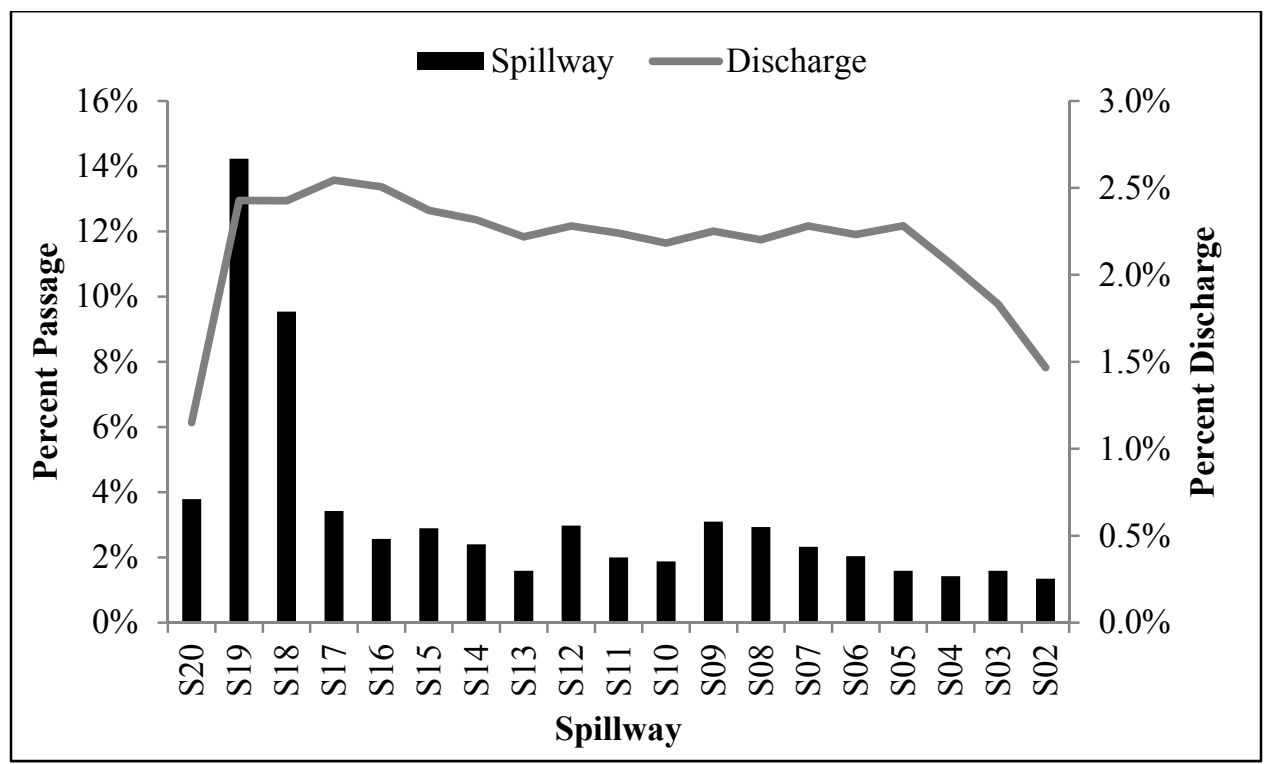

Figure 6.1. Spill bay route of passage and associated percent discharge.

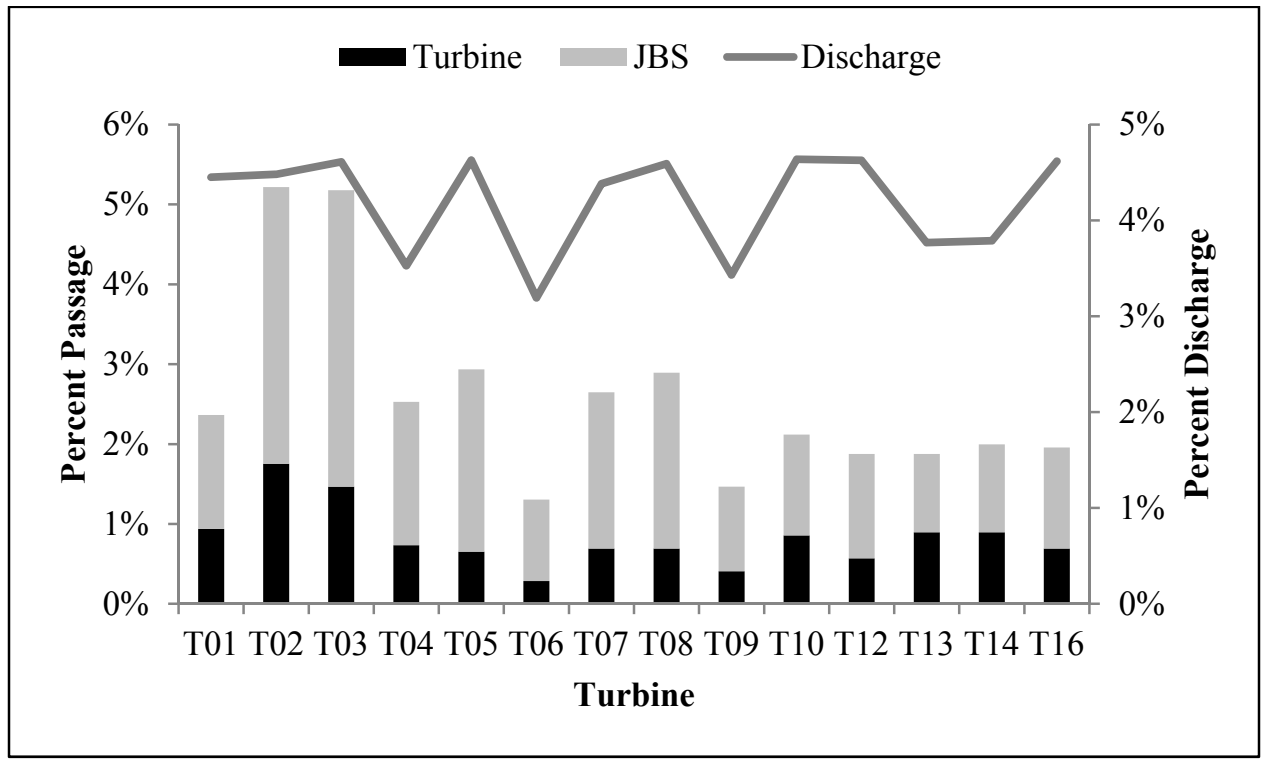

Figure 6.2. Passage distribution by percent discharge for turbine- and JBS-passed CH1 at John Day Dam in 2011 .

\subsubsection{Forebay Approach Distribution and Route Specific Passage Times}

The majority of $\mathrm{CH} 1$ that arrived at JDA approached and passed at the spillway ( $>40 \%$; Figure 6.3 ). Overall, minimal variation was observed when comparing approach and passage blocks by high spilldischarge levels ( $\geq 35 \%)$ and low-level discharge ( $<35 \%$; Figure 6.4$)$. There was however about 5\% difference in the distribution between high spill and low spill for $\mathrm{CH} 1$ approaching and passing at the spillway. Differences in day and night approach and passage routes were more notable than differences due to spill discharge levels (Figure 6.5). During the day, the greatest proportion of CH1 (47\%) approached and passed at the spillway, while at night the highest proportion (44\%) approached and 
passed at the powerhouse. The $\mathrm{CH} 1$ that approached the powerhouse at night were more likely to pass at the powerhouse than at the spillway. In contrast, $\mathrm{CH} 1$ approaching the powerhouse during the day were almost equally likely to pass at the powerhouse or the spillway.

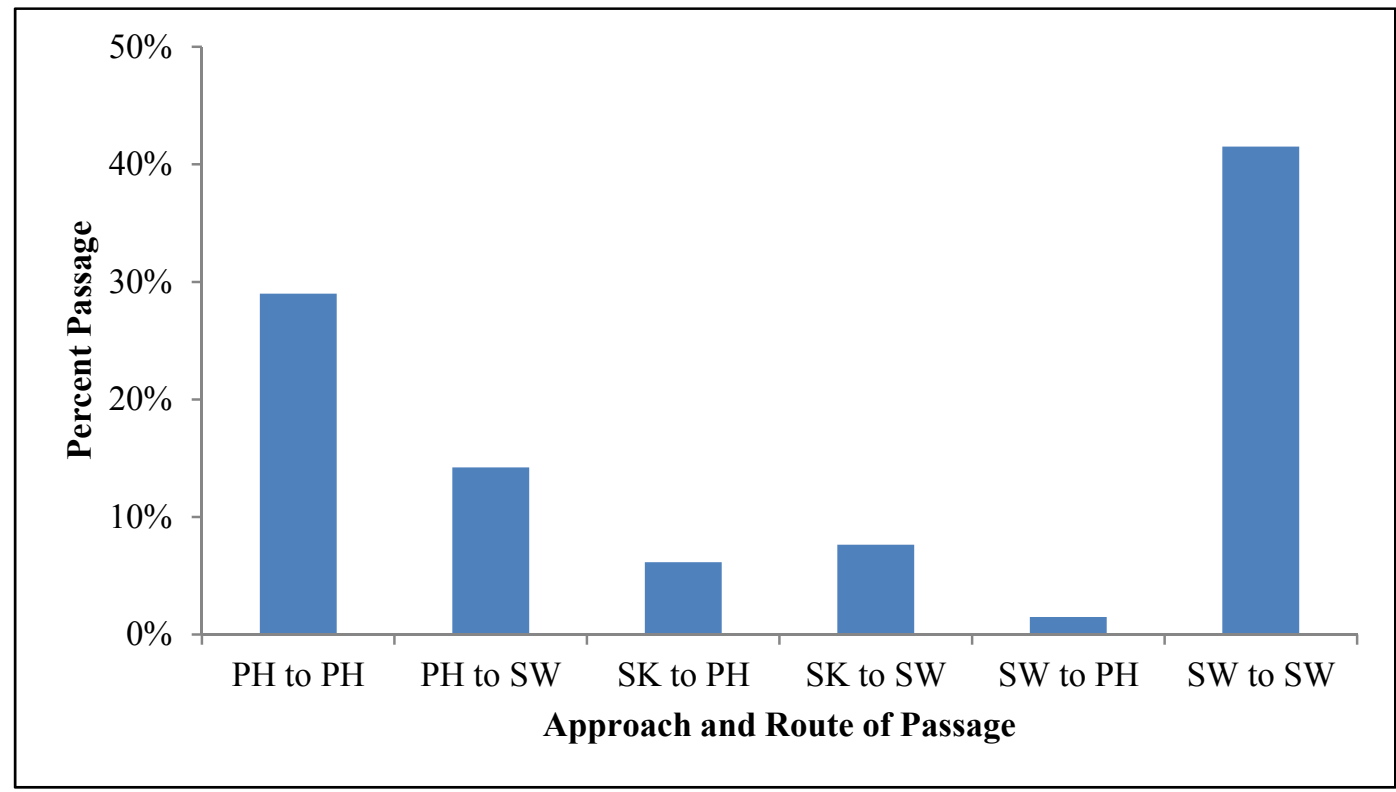

Figure 6.3. $\mathrm{CH} 1$ approach and passage distributions. The first abbreviation is for the approach location and the second is for the passage location $(\mathrm{PH}=$ powerhouse; $\mathrm{SK}=$ skeleton bay; $\mathrm{SW}=$ spillway).

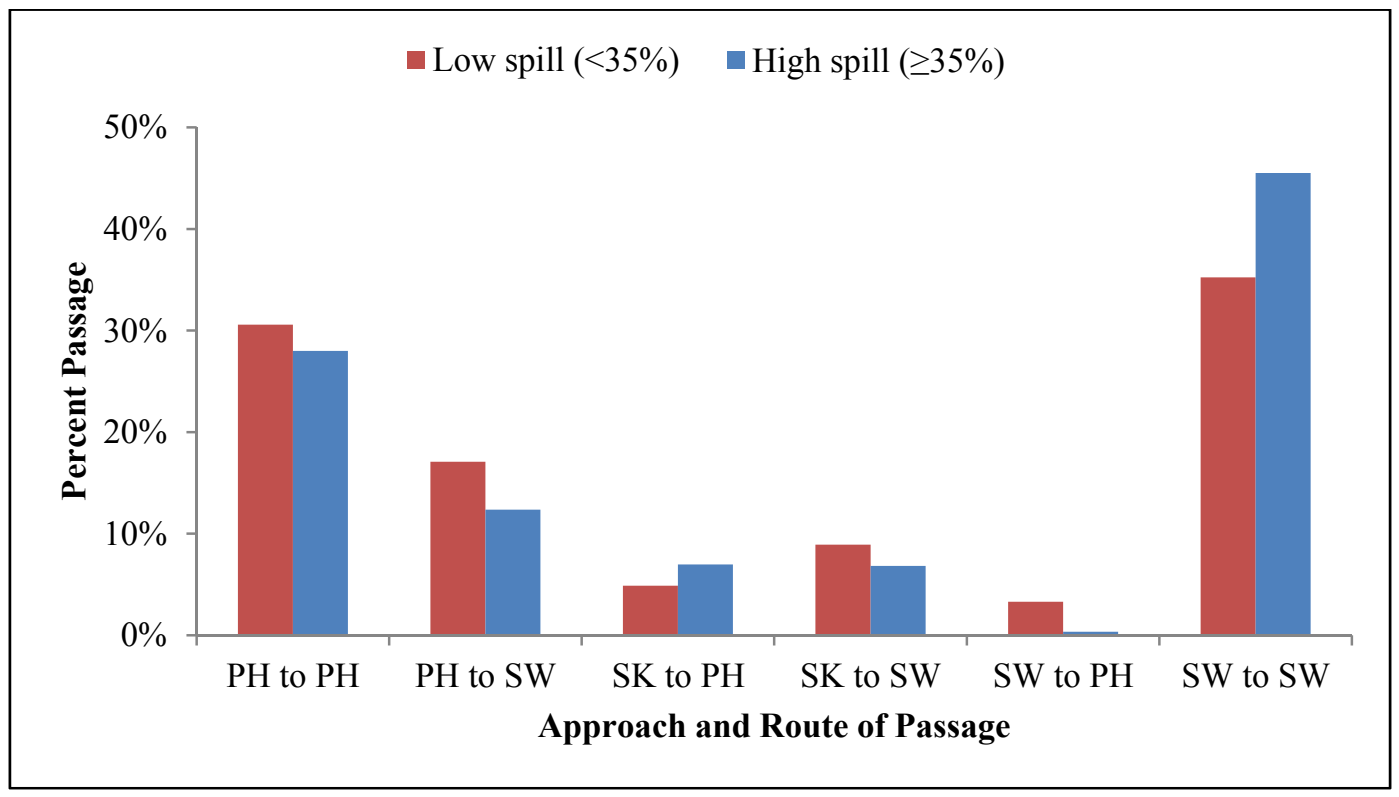

Figure 6.4. Approach and route of passage for $\mathrm{CH} 1$ passing during high spill ( $\geq 35 \%)$ and low spill $(<35 \%)$. The first abbreviation is for the approach location and the second is for the passage location $(\mathrm{PH}=$ powerhouse; $\mathrm{SK}=$ skeleton bay; $\mathrm{SW}=$ spillway). 


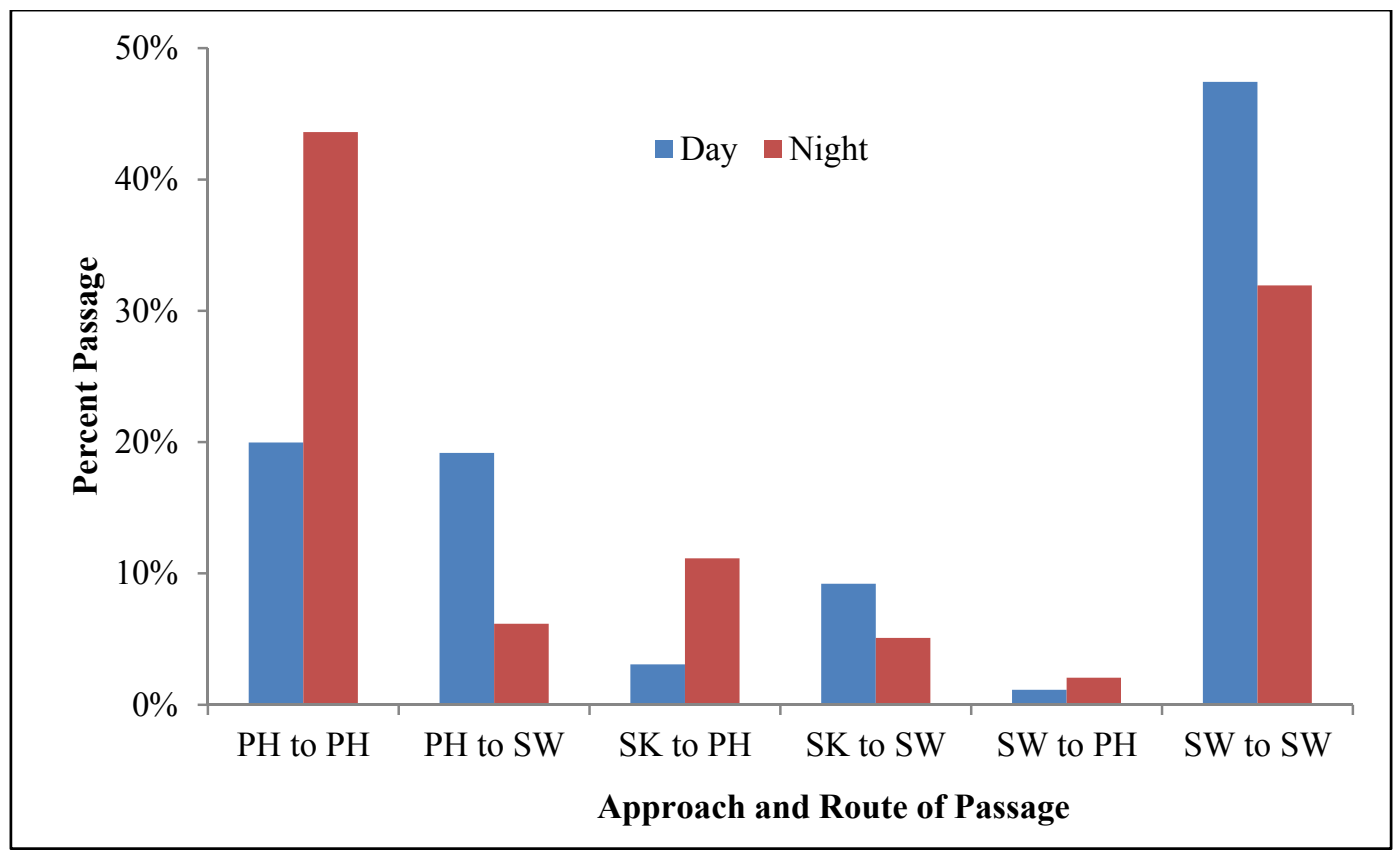

Figure 6.5. $\mathrm{CH} 1$ approach and passage distributions during day and night. The first abbreviation is for the approach location and the second is for the passage location $(\mathrm{PH}=$ powerhouse; $\mathrm{SK}=$ skeleton bay; $\mathrm{SW}=$ spillway).

Median residence times of $\mathrm{CH} 1$ approaching and passing JDA by various routes during all time periods and spill treatments were generally less than $1 \mathrm{~h}$ (Table 6.9). However, $\mathrm{CH} 1$ that approached the spillway and passed at the powerhouse or vice versa had residence times greater than $1 \mathrm{~h}$ except when spill exceeded $35 \%$. The shortest residence times $(\leq 0.10 \mathrm{~h})$ were observed for fish approaching and passing at the spillway during all treatments. The longest residence time $(3.60 \mathrm{~h})$ was observed for fish approaching the powerhouse and passing at the spillway during the night.

Table 6.9. $\mathrm{CH} 1$ forebay median residence time (h) by approach and passage routes during day, night, low spill $(<35 \%)$, and high spill $(\geq 35 \%)$.

\begin{tabular}{lccccc}
\hline & \multicolumn{5}{c}{ Median Forebay Residence Time $(\mathrm{h})$} \\
\cline { 2 - 6 } Approach and Passage & All & Day & Night & Spill $<35 \%$ & Spill $\geq 35 \%$ \\
\hline Powerhouse to powerhouse & 0.26 & 0.82 & 0.12 & 0.45 & 0.20 \\
Powerhouse to spillway & 1.85 & 1.52 & 3.60 & 1.96 & 1.77 \\
Skeleton bays to powerhouse & 0.34 & 0.96 & 0.22 & 0.78 & 0.28 \\
Skeleton bays to spillway & 0.22 & 0.27 & 0.19 & 0.33 & 0.18 \\
Spillway to powerhouse & 2.81 & 1.32 & 3.11 & 3.11 & 0.86 \\
Spillway to spillway & 0.06 & 0.05 & 0.06 & 0.10 & 0.04 \\
\hline
\end{tabular}




\subsubsection{Forebay Vertical Distribution}

Overall, $\mathrm{CH} 1$ were vertically distributed at depths $<8 \mathrm{~m}$ below the shallow reference hydrophone at the powerhouse (251.39 ft above MSL, about $4 \mathrm{~m}$ below the surface of the water) as they approached JDA from a distance of $75 \mathrm{~m}$ to $10 \mathrm{~m}$ (Figure 6.6). CH1 vertical distribution within $75 \mathrm{~m}$ of the JDA dam face was fairly uniform for both day and night, but fish approaching the powerhouse at night tended to migrate deeper $(\sim 2-3 \mathrm{~m})$ than fish approaching during the day (Figure 6.7; Figure 6.8). For CH1 approaching the powerhouse at a distance of $\leq 5 \mathrm{~m}$ from the dam face, the depth of travel increased to $\sim 25 \mathrm{~m}$, as expected for JBS- and turbine-passed fish.

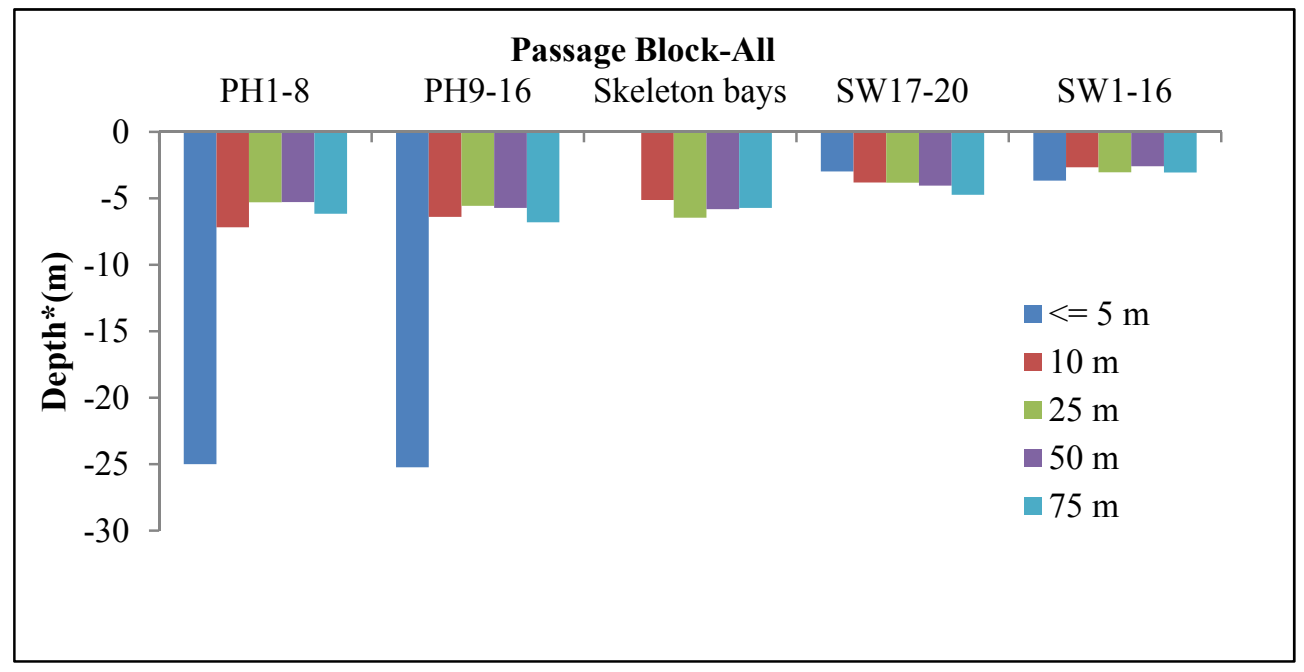

Figure 6.6. Median depth at last detection of tagged $\mathrm{CH} 1$ at John Day Dam (PH = powerhouse; $\mathrm{SW}=$ spillway). Depth distribution is referenced to hydrophone P00_01S at the south end of the powerhouse at $251.39 \mathrm{ft}$ above MSL, about $4 \mathrm{~m}$ below the surface of the water.

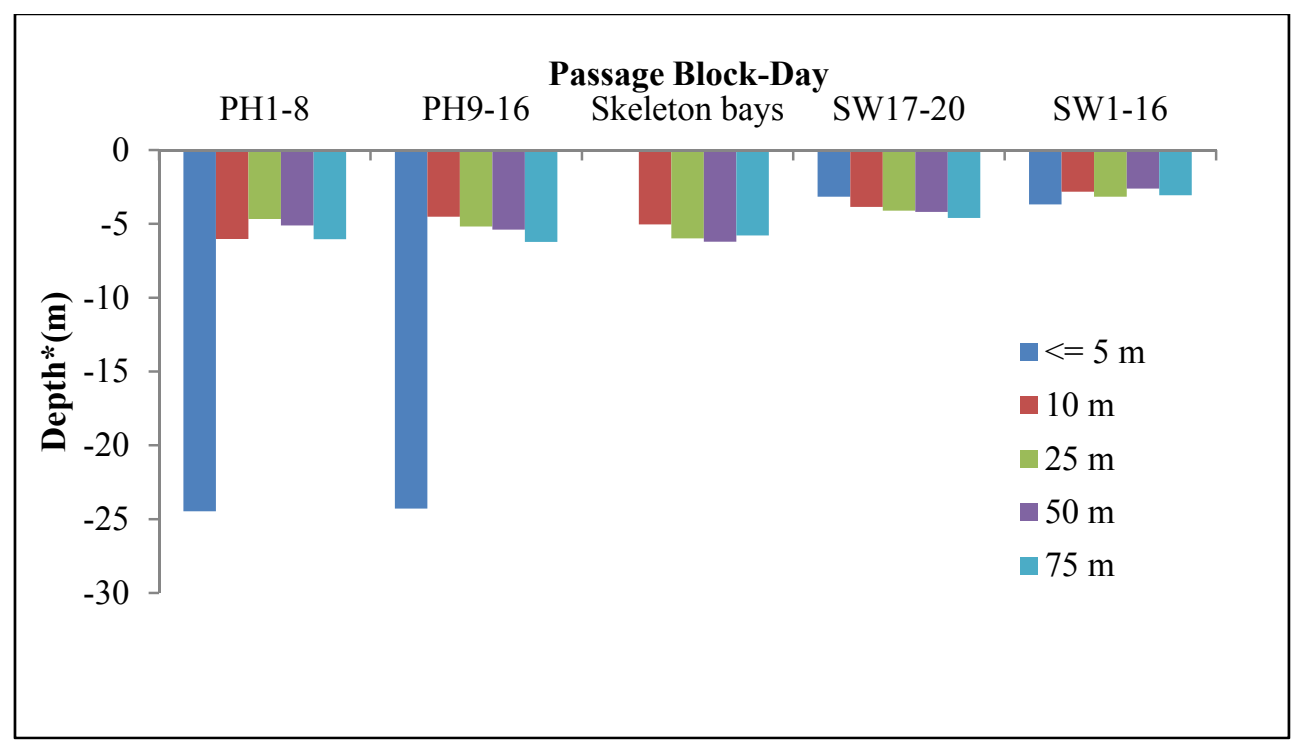

Figure 6.7. Median depth at last detection of tagged $\mathrm{CH} 1$ at John Day dam during the day $(\mathrm{PH}=$ powerhouse; $\mathrm{SB}=$ spill bay). Depth distribution is referenced to hydrophone P00_01S at the south end of the powerhouse at $251.39 \mathrm{ft}$ above MSL, about $4 \mathrm{~m}$ below the surface of the water. 


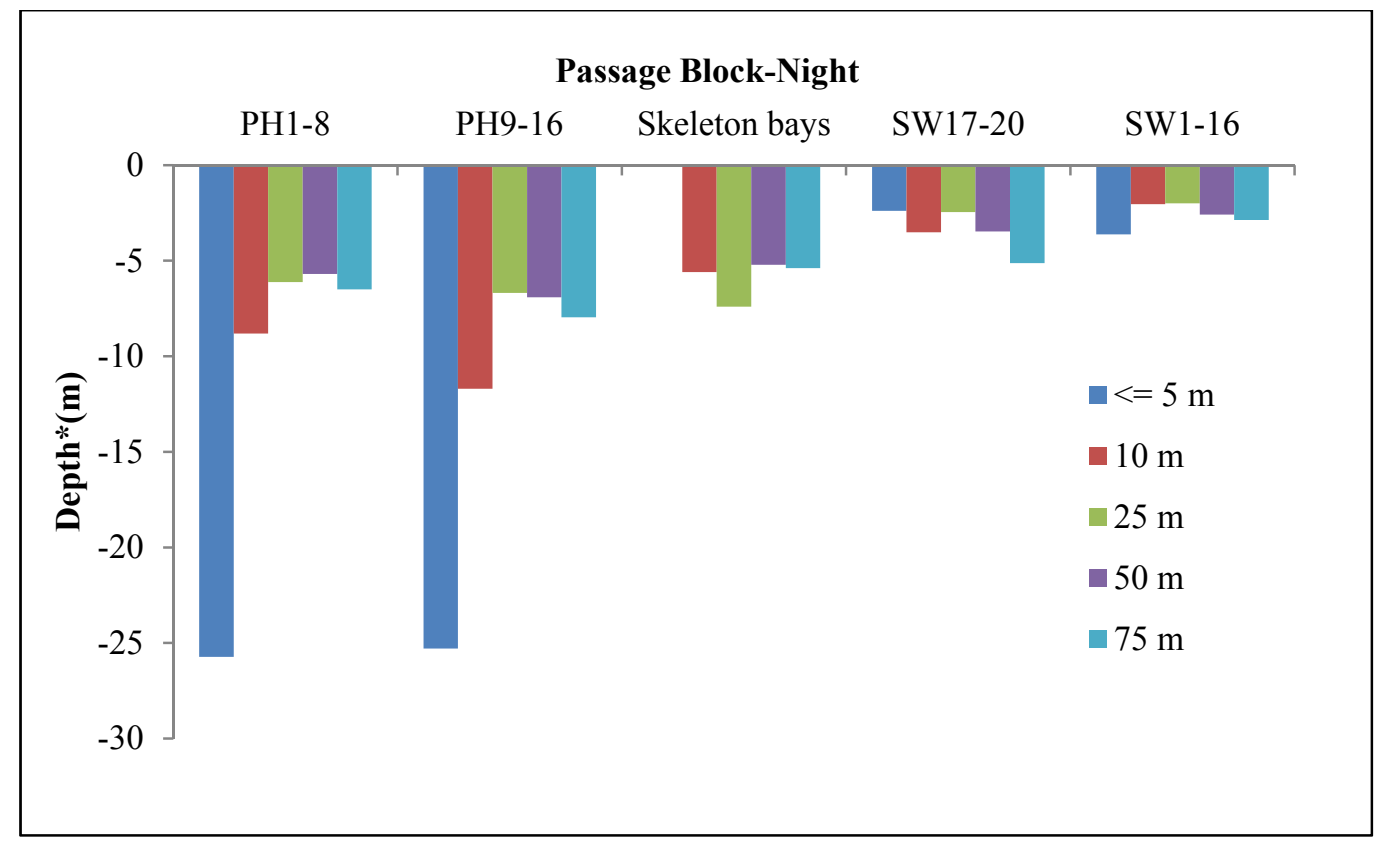

Figure 6.8. Median depth at last detection of tagged $\mathrm{CH} 1$ at John Day Dam at night $(\mathrm{PH}=$ powerhouse; $\mathrm{SB}=$ spill bay). Depth distribution is referenced to hydrophone P00_01S at the south end of the powerhouse at $251.39 \mathrm{ft}$ above MSL, about $4 \mathrm{~m}$ below the surface of the water. 


\subsection{Results - Juvenile Steelhead}

This section contains survival estimates, spill test effects, travel times, estimates of passage efficiency, and fish passage distributions for STH at JDA during the spring of 2011. Tagging and release data, capture-history data, detection and survival probabilities, and the performance of JSATS equipment are presented in Appendices C, E, F, and G, respectively. The assessment of model assumptions showed that the assumptions were met, allowing estimation of survival rates for STH (Appendix H).

\subsection{Survival Estimates}

Dam passage survival estimates $[\hat{\mathrm{S}}( \pm \mathrm{SE})]$ were determined using a virtual/paired-release model for 2,469 STH tagged with AMTs released at CR390 and regrouped at the JDA dam-face array, to form a virtual release $\left(V_{2}\right)$. Survival was estimated to CR346, the most downstream edge of the tailrace hydraulic influence. Paired releases of STH at CR346 $\left(R_{2} ; \mathrm{n}=1,196\right)$ and CR325 $\left(R_{3} ; \mathrm{n}=797\right)$ were used to estimate delayed mortality associated with dam passage and account for mortality associated with migration through various reaches downstream of JDA. Season-wide dam passage survival for STH was $98.7 \pm 0.006$ and forebay-to-tailrace survival (BRZ-to-BRZ) was $98.0 \pm 0.006$ (Table 7.1); both exceeded the BiOp criterion with $>96 \%$ survival and standard error estimates of $\leq 1.5$. Early season estimates met the BiOp criterion as well.

Route-specific survival for STH exceeded $98 \%$ for all routes except for turbine passage (Table 7.2). Turbine passage at JDA had the lowest survival estimate of $79.7 \pm 0.042$ and the least amount of tagged STH passed via this route. The highest survival rate was observed for fish passing through the JBS $(100.3 \pm 0.006)$.

Table 7.1. STH virtual/paired-release survival estimates from the John Day Dam forebay entrance and dam face to the John Day Dam tailrace.

\begin{tabular}{lcccc}
\hline & Early & \multicolumn{3}{c}{ Season } \\
Reach & Spring & SE & Wide & SE \\
\hline JDA dam passage survival (CR349 to CR346) & 0.986 & 0.008 & 0.987 & 0.006 \\
JDA forebay entrance to tailrace (CR351 to CR346) & 0.975 & 0.008 & 0.980 & 0.006 \\
\hline
\end{tabular}

Table 7.2. STH season-wide route-specific virtual/paired-release survival estimates from the dam face virtual release at John Day Dam to the JDA tailrace (CR349 to CR346).

\begin{tabular}{lccr}
\hline \multicolumn{1}{c}{ Route } & Estimate & SE & \multicolumn{1}{c}{$\mathrm{n}$} \\
\hline Spillway & 0.990 & 0.006 & 1,555 \\
TSW & 0.989 & 0.007 & 799 \\
Non-TSW & 0.990 & 0.007 & 756 \\
JBS & 1.003 & 0.006 & 815 \\
Turbines & 0.797 & 0.042 & 99 \\
\hline
\end{tabular}




\subsection{Estimates of Passage Efficiency}

During spring 2011, the FPE for STH was $96.0 \%$ and the SPE was $62.8 \%$ (Table 7.3). The TSWE relative to the dam and spillway were $32.3 \%$ and $51.4 \%$, respectively. Fish guidance efficiency was $89.3 \%$ and JBSE was $33.2 \%$.

Table 7.3. Season-wide estimates of major fish passage metrics for STH at John Day Dam in 2011.

\begin{tabular}{lcc}
\hline & \multicolumn{2}{c}{ All Season } \\
\cline { 2 - 3 } \multicolumn{1}{c}{ Metric } & Estimate & SE \\
\hline FPE $\|$ Dam $^{(a)}$ & 0.960 & 0.004 \\
SPE $\|$ Dam $^{(a)}$ & 0.628 & 0.010 \\
TSWE $\|$ Dam $^{(a)}$ & 0.323 & 0.009 \\
TSWE $\|$ Spillway & 0.514 & 0.013 \\
FGE (powerhouse screen efficiency) & 0.893 & 0.010 \\
JBSE $\|$ Dam $^{(\text {a) }}$ & 0.332 & 0.009 \\
\hline
\end{tabular}

(a) If dam route is included, proportions will not add to 1 .

\subsection{Day/Night Trends}

Steelhead passage data, divided into day (0600 to $2159 \mathrm{~h}$ ) and night (2200 to $0559 \mathrm{~h}$ ) periods, showed no significant differences in dam passage and forebay-to-tailrace (BRZ-to-BRZ) survival estimates between day and night (Table 7.4), as indicated by overlapping 95\% confidence intervals.

The FPE, SPE, and TSWE relative to the dam and the spillway were significantly higher during the daytime than at nighttime (Table 7.5), as indicated by $95 \%$ confidence intervals. In contrast, JBSE was significantly lower during the day than at night. There was no significant difference in FGE when comparing day and night.

Table 7.4. Comparison of day/night season-wide paired-release estimates of survival for STH for dam passage (CR349 to CR346) and forebay to tailrace (CR351 to CR346) survival. Estimates were not corrected for tag life.

\begin{tabular}{lcccccr}
\hline & \multicolumn{3}{c}{ Day } & \multicolumn{4}{c}{ Night } \\
\cline { 2 - 7 } \multicolumn{1}{c}{ Survival Reach } & Estimate & SE & $\mathrm{n}$ & Estimate & SE & \multicolumn{1}{c}{$\mathrm{n}$} \\
\hline Dam passage & 0.987 & 0.007 & 1,361 & 0.987 & 0.007 & 1,108 \\
Forebay array to tailrace & 0.978 & 0.007 & 1,515 & 0.984 & 0.007 & 974 \\
\hline
\end{tabular}


Table 7.5. Comparison of season-wide day and night passage efficiencies for STH at John Day Dam in spring 2011. Significant difference $(*)$ is related to the $95 \%$ confidence intervals.

\begin{tabular}{|c|c|c|c|c|c|}
\hline \multirow[b]{2}{*}{ Metric } & \multicolumn{2}{|c|}{ Day } & \multicolumn{2}{|c|}{ Night } & \multirow[b]{2}{*}{ Sig Diff } \\
\hline & Estimate & SE & Estimate & SE & \\
\hline FPE \| Dam ${ }^{(a)}$ & 0.978 & 0.004 & 0.946 & 0.006 & $*$ \\
\hline SPE $\| \operatorname{Dam}^{(a)}$ & 0.853 & 0.011 & 0.448 & 0.013 & $*$ \\
\hline TSWE $\| \operatorname{Dam}^{(\mathrm{a})}$ & 0.560 & 0.015 & 0.134 & 0.009 & $*$ \\
\hline TSWE || Spillway & 0.656 & 0.016 & 0.298 & 0.018 & $*$ \\
\hline FGE (powerhouse screen efficiency) & 0.852 & 0.028 & 0.901 & 0.011 & \\
\hline JBSE $\| \operatorname{Dam}^{(a)}$ & 0.126 & 0.010 & 0.497 & 0.013 & $*$ \\
\hline
\end{tabular}

(a) If dam route is included, proportions will not add up to 1.

\subsection{Spill Test}

Two spill test levels were independently tested during the early season of the 2011 survival study. From April 27 until May 16 (early season) river water levels permitted alternating spill regimes of 30\% and $40 \%$ percent, but after May 16 (late season) high river flows necessitated $>40 \%$ spill and $30 \%$ and $40 \%$ discharge levels could not be maintained. Table 7.6 shows survival and fish passage metrics at the $30 \%$ and $40 \%$ spill test levels for the early spring season for STH.

Table 7.6. Early spring (April 27-May 16, 2011) estimates of major fish passage metrics and survival of STH during $30 \%$ and $40 \%$ spill tests.

\begin{tabular}{|c|c|c|c|c|}
\hline \multirow[b]{2}{*}{ Metric } & \multicolumn{2}{|c|}{$30 \%$ Spill } & \multicolumn{2}{|c|}{$40 \%$ Spill } \\
\hline & Estimate & SE & Estimate & SE \\
\hline Survival - Dam passage (CR349 to CR346) & 0.984 & 0.009 & 0.990 & 0.010 \\
\hline Survival - Forebay entrance to tailrace (CR351 to CR346) & 0.972 & 0.010 & 0.982 & 0.010 \\
\hline FPE $\|$ Dam $^{(a)}$ & 0.950 & 0.007 & 0.973 & 0.007 \\
\hline SPE $\| \operatorname{Dam}^{(a)}$ & 0.609 & 0.016 & 0.715 & 0.018 \\
\hline TSWE $\| \operatorname{Dam}^{(a)}$ & 0.398 & 0.016 & 0.450 & 0.020 \\
\hline TSWE || Spillway & 0.654 & 0.020 & 0.629 & 0.023 \\
\hline FGE (powerhouse screen efficiency) & 0.871 & 0.018 & 0.906 & 0.022 \\
\hline JBSE $\| \operatorname{Dam}^{(\mathrm{a})}$ & 0.340 & 0.016 & 0.258 & 0.018 \\
\hline
\end{tabular}

(a) If dam route is included, proportions will not add up to 1 .

\subsection{Travel Times}

There were 2,474 STH tagged with AMTs detected on the forebay array for which residence time could be estimated; they had a median residence time of $2.91 \mathrm{~h}$ (CR351 to CR349; Table 7.7). Median travel time from the JDA dam face to the tailrace egress array was $0.58 \mathrm{~h}$ (CR349 to CR346). Median project passage time from the JDA forebay entrance to the JDA egress array was $5.42 \mathrm{~h}$ (CR351 to CR346). 
Table 7.7. Travel times (h) for STH at John Day Dam in spring 2011. Standard errors are in parentheses.

\begin{tabular}{lccc}
\hline \multicolumn{1}{c}{ Route } & $\mathrm{n}$ & Median & Mean \\
\hline Forebay (CR351 to CR349 ) & 2,474 & $2.91 \mathrm{~h}$ & $6.89 \mathrm{~h}(0.20)$ \\
JDA egress time (CR349 to CR346) & 2,120 & $0.58 \mathrm{~h}$ & $9.09 \mathrm{~h}(0.70)$ \\
Project passage time (CR351 to CR346) & 2,121 & $5.42 \mathrm{~h}$ & $16.35 \mathrm{~h}(0.75)$ \\
\hline
\end{tabular}

\subsection{Fish Passage Distributions}

Horizontal distributions, forebay approach, and forebay vertical distributions for STH at JDA in spring 2011 are summarized in the following sections.

\subsubsection{Horizontal Distributions}

Of the total number of STH passing through JDA, 32.3\% passed through the TSW bays (bays 18 and 19) and $30.5 \%$ passed through non-TSW bays (Table 7.8). Total discharge through each of the TSW bays was comparable to most other spill bays; however, proportionally the TSW bays passed higher numbers of STH (Figure 7.1). The highest percent passage was observed at the JBS, where $33.2 \%$ of the total project passage occurred. The remaining $4.0 \%$ passed through the turbine units; total discharge through each turbine unit ranged from $3.2 \%$ to $4.6 \%$ of total discharge (Figure 7.2 ). The highest proportions of STH passing via turbine or JBS routes were observed at turbine units $02(6.5 \%)$ and $03(4.5 \%)$ and the lowest proportions were observed at units $10(1.3 \%)$ and $13(1.3 \%)$.

Table 7.8. Percent of total passage by route for STH at John Day Dam in spring 2011.

\begin{tabular}{lc}
\hline \multicolumn{1}{c}{ Parameter } & STH \\
\hline Percentage of total TSW passage & $32.3 \%$ \\
Percentage of total NTSW passage & $30.5 \%$ \\
Percentage of total JBS passage & $33.2 \%$ \\
Percentage of total turbine passage & $4.0 \%$ \\
\hline JBS = Juvenile bypass system. \\
NTSW = Non-top-spill weir. \\
TSW = Top-spill weir. \\
\hline
\end{tabular}




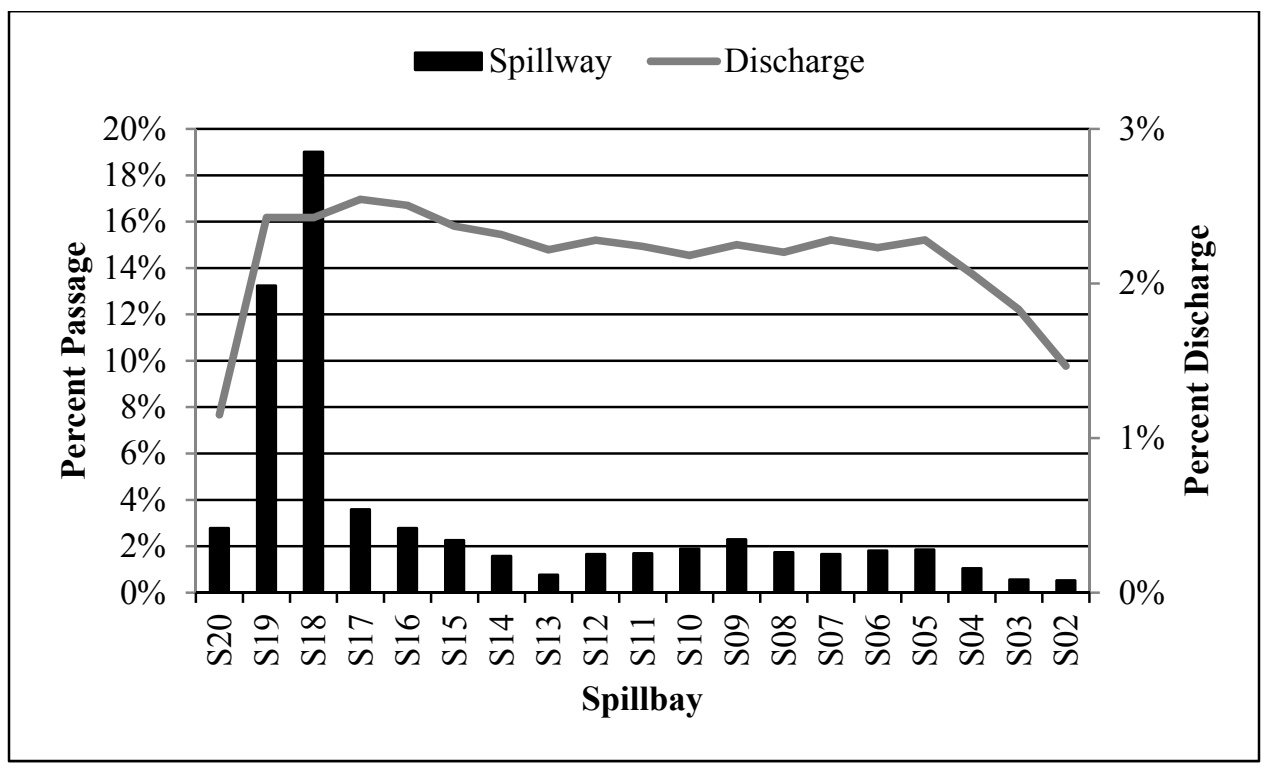

Figure 7.1. Percent discharge and passage proportions of STH by spill bay.

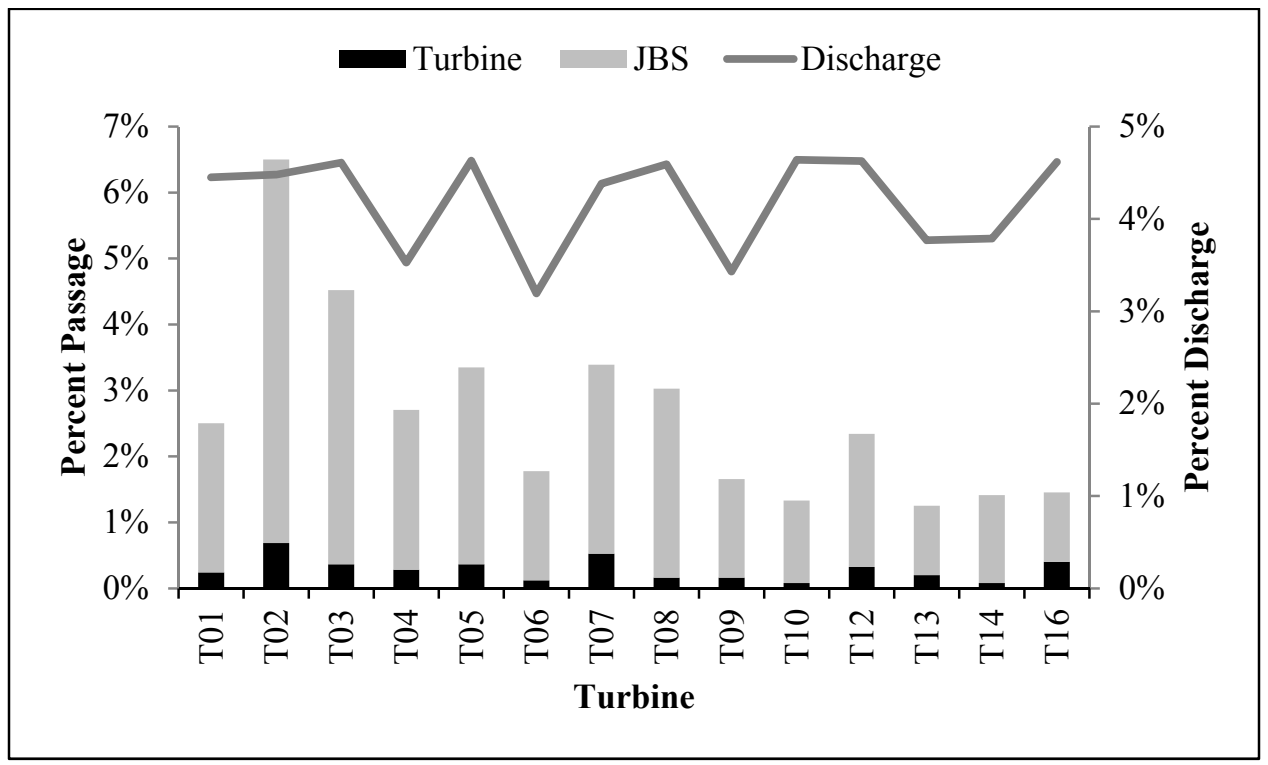

Figure 7.2. Passage distribution and percent discharge for turbine and JBS-passed STH at John Day Dam in 2011.

\subsubsection{Forebay Approach Distribution and Route Specific Passage Times}

The majority of STH that approached JDA approached and passed at the spillway ( 40\%; Figure 7.3). Minimal variation was observed when comparing approach and passage blocks by high spill-discharge levels ( $\geq 35 \%$ ) with low-level discharge ( $<35 \%$ ) (Figure 7.4$)$. There was however, $\sim 8 \%$ more STH approaching the spillway and passing by that same route during high spill. Approach and passage routes were more notable for day and night differences than for spill discharge levels (Table 7.9). The STH that approached the powerhouse at night were more likely to pass at the powerhouse than at the spillway, as was observed for STH approaching the powerhouse during the day (Figure 7.5). Approach and passage at 
the spillway was higher during the day than at night. A greater proportion of STH were observed approaching the powerhouse and passing at the spillway than vice versa during day and night periods.

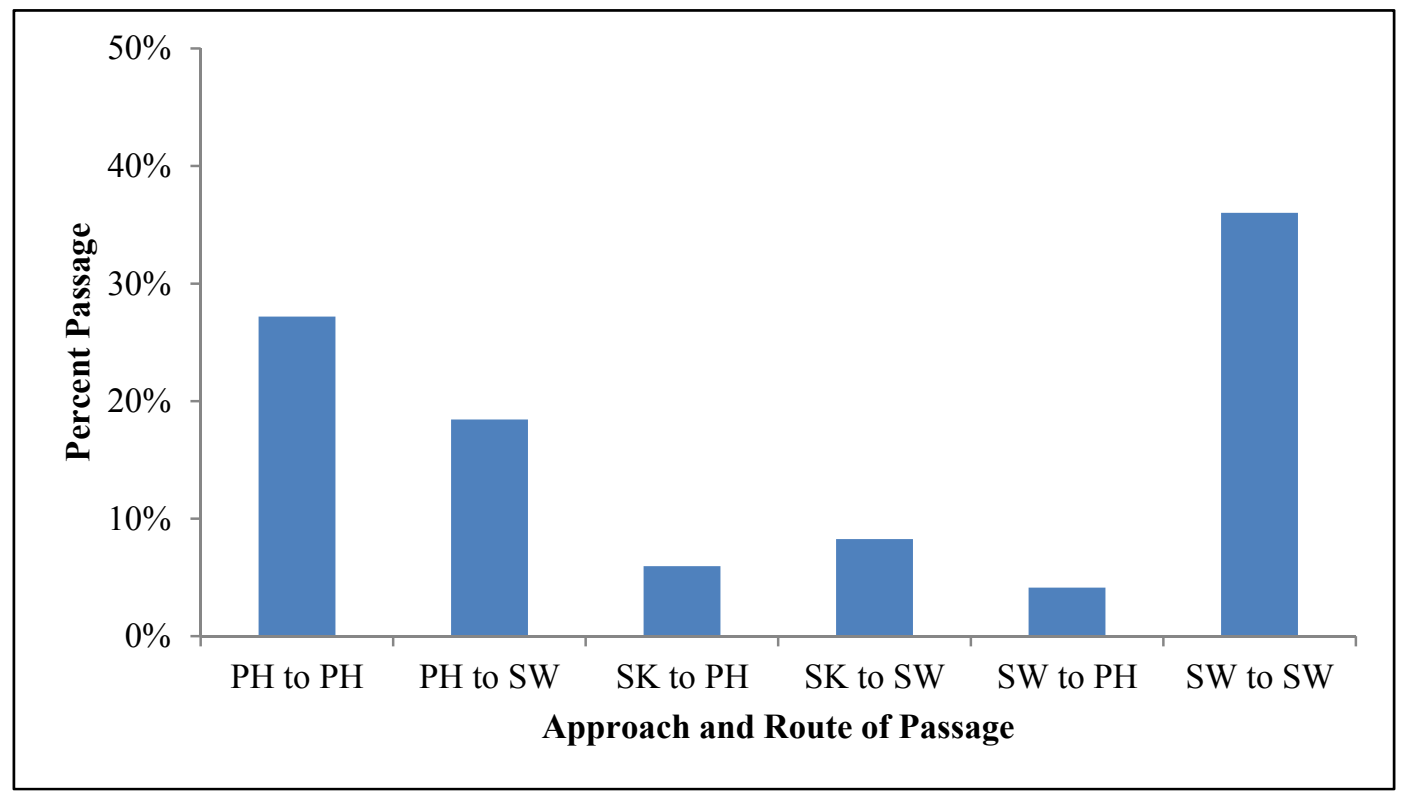

Figure 7.3. STH approach and passage distributions. The first abbreviation is for the approach location and the second is for the passage location $(\mathrm{PH}=$ powerhouse; $\mathrm{SK}=$ skeleton bay; $\mathrm{SW}=$ spillway).

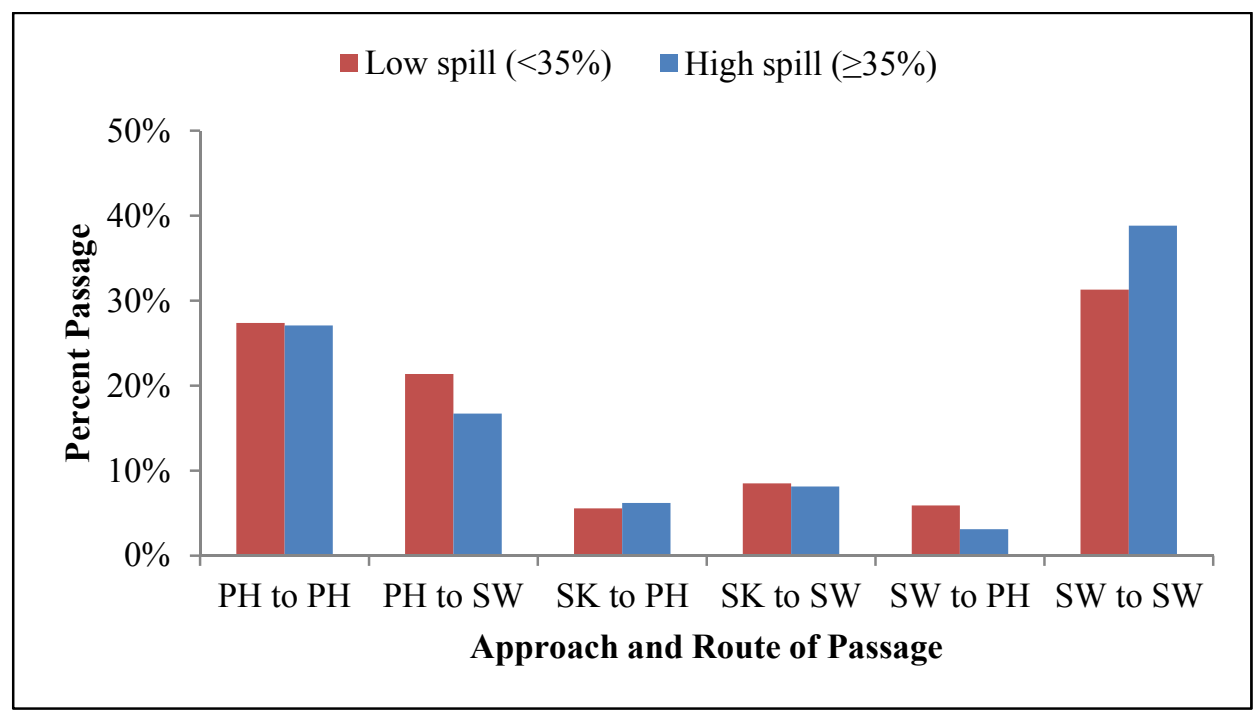

Figure 7.4. Approach and route of passage for STH passing during high spill ( $\geq 35 \%)$ and low spill $(<35 \%)$. The first abbreviation is for the approach location, and the second is for the passage location $(\mathrm{PH}=$ powerhouse; $\mathrm{SK}=$ skeleton bay; $\mathrm{SW}=$ spillway $)$. 
Table 7.9. STH median residence time (h) by approach and passage distributions during day, night, low spill $(<35 \%)$, and high spill ( $\geq 35 \%)$.

\begin{tabular}{lccccc}
\hline & \multicolumn{5}{c}{ Median Residence Time (h) } \\
\cline { 2 - 6 } Approach and Passage & All & Day & Night & Spill $<35 \%$ & Spill $\geq 35 \%$ \\
\hline Powerhouse to powerhouse & 0.31 & 0.79 & 0.25 & 0.35 & 0.29 \\
Powerhouse to spillway & 2.97 & 2.15 & 8.07 & 2.32 & 3.55 \\
Skeleton bays to powerhouse & 0.54 & 1.19 & 0.40 & 0.77 & 0.45 \\
Skeleton bays to spillway & 0.36 & 0.56 & 0.30 & 1.02 & 0.28 \\
Spillway to powerhouse & 8.45 & 5.82 & 8.62 & 9.67 & 7.88 \\
Spillway to spillway & 0.16 & 0.28 & 0.11 & 0.25 & 0.12 \\
\hline
\end{tabular}

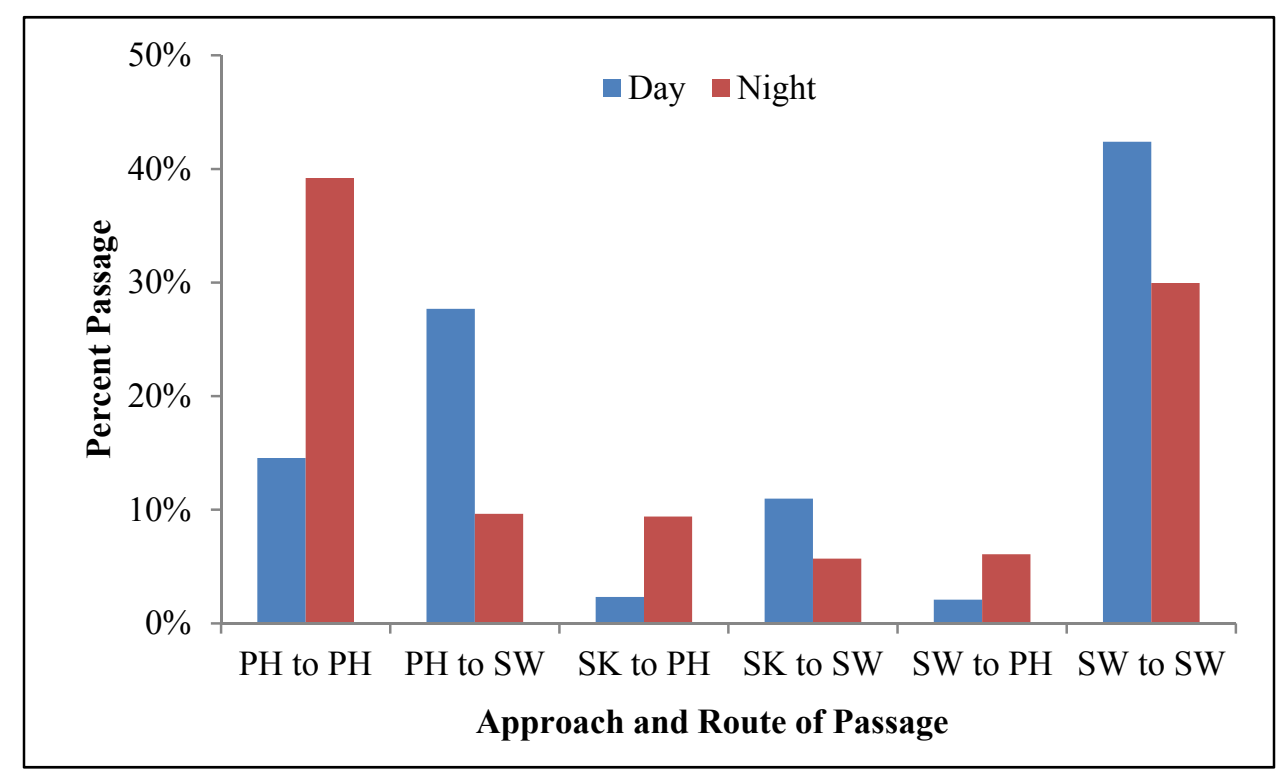

Figure 7.5. STH approach and passage distributions during day and night. The first abbreviation is for the approach location, and the second is for the passage location $(\mathrm{PH}=$ powerhouse; $\mathrm{SK}=$ skeleton bay; $\mathrm{SW}=$ spillway).

Median residence times of STH approaching and passing JDA via the same route during all time periods and spill treatments were less than $0.8 \mathrm{~h}$ (Table 7.9). In addition, STH that approached the skeleton bays and passed via the spillway or powerhouse had residences times of about $1 \mathrm{~h}$ or less. The STH that approached the spillway and passed at the powerhouse, or vice versa, had residence times greater than $2 \mathrm{~h}$. The shortest residence times $(\leq 0.28 \mathrm{~h})$ were generally observed for fish approaching and passing at the spillway during all treatments and periods.

\subsubsection{Forebay Vertical Distribution}

Overall, STH were vertically distributed at depths $<8 \mathrm{~m}$ below the shallow reference hydrophone (251.39 $\mathrm{ft}$ above MSL) at the powerhouse as they approached JDA from a distance of $75 \mathrm{~m}$ to $10 \mathrm{~m}$ from the dam face (Figure 7.6). Their vertical distribution within the 75-m range of the JDA dam face was fairly uniform for both day and night; however, STH tended to migrate deeper $(\sim 1-7 \mathrm{~m})$ at night than 
during the day for both powerhouse- and spillway-passed fish (Figure 7.7; Figure 7.8). The STH approaching the powerhouse at a distance of $\leq 5 \mathrm{~m}$ from the dam face travelled at increased depths of $\sim 25 \mathrm{~m}$, as expected for JBS- and turbine-passed fish.

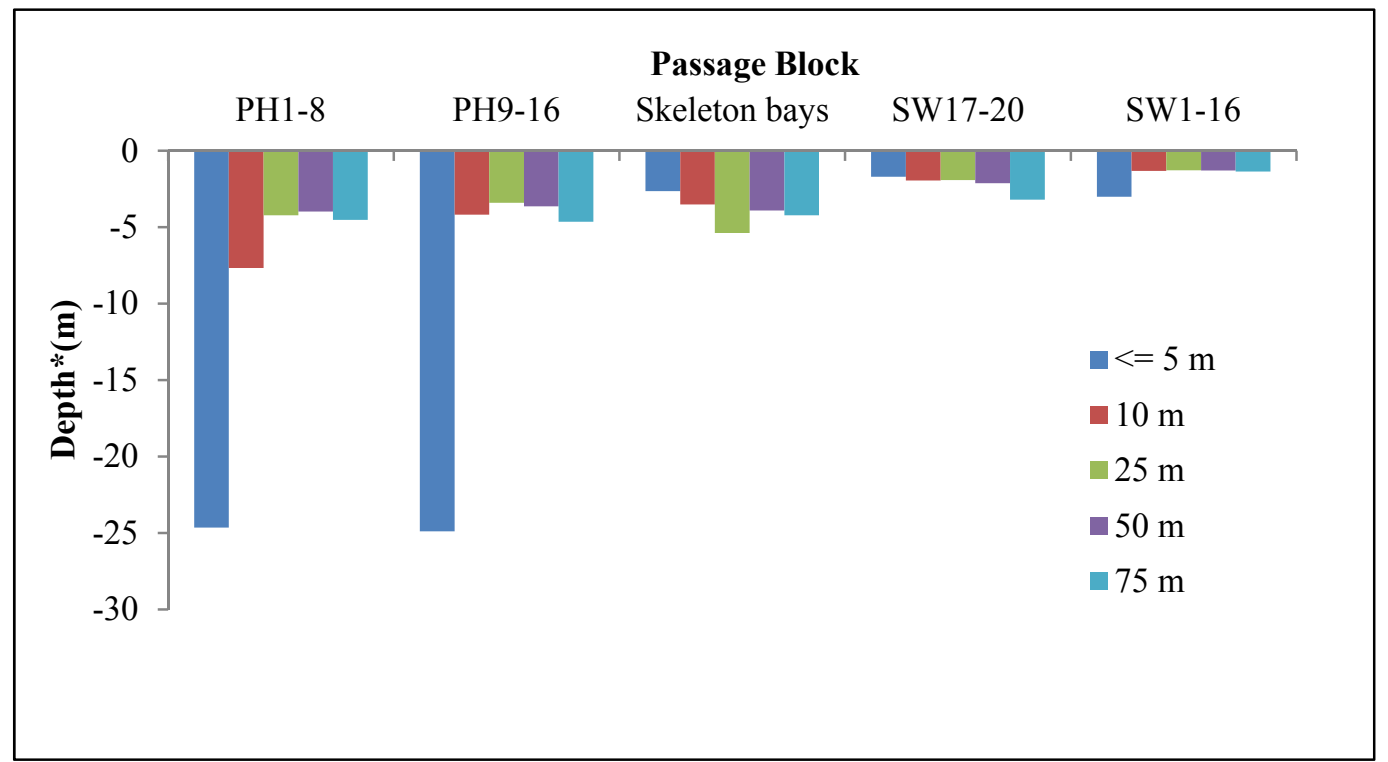

Figure 7.6. Median depth at last detection of tagged STH at John Day Dam (PH = powerhouse; $\mathrm{SB}=$ spill bay). Depth distribution is referenced to hydrophone P00_01S at the south end of the powerhouse at $251.39 \mathrm{ft}$ above MSL, about $4 \mathrm{~m}$ below the surface of the water.

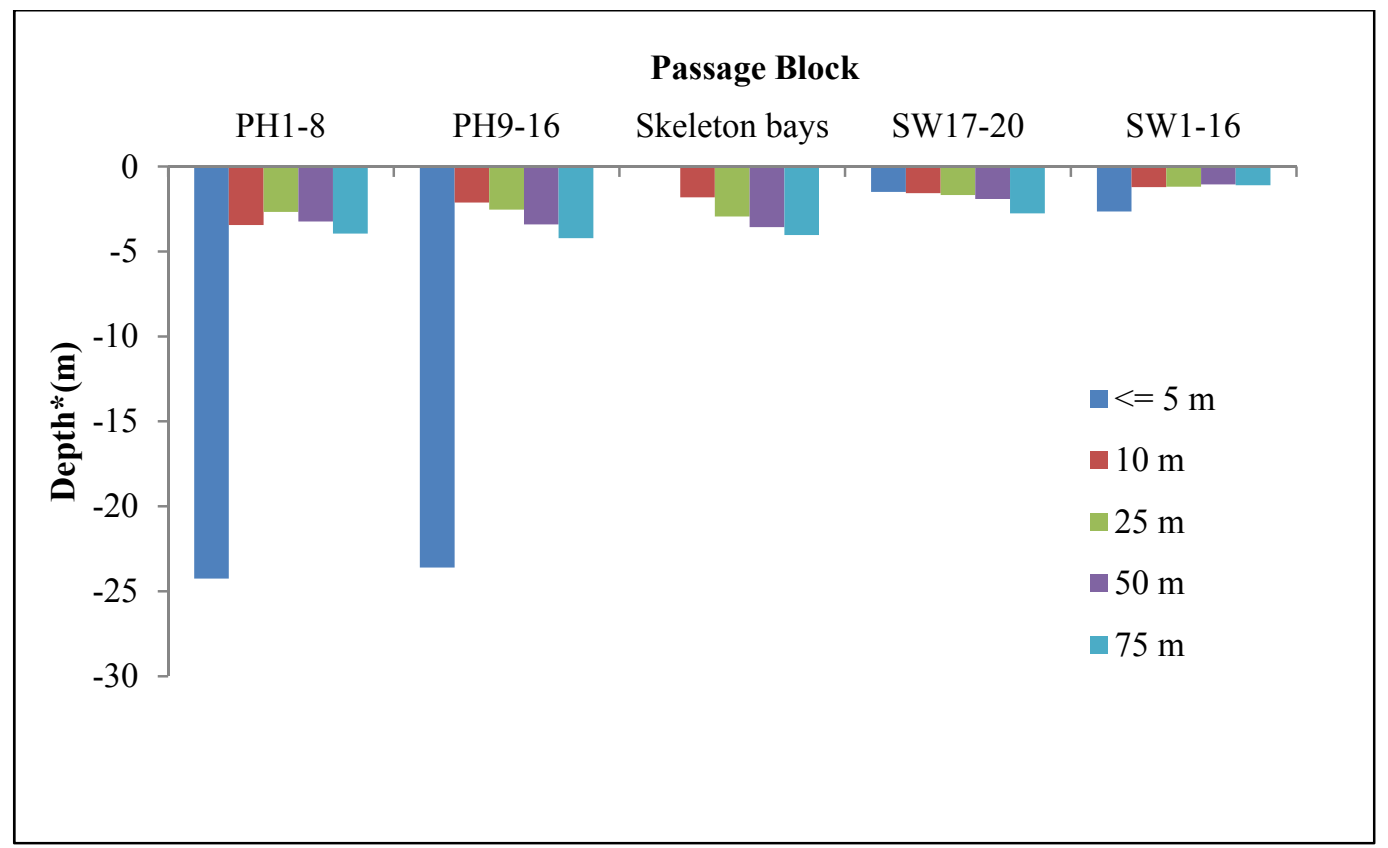

Figure 7.7. Median depth at last detection of tagged STH at John Day Dam during the day $(\mathrm{PH}=$ powerhouse; $\mathrm{SB}=$ spill bay). Depth distribution is referenced to hydrophone P00_01S at the south end of the powerhouse at $251.39 \mathrm{ft}$ above MSL, about $4 \mathrm{~m}$ below the surface of the water. 


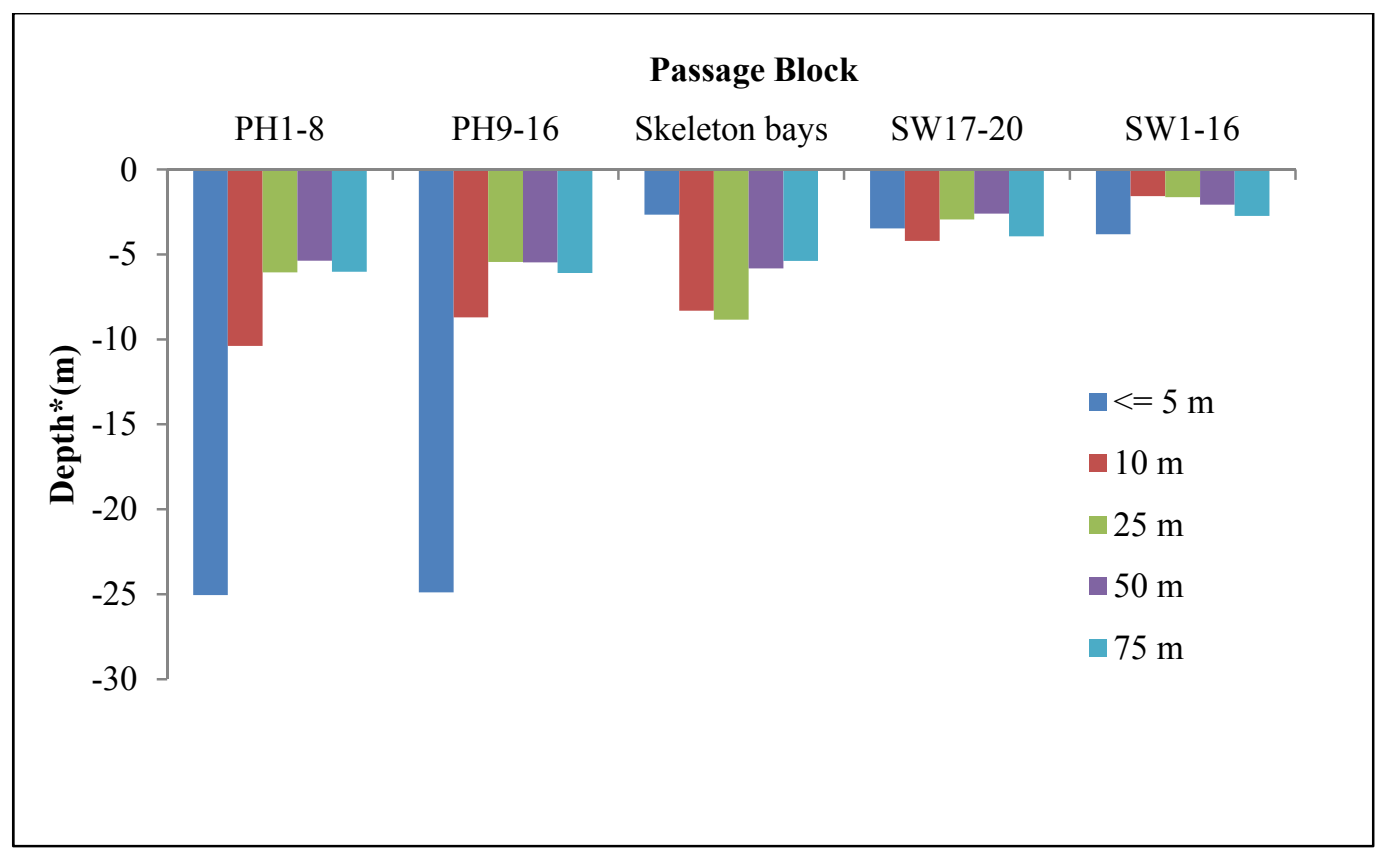

Figure 7.8. Median depth at last detection of tagged STH at John Day Dam at night $(\mathrm{PH}=$ powerhouse; $\mathrm{SB}=$ spill bay). Depth distribution is referenced to hydrophone P00_01S at the south end of the powerhouse at $251.39 \mathrm{ft}$ above MSL, about $4 \mathrm{~m}$ below the surface of the water. 


\subsection{Discussion}

This section includes discussions of statistical performance and survival model assumptions, and provides a historical context for survival estimates and passage efficiency results for $\mathrm{CH} 1$ and STH in spring 2011 at JDA.

\subsection{Statistical Performance and Survival Model Assumptions}

The 2011 survival study at JDA was an official BiOp compliance test for spring migrating CH1 and STH using the virtual/paired-release study design (Skalski et al. 2010). Previous studies at JDA (Weiland et al. 2009, 2011a, 2013) allowed researchers to design the 2011 study to meet precision requirements for survival estimates $(\mathrm{SE} \leq 0.015)$ set forth in the BiOp. In addition, researchers were able to verify that model assumptions were being met to ensure the study provided valid and precise data on fish survival rates, passage rates, and behavior (Skalski et al. 1998, 2009, 2010) (Appendix B, G, and H).

Results from JSATS hydrophone performance tests (Appendix G) and survival model assumptions tests (Appendix H) indicated that model assumptions were met during the 2011 study. The JSATS hydrophone arrays performed well as indicated by the high detection probabilities $(>85 \%)$. In particular, the JDA dam-face cabled arrays independently had $99 \%$ and $100 \%$ detection probabilities with a combined detection probability of $100 \%$ for both species. Detection probabilities at or near $100 \%$ for the JDA dam-face arrays in the 2010 and 2011 studies are the result of advancements in hydrophone technology and adjustments made to detection equipment after the 2009 survival study (Weiland et al. 2011a, 2013). The downstream detection arrays had detection probabilities $>85 \%$ and most exceeded $98 \%$. The average tag life was more than $30 \mathrm{~d}$, and the probability that an AMT was still active when a fish arrived at a downstream detection site exceeded $99 \%$. Therefore, only minimal tag-life corrections were used in survival estimates. The different tag lots used in the study had no significant effect on observed juvenile salmonid survival rates; therefore, fish tagged from all tag lots were used in the analyses. The fact none of the dead fish with acoustic transmitters released in the JDA spillway were detected indicates that the first downstream detection site used in survival estimates (i.e., rkm 325) was located far enough downstream to avoid false-positive detection of dead fish.

The tagged fish populations reasonably represented the respective runs-at-large. Comparison of fish tagged with AMT to ROR fish passing through the JDA SMF shows that the length frequency distributions were similar for both $\mathrm{CH} 1$ and $\mathrm{STH}$. In addition, the run timings of downstream migrating $\mathrm{CH} 1$ and STH, as indicated by the smolt passage index from the JDA Smolt Monitoring Program (SMP), were comparable to the run timing of fish tagged at the JDA SMF in 2011. Downstream mixing of different release groups was adequate. There was no consistent or reproducible evidence to suggest that the amount of time (i.e., distance) in-river had a subsequent effect on downriver juvenile salmonid survival for either $\mathrm{CH} 1$ or $\mathrm{STH}$ and survival rates did not differ significantly among tailrace release locations.

Because of the stringent methods used in the handling, tagging, and release procedures in addition to extensive surgical training, post-tagging mortality in spring 2011 was extremely low $(0.19 \%)$ for all fish tagged and released for the survival study. Specifically, mortality was $0.31 \%(n=24)$ for $\mathrm{CH} 1$ and $0.08 \%(n=6)$ for STH. Also, no tags were shed during the post-tagging and pre-release holding period. Analyses indicated no evidence of a delayed handling/tag effect influencing the survival studies. The 
tagging effort was appropriately balanced among all taggers, and fish tagged by all taggers were considered acceptable for the survival analyses.

These results confirmed that acoustic tag codes were accurately recorded at the detection sites, fish could be correctly assigned to specific release groups (e.g., virtual-release group), and detection probabilities were equal and independent. The results also confirm estimates of passage numbers at specific routes were correctly estimated and survival estimates were not biased (Skalski et al. 1998, 2009, 2010).

\subsection{Historical Context}

The following sections contain comparisons of historical survival estimates and passage efficiencies with information collected during the 2011 study. Historical comparisons include estimates of passage efficiencies during $30 \%$ and $40 \%$ spill treatments.

\subsubsection{Survival Estimates}

The spring compliance study at JDA in 2011 was interrupted by high flows on approximately May 16, when spill discharge exceeded $40 \%$ and was maintained at those levels for the duration of the spring study. However, dam passage and forebay-to- tailrace paired-release survival estimates for $\mathrm{CH} 1$ and STH were comparable for the early season (i.e., during 30\% and 40\% spill treatments) and the entire study period (i.e., when spill generally exceeded 40\%) (Table 8.1). Comparisons of survival between $30 \%$ and $40 \%$ spill treatments during the early part of the 2011 study were limited by sample size. However, the differences observed were minor. In addition, survival estimate comparisons in previous studies have not displayed consistent results and generally there were no significant differences between the spill treatments (Weiland et al. 2009, 2011a, 2013). The estimates for CH1 and STH met the $96 \%$ performance standard set forth in the $2008 \mathrm{BiOp}$ for spring migrants as well as precision requirements with $\mathrm{SE} \leq 0.015$.

Results from previous studies conducted in 2008, 2009, and 2010 (Weiland et al. 2009, 2011a, 2013) were comparable to results observed in 2011. Route-specific survival estimates for the four most recent JSATS survival studies at JDA are shown in Figure 8.1 (CH1) and Figure 8.2 (STH). Turbine passage had consistently lower survival rates for both species regardless of study year and this has been described at other Snake and Columbia River dams (Muir et al. 2001; Johnson et al. 2010). Numerous studies have described the potential sources of mortality associated with hydroelectric turbine passage including rapid pressure changes, cavitation, shear stress, turbulence, strike, and grinding and these factors likely play a role in the reduced survival rates observed at JDA (Cada 2001). In particular, STH turbine passage survival at JDA was consistently lower than that observed for $\mathrm{CH} 1$, which is likely attributed to size differences between the species. On average, STH are larger fish, and studies have shown that turbine passage mortality increases with juvenile salmonid size (Skalski et al. 2002). Point estimates of virtualrelease survival through the various routes at JDA for both species were generally higher in 2011 than in previous years, regardless of route of passage. The largest difference observed was for turbine-passed $\mathrm{CH} 1$ in 2011 with a survival estimate that was about 5\% higher than previously observed and about $13 \%$ higher than observed in 2010. 
Table 8.1. Survival from the John Day Dam forebay entrance and dam face to the John Day Dam tailrace (CR349 to CR346) in spring 2011.

\begin{tabular}{|c|c|c|c|c|c|}
\hline \multirow[b]{2}{*}{ Species } & \multirow[b]{2}{*}{ Metric } & \multicolumn{2}{|c|}{ Early Season } & \multicolumn{2}{|c|}{ Season Wide } \\
\hline & & Survival & SE & Survival & SE \\
\hline \multirow[b]{2}{*}{$\mathrm{CH} 1$} & JDA dam passage survival (CR349 to CR346) & 0.971 & 0.009 & 0.968 & 0.007 \\
\hline & $\begin{array}{l}\text { JDA forebay-to-tailrace survival (CR351 to } \\
\text { CR346) }\end{array}$ & 0.970 & 0.009 & 0.965 & 0.007 \\
\hline \multirow[b]{2}{*}{ STH } & JDA dam passage survival (CR349 to CR346) & 0.986 & 0.008 & 0.987 & 0.006 \\
\hline & $\begin{array}{l}\text { JDA forebay-to-tailrace survival (CR351 to } \\
\text { CR346) }\end{array}$ & 0.975 & 0.008 & 0.980 & 0.006 \\
\hline
\end{tabular}

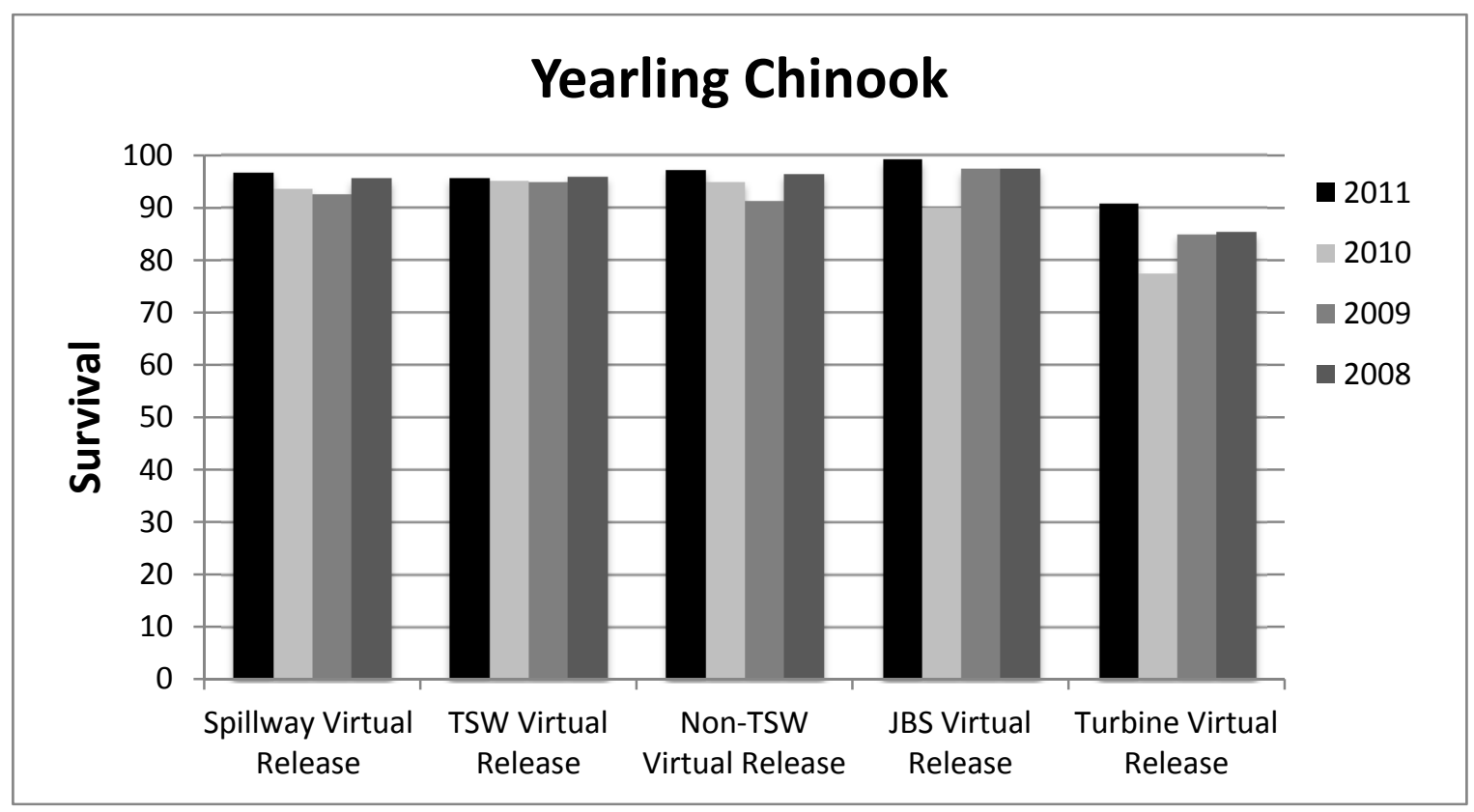

Figure 8.1. Route-specific survival for $\mathrm{CH} 1$ from the dam-face virtual release at John Day Dam to The Dalles Dam tailrace (CR349 to CR309), 2008-2011. 


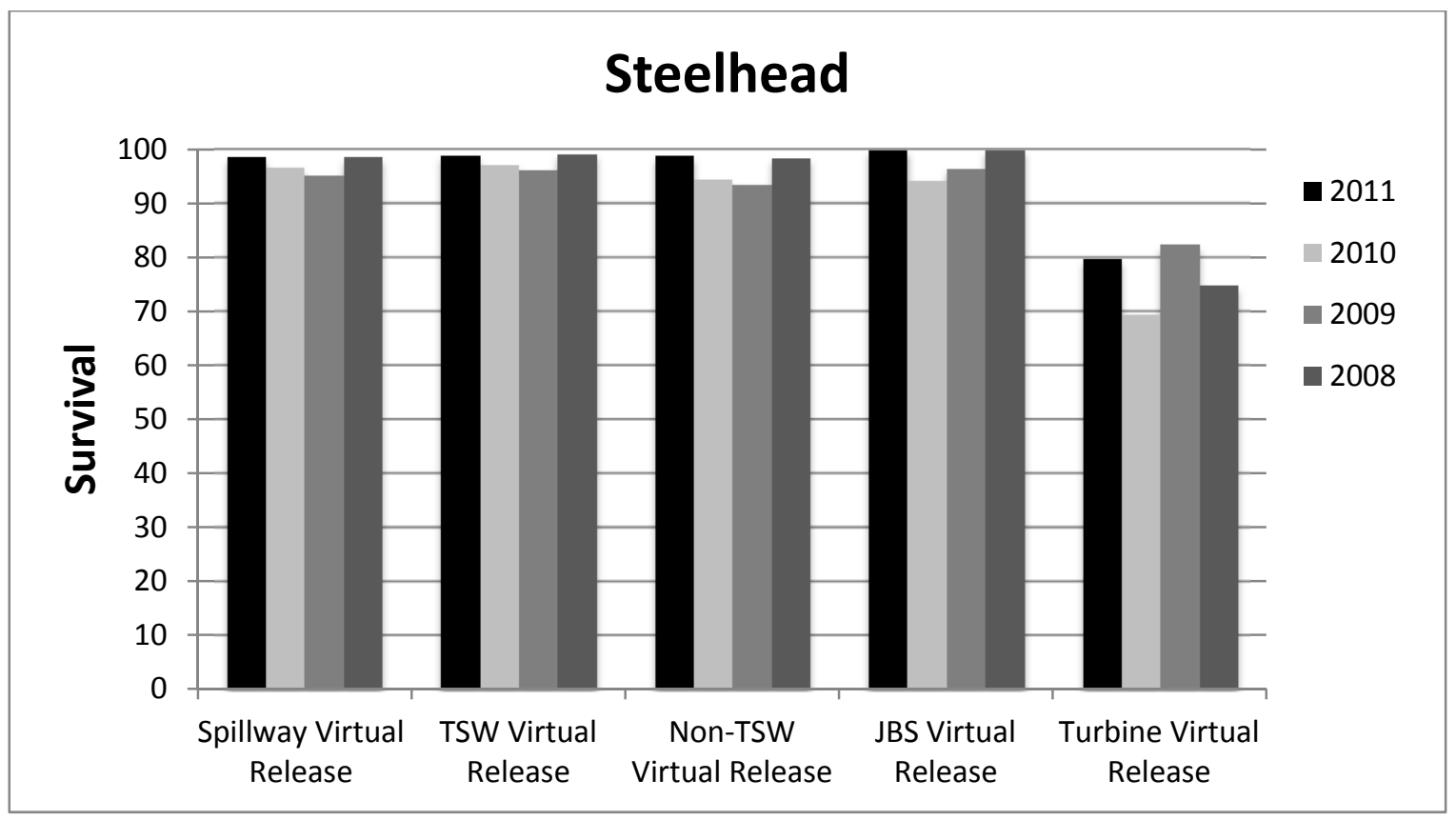

Figure 8.2. Route-specific survival for STH salmon from the dam-face virtual release at John Day Dam to The Dalles Dam tailrace (CR349 to CR309), 2008-2011.

\subsubsection{Passage Efficiency Estimates}

Point estimates of SPE were higher for the $40 \%$ spill discharge test than for the $30 \%$ spill test during the early spring season for both $\mathrm{CH} 1$ and $\mathrm{STH}$ when spill discharge levels were maintained at pre-defined study levels (April 27-May 16). In general, point estimates of SPE have been higher during the 40\% spill treatment in recent studies done at JDA (Weiland et al. 2009, 2011a, 2013). However, this result has not been consistently shown to be statistically different over the course of multiple studies with $30 \%$ and $40 \%$ spill treatments. Comparing results to the three previous years of study at JDA, season-wide SPE was $10 \%$ to $25 \%$ lower than it was during previous study years (2008 to 2010 ) for both CH1 and STH (Figure 8.3 and Figure 8.4). This could be an artifact of the high flows observed at JDA in 2011 possibly limiting the ability of fish to actively seek specific passage routes.

Fish passage efficiency was similar for the $30 \%$ and $40 \%$ spill tests (April 27-May 16) for CH1 and STH. This result has been observed in previous comparisons of these spill treatments (Weiland et al. 2009, 2011a, 2013). Fish passage efficiency for CH1 JBSE was the highest recorded during recent AT studies. More fish were observed passing at the powerhouse in 2011 as indicated by the low SPE, thus with a similar FGE compared to previous years, an increase in the proportion of fish passed via the JBS would be expected.

\subsubsection{Top-Spill Weir Performance}

The surface-flow outlets at JDA, called top-spill weirs or TSWs, were in their fourth year of evaluation using AT in 2011. For studies occurring during 2008 and 2009, the TSWs were installed at spill bays 15 and 16; in 2010 they were moved to spill bays 18 and 19. This study examined the second year passage metrics at the new locations closer to the powerhouse. Survival through the TSW route had 
been over $95 \%$ for both species during the three previous years and this was observed again in 2011 with survival rates of $95.8 \%$ and $98.9 \%$ for $\mathrm{CH} 1$ and STH, respectively (Figure 8.1 and Figure 8.2) (Weiland et al. 2009, 2011a, 2013). In particular, STH survival has been slightly higher through the TSW route than observed for $\mathrm{CH} 1$. The movement of the weirs does not appear to have dramatically changed survival through this route.

Overall, TSW passage efficiency (i.e., the proportion of fish passing via the TSW relative to the entire dam) was lower in 2011 than the three previous years for STH and for two out of the three previous years for $\mathrm{CH} 1$ (Figure 8.3 and Figure 8.4). This is potentially due to the high flows in 2011 limiting the ability of the spring juvenile salmonids to detect the flow signature created by the TSWs and actively seek out this passage route. It is difficult to determine whether the movement of the TSWs in 2010 led to the drastic increase in TSW passage efficiency observed for both species without having a repeated result in 2011, but this may have been muted by the high flows. Also, TSW passage efficiency was higher for STH during all previous studies at JDA, likely because STH tend to be more surface orientated than CH1 as they approach the dam (Weiland et al. 2009, 2011a, 2013). Point estimates of TSW passage efficiency during 30\% and $40 \%$ spill treatments tended to be higher during the $30 \%$ treatment for $\mathrm{CH} 1$, but no clear pattern has been observed for STH.

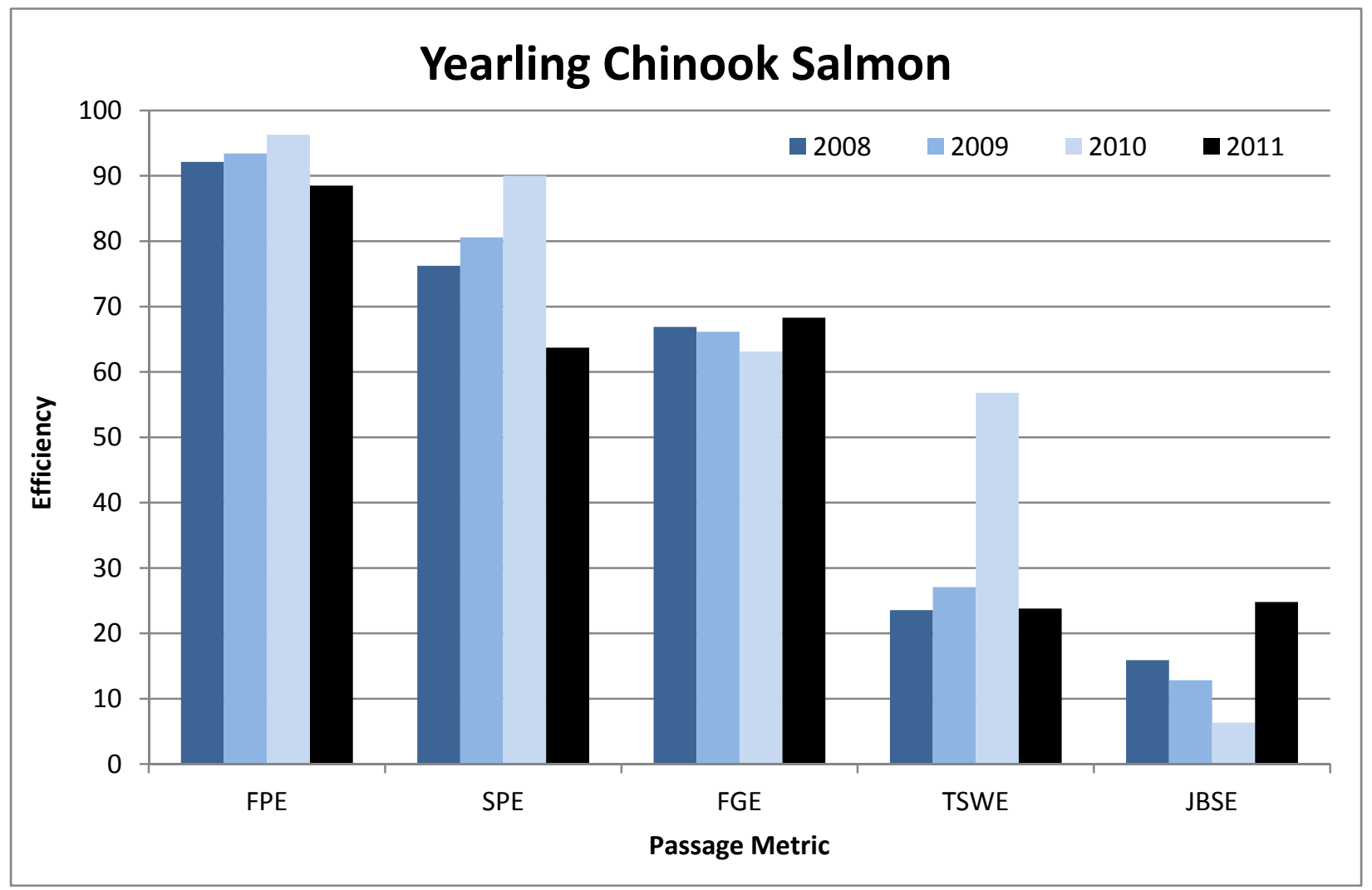

Figure 8.3. Summary of passage efficiency metrics for CH1 at John Day Dam, 2008 through 2011 $(\mathrm{FPE}=$ fish passage efficiency; $\mathrm{SPE}=$ spill passage efficiency; FGE $=$ fish guidance efficiency; TSWE = top-spill weir passage efficiency; JBSE = juvenile bypass system passage efficiency). 


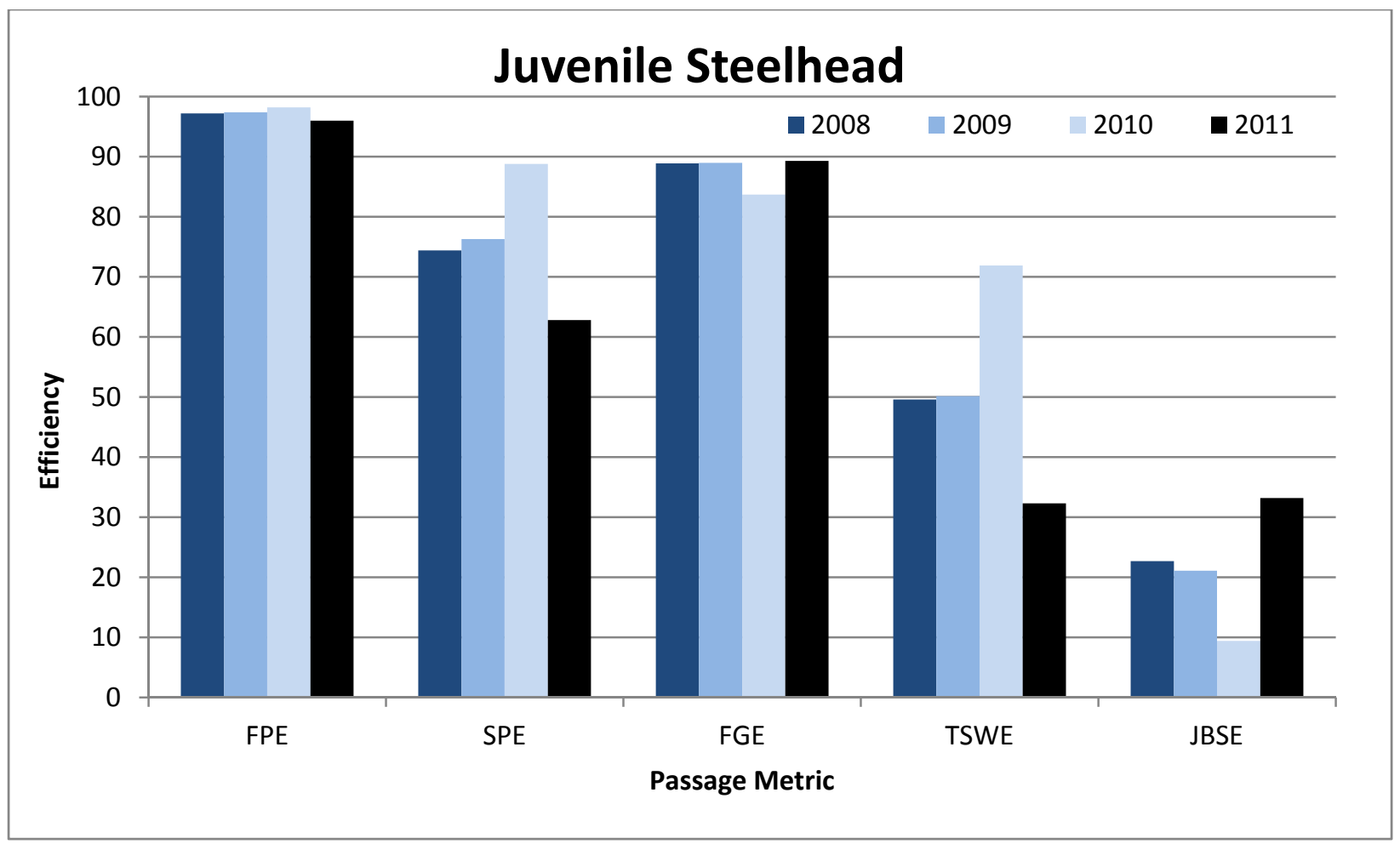

Figure 8.4. Summary of passage efficiency metrics for STH at John Day Dam, 2008 through 2011 $(\mathrm{FPE}=$ fish passage efficiency; $\mathrm{SPE}=$ spill passage efficiency; $\mathrm{FGE}=$ fish guidance efficiency; TSWE = top-spill weir passage efficiency; JBSE = juvenile bypass system passage efficiency). 


\subsection{References}

3 Treaty Tribes-Action Agencies. 2008. Memorandum of Agreement Among the Umatilla, Warm Springs and Yakama Tribes, Bonneville Power Administration, U.S. Army Corps of Engineers, and U.S. Bureau of Reclamation, Portland, Oregon, April 4, 2008. Available at:

http://www.salmonrecovery.gov/Files/BiologicalOpinions/3-tribe-AA-MOA-Final.pdf.

Anglea S, T Poe, and A Giorgi. 2001. Synthesis of Radio Telemetry, Hydroacoustic, and Survival Studies of Juvenile Salmon at John Day Dam (1980-2000). Battelle-Pacific Northwest Division, Richland, Washington.

Axel G, J Beeman, R Brown, B Eppard, S Fielding, E Hockersmith, T Liedtke, P Christopher, and C Woodley. 2011. Surgical Protocols for Implanting JSATS Transmitters into Juvenile Salmonids for Studies Conducted for the U.S. Army Corps of Engineers. Version 1.0. USACE, Portland District, Portland, Oregon.

Beeman JW, HC Hansel, PV Haner, K Hardiman, D Hardiman, and J Hardiman. 2003. Estimates of Fish and Spill Passage Efficiency of Radio-Tagged Juvenile Steelhead and Yearling and Subyearling Chinook Salmon at John Day Dam, 2000. Final report of research, U.S. Geological Survey, Cook, Washington.

Beeman JW, L Dingmon, S Juhnke, HC Hansel, B Hausmann, and P Haner. 2006. Estimates of Fish, Spill, and Juvenile Fish Bypass Passage Efficiencies of Radio-Tagged Juvenile Salmonids Relative to Spring and Summer Spill Treatments at John Day Dam in 2002. Final report of research, U.S. Geological Survey, Cook, Washington.

BioSonics, Inc. 1999. Hydroacoustic Evaluation and Studies at the John Day Dam, 1997. Final report, BioSonics, Inc., Seattle, Washington.

Burnham KP, DR Anderson, GC White, C Brownie, and KH Pollock. 1987. "Design and analysis methods for fish survival experiments based on release-recapture." American Fisheries Society Monograph 5:1-437.

Brown RS, SJ Cooke, GN Wagner, and MB Eppard. 2010. Methods for Surgical Implantation of Acoustic Transmitters in Juvenile Salmonids - A Review of Literature and Guidelines for Technique. U.S. Army Corps of Engineers, Portland District, Portland, Oregon.

Čada GF. 2001. "The development of advanced hydroelectric turbines to improve fish passage survival." Fisheries 26(9):14-23.

CH2M Hill/Montgomery Watson Joint Venture. 1998. John Day Lock and Dam Surface Bypass Spillway. Feature Design Memorandum No. 52, U.S. Army Corps of Engineers, Portland District, Portland, Oregon.

CH2M Hill/Montgomery Watson Joint Venture, Northwest Hydraulics Consultants, The Glosten Associates, and CivilTech. 2001. John Day Lock and Dam Removable Spillway Weir. Design Documentation Report No. 53, U.S. Army Corps of Engineers, Portland District, Portland, Oregon. 
Counihan TD, JH Petersen, NS Adams, RS Shively, and HC Hansel. 2000. Feasibility of Extracting Survival Information from Radio-Telemetry Studies at the John Day Dam, 1999. Annual report of research, U.S. Geological Survey, Cook, Washington.

Counihan TD, JH Petersen, and KJ Felton. 2002. Survival Estimates of Migrant Juvenile Salmonids in the Columbia River from John Day Dam through Bonneville Dam using Radio-Telemetry, 2000. Annual report of research, U.S. Geological Survey, Cook, Washington.

Counihan TD, GS Holmberg, and JH Peterson. 2006a. Survival Estimates of Migrant Juvenile Salmonids in the Columbia River through John Day Dam using Radio Telemetry, 2002. Final report of research, U.S. Geological Survey, Cook, Washington.

Counihan TD, GS Holmberg, CE Walker, and JM Hardiman. 2006b. Survival Estimates of Migrant Juvenile Salmonids in the Columbia River through John Day Dam using Radio- Telemetry, 2003. Final report of research, U.S. Geological Survey, Cook, Washington.

Deng Z, MA Weiland, TJ Carlson, and MB Eppard. 2010. "Design and Instrumentation of a Measurement and Calibration System for an Acoustic Telemetry System." Sensors 10(4):3090-3099.

Deng Z, MA Weiland, T Fu, TA Seim, BL Lamarche, EY Choi, TJ Carlson, and MB Eppard. 2011. “A Cabled Acoustic Telemetry System for Detecting and Tracking Juvenile Salmon: Part 2. ThreeDimensional Tracking and Passage Outcomes.” Sensors 11(6):5661-5676.

Endangered Species Act of 1973. 1973. Public Law 93-205, as amended, 16 USC 1521 et seq.

Giorgi AE and JR Stevenson. 1995. A Review of Biological Investigations Describing Smolt Passage Behavior at Portland District Corps of Engineer Projects: Implications to Surface Collection Systems. Draft, Don Chapman Consultants, Inc., Boise, Idaho.

Hansel HC, JW Beeman, TD Counihan, BD Liedtke, MS Novick, and JM Plumb. 2000. Movement, Distribution, and Behavior of Radio-Tagged Subyearling Chinook Salmon in the Forebay of John Day Dam, 1999. Final report of research, U.S. Geological Survey, Cook, Washington.

Hansel HC, JW Beeman, BJ Hausmann, SD Juhnke, PV Haner, and JL Phelps. 2004. Estimates of Fish, Spill, and Juvenile Fish Bypass Passage Efficiencies of Radio-Tagged Juvenile Salmonids Relative to Spring and Summer Spill Treatments at John Day Dam in 2003. Final Report of Research.

U.S. Geological Survey, Cook, Washington.

Hensleigh JE, RS Shively, HC Hansel, JM Hardiman, GS Holmberg, BD Liedtke, TL Liedtke, RE Wardell, RH Wertheimer, and TP Poe. 1999. Movement, Distribution, and Behavior of RadioTagged Juvenile Chinook Salmon and Steelhead in John Day, The Dalles, and Bonneville Dam Forebays, 1997. Annual Report of Research. U.S. Geological Survey, Cook, Washington.

Johnson G, T Carlson, M Weiland, E Fischer, F Khan, R Townsend, J Skalski, G Ploskey, D Deng, J Hughes, and J Kim. 2011. Survival and Passage of Yearling and Subyearling Chinook Salmon and Steelhead at The Dalles Dam, 2010. PNNL-20626, Pacific Northwest National Laboratory, Richland, Washington. 
Lady JM, P Westhagen, and JR Skalski. 2010. Program ATLAS 1: Active Tag Life Adjusted Survival. Columbia Basin Research, School of Aquatic and Fishery Sciences, University of Washington, Seattle, Washington.

Li T and JJ Anderson. 2009. "The vitality model: A way to understand population survival and demographic heterogeneity." Theoretical Population Biology 76(2):118-131.

Martinson RD, GM Kovalchuk, and D Ballinger. 2010. Monitoring of Downstream Salmon and Steelhead at Federal Hydroelectric Facilities. Annual Report. Project No. 87-127-01. Pacific States Marine Fisheries Commission, The Dalles, Oregon.

McMichael GA, MB Eppard, TJ Carlson, JA Carter, BD Ebberts, RS Brown, MA Weiland, GR Ploskey, RA Harnish, and Z Deng. 2010. “The Juvenile Salmon Acoustic Telemetry System: A New Tool." Fisheries 35(1):9-22.

Moursund RA, KD Ham, and PS Titzler. 2003. Hydroacoustic Evaluation of Downstream Fish Passage at John Day Dam in 2002. Final Report. PNWD-3236, Battelle-Pacific Northwest Division, Richland, Washington.

Muir WD, SG Smith, JG Williams, and BP Sandford. 2001. "Survival of juvenile salmonids through bypass systems, turbines, and spillways with and without flow deflectors at Snake River dams." North American Journal of Fisheries Management 21:135-146.

National Oceanic and Atmospheric Administration (NOAA) Fisheries. 2008. Biological Opinion Consultation on Remand for Operation of the Federal Columbia River Power System, 11 Bureau of Reclamation Projects in the Columbia Basin and ESA Section 10(a)(1)(A) Permit for Juvenile Fish Transportation Program (Revised and reissued pursuant to court order, NWF v. NMFS, Civ.

No. CV 01-640-RE (D. Oregon)). U.S. Department of Commerce, National Marine Fisheries Service, Northwest Regional Office, Seattle, Washington.

Ploskey GR, MA Weiland, JS Hughes, SR Zimmerman, RE Durham, ES Fischer, J Kim, RL Townsend, JR Skalski, and RL McComas. 2007. Acoustic Telemetry Studies of Juvenile Chinook Salmon Survival at the Lower Columbia River Projects in 2006. PNNL-16560, Pacific Northwest National Laboratory, Richland, Washington.

Seber GAF. 1982. The Estimation of Animal Abundance and Related Parameters, 2nd edition. MacMillan, New York.

Skalski JR, SG Smith, RN Iwamoto, JG Williams, and A Hoffman. 1998. "Use of PIT tags to estimate survival of migrating juvenile salmonids in the Snake and Columbia Rivers." Canadian Journal of Fisheries and Aquatic Sciences 59:1484-1493.

Skalski JR, D Mathur, and PG Heisey. 2002. "Effects of turbine operating efficiency on smolt passage survival." North American Journal of Fisheries Management 22:1193-1200.

Skalski JR, RA Buchanan, RL Townsend, TW Steig, and S Hemstrom. 2009. "A multiple-release model to estimate route-specific and dam passage survival at a hydroelectric project." North American Journal of Fisheries Management 29:670-679. 
Skalski JR, RL Townsend, TW Steig, and S Hemstrom. 2010. "Comparison of two alternative approaches for estimating dam passage survival using acoustic-tagged sockeye salmon smolts." North American Journal of Fisheries Management 30:831-839.

Sweeney CE, R Hall, AE Giorgi, M Miller, and GE Johnson. 2007. Surface Bypass Program Comprehensive Review Report. ENSR Document No. 09000-399-0409, ENSR Corporation, Redmond, Washington.

U.S. Army Corps of Engineers (USACE) Portland District. 2007. John Day Lock and Dam Configuration and Operation Plan. USACE, Portland District, Portland, Oregon.

Weiland MA, GR Ploskey, JS Hughes, and fifteen coauthors. 2009. Acoustic Telemetry Evaluation of Juvenile Salmonid Passage and Survival at John Day Dam with Emphasis on the Prototype Surface Flow Outlet, 2008. PNNL-18890, Pacific Northwest National Laboratory, Richland, Washington.

Weiland MA, GR Ploskey, JS Hughes, and sixteen coauthors. 2011a. Acoustic Telemetry Evaluation of Juvenile Salmonid Passage and Survival Proportions at John Day Dam, 2009. PNNL-20766, Pacific Northwest National Laboratory, Richland, Washington.

Weiland MA, ZD Deng, TA Seim, BL Lamarche, EY Choi, T Fu, TJ Carlson, AI Thronas, and MB Eppard. 2011b. "A cabled acoustic telemetry system for detecting and tracking juvenile salmon: Part 1. Engineering design and instrumentation." Sensors 11(6):5645-5660. doi:10.3390/s110605645.

Weiland, MA, CM Woodley, GR Ploskey, and twenty-three coauthors. 2013. Acoustic Telemetry Evaluation of Juvenile Salmonid Passage and Survival at John Day Dam, 2010. PNNL-22177, Pacific Northwest National Laboratory, Richland, Washington. 


\section{Appendix A}

Review of Fish Condition Associated with Juvenile Salmon Collected and Tagged for the Lower River Survival Study, 2011 


\title{
Appendix A
}

\section{Review of Fish Condition Associated with Juvenile Salmon Collected and Tagged for the Lower River Survival Study, 2011}

\author{
Prepared by CM Woodley, KA Wagner, and AL Miracle
}

In 2011, researchers from Pacific Northwest National Laboratory (PNNL) conducted a study to evaluate the condition of juvenile Chinook salmon (Oncorhynchus tshawytscha) and steelhead (O. mykiss) tagged with Juvenile Salmon Acoustic Telemetry System (JSATS) acoustic microtransmitters (AMTs) and passive integrated transponders (PITs). The purpose of this task was to test the assumptions that 1) tagged fish are representative of in-river fish and that 2) tagged fish did not have altered behavior or physiological costs compared to in-river fish. These assumptions are primary to the larger concurrent study - the Acoustic Telemetry Evaluation of Dam Passage Survival and Associated Metrics at John Day, The Dalles, and Bonneville Dams, 2011 (herein referred to as the Lower Columbia River [LCR] Survival Study) that monitored survival of juvenile salmonids as they migrated downstream through the Federal Columbia River Power System (FCRPS) for the U.S. Army Corps of Engineers (USACE), Portland District, as stipulated by the 2008 FCRPS Biological Opinion (BiOp; NOAA Fisheries 2008) and the Columbia Basin Fish Accords (Fish Accords; Three Treaty Tribes-Action Agencies 2008).

To evaluate fish condition throughout various stages of the tagging process, gross necropsy observations and physiological indicators were investigated in yearling Chinook salmon (CH1) and juvenile steelhead (STH) in the spring of 2011. This is a summary of juvenile salmon condition at the time of collection, before tagging, after tagging and transport to the Bonneville Dam (BON) Smolt Monitoring Facility (SMF), and lastly fish recollected at BON SMF using the sort-by-code (SByC) system as an assessment of the 2011 LCR survival study.

\section{A.1 Background}

Telemetry applications for fish range from monitoring fine spatial movements and habitat preferences to monitoring large-scale migratory patterns (Skalski 1998; Scruton et al. 2007). In the Columbia River, scientists have identified acoustic telemetry as an essential technology for observing behavior and estimating the survival of juvenile salmonids passing through the side channels and the main-stem FCRPS (Faber et al. 2001; McComas et al. 2005; Ploskey et al. 2007, 2008; Clemens et al. 2009). Telemetry methodology and survival models used within the FCRPS are based on a number of assumptions that are often poorly or not tested, thus weakening the resultant data and leading to potentially erroneous conclusions about the population of interest.

The first assumption of telemetry models is that the behavior, migration, and physiological state of the fish are not affected by the transmitter presence or tagging process (Skalski et al. 2001; Deriso et al. 2007). In addition, the transmitter presence or tagging process should not affect fish growth or survival (herein referred to as "tag effects"; Jepsen et al. 2002; Zale et al. 2005). This assumption was first 
investigated using gross necropsy and physiological markers in the 2010 LCR survival study. Prior to this, tag and/or tagging effects were examined by testing effects of taggers, correcting for early tag-life failure, and testing for tag-lot effects. Tag effect and/or the effect of tagging responses have been a staple of the telemetry literature since 1933 (Markus 1933) and have remained a concern as newer approaches and transmitter technologies have been developed (Moore et al. 1990; Jepsen et al. 2002; Welch et al. 2007). Some studies have found minimal to no tag effects on fish (Brown et al. 1999; Chittenden et al. 2009); while others, in particular studies that use surgical implantation of transmitters, have concluded that transmitter presence and/or the tagging process result in negative effects, such as reduced growth or increased mortality (Lacroix et al. 2004; Welch et al. 2007; Brown et al. 2010).

Acoustic transmitters, when used in fish survival studies, are usually surgically implanted into the coelomic cavity of the fish. Surgical implantation is a well-established method for attaching transmitters to study fish behavior and survival, although it does have disadvantages (Mulcahy 2003). Transmitter loss (or shedding) can occur through foreign body rejection processes (referred to as tag expulsion), the transmitter exiting through the incision due to poor apposition, or when external mechanical forces such as pressure are applied (Stephenson et al. 2010). In many cases, the expulsion of surgically implanted transmitters has occurred through a rupture of the incision zone (Lucas 1989; Moore et al. 1990; Petering and Johnson 1991). In other cases, the implants have exited by rupturing the abdominal body wall outside of the incision area (Marty and Summerfelt 1986; Lucas 1989) or have passed into the lumen of the intestine to be expelled by peristalsis (Martinelli et al. 1998; Baras and Westerloppe 1999). Regardless of the mechanisms or reasons for shedding, transmitter loss can affect data by indicating a mortality rate greater than the actual mortality rate. If the rate of transmitter loss and/or expulsion is determined, corrections for transmitter loss can be calculated into survival models. To account for transmitter loss and/or expulsion, a surgeon feedback task was included in the 2011 LCR survival study. More specifically, tagged fish were examined $24 \mathrm{~h}$ after tagging and then $7 \mathrm{~d}$ later to assess the quality of surgery and the likelihood of tag expulsion or drop. Tag-effects studies are useful; however, retaining out-migrating juvenile salmon tends to result in additional stress on the fish and subsequently accelerated disease rates and mortality.

The 2011 LCR survival study examined the survival model assumption that fish implanted with AMTs and PITs are representative of the population of inference. This second assumption, in previous years, was often tested by comparing the length distributions of fish at the JDA SMF with those of tagged fish collected from the JDA SMF collection system. However, stress, altered behavior, recovery time, and survivability for fish with pre-existing conditions or effects from tagging, which were not examined in previous survival studies, can critically affect the results and conclusions of research and monitoring programs. In 2010, we introduced fish condition metrics as a way to better evaluate this assumption (Weiland et al. 2013). The approach used indicated that external observations were not necessarily good indicators of internal and physiological states. Thus, programs based simply on external observation of fish condition are likely to underestimate or under describe the actual condition of the fish. In addition, internal damage was more extensive in the tagged fish and fish collected in the SByC system, which was hypothesized to cause delayed mortality, decreased performance, altered behavior, and increased physiological costs (Jepsen et al. 2002, Lacroix et al. 2004; Welch et al. 2007). However, samples sizes in 2010, in particular for the biochemistry evaluation were limited because the 2010 effort was a proof of concept approach.

In the FCRPS, researchers tasked with standardizing JSATS AMT surgical implantation procedures have noted that the time fish are held in induction anesthesia, ("knockdown" or surgical anesthesia to 
prepare them for surgery), could influence their survival (CBSPSC 2011). The extended knockdown time may lead to adverse effects on fish survival and an inability to compare results directly within or among survival studies. Lastly, surgery itself can cause immunosuppression. Poor sutures and/or open wounds can result in slow tissue healing, osmotic stress, tissue damage, or possible premature mortality (Fontenot and Neiffer 2004; Harms 2005; Greenburg and Clark 2009). Excessive suture tension on tissue can cause ischemic areas that reduce or slow revascularization; increase stretching, tearing, and necrosis; and ultimately slow healing. Improperly tied knots can become untied, thereby releasing wound margins, slowing healing, and allowing transmitter loss. Large knots can be a point source for tissue irritation due to the concentrated amount of foreign material making up the knot (van Rijssel et al. 1989). And thus, surgeon performance can cause behavioral or physiological differences between tagged fish and run-ofriver populations. Thus, our experimental design in 2011 allowed for surgeons to assess fish condition and/or surgeries as a predictor for survival.

In addition to tag and tagging effects, hydroelectric production systems expose migrating salmonids and other fish to physical hazards, such as structures, turbines, and hydraulic forces, which can lead to physical trauma, physiological imbalances, and immediate or delayed mortality. In the past, individual fish trauma and impaired condition induced by these stressors was commonly determined by observed injuries, such as embolisms in the kidney and open wounds (Carlson et al. 2011; Halvorsen et al. 2011). Observations of health and injury are relatively easy to collect from the juvenile fish bypass systems at the hydroelectric dams; however, the techniques are lethal and limited in the ability to assess nutrition, immune, and trauma conditions (Carlson et al. 2011; Woodley et al. 2011). Advances to more accurately assess both internal and external fish condition include the use of physiological measures, such as alpha II-spectrin that measure whole body internal injury from a plasma sample or traumatic brain injury from a brain tissue sample (Miracle et al. 2009). Understanding stressor effects on fish encountering hydroelectric systems or other underwater hazards and how the stressors affect individual condition, performance, and behavior will more accurately estimate individual survival and vitality to predict population level effects on fish in the coastal and estuarine regions.

The objective of this task was to assess the condition of fish that were 1) in-river at the time of tagging, 2) selected for tagging, 3) implanted and then transported to a release site, and 4) implanted with AMTs and PITs that travelled through the hydropower system. This assessment was conducted in a manner that would be sensitive to changes in physiological state as a result of handling, the effects of the tags, and the tagging process. The goal of the fish condition research is to further define measures used for population viability analyses that assess the vulnerability of a population to FCRPS and assist with the ranking of management priorities based on the condition of fish moving through the FCRPS. To provide an evaluation of injury we measured the presence of alpha II-spectrin and spectrin breakdown products (SBDPs). Alpha II-spectrin is a cytoskeletal protein and its breakdown protein fragments in brain tissue have been demonstrated to be a diagnostic marker of head injury in salmonids and have been correlated with mortality/malady metrics (Miracle et al. 2009). Presence of alpha II-spectrin and SBDPs in the blood is hypothesized to be indicative of cellular injury. To provide a broad assessment of immune function, we measured gene expression of several immune markers: interleukin-1 beta (IL1- $\beta$ ) and immunoglobulin M (IgM) from spleen tissue. Immune markers were chosen based on the availability of primer sequences and function of marker. IL1- $\beta$ is a cytokine involved in the innate immune response and is indicative of a generalized inflammation response to injury or pathogens. Up-regulated IL1- $\beta$ gene expression has been demonstrated in response to physical injury (Ingerslev et al. 2010). IgM genes are involved in adaptive immune responses against specific antigens (viral, bacterial, etc.). 


\section{A.2 Methods and Materials}

This study was conducted during one 5-wk sampling period in the spring of 2011. It involved the acquisition of fish, surgical implantation of transmitters, release of fish, physiological assessment of fish, and statistical analysis, as described below.

\section{A.2.1 Fish Acquisition}

In spring 2011, CH1 and STH were collected, tagged, and sampled from late April to late May. Only fish with a fork length between 95 and $288 \mathrm{~mm}$ were used for this study. All study fish were collected at the John Day Dam (JDA; rkm 349) SMF and sorted into one of the following four treatment groups:

- Run-of-River (ROR): During the fish collection for surgical implantation of AMTs, individuals were randomly subsampled for fish condition. Subsampling occurred before fish were accepted onto the concurrent LCR survival study, but after fish were sorted for species, size, and prior tagging. Thus, ROR samples included fish that may have been rejected from the LCR survival study due to noticeable external damage such as hemorrhaging, $>25 \%$ scale loss, etc. Fish with these conditions may not be capable of outmigration or may have high stress levels, and potential for delayed mortality; however, they are still representative of a small percentage of juvenile out-migrating salmon.

- Pre-Tagged (PRT): During the daily tagging process, fish were randomly selected for fish condition assessment prior to tag implantation. These fish were held 12 to $24 \mathrm{~h}$ after sorting before sampling for fish condition, as were the fish held for tagging. As fish were anesthetized for surgical implantation for the survival study, PRT fish were removed prior to tag assignment.

- Tagged (TGD): Fish were randomly selected to be tagged for fish condition assessment. Fish were held 12-24 h after sorting, implanted with a JSATS AMT and a PIT, held in recovery for at least $24 \mathrm{~h}$, and then transported (est. $1.5 \mathrm{~h}, 78$ miles) to the BON SMF for sampling.

- Sort-by-code (SBC): Fish were selected for tag implantation, implanted with a JSATS AMT and PIT, recovered for at least $24 \mathrm{~h}$, transported and released in river near Roosevelt, Washington, and recaptured downriver at BON (travel time 4-10 d) using the SByC system. Fish may have been held up to $24 \mathrm{~h}$ before sampling.

The number of fish collected for each treatment by week of collection are presented in Table A.1.

Table A.1. Sample sizes for fish condition assessment by species and week.

\begin{tabular}{rccccccc}
\hline \multirow{3}{*}{ Species } & Treatment & & & & & & \\
& Group & Week 1 & Week 2 & Week 3 & Week 4 & Week 5 & Total \\
\hline \multirow{4}{*}{ CH1 } & ROR & 18 & 20 & 20 & 20 & 20 & $\mathbf{9 8}$ \\
& PRT & 20 & 20 & 20 & 20 & 20 & $\mathbf{1 0 0}$ \\
& TGD & 24 & 23 & 24 & 23 & 24 & $\mathbf{1 1 8}$ \\
& SBC & 21 & 22 & 11 & 1 & 0 & $\mathbf{5 5}$ \\
& ROR & 21 & 20 & 20 & 20 & 20 & $\mathbf{1 0 1}$ \\
STH & PRT & 20 & 20 & 20 & 20 & 20 & $\mathbf{1 0 0}$ \\
& TGD & 24 & 25 & 24 & 25 & 24 & $\mathbf{1 2 2}$ \\
& SBC & 17 & 8 & 3 & 0 & 0 & $\mathbf{2 8}$ \\
\hline
\end{tabular}




\section{A.2.2 Surgical Implantation of Transmitters}

For the fish in the TGD and SBC treatment groups, each was surgically implanted with an AMT and PIT. The weights of the tags were $0.43 \mathrm{~g}$ in air for the JSATS AMT and $0.085 \mathrm{~g}$ in air for the PIT (combined weight of $0.52 \mathrm{~g}$ for the TGD and SBC treatment groups). Prior to surgical implantation, fish were anesthetized in buffered (with $80 \mathrm{mg} / \mathrm{L} \mathrm{NaHCO}_{3}$ ) tricaine methanesulfonate (MS-222; $80 \mathrm{mg} / \mathrm{L}$ ), until loss of equilibrium was observed (Stage 4; Summerfelt and Smith 1990). Anesthetized fish were immediately weighed, measured, and both flanks were photographed. Once properly anesthetized, fish were placed on the surgery table and given a maintenance anesthetic dose (river water containing $40 \mathrm{mg} / \mathrm{L}$ MS-222 and $40 \mathrm{mg} / \mathrm{L} \mathrm{NaHCO}_{3}$ ) through silicone rubber tubing from a gravity-fed cooler system. The surgeon controlled the anesthetic dose during the surgery by mixing river water with maintenance anesthetic water. With the fish facing ventral side up, a 5- to 7-mm incision was made along the linea alba, between the pectoral fin and pelvic girdle. An AMT and PIT were inserted into the coelomic cavity through the incision. The incision was closed with two, simple interrupted sutures using a $2 \times 2 \times 2 \times 2$ wrap knot with 5-0 Monocryl ${ }^{\mathrm{TM}}$ sutures. Post-surgery, fish were placed into 5-gal perforated recovery buckets (five fish per bucket) with fresh aerated river water and monitored to ensure recovery to equilibrium. The density of fish in each bucket did not exceed $15 \mathrm{~kg} / \mathrm{m}^{3}$. The buckets were placed into a larger holding tank supplied with flow-through river water. Fish were left to recover for 18 to $24 \mathrm{~h}$ before being transported. In addition to necropsy notes, daily notes included found transmitters or tags, water temperature at BON and JDA SMFs, dissolved oxygen levels, signs of disease, and general health. Water temperatures (Figure A.1) and dissolved gas percent increased (Figure A.2) at the JDA SMF and BON SMF over the study period.

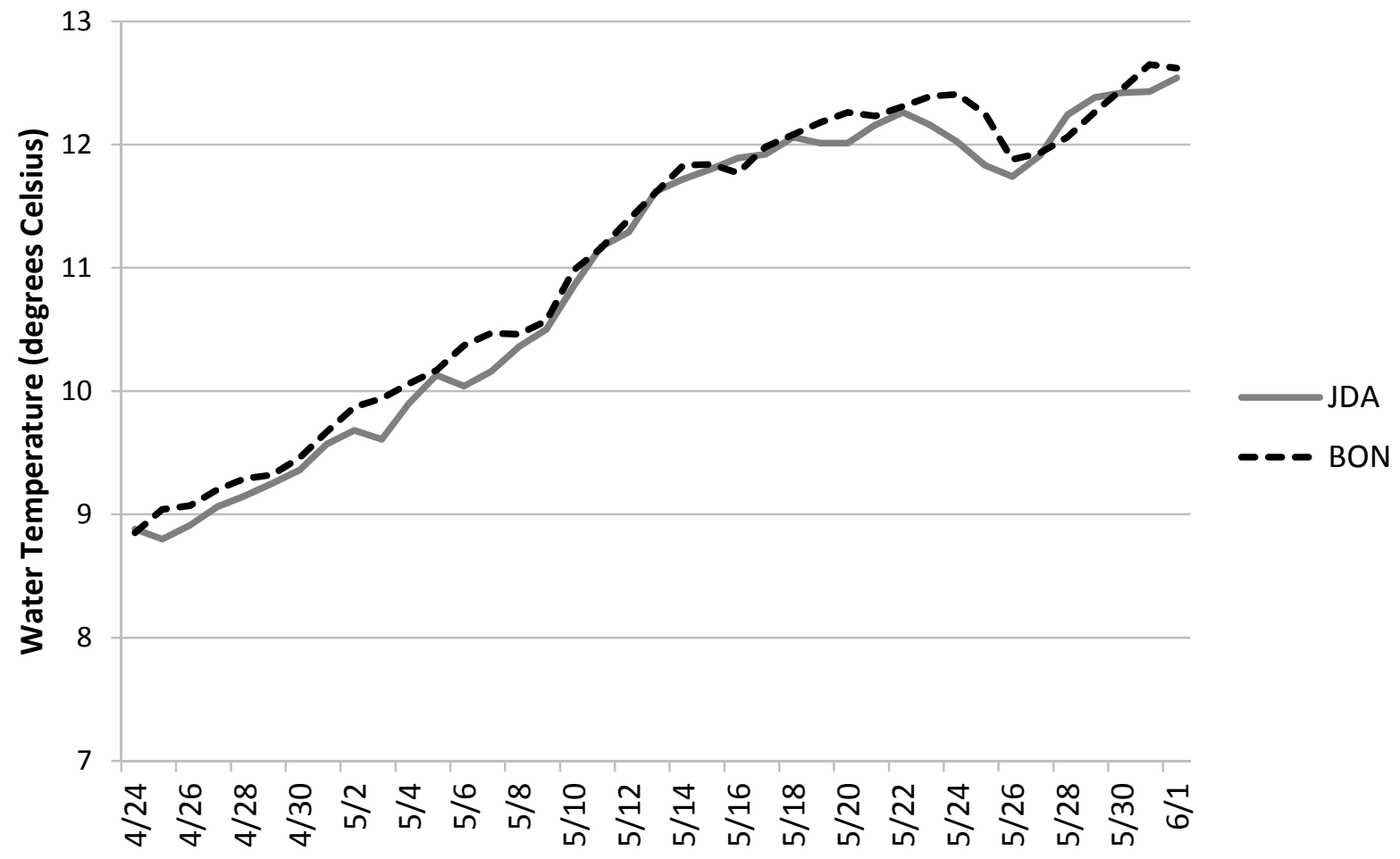

Figure A.1. Water temperature from April 24 through June 1, 2011 at the JDA SMF and the BON SMF. 


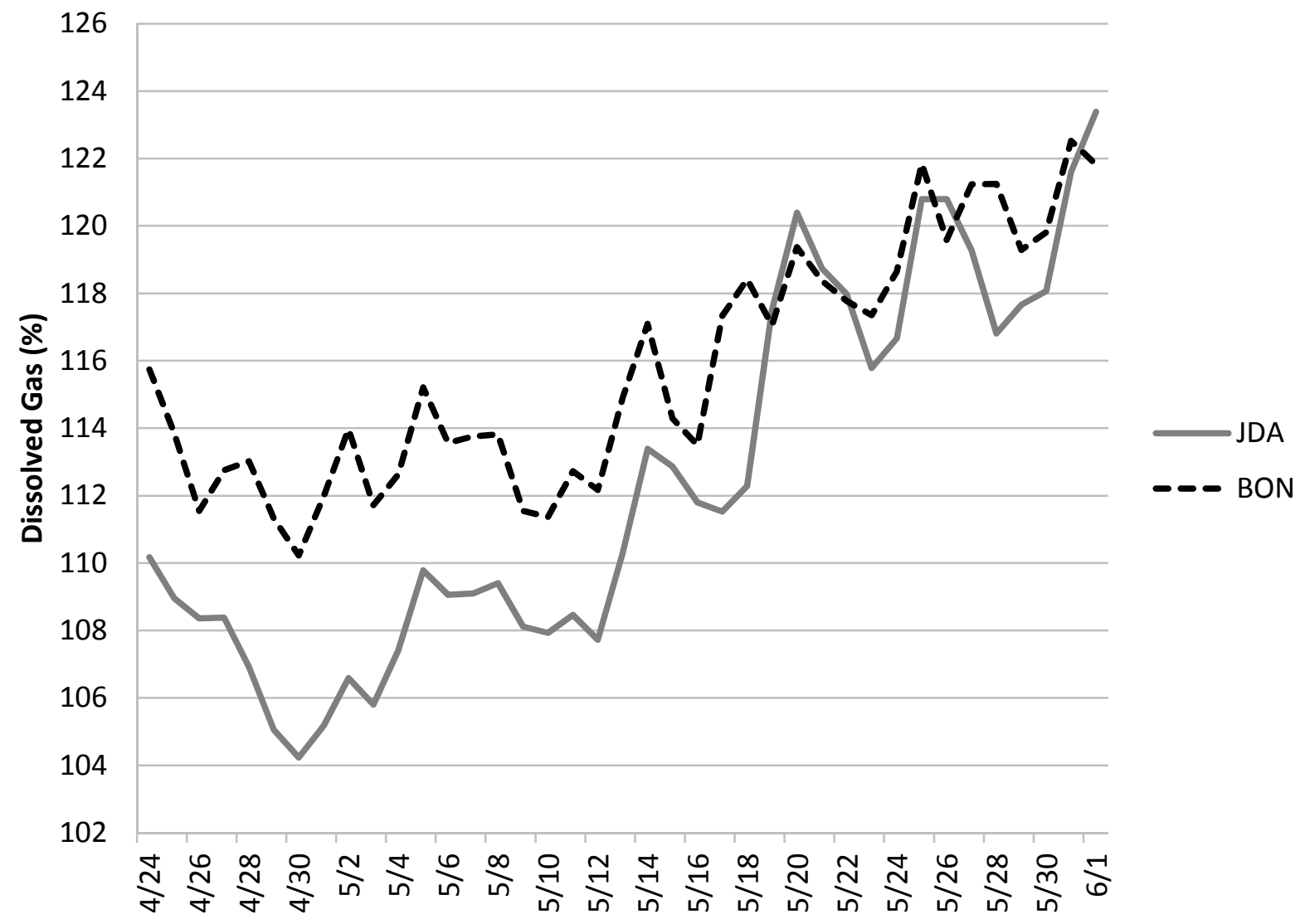

Figure A.2. Total dissolve gas percent from April 24 through June 1, 2011 at the JDA SMF and BON SMF.

\section{A.2.3 Fish Transportation and Release}

For transportation of TGD and SBC fish, 5-gal perforated buckets were placed in insulated transportation totes containing 200 gal of river water supplied with supplemental oxygen. During transportation, water temperature and dissolved oxygen were monitored to ensure that the tote water did not increase more than $1{ }^{\circ} \mathrm{C}$ from the reference temperature (holding water at JDA), and remained at or near saturation. The SBC fish (the same fish tagged for the survival studies) were transported to Roosevelt and upon arrival, water temperature and dissolved oxygen levels were noted. If needed, water temperature was adjusted to in-river water temperature with ice and then buckets were loaded into a boat. Upon reaching the release site, fish were transferred (water to water) from buckets to river. The PIT codes from the released fish were logged into the PIT Tag Information System (PTAGIS) fish database program. The TGD fish were transported to the BON SMF ( $\mathrm{rkm} 234 ; 78$ driving miles, average driving time $1.5 \mathrm{~h}$ ) for sampling. Upon arrival, water temperature and dissolved oxygen were noted. Perforated buckets were then transferred into 100-gal Bonar ${ }^{\mathrm{TM}}$ totes supplied with flow-through river water until sampling. 


\section{A.2.4 Sampling and Necropsy Techniques}

Fish were anesthetized in buffered MS-222 $(250 \mathrm{mg} / \mathrm{L})$ until stage 5 anesthesia (slowing of gill rate). Fish were immediately weighed and measured. Blood samples $(0.5 \mathrm{~mL})$ were taken from the caudal vein using a 23-gauge needle and $1 \mathrm{~mL}$ syringe containing $0.05 \mathrm{~mL}$ of sodium heparin. Blood samples were dispensed in a $1.0-\mathrm{mL}$ microcentrifuge tube, centrifuged at $3,000 \mathrm{~g}$ for $10 \mathrm{~min}$, and plasma was collected in a separate tube. Plasma samples were stored at $-80^{\circ} \mathrm{C}$ for later analyses. Both flanks of the fish were photographed, and fish were then euthanized by spinal transection while under stage 5 anesthesia. External and internal examinations were conducted to provide a thorough description of the fish condition. More than 150 observations of fish condition are noted for their presence/absence (Table A.2). Observations were scored on a presence or absence basis. After necropsy, brain tissue, liver, and spleen were harvested from each fish, placed in individual cryovials and frozen at $-80^{\circ} \mathrm{C}$ for later biochemistry analyses. The biochemistry analyses quantified plasma alpha II-spectrin and SBDPs and spleen gene expression of IL1- $\beta$ and IgM.

Table A.2. An abbreviated list of observations made on fish conditions (including health and trauma).

\begin{tabular}{ll}
\hline \multicolumn{1}{c}{ External } & \multicolumn{1}{c}{ Internal } \\
\hline Dead or Moribund & Damage: Ruptures, lacerations \\
Damage: Eye(s) & Embolism: Connective tissue \\
Damage: Vent (Prolapse) & Embolism: Pericardium \\
Deformities & Embolism: Renal \\
Emesis & Embolism: Swim bladder \\
Erosion & Hematoma: Fat \\
Exophthalmia & Hematoma: GI tract \\
Hematoma: Caudal peduncle & Hematoma: Hepatic \\
Hematoma: External body & Hematoma: Internal body wall \\
Hematoma: Fins & Hematoma: Pericardium \\
Hematoma: Isthmus & Hematoma: Pyloric caeca \\
Hematoma: Operculum & Hematoma: Swim bladder \\
Hematoma: Vent & Hemorrhage: Capillaries \\
Hemorrhage: Caudal peduncle & Hemorrhage: Fat \\
Hemorrhage: Eye(s) & Hemorrhage: GI tract \\
Hemorrhage: Fins & Hemorrhage: Hepatic \\
Hemorrhage: Gill(s) & Hemorrhage: Pericardium \\
Lacerations & Hemorrhage: Renal \\
Scale loss & Hemorrhage: Spleen \\
& Hemorrhage: Swim bladder \\
\hline
\end{tabular}

\section{A.2.4.1 Alpha II-Spectrin}

Plasma samples were disrupted by bead beating using a MiniBeadbeater-8 and 1.0-mm zirconia/silica beads (BioSpec Products, Inc., Bartlesville, OK) in a lysis buffer containing $50 \mathrm{mM}$ Tris (pH 7.4), $5 \mathrm{mM}$ EDTA, 1\% (v/v) Triton X-100, $1 \mathrm{mM}$ DTT, and protease inhibitor. The plasma lysates were then centrifuged at 14,000 rpm for $30 \mathrm{~min}$ to remove any insoluble debris, and snap-frozen and stored at $-80^{\circ} \mathrm{C}$ until further analysis. Lysate protein concentrations were determined by DC ${ }^{\mathrm{TM}}$ Protein assay (BioRad, Hercules, CA) with albumin standards. 
Thirty micrograms of total protein from each plasma sample were used for gel electrophoresis and electrotransfer as described by Miracle et al. (2009). Chemiluminescent development was performed by incubating membranes in Luminata Forte Western HRP Substrate (Millipore Corporation, Billerica, MA) for $5 \mathrm{~min}$. Semi-quantitative evaluation of alpha II-spectrin expression was evaluated via a digital image taken by a Canon EOS 50D imager (Quansys Biosciences, Logan, UT) and analyzed with Image J software (version 1.6; Rasband 2012). To assess the total amount of alpha II-spectrin and SBDPs present, we calculated the pixel density for intact and cleaved protein bands using density histograms with background subtraction and densities were normalized using rainbow ladder presence that was run on each gel.

\section{A.2.4.2 QPCR}

Differential expression in spleen ribonucleic acid (RNA) was determined using semi-quantitative polymerase chain reaction (qPCR; Freeman et al. 1999). Total RNA was isolated from spleen tissue using TriReagent (Ambion, Austin, TX), and relative concentrations were determined by ultraviolet spectrophotometry (GENE SYS 10). Complementary DNA (cDNA) was prepared using a High Capacity cDNA Reverse Transcription Kit (Applied Biosystems, Foster City, CA) and a GeneAMP ${ }^{\circledR}$ PCR system 9700 (Applied Biosystems, Foster City, CA). Primers for amplification were designed using PrimerQuest (IDT, Coralville, IA), and are listed in Table A.3. If Chinook salmon sequence information was not available, rainbow trout (O. mykiss) sequences were used for primer construction. Briefly, $1 \mu \mathrm{g}$ of total RNA from spleen samples was reverse transcribed with $50 \mu \mathrm{M}$ random hexamers, using reagents and protocols recommended by Applied Biosystems (Foster City, CA). One tenth of the cDNA was used for each PCR reaction along with a SYBR green master mix (Applied Biosystems, Foster City, CA) and 2 pmol of primers. Cycling was carried out with 40 cycles of $95^{\circ} \mathrm{C}$ for $20 \mathrm{~s}, 60^{\circ} \mathrm{C}$ for $20 \mathrm{~s}$, and $72^{\circ} \mathrm{C}$ for $10 \mathrm{~s}$. Target fluorescence was measured at the end of the $72^{\circ} \mathrm{C}$ step for each cycle. Each gene assay included a standard curve of gel purified, template-specific cDNA, which was amplified from identityconfirmed clones using different primer sets in serial dilutions for setting the cycle threshold. The cDNA expression levels for all samples were normalized to expression levels for 18S, using Ambion's Quantum RNA $^{\mathrm{TM}}$ primers (Austin, TX).

To authenticate that observed PCR products were specific for IL1- $\beta$ or IgM, mRNA respectively, DNA sequencing was performed on isolated amplification products from spleen tissues of hatchery Chinook salmon. Fragments were gel purified and cloned into a TA cloning ${ }^{\circledR}$ vector per vendor protocol (Applied Biosystems, Foster City, CA). Isolated colonies were shipped to Agencourt (Danvers, MA) for sequencing using M13 forward and reverse primers. The resulting DNA sequence information was compared with known sequences for identity using the BLAST (basic local alignment search tool) algorithm (http://blast.ncbi.nlm.nih.gov/) and both target sequences were confirmed.

Table A.3. Target gene with forward (F) and reverse (R) primer sequences derived from GenBank accession number (Acc).

\begin{tabular}{ll}
\hline \multicolumn{1}{c}{ Gene and Reference } & \multicolumn{1}{c}{ Primer Sequence } \\
\hline Interleukin 1-beta(IL1- $\beta) ;$ & F 5' AGCAGGGTTCAGCAGTACATCACA 3' \\
Acc\# FJ890361.1 & R 5' ATCAGGACCCAGCACTTGTTCTCA 3' \\
Immunoglobulin M (IgM), heavy chain & F 5' GTGACCCTGACTTGCTACGTCAAA 3' \\
constant domain; Acc\# DQ778947.1 & R 5' GCTCATCGTTAACAAGCCAAGCCA 3' \\
\hline
\end{tabular}




\section{A.2.5 Statistical Analysis}

Prior to statistical analyses, spleen relative immune gene expression was investigated for outliers. Values were considered outliers and removed from analyses if $18 \mathrm{~S}$ expression was more than 2 standard deviations greater or less than the plate mean.

To evaluate the effects of tagging and to determine if tagged fish are representative of in-river fish, necropsy observations, total plasma alpha II-spectrin and SBDPs, and spleen immune gene expression of the ROR, PRT, and TGD treatment groups were compared. To determine 24-h and in-river effects of tagging, necropsy observations and physiological metrics of the PRT, TGD and SBC treatment groups were compared. Necropsy observations for these analyses were totaled per fish and analyzed with analyses of variance (ANOVAs), followed by Tukey's honestly significant difference (HSD) post-hoc analyses. All assumptions for parametric statistics were met prior to testing. Linear regressions were also used to examine fish size relationships and detect outliers. Lastly, principal component analysis was used to investigate the relationship between fish size and condition. The frequency of plasma alpha II-spectrin and SBDPs was treated as binomial data, because the variable could either be present or absent (not detected) in each fish. The variables total plasma alpha II-spectrin and SBDPs, spleen IL1- $\beta$, and spleen IgM were continuous data. For the comparison of frequency of plasma alpha II-spectrin and SBDPs between treatments, a Chi Squared Test $\left(\chi^{2}\right)$ was used. To compare continuous variables between groups, a Kruskal-Wallis test was used followed by a Steel-Dwass all pairs comparison post hoc test (where applicable). Between species comparisons were not made. All analyses were performed using JMP ${ }^{\circledR}$ (Version 10) and the level of significance was tested at $P<0.05$.

\section{A.3 Results}

\section{A.3.1 Data Adjustments}

All plasma samples were processed for alpha II-spectrin presence with the following exceptions: clotted samples, insufficient sample volumes, or lack of sufficient protein following extraction (Table A.4).

All spleen samples were processed for relative immune gene expression with the exception of not enough cDNA or low RNA quantity or quality (Table A.5). In addition, samples were considered outliers if relative expression of $18 \mathrm{~S}$ (used for normalization) was more than 2 SDs greater or less than the plate mean.

Table A.4. Adjusted sample sizes for plasma $\alpha$ II-spectrin presence for CH1 and STH.

\begin{tabular}{|c|c|c|c|c|c|c|c|}
\hline Species & $\begin{array}{l}\text { Treatment } \\
\text { Group }\end{array}$ & Week 1 & Week 2 & Week 3 & Week 4 & Week 5 & Total \\
\hline \multirow{4}{*}{ CH1 } & ROR & 16 & 16 & 15 & 15 & 18 & 80 \\
\hline & PRT & 18 & 19 & 18 & 16 & 16 & 87 \\
\hline & TGD & 21 & 12 & 20 & 21 & 23 & 97 \\
\hline & SBC & 19 & 17 & 9 & 1 & 0 & 46 \\
\hline \multirow{4}{*}{ STH } & ROR & 21 & 18 & 15 & 19 & 20 & 93 \\
\hline & PRT & 20 & 20 & 17 & 20 & 20 & 97 \\
\hline & TGD & 20 & 19 & 24 & 25 & 24 & 112 \\
\hline & SBC & 15 & 7 & 3 & 0 & 0 & 25 \\
\hline
\end{tabular}


Table A.5. Adjusted sample sizes for relative spleen immune gene expression for $\mathrm{CH} 1$ and STH.

\begin{tabular}{rccccccr}
\hline \multirow{3}{*}{ Species } & Treatment & Week 1 & Week 2 & Week 3 & Week 4 & Week 5 & Total \\
\hline \multirow{5}{*}{ CH1 } & Roup & 16 & 17 & 20 & 19 & 20 & $\mathbf{9 2}$ \\
& PRT & 20 & 20 & 20 & 19 & 20 & $\mathbf{9 9}$ \\
& TGD & 24 & 23 & 24 & 23 & 23 & $\mathbf{1 1 7}$ \\
& SBC & 21 & 22 & 10 & 1 & 0 & $\mathbf{5 4}$ \\
& ROR & 21 & 20 & 18 & 20 & 19 & $\mathbf{9 8}$ \\
STH & PRT & 20 & 20 & 20 & 20 & 20 & $\mathbf{1 0 0}$ \\
& TGD & 24 & 25 & 24 & 24 & 24 & $\mathbf{1 2 1}$ \\
& SBC & 17 & 8 & 3 & 0 & 0 & $\mathbf{2 8}$ \\
\hline
\end{tabular}

\section{A.3.2 Size Variability}

At the time of sampling for ROR and PRT fish and at the time of tagging for TGD and SBC fish, fork lengths (FL) and wet weights (WW) ranged from 106 to $213 \mathrm{~mm}$ and 10.5 to $90.5 \mathrm{~g}$ for CH1; from 113 to $288 \mathrm{~mm}$ and 11.1 to $203.1 \mathrm{~g}$ for STH (Table A.6). Fish size (FL and WW) did not significantly vary by treatment for CH1 $($ all $F(3,367)<1.36 ; P>0.05)$ or for STH $($ all $F(3,346)<1.20 ; P>0.05)$. Wet weight for $\mathrm{CH} 1$ and STH significantly predicted FL (all $P<0.01$; Table A.7). Weekly FL and WW significantly varied over the study period for $\mathrm{CH} 1(P<0.0001)$, but was similar across all weeks for STH $(P>0.34$; Table A.8; Table A.9). For CH1, FL and WW were significantly greater in the first sampling week when compared to all other sampling weeks $(P<0.005)$.

Table A.6. Average fork length and wet weight of $\mathrm{CH} 1, \mathrm{STH}$, and $\mathrm{CH} 0$ by treatment and sampling week.

\begin{tabular}{|c|c|c|c|c|c|c|}
\hline Species & $\begin{array}{l}\text { Treatment } \\
\text { Group }\end{array}$ & Week 1 & Week 2 & Week 3 & Week 4 & Week 5 \\
\hline \multirow{4}{*}{$\mathrm{CH} 1$} & ROR & $\begin{array}{c}160(23.5) \mathrm{mm} \\
40.3(18.6) \mathrm{g}\end{array}$ & $\begin{array}{c}147(23.1) \mathrm{mm} \\
31.0(16.2) \mathrm{g}\end{array}$ & $\begin{array}{c}154(24.1) \mathrm{mm} \\
36.6(18.5) \mathrm{g}\end{array}$ & $\begin{array}{c}143(20.7) \mathrm{mm} \\
28.3(13.3) \mathrm{g}\end{array}$ & $\begin{array}{c}142(15.8) \mathrm{mm} \\
28.4(10.3) \mathrm{g}\end{array}$ \\
\hline & PRT & $\begin{array}{l}158(24.6) \mathrm{mm} \\
38.1(16.1) \mathrm{g}\end{array}$ & $\begin{array}{l}147(22.2) \mathrm{mm} \\
21.5(13.7) \mathrm{g}\end{array}$ & $\begin{array}{c}138(22.8) \mathrm{mm} \\
26.0(14.1) \mathrm{g}\end{array}$ & $\begin{array}{c}154(22.6) \mathrm{mm} \\
35.5(16.1) \mathrm{g}\end{array}$ & $\begin{array}{c}145(16.8) \mathrm{mm} \\
30.6(13.0) \mathrm{g}\end{array}$ \\
\hline & TGD & $\begin{array}{c}158(22.3) \mathrm{mm} \\
39.4(16.7) \mathrm{g}\end{array}$ & $\begin{array}{l}142(22.5) \mathrm{mm} \\
29.0(14.0) \mathrm{g}\end{array}$ & $\begin{array}{c}145(20.5) \mathrm{mm} \\
30.3(14.0) \mathrm{g}\end{array}$ & $\begin{array}{c}144(18.4) \mathrm{mm} \\
28.3(13.3) \mathrm{g}\end{array}$ & $\begin{array}{c}141(11.5) \mathrm{mm} \\
26.9(7.0) \mathrm{g}\end{array}$ \\
\hline & SBC & $\begin{array}{c}163(13.8) \mathrm{mm} \\
40.9(12.4) \mathrm{g}\end{array}$ & $\begin{array}{c}147(17.5) \mathrm{mm} \\
31.1(11.2) \mathrm{g}\end{array}$ & $\begin{array}{c}151(21.9) \mathrm{mm} \\
34.1(15.5) \mathrm{g}\end{array}$ & $\begin{array}{c}150(0.0) \mathrm{mm} \\
32.2(0.0) \mathrm{g}\end{array}$ & - \\
\hline \multirow{4}{*}{ STH } & ROR & $\begin{array}{l}203(22.9) \mathrm{mm} \\
72.5(26.2) \mathrm{g}\end{array}$ & $\begin{array}{l}210(15.0) \mathrm{mm} \\
78.3(17.0) \mathrm{g}\end{array}$ & $\begin{array}{l}206(20.3) \mathrm{mm} \\
75.5(22.5) \mathrm{g}\end{array}$ & $\begin{array}{l}206(33.3) \mathrm{mm} \\
79.4(35.8) \mathrm{g}\end{array}$ & $\begin{array}{c}203(24.2) \mathrm{mm} \\
72.2(22.1) \mathrm{g}\end{array}$ \\
\hline & PRT & $\begin{array}{c}208(22.3) \mathrm{mm} \\
72.1(21.9) \mathrm{g}\end{array}$ & $\begin{array}{c}206(18.1) \mathrm{mm} \\
72.1(22.1) \mathrm{g}\end{array}$ & $\begin{array}{c}212(25.1) \mathrm{mm} \\
80.9(32.3) \mathrm{g}\end{array}$ & $\begin{array}{l}211(26.2) \mathrm{mm} \\
82.3(29.6) \mathrm{g}\end{array}$ & $\begin{array}{c}205(29.8) \mathrm{mm} \\
74.5(32.4) \mathrm{g}\end{array}$ \\
\hline & TGD & $\begin{array}{c}205(23.5) \mathrm{mm} \\
75.5(29.0) \mathrm{g}\end{array}$ & $\begin{array}{c}198(24.7) \mathrm{mm} \\
66.6(22.1) \mathrm{g}\end{array}$ & $\begin{array}{c}205(29.9) \mathrm{mm} \\
77.1(36.5) \mathrm{g}\end{array}$ & $\begin{array}{c}203(31.7) \mathrm{mm} \\
76.0(30.6) \mathrm{g}\end{array}$ & $\begin{array}{c}209(28.3) \mathrm{mm} \\
78.2(29.2) \mathrm{g}\end{array}$ \\
\hline & SBC & $\begin{array}{c}194.5(23.3) \mathrm{mm} \\
62.5(24.2) \mathrm{g}\end{array}$ & $\begin{array}{c}218(33.9) \mathrm{mm} \\
89.5(40.8) \mathrm{g}\end{array}$ & $\begin{array}{c}207(4.6) \mathrm{mm} \\
73.6(2.2) \mathrm{g}\end{array}$ & - & - \\
\hline
\end{tabular}


Table A.7. Regression data for wet weight to fork length relationship by $\mathrm{CH} 1$ and STH.

\begin{tabular}{ccccccc}
\hline Species & Intercept & Slope & $r^{2}$ & $\mathrm{~N}$ & $F$ & $p$ \\
\hline CH1 & 103.0 & 1.40 & 0.94 & 371 & $5,814.5$ & $<0.0001$ \\
STH & 140.1 & 0.87 & 0.91 & 349 & $3,646.8$ & $<0.0001$ \\
\hline
\end{tabular}

Table A.8. Results of Tukey-Kramer HSD analyses for fork length by week and by CH1 and STH. Treatment is not included in these relationships.

\begin{tabular}{cccccc}
\hline Species & Week & Mean $(\mathrm{mm})$ & SD $(\mathrm{mm})$ & $\mathrm{N}$ & Significance \\
\hline \multirow{5}{*}{ CH1 } & $4 / 26 / 2011$ & 159.2 & 21.5 & 77 & $\mathrm{~A}$ \\
& $5 / 3 / 2011$ & 145.7 & 21.2 & 84 & $\mathrm{~B}$ \\
& $5 / 10 / 2011$ & 146.7 & 22.7 & 82 & $\mathrm{~B}$ \\
& $5 / 17 / 2011$ & 146.8 & 20.6 & 64 & $\mathrm{~B}$ \\
& $5 / 24 / 2011$ & 142.3 & 14.5 & 64 & $\mathrm{~B}$ \\
& $4 / 26 / 2011$ & 203.1 & 23.0 & 80 & \\
STH & $5 / 3 / 2011$ & 204.2 & 19.5 & 74 & \\
& $5 / 10 / 2011$ & 207.2 & 24.9 & 67 & $\mathrm{NS}$ \\
& $5 / 17 / 2011$ & 206.5 & 30.4 & 65 & \\
\hline
\end{tabular}

Table A.9. Results of Tukey-Kramer HSD analyses for wet weight by week and by CH1 and STH. Treatment is not included in these relationships.

\begin{tabular}{cccccc}
\hline Species & Week & Mean $(\mathrm{mm})$ & SD $(\mathrm{mm})$ & $\mathrm{N}$ & Significance \\
\hline \multirow{5}{*}{ CH1 } & $4 / 26 / 2011$ & 39.6 & 16.0 & 77 & $\mathrm{~A}$ \\
& $5 / 3 / 2011$ & 30.6 & 13.6 & 84 & $\mathrm{~B}$ \\
& $5 / 10 / 2011$ & 31.6 & 15.7 & 82 & $\mathrm{~B}$ \\
& $5 / 17 / 2011$ & 30.6 & 14.3 & 64 & $\mathrm{~B}$ \\
& $5 / 24 / 2011$ & 28.5 & 10.2 & 64 & $\mathrm{~B}$ \\
& $4 / 26 / 2011$ & 71.4 & 25.7 & 79 & \\
STH & $5 / 3 / 2011$ & 71.6 & 20.1 & 74 & \\
& $5 / 10 / 2011$ & 77.6 & 30.3 & 67 & $\mathrm{NS}$ \\
& $5 / 17 / 2011$ & 79.0 & 31.6 & 65 & \\
\hline
\end{tabular}

\section{A.3.3 Necropsy Observations}

During necropsy, the number of external observations of the condition for fish in the PRT treatment group was greater than those noted for fish in the ROR and TGD treatment groups of CH1 (all $P \leq 0.0009$; Table A.10). Similarly, external observations of the condition for PRT fish were greater in number than those noted for fish in the TGD treatment group $(P=0.0087)$ but not significantly different from the ROR treatment groups ( $P=0.2851$; Table A.10) of STH. This result was not the same for the internal observations where significantly more internal observations (e.g., trauma, tag damage, infection) 
were noted in the TGD group than in the ROR and PRT groups across the season for each species (Tukey-Kramer HSD, all $P<0.0001$; Table A.11). In the TGD groups, regardless of species, organs like the spleen, swim bladder, and fat were frequently observed to have tag-related irritation. Tag-related irritation included, hematomas, hemorrhaging, deflation, or impressions left on tissue and organs. The above analyses did not include surgery quality.

Table A.10. ANOVA results for ROR, PRT, and TGD comparisons of external and internal observations reported for each species.

\begin{tabular}{ccccccrr}
\hline \multirow{2}{*}{ Species } & Observation & \multicolumn{3}{c}{ Means } & \multicolumn{3}{c}{ ANOVA } \\
\cline { 3 - 8 } & Group & ROR & PRT & TDG & Df & \multicolumn{1}{c}{$F$} & \multicolumn{1}{c}{$P$} \\
\hline \multirow{2}{*}{ CH1 } & External & $2.77 \pm 0.24$ & $3.98 \pm 0.23$ & $2.49 \pm 0.22$ & 2,313 & 11.9646 & $<0.0001^{*}$ \\
& Internal & $1.62 \pm 0.19$ & $1.20 \pm 0.19$ & $4.52 \pm 0.17$ & 2,313 & 105.6106 & $<0.0001^{*}$ \\
\multirow{2}{*}{ STH } & External & $3.86 \pm 0.26$ & $4.43 \pm 0.26$ & $3.36 \pm 0.24$ & 2,320 & 4.4415 & $0.0125^{*}$ \\
& Internal & $2.43 \pm 0.19$ & $2.40 \pm 0.19$ & $5.72 \pm 0.17$ & 2,320 & 111.7499 & $<0.0001^{*}$ \\
\hline * Indicate significant differences.
\end{tabular}

Table A.11. Tukey-Kramer HSD results for ROR, PRT, and TGD comparisons of internal observations reported for each species.

\begin{tabular}{cccc}
\hline Species & Treatment Group & External HSD $P$ & Internal HSD $P$ \\
\hline \multirow{2}{*}{ CH1 } & ROR : PRT & $0.0009^{*}$ & 0.2591 \\
& PRT : TGD & $<0.0001^{*}$ & $<0.0001^{*}$ \\
& TGD : ROR & 0.6635 & $<0.0001^{*}$ \\
\multirow{2}{*}{ STH } & ROR : PRT & 0.2851 & 0.9944 \\
& PRT : TGD & $0.0087^{*}$ & $<0.0001^{*}$ \\
& TGD : ROR & 0.3426 & $<0.0001^{*}$ \\
\hline * Indicate significant differences. & & \\
\hline
\end{tabular}

For $\mathrm{CH} 1$, the external observations noted in the SBC treatment group were significantly greater than in the TGD treatment group but not in the PRT treatment group $(P<0.0001, P=0.9081$, respectively; Table A.12, Table A.13). For CH1 and STH, the more external observations were noted in the PRT treatment groups than in the TGD groups. The mean internal observations for $\mathrm{CH} 1$ and STH were greatest for the SBC treatment groups followed by TGD and then PRT treatment groups (all $P<0.0001$ ); the exception was in $\mathrm{STH}$, the SBC:TGD treatment group comparison was not significantly different $(P=$ 0.9502; Table A.13).

Table A.12. ANOVA results for PRT, TGD, and SBC comparisons of external and internal observations reported for each species.

\begin{tabular}{ccccccrr}
\hline \multirow{2}{*}{ Species } & Observation & \multicolumn{3}{c}{ Means } & \multicolumn{3}{c}{ ANOVA } \\
\cline { 3 - 8 } & Group & PRT & TDG & SBC & Df & \multicolumn{1}{c}{$F$} & \multicolumn{1}{c}{$P$} \\
\hline \multirow{2}{*}{ CH1 } & External & $3.98 \pm 0.23$ & $2.49 \pm 0.22$ & $4.14 \pm 0.29$ & 2,274 & 15.8621 & $<0.0001^{*}$ \\
& Internal & $1.20 \pm 0.22$ & $4.52 \pm 0.20$ & $6.07 \pm 0.29$ & 2,274 & 106.7852 & $<0.0001^{*}$ \\
\multirow{2}{*}{ STH } & External & $4.43 \pm 0.25$ & $3.36 \pm 0.23$ & $3.63 \pm 0.46$ & 2,249 & 5.0761 & $0.0069^{*}$ \\
& Internal & $2.43 \pm 0.22$ & $5.72 \pm 0.21$ & $5.86 \pm 0.41$ & 2,249 & 66.0942 & $<0.0001^{*}$ \\
\hline \multicolumn{7}{l}{ * Indicate significant differences. }
\end{tabular}


Table A.13. Tukey-Kramer HSD results for PRT, TDG, and SBC comparisons of external and internal observations reported for each species.

\begin{tabular}{cccc}
\hline Species & Treatment Group & External HSD $P$ & Internal HSD $P$ \\
\hline \multirow{3}{*}{ CH1 } & PRT: TGD & $<0.0001^{*}$ & $<0.0001^{*}$ \\
& TGD: SBC & $<0.0001^{*}$ & $<0.0001^{*}$ \\
& SBC: PRT & 0.9081 & $<0.0001^{*}$ \\
\multirow{2}{*}{ STH } & PRT: TGD & $0.0051^{*}$ & $<0.0001^{*}$ \\
& TGD: SBC & 0.8552 & 0.9502 \\
& SBC: PRT & 0.2813 & $<0.0001^{*}$ \\
\hline * Indicate significant differences. & & \\
\hline
\end{tabular}

To further elucidate factors that may have influenced the frequency of observed responses for each treatment group within and among species, ANOVAs were conducted to examine observed responses over time. External and internal observations were pooled and assigned a week of collection (WK 1 through 5) based on the $5 \mathrm{wk}$ for the tagging season (Table A.14). For CH1, WK 5 and WK 3 were significantly greater than WK $1(P \leq 0.0276$; Table A.15). The general trend for $\mathrm{CH} 1$ indicated a rise in observations over time with a slight increase in WK 3. This pattern was also detectable in the STH. For $\mathrm{STH}$, though, WK 5 had significantly more observations noted than in other weeks, and observations noted during WK 3 were significantly greater in number than those in WK 1, WK 2 and WK 4 (all $\mathrm{P} \leq 0.0321$; Table A.15).

Table A.14. ANOVA results for week comparisons of external and internal observations reported for each species.

\begin{tabular}{ccccccccc}
\hline & \multicolumn{3}{c}{ Means } & \multicolumn{3}{c}{ ANOVA } \\
\cline { 2 - 9 } Species & WK 1 & WK 2 & WK 3 & WK 4 & WK 5 & Df & $F$ & $P$ \\
\hline CH1 & $5.57 \pm 0.38$ & $6.22 \pm 0.37$ & $6.75 \pm 0.38$ & $6.30 \pm 0.43$ & $6.98 \pm 0.43$ & 4,370 & 1.9112 & 0.1079 \\
STH & $6.10 \pm 0.35$ & $6.82 \pm 0.36$ & $8.44 \pm 0.38$ & $7.21 \pm 0.39$ & $10.36 \pm 0.39$ & 4,348 & 19.9132 & $<0.0001$ \\
\hline
\end{tabular}

Table A.15. Tukey-Kramer HSD results for week comparisons of external and internal observations reported for each species.

\begin{tabular}{cccccc}
\hline Species & WK 1 & WK 2 & WK 3 & WK 4 & WK 5 \\
\hline CH1 & B & A, B & A & A, B & A \\
STH & D & C, D & B & C & A \\
\hline
\end{tabular}

Fork lengths of fish were examined to determine if the necropsy observations were influenced by fish size. After pooling all species, runs, and treatments, smaller fish (as measured by fork length) had more trauma- and disease-related external and internal observations than larger fish. The analysis yielded a two-factor solution, which accounted for $78.9 \%$ of the variance $(P<0.0001$; Figure A.3). The first factor naturally focused on the length and weight relationship explaining $48.5 \%$ of the variation. The second factor focused on the relationship between necropsy observations and adipose fin clipping, shown below as internal and external combined, explaining $30.3 \%$ of the data variation. 


\section{A.3.4 Alpha II-Spectrin}

For $\mathrm{CH} 1$, there was no significant difference between ROR, PRT, or TGD treatment groups in the frequency of the presence $\left(\mathrm{N}=264 ; \chi^{2}(2)=1.01 ; P=0.6020\right.$; Table A.16) or total presence $\left(\chi^{2}(2)=\right.$ $0.76 ; P=0.6828$; Figure A.4) of plasma alpha II-spectrin and SBDPs. For STH, there was a significant difference in the frequency of the presence of plasma alpha II-spectrin and SBDPs between ROR, PRT, and TGD treatment groups $\left(\mathrm{N}=302 ; \chi^{2}(2)=37.77 ; P<0.0001\right.$; Table A.16). TGD (50.9\%) STH had a significantly greater presence of plasma alpha II-spectrin and SBDPs followed by the ROR (19.4\%) then PRT (15.5\%) treatment groups. Similarly, total alpha II-spectrin and SBDPs significantly varied with ROR, PRT, and TGD treatments $\left(\chi^{2}(2)=2.34 ; P<0.0001\right.$; Figure A.4). TGD STH had significantly more alpha II-spectrin and SBDPs compared to STH in the ROR and PRT treatment groups (all $P<0.0001)$. There was no difference in total alpha II-spectrin and SBDPs between the ROR and PRT treatment groups $(P=0.5541)$.

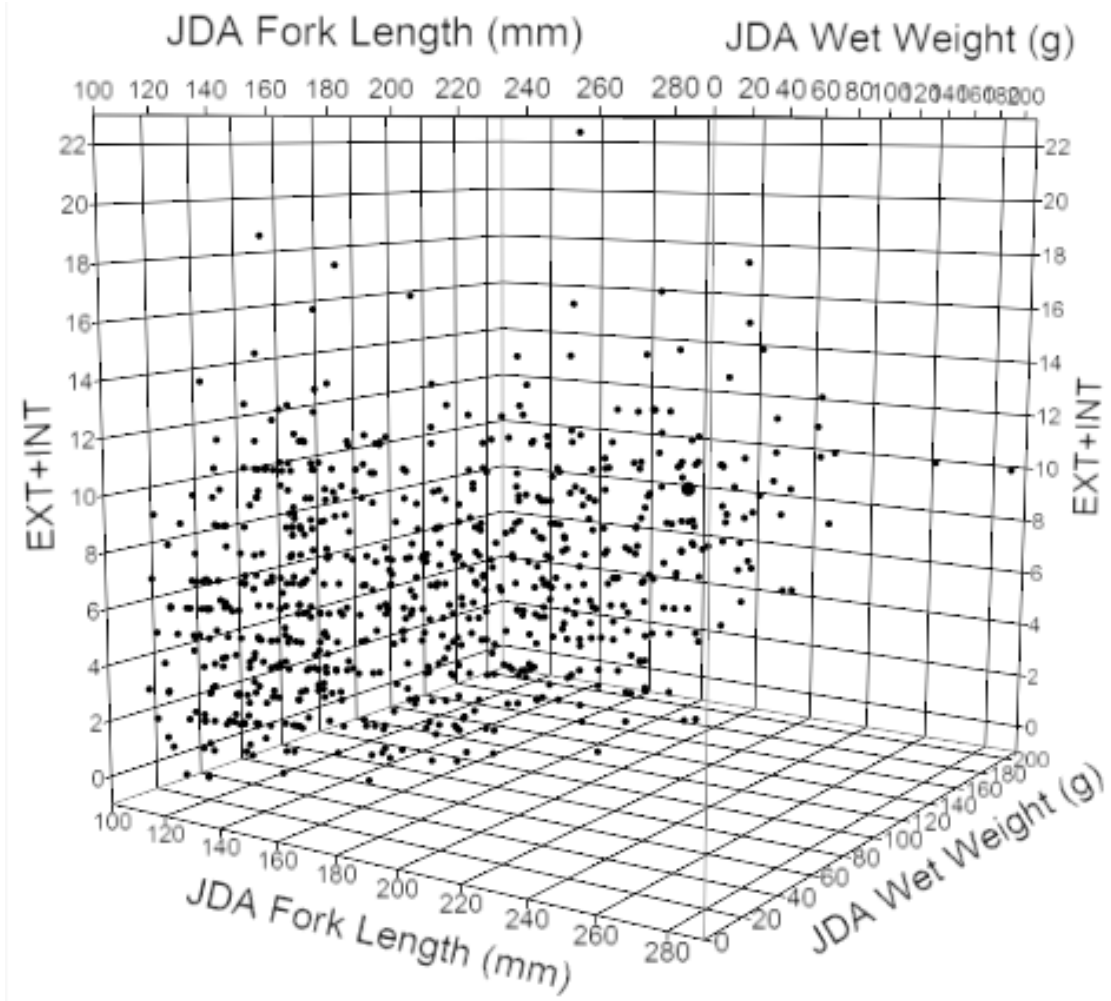

Figure A.3. The frequency of external and internal observations made per fish compared to the fork length and wet weight of all species and treatments combined.

Table A.16. Frequency of presence of plasma alpha II-spectrin and SBDPs for CH1 and STH.

\begin{tabular}{cccccc}
\hline \multirow{2}{*}{ Species } & $\begin{array}{c}\text { Alpha II-Spectrin } \\
\text { and SBDPs }\end{array}$ & ROR & PRT & TGD & SBC \\
\hline \multirow{2}{*}{ CH1 } & Present & $41(51.3 \%)$ & $39(44.8 \%)$ & $50(51.5 \%)$ & $22(47.8 \%)$ \\
& Absent & 39 & 48 & 47 & 24 \\
\multirow{2}{*}{ STH } & Present & $18(19.4 \%)$ & $15(15.5 \%)$ & $57(50.9 \%)$ & $4(16.0 \%)$ \\
& Absent & 75 & 82 & 55 & 21 \\
\hline
\end{tabular}


For $\mathrm{CH} 1$, the frequency of the presence $\left(\mathrm{N}=228 ; \chi^{2}(2)=1.13 ; P=0.5698\right.$; Table A.16) and total presence $\left(\chi^{2}(2)=1.31 ; P=0.5202\right.$; Figure A.5) of plasma alpha II-spectrin and SBDPs was not significantly different between PRT, TGD, and SBC treatment groups. For STH, the frequency of the presence $\left(\mathrm{N}=234 ; \chi^{2}(2)=34.28 ; P<0.001\right.$; Table A.16) and total presence $\left(\chi^{2}(2)=33.18 ; P<0.0001\right.$; Figure A.5) of alpha II-spectrin and SBDPs was significantly different between PRT, TGD, and SBC treatment groups. For both the frequency of presence and total presence, TGD STH had significantly greater alpha II-spectrin and SBDPs (all $P<0.01)$ compared to the PRT and SBC treatment groups and there was no difference between the PRT and SBC treatment groups $(P=0.9679)$.
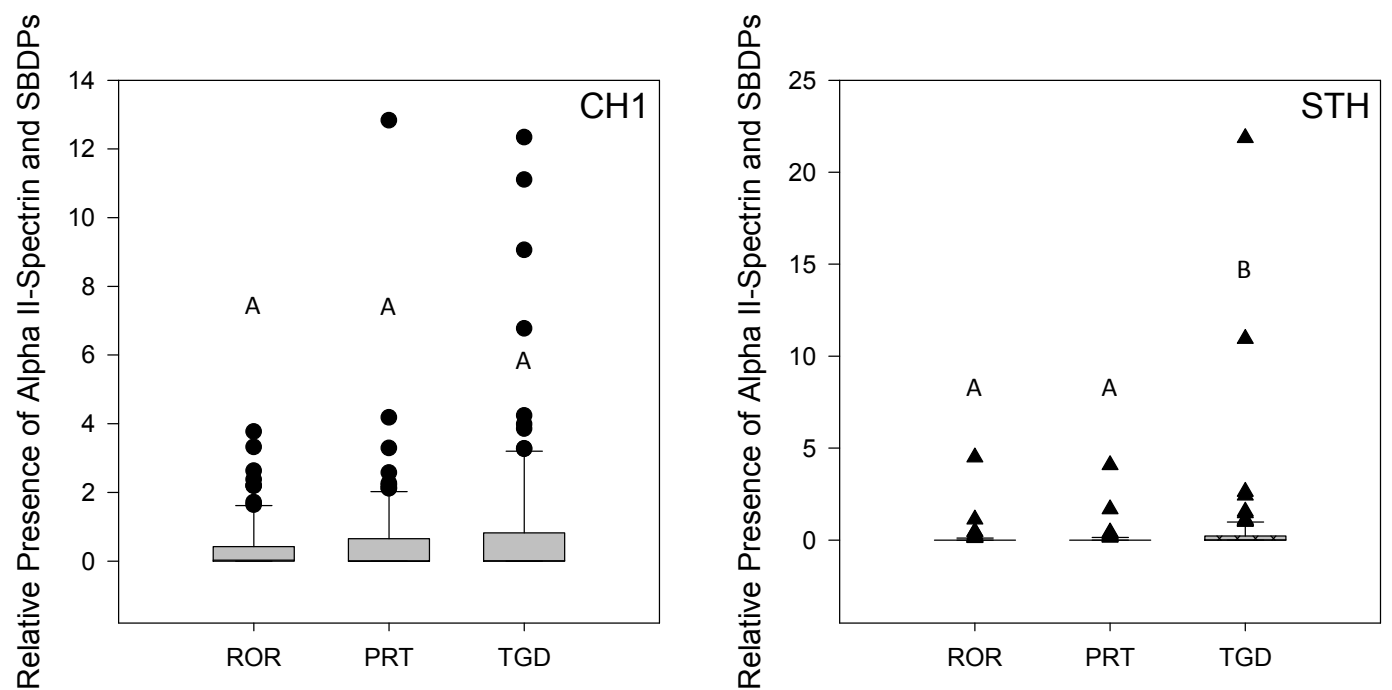

Figure A.4. Box plots of relative total presence of plasma alpha II-spectrin and SBDPs for ROR, PRT, and TGD treatments for $\mathrm{CH} 1(\bullet)$ and $\mathrm{STH}(\boldsymbol{\Delta})$. Each box plot represents the median and upper and lower quartiles for plasma alpha II-spectrin presence. Different uppercase letters indicate significant differences $(P<0.05)$.
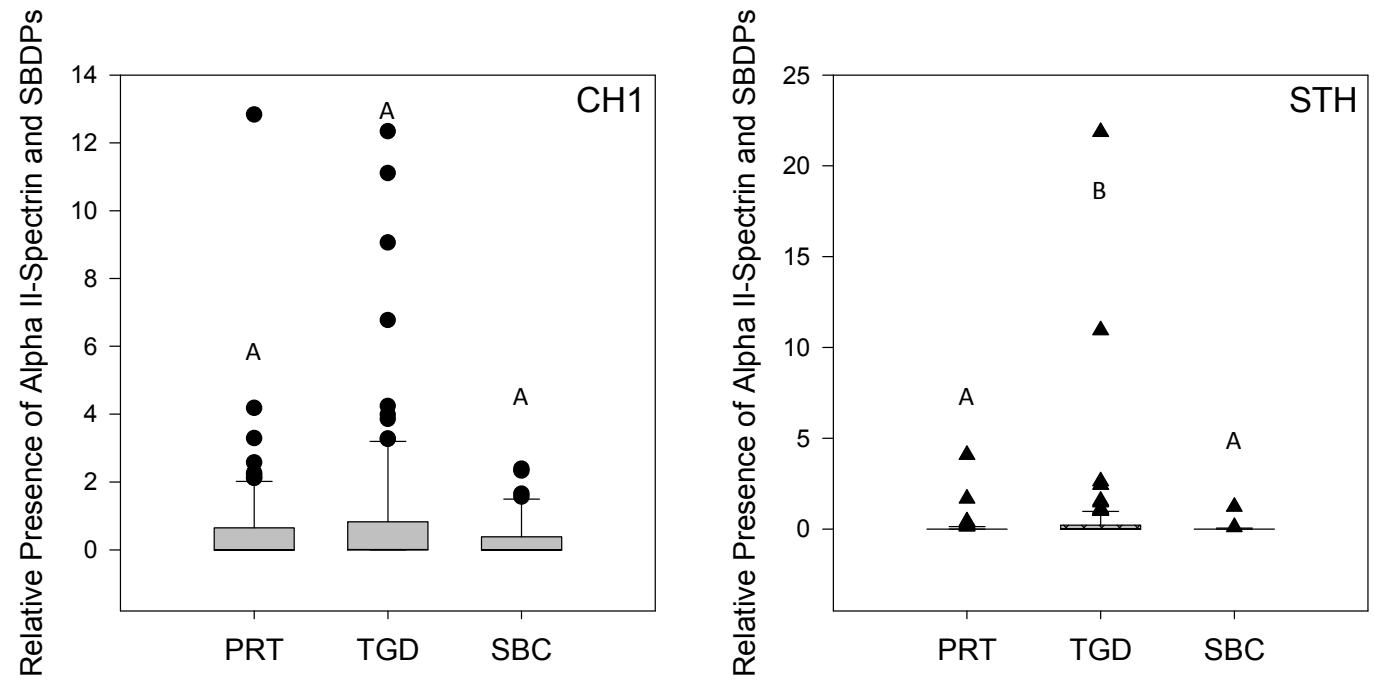

Figure A.5. Box plots of relative presence of plasma alpha II-spectrin and SBDPs for PRT, TGD, and SBC treatment groups for $\mathrm{CH} 1(\bullet)$ and STH $(\boldsymbol{\Delta})$. Each box plot represents the median and upper and lower quartiles for plasma alpha II-spectrin presence. Different uppercase letters indicate significant differences $(P<0.05)$. 


\section{A.3.5 Spleen Immune Gene Expression}

Spleen IL1- $\beta$ gene expression (Figure A.6) significantly varied with treatment for both $\mathrm{CH} 1\left(\chi^{2}(2)=\right.$ 58.00, $P<0.0001)$ and STH $\left(\chi^{2}(2)=22.83 ; P<0.0001\right)$. For CH1, the TGD treatment group had significantly higher IL1- $\beta$ gene expression than the ROR and PRT treatment groups (all $P<0.05)$. There was no significant difference in IL1- $\beta$ gene expression between the PRT and ROR treatment groups for CH1 $(P>0.05)$. For STH, IL1- $\beta$ gene expression was significantly higher in the ROR and TGD treatment groups compared to the PRT treatment group $(P<0.01)$. There was no significant difference in IL1- $\beta$ gene expression between the ROR and TGD treatment groups for STH $(P=0.0788)$. Spleen IgM gene expression (Figure A.6) significantly varied with treatment for both $\mathrm{CH} 1\left(\chi^{2}(2)=12.79 ; P=\right.$ $0.0017)$ and STH $\left(\chi^{2}(2)=31.16 ; P<0.005\right)$. For CH1, the TGD treatment group had significantly lower IgM expression compared to PRT treatment group (all $P<0.001$ ), but IgM gene expression for the ROR treatment group was not significantly different from PRT or TGD treatment groups (all $P>0.05$ ). For $\mathrm{STH}$, the TGD treatment group had significantly lower IgM expression than the ROR and PRT treatment groups (all $P<0.0003$ ). The IgM gene expression for STH in the ROR treatment group was not significantly different from that in the PRT treatment group $(P=0.5319)$.

Spleen IL1- $\beta$ expression (Figure A.7) was significantly different between treatments for both CH1 $\left(\chi^{2}(2)=55.00 ; P<0.0001\right)$ and STH $\left(\chi^{2}(2)=26.70 ; P<0.0001\right)$. For both CH1 and STH, the TGD treatment groups had significantly greater IL1- $\beta$ gene expression than the PRT and SBC treatment groups (all $P<0.005$ ). For $\mathrm{CH} 1$, the PRT treatment group had significantly greater IL1- $\beta$ expression than the SBC treatment group $(P=0.0495)$, but there was no difference in IL1- $\beta$ gene expression for between PRT and SBC treatment groups for STH $(P=0.7976)$. IgM expression (Figure A.7) was significantly different between PRT, TGD, and SBC treatment groups for CH1 $\left(\chi^{2}(1)=5.27 ; P=0.021\right)$ and STH $\left(\chi^{2}(1)=15.19 ; P<0.0001\right)$. For CH1 and STH, the PRT treatment group had the highest IgM gene expression followed by TGD, then SBC treatment groups (all $P<0.05$ ).

\section{A.4 Discussion}

\section{A.4.1 Necropsy}

The necropsy observations proved to be useful in determining juvenile salmon condition variation over time, size, and treatments. Species and/or run comparisons were not conducted. Because juvenile salmonids were collected and tagged at JDA for the concurrent survival study, the fish condition experimental design was developed to examine fish that were taken directly yet randomly from the sort table during the survival study collection periods, then during the survival study tagging events, and random tagged fish were transported to $\mathrm{BON}$ for examination of their conditions. External observations, when summed for total observations made per fish, for both species, indicated that the PRT treatment group had more external observations than ROR and TGD treatment groups. This indicates that the group of fish selected for tagging had more external trauma or disease observations noted than those fish deemed to be ROR fish. We did not expect to see a difference between the PRT and TGD treatment groups, because the fish were selected from the same tanks. Conversely, internal observations, again when summed for total observations made per fish, indicated that the TGD group had significantly more internal trauma- and disease-related issues compared to the ROR and PRT groups, regardless of species. Trauma associated with damage from the tagger, incised tissue or tag, and infection was noted most 
frequently as the causes of damage. For example, the internal examinations of fish in the TGD treatment group noted that the spleen, swim bladder, and fat were most often damaged or irritated by tag presence, additional pressure from the tag, which deflated or left impressions in tissues and organs and caused hematomas and hemorrhaging. The effects of tags and tagging within the first $24 \mathrm{~h}$ were quite pronounced in the TGD sample fish, though not further examined, are likely indicative of altered performance after release and perhaps even survival.
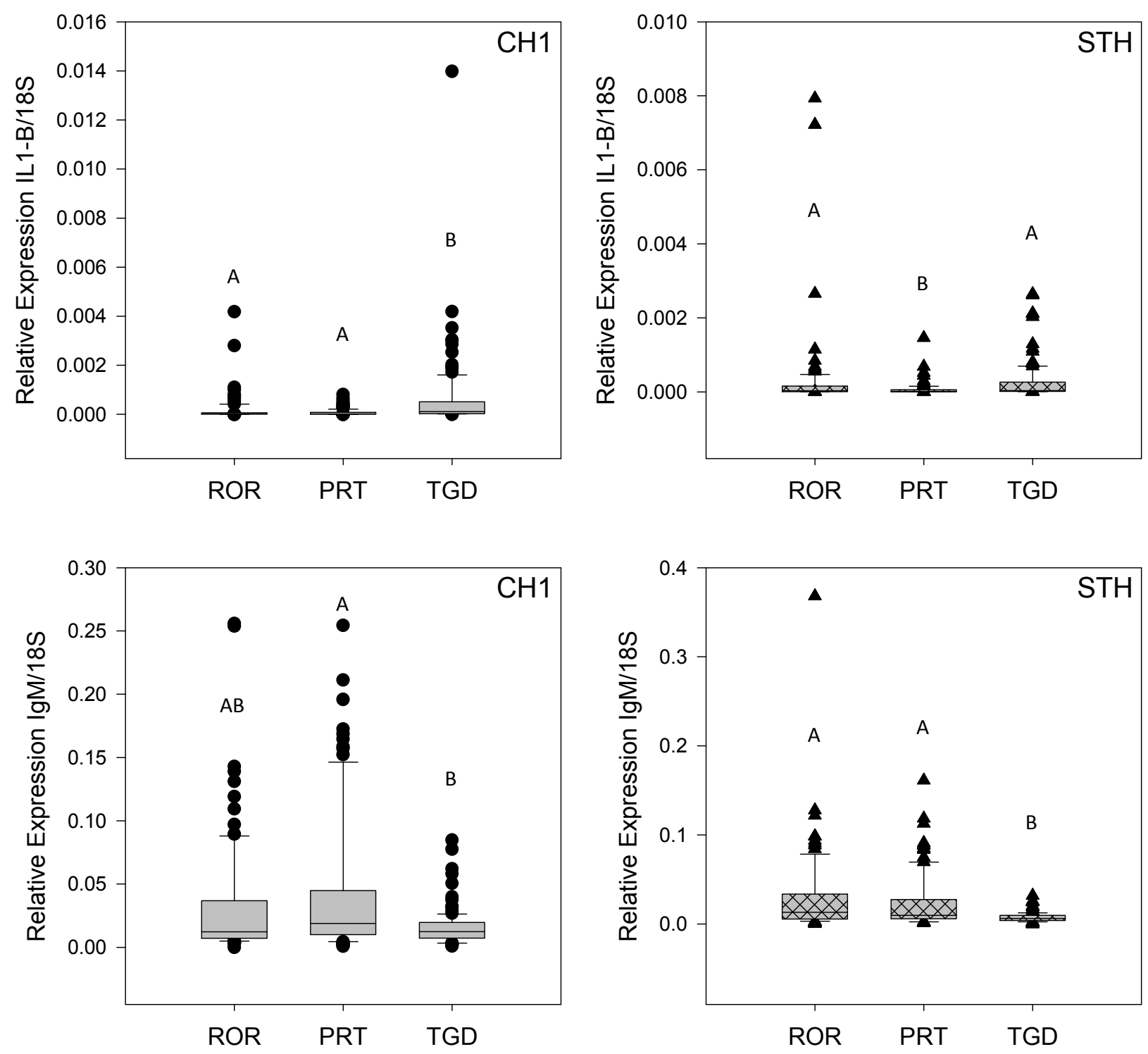

Figure A.6. Box plots of relative IL1- $\beta$ and IgM gene expression in the spleen for ROR, PRT, and TGD treatments during the tagging process for $\mathrm{CH} 1(\bullet)$ and $\mathrm{STH}(\boldsymbol{\Delta})$. Each box plot contains the median and upper and lower quartiles. Different uppercase letters indicate significant differences $(P<0.05)$. 

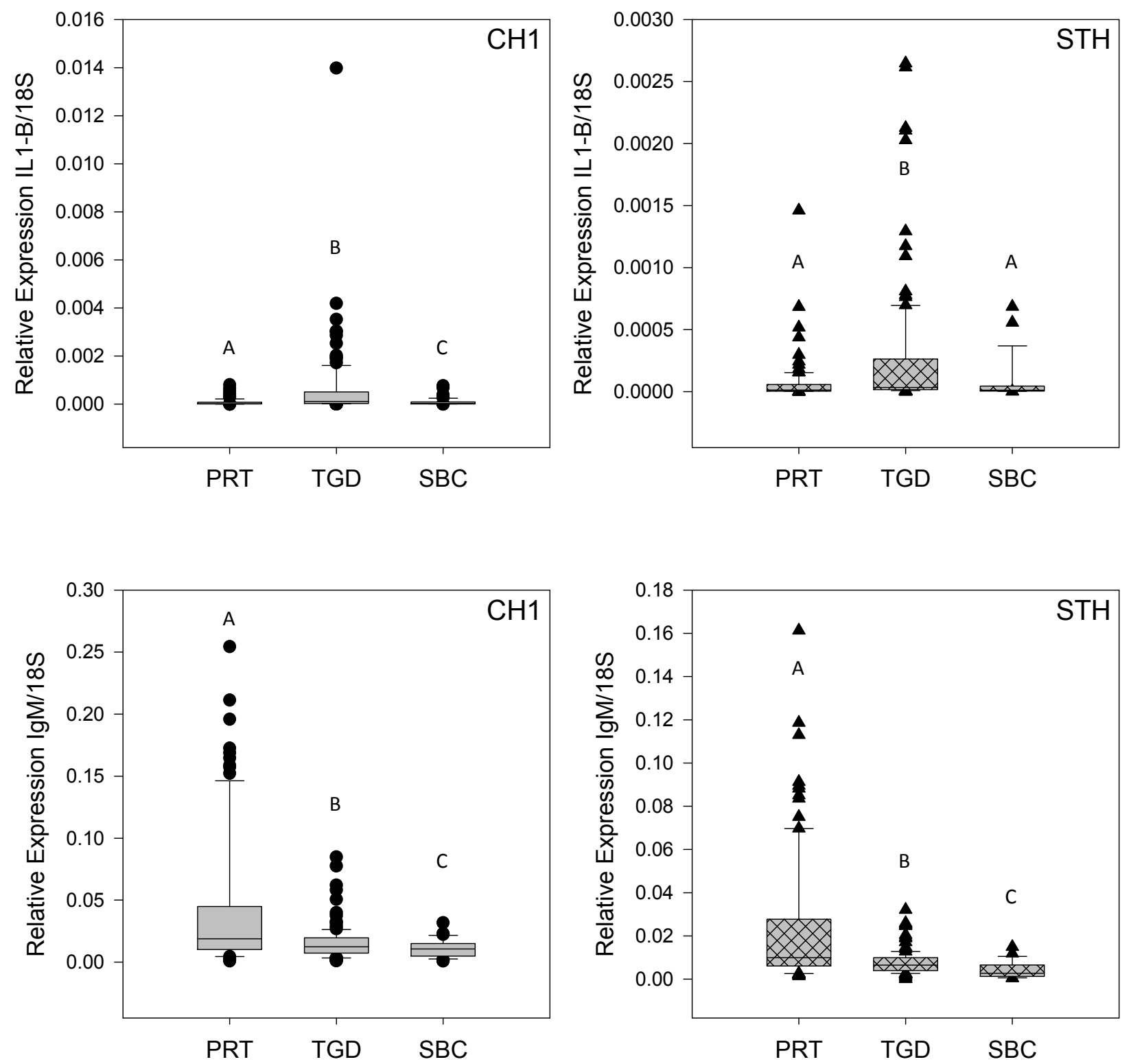

Figure A.7. Box plots of relative IL1- $\beta$ and IgM gene expression in the spleen for PRT, TGD, and SBC treatment groups during the tagging process for $\mathrm{CH} 1(\bullet)$ and $\mathrm{STH}(\boldsymbol{\Delta})$. Each box plot contains the median and upper and lower quartiles.

The study design allowed for the comparison of the PRT fish, TGD fish, and fish released in river that were later retrieved using the $\mathrm{SByC}$ system at $\mathrm{BON}$. Fish collected at BON were from the uppermost release point, Roosevelt at $390 \mathrm{rkm}$, taking 4-10 d to travel to BON. Significantly more observations of external health and trauma were noted for the acoustic-tagged $\mathrm{CH} 1$ recollected in BON SByC than for the TGD treatment group but not the PRT treatment group. Internally though, more observations were noted in the SBC treatment group than in the PRT or TGD treatment groups of CH1. Similar to above, tag and surgeon damage was a major factor causing internal trauma. External observations of acoustic-tagged STH recollected in BON SByC were not significantly different from TGD or PRT treatment groups. Internally, though, more observations were noted in the SBC treatment group than the PRT treatment 
groups of STH. Similar to above, tag and surgeon damage was a major factor causing internal trauma. In addition, in 2011, the water flow in the spring was greater than the 10-yr average, which may have led to higher levels of internal trauma from greater debris and total gas pressure in the river. The increased trauma may have been magnified by the tag and tagging process.

The fish condition necropsies also indicated that the overall condition of each species changed over time. The general trend of condition for $\mathrm{CH} 1$ and STH indicated that at the beginning of each tagging session (WK 1), the juvenile salmon, regardless of species, were in better condition than those fish towards the end of the tagging session (WK 5). This could be related to several factors, such as water temperature and/or flow, river debris, salmon origination, and/or state of smoltification. Efforts to predict fish condition over time as a factor of survival may prove to be useful for both monitoring survival across dams as well as facility operations to improve fish passage.

Lastly, in 2010, the combination of external and internal necropsy observations indicated that smaller fish tend to be in poor condition. Over the 2011 spring session, the combined observations (both external and internal) did not appear to be more sensitive to the size range of fish. However in spring 2011, the overall size range of fish was truncated compared to 2010, due to the elimination of the summer sampling of subyearling Chinook salmon from high water flows. Further analyses should be conducted with multiyear data sets to isolate, if possible, the interactions of treatments with species and fish condition.

\section{A.4.2 Alpha II-Spectrin}

Alpha II-spectrin is a cytoskeletal protein that is broken down by enzymatic activity following cellular damage or apoptotic events. In 2010, alpha II-spectrin and SBDPs were first measured in plasma as a possible indicator of internal injury based on the assumption that damaged cells would release this intact and broken structural protein into biological fluids (i.e., blood, cerebral spinal fluid). In 2010, alpha II-spectrin and SBDPs were detected through colorimetric appearance; however, in this study, the method for detection was modified to a more sensitive technique, chemiluminescence detection, thus values could not be directly compared to 2010 data, however, general trends between treatment groups may be comparable.

In this study, there was no significant difference in the frequency or total presence of plasma alpha II-spectrin and SBDPs for CH1; however, frequency and total presence of plasma alpha II-spectrin was significantly elevated for TGD STH compared to the STH in the ROR and PRT treatment groups. Whereas, in 2010 for CH1, the ROR and TGD treatment groups had a significantly greater presence of alpha II-spectrin and SBDPs compared to the PRT treatment group; for STH, there was no significant difference in the presence of alpha II-spectrin and SBDPs between treatment groups. When comparing PRT, TGD, and SBC treatment groups for the current study, there was no difference in alpha II-spectrin and SBDPs for CH1, but expression was significantly higher in the TGD STH treatment group compared to the PRT and SBC STH treatment groups. The elevated alpha II-spectrin had subsided in the STH SBC treatment group to near PRT levels. In 2010, there was no difference in alpha II-spectrin and SBDPs expression between TGD and SBC treatment groups for CH1 or STH.

While the expression of plasma alpha II-spectrin and SBDPs appears to be species dependent, year to year differences may be related to in-river conditions and the condition of the fish. This study had experienced high water flows, which resulted in the elimination of the summer portion of the study. 
In addition, plasma presence of alpha II-spectrin and SBDPs may be muddled by smoltification and downstream migration. During smoltification, fish undergo a series of morphological, biochemical, and physiological changes in preparation for seawater adaptation (Folmar and Dickhoff 1980).

Morphological changes involve tissue remodeling, including the elongation of the caudal peduncle (Winans and Nishioka 1987), which can possibly increase cellular apoptotic events and presence of alpha II-spectrin. A microarray analysis has demonstrated a significant upregulation in protein biosynthesis and degradation pathway gene expression during smoltification (Gallagher et al. 2008). Similarly, Seear et al. (2010) measured an increase in secreted protein, acidic, and rich in cysteine (SPARC) gene expression during smoltification of Atlantic salmon, which may be associated with increased tissue remodeling, morphogenesis, and tissue repair (Lane and Sage 1994). Downstream migration has been shown to result in muscle remodeling; specifically, muscle myosin heavy chain isoform switching, to favor sustained swimming performance (Mänttäri et al. 2005). Therefore, the increase in plasma cytoskeletal proteins may not be solely related to injury, but also to tissue remodeling during smoltification and downstream migration.

\section{A.4.3 Spleen Immune Gene Expression}

Teleosts have both innate and adaptive immune responses. Tagging is expected to elicit an innate immune response. Adaptive responses, such as upregulated IgM gene expression, may occur in response to antigen exposure that may be introduced during the tagging process or in support of the innate immune response.

IL1- $\beta$ is a cytokine indicative of a generalized inflammation response to injury or pathogens. IL1- $\beta$ gene expression has been demonstrated to increase in the muscle tissue of rainbow trout after physical injury (Ingerslev et al. 2010). In 2010, both CH1 and STH demonstrated upregulated IL1- $\beta$ gene expression in response to tagging (Weiland et al. 2013). In this study, IL1- $\beta$ gene expression was significantly elevated in the TGD treatment groups for both $\mathrm{CH} 1$ and STH; however, expression was also elevated in the ROR treatment groups, which may be a result of exposure to some other stressor during downriver migration. However, this elevated immune response had subsided in fish in the SBC treatment group to levels at or below the PRT treatment group.

IgM is a B cell surface receptor, involved in adaptive immunity. In 2010, IgM expression was highest in the TGD treatment group for both $\mathrm{CH} 1$ and STH when compared to ROR and PRT treatment groups (Weiland et al. 2013). Conversely, for both CH1 and STH in this study, IgM expression was lowest in the TGD treatment group. Lower IgM in the TGD treatment group may be a result of increased stress (i.e., cortisol). Cortisol has been found to have an inhibitory effect on IgM secretion (Saha et al. 2004). In both 2010 and 2011, IgM expression was lower in the SBC treatment group compared to the TGD and PRT treatment groups. At this time, it is unknown whether this is a result of chronic stress from tag implantation or whether the tag effects have subsided. In addition, during downstream migration, fish are undergoing exposure to other stresses, antigens, and smoltification, which increases stress and can alter immune responses. It is important to recognize that, because IgM is a marker of adaptive immunity, prior exposure to vaccines and pathogens, during hatchery operations or downriver migration, can alter the response to an antigen (Olsen et al. 2011). 


\section{A.5 Implications for Management}

In the Columbia River Basin, many programs assess fish condition by documenting external observations as an indicator of physiological state and internal damage. The approach used in this study, though, indicated that external observations were not necessarily good indicators of internal and physiological state. Thus, programs based simply on external observation of fish condition are likely to underestimate or under describe the actual condition of the fish. These programs and even this study would benefit from the development of indices for external and internal condition that would predict juvenile salmon condition. In addition, telemetry-based studies, such as the concurrent survival study, can benefit from the approach by increasing their ability to quantify the effects of surgery and transmitter implantation and separating the effects from anesthetic exposure (Woodley et al. 2012). Selected biochemistries further elaborate on fish condition for each treatment and warrant additional investigations into non-lethal fish condition assessments that do not underestimate condition. Internal physical damage that was more extensive in the TGD and SBC treatment groups, could cause delayed mortality, decreased performance, altered behavior, and increased physiological costs (Jepsen et al. 2002; Lacroix et al. 2004; Welch et al. 2007).

\section{A.6 References}

3 Treaty Tribes-Action Agencies. 2008. Memorandum of Agreement Among the Umatilla, Warm Springs and Yakama Tribes, Bonneville Power Administration, U.S. Army Corps of Engineers, and U.S. Bureau of Reclamation, Portland, Oregon, April 4, 2008. Available at: http://www.salmonrecovery.gov/Files/BiologicalOpinions/3-tribe-AA-MOA-Final.pdf.

Baras E and L Westerloppe. 1999. "Transitional expulsion of surgically implanted tags by African catfish Heterobranchus longifilis of variable size and age." Transactions of the American Fisheries Society 128(4):737-746.

Brown RS, SJ Cooke, WG Anderson, and RS Scott. 1999. "Evidence to challenge the "2\% rule" for biotelemetry." North American Journal of Fisheries Management 19:867-871.

Brown RS, RA Harnish, KM Carter, JW Boyd, KA Deters, and MB Eppard. 2010. "An evaluation of the maximum tag burden for implantation of acoustic transmitters in juvenile Chinook salmon." The American Journal of Fisheries Management 30:499-505.

Carlson TJ, GE Johnson, CM Woodley, and JR Skalski. 2011. Compliance Monitoring of Underwater Blasting for Rock Removal at Warrior Point - Columbia River Channel Improvement Project, 2009/2010. PNNL-20388, prepared for the U.S. Army Corps of Engineers, Portland District, Portland, Oregon, by Pacific Northwest National Laboratory, Richland, Washington.

CBSPSC (Columbia Basin Surgical Protocol Steering Committee). 2011. "Surgical Protocols for Implanting JSATS Transmitters into Juvenile Salmonids for Studies Conducted for the U.S. Army Corps of Engineers." Volume 1, U.S. Army Corps of Engineers, Portland District, Portland, Oregon.

Chittenden CM, KG Butterworth, KF Cubitt, MC Jacobs, A Ladouceur, DW Welch, and RS McKinley. 2009. "Maximum tag to body size ratios for an endangered coho salmon $(O$. kisutch) stock based on physiology and performance." Environmental Biology of Fishes 84(1):129-140. 
Clemens BJ, SP Clements, MD Karnowski, DB Jepsen, AI Gitelman, and CB Schreck. 2009. "Effects of transportation and other factors on survival estimates of juvenile salmonids in the unimpounded lower Columbia River." Transactions of the American Fisheries Society 138(1):169-188.

Deriso RB, MN Maunder, and JR Skalski. 2007. "Variance estimation in integrated assessment models and its importance for hypothesis testing." Canadian Journal of Fisheries and Aquatic Sciences 64(2):187-197.

Faber DM, MA Weiland, R Moursund, TJ Carlson, N Adams, and D Rhondorf. 2001. Evaluation of the Fish Passage Effectiveness of the Bonneville I Prototype Surface Collector Using Three-Dimensional Ultrasonic Fish Tracking. PNNL-13526, prepared for the U.S. Army Corps of Engineers, Portland, Oregon, Portland, Oregon, by Pacific Northwest National Laboratory, Richland, Washington.

Folmar LC and WW Dickhoff. 1980. "The parr-smolt transformation (smoltification) and seawater adaptation in salmonids: A review of selected literature." Aquaculture 21:1-37.

Fontenot DK and DL Neiffer. 2004. "Wound management in teleost fish: Biology of the healing process, evaluation, and treatment." The Veterinary Clinics: Exotic Animal Practice 7(1):57-86.

Freeman WM, SJ Walker, and KE Vrana. 1999. "Quantitative RT-PCR: Pitfalls and potential." BioTechniques 26:112-125.

Gallagher EP, HM LaVire, TK Bammler, PL Stapleton, RP Beyer, and FM Farin. 2008. "Hepatic expression profiling in smolting and adult coho salmon (Oncorhynchus kisutch)." Environmental Research 106:365-378.

Greenburg JA and RM Clark. 2009. "Advances in suture material for obstetric and gynecologic surgery." Reviews in Obstetrics and Gynecology 2(3):146-158.

Halvorsen MB, BM Casper, CM Woodley, TJ Carlson, and AN Popper AN. 2011. Predicting and mitigating hydroacoustic impacts on fish from pile installations. NCHRP Research Results Digest 363, Project 25-28, National Cooperative Highway Research Program, Transportation Research Board, National Academy of Sciences, Washington, D.C. Available at http://apps.trb.org/cmsfeed/TRBNetProjectDisplay.asp?ProjectID=763.

Harms CA. 2005. "Surgery in fish research: Common procedures and postoperative care." Lab Animal 34(1):28-34.

Ingerslev H, CG Ossum, T Lindenstrøm, and M Engelbrecht Nielsen. 2010. "Fibroblasts express immune relevant genes and are important sentinel cells during tissue damage in rainbow trout (Oncorhynchus mykiss). PLoS ONE 5(2):e9304. Doi:10.1371/journal.pone.0009304.

Jepsen N, A Koed, EB Thorstad, and E Baras. 2002. "Surgical implantation of telemetry transmitters in fish: How much have we learned?" Hydrobiologia 483(1-3):239-248.

Lacroix GL, D Knox, and P McCurdy. 2004. "Effects of implanted dummy acoustic transmitters on juvenile Atlantic salmon." Transactions of the American Fisheries Society 133(1):211-220. 
Lane TF and EH Sage. 1994. "The biology of SPARC, a protein that modulates cell-matrix interactions." The Journal of the Federation of American Societies for Experimental Biology 8:163-173.

Lucas MC. 1989. "Effects of implanted dummy transmitters on mortality, growth and tissue reaction in rainbow trout, Salmo gairdneri Richardson." Journal of Fish Biology 35:577-587.

Mänttäri S, K Anttila, and M Järvilehto. 2005. "Effects of downstream migration on myosin heavy chain expression and dihydropyridine receptor density in farmed smolt of Atlantic salmon." Journal of Fish Biology 66:1437-1446.

Markus HC. 1933. "The effects of tags upon fresh water fishes." American Fisheries Society 63(1):319-325.

Martinelli TL, HC Hansel, and RS Sively. 1998. "Growth and physiological responses to surgical and gastric radio transmitter implantation techniques in subyearling Chinook salmon (Oncorhynchus tshawytscha)." Hydrobiologia 371/372:79-87.

Marty GD and RC Summerfelt. 1986. "Pathways and mechanisms for expulsion of surgically implanted dummy transmitters from channel catfish." Transactions of the American Fisheries Society 115:577-589.

McComas RL, D Frost, SG Smith, JW Ferguson, TJ Carlson, and T Aboellail. 2005. A Study to Estimate Salmonid Survival Through the Columbia River Estuary Using Acoustic Tags, 2002. Report to the U.S. Army Corps of Engineers, Portland, Oregon. Contract E86910060, National Oceanic and Atmospheric Administration-National Marine Fisheries Service, Northwest Fisheries Science Center, Seattle, Washington.

Miracle A, ND Denslow, KJ Kroll, MC Liu, and KKW Wang. 2009. “Spillway-induced salmon head injury triggers the generation of Brain $\alpha$ II-spectrin breakdown product biomarkers similar to mammalian traumatic brain injury." PLOS ONE 4(2):e4491. Doi:10.1371/journal.pone.0004491.

Moore A, IC Russell, and ECE Potter. 1990. "The effects of intraperitoneally implanted dummy acoustic transmitters on the behavior and physiology of juvenile Atlantic salmon, Salmo salar L." Journal of Fish Biology 37:713-721.

Mulcahy DM. 2003. "Surgical implantation of transmitters into fish.” ILAR Journal 44(4):295-306.

NOAA Fisheries. 2008. Biological Opinion (BiOp) on the operation of the Federal Columbia River Power System (FCRPS). U.S. Department of Commerce, National Marine Fisheries Service, Northwest Regional Office, Seattle, Washington.

Olsen, MM, PW Kania, RD Heinecke, K Skjoedt, KJ Rasmussen, and K Buchmann. 2011. "Cellular and humoral factors involved in the response of rainbow trout gills to Ichthyophthirius multifiliis infections: molecular and immunohistochemical studies." Fish \& Shellfish Immunology 30:859-869.

Petering RW and DL Johnson. 1991. "Suitability of a cyanoacrylate adhesive to close incisions in black crappies used in telemetry studies." Transactions of the American Fisheries Society 120:535-537. 
Ploskey GR, MA Weiland, JS Hughes, SR Zimmerman, RE Durham, ES Fischer, J Kim, RL Townsend, JR Skalski, and RL McComas. 2007. Acoustic Telemetry Studies of Juvenile Chinook Salmon Survival at the Lower Columbia Projects in 2006. PNNL-16560, prepared for U.S. Army Corps of Engineers District, Portland, Oregon, by Pacific Northwest National Laboratory, Richland, Washington.

Ploskey GR, MA Weiland, JS Hughes, SR Zimmerman, RE Durham, ES Fischer, J Kim, RL Townsend, JR Skalski, RA Buchanan, and RL McComas. 2008. Survival of Juvenile Chinook Salmon Passing the Bonneville Dam Spillway in 2007. PNNL-18113, prepared for U.S. Army Corps of Engineers, Portland District, Portland, Oregon, by Pacific Northwest National Laboratory, Richland, Washington.

Rasband WS. 2012. ImageJ, U.S. National Institutes of Health, Bethesda, Maryland, USA. Available at http://imagej.nih.gov/ij/, 1997-2012.

Saha NR, T Usami, and Y Suzuki. 2004. "In vitro effects of steroid hormones on IgM-secreting cells and IgM secretion in common carp (Cyprinus carpio).” Fish \& Shellfish Immunology 17:149-158.

Scruton DA, CJ Pennell, CE Bourgeois, RF Goosney, TR Porter, and KD Clarke. 2007. “Assessment of a retrofitted downstream fish bypass system for wild Atlantic salmon (Salmo salar) smolts and kelts at a hydroelectric facility on the Exploits River, Newfoundland, Canada." Hydrobiologia 582(1):155-169.

Seear PJ, SN Carmichael, R Talbot, JB Taggart, JE Bron, and GE Sweeney. 2010. "Differential gene expression during smoltification of Atlantic salmon (Salmo salar L.): A first large-scale microarray study." Marine Biotechnology 12:126-140.

Skalski JR. 1998. "Estimating season-wide survival rates of outmigrating salmon smolt in the Snake River, Washington.” Canadian Journal of Fisheries and Aquatic Sciences 55(3):761-769.

Skalski JR, J Lady, R Townsend, AE Giorgi, JR Stevenson, CM Peven, and RD McDonald. 2001. "Estimating in-river survival of migrating salmonids smolts using radiotelemetry." Canadian Journal of Fisheries and Aquatic Sciences 58:1987-1997.

Stephenson JR, AJ Gingerich, RS Brown, BD Pflugrath, Z Deng, TJ Carlson, MJ Langeslay, ML Ahmann, RL Johnson, and AG Seaburg. 2010. "Assessing barotrauma in neutrally and negatively buoyant juvenile salmonids exposed to simulated hydro-turbine passage using a mobile aquatic barotrauma laboratory." Fisheries Research 106(3):271-278.

Summerfelt RC and LS Smith. 1990. Anesthesia, surgery, and related techniques. Pages 213-263 in CB Schreck and PB Moyle (eds). Methods for Fish Biology. American Fisheries Society, Bethesda, Maryland.

van Rijssel EJ, R Brand, C Admiraal, I Smit, and JB Trimbos. 1989. "Tissue reaction and surgical knots: The effect of suture size, knot configuration, and knot volume." Obstetrics and Gynecology 74(1):64-68.

Weiland, MA, CM Woodley, GR Ploskey and twenty-three coauthors. 2013. Acoustic Telemetry Evaluation of Juvenile Salmonid Passage and Survival at John Day Dam, 2010. PNNL-22177, Pacific Northwest National Laboratory, Richland, Washington. 
Welch DW, SD Batten, and BR Ward. 2007. "Growth, survival, and tag retention of steelhead trout (O. mykiss) surgically implanted with dummy acoustic tags.” Hydrobiologia 582:289-299.

Winans GA and RS Nishioka. 1987. "A multivariate description of change in body shape of coho salmon (Oncorhynchus kisutch) during smoltification.” Aquaculture 66:235-245.

Woodley CM, KM Knox, SM Carpenter, KM Carter, JA Kim, KA Wagner, IM Royer and RS Brown. 2011. The Effects of Surgically Implanted JSATS Micro-acoustic Transmitter on Expulsion and Survival of Juvenile Chinook and Steelhead, 2010. PNNL-20570, Pacific Northwest National Laboratory, Richland, Washington.

Woodley CM, KA Wagner, KM Knox. 2012. Determine the Influence of Time Held in "Knockdown" Anesthesia on Survival and Stress of Surgically Implanted Juvenile Salmonids. PNNL-21096, Pacific Northwest National Laboratory, Richland, Washington.

Zale AV, C Brooke, and WC Fraser. 2005. "Effects of surgically implanted transmitter weights on growth and survival stamina of small adult Westslope cutthroat trout." Transactions of the American Fisheries Society 134:653-660.

\section{Acknowledgments}

We would like to thank the project staff and individuals that helped us develop our approach. From PNNL, we thank Susan Ennor, Scott Carpenter, Danielle Saunders, Kathleen Carter, Marybeth Gay, Jina Kim, Guri Roesijadi, Charlie Brandt, Gayle Dirkes, Eric Fischer, Gary Johnson, Kasey Knox, Fenton Khan, Brian LaMarche, Jayson Martinez, Gene Ploskey, Ida Royer, Jeni Smith, and Nathan Trimble. From PSMFC, we thank Greg Kovalchuk and staff at John Day Dam Juvenile Smolt Facility, Dean Ballinger and staff at Bonneville Dam Juvenile Smolt Facility, Rick Martinson and Nicole Tancreto for providing technical support and advice. 


\section{Appendix B}

Surgeon Assessment and Feedback for the Lower Columbia River Acoustic-Tag Investigations of Dam Passage Survival and Associated Metrics, 2011 


\title{
Appendix B
}

\section{Surgeon Assessment and Feedback for the Lower Columbia River Acoustic-Tag Investigations of Dam Passage Survival and Associated Metrics, 2011}

\author{
Prepared by CM Woodley
}

\begin{abstract}
Although subtle, the variation in surgical process and training among surgeons can greatly alter fish recovery and survival estimates; thus it is ideal to have standardization among research studies within and between institutions and agencies. A set of recommended guidelines for fish handling, surgical process and training is recommended by the Columbia Basin Surgical Protocol Steering Committee (CBSPSC 2011; an advisory group to the U.S. Army Corps of Engineers [USACE]) for all projects supported by the USACE, Portland District. CBSPSC (2011) provides recommendations on the minimum standards for fish handling and surgeries, but does not address how to quantify surgeon assessment or suggest methods for long-term monitoring of surgeons over the season. This appendix presents a multi-stage surgeon training and evaluation program that includes the methodology for surgeon training (based on the FittsPosner model), surgeon evaluation criteria (based on objective structured assessment of technical skills model; OSATS), and an in-season monitoring approach of surgeon performance on intra-coelomic surgeries. The program is patterned around human and veterinary surgical training, and outlines key components of successful training programs. The 2011 Lower Columbia River (LCR) survival study methods and surgeon criteria were designed for the intra-coelomic implantation of acoustic microtransmitters (AMTs) and passive integrated transponders (PITs), but the approach could be modified and used for any surgical process. In addition, the approach addresses the minimum time needed to acquire new motor skills, provides a critical timeline to allow for proper surgeon training, outlines processes by which fish should be graded to minimize grader bias, and allows for constructive feedback and follow-up to allow for the best possible outcome for the research project.
\end{abstract}

\section{B.1 Background}

Medical and veterinary surgeon training has quickly advanced in the last 10 years by use of simulation programs, computer tracking techniques, and dexterity modeling (Panait et al. 2011). Conversely, researchers working with non-mammalian animals, such as fish biologists are still learning their skills through other graduate students or technicians in an academic setting (likely a Halstead approach), 4-hour technique classes offered at conferences, reading, and trial and error (Cooke and Wagner 2004; Cooke et al. 2011a, 2011b). Fisheries science has recently begun to address surgeon training more thoroughly and using lessons learned from the medical and veterinary industries, fisheries scientists can quickly catch up to current day medical and veterinary standards. For example, Jepsen et al. (2002) addressed the state of knowledge for surgical implantation of tags in fish, and this was followed by a series of review articles on surgeon training and surgeon effects by Mulcahy (2003), Bridger and Booth (2003), Cooke and Wagner (2004), Wagner and Cooke (2005), Welch et al. (2007), and finally a recent set of thorough companion articles in Reviews in Fish Biology and Fisheries (Nielson 2011) that discussed various stages of the surgical process. While many fish biologists have always been concerned for the animals' well-being, the recent driver for the increased awareness is likely due to the changing 
attitude about research animals, guidelines set forth by institutional animal care and use committees (IACUCs) and professional agencies (Fisheries Society of the British Isles 2002; AFS et al. 2004; Canadian Council on Animal Care 2005), and increased pressure for structured quantitative and objective surgeon training programs, and the advancement of bio-monitoring, such as telemetry.

As a result of recent publications and review committees, fisheries biologists and large programs that frequently conduct bio-monitoring and telemetry are working toward improving fish care and handling, as well as surgeon training. Within the Columbia River Basin, the USACE Portland District assembled a panel of researchers (National Oceanic and Atmospheric Administration, Pacific Northwest National Laboratory [PNNL], USACE, U.S. Geological Survey, U.S. Fish and Wildlife Service) to develop a set of guidelines for the surgical intra-coelomic implantation of JSATS AMTs and PITs into juvenile salmonids (CBSPSC 2011). The recommendations give detailed approaches for juvenile salmon handling, surgeries, and training criteria. The criteria for training include that, first, all trainees must surgically implant tags into a minimum of 75 live fish in a single day; unless the study itself calls for tagging fewer than 50 fish per tag day, then trainees may tag the 75 fish over 2 days. The tagged fish are to be held a minimum of 14 days post tagging to evaluate survival and tag retention. The second criterion requires that the last 20 fish tagged (i.e., fish 56 to 75), are to be held separately for 14 days to examine suture retention and incision healing. The evaluations should include pictures on Day 0, Day 7, and Day 14 for the images to be provided back to the training surgeon. Both criteria require that an expert surgeon will implant tags in fish at the same time as trainees to ensure there is a control for fish in poor condition that may become ill, infected, or die during the 14-day holding time. Overall, the fish (and by inference the surgeon) are qualitatively observed and then compared to the fish sutured by an expert surgeon. The new surgeon is approved to conduct surgeries in the field, if the trainer feels that the new surgeon performed wellexecuted surgeries by virtue of Day 14 outcome, or if the performance of the expert surgeon was poor and thereby exculpating the new surgeon, clearing that person for field surgeries.

In 2010, using CBSPSC and Cooke et al. (2011b) structures, we asked surgeons for informal feedback. Novice surgical students indicated that they felt that 1) overarching project goals and assumptions and the need for surgeon competency were not well addressed; 2) not enough time was allotted to learn the material on fish handling, physiology, and the overall process one would experience during the fieldwork; 3) not enough feedback or time was allotted to increase surgeon competency before final testing; 4) unclear descriptions of the grading from how the graders integrated the changes over time or if a set of pictures was weighted more than another; and 5) the grading system was subjective and not quantitative. A few trainees thought the training feedback was often negative, pinpointing what one did poorly rather than having a balanced approach of good and bad performance, were anxious about the practical exam, and felt ill-prepared for the field season. From the feedback, we gathered that 1) course work information should be distributed before training to give trainees time to read and develop ideas, 2) training time for novice surgeons should be extended with more time for feedback and practicing to build confidence, and 3 ) hands-on training after the training program and during the field season should be conducted with timely feedback to surgeons.

\section{B.2 Objective}

To address these concerns and criticisms, while taking into account the lessons learned from the medical industry, we developed a surgeon training program for intra-coelomic transmitter implantation that uses the Fitts-Posner three-stage theory of motor skill acquisition, a modified OSATS that consists of 
three stages (bench top models, dead fish, and then live fish; Anastakis et al. 1999; Moorthy et al. 2003; Bann and Darzi 2005; Reznick and MacRae 2006), and developed an in-season feedback program to give constructive feedback about techniques.

\section{B.3 Fitts-Posner Skill Acquisition Model}

The Fitts-Posner three-stage theory of motor skills model has become a tenet in surgeon training (Peyre and Ashley 2011). The first stage, cognitive or cognition, requires the trainees to engage in a high degree of cognitive activity where the trainee is learning the overall concept of the motor skills through observations, verbal feedback from others, and internal muscle repetition. During the associative or integration stage, the trainees begin to develop a consistency of performance, including the ability to identify errors, attempt error corrections, and the lessening of the overall gross error rate. During the final or automation stage, the trainee's movements appear automatic, stable, and somewhat effortless.

How much time does a new surgeon need? While we used a structured approach, it is understood that timelines may vary between institutions as funding and surgeons become available for training. Our suggested approach is sensitive to the timeline needed for a new surgical trainee to learn new fine motor skills, for the fish to be assessed and graded, and for the trainee to receive and process training feedback. The time allocated above facilitates motor skill retention and continually builds on the feedback given to the trainee. Depending on the number of surgeons, surgical training should begin such that the final person trained finishes at least 1 month prior to tagging. The month between completion of surgical training and beginning of tagging can be used for field setup and extra training of surgeons that need more time to develop skills or used to facilitate new skill maintenance.

\section{B.4 Objective Structured Assessment of Technical Skills (OSATS)}

OSATS typically uses a task-specific checklist, global rating scale, a pass/fail grade, and structured feedback. We have modified common surgical OSATS (referred to as the surgeon assessment model or SAM) by building a structured rubric that involves specific requirements for fish surgeries, uses the expert surgeon scores to control for individual and cohort fish condition variation, and is conducted by graders that are not familiar with the trainees.

These approaches include the Objective Structured Clinical Examinations (OSCE; Reznick and MacRae 2006), OSATS (Moorthy et al. 2003), and outcome measures (e.g., suture spacing, healing, etc.). The common use of morbidity and mortality data, often used in survival models, as surrogate markers of surgeon performance are influenced by the condition of the fish; which in the human world is thought to poorly reflect surgical competence (Moorthy et al. 2003). Objective assessments and feedback provided by a collaborating team and developed program should be used in place of single or few trainers and graders to ensure that the surgeons can incorporate the needed decision-making and communication skills in addition to dexterity and technical skills (Taffinder et al. 1998; Moorthy et al. 2003; Al-Ruzzeh 2007). This approach ensures that surgeon assessments are objective, feasible, and that the test is reliable (Shah and Darzi 2001). 


\section{B.5 Methods and Materials}

This study, conducted over 2 months in early spring 2011, involved the acquisition of fish, surgical implantation of transmitters, and statistical analysis, as described below.

\section{B.5.1 Fish Acquisition}

Yearling Chinook and Coho salmon (wet weight [WW] $19.4 \pm 11.4 \mathrm{~g}$, fork length [FL] $120.4 \pm$ $19.4 \mathrm{~mm}$ [mean \pm std dev], $\mathrm{N}=520$ ) reared at the PNNL Aquatics Research Laboratory (Richland, Washington), Leavenworth National Fish Hatchery (Leavenworth, Washington), and Bonneville Dam Fish Hatchery (Cascade Locks, Oregon) were used for this study. Fish were held in an aerated flowthrough system on a natural photoperiod. Water temperatures ranged between 8 and $12^{\circ} \mathrm{C}$. All fish were fed twice daily with BioDiet pellets (Bio-Oregon, Longview, WA) at 1.2\% of the average body weight during the acclimation and assessment periods. The tanks were cleaned twice a day to minimize food and fungal accumulation. Once surgeries were conducted, the yearling Chinook were held in 80-gal circular tanks for 14 days. Coho salmon were only used as non-living models and to give surgeons experience with a different species. The surgeon assessment model was built using only data acquired from surgeries conducted on yearling Chinook salmon. All methods were approved by the Institutional Animal Care and Use Committee (IACUC Protocol \# 2010-08).

\section{B.5.2 Surgeon Assessment Model (SAM)}

To grade surgeons fairly, a based rubric was made that highlights the frequency of common actions that result in reduced functional sutures and tissue damage. Rubrics save time because they can tally, weight, and calculate final scores on individuals, yet remove grader bias. Even the most unbiased graders are influenced by simple things such as their mood, day's events, fish appearance, etc. More importantly, a rubric can be used to show surgeons what the principal investigator or client feels is important, explains the consequence of their actions before they begin practicing and testing, and offers feedback about the surgeon's performance per fish and per observation day and the frequency of techniques that caused their final score.

The rubric created for surgeon grading emphasized functional sutures and tag presences over tissue trauma. Functional suture was defined as any suture that was present in the fish, remained knotted, was of appropriate tension across the wound, and did not tear through the body wall of the fish (modified from Deters et al. 2009). Consequently, functional sutures reduce tag loss, which greatly affects the outcome of survival studies. Lost tags often are not further detected by an acoustical array or passive detection system, thus the fish that held the dropped tags would be counted as a mortality or loss of the animal from the study population. Lost tags, whether due to poor closure and apposition (e.g., gaping incisions) or physical forces (i.e., pressure, friction, shear stress), are weighted as heavily in the rubric as functional suture. After 14 days, when the final grade has been given, the grader may re-evaluate tag loss if it is found to be more associated with fish condition or surgeon technique (i.e., poor closure).

Though attributes of the functional suture are weighted heavier in the rubric, tissue trauma from the surgeon is still an important aspect to consider because it can be detrimental to the fish. Tissue damage increases the likelihood of energy reallocation to the injured site, thereby affecting energetic resources available to fish. Potential outcomes of infections include altered behavior, increased immune 
compensation, decreased energetics for smoltification and outmigration, and ultimately increased mortality. These outcomes are undesirable for survival studies because they invalidate telemetry and survival assumptions, and they directly alter the results.

\section{B.5.3 Surgical Procedure}

Fish were anesthetized and handled similarly regardless of surgeon. A buffered anesthetic solution (with $80 \mathrm{mg} / \mathrm{L} \mathrm{Na}^{2} \mathrm{CO}_{3}$ ) was prepared using aerated river water and tricaine methanesulfonate (MS-222; $80 \mathrm{mg} / \mathrm{L}$ ). Prior to surgery, fish were anesthetized in buckets until loss of equilibrium was observed (Stage 4; Summerfelt and Smith 1990). Anesthetized fish were immediately weighed, measured, and both flanks were photographed. Fish were randomly assigned to one of the testing surgeons. The control (non-surgery) fish bypassed the surgery stations, were placed into 5-gal, perforated recovery buckets (5 fish per bucket) with fresh aerated river water, and were monitored to ensure they recovered from anesthesia.

Once properly anesthetized, fish receiving surgical implants were placed on the surgery table and given a maintenance anesthetic dose (river water containing $40 \mathrm{mg} / \mathrm{L} \mathrm{MS}-222$ ) through silicone rubber tubing from a gravity-fed bucket. The surgeon controlled the dose during the procedure by mixing river water with maintenance anesthetic water. With the fish facing ventral side up, a 5- to 7-mm incision was made along the linea alba, between the pectoral fin and pelvic girdle. After surgery, a picture was taken of the closed incision and fish were placed in fresh aerated water to recover. Once fish regained equilibrium after surgery they were added to one of two circular tanks and provided with flow-through river water.

\section{B.5.4 Response Examinations}

All fish were examined on Day 0, 7, and 14 following surgery (herein referred to as day 0, day 7, and day 14). Prior to examinations, each fish was anesthetized with $80 \mathrm{mg} / \mathrm{L} \mathrm{MS}-222$ to Stage 3 (Summerfelt and Smith 1990). Fish were removed from the bath, measured for fork length (mm) and wet weight (g) and placed on a foam pad, ventral side up. Maintenance anesthetic of up to $40 \mathrm{mg} / \mathrm{L}$ MS-222 was supplied to the fish in the same manner as for surgery. The incision, suture, and surrounding area were examined through a stereomicroscope (0.65x magnification; Stemi 2000-CS; Zeiss AG, Jena, Germany) connected to a computer.

The incision area was broken down into suture sites that consisted of an entry and exit pair. On exam Days 7 and 14 the presence of suture material was noted for each site and marked as a binary response (present or absent). The incision length (initially estimated using a reticule), and area $\left(\mathrm{mm}^{2}\right)$ of redness, ulceration, and incision openness were outlined and quantified (Figure B.1) using the "Image J" image processing program (public domain software, National Institute of Health, Bethesda, MD, $\mathrm{http} / / / \mathrm{rsb}$.info.nih.gov/ij/). If there was more than one area on the fish exhibiting either redness of ulceration, the individual measurements were summed for the analyses.

All fish were necropsied after the Day 14 exam. Suture presence was noted (present or absent), and any bio-compatibility effects, such as tag damage, tag bulging (present or absent), and fibrotic tissue (absent, minor, pocket developing around the AMT), etc. 

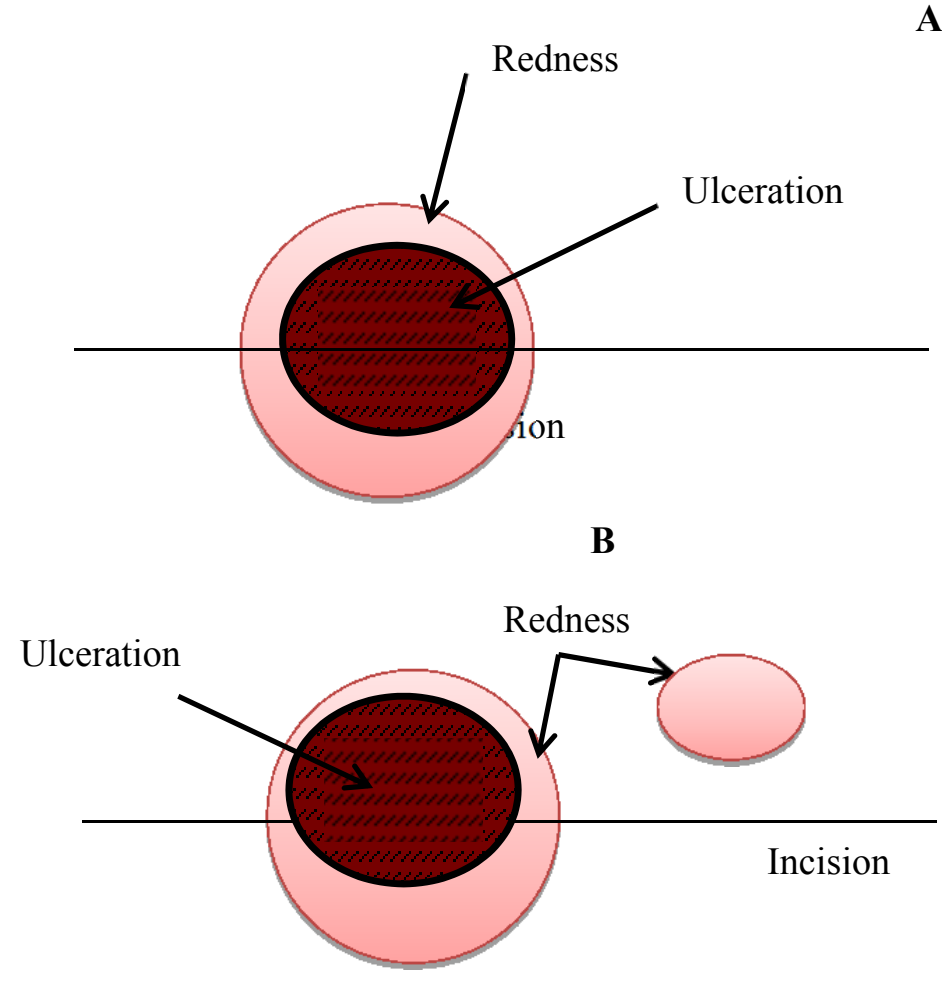

Figure B.1. Wound redness and ulceration differentiation. Redness was differentiated from ulceration by the consistency of the wound and area affected. In the above diagram, redness scores would only include the pink area, not the maroon-hashed area. Ulceration scores would only include the maroon-hashed area (inner circles in A and B) and not the pink areas. A) Only the pink area, outer ring would be included in the redness score. Any redness in the ulcerated area was included in the ulceration score, not the redness score. B) The redness score would include the pink areas for each noted wound or affected area, by adding the total pink area together. Ulcerations, if more than one, would be summed similarly. This approach allowed for the distinction between red inflamed areas and areas with exposed underlying tissue.

\section{B.5.5 Statistical Analysis}

Individual fish were examined for multiple failures in suture function and tissue trauma. The various types of suture function failure and tissue trauma were given a value of $0-10$, depending on the severity of the category (Table B.1). Scores were then weighted again based on the relative weighting of functional suture scores versus tissue trauma scores (see Section B.6.2, Figure B.2). The surgeon assessment model (SAM; OSATS-based approach) scores were calculated for 7 and 14 days post-surgery. The lower SAM scores indicated more proficient the surgeons. 
Table B.1. SAM categories and associated weights. Weighting is distributed such that proper procedures and no trauma receive a score of 0 .

\begin{tabular}{lclc}
\hline \multicolumn{1}{c}{ Functional $(\mathrm{x})$} & Weight & \multicolumn{1}{c}{ Tissue Trauma $(\mathrm{y})$} & Weight \\
\hline Mortality & 10 & Damage & $0-5$ \\
PIT or AMT Absent & 10 & Erythema & $0-5$ \\
Incision Length & $0-5$ & Ulceration & $0-5$ \\
Suture Presence & 5 & & \\
Apposition & $0-10$ & & \\
\hline
\end{tabular}

At 14 days post-surgery, each fish was also given a visual score of high pass $=1$, pass $=2$, low pass $=$ 3 , or fail $=4$. Fish were tagged on six separate occasions, called cohorts. Each cohort had between 3 and 6 surgeons, all tagging 20 test fish. There were 18 surgeons over 5 cohorts with 1 "expert" surgeon tagging in 5 cohorts. The expert surgeon data were examined by cohort and over the examination period. All surgeons were designated as "Expert," "Experienced," or "Novice" based on their past tagging experience. Once the model was constructed, we developed a series of questions to test the model for functionality, as presented in the results.

\section{B.6 Results}

\section{B.6.1 Time Efficacy of Approach}

We first tested the efficacy of the time spent using SAM compared to the qualitative observations (QO) method. We noted that the SAM scoring and the QO method took an estimated 5-15 seconds per fish. However, QO required comparisons to expert surgeons. Because the grading was conducted blind, the grades and photos were post-processed. The QO method time increased to 5-10 minutes per surgeon depending on the size of the cohort because each surgeon had to be compared to the cohort and then the expert surgeon. The post-processing effort between expert and trainee for SAM was a visual test to ensure that each surgeon final mean score was below the maximum allowable score for passing. The maximum allowable score was determined by the data gaps defining natural performance groups. This step took 1-5 minutes per surgeon depending on the size of the cohort. Clearly, the SAM approach is more time efficient during the post-processing stage.

\section{B.6.2 Weighting for Functional Suture vs. Tissue Trauma}

The functional suture score and tissue trauma score were combined to create a summary SAM score for each fish. To find the best weighting between functional suture and tissue trauma, SAM scores were compared against the QO scores for each fish (Figure B.2). The correlation between SAM score and QO score were measured using $\mathrm{R}^{2}$ values. The weighting of functional suture within the SAM formula was adjusted to find the highest $\mathrm{R}^{2}$ value between fish condition scores and visual scores. The maximum $\mathrm{R}^{2}$ value was at a weight of 1.3. Notably, the low pass (LP) and failed (F) surgeries have averages greater than 20 (23.6 and 27.8, respectively), while pass (P) and high pass (HP) had mean scores less than 20 (16.2 and 9.2, respectively). The five lowest scoring F fish were graded and added to the model even though the five fish were moribund/mortalities; and surgeon(s) were requested to retrain. This relationship provided us with a maximum achievable final score (21) that was used to accept surgeons 
onto the project or request them to retrain. In addition, any surgeon that had more than 3 surgeries (i.e., $15 \%$ of surgeries conducted) scored above 21 could be requested to retrain.

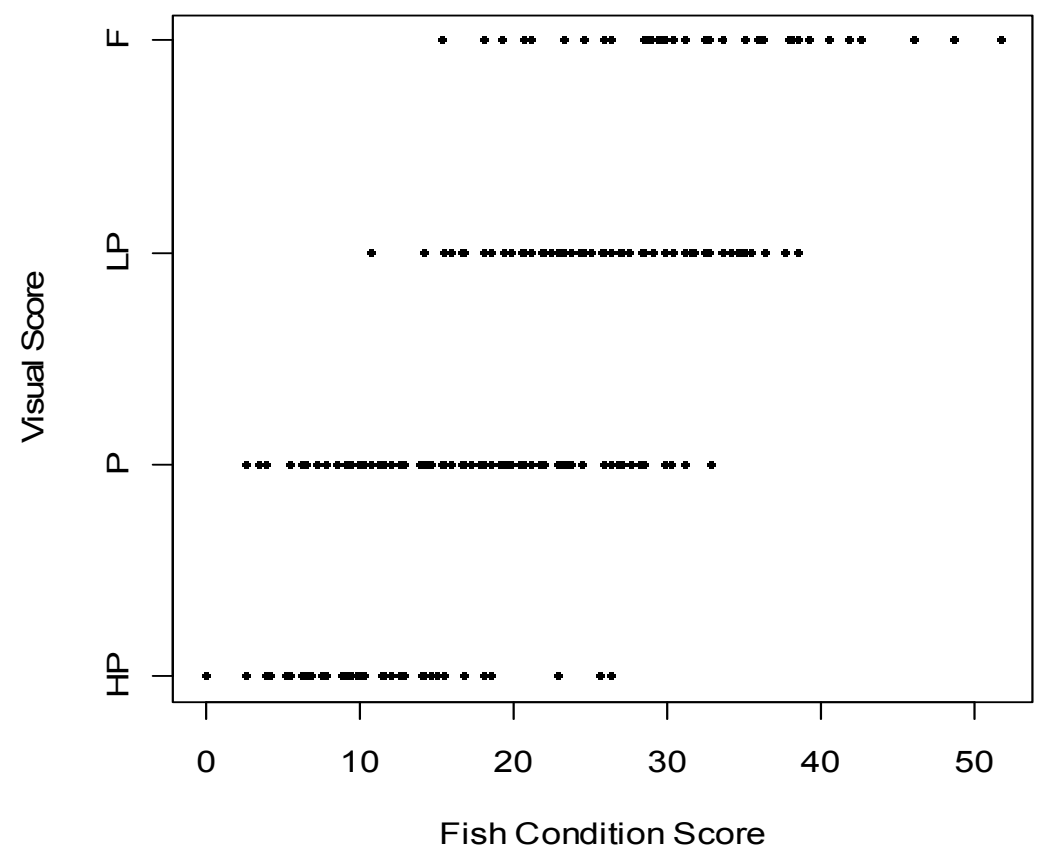

Figure B.2. Plot of SAM score and QO score for all surgeries. HP = high pass, $\mathrm{P}=$ pass, $\mathrm{LP}=$ pass, and $\mathrm{F}=$ failure.

The weight that produced the highest $\mathrm{R}^{2}$ value between SAM scores and QO scores was 1.3 (Figure B.3). For the following results, the rubric emphasis on functional suture score will be weighted 1.3:1.0. The curve "flattening" indicates the overall SAM score is relatively robust for weight $1 \leq w \leq 3$.

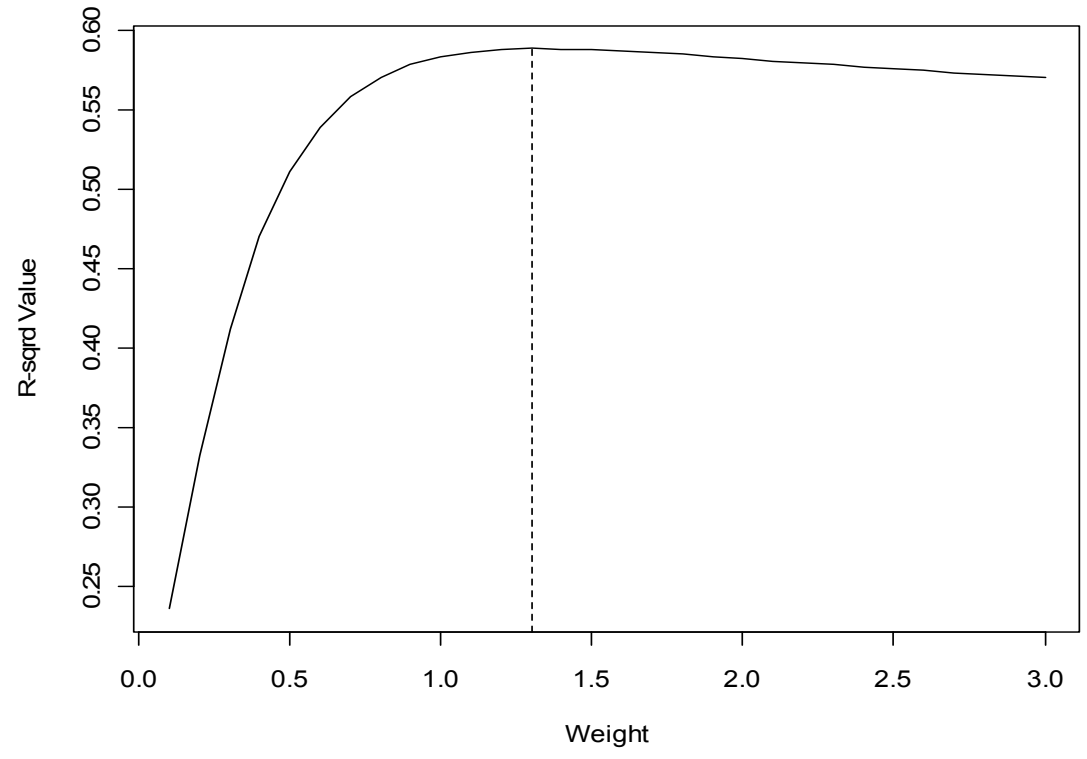

Figure B.3. $\mathrm{R}^{2}$ values for weights between 0 and 3. 


\section{B.6.3 Expert Surgeon Comparison}

Next, the performances of our "expert" surgeons, an in-field surgeon and a laboratory surgeon, were compared to ensure that the assessment model scored the expert surgeons similarly. Using SAMgenerated scores, no significant difference could be detected between expert surgeons $(P=0.8452$; Table B.2; Figure B.4).

Table B.2. ANOVA results for SAM score between surgeons E and J.

\begin{tabular}{lccccc}
\hline & DF & Sum Squares & Mean Squares & F & $\operatorname{Pr}(>\mathrm{F})$ \\
\hline Surgeon & 1 & 1.06 & 1.0563 & 0.0387 & 0.8452 \\
Residuals & 38 & $1,038.08$ & 27.3179 & & \\
\hline
\end{tabular}

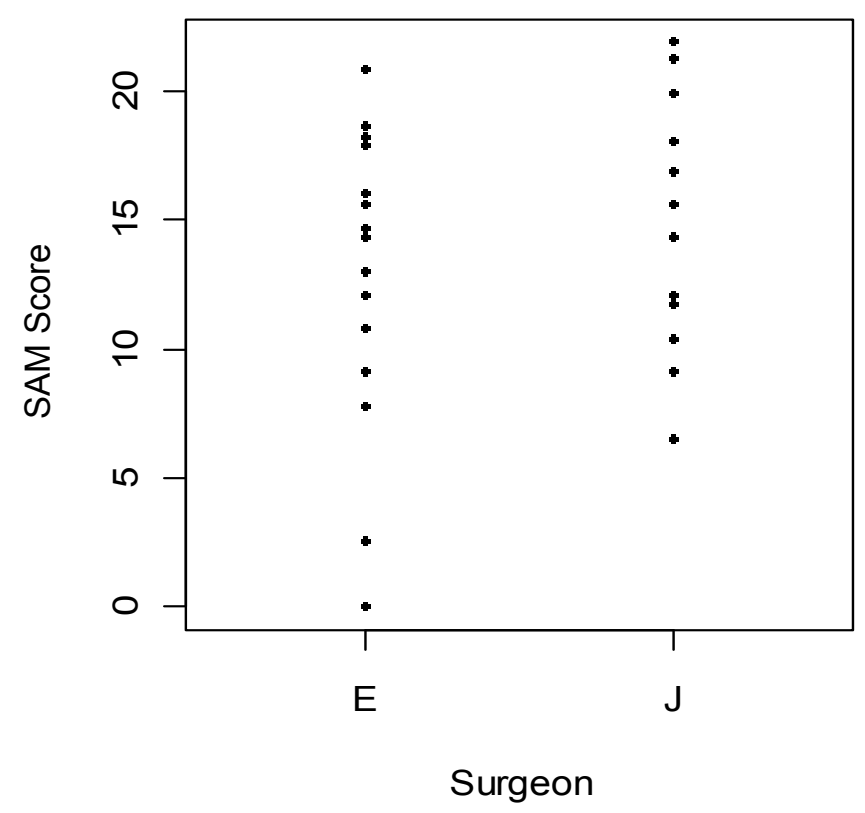

Figure B.4. SAM scores for expert surgeons E and J.

\section{B.6.4 Expert Surgeon Performance Temporal Stability}

Before applying SAM to novice and experienced surgeons, expert surgeon E was examined over time. In particular, we wanted to determine if the program used one expert surgeon continually over a long training period (i.e., 2 months), would that expert surgeon improve his/her technique over the training period? For this test, we examined expert surgeon $\mathrm{E}$ because expert surgeon $\mathrm{J}$ was not present for all five cohorts. Over the five cohorts, expert surgeon E's performance did not significantly change $(P=$ 0.0534; Table B.3). Due to the cohort, and concomitantly temporal, trend (Figure B.5), surgeon E was examined using the linear trend with week as a numerical value, resulting in expert surgeon E's SAM score significantly decreasing over time $5(P=0.0136$; Figure B.5). 
Table B.3. ANOVA results for SAM scores by cohort for expert surgeon E. Cohort is treated as a factor for contrast analysis.

\begin{tabular}{lccccc}
\hline & DF & Sum Squares & Mean Square & F & $\operatorname{Pr}(>\mathrm{F})$ \\
\hline Cohort & 4 & 426.4 & 106.603 & 2.4243 & 0.0534 \\
Residuals & 95 & $4,177.4$ & 43.972 & & \\
\hline \multicolumn{1}{c}{ Contrast } & DF & Contrast SS & Mean Square & F & $\operatorname{Pr}(>\mathrm{F})$ \\
\hline Linear trend & 1 & 278.01 & 278.01 & 6.3224 & 0.0136 \\
\hline
\end{tabular}

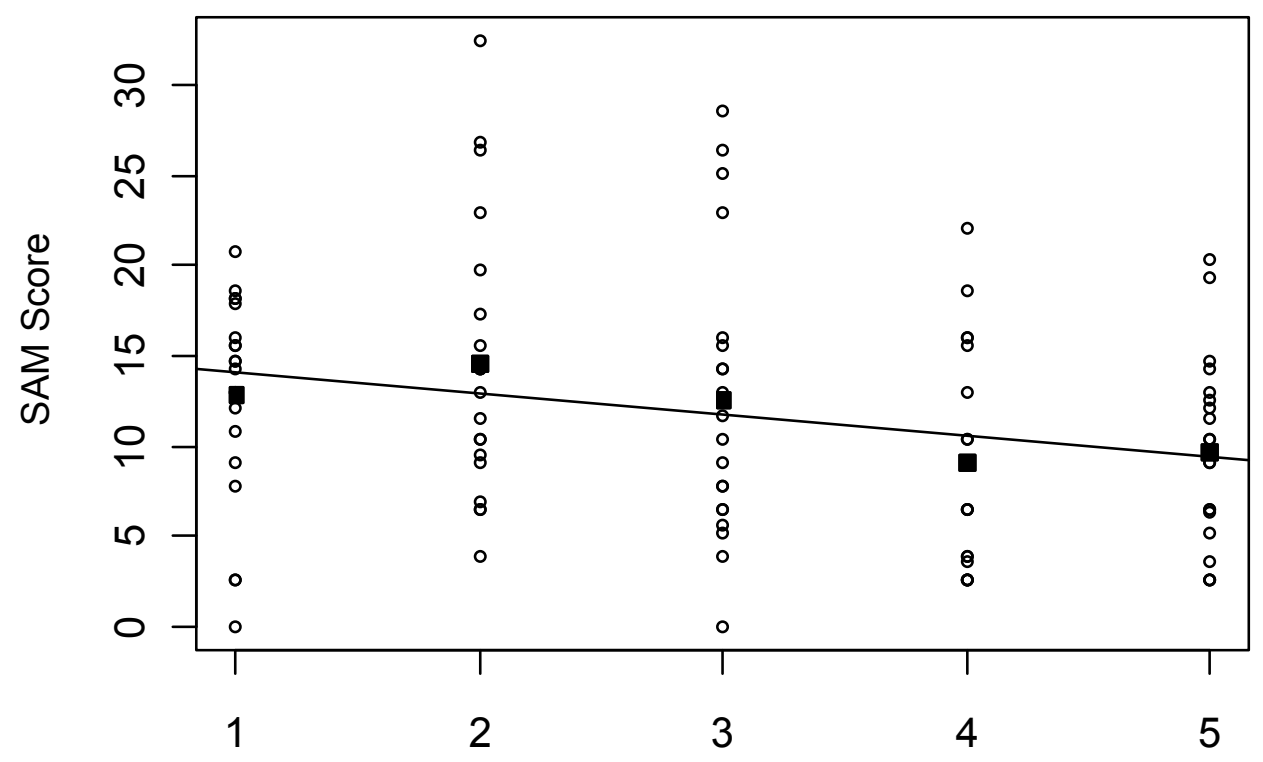

\section{Cohort}

Figure B.5. SAM scores by cohort for expert surgeon E. The open circles (O) are expert surgeon E individual SAM scores for each fish grouped by cohorts, and thus time. The black squares (घ) indicate the average SAM score for each cohort. The line represents the best fit linear relationship when cohort is treated as a numeric variable.

\section{B.6.5 Surgeon Exclusion}

Before scores were ranked and the model was completed, the QO method indicated that there were two surgeons whose performance was unacceptable for the project. One surgeon, Z, was given the opportunity to test twice with a total of 8 days of pre-test training. Surgeon $\mathrm{Z}$ tested in cohort 2 and 5; while surgeon $\mathrm{N}$ tested only in cohort 5 . A plot showing SAM scores by surgeon in cohort 2 was constructed (Figure B.6). In cohort 2, surgeon $\mathrm{Z}$ had significantly higher SAM scores than the other surgeons $(P<0.0001$; Table B.4). 


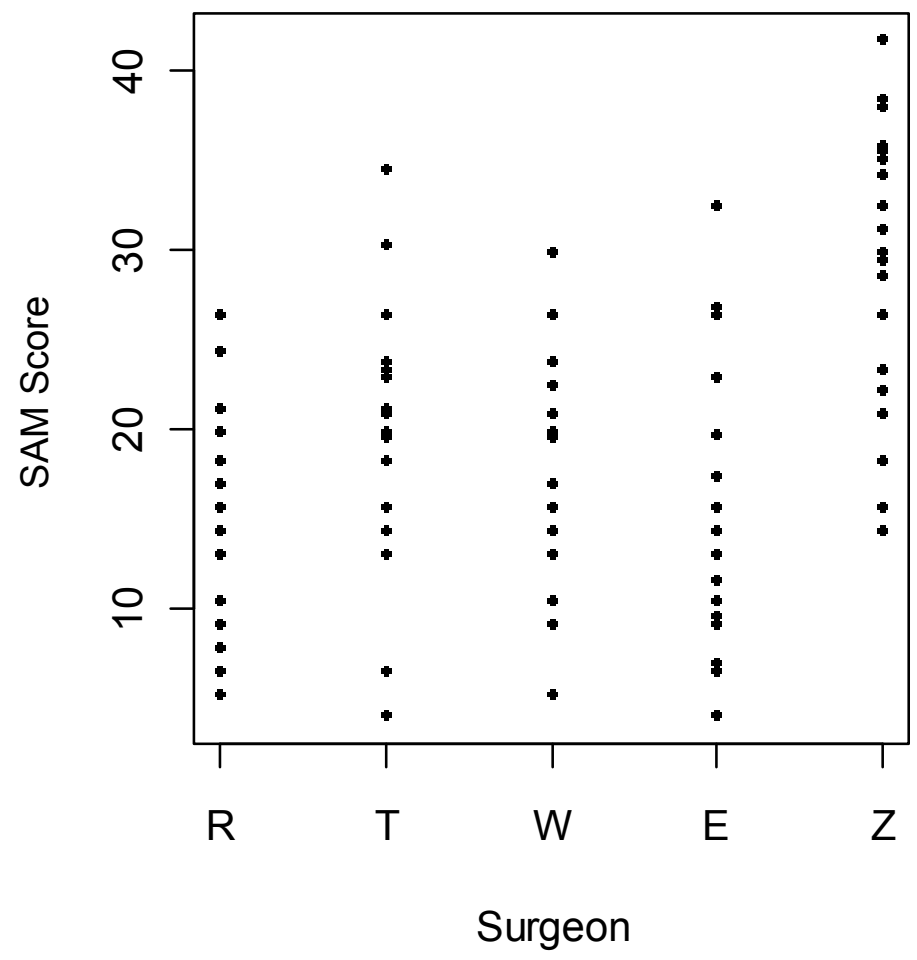

Figure B.6. SAM scores by surgeon in cohort 2 .

Table B.4. ANOVA results with contrast for SAM scores comparing all surgeons in cohort 2.

\begin{tabular}{lccccc}
\hline \multicolumn{1}{c}{ Source } & DF & Sum Squares & Mean Square & F & $\operatorname{Pr}(>\mathrm{F})$ \\
\hline Surgeon & 4 & $2,979.7$ & 744.93 & 14.742 & $<0.0001$ \\
Residuals & 95 & $4,800.5$ & 50.53 & & \\
\hline \multicolumn{1}{c}{ Contrast } & DF & Contrast SS & Mean Square & F & $\operatorname{Pr}(>\mathrm{F})$ \\
\hline Z vs. others & 1 & $2,721.2$ & $2,721.19$ & 53.85296 & $<0.0001$ \\
\hline
\end{tabular}

For cohort 5, surgeons $\mathrm{N}$ and $\mathrm{Z}$ (combined; surgeon $\mathrm{Z}$ cohort 5 re-test scores only) and all other surgeons were tested (Figure B.7). In cohort 5, surgeons $\mathrm{N}$ and $\mathrm{Z}$ had significantly higher SAM scores than the other surgeons $(P<0.0001$; Table B.5). 


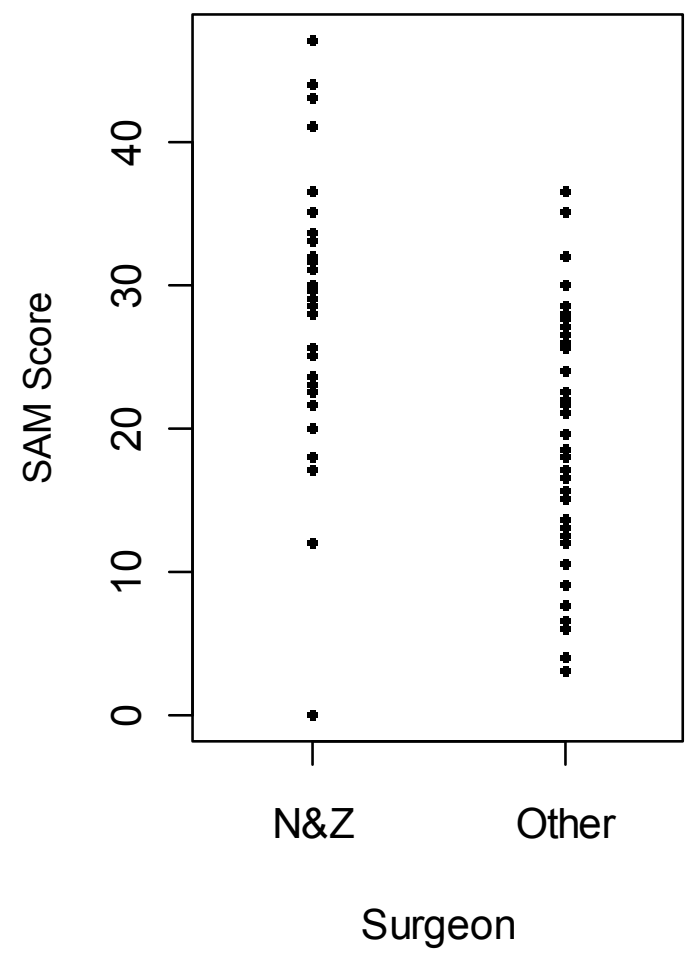

Figure B.7. SAM scores for surgeons $\mathrm{N}$ and $\mathrm{Z}$ and all other surgeons in cohort 5.

Table B.5. ANOVA results with contrasts for SAM scores comparing all surgeons in cohort 5.

\begin{tabular}{lrcccc}
\hline \multicolumn{1}{c}{ Source } & DF & Sum Squares & Mean Square & F & $\operatorname{Pr}(>\mathrm{F})$ \\
\hline Surgeon & 5 & $6,587.8$ & $1,317.56$ & 17.442 & $<0.0001$ \\
Residuals & 114 & $8,611.6$ & 75.54 & & \\
\hline \multicolumn{1}{c}{ Contrast } & DF & Contrast SS & Mean Square & F & $\operatorname{Pr}(>\mathrm{F})$ \\
\hline $\mathrm{N}$ and Z vs. others & 1 & $5,288.4$ & $5,288.4$ & 70.00794 & $<0.0001$ \\
\hline
\end{tabular}

\section{B.6.6 Surgeon Experience as a Predictor for Performance}

The next test focused on the presumption that experienced surgeons retain the critical skills and muscle memory between yearly experiments; thus refresher training (of 3 days), instead of full training ( 5 days), is acceptable. To test this assertion, we examined "surgeon experience" as a predictor of SAM performance. More specifically, experienced surgeons with 3 days of training where compared to novice surgeons with 5 days of training, and experienced surgeons with 0 days of training were compared to novice surgeons with 0 days of training. Table B.6 shows the surgeries conducted by days of training and experience level. Experienced surgeons with 3 days of training did not show significantly lower SAM scores when compared to novice surgeons with 5 days of training $(P=0.3295$; Table B.7, Figure B.8). 
Table B.6. Fish counts by days training and experience level.

\begin{tabular}{|c|c|c|c|c|c|}
\hline & \multicolumn{4}{|c|}{ Days Training } & \multirow{2}{*}{$\begin{array}{l}\text { Surgeries Conducted } \\
\text { (excluding knots) }\end{array}$} \\
\hline & 0 & 1 & 3 & 5 & \\
\hline \multicolumn{6}{|l|}{ Test 1: } \\
\hline Experienced & 100 knots & 40 & 80 & - & 120 \\
\hline $\begin{array}{l}\text { Novice } \\
\text { Test 2: }\end{array}$ & 100 knots & 20 & 20 & 160 & 180 \\
\hline Experienced & 20 & - & - & - & 20 \\
\hline Novice & 20 & - & - & - & 20 \\
\hline
\end{tabular}

Table B.7. ANOVA results for SAM scores comparing experienced surgeons with 3 days of training and novice surgeons with 5 days of training.

\begin{tabular}{lccccc}
\hline & DF & Sum Squares & Mean Square & F & $\operatorname{Pr}(>\mathrm{F})$ \\
\hline Experience Level & 1 & 20.897 & 20.897 & 1.0509 & 0.3295 \\
Residuals & 10 & 198.85 & 19.885 & & \\
\hline
\end{tabular}

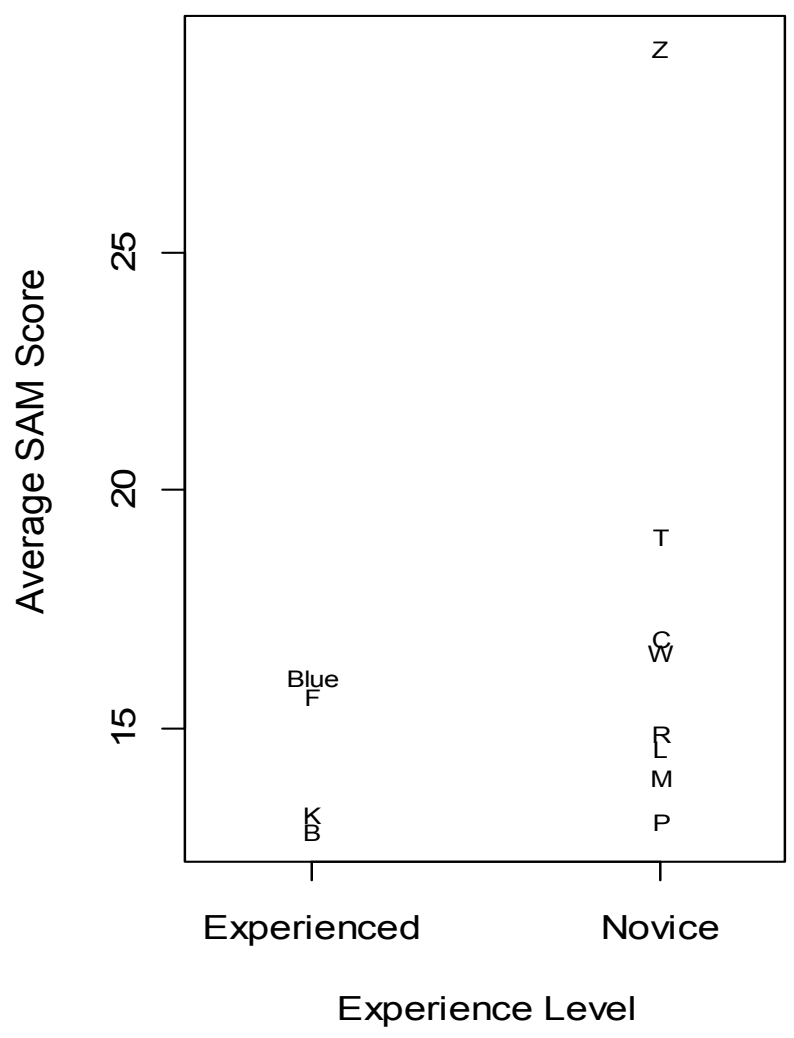

Figure B.8. SAM scores for experienced surgeons with 3 days of training and novice surgeons with 5 days of training. 
Similarly, experienced surgeons with 0 days of training did not have significantly lower SAM scores when compared to novice surgeons with 0 days of training $(P=0.0737$; Table B.8). A plot showing fish condition scores for experienced surgeons with 0 days training and novice surgeons with 0 days training was constructed (Figure B.9).

Table B.8. ANOVA results for SAM scores comparing experienced surgeons with 0 days of training and novice surgeons with 0 days of training.

\begin{tabular}{lccccc}
\hline & DF & Sum Squares & Mean Square & F & $\operatorname{Pr}(>\mathrm{F})$ \\
\hline Experience Level & 1 & 169.5 & 169.5 & 74.022 & 0.0737 \\
Residuals & 1 & 2.29 & 2.29 & & \\
\hline
\end{tabular}

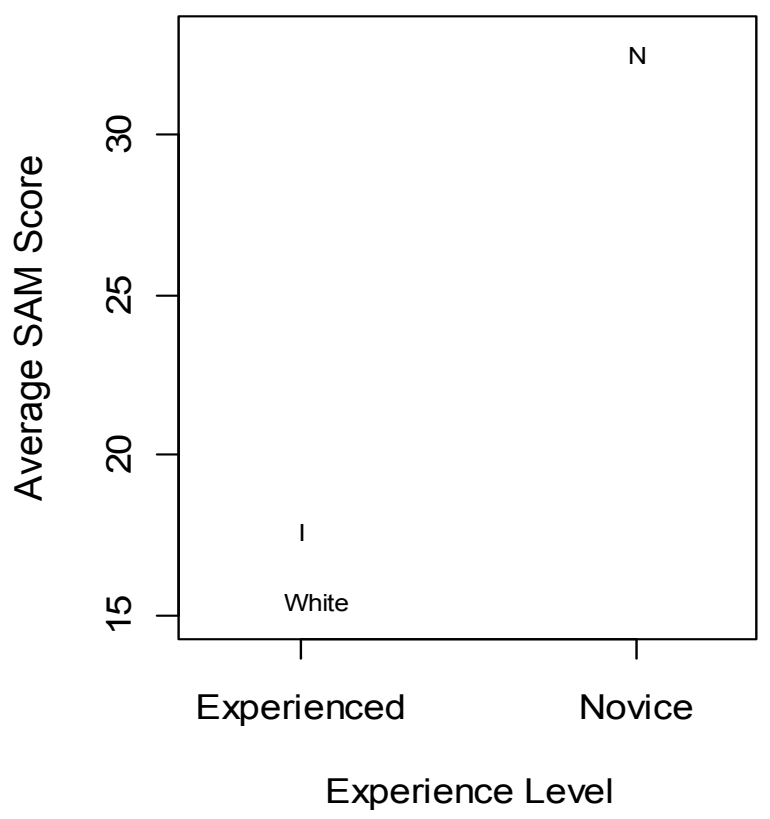

Figure B.9. SAM scores for experienced surgeons with 0 days of training and novice surgeons with 0 days of training.

\section{B.6.7 Intermediate Days as Predictors of Performance}

Knowing that SAM was a more efficient approach than the QO for surgeon assessment and postprocessing, the ability to further minimize fish handling and data processing would be advantageous. To do this, we examined scores on Day 7 and Day 14 to determine if both days were needed for analyses in SAM or if the potential for using only one (whether Day 7 or Day 14) was effective in predicting final outcome. A plot of SAM scores at Day 7 and Day 14 for all fish was constructed (Figure B.10). An $\mathrm{R}^{2}$ value of 0.1353 indicated that the correlation between SAM score at Day 7 and SAM score at Day 14 was poor. Thus, SAM score on Day 7 was not a good predictor of SAM score by Day 14 . 


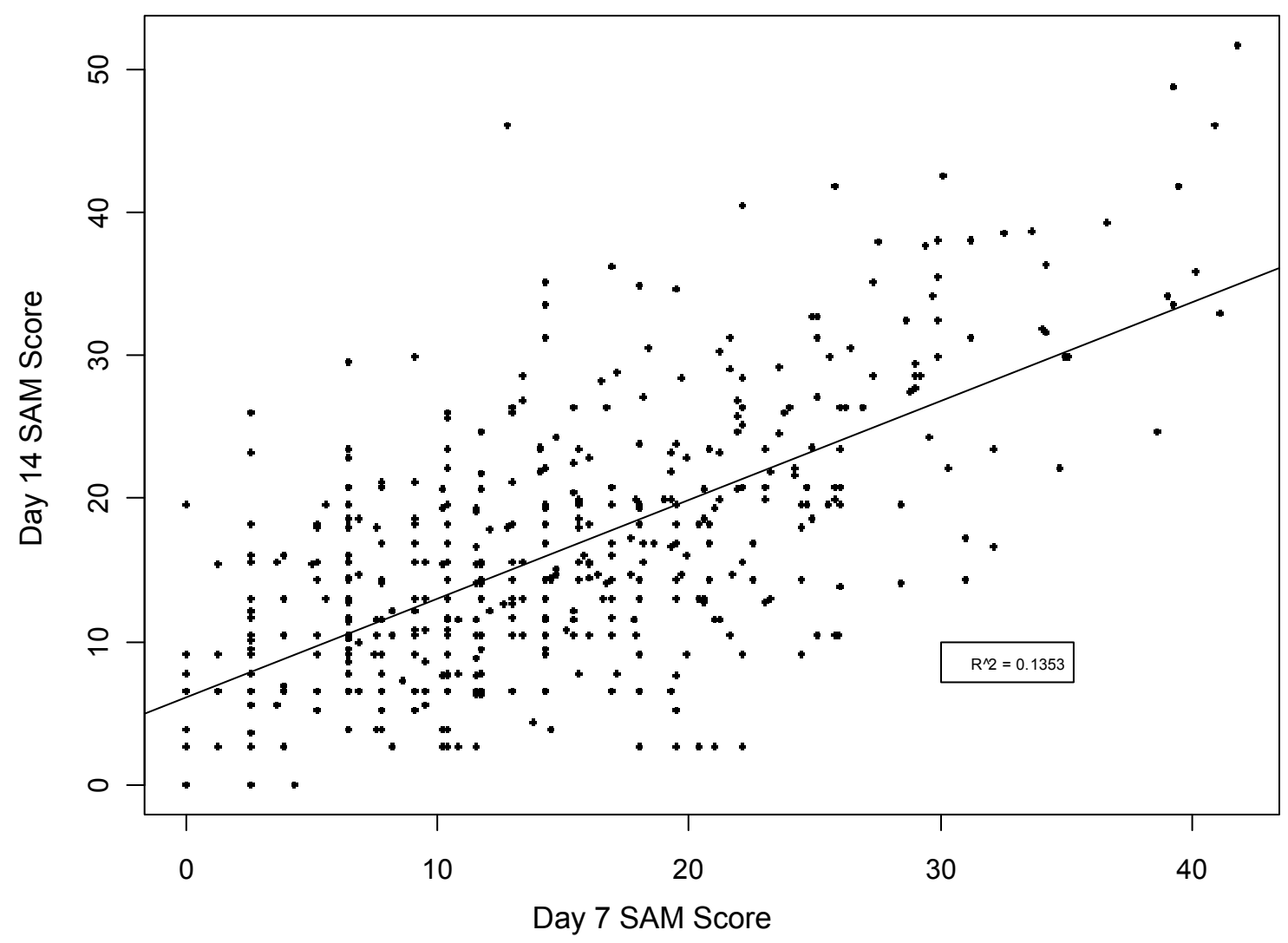

Figure B.10. SAM scores at Day 7 and Day 14 for all fish.

\section{B.6.8 QO as Predictor for Day 14 Performance}

Finally, SAM was tested against QO for performance assessment of all surgeons. Box plots of visual scores for surgeons from cohort 2 and cohort 5 were constructed (Figure B.11 and Figure B.12. Using either SAM score (Table B.4 and Table B.5) or QO score (Figure B.12, Table B.9 and Table B.10) as the response variable, surgeon $\mathrm{Z}$ in cohort 2 and surgeon $\mathrm{N}$ and $\mathrm{Z}$ in cohort 5 all had significantly worse tagger performance scores $(\mathrm{P}<0.0001 \& \mathrm{P}<0.0001$, respectively).

We used the QO of each fish to adjust the weighting within the SAM formula. The QO score had a maximum R2 value of 0.58 with the SAM scores (Figure B.3). Within any QO, there was about a 30-point range in the SAM scores (Figure B.2). On average the two values match, but on a fish-by-fish basis there was considerable loss of information using the visual score. 


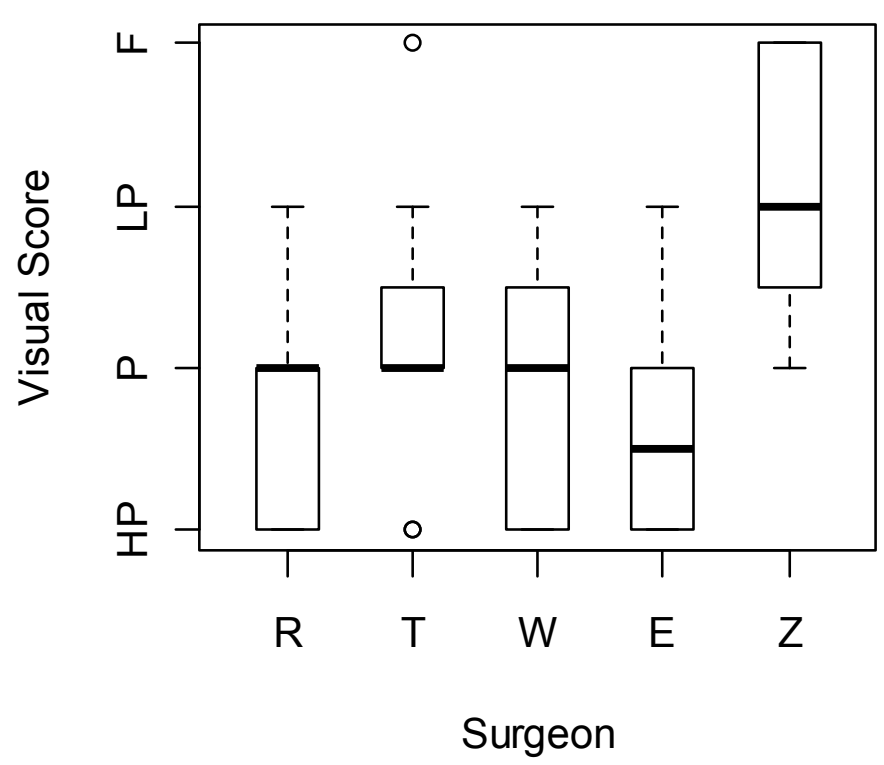

Figure B.11. Boxplots of $\mathrm{QO}$ scores for surgeons from cohort 2. $\mathrm{HP}=1, \mathrm{P}=2, \mathrm{LP}=3, \mathrm{~F}=4$.

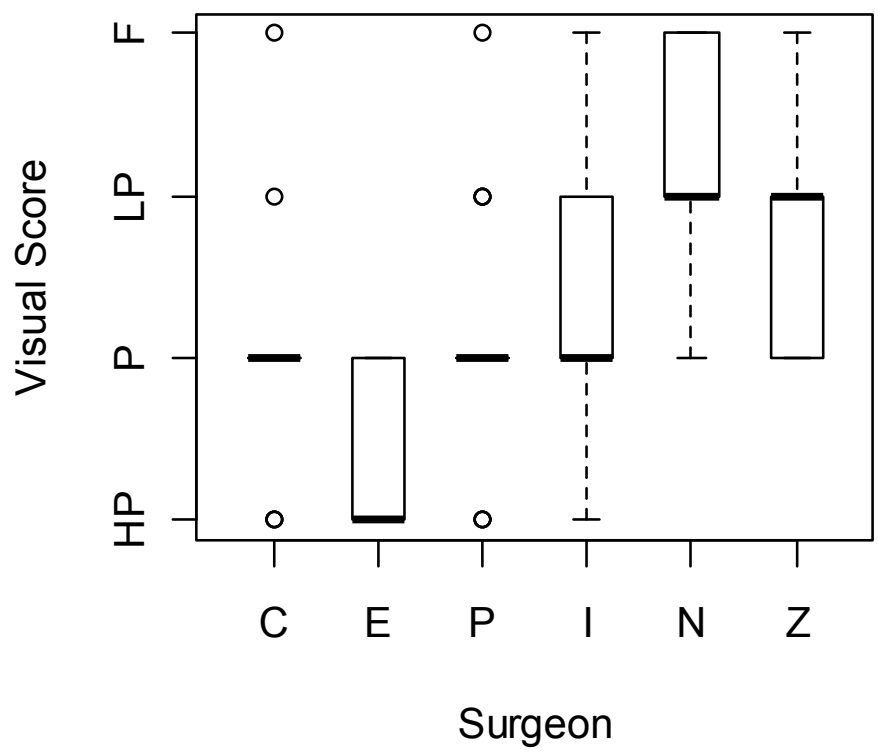

Figure B.12. Boxplots of $\mathrm{QO}$ scores for surgeons from cohort 5. $\mathrm{HP}=1, \mathrm{P}=2, \mathrm{LP}=3, \mathrm{~F}=4$.

Table B.9. ANOVA results with contrast for QO scores as a numeric response variable comparing surgeon $\mathrm{Z}$ with all other surgeons in cohort $2 . \mathrm{HP}=1, \mathrm{P}=2, \mathrm{LP}=3, \mathrm{~F}=4$.

\begin{tabular}{lrcccc}
\hline \multicolumn{1}{c}{ Source } & DF & Sum Squares & Mean Square & F & $\operatorname{Pr}(>\mathrm{F})$ \\
\hline Surgeon & 4 & 30.46 & 7.615 & 14.809 & $<0.0001$ \\
Residuals & 95 & 48.85 & 0.5142 & & \\
\hline \multicolumn{1}{c}{ Contrast } & DF & Contrast SS & Mean Square & F & $\operatorname{Pr}(>\mathrm{F})$ \\
\hline Z vs. others & 1 & 26.01 & 26.01 & 50.58343 & $<0.0001$ \\
\hline
\end{tabular}


Table B.10. ANOVA results with contrast for QO scores as a numeric response variable comparing surgeons $\mathrm{N}$ and $\mathrm{Z}$ with all other surgeons in cohort 5 . $\mathrm{HP}=1, \mathrm{P}=2, \mathrm{LP}=3, \mathrm{~F}=4$.

\begin{tabular}{lrcccc}
\hline Source & DF & Sum Square & Mean Square & F & $\operatorname{Pr}(>\mathrm{F})$ \\
\hline Surgeon & 5 & 47.274 & 9.4548 & 21.329 & $<0.0001$ \\
Residuals & 110 & 48.761 & 0.4433 & & \\
\hline \multicolumn{1}{c}{ Contrast } & DF & Contrast SS & Mean Square & F & $\operatorname{Pr}(>\mathrm{F})$ \\
\hline $\mathrm{N}$ and $\mathrm{Z}$ vs. others & 1 & 32.601 & 32.601 & 73.54162 & $<0.0001$ \\
\hline
\end{tabular}

\section{B.6.9 Surgeon Feedback on Program}

Using Survey Monkey, an anonymous survey was developed to enable trainees to provide feedback on the program and trainers. The questions for the general course are listed below along with average score or frequency of comments. In general, surgeons seemed pleased with the program outcome and were able to make constructive comments for goals to address for future years (Table B.11). Recommendations for program improvement included that the trainers agree on approaches or at least learn to debate approach while trainees are not present (Table B.12). Generally, the surgeons found the live instruction and classroom modules to be effective. In addition, questions about trainer performance revealed that each had strengths and weaknesses, although trainer E overall had higher scores (Table B.13).

Table B.11. General program questions.

\begin{tabular}{lc}
\hline \multicolumn{1}{c}{ Questions } & Average \\
& Score \\
\hline The overall quality of this course was high. & 4.50 \\
I learned a great deal in this course. & 4.15 \\
The course objectives and requirements were outlined in the course syllabus and by each & 4.42 \\
presenter or instructor. & 4.08 \\
Required assignments contributed positively to my learning experiences in this course. & 4.17 \\
Required readings were beneficial as a technical reference now and for other applications. & 4.64 \\
In-class presentations augmented the required readings. & 4.38 \\
Did this course prepare you for performing surgeries for the field season? & 4.64 \\
The course was designed to help one master the technical task. & 4.64 \\
Would you recommend this course for anyone interested in learning surgical implantation of & \\
acoustic tags? & \\
\hline
\end{tabular}


Table B.12. General program comments.

\begin{tabular}{|c|c|c|c|c|}
\hline Question & Effective & Count & Not Effective & Count \\
\hline \multirow{7}{*}{$\begin{array}{l}\text { Were there any aspects } \\
\text { of this course that were } \\
\text { particularly effective in } \\
\text { stimulating your interest } \\
\text { or performance in the } \\
\text { materials presented or in } \\
\text { fostering your learning? }\end{array}$} & $\begin{array}{l}\text { Live instruction: Working one on } \\
\text { one with the instructors and } \\
\text { instant feedback }\end{array}$ & 5 & \multirow[t]{7}{*}{$\begin{array}{l}\text { Trainer } \\
\text { disagreements on } \\
\text { techniques and } \\
\text { protocols }\end{array}$} & \multirow[t]{7}{*}{2} \\
\hline & $\begin{array}{l}\text { Learning delayed tagging effects } \\
\text { and physiological aspects }\end{array}$ & 4 & & \\
\hline & Delayed feedback: & & & \\
\hline & $\begin{array}{l}\text { Post-surgery photos and rubric } \\
\text { feedback }\end{array}$ & 2 & & \\
\hline & Prep for field season conditions & 1 & & \\
\hline & Model practice & 1 & & \\
\hline & Practice fish necropsies & 1 & & \\
\hline
\end{tabular}

Table B.13. Trainer performance questions.

\begin{tabular}{lcc}
\hline \multicolumn{1}{c}{ Questions } & $\begin{array}{c}\text { Trainer E } \\
\text { Average Score }\end{array}$ & $\begin{array}{c}\text { Trainer J } \\
\text { Average Score }\end{array}$ \\
\hline How clearly did your instructor explain the objectives of the course? & 3.85 & 4.0 \\
How knowledgeable in the course content was your instructor? & 4.29 & 4.2 \\
How clearly did your instructor explain difficult material? & 3.86 & 3.5 \\
$\begin{array}{l}\text { How well did your instructor distinguish between the most important } \\
\text { topics and the least important topics? }\end{array}$ & 4.0 & 3.3 \\
$\begin{array}{l}\text { Did your instructor present the material at about the right speed and } \\
\text { level for your experience? }\end{array}$ & 3.86 & 3.9 \\
$\begin{array}{l}\text { How motivating was your instructor? } \\
\text { How easy was it to meet with your instructor outside of class? }\end{array}$ & 4.14 & 3.3 \\
$\begin{array}{l}\text { Could your instructor describe the mechanical process needed to } \\
\text { accomplish the task? }\end{array}$ & 4.15 & 4.29 \\
$\begin{array}{l}\text { Could your instructor assist you with changing and/or correcting your } \\
\text { needed mechanical process to accomplish this task? }\end{array}$ & 4.43 & 3.7 \\
\hline
\end{tabular}

\section{B.7 Discussion}

The overarching goal of this surgeon training program was to further develop the recommended approach by CBSPSC (2011) and Cooke et al. (2011b) to include a multifaceted learning environment with objective structured assessments. Using the lessons learned from the medical industry, we developed a surgeon training program for intra-coelomic acoustic transmitter implantation in juvenile salmon that uses the Fitts-Posner three-stage theory of motor skill acquisition that includes three stages of surgeries (bench top models, dead fish and then live fish; Anastakis et al. 1999; Moorthy et al. 2003; Bann and Darzi 2005; Reznick and MacRae 2006), a modified objective structured assessment of technical skills, and developed a feedback program on skills-SAM. The training program provided a critical set of skills to surgeons that included comprehension of the project by introducing studyassociated goals and work flow, understanding of fish health, physiology and stress by providing reading materials and classroom instruction (e.g., handling, anesthesia induction, fish physiology, stress, etc.), and ultimately automation-level motor skill acquisition sensitive to the surgeons experience level. Based on 
the SAM outputs, surgeon feedback on the program, and survival study assumption tests (presented in Appendix H), the program and associated model were successful.

SAM is a novel model in fisheries science that uses an unbiased structure assessment, which relies on mortality, tag presence, functional sutures, and tissue trauma. Through a series of tests, the model was examined for functionality and repeatability. The first test examined SAM compatibility with visual QO approach. The model scores overlapped with the QO categories scores as expected. Using the visual QO high pass range, the SAM score of 21, which represented $98 \%$ of all QO HP surgeries, was considered as the maximum allowable average SAM score for eligibility to conduct surgeries for the 2011 LCR survival project. This criterion was used in addition to the CBSPSC (2011) criteria where a surgeon's exam fish should survive 14 days and not have lost tags (PIT or AT) (assuming an expert surgeon did not have mortalities or tag losses). In addition, each surgeon had built a portfolio of scores (frequency of occurrence for each fish and overall performance) that would be considered and used to recommend post-training (in between training and field season) maintenance program. Therefore, we had a programmatic maximum score, individual performance score, and individual portfolio of technique frequency that were used to assess 1) if a surgeon was eligible for project acceptance, and 2) if the surgeon would be requested to continue training with a trainer before the field season or train independently to maintain skill set. The overall performance was presented in portfolio along with pictures to assist the surgeon with post-training skill maintenance.

Once a maximum score was established for SAM, trainee assessment (and even trainer assessment) was focused on the individual's performance versus a comparison between a trainer and trainee. Trainer scores are needed not to determine a trainee performance (i.e., good or bad performance compared to the trainer), but to determine if fish health played a role in surgeon performance (both trainers and trainees) within a cohort and/or across time. This alleviates the occasional issue when expert/trainers do not perform as well as the trainees. For example, when surgeon $J$ (expert/trainer) had a fish mortality, it would not affect the grader's ability to score the cohort, analyze, and recommend project eligibility and a post-training skill maintenance program.

In agreement with the medical literature, survivorship is a gross measure when considering the success of a surgery, and it may not be indicative of surgeon skill. For example, surgeon Z (cohort 2) had no mortalities, no dropped tags, or major tissue trauma, and thus could have passed using the current criteria. However, surgeon Z's SAM average score of 28.5 precluded this surgeon from project acceptance. Surgeries should result in fish that indicate minimal effects from the surgery or tag, thus, using the QO HP range to determine a maximum allowable score limits substandard surgeries (and thus surgeons) and unwanted effects on fish.

The SAM analyses could not detect a significant difference between 3 days of training time for experienced surgeons and 5 days for novice surgeons. Within experienced surgeons and novice groups, surgeons tend to cluster into groups. For example, experienced surgeons average SAM scores clustered around 13 or 15 , novice surgeons scores clustered around 13,17,20, or failing. Thus, we do not recommend the 3 and 5 days of maximum training times, but that this amount of training time could be used as a guide for future efforts. Again, for this project, we encouraged surgeons to work together between training sessions and the start of the project to fine tune skills and learn from each other to 1) lessen potential tagger effects discrepancies in the main study, 2) provide novice surgeons the ability to be more comfortable with their new skill set and maintain new skills, and lastly, 3) allow experienced surgeons to mentor novice surgeons on various approaches and thus increase their own skill sets as well as build a team. 
Time efficacy is important to projects from the standpoint of fish health and handling as well as project management. The SAM analyses indicated that Day 7 data were not a strong predictor of Day 14 analyses. Day 7 examinations may not be necessary because Day 14 provided the better relationship between SAM and QO. We do not recommend eliminating Day 7 examinations, in case of laboratory accidents, poor fish condition, etc., but Day 7 examinations should be conducted and held in case of accidents or to examine Day 14 scores when needed to explain surgeon trends or events between Day 7 and Day 14 (e.g., tag loss). Day 7 scores, though, do not needed to be used in SAM, consequently, reducing time needed for final analyses.

\section{B.8 References}

American Fisheries Society. 2004. Guidelines for the Use of Fishes in Research. Available at http://fisheries.org/docs/policy_useoffishes.pdf.

Al-Ruzzeh S, S Karthik, and D O’Regan. 2007. “Objective surgical skill assessment: The diagonal operating matrix.” Interactive Cardiovascular and Thoracic Surgery 6(2):188-191.

Anastakis DJ, G Regehr, RK Reznick, M Cusimano, J Murnaghan, M Brown, and C Hutchison. 1999. "Assessment of technical skills transfer from bench training model to the human model." The American Journal of Surgery 177(2):167-170.

Bann S and A Darzi. 2005. "Selection of individuals for training in surgery." The American Journal of Surgery 190:98-102.

Bridger CJ and RK Booth. 2003. "The effects of biotelemetry transmitter presence and attachment procedures on fish physiology and behavior." Reviews in Fisheries Science 11(1):13-34.

Canadian Council on Animal Care. 2005. CCAC guidelines on: The care and use of fish in research, teaching and testing. Available at http://www.ccac.ca/Documents/Standards/Guidelines/Fish.pdf.

(CBSPSC) Columbia Basin Surgical Protocols Steering Committee. 2011. Surgical Protocols for Implanting JSATS Transmitters into Juvenile Salmonids for Studies Conducted for the U.S. Army Corps of Engineers, Version 1.0. Available at http://www.nwp.usace.army.mil/environment/docs/afep/system/USACE_SurgicalProtocols_V1.pdf.

Cooke SJ and GN Wagner. 2004. "Training, experience, and opinions of researchers who use surgical techniques to implant telemetry devices into fish." Fisheries 29(12) 10-18.

Cooke SJ, GN Wagner, RS Brown, and KA Deters. 2011a. "Training considerations for the intracoelomic implantation of electronic tags in fish with a summary of surgical errors." Reviews in Fish Biology and Fisheries 21:11-24.

Cooke SJ, CM Woodley, MB Eppard, RS Brown, and JL Nielsen. 2011b. "Advancing the surgical implantation of electronic tags in fish: A gap analysis and research agenda based on a review of trends in intracoelomic tagging effects studies." Reviews in Fish Biology and Fisheries 21(1):127-151. 
Deters KA, RS Brown, KM Carter, and JW Boyd. 2009. "Performance Assessment of Suture Type in Juvenile Chinook Salmon Surgically Implanted with Acoustic Transmitters." PNNL-18010, Pacific Northwest National Laboratory, Richland, Washington.

Fisheries Society of the British Isles. 2002. Briefing Paper 2: Fish Welfare. Cambridge. Available at http://www.fsbi.org.uk/assets/brief-welfare-refs.pdf.

Jepsen N, A Koed, EB Thorstad, and E Baras. 2002. "Surgical implantation of telemetry transmitters in fish: How much have we learned?" Hydrobiologia 483(1-3):239-248.

Moorthy K, Y Munz, SK Sarker, and A Darzi. 2003. "Objective assessment of technical skills in surgery." BMJ 327:1032-1037.

Mulcahy DM. 2003. "Surgical implantation of transmitters into fish.” ILAR Journal 44(4):295-306.

Nielsen JL (ed). 2011. "Special Issue: Advancing the science and practice of surgical implantation of electronic tags in fish." Reviews in Fish Biology and Fisheries, Volume 21, Issue 1, Springer, Netherlands. Springer Link, available at http://link.springer.com/journal/11160/21/1/page/1.

Panait L, JM Larios, RA Brenes, TT Fancher, MS Ajemian, SJ Dudrick, and JA Sanchez. 2011. "Surgical Skills Assessment of Applicants to General Surgery Residency." Journal of Surgical Research 170(2):189-194.

Peyre SE and SW Ashley. 2011. "Teaching uncommon and highly complex operations: Maximizing the teaching and learning." Journal of Gastrointestinal Surgery 15(10):1724-1725

Reznick M and H MacRae. 2006. "Teaching surgical skills - changes in the wind." The New England Journal of Medicine 355(22):2664-2669.

Shah J and A Darzi. 2001. "Surgical skills assessment: An ongoing debate.” British Journal of Urology International 88:655-660.

Summerfelt RC and LS Smith. 1990. Anesthesia, surgery, and related techniques. Pages 213-263 in CB Schreck and PB Moyle (eds.), Methods for Fish Biology. American Fisheries Society, Bethesda, Maryland.

Taffinder NJ, RCG Russell, IC McManus, J Jansen, and A Darzi. 1998. “Objective Measurement of Surgical Dexterity_Validation of the Imperial College Surgical Assessment Device.” Minimally Invasive Surgery and Allied Techniques, vol. 7, suppl. 1.

Wagner GN and SJ Cooke. 2005. "Methodological approaches and opinions of researchers involved in the surgical implantation of telemetry transmitters in fish." Journal of Aquatic Animal Health 17:160-169.

Welch DW, SD Batten, and BR Ward. 2007. "Growth, survival, and tag retention of steelhead trout (O. mykiss) surgically implanted with dummy acoustic tags." Hydrobiologia 582:289-299. 
Appendix C

Fish-Tagging Tables 


\section{Appendix C}

\section{Fish-Tagging Tables}

Table C.1. Yearling Chinook salmon tagged at John Day Dam in 2011.

\begin{tabular}{|c|c|c|c|c|}
\hline Tag Date & Number Tagged & Release Date & Release Location & Number Released \\
\hline 2011-04-25 & 80 & 2011-04-26 & Roosevelt & 80 \\
\hline 2011-04-26 & 81 & 2011-04-27 & Roosevelt & 81 \\
\hline \multirow[t]{4}{*}{ 2011-04-27 } & 185 & 2011-04-28 & Celilo & 25 \\
\hline & & & JDA_tailrace & 75 \\
\hline & & & Roosevelt & 84 \\
\hline & & 2011-04-29 & JDA_SPILL $^{(a)}$ & 1 \\
\hline \multirow[t]{3}{*}{$2011-04-28$} & 208 & 2011-04-29 & Celilo & 25 \\
\hline & & & JDA_SPILL $^{(a)}$ & 2 \\
\hline & & & Roosevelt & 81 \\
\hline \multirow[t]{3}{*}{ 2011-04-29 } & 233 & 2011-04-30 & Celilo & 25 \\
\hline & & & JDA_tailrace & 76 \\
\hline & & & Roosevelt & 81 \\
\hline \multirow[t]{2}{*}{ 2011-04-30 } & 255 & 2011-05-01 & Celilo & 25 \\
\hline & & & Roosevelt & 82 \\
\hline \multirow[t]{3}{*}{ 2011-05-01 } & 232 & 2011-05-02 & Celilo & 25 \\
\hline & & & JDA_tailrace & 75 \\
\hline & & & Roosevelt & 82 \\
\hline \multirow[t]{2}{*}{ 2011-05-02 } & 255 & 2011-05-03 & Celilo & 25 \\
\hline & & & Roosevelt & 82 \\
\hline \multirow[t]{5}{*}{ 2011-05-03 } & 243 & 2011-05-03 & JDA_SPILL $^{(a)}$ & $5^{(\mathrm{b})}$ \\
\hline & & 2011-05-04 & Celilo & 25 \\
\hline & & & JDA_tailrace & 74 \\
\hline & & & Roosevelt & 82 \\
\hline & & 2011-05-10 & JDA_SPILL $^{(a)}$ & 2 \\
\hline \multirow[t]{3}{*}{ 2011-05-04 } & 254 & 2011-05-05 & Celilo & 25 \\
\hline & & & Roosevelt & 82 \\
\hline & & 2011-05-10 & JDA_SPILL $^{(a)}$ & 2 \\
\hline \multirow[t]{3}{*}{$2011-05-05$} & 233 & 2011-05-06 & Celilo & 25 \\
\hline & & & JDA_tailrace & 76 \\
\hline & & & Roosevelt & 82 \\
\hline \multirow[t]{2}{*}{ 2011-05-06 } & 257 & 2011-05-07 & Celilo & 25 \\
\hline & & & Roosevelt & 82 \\
\hline \multirow[t]{3}{*}{ 2011-05-07 } & 233 & 2011-05-08 & Celilo & 25 \\
\hline & & & JDA_tailrace & 76 \\
\hline & & & Roosevelt & 82 \\
\hline
\end{tabular}

C.1 
Table C.1. (contd)

\begin{tabular}{|c|c|c|c|c|}
\hline Tag Date & Number Tagged & Release Date & Release Location & Number Released \\
\hline \multirow[t]{2}{*}{ 2011-05-08 } & 257 & 2011-05-09 & Celilo & 25 \\
\hline & & & Roosevelt & 82 \\
\hline \multirow[t]{3}{*}{ 2011-05-09 } & 233 & 2011-05-10 & Celilo & 25 \\
\hline & & & JDA_tailrace & 76 \\
\hline & & & Roosevelt & 82 \\
\hline \multirow[t]{3}{*}{ 2011-05-10 } & 257 & 2011-05-11 & Celilo & 25 \\
\hline & & & Roosevelt & 81 \\
\hline & & 2011-05-15 & JDA_SPILL ${ }^{(a)}$ & 1 \\
\hline \multirow[t]{3}{*}{ 2011-05-11 } & 233 & 2011-05-12 & Celilo & 25 \\
\hline & & & JDA_tailrace & 76 \\
\hline & & & Roosevelt & 82 \\
\hline \multirow[t]{2}{*}{ 2011-05-12 } & 255 & 2011-05-13 & Celilo & 25 \\
\hline & & & Roosevelt & 81 \\
\hline \multirow[t]{3}{*}{ 2011-05-13 } & 233 & 2011-05-14 & Celilo & 25 \\
\hline & & & JDA_tailrace & 76 \\
\hline & & & Roosevelt & 82 \\
\hline \multirow[t]{3}{*}{ 2011-05-14 } & 255 & 2011-05-15 & Celilo & 24 \\
\hline & & & JDA_SPILL $^{(a)}$ & 1 \\
\hline & & & Roosevelt & 82 \\
\hline \multirow[t]{4}{*}{$2011-05-15$} & 233 & 2011-05-15 & JDA_SPILL $^{(a)}$ & 1 \\
\hline & & 2011-05-16 & Celilo & 25 \\
\hline & & & JDA_tailrace & 75 \\
\hline & & & Roosevelt & 82 \\
\hline \multirow[t]{2}{*}{ 2011-05-16 } & 256 & 2011-05-17 & Celilo & 25 \\
\hline & & & Roosevelt & 82 \\
\hline \multirow[t]{3}{*}{ 2011-05-17 } & 243 & 2011-05-18 & Celilo & 25 \\
\hline & & & JDA_tailrace & 76 \\
\hline & & & Roosevelt & 82 \\
\hline \multirow[t]{2}{*}{ 2011-05-18 } & 256 & 2011-05-19 & Celilo & 25 \\
\hline & & & Roosevelt & 82 \\
\hline \multirow[t]{3}{*}{ 2011-05-19 } & 233 & 2011-05-20 & Celilo & 25 \\
\hline & & & JDA_tailrace & 76 \\
\hline & & & Roosevelt & 81 \\
\hline \multirow[t]{2}{*}{ 2011-05-20 } & 255 & 2011-05-21 & Celilo & 25 \\
\hline & & & Roosevelt & 82 \\
\hline \multirow[t]{3}{*}{ 2011-05-21 } & 233 & 2011-05-22 & Celilo & 25 \\
\hline & & & JDA_tailrace & 75 \\
\hline & & & Roosevelt & 82 \\
\hline \multirow[t]{2}{*}{$2011-05-22$} & 257 & $2011-05-23$ & Celilo & 25 \\
\hline & & & Roosevelt & 82 \\
\hline
\end{tabular}


Table C.1. (contd)

\begin{tabular}{ccccc}
\hline Tag Date & Number Tagged & Release Date & Release Location & Number Released \\
\hline $2011-05-23$ & 233 & $2011-05-24$ & Celilo & 25 \\
& & & JDA_tailrace & 75 \\
& & & Roosevelt & 82 \\
$2011-05-24$ & 140 & $2011-05-25$ & Celilo & 20 \\
$2011-05-25$ & 221 & $2011-05-26$ & Celilo & 25 \\
& & & JDA_tailrace & 76 \\
& & & Roosevelt & 68 \\
$2011-05-26$ & 245 & $2011-05-27$ & Celilo & 25 \\
& & & Roosevelt & 70 \\
$2011-05-27$ & 135 & $2011-05-28$ & Celilo & 25 \\
& & & JDA_tailrace & 60 \\
$2011-05-28$ & 205 & $2011-05-29$ & Celilo & 30 \\
\hline
\end{tabular}

(a) Dead fish release location. 
Table C.2. Juvenile steelhead tagged at John Day Dam in 2011.

\begin{tabular}{|c|c|c|c|c|}
\hline Tag Date & Number Tagged & Release Date & Release Location & Number Released \\
\hline $2011-04-25$ & 80 & $2011-04-26$ & Roosevelt & 80 \\
\hline $2011-04-26$ & 82 & 2011-04-27 & Roosevelt & 82 \\
\hline \multirow[t]{3}{*}{$2011-04-27$} & \multirow[t]{3}{*}{183} & \multirow[t]{3}{*}{$2011-04-28$} & Celilo & 25 \\
\hline & & & JDA_tailrace & 76 \\
\hline & & & Roosevelt & 82 \\
\hline \multirow[t]{3}{*}{ 2011-04-28 } & \multirow[t]{3}{*}{207} & \multirow[t]{3}{*}{ 2011-04-29 } & Celilo & 25 \\
\hline & & & JDA_SPILL ${ }^{(a)}$ & 1 \\
\hline & & & Roosevelt & 81 \\
\hline \multirow[t]{3}{*}{ 2011-04-29 } & \multirow[t]{3}{*}{233} & \multirow[t]{3}{*}{ 2011-04-30 } & Celilo & 25 \\
\hline & & & JDA_tailrace & 76 \\
\hline & & & Roosevelt & 82 \\
\hline \multirow[t]{2}{*}{$2011-04-30$} & \multirow[t]{2}{*}{257} & \multirow[t]{2}{*}{ 2011-05-01 } & Celilo & 25 \\
\hline & & & Roosevelt & 82 \\
\hline \multirow[t]{3}{*}{$2011-05-01$} & \multirow[t]{3}{*}{233} & \multirow[t]{3}{*}{ 2011-05-02 } & Celilo & 25 \\
\hline & & & JDA_tailrace & 76 \\
\hline & & & Roosevelt & 82 \\
\hline \multirow[t]{2}{*}{$2011-05-02$} & \multirow[t]{2}{*}{257} & \multirow[t]{2}{*}{$2011-05-03$} & Celilo & 25 \\
\hline & & & Roosevelt & 82 \\
\hline \multirow[t]{3}{*}{$2011-05-03$} & \multirow[t]{3}{*}{243} & \multirow[t]{3}{*}{$2011-05-04$} & Celilo & 25 \\
\hline & & & JDA_tailrace & 76 \\
\hline & & & Roosevelt & 82 \\
\hline \multirow[t]{2}{*}{ 2011-05-04 } & \multirow[t]{2}{*}{257} & \multirow[t]{2}{*}{$2011-05-05$} & Celilo & 22 \\
\hline & & & Roosevelt & 82 \\
\hline \multirow[t]{3}{*}{$2011-05-05$} & \multirow[t]{3}{*}{232} & \multirow[t]{3}{*}{ 2011-05-06 } & Celilo & 25 \\
\hline & & & JDA_tailrace & 76 \\
\hline & & & Roosevelt & 82 \\
\hline $2011-05-06$ & 257 & $2011-05-07$ & Celilo & 25 \\
\hline & & & Roosevelt & 82 \\
\hline $2011-05-07$ & 230 & $2011-05-08$ & Celilo & 25 \\
\hline & & & JDA_tailrace & 76 \\
\hline & & & Roosevelt & 80 \\
\hline $2011-05-08$ & 257 & $2011-05-09$ & Celilo & 25 \\
\hline & & & Roosevelt & 82 \\
\hline 2011-05-09 & 230 & $2011-05-10$ & Celilo & 25 \\
\hline & & & JDA_tailrace & 74 \\
\hline & & & Roosevelt & 82 \\
\hline $2011-05-10$ & 257 & $2011-05-11$ & Celilo & 25 \\
\hline & & & Roosevelt & 82 \\
\hline
\end{tabular}


Table C.2. (contd)

\begin{tabular}{|c|c|c|c|c|}
\hline Tag Date & Number Tagged & Release Date & Release Location & Number Released \\
\hline \multirow[t]{3}{*}{ 2011-05-11 } & \multirow[t]{3}{*}{230} & \multirow[t]{3}{*}{$2011-05-12$} & Celilo & 25 \\
\hline & & & JDA_tailrace & 75 \\
\hline & & & Roosevelt & 80 \\
\hline \multirow[t]{2}{*}{$2011-05-12$} & \multirow[t]{2}{*}{257} & \multirow[t]{2}{*}{$2011-05-13$} & Celilo & 25 \\
\hline & & & Roosevelt & 82 \\
\hline \multirow[t]{3}{*}{$2011-05-13$} & \multirow[t]{3}{*}{226} & \multirow[t]{3}{*}{ 2011-05-14 } & Celilo & 25 \\
\hline & & & JDA_tailrace & 72 \\
\hline & & & Roosevelt & 82 \\
\hline \multirow[t]{2}{*}{ 2011-05-14 } & \multirow[t]{2}{*}{257} & \multirow[t]{2}{*}{ 2011-05-15 } & Celilo & 25 \\
\hline & & & Roosevelt & 82 \\
\hline \multirow[t]{3}{*}{ 2011-05-15 } & \multirow[t]{3}{*}{232} & \multirow[t]{3}{*}{ 2011-05-16 } & Celilo & 25 \\
\hline & & & JDA_tailrace & 76 \\
\hline & & & Roosevelt & 82 \\
\hline \multirow[t]{3}{*}{ 2011-05-16 } & \multirow[t]{3}{*}{256} & \multirow[t]{2}{*}{ 2011-05-17 } & Celilo & 25 \\
\hline & & & Roosevelt & 77 \\
\hline & & 2011-05-22 & JDA_SPILL $^{(a)}$ & 2 \\
\hline \multirow[t]{4}{*}{$2011-05-17$} & \multirow[t]{4}{*}{243} & 2011-05-17 & JDA_SPILL ${ }^{(a)}$ & $5^{(\mathrm{b})}$ \\
\hline & & 2011-05-18 & Celilo & 25 \\
\hline & & & JDA_tailrace & 76 \\
\hline & & & Roosevelt & 82 \\
\hline \multirow{2}{*}{ 2011-05-18 } & \multirow[t]{2}{*}{257} & \multirow{2}{*}{ 2011-05-19 } & Celilo & 25 \\
\hline & & & Roosevelt & 82 \\
\hline \multirow[t]{4}{*}{ 2011-05-19 } & \multirow[t]{4}{*}{232} & \multirow[t]{3}{*}{ 2011-05-20 } & Celilo & 25 \\
\hline & & & JDA_tailrace & 75 \\
\hline & & & Roosevelt & 81 \\
\hline & & 2011-05-22 & JDA_SPILL $^{(a)}$ & 1 \\
\hline $2011-05-20$ & 257 & 2011-05-21 & Celilo & 25 \\
\hline & & & Roosevelt & 82 \\
\hline $2011-05-21$ & 232 & $2011-05-22$ & Celilo & 25 \\
\hline & & & JDA_tailrace & 75 \\
\hline & & & Roosevelt & 82 \\
\hline $2011-05-22$ & 257 & $2011-05-23$ & Celilo & 25 \\
\hline & & & Roosevelt & 82 \\
\hline $2011-05-23$ & 233 & $2011-05-24$ & Celilo & 25 \\
\hline & & & JDA_tailrace & 76 \\
\hline & & & Roosevelt & 82 \\
\hline $2011-05-24$ & 252 & $2011-05-25$ & Celilo & 25 \\
\hline & & & Roosevelt & 82 \\
\hline $2011-05-25$ & 220 & $2011-05-26$ & Celilo & 25 \\
\hline & & & JDA_tailrace & 76 \\
\hline & & & Roosevelt & 70 \\
\hline
\end{tabular}


Table C.2. (contd)

\begin{tabular}{ccccc}
\hline Tag Date & Number Tagged & Release Date & Release Location & Number Released \\
\hline $2011-05-26$ & 245 & $2011-05-27$ & Celilo & 25 \\
& & & Roosevelt & 70 \\
$2011-05-27$ & 139 & $2011-05-28$ & Celilo & 25 \\
& & & JDA_tailrace & 65 \\
$2011-05-28$ & 175 & $2011-05-29$ & Celilo & 25 \\
\hline
\end{tabular}

(a) Dead fish release location. 


\section{Appendix D}

Hydrophone and Autonomous Node Deployment Tables 


\section{Appendix D}

\section{Hydrophone and Autonomous Node Deployment Tables}

Table D.1. Hydrophone locations in the John Day Dam-face array in 2011.

\begin{tabular}{|c|c|c|c|}
\hline Hydrophone Name & Latitude (NAD83) & Longitude (NAD83) & Elevation (NAVD88, ft) \\
\hline JDA_P00S & 45.7119308 & -120.6888983 & 255.93 \\
\hline JDA_P00N & 45.7120616 & -120.6890346 & 256.30 \\
\hline JDA_P00_01S & 45.7122102 & -120.6891706 & 251.39 \\
\hline JDA_P00_01D & 45.7122343 & -120.6891232 & 165.02 \\
\hline JDA_P01_02S & 45.7124075 & -120.6893715 & 251.63 \\
\hline JDA_P01_02D & 45.7124252 & -120.6893366 & 165.26 \\
\hline JDA_P02_03S & 45.7126069 & -120.6895783 & 251.46 \\
\hline JDA_P02_03D & 45.7126246 & -120.6895433 & 165.09 \\
\hline JDA_P03_04S & 45.7128070 & -120.6897846 & 251.77 \\
\hline JDA_P03_04D & 45.7128247 & -120.6897497 & 165.40 \\
\hline JDA_P04_05S & 45.7130057 & -120.6899920 & 251.46 \\
\hline JDA_P04_05D & 45.7130234 & -120.6899571 & 165.09 \\
\hline JDA_P05_06S & 45.7132061 & -120.6901988 & 251.62 \\
\hline JDA_P05_06D & 45.7132239 & -120.6901639 & 165.25 \\
\hline JDA_P06_07S & 45.7134054 & -120.6904059 & 251.50 \\
\hline JDA_P06_07D & 45.7134231 & -120.6903710 & 165.13 \\
\hline JDA_P07_08S & 45.7136058 & -120.6906126 & 251.62 \\
\hline JDA_P07_08D & 45.7136236 & -120.6905777 & 165.25 \\
\hline JDA_P08_09S & 45.7138050 & -120.6908196 & 251.45 \\
\hline JDA_P08_09D & 45.7138228 & -120.6907847 & 165.08 \\
\hline JDA_P09_10S & 45.7140048 & -120.6910270 & 251.56 \\
\hline JDA_P09_10D & 45.7140226 & -120.6909920 & 165.19 \\
\hline JDA_P10_11S & 45.7142048 & -120.6912344 & 251.63 \\
\hline JDA_P10_11D & 45.7142225 & -120.6911995 & 165.26 \\
\hline JDA_P11_12S & 45.7144046 & -120.6914413 & 251.41 \\
\hline JDA_P11_12D & 45.7144224 & -120.6914064 & 165.04 \\
\hline JDA_P12_13S & 45.7146043 & -120.6916480 & 251.45 \\
\hline JDA_P12_13D & 45.7146220 & -120.6916131 & 165.08 \\
\hline JDA_P13_14S & 45.7148036 & -120.6918551 & 251.22 \\
\hline JDA_P13_14D & 45.7148214 & -120.6918202 & 164.85 \\
\hline JDA_P14_15S & 45.7150033 & -120.6920615 & 251.15 \\
\hline JDA_P14_15D & 45.7150210 & -120.6920266 & 164.78 \\
\hline JDA_P15_16S & 45.7152026 & -120.6922691 & 251.16 \\
\hline JDA_P15_16D & 45.7152204 & -120.6922342 & 164.79 \\
\hline JDA_P16_17S & 45.7154027 & -120.6924757 & 251.43 \\
\hline
\end{tabular}


Table D.1. (contd)

\begin{tabular}{|c|c|c|c|}
\hline Hydrophone Name & Latitude (NAD83) & Longitude (NAD83) & Elevation (NAVD88, ft) \\
\hline JDA_P16_17D & 45.7154204 & -120.6924408 & 165.06 \\
\hline JDA_P17_18S & 45.7156023 & -120.6926827 & 251.35 \\
\hline JDA_P17_18D & 45.7156201 & -120.6926478 & 164.98 \\
\hline JDA_P18_19S & 45.7158018 & -120.6928894 & 251.29 \\
\hline JDA_P18_19D & 45.7158196 & -120.6928545 & 164.92 \\
\hline JDA_P19_20S & 45.7160019 & -120.6930966 & 251.25 \\
\hline JDA_P19_20D & 45.7160196 & -120.6930617 & 164.88 \\
\hline JDA_P20S & 45.7161978 & -120.6933180 & 250.94 \\
\hline JDA_P20D & 45.7162062 & -120.6933014 & 193.20 \\
\hline JDA_S20D & 45.7162635 & -120.6934228 & 228.10 \\
\hline JDA_S20S & 45.7162635 & -120.6934228 & 255.60 \\
\hline JDA_S19_20D & 45.7163994 & -120.6935661 & 228.64 \\
\hline JDA_S19_20S & 45.7163994 & -120.6935661 & 256.14 \\
\hline JDA_S18_19D & 45.7165371 & -120.6937088 & 228.61 \\
\hline JDA_S18_19S & 45.7165371 & -120.6937088 & 256.11 \\
\hline JDA_S17_18D & 45.7166748 & -120.6938514 & 228.74 \\
\hline JDA_S17_18S & 45.7166748 & -120.6938514 & 256.24 \\
\hline JDA_S16_17D & 45.7168128 & -120.6939943 & 228.51 \\
\hline JDA_S16_17S & 45.7168128 & -120.6939943 & 256.01 \\
\hline JDA_S15_16D & 45.7169506 & -120.6941369 & 228.49 \\
\hline JDA_S15_16S & 45.7169506 & -120.6941369 & 255.99 \\
\hline JDA_S14_15D & 45.7170879 & -120.6942794 & 228.60 \\
\hline JDA_S14_15S & 45.7170879 & -120.6942794 & 256.10 \\
\hline JDA_S13_14D & 45.7172260 & -120.6944221 & 228.69 \\
\hline JDA_S13_14S & 45.7172260 & -120.6944221 & 256.19 \\
\hline JDA_S12_13D & 45.7173638 & -120.6945648 & 228.61 \\
\hline JDA_S12_13S & 45.7173638 & -120.6945648 & 256.11 \\
\hline JDA_S11_12D & 45.7175009 & -120.6947069 & 228.60 \\
\hline JDA_S11_12S & 45.7175009 & -120.6947069 & 256.10 \\
\hline JDA_S10_11D & 45.7176385 & -120.6948496 & 228.79 \\
\hline JDA_S10_11S & 45.7176385 & -120.6948496 & 256.29 \\
\hline JDA_S09_10D & 45.7177758 & -120.6949920 & 228.54 \\
\hline JDA_S09_10S & 45.7177758 & -120.6949920 & 256.04 \\
\hline JDA_S08_09D & 45.7179136 & -120.6951349 & 228.62 \\
\hline JDA_S08_09S & 45.7179136 & -120.6951349 & 256.12 \\
\hline JDA_S07_08D & 45.7180514 & -120.6952774 & 228.66 \\
\hline JDA_S07_08S & 45.7180514 & -120.6952774 & 256.16 \\
\hline JDA_S06_07D & 45.7181902 & -120.6954210 & 228.67 \\
\hline JDA_S06_07S & 45.7181902 & -120.6954210 & 256.17 \\
\hline JDA_S05_06D & 45.7183272 & -120.6955630 & 228.57 \\
\hline JDA_S05_06S & 45.7183272 & -120.6955630 & 256.07 \\
\hline JDA_S04_05D & 45.7184643 & -120.6957052 & 228.69 \\
\hline
\end{tabular}


Table D.1. (contd)

\begin{tabular}{lccc}
\hline \multicolumn{1}{c}{ Hydrophone Name } & Latitude (NAD83) & Longitude (NAD83) & Elevation (NAVD88, ft) \\
\hline JDA_S04_05S & 45.7184643 & -120.6957052 & 256.19 \\
JDA_S03_04D & 45.7186014 & -120.6958475 & 228.72 \\
JDA_S03_04S & 45.7186014 & -120.6958475 & 256.22 \\
JDA_S02_03D & 45.7187389 & -120.6959898 & 228.82 \\
JDA_S02_03S & 45.7187389 & -120.6959898 & 256.32 \\
JDA_S01_02D & 45.7188768 & -120.6961327 & 228.81 \\
JDA_S01_02S & 45.7188768 & -120.6961327 & 256.31 \\
JDA_SSOUTH & 45.7190277 & -120.6962912 & 255.91 \\
JDA_SNORTH & 45.7192277 & -120.6964222 & 255.77 \\
\hline
\end{tabular}


Table D.2. Approximate global positioning system coordinates of autonomous nodes deployed in arrays above and below John Day Dam in 2011. Array_Node is a concatenation of an array name and an autonomous node number. The array name is a concatenation of "CR" for Columbia River, with a three-digit number corresponding to river kilometer upstream of the mouth of the Columbia River. Nodes within an array are numbered from the Washington to the Oregon shore.

\begin{tabular}{lcccc}
\hline Array_Node & Array Function & $\begin{array}{c}\text { Latitude Degrees } \\
\text { North }\end{array}$ & $\begin{array}{c}\text { Longitude Degrees } \\
\text { West }\end{array}$ & $\begin{array}{c}\text { Approximate } \\
\text { Depth (ft.) }\end{array}$ \\
\hline CR351.0_01 & JDA Forebay Entrance, $V_{1}$ & 45.7263480 & -120.6850310 & 102.83 \\
\hline CR351.0_02 & & 45.7252350 & -120.6839480 & 115.50 \\
CR351.0_03 & & 45.7241920 & -120.6829290 & 113.83 \\
\hline CR351.0_04 & 45.7230820 & -120.6816760 & 118.83 \\
\hline CR351.0_05 & & 45.7219190 & -120.6805270 & 99.33 \\
\hline CR351.0_06 & & 45.7208840 & -120.6793880 & 120.33 \\
\hline CR351.0_07 & & 45.7197450 & -120.6781820 & 110.67 \\
\hline CR351.0_08 & & 45.7186490 & -120.6769790 & 73.83 \\
CR346.0_01 & JDA Egress, $R_{2}$ & 45.7085740 & -120.7246590 & 18.67 \\
\hline CR346.0_02 & & 45.7074530 & -120.7238100 & 21.67 \\
\hline CR346.0_03 & & 45.7062870 & -120.7228740 & 46.00 \\
\hline CR346.0_04 & & 45.7051500 & -120.7219640 & 60.00 \\
\hline CR325.0_01 & JDA Tailrace, $R_{3}$ & 45.6555966 & -120.9658891 & 30.17 \\
\hline CR325.0_02 & & 45.6548042 & -120.9653076 & 47.17 \\
\hline CR325.0_03 & & 45.6540626 & -120.9647451 & 49.33 \\
\hline CR325.0_04 & & 45.6532889 & -120.9642236 & 91.17 \\
\hline CR325.0_05 & & 45.6524865 & -120.9636421 & 76.00 \\
\hline CR325.0_06 & & 45.6517051 & -120.9630304 & 48.33 \\
\hline CR275.0_01 & JDA Secondary & 45.7091259 & -121.4712970 & 22.50 \\
\hline CR275.0_02 & & 45.7086224 & -121.4717591 & 37.67 \\
\hline CR275.0_03 & & 45.7078330 & -121.4724400 & 63.92 \\
\hline CR275.0_04 & & 45.7072915 & -121.4729401 & 74.83 \\
\hline CR275.0_05 & & 45.7066440 & -121.4735049 & 112.00 \\
\hline CR275.0_06 & & 45.7057667 & -121.4734667 & 135.67 \\
\hline & & & & \\
\hline
\end{tabular}


Appendix E

Capture Histories 


\section{Appendix E}

\section{Capture Histories}

This appendix contains detailed capture histories for each of the two runs of fish studied at John Day Dam in 2011.

\section{E.1 Capture Histories of Yearling Chinook Salmon in Spring}

Table E.1. Capture histories at sites at rkm 325, 309, 275, 234, 161, 113, and 86 for release group $V_{1}$ for yearling Chinook salmon used in estimating dam passage survival and BRZ-to-BRZ survival. A " 1 " denotes detection, " 0 " denotes nondetection, and " 2 " denotes detection and censoring due to removal.

\begin{tabular}{|c|c|c|}
\hline \multirow[b]{2}{*}{$\begin{array}{l}\text { Capture } \\
\text { History }\end{array}$} & \multicolumn{2}{|c|}{$V_{1}$ (Season-Wide) } \\
\hline & $\begin{array}{c}\text { Dam Passage } \\
\text { Survival }\end{array}$ & $\begin{array}{c}\text { BRZ-to-BRZ } \\
\text { Survival }\end{array}$ \\
\hline $1111111:$ & 910 & 911 \\
\hline $0111111118:$ & 4 & 4 \\
\hline 10111118 & 3 & 3 \\
\hline $1101111:$ & 30 & 30 \\
\hline 1001111 : & 1 & 1 \\
\hline $1111011:$ & 115 & 116 \\
\hline 010110101 : & 1 & 1 \\
\hline 1011011 : & 2 & 2 \\
\hline 1101011 : & 7 & 7 \\
\hline 010101011 : & 1 & 1 \\
\hline $1111101:$ & 274 & 274 \\
\hline $0111111101:$ & 1 & 1 \\
\hline $1101101:$ & 13 & 13 \\
\hline $01011101:$ & 1 & 1 \\
\hline $1111001:$ & 50 & 50 \\
\hline $01111001:$ & 1 & 1 \\
\hline $1101001:$ & 3 & 3 \\
\hline $0101001:$ & 1 & 1 \\
\hline 1111110 : & 287 & 287 \\
\hline 011111110 : & 7 & 7 \\
\hline 1011110 : & 8 & 8 \\
\hline 1101110 : & 44 & 44 \\
\hline 01011110 : & 1 & 1 \\
\hline 1111010 : & 64 & 64 \\
\hline $0 \begin{array}{llllll:}0 & 1 & 1 & 0 & 1 & 0:\end{array}$ & 4 & 4 \\
\hline 1011010 : & 1 & 1 \\
\hline 1101010 : & 13 & 13 \\
\hline 010101010 : & 1 & 1 \\
\hline $1111100:$ & 149 & 149 \\
\hline
\end{tabular}


Table E.1. (contd)

\begin{tabular}{|c|c|c|}
\hline \multirow[b]{2}{*}{$\begin{array}{l}\text { Capture } \\
\text { History }\end{array}$} & \multicolumn{2}{|c|}{$V_{1}($ Season-Wide $)$} \\
\hline & $\begin{array}{l}\text { Dam Passage } \\
\text { Survival }\end{array}$ & $\begin{array}{c}\text { BRZ-to-BRZ } \\
\text { Survival }\end{array}$ \\
\hline $0 \begin{array}{lllllll:}0 & 1 & 1 & 1 & 1 & 0 & 0:\end{array}$ & 5 & 5 \\
\hline 1011100 : & 1 & 1 \\
\hline 1101100 : & 36 & 35 \\
\hline $\begin{array}{lllllll}0 & 1 & 0 & 1 & 1 & 0 & 0\end{array}$ & 2 & 2 \\
\hline 1112000 : & 58 & 58 \\
\hline 1111000 : & 116 & 116 \\
\hline 01111000 : & 2 & 2 \\
\hline $\begin{array}{lllllll}1 & 1 & 1 & 0 & 0 & 0.8\end{array}$ & 3 & 3 \\
\hline $110101000:$ & 8 & 8 \\
\hline $\begin{array}{llllllll:}0 & 1 & 0 & 1 & 0 & 0 & 0:\end{array}$ & 2 & 2 \\
\hline 1001000 : & 1 & 1 \\
\hline $111100000:$ & 10 & 10 \\
\hline $\begin{array}{lllllll:}0 & 1 & 1 & 0 & 0 & 0 & 0:\end{array}$ & 1 & 1 \\
\hline 1100000 : & 84 & 84 \\
\hline $\begin{array}{lllllll:}0 & 1 & 0 & 0 & 0 & 0 & 0:\end{array}$ & 2 & 2 \\
\hline 1000000 : & 19 & 19 \\
\hline $\begin{array}{lllllll:}0 & 0 & 0 & 0 & 0 & 0 & 0 .\end{array}$ & 94 & 102 \\
\hline Total & 2,441 & 2,450 \\
\hline
\end{tabular}

Table E.2. Capture histories at sites at rkm 309, 275, 234, 161, 113, and 86 for release groups $R_{2}$ and $R_{3}$ for yearling Chinook salmon used in estimating all dam passage survival. A "1" denotes detection, "0" denotes nondetection, and "2" denotes detection and censoring due to removal.

\begin{tabular}{|c|c|c|}
\hline \multirow[b]{2}{*}{ Capture History } & \multicolumn{2}{|c|}{ Reference Release (Season Wide) } \\
\hline & $R_{2}$ & $R_{3}$ \\
\hline $111111:$ & 454 & 314 \\
\hline 011111 : & 1 & 3 \\
\hline 101111 : & 14 & 13 \\
\hline 0011111 : & 0 & 0 \\
\hline 110111 : & 0 & 0 \\
\hline 010111 : & 0 & 0 \\
\hline 100111 : & 0 & 0 \\
\hline 0000111 : & 0 & 0 \\
\hline 111011 : & 75 & 31 \\
\hline 011011 : & 0 & 1 \\
\hline 101011 : & 4 & 3 \\
\hline 001011 : & 0 & 0 \\
\hline $110011:$ & 0 & 0 \\
\hline 010011 : & 0 & 0 \\
\hline $100011:$ & 0 & 0 \\
\hline $0000011:$ & 0 & 0 \\
\hline $111101:$ & 140 & 83 \\
\hline $0111101:$ & 0 & 1 \\
\hline
\end{tabular}


Table E.2. (contd)

\begin{tabular}{|c|c|c|}
\hline \multirow[b]{2}{*}{ Capture History } & \multicolumn{2}{|c|}{ Reference Release (Season Wide) } \\
\hline & $R_{2}$ & $R_{3}$ \\
\hline $101101:$ & 11 & 5 \\
\hline $001101:$ & 0 & 0 \\
\hline $110101:$ & 0 & 0 \\
\hline $010101:$ & 0 & 0 \\
\hline $100101:$ & 0 & 0 \\
\hline $\begin{array}{llllll:}0 & 0 & 0 & 1 & 0 & 1:\end{array}$ & 0 & 0 \\
\hline $111001:$ & 20 & 18 \\
\hline $0111001:$ & 0 & 1 \\
\hline $101001:$ & 5 & 2 \\
\hline $001001:$ & 0 & 0 \\
\hline $110001:$ & 0 & 0 \\
\hline $0100001:$ & 0 & 0 \\
\hline $1000001:$ & 0 & 0 \\
\hline $0000001:$ & 0 & 0 \\
\hline 111120 : & 0 & 0 \\
\hline 0111120 : & 0 & 0 \\
\hline 101120 : & 0 & 0 \\
\hline 0011120 : & 0 & 0 \\
\hline 110120 : & 0 & 0 \\
\hline 01012120 : & 0 & 0 \\
\hline 100120 : & 0 & 0 \\
\hline $\begin{array}{llllll}0 & 0 & 0 & 1 & 2 & 0:\end{array}$ & 0 & 0 \\
\hline 111020 : & 0 & 0 \\
\hline $\begin{array}{llllll:}0 & 1 & 1 & 0 & 2 & 0:\end{array}$ & 0 & 0 \\
\hline 101020 : & 0 & 0 \\
\hline $\begin{array}{llllll:}0 & 0 & 1 & 0 & 2 & 0:\end{array}$ & 0 & 0 \\
\hline 110020 : & 0 & 0 \\
\hline $\begin{array}{llllll:}0 & 1 & 0 & 0 & 2 & 0:\end{array}$ & 0 & 0 \\
\hline 1000020 : & 0 & 0 \\
\hline $\begin{array}{llllll:}0 & 0 & 0 & 0 & 2 & 0:\end{array}$ & 0 & 0 \\
\hline 111110 : & 129 & 107 \\
\hline $01111110:$ & 1 & 0 \\
\hline 101110 : & 31 & 25 \\
\hline $\begin{array}{llllll:}0 & 0 & 1 & 1 & 1 & 0 \text { : }\end{array}$ & 0 & 0 \\
\hline 110110 : & 0 & 0 \\
\hline 01010110 : & 0 & 0 \\
\hline 100110 : & 0 & 0 \\
\hline $0000110:$ & 0 & 0 \\
\hline 111010 : & 37 & 26 \\
\hline $01110010:$ & 0 & 0 \\
\hline 101010 : & 10 & 6 \\
\hline $\begin{array}{llllll:}0 & 0 & 1 & 0 & 1 & 0:\end{array}$ & 0 & 0 \\
\hline 110010 : & 0 & 0 \\
\hline $\begin{array}{llllll:}0 & 1 & 0 & 0 & 1 & 0:\end{array}$ & 0 & 0 \\
\hline 1000010 : & 0 & 0 \\
\hline $\begin{array}{lllllll:}0 & 0 & 0 & 0 & 1 & 0\end{array}$ & 0 & 0 \\
\hline
\end{tabular}


Table E.2. (contd)

\begin{tabular}{|c|c|c|}
\hline \multirow[b]{2}{*}{ Capture History } & \multicolumn{2}{|c|}{ Reference Release (Season Wide) } \\
\hline & $R_{2}$ & $R_{3}$ \\
\hline $1111200:$ & 0 & 0 \\
\hline 0111200 : & 0 & 0 \\
\hline 101200 : & 0 & 0 \\
\hline 001200 : & 0 & 0 \\
\hline $110200:$ & 0 & 0 \\
\hline 010200 : & 0 & 0 \\
\hline 100200 : & 0 & 0 \\
\hline 0000200 : & 0 & 0 \\
\hline $111100:$ & 74 & 47 \\
\hline 0111100 : & 1 & 1 \\
\hline $101100:$ & 24 & 7 \\
\hline 0011100 : & 0 & 0 \\
\hline $110100:$ & 0 & 0 \\
\hline $01010100:$ & 0 & 0 \\
\hline $100100:$ & 0 & 0 \\
\hline 0000100 : & 0 & 0 \\
\hline 112000 : & 3 & 0 \\
\hline 012000 : & 0 & 0 \\
\hline 102000 : & 0 & 0 \\
\hline 002000 : & 0 & 0 \\
\hline $111000:$ & 62 & 43 \\
\hline 0111000 : & 1 & 0 \\
\hline $101000:$ & 10 & 6 \\
\hline $\begin{array}{llllll:}0 & 0 & 1 & 0 & 0 & 0:\end{array}$ & 0 & 0 \\
\hline $120000:$ & 0 & 0 \\
\hline 020000 : & 0 & 0 \\
\hline $110000:$ & 6 & 6 \\
\hline $\begin{array}{llllll:}0 & 1 & 0 & 0 & 0 & 0:\end{array}$ & 0 & 0 \\
\hline $2000000:$ & 0 & 0 \\
\hline $1000000:$ & 55 & 38 \\
\hline $\begin{array}{llllll:}0 & 0 & 0 & 0 & 0 & 0:\end{array}$ & 25 & 12 \\
\hline Total & 1,193 & 799 \\
\hline
\end{tabular}


Table E.3. Capture histories at sites at rkm 325, 309, 275, 234, 161, 113, and 86 for release group $V_{1}$ for yearling Chinook salmon used in estimating dam passage survival daytime and nighttime survival. A " 1 " denotes detection, " 0 " denotes nondetection, and " 2 " denotes detection and censoring due to removal.

\begin{tabular}{|c|c|c|}
\hline \multirow[b]{2}{*}{ Capture History } & \multicolumn{2}{|c|}{$V_{1}($ Season Wide) } \\
\hline & Daytime & Nighttime \\
\hline $\begin{array}{lllllll:}1 & 1 & 1 & 1 & 11\end{array}$ & 572 & 338 \\
\hline 011111111 : & 2 & 2 \\
\hline 1011111 : & 1 & 2 \\
\hline 1101111 : & 14 & 16 \\
\hline 1001111 : & 1 & 0 \\
\hline 1111011 : & 73 & 42 \\
\hline $0111011:$ & 0 & 1 \\
\hline 1011011 : & 1 & 1 \\
\hline 1101011 : & 4 & 3 \\
\hline $01001011:$ & 1 & 0 \\
\hline $1111101:$ & 174 & 100 \\
\hline $01111101:$ & 1 & 0 \\
\hline $1101101:$ & 6 & 7 \\
\hline $01011101:$ & 0 & 1 \\
\hline $1111001:$ & 34 & 16 \\
\hline $01111001:$ & 0 & 1 \\
\hline $1101001:$ & 0 & 3 \\
\hline $0101001:$ & 0 & 1 \\
\hline 1111110 : & 165 & 122 \\
\hline 0111110 : & 3 & 4 \\
\hline 1011110 : & 4 & 4 \\
\hline 1101110 : & 24 & 20 \\
\hline 0101110 : & 1 & 0 \\
\hline 1111010 : & 31 & 33 \\
\hline $0111010:$ & 2 & 2 \\
\hline 1011010 : & 0 & 1 \\
\hline 1101010 : & 10 & 3 \\
\hline $0101010:$ & 1 & 0 \\
\hline $1111100:$ & 78 & 71 \\
\hline 01111100 : & 4 & 1 \\
\hline 0101010 : & 1 & 0 \\
\hline 1101100 : & 23 & 13 \\
\hline 0101010 : & 0 & 2 \\
\hline 1112000 : & 38 & 20 \\
\hline $1111000:$ & 68 & 48 \\
\hline 1011000 : & 0 & 3 \\
\hline $0111000:$ & 2 & 0 \\
\hline 1101000 : & 3 & 5 \\
\hline $010101000:$ & 1 & 1 \\
\hline 1001000 : & 0 & 1 \\
\hline 1110000 : & 7 & 3 \\
\hline $\begin{array}{lllllll:}0 & 1 & 1 & 0 & 0 & 0 & 0\end{array}$ & 1 & 0 \\
\hline
\end{tabular}


Table E.3. (contd)

\begin{tabular}{|c|c|c|}
\hline \multirow[b]{2}{*}{ Capture History } & \multicolumn{2}{|c|}{$V_{1}$ (Season Wide) } \\
\hline & Daytime & Nighttime \\
\hline $110000000:$ & 54 & 30 \\
\hline $0100000:$ & 0 & 2 \\
\hline $1000000:$ & 11 & 8 \\
\hline $\begin{array}{lllllll:}0 & 0 & 0 & 0 & 0 & 0 & 0:\end{array}$ & 61 & 33 \\
\hline Total & 1,477 & 964 \\
\hline
\end{tabular}

Table E.4. Capture histories at sites at rkm 325, 309, 275, 234, 161, 113, and 86 for release group $V_{1}$ for yearling Chinook salmon used in estimating dam passage survival by route survival. A " 1 " denotes detection, " 0 " denotes nondetection, and " 2 " denotes detection and censoring due to removal.

\begin{tabular}{|c|c|c|c|c|c|}
\hline \multirow[b]{2}{*}{ Capture History } & \multicolumn{5}{|c|}{$V_{1}$ by Route (Season Wide) } \\
\hline & JBS & Turbine & Spillway & TSW & non-TSW \\
\hline $1111111:$ & 209 & 109 & 592 & 248 & 344 \\
\hline 01111111 : & 1 & 2 & 1 & 1 & 0 \\
\hline 1011111 : & 1 & 2 & 0 & 0 & 0 \\
\hline $1101111:$ & 6 & 1 & 23 & 6 & 17 \\
\hline 1001111 : & 0 & 0 & 1 & 0 & 1 \\
\hline $1111011:$ & 41 & 13 & 61 & 20 & 41 \\
\hline 01111011 : & 0 & 0 & 1 & 0 & 1 \\
\hline 1011011 : & 0 & 0 & 2 & 1 & 1 \\
\hline $1101011:$ & 0 & 2 & 5 & 0 & 5 \\
\hline $0101011:$ & 0 & 0 & 1 & 0 & 1 \\
\hline $1111101:$ & 72 & 21 & 181 & 76 & 105 \\
\hline 01111101 : & 0 & 0 & 1 & 0 & 1 \\
\hline $1101101:$ & 5 & 3 & 5 & 1 & 4 \\
\hline $0101101:$ & 0 & 0 & 1 & 0 & 1 \\
\hline $1111001:$ & 14 & 9 & 27 & 9 & 18 \\
\hline $0111001:$ & 0 & 1 & 0 & 0 & 0 \\
\hline $1101001:$ & 1 & 1 & 1 & 0 & 1 \\
\hline 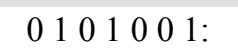 & 0 & 0 & 1 & 0 & 1 \\
\hline 1111110 : & 76 & 32 & 179 & 63 & 115 \\
\hline 01111110 : & 1 & 0 & 6 & 1 & 5 \\
\hline 1011110 : & 1 & 1 & 6 & 1 & 5 \\
\hline 1101110 : & 11 & 3 & 30 & 8 & 22 \\
\hline 01011110 : & 0 & 0 & 1 & 0 & 1 \\
\hline 1111010 : & 22 & 5 & 37 & 12 & 25 \\
\hline 01111010 : & 1 & 0 & 3 & 1 & 2 \\
\hline 1011010 : & 0 & 0 & 1 & 0 & 1 \\
\hline 1101010 : & 1 & 0 & 12 & 3 & 9 \\
\hline 0101010 : & 0 & 0 & 1 & 0 & 1 \\
\hline $11111100:$ & 41 & 12 & 96 & 33 & 63 \\
\hline $01111100:$ & 0 & 0 & 5 & 0 & 5 \\
\hline 1011100 : & 0 & 0 & 1 & 0 & 1 \\
\hline
\end{tabular}


Table E.4. (contd)

\begin{tabular}{|c|c|c|c|c|c|}
\hline \multirow[b]{2}{*}{ Capture History } & \multicolumn{5}{|c|}{$V_{1}$ by Route (Season Wide) } \\
\hline & JBS & Turbine & Spillway & TSW & non-TSW \\
\hline $1101100:$ & 8 & 1 & 27 & 3 & 24 \\
\hline 0101100 : & 0 & 1 & 1 & 0 & 1 \\
\hline 1112000 : & 15 & 9 & 34 & 15 & 19 \\
\hline 1111000 : & 30 & 11 & 75 & 26 & 49 \\
\hline 01111000 : & 0 & 0 & 2 & 0 & 2 \\
\hline 1011000 : & 2 & 0 & 1 & 0 & 1 \\
\hline 1101000 : & 2 & 1 & 5 & 0 & 5 \\
\hline $0101000:$ & 1 & 1 & 0 & 0 & 0 \\
\hline 1001000 : & 1 & 0 & 0 & 0 & 0 \\
\hline 1110000 : & 3 & 1 & 6 & 3 & 3 \\
\hline 01110000 : & 0 & 0 & 1 & 0 & 1 \\
\hline 1100000 : & 19 & 10 & 55 & 20 & 35 \\
\hline 0100000 : & 1 & 0 & 1 & 0 & 1 \\
\hline $1000000:$ & 5 & 3 & 11 & 3 & 8 \\
\hline $\begin{array}{lllllll:}0 & 0 & 0 & 0 & 0 & 0 & 0:\end{array}$ & 8 & 27 & 59 & 28 & 31 \\
\hline Total & 599 & 282 & 1,560 & 582 & 977 \\
\hline
\end{tabular}

Table E.5. Capture histories at sites at rkm 325, 309, 275, 234, 161, 113, and 86 for release group $V_{1}$ for yearling Chinook salmon used in estimating dam passage and BRZ-to-BRZ early spring survival. A " 1 " denotes detection, " 0 " denotes nondetection, and "2" denotes detection and censoring due to removal.

\begin{tabular}{|c|c|c|}
\hline \multirow[b]{2}{*}{ Capture History } & \multicolumn{2}{|c|}{$V_{1}$ (Early Spring) } \\
\hline & Dam & BRZ-to-BRZ \\
\hline $\begin{array}{lllllll:}1 & 1 & 1 & 1 & 1 & 1:\end{array}$ & $\overline{780}$ & 781 \\
\hline 1011111 : & 1 & 1 \\
\hline 1101111 : & 4 & 5 \\
\hline 1111011 : & 67 & 68 \\
\hline $1111101:$ & 220 & 220 \\
\hline $1101101:$ & 1 & 1 \\
\hline $1111001:$ & 34 & 34 \\
\hline $1101001:$ & 1 & 1 \\
\hline 1111110 : & 119 & 119 \\
\hline 1101110 : & 3 & 3 \\
\hline 1111010 : & 31 & 31 \\
\hline 1101010 : & 2 & 2 \\
\hline 1111100 : & 50 & 50 \\
\hline $1101100:$ & 2 & 2 \\
\hline 1112000 : & 55 & 55 \\
\hline 1111000 : & 66 & 66 \\
\hline 1110000 : & 6 & 6 \\
\hline 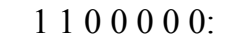 & 56 & 56 \\
\hline $\begin{array}{lllllll}1 & 0 & 0 & 0 & 0 & 0 & 0\end{array}$ & 14 & 14 \\
\hline $\begin{array}{llllllll:}0 & 0 & 0 & 0 & 0 & 0 & 0\end{array}$ & 68 & 70 \\
\hline Total & 1,580 & 1,585 \\
\hline
\end{tabular}

E.7 
Table E.6. Capture histories at sites at rkm 325, 309, 275, 234, 161, 113, and 86 for release group $V_{1}$ for yearling Chinook salmon used in estimating dam passage survival-early spring $30 \%$ spill and $40 \%$ spill survival. A " 1 " denotes detection, " 0 " denotes nondetection, and " 2 " denotes detection and censoring due to removal.

\begin{tabular}{|c|c|c|}
\hline \multirow[b]{2}{*}{ Capture History } & \multicolumn{2}{|c|}{$V_{1}$ (Dam Passage Survival-Early Spring) } \\
\hline & $30 \%$ & $40 \%$ \\
\hline $1111111:$ & 383 & 379 \\
\hline 1011111 : & 1 & \\
\hline 1101111 : & 4 & \\
\hline $1111011:$ & 45 & 20 \\
\hline $1111101:$ & 143 & 74 \\
\hline $1101101:$ & 1 & \\
\hline $1111001:$ & 28 & 5 \\
\hline $1101001:$ & 1 & \\
\hline 1111110 : & 85 & 33 \\
\hline $1101110:$ & 3 & \\
\hline 1111010 : & 27 & 3 \\
\hline $1101010:$ & 2 & \\
\hline 1111100 : & 42 & 8 \\
\hline $1101100:$ & 2 & \\
\hline $1112000:$ & 34 & 19 \\
\hline 1111000 : & 40 & 25 \\
\hline $1110000:$ & 3 & 3 \\
\hline 1100000 : & 33 & 23 \\
\hline $1000000:$ & 10 & 4 \\
\hline $\begin{array}{lllllll:}0 & 0 & 0 & 0 & 0 & 0 & 0:\end{array}$ & 44 & 22 \\
\hline Total & 931 & 618 \\
\hline
\end{tabular}


Table E.7. Capture histories at sites at rkm 325, 309, 275, 234, 161, 113, and 86 for release group $V_{1}$ for yearling Chinook salmon used in estimating BRZ-to-BRZ survival-early spring $30 \%$ spill and $40 \%$ spill survival. A " 1 " denotes detection, " 0 " denotes nondetection, and " 2 " denotes detection and censoring due to removal.

\begin{tabular}{|c|c|c|}
\hline \multirow{2}{*}{$\begin{array}{l}\text { Capture } \\
\text { History }\end{array}$} & \multicolumn{2}{|c|}{$V_{1}$ (BRZ-to-BRZ Survival-Early Spring) } \\
\hline & $30 \%$ & $40 \%$ \\
\hline $111111111:$ & 374 & 386 \\
\hline 1011111 : & 1 & \\
\hline $1101111:$ & 5 & \\
\hline 1111011 : & 44 & 23 \\
\hline $1111101:$ & 138 & 71 \\
\hline $1101101:$ & 1 & \\
\hline $1111001:$ & 28 & 5 \\
\hline $1101001:$ & 1 & \\
\hline 1111110 : & 78 & 34 \\
\hline $1101110:$ & 3 & \\
\hline 1111010 : & 27 & 3 \\
\hline $1101010:$ & 2 & \\
\hline $1111100:$ & 37 & 9 \\
\hline $1101100:$ & 2 & \\
\hline $1112000:$ & 32 & 19 \\
\hline 1111000 : & 40 & 25 \\
\hline 1110000 : & 3 & 3 \\
\hline 1100000 : & 32 & 24 \\
\hline 10000000 : & 9 & 4 \\
\hline $000000000:$ & 43 & 26 \\
\hline Total & 900 & 632 \\
\hline
\end{tabular}


Table E.8. Capture histories at sites at rkm 309, 275, 234, 161, 113, and 86 for release groups $R_{2}$ and $R_{3}$ for yearling Chinook salmon used in estimating all early spring survival. A " 1 " denotes detection, " 0 " denotes nondetection, and " 2 " denotes detection and censoring due to removal.

\begin{tabular}{|c|c|c|}
\hline \multirow[b]{2}{*}{ Capture History } & \multicolumn{2}{|c|}{ Reference Release-Early Spring } \\
\hline & $R_{2}$ & $R_{3}$ \\
\hline $111111:$ & 372 & 258 \\
\hline 011111 : & 1 & 0 \\
\hline 101111 : & 0 & 0 \\
\hline $000111111:$ & 0 & 0 \\
\hline 110111 : & 0 & 0 \\
\hline $010111:$ & 0 & 0 \\
\hline 100111 : & 0 & 0 \\
\hline 0000111 : & 0 & 0 \\
\hline $111011:$ & 44 & 19 \\
\hline 0111011 : & 0 & 0 \\
\hline 101011 : & 0 & 0 \\
\hline $001011:$ & 0 & 0 \\
\hline $1100011:$ & 0 & 0 \\
\hline 0100011 : & 0 & 0 \\
\hline $100011:$ & 0 & 0 \\
\hline $0000011:$ & 0 & 0 \\
\hline $111101:$ & 107 & 55 \\
\hline $0111101:$ & 0 & 0 \\
\hline $101101:$ & 1 & 1 \\
\hline $001101:$ & 0 & 0 \\
\hline $110101:$ & 0 & 0 \\
\hline $010101:$ & 0 & 0 \\
\hline $100101:$ & 0 & 0 \\
\hline $000101:$ & 0 & 0 \\
\hline $111001:$ & 10 & 12 \\
\hline $0111001:$ & 0 & 1 \\
\hline $101001:$ & 1 & 0 \\
\hline $001001:$ & 0 & 0 \\
\hline $110001:$ & 0 & 0 \\
\hline $010001:$ & 0 & 0 \\
\hline $1000001:$ & 0 & 0 \\
\hline $\begin{array}{llllll:}0 & 0 & 0 & 0 & 0 & 1:\end{array}$ & 0 & 0 \\
\hline 111120 : & 0 & 0 \\
\hline 011120 : & 0 & 0 \\
\hline 101120 : & 0 & 0 \\
\hline 001120 : & 0 & 0 \\
\hline 110120 : & 0 & 0 \\
\hline $01010120:$ & 0 & 0 \\
\hline $100120:$ & 0 & 0 \\
\hline 000120 : & 0 & 0 \\
\hline $111020:$ & 0 & 0 \\
\hline $0 \begin{array}{llllll}0 & 1 & 1 & 0 & 2 & 0:\end{array}$ & 0 & 0 \\
\hline
\end{tabular}


Table E.8. (contd)

\begin{tabular}{|c|c|c|}
\hline \multirow[b]{2}{*}{ Capture History } & \multicolumn{2}{|c|}{ Reference Release-Early Spring } \\
\hline & $R_{2}$ & $R_{3}$ \\
\hline $10101020:$ & 0 & 0 \\
\hline $\begin{array}{llllll}0 & 0 & 1 & 0 & 2 & 0:\end{array}$ & 0 & 0 \\
\hline 110020 : & 0 & 0 \\
\hline $\begin{array}{llllll:}0 & 1 & 0 & 0 & 2 & 0:\end{array}$ & 0 & 0 \\
\hline 100020 : & 0 & 0 \\
\hline $\begin{array}{llllll:}0 & 0 & 0 & 0 & 2 & 0:\end{array}$ & 0 & 0 \\
\hline 111110 : & 49 & 29 \\
\hline 0111110 : & 0 & 0 \\
\hline $101110:$ & 0 & 0 \\
\hline $0011110:$ & 0 & 0 \\
\hline $110110:$ & 0 & 0 \\
\hline 010110 : & 0 & 0 \\
\hline 100110 : & 0 & 0 \\
\hline 000110 : & 0 & 0 \\
\hline 111010 : & 13 & 9 \\
\hline 0111010 : & 0 & 0 \\
\hline 101010 : & 1 & 0 \\
\hline $0001010:$ & 0 & 0 \\
\hline $110010:$ & 0 & 0 \\
\hline $0100010:$ & 0 & 0 \\
\hline 100010 : & 0 & 0 \\
\hline $\begin{array}{llllll:}0 & 0 & 0 & 0 & 1 & 0:\end{array}$ & 0 & 0 \\
\hline 111200 : & 0 & 0 \\
\hline $0111200:$ & 0 & 0 \\
\hline 101200 : & 0 & 0 \\
\hline $001200:$ & 0 & 0 \\
\hline $110200:$ & 0 & 0 \\
\hline $010200:$ & 0 & 0 \\
\hline $100200:$ & 0 & 0 \\
\hline 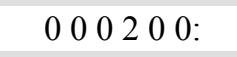 & 0 & 0 \\
\hline 111100 : & 21 & 14 \\
\hline 01111100 : & 0 & 0 \\
\hline 101100 : & 0 & 0 \\
\hline $\begin{array}{llllll:}0 & 0 & 1 & 1 & 0 & 0:\end{array}$ & 0 & 0 \\
\hline 110100 : & 0 & 0 \\
\hline $\begin{array}{llllll:}0 & 1 & 0 & 1 & 0 & 0:\end{array}$ & 0 & 0 \\
\hline 100100 : & 0 & 0 \\
\hline $\begin{array}{llllll:}0 & 0 & 0 & 1 & 0 & 0:\end{array}$ & 0 & 0 \\
\hline 112000 : & 3 & 0 \\
\hline $012000:$ & 0 & 0 \\
\hline 102000 : & 0 & 0 \\
\hline $\begin{array}{llllll:}0 & 0 & 2 & 0 & 0 & 0:\end{array}$ & 0 & 0 \\
\hline 111000 : & 34 & 19 \\
\hline $\begin{array}{llllll:}0 & 1 & 1 & 0 & 0 & 0:\end{array}$ & 0 & 0 \\
\hline $101000:$ & 1 & 2 \\
\hline $\begin{array}{llllll:}0 & 0 & 1 & 0 & 0 & 0:\end{array}$ & 0 & 0 \\
\hline
\end{tabular}


Table E.8. (contd)

\begin{tabular}{|c|c|c|}
\hline \multirow[b]{2}{*}{ Capture History } & \multicolumn{2}{|c|}{ Reference Release-Early Spring } \\
\hline & $R_{2}$ & $R_{3}$ \\
\hline 1200000 : & 0 & 0 \\
\hline $\begin{array}{llllll:}0 & 2 & 0 & 0 & 0 & 0\end{array}$ & 0 & 0 \\
\hline $\begin{array}{llllll}1 & 1 & 0 & 0 & 0 & 0:\end{array}$ & 5 & 6 \\
\hline $\begin{array}{lllllll:}0 & 1 & 0 & 0 & 0 & 0 \text { : }\end{array}$ & 0 & 0 \\
\hline 200000 : & 0 & 0 \\
\hline $\begin{array}{llllll:}1 & 0 & 0 & 0 & 0 & 0\end{array}$ & 37 & 19 \\
\hline $00000000:$ & 18 & 5 \\
\hline Total & 718 & 449 \\
\hline
\end{tabular}

\section{E.2 Capture Histories of Juvenile Steelhead Salmon in Spring}

Table E.9. Capture histories at sites at rkm 325, 309, 275, 234, 161, 113, and 86 for release group $V_{1}$ for juvenile steelhead salmon used in estimating dam passage survival and BRZ-to-BRZ survival. A " 1 " denotes detection, " 0 " denotes nondetection, and " 2 " denotes detection and censoring due to removal.

\begin{tabular}{|c|c|c|}
\hline \multirow[b]{2}{*}{$\begin{array}{l}\text { Capture } \\
\text { History }\end{array}$} & \multicolumn{2}{|c|}{$V_{1}($ Season-Wide $)$} \\
\hline & $\begin{array}{c}\text { Dam Passage } \\
\text { Survival }\end{array}$ & $\begin{array}{c}\text { BRZ-to-BRZ } \\
\text { Survival }\end{array}$ \\
\hline $1111111:$ & 851 & 852 \\
\hline 0111111111 : & 4 & 4 \\
\hline 10111111 : & 1 & 1 \\
\hline $1101111:$ & 40 & 40 \\
\hline $0101111:$ & 1 & 1 \\
\hline $1001111:$ & 1 & 1 \\
\hline 1111011 : & 53 & 53 \\
\hline $1011011:$ & 1 & 1 \\
\hline 1101011 : & 7 & 7 \\
\hline $1111101:$ & 273 & 274 \\
\hline $0111101:$ & 2 & 2 \\
\hline $1011101:$ & 1 & 1 \\
\hline $1101101:$ & 29 & 29 \\
\hline $01011101:$ & 1 & 1 \\
\hline $1111001:$ & 17 & 17 \\
\hline $1101001:$ & 5 & 5 \\
\hline $010101001:$ & 1 & 1 \\
\hline 1111110 : & 403 & 403 \\
\hline $01111110:$ & 12 & 12 \\
\hline 1011110 : & 4 & 4 \\
\hline $11011110:$ & 98 & 98 \\
\hline $01011110:$ & 3 & 3 \\
\hline 1111010 : & 59 & 59 \\
\hline 1011010 : & 1 & 1 \\
\hline
\end{tabular}


Table E.9. (contd)

\begin{tabular}{|c|c|c|}
\hline \multirow[b]{2}{*}{$\begin{array}{l}\text { Capture } \\
\text { History }\end{array}$} & \multicolumn{2}{|c|}{$V_{1}$ (Season-Wide) } \\
\hline & $\begin{array}{c}\text { Dam Passage } \\
\text { Survival }\end{array}$ & $\begin{array}{c}\text { BRZ-to-BRZ } \\
\text { Survival }\end{array}$ \\
\hline $11001010:$ & 11 & 11 \\
\hline $1111100:$ & 187 & 188 \\
\hline 011111100 : & 5 & 5 \\
\hline 1011100 : & 5 & 5 \\
\hline 1101100 : & 46 & 46 \\
\hline $\begin{array}{llllllll}0 & 1 & 0 & 1 & 1 & 0 & 0\end{array}$ & 3 & 3 \\
\hline 1112000 : & 33 & 33 \\
\hline 1111000 : & 113 & 113 \\
\hline 01111000 : & 1 & 1 \\
\hline 1011000 : & 3 & 3 \\
\hline 1101000 : & 21 & 21 \\
\hline 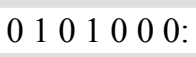 & 3 & 3 \\
\hline 1001000 : & 1 & 1 \\
\hline 1110000 : & 36 & 36 \\
\hline $11000000:$ & 53 & 53 \\
\hline $\begin{array}{lllllll:}0 & 1 & 0 & 0 & 0 & 0 & 0:\end{array}$ & 1 & 1 \\
\hline 10000000 : & 17 & 17 \\
\hline 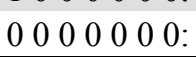 & 62 & 79 \\
\hline Total & 2,469 & 2,489 \\
\hline
\end{tabular}

Table E.10. Capture histories at sites at rkm 309, 275, 234, 161, 113, and 86 for release groups $R_{2}$ and $R_{3}$ for juvenile steelhead salmon used in estimating all passage survival. A " 1 " denotes detection, "0" denotes nondetection, and "2" denotes detection and censoring due to removal.

\begin{tabular}{|c|c|c|}
\hline \multirow[b]{2}{*}{ Capture History } & \multicolumn{2}{|c|}{ Reference Release (Season-Wide) } \\
\hline & $R_{2}$ & $R_{3}$ \\
\hline $111111:$ & 431 & 258 \\
\hline $\begin{array}{llllll:}0 & 1 & 1 & 1 & 1 & 1\end{array}$ & 1 & 0 \\
\hline 1011111 : & 25 & 15 \\
\hline 0011111 : & 0 & 0 \\
\hline $110111:$ & 0 & 0 \\
\hline 010111 : & 0 & 0 \\
\hline 100111 : & 0 & 0 \\
\hline 0000111 : & 0 & 0 \\
\hline 111011 : & 21 & 15 \\
\hline 0111011 : & 0 & 0 \\
\hline $101011:$ & 3 & 3 \\
\hline 001011 : & 0 & 0 \\
\hline $110011:$ & 0 & 0 \\
\hline 0100101 : & 0 & 0 \\
\hline 100011 : & 0 & 0 \\
\hline 0000011 : & 0 & 0 \\
\hline $111101:$ & 134 & 92 \\
\hline
\end{tabular}


Table E.10. (contd)

\begin{tabular}{|c|c|c|}
\hline \multirow[b]{2}{*}{ Capture History } & \multicolumn{2}{|c|}{ Reference Release (Season-Wide) } \\
\hline & $R_{2}$ & $R_{3}$ \\
\hline $01111101:$ & 0 & 1 \\
\hline $101101:$ & 16 & 5 \\
\hline $0011101:$ & 0 & 0 \\
\hline $110101:$ & 0 & 0 \\
\hline $010101:$ & 0 & 0 \\
\hline $100101:$ & 0 & 0 \\
\hline $0000101:$ & 0 & 0 \\
\hline $111001:$ & 13 & 7 \\
\hline $0111001:$ & 0 & 0 \\
\hline $101001:$ & 1 & 4 \\
\hline $001001:$ & 0 & 0 \\
\hline $110001:$ & 0 & 0 \\
\hline $\begin{array}{lllllll:}0 & 1 & 0 & 0 & 0 & 1:\end{array}$ & 0 & 0 \\
\hline $100001:$ & 0 & 0 \\
\hline $0000001:$ & 0 & 0 \\
\hline 111120 : & 0 & 0 \\
\hline 0111120 : & 0 & 0 \\
\hline $101120:$ & 0 & 0 \\
\hline 001120 : & 0 & 0 \\
\hline 110120 : & 0 & 0 \\
\hline 010120 : & 0 & 0 \\
\hline 100120 : & 0 & 0 \\
\hline $000120:$ & 0 & 0 \\
\hline 111020 : & 0 & 0 \\
\hline 0111020 : & 0 & 0 \\
\hline 101020 : & 0 & 0 \\
\hline 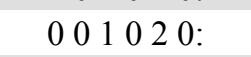 & 0 & 0 \\
\hline 110020 : & 0 & 0 \\
\hline $0100020:$ & 0 & 0 \\
\hline 100020 : & 0 & 0 \\
\hline $\begin{array}{llllll:}0 & 0 & 0 & 0 & 2 & 0:\end{array}$ & 0 & 0 \\
\hline $111110:$ & 194 & 159 \\
\hline $0 \begin{array}{llllll}0 & 1 & 1 & 1 & 1 & 0:\end{array}$ & 0 & 0 \\
\hline 101110 : & 46 & 30 \\
\hline $\begin{array}{llllll:}0 & 0 & 1 & 1 & 1 & 0:\end{array}$ & 0 & 0 \\
\hline 110110 : & 0 & 0 \\
\hline $01010110:$ & 0 & 0 \\
\hline 100110 : & 0 & 0 \\
\hline $0000110:$ & 0 & 0 \\
\hline 111010 : & 25 & 19 \\
\hline $0111010:$ & 0 & 0 \\
\hline 101010 : & 6 & 14 \\
\hline $\begin{array}{llllll:}0 & 0 & 1 & 0 & 1 & 0:\end{array}$ & 0 & 0 \\
\hline 110010 : & 0 & 0 \\
\hline $\begin{array}{llllll:}0 & 1 & 0 & 0 & 1 & 0:\end{array}$ & 0 & 0 \\
\hline 100010 : & 0 & 0 \\
\hline
\end{tabular}


Table E.10. (contd)

\begin{tabular}{|c|c|c|}
\hline \multirow[b]{2}{*}{ Capture History } & \multicolumn{2}{|c|}{ Reference Release (Season-Wide) } \\
\hline & $R_{2}$ & $R_{3}$ \\
\hline $0000010:$ & 0 & 0 \\
\hline $111200:$ & 0 & 0 \\
\hline $0111200:$ & 0 & 0 \\
\hline 101200 : & 0 & 0 \\
\hline 001200 : & 0 & 0 \\
\hline 110200 : & 0 & 0 \\
\hline $010200:$ & 0 & 0 \\
\hline $100200:$ & 0 & 0 \\
\hline $000200:$ & 0 & 0 \\
\hline 111100 : & 100 & 56 \\
\hline 0111100 : & 0 & 0 \\
\hline 101100 : & 32 & 23 \\
\hline $\begin{array}{llllll}0 & 0 & 1 & 1 & 0 & 0:\end{array}$ & 0 & 0 \\
\hline 110100 : & 0 & 0 \\
\hline 010100 : & 0 & 0 \\
\hline 100100 : & 0 & 0 \\
\hline $\begin{array}{llllll}0 & 0 & 0 & 1 & 0 & 0:\end{array}$ & 0 & 0 \\
\hline 112000 : & 1 & 0 \\
\hline 012000 : & 0 & 0 \\
\hline 102000 : & 0 & 0 \\
\hline $\begin{array}{llllll:}0 & 0 & 2 & 0 & 0 & 0:\end{array}$ & 0 & 0 \\
\hline 111000 : & 73 & 36 \\
\hline $\begin{array}{llllll:}0 & 1 & 1 & 0 & 0 & 0:\end{array}$ & 0 & 0 \\
\hline 101000 : & 10 & 11 \\
\hline $\begin{array}{llllll:}0 & 0 & 1 & 0 & 0 & 0:\end{array}$ & 0 & 0 \\
\hline 120000 : & 0 & 0 \\
\hline 020000 : & 0 & 0 \\
\hline $110000:$ & 11 & 13 \\
\hline $010000:$ & 0 & 0 \\
\hline $2000000:$ & 0 & 0 \\
\hline $100000:$ & 29 & 29 \\
\hline $\begin{array}{llllll:}0 & 0 & 0 & 0 & 0 & 0:\end{array}$ & 24 & 7 \\
\hline Total & 1,196 & 797 \\
\hline
\end{tabular}


Table E.11. Capture histories at sites at rkm 325, 309, 275, 234, 161, 113, and 86 for release group $V_{1}$ for juvenile steelhead salmon used in estimating dam passage survival daytime and nighttime survival. A " 1 " denotes detection, " 0 " denotes nondetection, and " 2 " denotes detection and censoring due to removal.

\begin{tabular}{|c|c|c|}
\hline \multirow[b]{2}{*}{ Capture History } & \multicolumn{2}{|c|}{$V_{1}$ (Season-Wide) } \\
\hline & Daytime & Nighttime \\
\hline $11111111:$ & 495 & 356 \\
\hline $00111111111:$ & 3 & 1 \\
\hline 1011111 : & 0 & 1 \\
\hline 1101111 : & 18 & 22 \\
\hline 0101111 : & 0 & 1 \\
\hline 1001111 : & 0 & 1 \\
\hline 1111011 : & 27 & 26 \\
\hline 1011011 : & 1 & 0 \\
\hline 1101011 : & 3 & 4 \\
\hline $1111101:$ & 154 & 119 \\
\hline $01111101:$ & 0 & 2 \\
\hline $1011101:$ & 0 & 1 \\
\hline $1101101:$ & 11 & 18 \\
\hline $01010101:$ & 0 & 1 \\
\hline $1111001:$ & 9 & 8 \\
\hline $1101001:$ & 3 & 2 \\
\hline $0101001:$ & 0 & 1 \\
\hline $1111110:$ & 208 & 195 \\
\hline $01111110:$ & 8 & 4 \\
\hline 1011110 : & 2 & 2 \\
\hline 1101110 : & 46 & 52 \\
\hline $01011110:$ & 2 & 1 \\
\hline 1111010 : & 26 & 33 \\
\hline 1011010 : & 1 & 0 \\
\hline 1101010 : & 2 & 9 \\
\hline $1111100:$ & 100 & 87 \\
\hline $011111100:$ & 2 & 3 \\
\hline 1011100 : & 3 & 2 \\
\hline 1101100 : & 30 & 16 \\
\hline 0101100 : & 1 & 2 \\
\hline 1112000 : & 25 & 8 \\
\hline 1111000 : & 60 & 53 \\
\hline 1011010 : & 1 & 0 \\
\hline 1011000 : & 2 & 1 \\
\hline 1101000 : & 13 & 8 \\
\hline 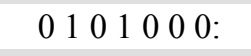 & 0 & 3 \\
\hline $1001000:$ & 1 & 0 \\
\hline $11100000:$ & 20 & 16 \\
\hline 1100000 : & 36 & 17 \\
\hline 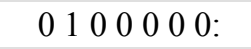 & 1 & 0 \\
\hline $10000000:$ & 13 & 4 \\
\hline $\begin{array}{lllllll:}0 & 0 & 0 & 0 & 0 & 0 & 0:\end{array}$ & 34 & 28 \\
\hline Total & 1,477 & 964 \\
\hline
\end{tabular}


Table E.12. Capture histories at sites at rkm 325, 309, 275, 234, 161, 113, and 86 for release group $V_{1}$ for juvenile steelhead salmon used in estimating dam passage survival by route survival. A " 1 " denotes detection, " 0 " denotes nondetection, and " 2 " denotes detection and censoring due to removal.

\begin{tabular}{|c|c|c|c|c|c|}
\hline \multirow[b]{2}{*}{ Capture History } & \multicolumn{5}{|c|}{$V_{1}$ by Route (Season Wide) } \\
\hline & JBS & Turbine & Spillway & TSW & non-TSW \\
\hline $1111111:$ & 250 & 31 & 570 & 343 & 227 \\
\hline $0101111111:$ & 0 & 0 & 4 & 1 & 3 \\
\hline 1011111 : & 1 & 0 & 0 & 0 & 0 \\
\hline $1101111:$ & 17 & 1 & 22 & 6 & 16 \\
\hline 1001111 : & 0 & 0 & 1 & 1 & 0 \\
\hline $01011111:$ & 1 & 0 & 0 & 0 & 0 \\
\hline $1111011:$ & 25 & 3 & 25 & 9 & 16 \\
\hline 01111011 : & 0 & 0 & 0 & 0 & 0 \\
\hline 1011011 : & 0 & 0 & 1 & 0 & 1 \\
\hline $1101011:$ & 4 & 0 & 3 & 1 & 2 \\
\hline 0101011 : & 0 & 0 & 0 & 0 & 0 \\
\hline $1111101:$ & 88 & 8 & 177 & 98 & 79 \\
\hline 0111101 : & 0 & 0 & 2 & 2 & 0 \\
\hline $1011101:$ & 1 & 0 & 0 & 0 & 0 \\
\hline $1101101:$ & 9 & 0 & 20 & 5 & 15 \\
\hline $0101101:$ & 0 & 0 & 1 & 0 & 1 \\
\hline $1111001:$ & 5 & 0 & 12 & 5 & 7 \\
\hline $0111001:$ & 0 & 0 & 0 & 0 & 0 \\
\hline $1101001:$ & 3 & 0 & 2 & 1 & 1 \\
\hline $0101001:$ & 1 & 0 & 0 & 0 & 0 \\
\hline $1111110:$ & 161 & 11 & 231 & 118 & 113 \\
\hline $0111110:$ & 2 & 0 & 10 & 4 & 6 \\
\hline $1011110:$ & 1 & 1 & 2 & 0 & 2 \\
\hline $1101110:$ & 43 & 4 & 51 & 14 & 37 \\
\hline $0101110:$ & 1 & 0 & 2 & 0 & 2 \\
\hline $1111010:$ & 22 & 1 & 36 & 11 & 25 \\
\hline $0111010:$ & 0 & 0 & 0 & 0 & 0 \\
\hline 1011010 : & 1 & 0 & 0 & 0 & 0 \\
\hline $1101010:$ & 2 & 0 & 9 & 2 & 7 \\
\hline $0101010:$ & 0 & 0 & 0 & 0 & 0 \\
\hline $1111100:$ & 64 & 10 & 113 & 45 & 68 \\
\hline $01111100:$ & 2 & 0 & 3 & 1 & 2 \\
\hline 1011100 : & 1 & 0 & 4 & 0 & 4 \\
\hline 1101100 : & 15 & 0 & 31 & 9 & 22 \\
\hline $0101100:$ & 1 & 0 & 2 & 1 & 1 \\
\hline 1112000 : & 9 & 0 & 24 & 20 & 4 \\
\hline 1111000 : & 34 & 3 & 76 & 38 & 38 \\
\hline $01111000:$ & 0 & 0 & 1 & 1 & 0 \\
\hline 1011000 : & 1 & 0 & 2 & 0 & 2 \\
\hline $1101000:$ & 8 & 1 & 12 & 4 & 8 \\
\hline $0101000:$ & 1 & 0 & 2 & 0 & 2 \\
\hline 1001000 : & 1 & 0 & 0 & 0 & 0 \\
\hline
\end{tabular}


Table E.12. (contd)

\begin{tabular}{|c|c|c|c|c|c|}
\hline \multirow[b]{2}{*}{ Capture History } & \multicolumn{5}{|c|}{$V_{1}$ by Route (Season Wide) } \\
\hline & JBS & Turbine & Spillway & TSW & non-TSW \\
\hline $11100000:$ & 15 & 1 & 20 & 12 & 8 \\
\hline 0110000 : & 0 & 0 & 0 & 0 & 0 \\
\hline $1100000:$ & 12 & 2 & 39 & 24 & 15 \\
\hline $\begin{array}{lllllll:}0 & 1 & 0 & 0 & 0 & 0 & 0:\end{array}$ & 1 & 0 & 0 & 0 & 0 \\
\hline $10000000:$ & 4 & 1 & 12 & 6 & 6 \\
\hline $\begin{array}{llllllll}0 & 0 & 0 & 0 & 0 & 0 & 0\end{array}$ & 8 & 21 & 33 & 17 & 16 \\
\hline Total & 815 & 99 & 1,555 & 799 & 756 \\
\hline
\end{tabular}

Table E.13. Capture histories at sites at $\mathrm{rkm} 325,309,275,234,161,113$, and 86 for release group $V_{1}$ for juvenile steelhead salmon used in estimating dam passage and BRZ-to-BRZ early spring survival. A "1" denotes detection, "0" denotes nondetection, and "2" denotes detection and censoring due to removal.

\begin{tabular}{|c|c|c|}
\hline \multirow[b]{2}{*}{ Capture History } & \multicolumn{2}{|c|}{$V_{1}$ (Early Spring) } \\
\hline & Dam & BRZ-to-BRZ \\
\hline $1111111:$ & 745 & 746 \\
\hline $0111111118:$ & 1 & 1 \\
\hline $11011111:$ & 2 & 3 \\
\hline 1111011 : & 27 & 27 \\
\hline $1111101:$ & 214 & 215 \\
\hline $011111101:$ & 1 & 1 \\
\hline $1101101:$ & 2 & 2 \\
\hline $1111001:$ & 11 & 11 \\
\hline $0101001:$ & 1 & 1 \\
\hline 1111110 : & 205 & 205 \\
\hline 011111110 : & 1 & 1 \\
\hline 1101110 : & 8 & 8 \\
\hline 1111010 : & 19 & 19 \\
\hline 1101010 : & 1 & 1 \\
\hline $1111100:$ & 68 & 68 \\
\hline 011111100 : & 1 & 1 \\
\hline 1011100 : & 1 & 1 \\
\hline $1101100:$ & 1 & 1 \\
\hline 1112000 : & 31 & 31 \\
\hline $1111000:$ & 58 & 58 \\
\hline 1011000 : & 1 & 1 \\
\hline 1101000 : & 3 & 3 \\
\hline 1110000 : & 31 & 31 \\
\hline 1100000 : & 40 & 40 \\
\hline 1000000 : & 8 & 8 \\
\hline 00000000 : & 47 & 64 \\
\hline Total & 1,528 & 1,548 \\
\hline
\end{tabular}


Table E.14. Capture histories at sites at rkm 325, 309, 275, 234, 161, 113, and 86 for release group $V_{1}$ for juvenile steelhead salmon used in estimating dam passage survival-early spring $30 \%$ spill and $40 \%$ spill survival. A " 1 " denotes detection, " 0 " denotes nondetection, and " 2 " denotes detection and censoring due to removal.

\begin{tabular}{|c|c|c|}
\hline \multirow[b]{2}{*}{ Capture History } & \multicolumn{2}{|c|}{$V_{1}$ (Dam Passage Survival-Early Spring) } \\
\hline & $30 \%$ & $40 \%$ \\
\hline $1111111:$ & 401 & 343 \\
\hline 0111111 : & 1 & 0 \\
\hline $1101111:$ & 1 & 1 \\
\hline $1111011:$ & 24 & 3 \\
\hline $1111101:$ & 130 & 83 \\
\hline 0111101 : & 1 & 0 \\
\hline $1101101:$ & 2 & 0 \\
\hline $1111001:$ & 9 & 1 \\
\hline $0101001:$ & 1 & 0 \\
\hline $1111110:$ & 144 & 57 \\
\hline 0111110 : & 1 & 0 \\
\hline $1101110:$ & 8 & 0 \\
\hline 1111010 : & 15 & 3 \\
\hline $1101010:$ & 1 & 0 \\
\hline $1111100:$ & 54 & 14 \\
\hline 01111100 : & 1 & 0 \\
\hline $1011100:$ & 0 & 1 \\
\hline 1101100 : & 1 & 0 \\
\hline 1112000 : & 15 & 16 \\
\hline 1111000 : & 32 & 25 \\
\hline 1011000 : & 0 & 1 \\
\hline 1101000 : & 3 & 0 \\
\hline $1110000:$ & 17 & 14 \\
\hline $1100000:$ & 23 & 16 \\
\hline $1000000:$ & 4 & 4 \\
\hline $\begin{array}{lllllll:}0 & 0 & 0 & 0 & 0 & 0 & 0:\end{array}$ & 30 & 16 \\
\hline Total & 919 & 598 \\
\hline
\end{tabular}


Table E.15. Capture histories at sites at rkm 325, 309, 275, 234, 161, 113, and 86 for release group $V_{1}$ for juvenile steelhead salmon used in estimating BRZ-to-BRZ survival-early spring $30 \%$ spill and $40 \%$ spill survival. A " 1 " denotes detection, " 0 " denotes nondetection, and " 2 " denotes detection and censoring due to removal.

\begin{tabular}{|c|c|c|}
\hline \multirow{2}{*}{$\begin{array}{l}\text { Capture } \\
\text { History }\end{array}$} & \multicolumn{2}{|c|}{$V_{1}$ (BRZ-to-BRZ Survival-Early Spring) } \\
\hline & $30 \%$ & $40 \%$ \\
\hline $1111111:$ & 397 & 339 \\
\hline 0111111111 : & 1 & \\
\hline $1101111:$ & 2 & 1 \\
\hline $1111011:$ & 24 & 3 \\
\hline $1111101:$ & 128 & 84 \\
\hline $01111101:$ & 1 & \\
\hline $1101101:$ & 2 & \\
\hline $1111001:$ & 10 & 1 \\
\hline 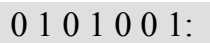 & 1 & \\
\hline 1111110 : & 142 & 58 \\
\hline $0111110:$ & 1 & \\
\hline 1101110 : & 8 & \\
\hline 1111010 : & 14 & 4 \\
\hline $1101010:$ & 1 & \\
\hline 1111100 : & 51 & 15 \\
\hline $01111100:$ & 1 & \\
\hline $1011100:$ & & 1 \\
\hline 11011100 : & 1 & \\
\hline $1112000:$ & 15 & 16 \\
\hline $1111000:$ & 31 & 26 \\
\hline $1011000:$ & & 1 \\
\hline $1101000:$ & 3 & \\
\hline 1110000 : & 18 & 13 \\
\hline $11000000:$ & 23 & 16 \\
\hline $1000000:$ & 4 & 4 \\
\hline $000000000:$ & 41 & 21 \\
\hline Total & 920 & 603 \\
\hline
\end{tabular}


Table E.16. Capture histories at sites at rkm 309, 275, 234, 161, 113, and 86 for release groups $R_{2}$ and $R_{3}$ for juvenile steelhead salmon used in estimating all dam passage survival-early spring. A " 1 " denotes detection, " 0 " denotes nondetection, and " 2 " denotes detection and censoring due to removal.

\begin{tabular}{|c|c|c|}
\hline \multirow[b]{2}{*}{ Capture History } & \multicolumn{2}{|c|}{ Reference Release-Early Spring } \\
\hline & $R_{2}$ & $R_{3}$ \\
\hline $111111:$ & 370 & 226 \\
\hline 0111111 : & 0 & 0 \\
\hline 101111 : & 0 & 0 \\
\hline $00011111:$ & 0 & 0 \\
\hline 110111 : & 0 & 0 \\
\hline 010111 : & 0 & 0 \\
\hline 100111 : & 0 & 0 \\
\hline 000111 : & 0 & 0 \\
\hline 111011 : & 15 & 7 \\
\hline $01110011:$ & 0 & 0 \\
\hline 101011 : & 0 & 0 \\
\hline 001011 : & 0 & 0 \\
\hline $110011:$ & 0 & 0 \\
\hline $0100011:$ & 0 & 0 \\
\hline 100011 : & 0 & 0 \\
\hline $0000011:$ & 0 & 0 \\
\hline $111101:$ & 103 & 67 \\
\hline $011101:$ & 0 & 0 \\
\hline $101101:$ & 0 & 0 \\
\hline $001101:$ & 0 & 0 \\
\hline $110101:$ & 0 & 0 \\
\hline $010101:$ & 0 & 0 \\
\hline $100101:$ & 0 & 0 \\
\hline $000101:$ & 0 & 0 \\
\hline $111001:$ & 9 & 3 \\
\hline $0111001:$ & 0 & 0 \\
\hline $101001:$ & 0 & 0 \\
\hline $\begin{array}{llllll:}0 & 0 & 1 & 0 & 0 & 1: \text { : }\end{array}$ & 0 & 0 \\
\hline $1100001:$ & 0 & 0 \\
\hline $\begin{array}{llllll:}0 & 1 & 0 & 0 & 0 & 1:\end{array}$ & 0 & 0 \\
\hline $1000001:$ & 0 & 0 \\
\hline $\begin{array}{llllll:}0 & 0 & 0 & 0 & 0 & 1:\end{array}$ & 0 & 0 \\
\hline 111120 : & 0 & 0 \\
\hline 0111120 : & 0 & 0 \\
\hline 101120 : & 0 & 0 \\
\hline 0011120 : & 0 & 0 \\
\hline 110120 : & 0 & 0 \\
\hline 010120 : & 0 & 0 \\
\hline 100120 : & 0 & 0 \\
\hline $000120:$ & 0 & 0 \\
\hline 1111020 : & 0 & 0 \\
\hline $\begin{array}{llllll:}0 & 1 & 1 & 0 & 2 & 0:\end{array}$ & 0 & 0 \\
\hline
\end{tabular}


Table E.16. (contd)

\begin{tabular}{|c|c|c|}
\hline \multirow[b]{2}{*}{ Capture History } & \multicolumn{2}{|c|}{ Reference Release-Early Spring } \\
\hline & $R_{2}$ & $R_{3}$ \\
\hline $101020:$ & 0 & 0 \\
\hline 001020 : & 0 & 0 \\
\hline 110020 : & 0 & 0 \\
\hline 010020 : & 0 & 0 \\
\hline 100020 : & 0 & 0 \\
\hline $0000020:$ & 0 & 0 \\
\hline $111110:$ & 92 & 65 \\
\hline 0111110 : & 0 & 0 \\
\hline 101110 : & 1 & 0 \\
\hline 0011110 : & 0 & 0 \\
\hline 110110 : & 0 & 0 \\
\hline $0101110:$ & 0 & 0 \\
\hline $100110:$ & 0 & 0 \\
\hline 0000110 : & 0 & 0 \\
\hline $111010:$ & 6 & 5 \\
\hline 0111010 : & 0 & 0 \\
\hline 101010 : & 0 & 0 \\
\hline 001010 : & 0 & 0 \\
\hline $110010:$ & 0 & 0 \\
\hline 010010 : & 0 & 0 \\
\hline $100010:$ & 0 & 0 \\
\hline $0000010:$ & 0 & 0 \\
\hline $111200:$ & 0 & 0 \\
\hline 0111200 : & 0 & 0 \\
\hline 101200 : & 0 & 0 \\
\hline 001200 : & 0 & 0 \\
\hline $110200:$ & 0 & 0 \\
\hline 010200 : & 0 & 0 \\
\hline 100200 : & 0 & 0 \\
\hline $\begin{array}{llllll:}0 & 0 & 0 & 2 & 0 & 0:\end{array}$ & 0 & 0 \\
\hline $111100:$ & 35 & 19 \\
\hline 0111100 : & 0 & 0 \\
\hline 101100 : & 0 & 0 \\
\hline $\begin{array}{llllll:}0 & 0 & 1 & 1 & 0 & 0:\end{array}$ & 0 & 0 \\
\hline $110100:$ & 0 & 0 \\
\hline $\begin{array}{llllll:}0 & 1 & 0 & 1 & 0 & 0\end{array}$ & 0 & 0 \\
\hline $100100:$ & 0 & 0 \\
\hline $\begin{array}{llllll:}0 & 0 & 0 & 1 & 0 & 0\end{array}$ & 0 & 0 \\
\hline 112000 : & 0 & 0 \\
\hline 012000 : & 0 & 0 \\
\hline 102000 : & 0 & 0 \\
\hline 0022000 : & 0 & 0 \\
\hline 111000 : & 42 & 20 \\
\hline 0111000 : & 0 & 0 \\
\hline $101000:$ & 0 & 0 \\
\hline $\begin{array}{llllll:}0 & 0 & 1 & 0 & 0 & 0:\end{array}$ & 0 & 0 \\
\hline
\end{tabular}


Table E.16. (contd)

\begin{tabular}{|c|c|c|}
\hline \multirow[b]{2}{*}{ Capture History } & \multicolumn{2}{|c|}{ Reference Release-Early Spring } \\
\hline & $R_{2}$ & $R_{3}$ \\
\hline $1200000:$ & 0 & 0 \\
\hline $0200000:$ & 0 & 0 \\
\hline $110000:$ & 10 & 11 \\
\hline $\begin{array}{llllllll}0 & 1 & 0 & 0 & 0 & 0:\end{array}$ & 0 & 0 \\
\hline $2000000:$ & 0 & 0 \\
\hline $1000000:$ & 16 & 21 \\
\hline $\begin{array}{lllllll}0 & 0 & 0 & 0 & 0 & 0:\end{array}$ & 16 & 3 \\
\hline Total & 715 & 447 \\
\hline
\end{tabular}




\section{Appendix F}

\section{Detection and Survival Probabilities}




\section{F.1 Detection and Survival of Yearling Chinook Salmon}

\section{F.1.1 Dam Passage (Season-Wide)}

Table F.1. John Day Dam passage virtual release detection and survival probabilities for yearling Chinook salmon.

Dam Survival:

\begin{tabular}{|l|c|c|}
\hline & Estimate & s.e. $\dagger$ \\
\hline Dam Survival: & 0.9676 & 0.007114 \\
\hline
\end{tabular}

Survival Summary:

\begin{tabular}{|l|c|c|}
\hline & Estimate & s.e. $\dagger$ \\
\hline V1 & 0.9620 & 0.003917 \\
\hline R2 & 0.9816 & 0.004357 \\
\hline R3 & 0.9874 & 0.004683 \\
\hline
\end{tabular}

Survival Detail for Fitted Model:

\begin{tabular}{|c|c|c|c|c|c|c|c|c|c|c|c|c|c|c|}
\hline & \multicolumn{2}{|c|}{ CR349.0 to CR325.0 } & \multicolumn{2}{|c|}{ CR325.0 to CR309.0 } & \multicolumn{2}{|c|}{ Release to CR309.0 } & \multicolumn{2}{|c|}{ CR309.0 to CR275.0 } & \multicolumn{2}{|c|}{ CR275.0 to CR234.0 } & \multicolumn{2}{|c|}{ CR234.0 to CR161.0 } & \multicolumn{2}{|c|}{ CR161.0 to CR113.0 } \\
\hline & Estimate & s.e. $\dagger$ & Estimate & s.e.* & Estimate & s.e. $\dagger$ & Estimate & s.e.* & Estimate & s.e.* & Estimate & s.e.* & Estimate & s.e.* \\
\hline R1_CR390 11U & 0.9620 & 0.003917 & 0.9924 & 0.001882 & --- & --- & 0.9635 & 0.003947 & 0.9953 & 0.001593 & 0.9547 & 0.005397 & 0.9581 & 0.009369 \\
\hline R2_CR346 11U & --- & --- & --- & --- & 0.9816 & 0.004357 & 0.9538 & 0.006230 & 0.9947 & 0.002434 & 0.9518 & 0.007951 & 0.9515 & 0.013264 \\
\hline R3_CR325 11U & --- & --- & --- & --- & 0.9874 & 0.004683 & 0.9525 & 0.007725 & 0.9919 & 0.003578 & 0.9464 & 0.009450 & 0.9799 & 0.015464 \\
\hline
\end{tabular}

Capture Detail for Fitted Model:

\begin{tabular}{|l|c|c|c|c|c|c|c|c|c|c|c|c|c|c|}
\hline & \multicolumn{2}{|c|}{ CR325.0 } & \multicolumn{2}{c|}{ CR309.0 } & \multicolumn{2}{c|}{ CR275.0 } & \multicolumn{3}{c|}{ CR234.0 } & \multicolumn{2}{c|}{ CR161.0 } & \multicolumn{2}{c|}{ CR086.2 Survival* } \\
Capture
\end{tabular}

Notes:

* Standard error is based on only the inverse Hessian.

$\dagger$ Standard error is based on bootstrapping. 


\section{F.1.2 BRZ-to-BRZ (Season-Wide)}

Table F.2. Forebay virtual release detection and survival probabilities for yearling Chinook salmon.

Dam Survival:

\begin{tabular}{|l|c|c|}
\hline & Estimate & s.e. $\dagger$ \\
\hline Dam Survival: & 0.9646 & 0.007215 \\
\hline
\end{tabular}

\section{Survival Summary:}

\begin{tabular}{|l|c|c|}
\hline & Estimate & s.e. $\dagger$ \\
\hline V1 & 0.9589 & 0.004113 \\
\hline R2 & 0.9816 & 0.004632 \\
\hline R3 & 0.9874 & 0.005075 \\
\hline
\end{tabular}

Survival Detail for Fitted Model:

\begin{tabular}{|c|c|c|c|c|c|c|c|c|c|c|c|c|c|c|}
\hline & \multicolumn{2}{|c|}{ CR351.0 to CR325.0 } & \multicolumn{2}{|c|}{ CR325.0 to CR309.0 } & \multicolumn{2}{|c|}{ Release to CR309.0 } & \multicolumn{2}{|c|}{ CR309.0 to CR275.0 } & \multicolumn{2}{|c|}{ CR275.0 to CR234.0 } & \multicolumn{2}{|c|}{ CR234.0 to CR161.0 } & \multicolumn{2}{|c|}{ CR161.0 to CR113.0 } \\
\hline & Estimate & s.e. $\dagger$ & Estimate & s.e.* & Estimate & s.e. $\dagger$ & Estimate & s.e.* & Estimate & s.e.* & Estimate & s.e.* & Estimate & s.e.* \\
\hline R1_CR390 11U & 0.9589 & 0.004113 & 0.9924 & 0.001881 & --- & --- & 0.9635 & 0.003946 & 0.9953 & 0.001591 & 0.9547 & 0.005394 & 0.9586 & 0.009346 \\
\hline R2_CR346 11U & --- & --- & --- & --- & 6 & 0.004632 & 0.9538 & 0.006230 & 0.9947 & 0.002434 & 0.9518 & 0.007951 & 0.9515 & 0.013264 \\
\hline R3_CR325 11U & --- & --- & --- & --- & 0.9874 & 0.005075 & 0.9525 & 0.007725 & 0.9919 & 0.003578 & 0.9464 & 0.009450 & 0.9799 & 0.015464 \\
\hline
\end{tabular}

Capture Detail for Fitted Model:

\begin{tabular}{|c|c|c|c|c|c|c|c|c|c|c|c|c|c|c|}
\hline & \multicolumn{2}{|c|}{ CR325.0 } & \multicolumn{2}{|c|}{ CR309.0 } & \multicolumn{2}{|c|}{ CR275.0 } & \multicolumn{2}{|c|}{ CR234.0 } & \multicolumn{2}{|c|}{ CR161.0 } & \multicolumn{2}{|c|}{ CR113.0 } & \multicolumn{2}{|c|}{$\begin{array}{c}\text { CR086.2 } \\
\text { Survival*Capture }\end{array}$} \\
\hline & Estimate & s.e.* & Estimate & s.e.* & Estimate & s.e.* & Estimate & s.e.* & Estimate & s.e.* & Estimate & s.e.* & Estimate & s.e.* \\
\hline $\begin{array}{l}\text { R1_CR390 } \\
11 \bar{U}\end{array}$ & 0.9841 & 0.002591 & 0.9911 & 0.001985 & 0.9265 & 0.005523 & 1.0000 & 0.000000 & 0.8567 & 0.008145 & 0.7577 & 0.011370 & 0.7146 & 0.011641 \\
\hline $\begin{array}{l}\mathrm{R} 2_{11 \mathrm{U}} \mathrm{CR} 346 \\
\end{array}$ & --- & --- & 0.9964 & 0.001794 & 0.9015 & 0.008955 & 1.0000 & 0.000000 & 0.8380 & 0.012070 & 0.7569 & 0.015942 & 0.7249 & 0.016244 \\
\hline $\begin{array}{l}\text { R3_CR325 } \\
11 \bar{U}\end{array}$ & --- & --- & 0.9907 & 0.003516 & 0.9098 & 0.010507 & 1.0000 & 0.000000 & 0.8623 & 0.013633 & 0.7684 & 0.019355 & 0.6902 & 0.020114 \\
\hline
\end{tabular}

Notes:

* Standard error is based on only the inverse Hessian.

$\uparrow$ Standard error is based on bootstrapping. 


\section{F.1.3 Dam Passage Daytime and Nighttime (Season-Wide)}

Table F.3. John Day Dam daytime virtual release detection and survival probabilities for yearling Chinook salmon.

Dam Survival:

\begin{tabular}{|l|c|c|}
\hline & Estimate & s.e. $\dagger$ \\
\hline Dam Survival: & 0.9648 & 0.007861 \\
\hline
\end{tabular}

\section{Survival Summary:}

\begin{tabular}{|l|c|c|}
\hline & Estimate & s.e. $\uparrow$ \\
\hline V1 & 0.9592 & 0.005184 \\
\hline R2 & 0.9816 & 0.004238 \\
\hline R3 & 0.9874 & 0.004349 \\
\hline
\end{tabular}

Survival Detail for Fitted Model:

\begin{tabular}{|c|c|c|c|c|c|c|c|c|c|c|c|c|c|c|}
\hline & \multicolumn{2}{|c|}{ CR349.0 to CR325.0 } & \multicolumn{2}{|c|}{ CR325.0 to CR309.0 } & \multicolumn{2}{|c|}{ Release to CR309.0 } & \multicolumn{2}{|c|}{ CR309.0 to CR275.0 } & \multicolumn{2}{|c|}{ CR275.0 to CR234.0 } & \multicolumn{2}{|c|}{ CR234.0 to CR161.0 } & \multicolumn{2}{|c|}{ CR161.0 to CR113.0 } \\
\hline & Estimate & s.e. $\dagger$ & Estimate & s.e.* & Estimate & s.e. $\dagger$ & Estimate & s.e.* & Estimate & s.e.* & Estimate & s.e.* & Estimate & s.e.* \\
\hline R1_CR390 11U & 0.9592 & 0.005184 & 0.9926 & 0.002367 & --- & --- & 0.9622 & 0.005164 & 0.9942 & 0.002235 & 0.9572 & 0.006707 & 0.9637 & 0.011442 \\
\hline R2_CR346 11U & --- & --- & --- & --- & 0.9 & 0.004 & 0.9538 & 0.006230 & 0.9947 & 0.002434 & 0.9518 & 0.007951 & 0.9515 & 0.013264 \\
\hline R3_CR325 11U & --- & --- & --- & --- & 0.9874 & 0.004349 & 0.9525 & 0.007725 & 0.9919 & 0.003578 & 0.9464 & 0.009450 & 0.9799 & 0.015464 \\
\hline
\end{tabular}

Capture Detail for Fitted Model:

\begin{tabular}{|c|c|c|c|c|c|c|c|c|c|c|c|c|c|c|}
\hline & \multicolumn{2}{|c|}{ CR325.0 } & \multicolumn{2}{|c|}{ CR309.0 } & \multicolumn{2}{|c|}{ CR275.0 } & \multicolumn{2}{|c|}{ CR234.0 } & \multicolumn{2}{|c|}{ CR161.0 } & \multicolumn{2}{|c|}{ CR113.0 } & \multicolumn{2}{|c|}{$\begin{array}{c}\text { CR086.2 } \\
\text { Survival*Capture }\end{array}$} \\
\hline & Estimate & s.e.* & Estimate & s.e.* & Estimate & s.e.* & Estimate & s.e.* & Estimate & s.e.* & Estimate & s.e.* & Estimate & s.e.* \\
\hline $\begin{array}{l}\text { R1_CR390 } \\
11 \bar{U}\end{array}$ & 0.9865 & 0.003081 & 0.9941 & 0.002087 & 0.9337 & 0.006788 & 1.0000 & 0.000000 & 0.8604 & 0.010332 & 0.7568 & 0.014430 & 0.7353 & 0.014630 \\
\hline $\begin{array}{l}\mathrm{R} 2_{11 \mathrm{U}} \mathrm{CR} 346 \\
\end{array}$ & --- & --- & 0.9964 & 0.001794 & 0.9015 & 0.008955 & 1.0000 & 0.000000 & 0.8380 & 0.012070 & 0.7569 & 0.015942 & 0.7249 & 0.016244 \\
\hline $\begin{array}{l}\text { R3_CR325 } \\
11 \bar{U}\end{array}$ & --- & --- & 0.9907 & 0.003516 & 0.9098 & 0.010507 & 1.0000 & 0.000000 & 0.8623 & 0.013633 & 0.7684 & 0.019355 & 0.6902 & 0.020114 \\
\hline
\end{tabular}

Notes:

* Standard error is based on only the inverse Hessian.

$\uparrow$ Standard error is based on bootstrapping. 
Table F.4. John Day Dam nighttime virtual release detection and survival probabilities for yearling Chinook salmon.

\section{Dam Survival:}

\begin{tabular}{|l|c|c|}
\hline & Estimate & s.e. $\dagger$ \\
\hline Dam Survival: & 0.9720 & 0.008380 \\
\hline
\end{tabular}

\section{Survival Summary:}

\begin{tabular}{|l|c|c|}
\hline & Estimate & s.e. $\dagger$ \\
\hline V1 & 0.9663 & 0.005877 \\
\hline R2 & 0.9816 & 0.004391 \\
\hline R3 & 0.9874 & 0.004687 \\
\hline
\end{tabular}

\section{Survival Detail for Fitted Model:}

\begin{tabular}{|c|c|c|c|c|c|c|c|c|c|c|c|c|c|c|}
\hline & \multicolumn{2}{|c|}{ CR349.0 to CR325.0 } & \multicolumn{2}{|c|}{ CR325.0 to CR309.0 } & \multicolumn{2}{|c|}{ Release to CR309.0 } & \multicolumn{2}{|c|}{ CR309.0 to CR275.0 } & \multicolumn{2}{|c|}{ CR275.0 to CR234.0 } & \multicolumn{2}{|c|}{ CR234.0 to CR161.0 } & \multicolumn{2}{|c|}{ CR161.0 to CR113.0 } \\
\hline & Estimate & s.e. $\dagger$ & Estimate & s.e.* & Estimate & s.e. $\dagger$ & Estimate & s.e.* & Estimate & s.e.* & Estimate & s.e.* & Estimate & s.e.* \\
\hline R1_CR390 11U & 0.9663 & 0.005877 & 0.9919 & 0.003090 & --- & --- & 0.9656 & 0.006107 & 0.9969 & 0.002119 & 0.9512 & 0.009005 & 0.9495 & 0.016013 \\
\hline R2_CR346 11U & --- & --- & --- & --- & 0.9816 & 0.004391 & 0.9538 & 0.006230 & 0.9947 & 0.002434 & 0.9518 & 0.007951 & 0.9515 & 0.013264 \\
\hline R3_CR325 11U & --- & --- & --- & --- & 0.9874 & 0.004687 & 0.9525 & 0.007725 & 0.9919 & 0.003578 & 0.9464 & 0.009450 & 0.9799 & 0.015464 \\
\hline
\end{tabular}

\section{Capture Detail for Fitted Model:}

\begin{tabular}{|c|c|c|c|c|c|c|c|c|c|c|c|c|c|c|}
\hline & \multicolumn{2}{|c|}{ CR325.0 } & \multicolumn{2}{|c|}{ CR309.0 } & \multicolumn{2}{|c|}{ CR275.0 } & \multicolumn{2}{|c|}{ CR234.0 } & \multicolumn{2}{|c|}{ CR161.0 } & \multicolumn{2}{|c|}{ CR113.0 } & \multicolumn{2}{|c|}{$\begin{array}{c}\text { CR086.2 } \\
\text { Survival*Capture }\end{array}$} \\
\hline & Estimate & s.e.* & Estimate & s.e.* & Estimate & s.e.* & Estimate & s.e.* & Estimate & s.e.* & Estimate & s.e.* & Estimate & s.e.* \\
\hline $\begin{array}{l}\text { R1_CR390 } \\
11 \bar{U}\end{array}$ & 0.9805 & 0.004552 & 0.9865 & 0.003861 & 0.9144 & 0.009388 & 1.0000 & 0.000000 & 0.8520 & 0.013207 & 0.7584 & 0.018523 & 0.6819 & 0.019113 \\
\hline $\begin{array}{l}\text { R2_CR346 } \\
11 \bar{U}\end{array}$ & --- & --- & 0.9964 & 0.001794 & 0.9015 & 0.008955 & 1.0000 & 0.000000 & 0.8380 & 0.012070 & 0.7569 & 0.015942 & 0.7249 & 0.016244 \\
\hline $\begin{array}{l}\text { R3_CR325 } \\
11 \bar{U}\end{array}$ & --- & --- & 0.9907 & 0.003516 & 0.9098 & 0.010507 & 1.0000 & 0.000000 & 0.8623 & 0.013633 & 0.7684 & 0.019355 & 0.6902 & 0.020114 \\
\hline
\end{tabular}

\section{Notes:}

* Standard error is based on only the inverse Hessian.

$\dagger$ Standard error is based on bootstrapping. 


\section{F.1.4 Dam Passage - by Route (Season-Wide)}

Table F.5. John Day Dam JBS virtual release detection and survival probabilities for yearling Chinook salmon.

Dam Survival:

\begin{tabular}{|l|c|c|}
\hline & Estimate & s.e. $\dagger$ \\
\hline Dam Survival: & 0.9934 & 0.007694 \\
\hline
\end{tabular}

\section{Survival Summary:}

\begin{tabular}{|l|c|c|}
\hline & Estimate & s.e. $\dagger$ \\
\hline V1 & 0.9876 & 0.004706 \\
\hline R2 & 0.9816 & 0.004343 \\
\hline R3 & 0.9874 & 0.004612 \\
\hline
\end{tabular}

Survival Detail for Fitted Model:

\begin{tabular}{|c|c|c|c|c|c|c|c|c|c|c|c|c|c|c|}
\hline & \multicolumn{2}{|c|}{ CR349.0 to CR325.0 } & \multicolumn{2}{|c|}{ CR325.0 to CR309.0 } & \multicolumn{2}{|c|}{ Release to CR309.0 } & \multicolumn{2}{|c|}{ CR309.0 to CR275.0 } & \multicolumn{2}{|c|}{ CR275.0 to CR234.0 } & \multicolumn{2}{|c|}{ CR234.0 to CR161.0 } & \multicolumn{2}{|c|}{ CR161.0 to CR113.0 } \\
\hline & Estimate & s.e. $\dagger$ & Estimate & s.e.* & Estimate & s.e. $\dagger$ & Estimate & s.e.* & Estimate & s.e.* & Estimate & s.e.* & Estimate & s.e.* \\
\hline R1_CR390 11U & 0.9876 & 0.004706 & 0.9921 & 0.003804 & --- & --- & 0.9664 & 0.007573 & 0.9949 & 0.003260 & 0.9536 & 0.011331 & 0.9640 & 0.020073 \\
\hline R2_CR346 11U & --- & --- & --- & --- & 0.9816 & 0.004343 & 0.9538 & 0.006230 & 0.9947 & 0.002434 & 0.9518 & 0.007951 & 0.9515 & 0.013264 \\
\hline R3_CR325 11U & --- & --- & --- & --- & 0.9874 & 0.004612 & 0.9525 & 0.007725 & 0.9919 & 0.003578 & 0.9464 & 0.009450 & 0.9799 & 0.015464 \\
\hline
\end{tabular}

Capture Detail for Fitted Model:

\begin{tabular}{|c|c|c|c|c|c|c|c|c|c|c|c|c|c|c|}
\hline & \multicolumn{2}{|c|}{ CR325.0 } & \multicolumn{2}{|c|}{ CR309.0 } & \multicolumn{2}{|c|}{ CR275.0 } & \multicolumn{2}{|c|}{ CR234.0 } & \multicolumn{2}{|c|}{ CR161.0 } & \multicolumn{2}{|c|}{ CR113.0 } & \multicolumn{2}{|c|}{$\begin{array}{c}\text { CR086.2 } \\
\text { Survival*Capture }\end{array}$} \\
\hline & Estimate & s.e.* & Estimate & s.e.* & Estimate & s.e.* & Estimate & s.e.* & Estimate & s.e.* & Estimate & s.e.* & Estimate & s.e.* \\
\hline $\begin{array}{l}\text { R1_CR390 } \\
11 \bar{U}\end{array}$ & 0.9915 & 0.003800 & 0.9912 & 0.003933 & 0.9361 & 0.010311 & 1.0000 & 0.000000 & 0.8272 & 0.017571 & 0.7371 & 0.023529 & 0.6955 & 0.023897 \\
\hline $\begin{array}{l}\mathrm{R} 2_{11 \mathrm{U}} \mathrm{CR} 346 \\
\end{array}$ & --- & --- & 0.9964 & 0.001794 & 0.9015 & 0.008955 & 1.0000 & 0.000000 & 0.8380 & 0.012070 & 0.7569 & 0.015942 & 0.7249 & 0.016244 \\
\hline $\begin{array}{l}\text { R3_CR325 } \\
11 \bar{U}\end{array}$ & --- & --- & 0.9907 & 0.003516 & 0.9098 & 0.010507 & 1.0000 & 0.000000 & 0.8623 & 0.013633 & 0.7684 & 0.019355 & 0.6902 & 0.020114 \\
\hline
\end{tabular}

Notes:

* Standard error is based on only the inverse Hessian.

$\dagger$ Standard error is based on bootstrapping. 
Table F.6. John Day Dam TSW virtual release detection and survival probabilities for yearling Chinook salmon.

\section{Dam Survival:}

\begin{tabular}{|l|c|c|}
\hline & Estimate & s.e. $\dagger$ \\
\hline Dam Survival: & 0.9578 & 0.010672 \\
\hline
\end{tabular}

\section{Survival Summary:}

\begin{tabular}{|l|c|c|}
\hline & Estimate & s.e. $\dagger$ \\
\hline V1 & 0.9522 & 0.008881 \\
\hline R2 & 0.9816 & 0.004459 \\
\hline R3 & 0.9874 & 0.004832 \\
\hline
\end{tabular}

\section{Survival Detail for Fitted Model:}

\begin{tabular}{|c|c|c|c|c|c|c|c|c|c|c|c|c|c|c|}
\hline & \multicolumn{2}{|c|}{ CR349.0 to CR325.0 } & \multicolumn{2}{|c|}{ CR325.0 to CR309.0 } & \multicolumn{2}{|c|}{ Release to CR309.0 } & \multicolumn{2}{|c|}{ CR309.0 to CR275.0 } & \multicolumn{2}{|c|}{ CR275.0 to CR234.0 } & \multicolumn{2}{|c|}{ CR234.0 to CR161.0 } & \multicolumn{2}{|c|}{ CR161.0 to CR113.0 } \\
\hline & Estimate & s.e. $\dagger$ & Estimate & s.e.* & Estimate & s.e. $\dagger$ & Estimate & s.e.* & Estimate & s.e.* & Estimate & s.e.* & Estimate & s.e.* \\
\hline R1_CR390 11U & 0.9522 & 0.008881 & 0.9951 & 0.003138 & --- & --- & 0.9643 & 0.008003 & 0.9947 & 0.003387 & 0.9581 & 0.009935 & 0.9751 & 0.016404 \\
\hline R2_CR346 11U & --- & --- & --- & --- & 0.9816 & 0.004459 & 0.9538 & 0.006230 & 0.9947 & 0.002434 & 0.9518 & 0.007951 & 0.9515 & 0.013264 \\
\hline R3_CR325 11U & --- & --- & --- & --- & 0.9874 & 0.004832 & 0.9525 & 0.007725 & 0.9919 & 0.003578 & 0.9464 & 0.009450 & 0.9799 & 0.015464 \\
\hline
\end{tabular}

\section{Capture Detail for Fitted Model:}

\begin{tabular}{|c|c|c|c|c|c|c|c|c|c|c|c|c|c|c|}
\hline & \multicolumn{2}{|c|}{ CR325.0 } & \multicolumn{2}{|c|}{ CR309.0 } & \multicolumn{2}{|c|}{ CR275.0 } & \multicolumn{2}{|c|}{ CR234.0 } & \multicolumn{2}{|c|}{ CR161.0 } & \multicolumn{2}{|c|}{ CR113.0 } & \multicolumn{2}{|c|}{$\begin{array}{c}\text { CR086.2 } \\
\text { Survival }{ }^{*} \text { Capture }\end{array}$} \\
\hline & Estimate & s.e.* & Estimate & s.e.* & Estimate & s.e.* & Estimate & s.e.* & Estimate & s.e.* & Estimate & s.e.* & Estimate & s.e.* \\
\hline $\begin{array}{l}\text { R1_CR390 } \\
\text { 11U }\end{array}$ & 0.9946 & 0.003135 & 0.9962 & 0.002659 & 0.9602 & 0.008504 & 1.0000 & 0.000000 & 0.8980 & 0.014252 & 0.7624 & 0.022369 & 0.7563 & 0.022481 \\
\hline $\begin{array}{l}\text { R2_CR346 } \\
11 \bar{U}\end{array}$ & --- & --- & 0.9964 & 0.001794 & 0.9015 & 0.008955 & 1.0000 & 0.000000 & 0.8380 & 0.012070 & 0.7569 & 0.015942 & 0.7249 & 0.016244 \\
\hline $\begin{array}{l}\text { R3_CR325 } \\
11 \mathrm{U}\end{array}$ & --- & --- & 0.9907 & 0.003516 & 0.9098 & 0.010507 & 1.0000 & 0.000000 & 0.8623 & 0.013633 & 0.7684 & 0.019355 & 0.6902 & 0.020114 \\
\hline
\end{tabular}

\section{Notes:}

* Standard error is based on only the inverse Hessian.

$\dagger$ Standard error is based on bootstrapping. 
Table F.7. John Day Dam non-TSW virtual release detection and survival probabilities for yearling Chinook salmon.

\section{Dam Survival:}

\begin{tabular}{|l|c|c|}
\hline & Estimate & s.e. $\dagger$ \\
\hline Dam Survival: & 0.9744 & 0.008212 \\
\hline
\end{tabular}

\section{Survival Summary:}

\begin{tabular}{|l|c|c|}
\hline & Estimate & s.e. $\dagger$ \\
\hline V1 & 0.9687 & 0.005622 \\
\hline R2 & 0.9816 & 0.004413 \\
\hline R3 & 0.9874 & 0.004728 \\
\hline
\end{tabular}

\section{Survival Detail for Fitted Model:}

\begin{tabular}{|c|c|c|c|c|c|c|c|c|c|c|c|c|c|c|}
\hline & \multicolumn{2}{|c|}{ CR349.0 to CR325.0 } & \multicolumn{2}{|c|}{ CR325.0 to CR309.0 } & \multicolumn{2}{|c|}{ Release to CR309.0 } & \multicolumn{2}{|c|}{ CR309.0 to CR275.0 } & \multicolumn{2}{|c|}{ CR275.0 to CR234.0 } & \multicolumn{2}{|c|}{ CR234.0 to CR161.0 } & \multicolumn{2}{|c|}{ CR161.0 to CR113.0 } \\
\hline & Estimate & s.e. $\dagger$ & Estimate & s.e.* & Estimate & s.e. $\dagger$ & Estimate & s.e.* & Estimate & s.e.* & Estimate & s.e.* & Estimate & s.e.* \\
\hline R1_CR390 11U & 0.9687 & 0.005622 & 0.9920 & 0.003060 & --- & --- & 0.9621 & 0.006350 & 0.9957 & 0.002469 & 0.9542 & 0.008875 & 0.9396 & 0.016041 \\
\hline R2_CR346 11U & --- & --- & --- & --- & 0.9816 & 0.004413 & 0.9538 & 0.006230 & 0.9947 & 0.002434 & 0.9518 & 0.007951 & 0.9515 & 0.013264 \\
\hline R3_CR325 11U & --- & --- & --- & --- & 0.9874 & 0.004728 & 0.9525 & 0.007725 & 0.9919 & 0.003578 & 0.9464 & 0.009450 & 0.9799 & 0.015464 \\
\hline
\end{tabular}

\section{Capture Detail for Fitted Model:}

\begin{tabular}{|c|c|c|c|c|c|c|c|c|c|c|c|c|c|c|}
\hline & \multicolumn{2}{|c|}{ CR325.0 } & \multicolumn{2}{|c|}{ CR309.0 } & \multicolumn{2}{|c|}{ CR275.0 } & \multicolumn{2}{|c|}{ CR234.0 } & \multicolumn{2}{|c|}{ CR161.0 } & \multicolumn{2}{|c|}{ CR113.0 } & \multicolumn{2}{|c|}{$\begin{array}{c}\text { CR086.2 } \\
\text { Survival*Capture }\end{array}$} \\
\hline & Estimate & s.e.* & Estimate & s.e.* & Estimate & s.e.* & Estimate & s.e.* & Estimate & s.e.* & Estimate & s.e.* & Estimate & s.e.* \\
\hline $\begin{array}{l}\text { R1_CR390 } \\
11 \bar{U}\end{array}$ & 0.9744 & 0.005156 & 0.9889 & 0.003486 & 0.8953 & 0.010216 & 1.0000 & 0.000000 & 0.8530 & 0.013124 & 0.7583 & 0.018389 & 0.6886 & 0.018958 \\
\hline $\begin{array}{l}\mathrm{R2}_{11 \bar{U}} \mathrm{CR} 346 \\
\end{array}$ & --- & --- & 0.9964 & 0.001794 & 0.9015 & 0.008955 & 1.0000 & 0.000000 & 0.8380 & 0.012070 & 0.7569 & 0.015942 & 0.7249 & 0.016244 \\
\hline $\begin{array}{l}\text { R3_CR325 } \\
11 \bar{U}\end{array}$ & --- & --- & 0.9907 & 0.003516 & 0.9098 & 0.010507 & 1.0000 & 0.000000 & 0.8623 & 0.013633 & 0.7684 & 0.019355 & 0.6902 & 0.020114 \\
\hline
\end{tabular}

\section{Notes:}

* Standard error is based on only the inverse Hessian.

$\dagger$ Standard error is based on bootstrapping. 
Table F.8. John Day Dam spillway virtual release detection and survival probabilities for yearling Chinook salmon.

\section{Dam Survival:}

\begin{tabular}{|l|c|c|}
\hline & Estimate & s.e. $\dagger$ \\
\hline Dam Survival: & 0.9683 & 0.007654 \\
\hline
\end{tabular}

\section{Survival Summary:}

\begin{tabular}{|l|c|c|}
\hline & Estimate & s.e. $\dagger$ \\
\hline V1 & 0.9626 & 0.004839 \\
\hline R2 & 0.9816 & 0.004280 \\
\hline R3 & 0.9874 & 0.004519 \\
\hline
\end{tabular}

\section{Survival Detail for Fitted Model:}

\begin{tabular}{|c|c|c|c|c|c|c|c|c|c|c|c|c|c|c|}
\hline & \multicolumn{2}{|c|}{ CR349.0 to CR325.0 } & \multicolumn{2}{|c|}{ CR325.0 to CR309.0 } & \multicolumn{2}{|c|}{ Release to CR309.0 } & \multicolumn{2}{|c|}{ CR309.0 to CR275.0 } & \multicolumn{2}{|c|}{ CR275.0 to CR234.0 } & \multicolumn{2}{|c|}{ CR234.0 to CR161.0 } & \multicolumn{2}{|c|}{ CR161.0 to CR113.0 } \\
\hline & Estimate & s.e. $\dagger$ & Estimate & s.e.* & Estimate & s.e. $\dagger$ & Estimate & s.e.* & Estimate & s.e.* & Estimate & s.e.* & Estimate & s.e.* \\
\hline R1_CR390 11U & 0.9626 & 0.004839 & 0.9931 & 0.002245 & --- & --- & 0.9629 & 0.004973 & 0.9953 & 0.002001 & 0.9550 & 0.006654 & 0.9535 & 0.011727 \\
\hline R2_CR346 11U & --- & --- & --- & --- & 0.9816 & 0.004280 & 0.9538 & 0.006230 & 0.9947 & 0.002434 & 0.9518 & 0.007951 & 0.9515 & 0.013264 \\
\hline R3_CR325 11U & --- & --- & --- & --- & 0.9874 & 0.004519 & 0.9525 & 0.007725 & 0.9919 & 0.003578 & 0.9464 & 0.009450 & 0.9799 & 0.015464 \\
\hline
\end{tabular}

\section{Capture Detail for Fitted Model:}

\begin{tabular}{|c|c|c|c|c|c|c|c|c|c|c|c|c|c|c|}
\hline & \multicolumn{2}{|c|}{ CR325.0 } & \multicolumn{2}{|c|}{ CR309.0 } & \multicolumn{2}{|c|}{ CR275.0 } & \multicolumn{2}{|c|}{ CR234.0 } & \multicolumn{2}{|c|}{ CR161.0 } & \multicolumn{2}{|c|}{ CR113.0 } & \multicolumn{2}{|c|}{$\begin{array}{c}\text { CR086.2 } \\
\text { Survival*Capture }\end{array}$} \\
\hline & Estimate & s.e.* & Estimate & s.e.* & Estimate & s.e.* & Estimate & s.e.* & Estimate & s.e.* & Estimate & s.e.* & Estimate & s.e.* \\
\hline $\begin{array}{l}\text { R1_CR390 } \\
11 \bar{U}\end{array}$ & 0.9819 & 0.003456 & 0.9916 & 0.002406 & 0.9194 & 0.007205 & 1.0000 & 0.000000 & 0.8703 & 0.009780 & 0.7600 & 0.014205 & 0.7135 & 0.014574 \\
\hline $\begin{array}{l}\mathrm{R2}_{11 \bar{U}} \mathrm{CR} 346 \\
\end{array}$ & --- & --- & 0.9964 & 0.001794 & 0.9015 & 0.008955 & 1.0000 & 0.000000 & 0.8380 & 0.012070 & 0.7569 & 0.015942 & 0.7249 & 0.016244 \\
\hline $\begin{array}{l}\text { R3_CR325 } \\
11 \bar{U}\end{array}$ & --- & --- & 0.9907 & 0.003516 & 0.9098 & 0.010507 & 1.0000 & 0.000000 & 0.8623 & 0.013633 & 0.7684 & 0.019355 & 0.6902 & 0.020114 \\
\hline
\end{tabular}

\section{Notes:}

* Standard error is based on only the inverse Hessian.

$\uparrow$ Standard error is based on bootstrapping. 
Table F.9. John Day Dam turbine virtual release detection and survival probabilities for yearling Chinook salmon.

\section{Dam Survival:}

\begin{tabular}{|l|c|c|}
\hline & Estimate & s.e. $\dagger$ \\
\hline Dam Survival: & 0.9100 & 0.018499 \\
\hline
\end{tabular}

\section{Survival Summary:}

\begin{tabular}{|l|c|c|}
\hline & Estimate & s.e. $\dagger$ \\
\hline V1 & 0.9047 & 0.017539 \\
\hline R2 & 0.9816 & 0.004350 \\
\hline R3 & 0.9874 & 0.004588 \\
\hline
\end{tabular}

\section{Survival Detail for Fitted Model:}

\begin{tabular}{|c|c|c|c|c|c|c|c|c|c|c|c|c|c|c|}
\hline & \multicolumn{2}{|c|}{ CR349.0 to CR325.0 } & \multicolumn{2}{|c|}{ CR325.0 to CR309.0 } & \multicolumn{2}{|c|}{ Release to CR309.0 } & \multicolumn{2}{|c|}{ CR309.0 to CR275.0 } & \multicolumn{2}{|c|}{ CR275.0 to CR234.0 } & \multicolumn{2}{|c|}{ CR234.0 to CR161.0 } & \multicolumn{2}{|c|}{ CR161.0 to CR113.0 } \\
\hline & Estimate & s.e. $\dagger$ & Estimate & s.e.* & Estimate & s.e. $\dagger$ & Estimate & s.e.* & Estimate & s.e.* & Estimate & s.e.* & Estimate & s.e.* \\
\hline R1_CR390 11U & 0.9047 & 0.017539 & 0.9886 & 0.006899 & --- & --- & 0.9606 & 0.012454 & 0.9960 & 0.004378 & 0.9553 & 0.015673 & 0.9762 & 0.023426 \\
\hline R2_CR346 11U & --- & --- & --- & --- & 0.9816 & 0.004350 & 0.9538 & 0.006230 & 0.9947 & 0.002434 & 0.9518 & 0.007951 & 0.9515 & 0.013264 \\
\hline R3_CR325 11U & --- & --- & --- & --- & 0.9874 & 0.004588 & 0.9525 & 0.007725 & 0.9919 & 0.003578 & 0.9464 & 0.009450 & 0.9799 & 0.015464 \\
\hline
\end{tabular}

\section{Capture Detail for Fitted Model:}

\begin{tabular}{|c|c|c|c|c|c|c|c|c|c|c|c|c|c|c|}
\hline & \multicolumn{2}{|c|}{ CR325.0 } & \multicolumn{2}{|c|}{ CR309.0 } & \multicolumn{2}{|c|}{ CR275.0 } & \multicolumn{2}{|c|}{ CR234.0 } & \multicolumn{2}{|c|}{ CR161.0 } & \multicolumn{2}{|c|}{ CR113.0 } & \multicolumn{2}{|c|}{$\begin{array}{c}\text { CR086.2 } \\
\text { Survival*Capture }\end{array}$} \\
\hline & Estimate & s.e.* & Estimate & s.e.* & Estimate & s.e.* & Estimate & s.e.* & Estimate & s.e.* & Estimate & s.e.* & Estimate & s.e.* \\
\hline $\begin{array}{l}\text { R1_CR390 } \\
11 \mathrm{U}\end{array}$ & 0.9802 & 0.008786 & 0.9876 & 0.007112 & 0.9419 & 0.015069 & 1.0000 & 0.000000 & 0.8488 & 0.025023 & 0.7866 & 0.031993 & 0.7589 & 0.032816 \\
\hline $\begin{array}{l}\text { R2_CR346 } \\
11 \bar{U}\end{array}$ & --- & --- & 0.9964 & 0.001794 & 0.9015 & 0.008955 & 1.0000 & 0.000000 & 0.8380 & 0.012070 & 0.7569 & 0.015942 & 0.7249 & 0.016244 \\
\hline $\begin{array}{l}\text { R3_CR325 } \\
11 \bar{U}\end{array}$ & --- & --- & 0.9907 & 0.003516 & 0.9098 & 0.010507 & 1.0000 & 0.000000 & 0.8623 & 0.013633 & 0.7684 & 0.019355 & 0.6902 & 0.020114 \\
\hline
\end{tabular}

\section{Notes:}

* Standard error is based on only the inverse Hessian.

$\dagger$ Standard error is based on bootstrapping. 


\section{F.1.5 Dam Passage (Early Spring)}

Table F.10. John Day Dam passage virtual release detection and survival probabilities for yearling Chinook salmon.

Dam Survival:

\begin{tabular}{|l|c|c|}
\hline & Estimate & s.e. $\dagger$ \\
\hline Dam Survival: & 0.9709 & 0.009156 \\
\hline
\end{tabular}

\section{Survival Summary:}

\begin{tabular}{|l|c|c|}
\hline & Estimate & s.e. $\dagger$ \\
\hline V1 & 0.9574 & 0.005126 \\
\hline R2 & 0.9776 & 0.005946 \\
\hline R3 & 0.9914 & 0.005015 \\
\hline
\end{tabular}

Survival Detail for Fitted Model:

\begin{tabular}{|c|c|c|c|c|c|c|c|c|c|c|c|c|c|c|}
\hline & \multicolumn{2}{|c|}{ CR349.0 to CR325.0 } & \multicolumn{2}{|c|}{ CR325.0 to CR309.0 } & \multicolumn{2}{|c|}{ Release to CR309.0 } & \multicolumn{2}{|c|}{ CR309.0 to CR275.0 } & \multicolumn{2}{|c|}{ CR275.0 to CR234.0 } & \multicolumn{2}{|c|}{ CR234.0 to CR161.0 } & \multicolumn{2}{|c|}{ CR161.0 to CR113.0 } \\
\hline & Estimate & s.e. $\dagger$ & Estimate & s.e.* & Estimate & s.e. $\dagger$ & Estimate & s.e.* & Estimate & s.e.* & Estimate & s.e.* & Estimate & s.e.* \\
\hline R1_CR390 11U & 0.9574 & 0.005126 & 0.9911 & 0.002464 & --- & --- & 0.9631 & 0.004907 & 0.9965 & 0.001711 & 0.9576 & 0.005820 & 0.9916 & 0.007195 \\
\hline R2_CR346 11U & --- & --- & --- & --- & 0.9776 & 0.005946 & 0.9476 & 0.008474 & 0.9930 & 0.003382 & 0.9516 & 0.008895 & 0.9912 & 0.009566 \\
\hline R3_CR325 11U & --- & --- & --- & --- & 0.9914 & 0.005015 & 0.9578 & 0.009633 & 0.9864 & 0.005766 & 0.9548 & 0.010786 & 0.9849 & 0.011592 \\
\hline
\end{tabular}

Capture Detail for Fitted Model:

\begin{tabular}{|c|c|c|c|c|c|c|c|c|c|c|c|c|c|c|}
\hline & \multicolumn{2}{|c|}{ CR325.0 } & \multicolumn{2}{|c|}{ CR309.0 } & \multicolumn{2}{|c|}{ CR275.0 } & \multicolumn{2}{|c|}{ CR234.0 } & \multicolumn{2}{|c|}{ CR161.0 } & \multicolumn{2}{|c|}{ CR113.0 } & \multicolumn{2}{|c|}{$\begin{array}{c}\text { CR086.2 } \\
\text { Survival*Capture }\end{array}$} \\
\hline & Estimate & s.e.* & Estimate & s.e.* & Estimate & s.e.* & Estimate & s.e.* & Estimate & s.e.* & Estimate & s.e.* & Estimate & s.e.* \\
\hline $\begin{array}{l}\text { R1_CR390 } \\
11 \bar{U}\end{array}$ & 1.0000 & 0.000000 & 0.9993 & 0.000693 & 0.9909 & 0.002499 & 1.0000 & 0.000000 & 0.8931 & 0.008695 & 0.7690 & 0.012663 & 0.8462 & 0.011374 \\
\hline $\begin{array}{l}\mathrm{R} 2_{11 \mathrm{U}} \mathrm{CR} 346 \\
\end{array}$ & --- & --- & 0.9985 & 0.001507 & 0.9939 & 0.003030 & 1.0000 & 0.000000 & 0.8848 & 0.013045 & 0.7780 & 0.017951 & 0.8689 & 0.015416 \\
\hline $\begin{array}{l}\text { R3_CR325 } \\
11 \bar{U}\end{array}$ & --- & --- & 0.9976 & 0.002350 & 0.9928 & 0.004119 & 1.0000 & 0.000000 & 0.8932 & 0.015760 & 0.8006 & 0.021481 & 0.8796 & 0.018355 \\
\hline
\end{tabular}

Notes:

* Standard error is based on only the inverse Hessian.

$\uparrow$ Standard error is based on bootstrapping. 


\section{F.1.6 BRZ-to-BRZ (Early Spring)}

Table F.11. Forebay virtual release detection and survival probabilities for yearling Chinook salmon.

Dam Survival:

\begin{tabular}{|l|c|c|}
\hline & Estimate & s.e. $\dagger$ \\
\hline Dam Survival: & 0.9698 & 0.0092 \\
\hline
\end{tabular}

\section{Survival Summary:}

\begin{tabular}{|l|c|c|}
\hline & Estimate & s.e.† \\
\hline V1 & 0.9564 & 0.0052 \\
\hline R2 & 0.9776 & 0.0059 \\
\hline R3 & 0.9914 & 0.0050 \\
\hline
\end{tabular}

\section{Survival Detail for Fitted Model:}

\begin{tabular}{|c|c|c|c|c|c|c|c|c|c|c|c|c|c|c|}
\hline & \multicolumn{2}{|c|}{ CR351.0 to CR325.0 } & \multicolumn{2}{|c|}{ CR325.0 to CR309.0 } & \multicolumn{2}{|c|}{ Release to CR309.0 } & \multicolumn{2}{|c|}{ CR309.0 to CR275.0 } & \multicolumn{2}{|c|}{ CR275.0 to CR234.0 } & \multicolumn{2}{|c|}{ CR234.0 to CR161.0 } & \multicolumn{2}{|c|}{ CR161.0 to CR113.0 } \\
\hline & Estimate & s.e. $\dagger$ & Estimate & s.e.* & Estimate & s.e. $\dagger$ & Estimate & s.e.* & Estimate & s.e.* & Estimate & s.e.* & Estimate & s.e.* \\
\hline R1_CR390 11U & 0.9564 & 0.0052 & 0.9911 & 0.0025 & --- & --- & 0.9632 & 0.0049 & 0.9966 & 0.0017 & 0.9578 & 0.0058 & 0.9915 & 0.0072 \\
\hline R2_CR346 11U & --- & --- & --- & --- & 0.9776 & 0.0059 & 0.9476 & 0.0085 & 0.9930 & 0.0034 & 0.9516 & 0.0089 & 0.9912 & 0.0096 \\
\hline R3_CR325 11U & --- & -- & --- & --- & 0.9914 & 0.0050 & 0.9578 & 0.0096 & 0.9864 & 0.0058 & 0.9548 & 0.0108 & 0.9849 & 0.0116 \\
\hline
\end{tabular}

\section{Capture Detail for Fitted Model:}

\begin{tabular}{|c|c|c|c|c|c|c|c|c|c|c|c|c|c|c|}
\hline & \multicolumn{2}{|c|}{ CR325.0 } & \multicolumn{2}{|c|}{ CR309.0 } & \multicolumn{2}{|c|}{ CR275.0 } & \multicolumn{2}{|c|}{ CR234.0 } & \multicolumn{2}{|c|}{ CR161.0 } & \multicolumn{2}{|c|}{ CR113.0 } & \multicolumn{2}{|c|}{ CR086.2 Survival*Capture } \\
\hline & Estimate & s.e.* & Estimate & s.e.* & Estimate & s.e.* & Estimate & s.e.* & Estimate & s.e.* & Estimate & s.e.* & Estimate & s.e.* \\
\hline R1_CR390 11U & 1.0000 & 0.0000 & 0.9993 & 0.0007 & 0.9903 & 0.0026 & 1.0000 & 0.0000 & 0.8926 & 0.0087 & 0.7696 & 0.0126 & 0.8467 & 0.0113 \\
\hline R2_CR346 11U & --- & --- & 0.9985 & 0.0015 & 0.9939 & 0.0030 & 1.0000 & 0.0000 & 0.8848 & 0.0130 & 0.7780 & 0.0180 & 0.8689 & 0.0154 \\
\hline R3_CR325 11U & --- & --- & 0.9976 & 0.0024 & 0.9928 & 0.0041 & 1.0000 & 0.0000 & 0.8932 & 0.0158 & 0.8006 & 0.0215 & 0.8796 & 0.0184 \\
\hline
\end{tabular}

Notes:

* Standard error is based on only the inverse Hessian.

$\uparrow$ Standard error is based on bootstrapping. 


\section{F.1.7 Dam Passage $30 \%$ and 40\% Spill (Early Spring)}

Table F.12. John Day Dam 30\% spill virtual release detection and survival probabilities for yearling Chinook salmon.

Dam Survival:

\begin{tabular}{|l|c|c|}
\hline & Estimate & s.e. $\dagger$ \\
\hline Dam Survival: & 0.9666 & 0.010363 \\
\hline
\end{tabular}

\section{Survival Summary:}

\begin{tabular}{|l|c|c|}
\hline & Estimate & s.e. $\uparrow$ \\
\hline V1 & 0.9532 & 0.006987 \\
\hline R2 & 0.9776 & 0.006149 \\
\hline R3 & 0.9914 & 0.005030 \\
\hline
\end{tabular}

Survival Detail for Fitted Model:

\begin{tabular}{|c|c|c|c|c|c|c|c|c|c|c|c|c|c|c|}
\hline & \multicolumn{2}{|c|}{ CR349.0 to CR325.0 } & \multicolumn{2}{|c|}{ CR325.0 to CR309.0 } & \multicolumn{2}{|c|}{ Release to CR309.0 } & \multicolumn{2}{|c|}{ CR309.0 to CR275.0 } & \multicolumn{2}{|c|}{ CR275.0 to CR234.0 } & \multicolumn{2}{|c|}{ CR234.0 to CR161.0 } & \multicolumn{2}{|c|}{ CR161.0 to CR113.0 } \\
\hline & Estimate & s.e. $\dagger$ & Estimate & s.e.* & Estimate & s.e. $\dagger$ & Estimate & s.e.* & Estimate & s.e.* & Estimate & s.e.* & Estimate & s.e.* \\
\hline R1_CR390 11U & 0.9532 & 0.006987 & 0.9890 & 0.003546 & --- & --- & 0.9628 & 0.006436 & 0.9971 & 0.002081 & 0.9603 & 0.007892 & 0.9945 & 0.012702 \\
\hline R2_CR346 11U & --- & --- & --- & --- & 0.9776 & 0.006149 & 0.9476 & 0.008474 & 0.9930 & 0.003382 & 0.9516 & 0.008895 & 0.9912 & 0.009566 \\
\hline R3_CR325 11U & --- & --- & --- & --- & 0.9914 & 0.005030 & 0.9578 & 0.009633 & 0.9864 & 0.005766 & 0.9548 & 0.010786 & 0.9849 & 0.011592 \\
\hline
\end{tabular}

Capture Detail for Fitted Model:

\begin{tabular}{|c|c|c|c|c|c|c|c|c|c|c|c|c|c|c|}
\hline & \multicolumn{2}{|c|}{ CR325.0 } & \multicolumn{2}{|c|}{ CR309.0 } & \multicolumn{2}{|c|}{ CR275.0 } & \multicolumn{2}{|c|}{ CR234.0 } & \multicolumn{2}{|c|}{ CR161.0 } & \multicolumn{2}{|c|}{ CR113.0 } & \multicolumn{2}{|c|}{$\begin{array}{c}\text { CR086.2 } \\
\text { Survival*Capture }\end{array}$} \\
\hline & Estimate & s.e.* & Estimate & s.e.* & Estimate & s.e.* & Estimate & s.e.* & Estimate & s.e.* & Estimate & s.e.* & Estimate & s.e.* \\
\hline $\begin{array}{l}\text { R1_CR390 } \\
11 \bar{U}\end{array}$ & 1.0000 & 0.000000 & 0.9988 & 0.001184 & 0.9845 & 0.004253 & 1.0000 & 0.000000 & 0.8575 & 0.012999 & 0.7145 & 0.018347 & 0.7874 & 0.017452 \\
\hline $\begin{array}{l}\mathrm{R} 2_{11 \mathrm{U}} \mathrm{CR} 346 \\
\end{array}$ & --- & --- & 0.9985 & 0.001507 & 0.9939 & 0.003030 & 1.0000 & 0.000000 & 0.8848 & 0.013045 & 0.7780 & 0.017951 & 0.8689 & 0.015416 \\
\hline $\begin{array}{l}\text { R3_CR325 } \\
11 \bar{U}\end{array}$ & --- & --- & 0.9976 & 0.002350 & 0.9928 & 0.004119 & 1.0000 & 0.000000 & 0.8932 & 0.015760 & 0.8006 & 0.021481 & 0.8796 & 0.018355 \\
\hline
\end{tabular}

Notes:

* Standard error is based on only the inverse Hessian.

$\uparrow$ Standard error is based on bootstrapping. 
Table F.13. John Day Dam 40\% spill virtual release detection and survival probabilities for yearling Chinook salmon.

\section{Dam Survival:}

\begin{tabular}{|l|c|c|}
\hline & Estimate & s.e. $\dagger$ \\
\hline Dam Survival: & 0.9784 & 0.010753 \\
\hline
\end{tabular}

\section{Survival Summary:}

\begin{tabular}{|l|c|c|}
\hline & Estimate & s.e. $\dagger$ \\
\hline V1 & 0.9649 & 0.007467 \\
\hline R2 & 0.9776 & 0.005974 \\
\hline R3 & 0.9914 & 0.005031 \\
\hline
\end{tabular}

\section{Survival Detail for Fitted Model:}

\begin{tabular}{|c|c|c|c|c|c|c|c|c|c|c|c|c|c|c|}
\hline & \multicolumn{2}{|c|}{ CR349.0 to CR325.0 } & \multicolumn{2}{|c|}{ CR325.0 to CR309.0 } & \multicolumn{2}{|c|}{ Release to CR309.0 } & \multicolumn{2}{|c|}{ CR309.0 to CR275.0 } & \multicolumn{2}{|c|}{ CR275.0 to CR234.0 } & \multicolumn{2}{|c|}{ CR234.0 to CR161.0 } & \multicolumn{2}{|c|}{ CR161.0 to CR113.0 } \\
\hline & Estimate & s.e. $\dagger$ & Estimate & s.e.* & Estimate & s.e. $\dagger$ & Estimate & s.e.* & Estimate & s.e.* & Estimate & s.e.* & Estimate & s.e.* \\
\hline R1_CR390 11U & 0.9649 & 0.007467 & 0.9937 & 0.003346 & --- & --- & 0.9617 & 0.007947 & 0.9954 & 0.003038 & 0.9562 & 0.008954 & 0.9979 & 0.006389 \\
\hline R2_CR346 11U & --- & --- & --- & --- & 0.9776 & 0.005974 & 0.9476 & 0.008474 & 0.9930 & 0.003382 & 0.9516 & 0.008895 & 0.9912 & 0.009566 \\
\hline R3_CR325 11U & --- & --- & --- & --- & 0.9914 & 0.005031 & 0.9578 & 0.009633 & 0.9864 & 0.005766 & 0.9548 & 0.010786 & 0.9849 & 0.011592 \\
\hline
\end{tabular}

\section{Capture Detail for Fitted Model:}

\begin{tabular}{|c|c|c|c|c|c|c|c|c|c|c|c|c|c|c|}
\hline & \multicolumn{2}{|c|}{ CR325.0 } & \multicolumn{2}{|c|}{ CR309.0 } & \multicolumn{2}{|c|}{ CR275.0 } & \multicolumn{2}{|c|}{ CR234.0 } & \multicolumn{2}{|c|}{ CR161.0 } & \multicolumn{2}{|c|}{ CR113.0 } & \multicolumn{2}{|c|}{$\begin{array}{c}\text { CR086.2 } \\
\text { Survival*Capture }\end{array}$} \\
\hline & Estimate & s.e.* & Estimate & s.e.* & Estimate & s.e.* & Estimate & s.e.* & Estimate & s.e.* & Estimate & s.e.* & Estimate & s.e.* \\
\hline $\begin{array}{l}\text { R1_CR390 } \\
11 \bar{U}\end{array}$ & 1.0000 & 0.000000 & 1.0000 & 0.000000 & 1.0000 & 0.000000 & 1.0000 & 0.000000 & 0.9455 & 0.010011 & 0.8347 & 0.016988 & 0.9175 & 0.013213 \\
\hline $\begin{array}{l}\mathrm{R} 2_{11} \mathrm{CR} 346 \\
\mathrm{U}\end{array}$ & --- & --- & 0.9985 & 0.001507 & 0.9939 & 0.003030 & 1.0000 & 0.000000 & 0.8848 & 0.013045 & 0.7780 & 0.017951 & 0.8689 & 0.015416 \\
\hline $\begin{array}{l}\mathrm{R3}_{11 \mathrm{U}} \mathrm{CR} 325 \\
\end{array}$ & --- & --- & 0.9976 & 0.002350 & 0.9928 & 0.004119 & 1.0000 & 0.000000 & 0.8932 & 0.015760 & 0.8006 & 0.021481 & 0.8796 & 0.018355 \\
\hline
\end{tabular}

Notes:

* Standard error is based on only the inverse Hessian.

$\dagger$ Standard error is based on bootstrapping. 


\section{F.1.8 BRZ-to-BRZ $30 \%$ and $40 \%$ Spill (Early Spring)}

Table F.14. John Day Dam 30\% spill virtual release detection and survival probabilities for yearling Chinook salmon.

Dam Survival:

\begin{tabular}{|l|c|c|}
\hline & Estimate & s.e. $\dagger$ \\
\hline Dam Survival: & 0.9661 & 0.0104 \\
\hline
\end{tabular}

\section{Survival Summary:}

\begin{tabular}{|l|c|c|}
\hline & Estimate & s.e. $\dagger$ \\
\hline V1 & 0.9528 & 0.0071 \\
\hline R2 & 0.9776 & 0.0059 \\
\hline R3 & 0.9914 & 0.0050 \\
\hline
\end{tabular}

Survival Detail for Fitted Model:

\begin{tabular}{|c|c|c|c|c|c|c|c|c|c|c|c|c|c|c|}
\hline & \multicolumn{2}{|c|}{ CR351.0 to CR325.0 } & \multicolumn{2}{|c|}{ CR325.0 to CR309.0 } & \multicolumn{2}{|c|}{ Release to CR309.0 } & \multicolumn{2}{|c|}{ CR309.0 to CR275.0 } & \multicolumn{2}{|c|}{ CR275.0 to CR234.0 } & \multicolumn{2}{|c|}{ CR234.0 to CR161.0 } & \multicolumn{2}{|c|}{ CR161.0 to CR113.0 } \\
\hline & Estimate & s.e. $\dagger$ & Estimate & s.e.* & Estimate & s.e. $\dagger$ & Estimate & s.e.* & Estimate & s.e.* & Estimate & s.e.* & Estimate & s.e.* \\
\hline R1_CR390 11U & 0.9528 & 0.0071 & 0.9898 & 0.0035 & --- & --- & 0.9627 & 0.0066 & 0.9971 & 0.0022 & 0.9582 & 0.0081 & 0.9977 & 0.0125 \\
\hline R2_CR346 11U & --- & --- & --- & --- & 0.9776 & 0.0059 & 0.9476 & 0.0085 & 0.9930 & 0.0034 & 0.9516 & 0.0089 & 0.9912 & 0.0096 \\
\hline R3_CR325 11U & --- & --- & --- & --- & 0.9914 & 0.0050 & 0.9578 & 0.0096 & 0.9864 & 0.0058 & 0.9548 & 0.0108 & 0.9849 & 0.0116 \\
\hline
\end{tabular}

\section{Capture Detail for Fitted Model:}

\begin{tabular}{|c|c|c|c|c|c|c|c|c|c|c|c|c|c|c|}
\hline & \multicolumn{2}{|c|}{ CR325.0 } & \multicolumn{2}{|c|}{ CR309.0 } & \multicolumn{2}{|c|}{ CR275.0 } & \multicolumn{2}{|c|}{ CR234.0 } & \multicolumn{2}{|c|}{ CR161.0 } & \multicolumn{2}{|c|}{ CR113.0 } & \multicolumn{2}{|c|}{ CR086.2 Survival*Capture } \\
\hline & Estimate & s.e.* & Estimate & s.e.* & Estimate & s.e.* & Estimate & s.e.* & Estimate & s.e.* & Estimate & s.e.* & Estimate & s.e.* \\
\hline R1_CR390 11U & 1.0000 & 0.0000 & 0.9988 & 0.0012 & 0.9828 & 0.0046 & 1.0000 & 0.0000 & 0.8547 & 0.0133 & 0.7162 & 0.0185 & 0.7941 & 0.0175 \\
\hline R2_CR346 11U & --- & --- & 0.9985 & 0.0015 & 0.9939 & 0.0030 & 1.0000 & 0.0000 & 0.8848 & 0.0130 & 0.7780 & 0.0180 & 0.8689 & 0.0154 \\
\hline R3_CR325 11U & --- & --- & 0.9976 & 0.0024 & 0.9928 & 0.0041 & 1.0000 & 0.0000 & 0.8932 & 0.0158 & 0.8006 & 0.0215 & 0.8796 & 0.0184 \\
\hline
\end{tabular}

Notes:

* Standard error is based on only the inverse Hessian.

$\uparrow$ Standard error is based on bootstrapping. 
Table F.15. John Day Dam 40\% spill virtual release detection and survival probabilities for yearling Chinook salmon.

\section{Dam Survival:}

\begin{tabular}{|l|c|c|}
\hline & Estimate & s.e. $\dagger$ \\
\hline Dam Survival: & 0.9729 & 0.0110 \\
\hline
\end{tabular}

\section{Survival Summary:}

\begin{tabular}{|l|c|c|}
\hline & Estimate & s.e. $\dagger$ \\
\hline V1 & 0.9594 & 0.0079 \\
\hline R2 & 0.9776 & 0.0060 \\
\hline R3 & 0.9914 & 0.0050 \\
\hline
\end{tabular}

\section{Survival Detail for Fitted Model:}

\begin{tabular}{|c|c|c|c|c|c|c|c|c|c|c|c|c|c|c|}
\hline & \multicolumn{2}{|c|}{ CR351.0 to CR325.0 } & \multicolumn{2}{|c|}{ CR325.0 to CR309.0 } & \multicolumn{2}{|c|}{ Release to CR309.0 } & \multicolumn{2}{|c|}{ CR309.0 to CR275.0 } & \multicolumn{2}{|c|}{ CR275.0 to CR234.0 } & \multicolumn{2}{|c|}{ CR234.0 to CR161.0 } & \multicolumn{2}{|c|}{ CR161.0 to CR113.0 } \\
\hline & Estimate & s.e. $\dagger$ & Estimate & s.e.* & Estimate & s.e. $\dagger$ & Estimate & s.e.* & Estimate & s.e.* & Estimate & s.e.* & Estimate & s.e.* \\
\hline R1_CR390 11U & 0.9594 & 0.0079 & 0.9938 & 0.0033 & --- & --- & 0.9607 & 0.0080 & 0.9955 & 0.0030 & 0.9572 & 0.0088 & 0.9954 & 0.0066 \\
\hline R2_CR346 11U & --- & --- & --- & --- & 0.9776 & 0.0060 & 0.9476 & 0.0085 & 0.9930 & 0.0034 & 0.9516 & 0.0089 & 0.9912 & 0.0096 \\
\hline R3_CR325 11U & --- & --- & --- & --- & 0.9914 & 0.0050 & 0.9578 & 0.0096 & 0.9864 & 0.0058 & 0.9548 & 0.0108 & 0.9849 & 0.0116 \\
\hline
\end{tabular}

\section{Capture Detail for Fitted Model:}

\begin{tabular}{|c|c|c|c|c|c|c|c|c|c|c|c|c|c|c|}
\hline & \multicolumn{2}{|c|}{ CR325.0 } & \multicolumn{2}{|c|}{ CR309.0 } & \multicolumn{2}{|c|}{ CR275.0 } & \multicolumn{2}{|c|}{ CR234.0 } & \multicolumn{2}{|c|}{ CR161.0 } & \multicolumn{2}{|c|}{ CR113.0 } & \multicolumn{2}{|c|}{ CR086.2 Survival ${ }^{*}$ Capture } \\
\hline & Estimate & s.e.* & Estimate & s.e.* & Estimate & s.e.* & Estimate & s.e.* & Estimate & s.e.* & Estimate & s.e.* & Estimate & s.e.* \\
\hline R1_CR390 11U & 1.0000 & 0.0000 & 1.0000 & 0.0000 & 1.0000 & 0.0000 & 1.0000 & 0.0000 & 0.9406 & 0.0103 & 0.8433 & 0.0165 & 0.9173 & 0.0131 \\
\hline R2_CR346 11U & --- & --- & 0.9985 & 0.0015 & 0.9939 & 0.0030 & 1.0000 & 0.0000 & 0.8848 & 0.0130 & 0.7780 & 0.0180 & 0.8689 & 0.0154 \\
\hline R3_CR325 11U & --- & --- & 0.9976 & 0.0024 & 0.9928 & 0.0041 & 1.0000 & 0.0000 & 0.8932 & 0.0158 & 0.8006 & 0.0215 & 0.8796 & 0.0184 \\
\hline
\end{tabular}

\section{Notes:}

* Standard error is based on only the inverse Hessian.

$\dagger$ Standard error is based on bootstrapping. 


\section{F.2 Detection and Survival of Juvenile Steelhead}

\section{F.2.1 Dam Passage (Season-Wide)}

Table F.16. John Day Dam passage virtual release detection and survival probabilities for juvenile steelhead.

Dam Survival:

\begin{tabular}{|l|c|c|}
\hline & Estimate & s.e. $\dagger$ \\
\hline Dam Survival: & 0.9867 & 0.006100 \\
\hline
\end{tabular}

Survival Summary:

\begin{tabular}{|l|c|c|}
\hline & Estimate & s.e. $\dagger$ \\
\hline V1 & 0.9757 & 0.003242 \\
\hline R2 & 0.9821 & 0.004404 \\
\hline R3 & 0.9932 & 0.003435 \\
\hline
\end{tabular}

Survival Detail for Fitted Model:

\begin{tabular}{|c|c|c|c|c|c|c|c|c|c|c|c|c|c|c|}
\hline & \multicolumn{2}{|c|}{ CR349.0 to CR325.0 } & \multicolumn{2}{|c|}{ CR325.0 to CR309.0 } & \multicolumn{2}{|c|}{ Release to CR309.0 } & \multicolumn{2}{|c|}{ CR309.0 to CR275.0 } & \multicolumn{2}{|c|}{ CR275.0 to CR234.0 } & \multicolumn{2}{|c|}{ CR234.0 to CR161.0 } & \multicolumn{2}{|c|}{ CR161.0 to CR113.0 } \\
\hline & Estimate & s.e. $\dagger$ & Estimate & s.e.* & Estimate & s.e. $\dagger$ & Estimate & s.e.* & Estimate & s.e.* & Estimate & s.e.* & Estimate & s.e.* \\
\hline R1_CR390 35U & 0.9757 & 0.003242 & 0.9932 & 0.001735 & --- & --- & 0.9799 & 0.003091 & 0.9831 & 0.002882 & 0.9478 & 0.005244 & 0.9693 & 0.010713 \\
\hline R2_CR346 35U & --- & --- & --- & --- & 0.9821 & 0.004404 & 0.9769 & 0.004568 & 0.9895 & 0.003287 & 0.9367 & 0.007966 & 0.9528 & 0.015054 \\
\hline R3_CR325 35U & --- & --- & --- & --- & 0.9932 & 0.003435 & 0.9663 & 0.006766 & 0.9807 & 0.005444 & 0.9495 & 0.009209 & 0.9938 & 0.020761 \\
\hline
\end{tabular}

Capture Detail for Fitted Model:

\begin{tabular}{|c|c|c|c|c|c|c|c|c|c|c|c|c|c|c|}
\hline & \multicolumn{2}{|c|}{ CR325.0 } & \multicolumn{2}{|c|}{ CR309.0 } & \multicolumn{2}{|c|}{ CR275.0 } & \multicolumn{2}{|c|}{ CR234.0 } & \multicolumn{2}{|c|}{ CR161.0 } & \multicolumn{2}{|c|}{ CR113.0 } & \multicolumn{2}{|c|}{$\begin{array}{c}\text { CR086.2 } \\
\text { Survival*Capture }\end{array}$} \\
\hline & $\begin{array}{c}\text { Estim } \\
\text { ate }\end{array}$ & s.e.* & Estimate & s.e.* & Estimate & s.e.* & Estimate & s.e.* & Estimate & s.e.* & Estimate & s.e.* & Estimate & s.e.* \\
\hline R1_CR390 35U & 0.9845 & 0.002525 & 0.9923 & 0.001809 & 0.8822 & 0.006723 & 1.0000 & 0.000000 & 0.9175 & 0.006347 & 0.7446 & 0.012151 & 0.6188 & 0.012339 \\
\hline R2_CR346 35U & --- & --- & 0.9991 & 0.000874 & 0.8772 & 0.009755 & 1.0000 & 0.000000 & 0.9247 & 0.008720 & 0.7457 & 0.017146 & 0.6397 & 0.017510 \\
\hline R3_CR325 35U & --- & --- & 0.9987 & 0.001313 & 0.8596 & 0.012701 & 1.0000 & 0.000000 & 0.9003 & 0.012012 & 0.7275 & 0.022262 & 0.5674 & 0.021879 \\
\hline
\end{tabular}

Notes:

* Standard error is based on only the inverse Hessian.

$\dagger$ Standard error is based on bootstrapping. 


\section{F.2.2 BRZ-to-BRZ (Season-Wide)}

Table F.17. Forebay virtual release detection and survival probabilities for juvenile steelhead.

Dam Survival:

\begin{tabular}{|l|c|c|}
\hline & Estimate & s.e. $\dagger$ \\
\hline Dam Survival: & 0.9801 & 0.006289 \\
\hline
\end{tabular}

\section{Survival Summary:}

\begin{tabular}{|l|c|c|}
\hline & Estimate & s.e. $\dagger$ \\
\hline V1 & 0.9692 & 0.003552 \\
\hline R2 & 0.9821 & 0.004247 \\
\hline R3 & 0.9932 & 0.003381 \\
\hline
\end{tabular}

Survival Detail for Fitted Model:

\begin{tabular}{|c|c|c|c|c|c|c|c|c|c|c|c|c|c|c|}
\hline & \multicolumn{2}{|c|}{ CR351.0 to CR325.0 } & \multicolumn{2}{|c|}{ CR325.0 to CR309.0 } & \multicolumn{2}{|c|}{ Release to CR309.0 } & \multicolumn{2}{|c|}{ CR309.0 to CR275.0 } & \multicolumn{2}{|c|}{ CR275.0 to CR234.0 } & \multicolumn{2}{|c|}{ CR234.0 to CR161.0 } & \multicolumn{2}{|c|}{ CR161.0 to CR113.0 } \\
\hline & Estimate & s.e. $\dagger$ & Estimate & s.e.* & Estimate & s.e. $\dagger$ & Estimate & s.e.* & Estimate & s.e.* & Estimate & s.e.* & Estimate & s.e.* \\
\hline R1_CR390 35U & 0.9692 & 0.003552 & 0.9932 & 0.001732 & --- & --- & 0.9799 & 0.003088 & 0.9831 & 0.002877 & 0.9479 & 0.005237 & 0.9690 & 0.010714 \\
\hline R2_CR346 35U & --- & --- & --- & --- & 0.9821 & 0.004247 & 0.9769 & 0.004568 & 0.9895 & 0.003287 & 0.9367 & 0.007966 & 0.9528 & 0.015054 \\
\hline R3_CR325 35U & --- & --- & --- & --- & 0.9932 & 0.003381 & 0.9663 & 0.006766 & 0.9807 & 0.005444 & 0.9495 & 0.009209 & 0.9938 & 0.020761 \\
\hline
\end{tabular}

Capture Detail for Fitted Model:

\begin{tabular}{|c|c|c|c|c|c|c|c|c|c|c|c|c|c|c|}
\hline & \multicolumn{2}{|c|}{ CR325.0 } & \multicolumn{2}{|c|}{ CR309.0 } & \multicolumn{2}{|c|}{ CR275.0 } & \multicolumn{2}{|c|}{ CR234.0 } & \multicolumn{2}{|c|}{ CR161.0 } & \multicolumn{2}{|c|}{ CR113.0 } & \multicolumn{2}{|c|}{$\begin{array}{c}\text { CR086.2 } \\
\text { Survival*Capture }\end{array}$} \\
\hline & Estimate & s.e.* & Estimate & s.e.* & Estimate & s.e.* & Estimate & s.e.* & Estimate & s.e.* & Estimate & s.e.* & Estimate & s.e.* \\
\hline $\begin{array}{l}\text { R1_CR390 } \\
\text { 35U }\end{array}$ & 0.9845 & 0.002522 & 0.9923 & 0.001807 & 0.8823 & 0.006714 & 1.0000 & 0.000000 & 0.9176 & 0.006341 & 0.7442 & 0.012148 & 0.6191 & 0.012334 \\
\hline $\begin{array}{l}\text { R2_CR346 } \\
35 \bar{U}\end{array}$ & --- & --- & 0.9991 & 0.000874 & 0.8772 & 0.009755 & 1.0000 & 0.000000 & 0.9247 & 0.008720 & 0.7457 & 0.017146 & 0.6397 & 0.017510 \\
\hline $\begin{array}{l}\text { R3_CR325 } \\
\text { 35U }\end{array}$ & --- & --- & 0.9987 & 0.001313 & 0.8596 & 0.012701 & 1.0000 & 0.000000 & 0.9003 & 0.012012 & 0.7275 & 0.022262 & 0.5674 & 0.021879 \\
\hline
\end{tabular}

Notes:

* Standard error is based on only the inverse Hessian.

$\uparrow$ Standard error is based on bootstrapping. 


\section{F.2.3 Dam Passage Daytime and Nighttime (Season-Wide)}

Table F.18. John Day Dam daytime virtual release detection and survival probabilities for juvenile steelhead.

Dam Survival:

\begin{tabular}{|l|c|c|}
\hline & Estimate & s.e. $\dagger$ \\
\hline Dam Survival: & 0.9868 & 0.006760 \\
\hline
\end{tabular}

\section{Survival Summary:}

\begin{tabular}{|l|c|c|}
\hline & Estimate & s.e. $\dagger$ \\
\hline V1 & 0.9758 & 0.004244 \\
\hline R2 & 0.9821 & 0.004147 \\
\hline R3 & 0.9932 & 0.003336 \\
\hline
\end{tabular}

Survival Detail for Fitted Model:

\begin{tabular}{|c|c|c|c|c|c|c|c|c|c|c|c|c|c|c|}
\hline & \multicolumn{2}{|c|}{ CR349.0 to CR325.0 } & \multicolumn{2}{|c|}{ CR325.0 to CR309.0 } & \multicolumn{2}{|c|}{ Release to CR309.0 } & \multicolumn{2}{|c|}{ CR309.0 to CR275.0 } & \multicolumn{2}{|c|}{ CR275.0 to CR234.0 } & \multicolumn{2}{|c|}{ CR234.0 to CR161.0 } & \multicolumn{2}{|c|}{ CR161.0 to CR113.0 } \\
\hline & Estimate & s.e. $\dagger$ & Estimate & s.e.* & Estimate & s.e. $\dagger$ & Estimate & s.e.* & Estimate & s.e.* & Estimate & s.e.* & Estimate & s.e.* \\
\hline R1_CR390 35U & 0.9758 & 0.004244 & 0.9905 & 0.002743 & --- & --- & 0.9738 & 0.004628 & 0.9831 & 0.003867 & 0.9465 & 0.007070 & 0.9567 & 0.013702 \\
\hline R2_CR346 35U & --- & --- & --- & --- & 0.9821 & 0.004147 & 0.9769 & 0.004568 & & 0.003287 & 0.9367 & 0.007966 & 0.9528 & 0.015054 \\
\hline R3_CR325 35U & --- & --- & --- & --- & 0.9932 & 0.003336 & 0.9663 & 0.006766 & 0.9807 & 0.005444 & 0.9495 & 0.009209 & 0.9938 & 0.020761 \\
\hline
\end{tabular}

Capture Detail for Fitted Model:

\begin{tabular}{|c|c|c|c|c|c|c|c|c|c|c|c|c|c|c|}
\hline & \multicolumn{2}{|c|}{ CR325.0 } & \multicolumn{2}{|c|}{ CR309.0 } & \multicolumn{2}{|c|}{ CR275.0 } & \multicolumn{2}{|c|}{ CR234.0 } & \multicolumn{2}{|c|}{ CR161.0 } & \multicolumn{2}{|c|}{ CR113.0 } & \multicolumn{2}{|c|}{$\begin{array}{c}\text { CR086.2 } \\
\text { Survival*Capture }\end{array}$} \\
\hline & Estimate & s.e.* & Estimate & s.e.* & Estimate & s.e.* & Estimate & s.e.* & Estimate & s.e.* & Estimate & s.e.* & Estimate & s.e.* \\
\hline $\begin{array}{l}\text { R1_CR390 } \\
\text { 35U }\end{array}$ & 0.9863 & 0.003207 & 0.9922 & 0.002467 & 0.8966 & 0.008589 & 1.0000 & 0.000000 & 0.9293 & 0.008028 & 0.7555 & 0.015972 & 0.6497 & 0.016444 \\
\hline $\begin{array}{l}\text { R2_CR346 } \\
35 \mathrm{U}\end{array}$ & --- & --- & 0.9991 & 0.000874 & 0.8772 & 0.009755 & 1.0000 & 0.000000 & 0.9247 & 0.008720 & 0.7457 & 0.017146 & 0.6397 & 0.017510 \\
\hline $\begin{array}{l}\text { R3_CR325 } \\
\text { 35U }\end{array}$ & --- & --- & 0.9987 & 0.001313 & 0.8596 & 0.012701 & 1.0000 & 0.000000 & 0.9003 & 0.012012 & 0.7275 & 0.022262 & 0.5674 & 0.021879 \\
\hline
\end{tabular}

Notes:

* Standard error is based on only the inverse Hessian.

$\uparrow$ Standard error is based on bootstrapping. 
Table F.19. John Day Dam nighttime virtual release detection and survival probabilities for juvenile steelhead.

\section{Dam Survival:}

\begin{tabular}{|l|c|c|}
\hline & Estimate & s.e. $\dagger$ \\
\hline Dam Survival: & 0.9866 & 0.007033 \\
\hline
\end{tabular}

\section{Survival Summary:}

\begin{tabular}{|l|c|c|}
\hline & Estimate & s.e. $\dagger$ \\
\hline V1 & 0.9756 & 0.004825 \\
\hline R2 & 0.9821 & 0.004623 \\
\hline R3 & 0.9932 & 0.003503 \\
\hline
\end{tabular}

\section{Survival Detail for Fitted Model:}

\begin{tabular}{|c|c|c|c|c|c|c|c|c|c|c|c|c|c|c|}
\hline & \multicolumn{2}{|c|}{ CR349.0 to CR325.0 } & \multicolumn{2}{|c|}{ CR325.0 to CR309.0 } & \multicolumn{2}{|c|}{ Release to CR309.0 } & \multicolumn{2}{|c|}{ CR309.0 to CR275.0 } & \multicolumn{2}{|c|}{ CR275.0 to CR234.0 } & \multicolumn{2}{|c|}{ CR234.0 to CR161.0 } & \multicolumn{2}{|c|}{ CR161.0 to CR113.0 } \\
\hline & Estimate & s.e. $\dagger$ & Estimate & s.e.* & Estimate & s.e. $\dagger$ & Estimate & s.e.* & Estimate & s.e.* & Estimate & s.e.* & Estimate & s.e.* \\
\hline R1_CR390 35U & 0.9756 & 0.004825 & 0.9965 & 0.001883 & --- & --- & 0.9872 & 0.003890 & 0.9830 & 0.004321 & 0.9494 & 0.007818 & 0.9863 & 0.017141 \\
\hline R2_CR346 35U & --- & --- & --- & --- & 0.9821 & 0.004623 & 0.9769 & 0.004568 & 0.9895 & 0.003287 & 0.9367 & 0.007966 & 0.9528 & 0.015054 \\
\hline R3_CR325 35U & --- & --- & --- & --- & 0.9932 & 0.003503 & 0.9663 & 0.006766 & 0.9807 & 0.005444 & 0.9495 & 0.009209 & 0.9938 & 0.020761 \\
\hline
\end{tabular}

\section{Capture Detail for Fitted Model:}

\begin{tabular}{|c|c|c|c|c|c|c|c|c|c|c|c|c|c|c|}
\hline & \multicolumn{2}{|c|}{ CR325.0 } & \multicolumn{2}{|c|}{ CR309.0 } & \multicolumn{2}{|c|}{ CR275.0 } & \multicolumn{2}{|c|}{ CR234.0 } & \multicolumn{2}{|c|}{ CR161.0 } & \multicolumn{2}{|c|}{ CR113.0 } & \multicolumn{2}{|c|}{$\begin{array}{c}\text { CR086.2 } \\
\text { Survival*Capture }\end{array}$} \\
\hline & Estimate & s.e.* & Estimate & s.e.* & Estimate & s.e.* & Estimate & s.e.* & Estimate & s.e.* & Estimate & s.e.* & Estimate & s.e.* \\
\hline $\begin{array}{l}\text { R1_CR390 } \\
\text { 35U }\end{array}$ & 0.9823 & 0.004015 & 0.9924 & 0.002661 & 0.8648 & 0.010588 & 1.0000 & 0.000000 & 0.9035 & 0.010071 & 0.7305 & 0.018683 & 0.5821 & 0.018542 \\
\hline $\begin{array}{l}\text { R2_CR346 } \\
35 \bar{U}\end{array}$ & --- & --- & 0.9991 & 0.000874 & 0.8772 & 0.009755 & 1.0000 & 0.000000 & 0.9247 & 0.008720 & 0.7457 & 0.017146 & 0.6397 & 0.017510 \\
\hline $\begin{array}{l}\text { R3_CR325 } \\
\text { 35U }\end{array}$ & --- & --- & 0.9987 & 0.001313 & 0.8596 & 0.012701 & 1.0000 & 0.000000 & 0.9003 & 0.012012 & 0.7275 & 0.022262 & 0.5674 & 0.021879 \\
\hline
\end{tabular}

\section{Notes:}

* Standard error is based on only the inverse Hessian.

$\uparrow$ Standard error is based on bootstrapping. 


\section{F.2.4 Dam Passage by Route (Season-Wide)}

Table F.20. John Day Dam JBS virtual release detection and survival probabilities for juvenile steelhead.

Dam Survival:

\begin{tabular}{|l|c|c|}
\hline & Estimate & s.e. $\dagger$ \\
\hline Dam Survival: & 1.0034 & 0.006395 \\
\hline
\end{tabular}

\section{Survival Summary:}

\begin{tabular}{|l|c|c|}
\hline & Estimate & s.e. $\dagger$ \\
\hline V1 & 0.9922 & 0.003520 \\
\hline R2 & 0.9821 & 0.004708 \\
\hline R3 & 0.9932 & 0.003544 \\
\hline
\end{tabular}

Survival Detail for Fitted Model:

\begin{tabular}{|c|c|c|c|c|c|c|c|c|c|c|c|c|c|c|}
\hline & \multicolumn{2}{|c|}{ CR349.0 to CR325.0 } & \multicolumn{2}{|c|}{ CR325.0 to CR309.0 } & \multicolumn{2}{|c|}{ Release to CR309.0 } & \multicolumn{2}{|c|}{ CR309.0 to CR275.0 } & \multicolumn{2}{|c|}{ CR275.0 to CR234.0 } & \multicolumn{2}{|c|}{ CR234.0 to CR161.0 } & \multicolumn{2}{|c|}{ CR161.0 to CR113.0 } \\
\hline & Estimate & s.e. $\dagger$ & Estimate & s.e.* & Estimate & s.e. $\dagger$ & Estimate & s.e.* & Estimate & s.e.* & Estimate & s.e.* & Estimate & s.e.* \\
\hline R1_CR390 35U & 0.9922 & 0.003520 & 0.9953 & 0.002505 & --- & --- & 0.9871 & 0.004583 & 0.9786 & 0.005611 & 0.9538 & 0.008838 & 0.9886 & 0.020421 \\
\hline R2_CR346 35U & --- & --- & --- & --- & 0.9821 & 0.004708 & 0.9769 & 0.004568 & 0.9895 & 0.003287 & 0.9367 & 0.007966 & 0.9528 & 0.015054 \\
\hline R3_CR325 35U & --- & --- & --- & --- & 0.9932 & 0.003544 & 0.9663 & 0.006766 & 0.9807 & 0.005444 & 0.9495 & 0.009209 & 0.9938 & 0.020761 \\
\hline
\end{tabular}

Capture Detail for Fitted Model:

\begin{tabular}{|c|c|c|c|c|c|c|c|c|c|c|c|c|c|c|}
\hline & \multicolumn{2}{|c|}{ CR325.0 } & \multicolumn{2}{|c|}{ CR309.0 } & \multicolumn{2}{|c|}{ CR275.0 } & \multicolumn{2}{|c|}{ CR234.0 } & \multicolumn{2}{|c|}{ CR161.0 } & \multicolumn{2}{|c|}{ CR113.0 } & \multicolumn{2}{|c|}{$\begin{array}{c}\text { CR086.2 } \\
\text { Survival*Capture }\end{array}$} \\
\hline & Estimate & s.e.* & Estimate & s.e.* & Estimate & s.e.* & Estimate & s.e.* & Estimate & s.e.* & Estimate & s.e.* & Estimate & s.e.* \\
\hline $\begin{array}{l}\text { R1_CR390 } \\
\text { 35U }\end{array}$ & 0.9875 & 0.003914 & 0.9911 & 0.003334 & 0.8619 & 0.012392 & 1.0000 & 0.000000 & 0.9013 & 0.011810 & 0.7358 & 0.021909 & 0.5614 & 0.021542 \\
\hline $\begin{array}{l}\text { R2_CR346 } \\
35 \mathrm{U}\end{array}$ & --- & --- & 0.9991 & 0.000874 & 0.8772 & 0.009755 & 1.0000 & 0.000000 & 0.9247 & 0.008720 & 0.7457 & 0.017146 & 0.6397 & 0.017510 \\
\hline $\begin{array}{l}\text { R3_CR325 } \\
\text { 35U }\end{array}$ & --- & --- & 0.9987 & 0.001313 & 0.8596 & 0.012701 & 1.0000 & 0.000000 & 0.9003 & 0.012012 & 0.7275 & 0.022262 & 0.5674 & 0.021879 \\
\hline
\end{tabular}

Notes:

* Standard error is based on only the inverse Hessian.

$\uparrow$ Standard error is based on bootstrapping. 
Table F.21. John Day Dam TSW virtual release detection and survival probabilities for juvenile steelhead.

\section{Dam Survival:}

\begin{tabular}{|l|c|c|}
\hline & Estimate & s.e. $\dagger$ \\
\hline Dam Survival: & 0.9890 & 0.007019 \\
\hline
\end{tabular}

\section{Survival Summary:}

\begin{tabular}{|l|c|c|}
\hline & Estimate & s.e. $\dagger$ \\
\hline V1 & 0.9793 & 0.004814 \\
\hline R2 & 0.9822 & 0.004647 \\
\hline R3 & 0.9919 & 0.003501 \\
\hline
\end{tabular}

\section{Survival Detail for Fitted Model:}

\begin{tabular}{|c|c|c|c|c|c|c|c|c|c|c|c|c|c|c|}
\hline & \multicolumn{2}{|c|}{ CR349.0 to CR325.0 } & \multicolumn{2}{|c|}{ CR325.0 to CR309.0 } & \multicolumn{2}{|c|}{ Release to CR309.0 } & \multicolumn{2}{|c|}{ CR309.0 to CR275.0 } & \multicolumn{2}{|c|}{ CR275.0 to CR234.0 } & \multicolumn{2}{|c|}{ CR234.0 to CR161.0 } & \multicolumn{2}{|c|}{ CR161.0 to CR113.0 } \\
\hline & Estimate & s.e. $\dagger$ & Estimate & s.e.* & Estimate & s.e. $\dagger$ & Estimate & s.e.* & Estimate & s.e.* & Estimate & s.e.* & Estimate & s.e.* \\
\hline R1_CR390 35U & 0.9793 & 0.004814 & 0.9920 & 0.000000 & --- & --- & 0.9773 & 0.000000 & 0.6161 & 0.000000 & 1.4373 & 0.000000 & 0.4799 & 0.000000 \\
\hline R2_CR346 35U & --- & --- & --- & --- & 0.9822 & 0.004647 & 0.9945 & 0.000000 & 0.4703 & 0.000000 & 1.0228 & 0.000000 & 0.9021 & 0.000000 \\
\hline R3_CR325 35U & --- & --- & --- & --- & 0.9919 & 0.003501 & 0.9900 & 0.000000 & 0.5869 & 0.000000 & 1.0355 & 0.000000 & 0.9073 & 0.000000 \\
\hline
\end{tabular}

\section{Capture Detail for Fitted Model:}

\begin{tabular}{|c|c|c|c|c|c|c|c|c|c|c|c|c|c|c|}
\hline & \multicolumn{2}{|c|}{ CR325.0 } & \multicolumn{2}{|c|}{ CR309.0 } & \multicolumn{2}{|c|}{ CR275.0 } & \multicolumn{2}{|c|}{ CR234.0 } & \multicolumn{2}{|c|}{ CR161.0 } & \multicolumn{2}{|c|}{ CR113.0 } & \multicolumn{2}{|c|}{$\begin{array}{c}\text { CR086.2 } \\
\text { Survival*Capture }\end{array}$} \\
\hline & Estimate & s.e.* & Estimate & s.e.* & Estimate & s.e.* & Estimate & s.e.* & Estimate & s.e.* & Estimate & s.e.* & Estimate & s.e.* \\
\hline $\begin{array}{l}\text { R1_CR390 } \\
\text { 35U }\end{array}$ & 0.9885 & 0.000000 & 0.9971 & 0.000000 & 0.9401 & 0.000000 & 672.2097 & 0.000000 & 0.4632 & 0.000000 & 0.6659 & 0.000000 & 0.7132 & 0.000000 \\
\hline$\underset{35 \bar{U}}{R 2 C R 346}$ & --- & --- & 0.9996 & 0.000000 & 0.8541 & 0.000000 & 888.2860 & 0.000000 & 0.8778 & 0.000000 & 0.7451 & 0.000000 & 0.6403 & 0.000000 \\
\hline $\begin{array}{l}\text { R3_CR325 } \\
\text { 35U }\end{array}$ & --- & --- & 0.9978 & 0.000000 & 0.8392 & 0.000000 & 665.1356 & 0.000000 & 0.8330 & 0.000000 & 0.7235 & 0.000000 & 0.5595 & 0.000000 \\
\hline
\end{tabular}

\section{Notes:}

* Standard error is based on only the inverse Hessian.

$\dagger$ Standard error is based on bootstrapping. 
Table F.22. John Day Dam non-TSW virtual release detection and survival probabilities for juvenile steelhead.

\section{Dam Survival:}

\begin{tabular}{|l|c|c|}
\hline & Estimate & s.e. $\dagger$ \\
\hline Dam Survival: & 0.9904 & 0.007417 \\
\hline
\end{tabular}

\section{Survival Summary:}

\begin{tabular}{|l|c|c|}
\hline & Estimate & s.e. $\dagger$ \\
\hline V1 & 0.9793 & 0.005255 \\
\hline R2 & 0.9821 & 0.004819 \\
\hline R3 & 0.9932 & 0.003596 \\
\hline
\end{tabular}

\section{Survival Detail for Fitted Model:}

\begin{tabular}{|c|c|c|c|c|c|c|c|c|c|c|c|c|c|c|}
\hline & \multicolumn{2}{|c|}{ CR349.0 to CR325.0 } & \multicolumn{2}{|c|}{ CR325.0 to CR309.0 } & \multicolumn{2}{|c|}{ Release to CR309.0 } & \multicolumn{2}{|c|}{ CR309.0 to CR275.0 } & \multicolumn{2}{|c|}{ CR275.0 to CR234.0 } & \multicolumn{2}{|c|}{ CR234.0 to CR161.0 } & \multicolumn{2}{|c|}{ CR161.0 to CR113.0 } \\
\hline & Estimate & s.e. $\dagger$ & Estimate & s.e.* & Estimate & s.e. $\dagger$ & Estimate & s.e.* & Estimate & s.e.* & Estimate & s.e.* & Estimate & s.e.* \\
\hline R1_CR390 35U & 0.9793 & 0.005255 & 0.9921 & 0.003377 & --- & --- & 0.9825 & 0.005356 & 0.9873 & 0.004646 & 0.9463 & 0.010181 & 0.9482 & 0.022389 \\
\hline R2_CR346 35U & --- & --- & --- & --- & 0.9821 & 0.004819 & 0.9769 & 0.004568 & 0.9895 & 0.003287 & 0.9367 & 0.007966 & 0.9528 & 0.015054 \\
\hline R3_CR325 35U & --- & --- & --- & --- & 0.9932 & 0.003596 & 0.9663 & 0.006766 & 0.9807 & 0.005444 & 0.9495 & 0.009209 & 0.9938 & 0.020761 \\
\hline
\end{tabular}

\section{Capture Detail for Fitted Model:}

\begin{tabular}{|c|c|c|c|c|c|c|c|c|c|c|c|c|c|c|}
\hline & \multicolumn{2}{|c|}{ CR325.0 } & \multicolumn{2}{|c|}{ CR309.0 } & \multicolumn{2}{|c|}{ CR275.0 } & \multicolumn{2}{|c|}{ CR234.0 } & \multicolumn{2}{|c|}{ CR161.0 } & \multicolumn{2}{|c|}{ CR113.0 } & \multicolumn{2}{|c|}{$\begin{array}{c}\text { CR086.2 } \\
\text { Survival*Capture }\end{array}$} \\
\hline & Estimate & s.e.* & Estimate & s.e.* & Estimate & s.e.* & Estimate & s.e.* & Estimate & s.e.* & Estimate & s.e.* & Estimate & s.e.* \\
\hline $\begin{array}{l}\text { R1_CR390 } \\
35 \bar{U}\end{array}$ & 0.9768 & 0.005552 & 0.9875 & 0.004146 & 0.8397 & 0.013761 & 1.0000 & 0.000000 & 0.8946 & 0.012976 & 0.7201 & 0.023403 & 0.5799 & 0.023091 \\
\hline${ }_{35 \bar{U}}^{R 2 C R 346}$ & --- & --- & 0.9991 & 0.000874 & 0.8772 & 0.009755 & 1.0000 & 0.000000 & 0.9247 & 0.008720 & 0.7457 & 0.017146 & 0.6397 & 0.017510 \\
\hline${ }_{35 \bar{U}}^{R 3 C R 325}$ & --- & --- & 0.9987 & 0.001313 & 0.8596 & 0.012701 & 1.0000 & 0.000000 & 0.9003 & 0.012012 & 0.7275 & 0.022262 & 0.5674 & 0.021879 \\
\hline
\end{tabular}

\section{Notes:}

* Standard error is based on only the inverse Hessian.

$\uparrow$ Standard error is based on bootstrapping. 
Table F.23. John Day Dam spillway virtual release detection and survival probabilities for juvenile steelhead.

\section{Dam Survival:}

\begin{tabular}{|l|c|c|}
\hline & Estimate & s.e. $\dagger$ \\
\hline Dam Survival: & 0.9903 & 0.006419 \\
\hline
\end{tabular}

\section{Survival Summary:}

\begin{tabular}{|l|c|c|}
\hline & Estimate & s.e. $\dagger$ \\
\hline V1 & 0.9793 & 0.003665 \\
\hline R2 & 0.9821 & 0.004222 \\
\hline R3 & 0.9932 & 0.003370 \\
\hline
\end{tabular}

\section{Survival Detail for Fitted Model:}

\begin{tabular}{|c|c|c|c|c|c|c|c|c|c|c|c|c|c|c|}
\hline & \multicolumn{2}{|c|}{ CR349.0 to CR325.0 } & \multicolumn{2}{|c|}{ CR325.0 to CR309.0 } & \multicolumn{2}{|c|}{ Release to CR309.0 } & \multicolumn{2}{|c|}{ CR309.0 to CR275.0 } & \multicolumn{2}{|c|}{ CR275.0 to CR234.0 } & \multicolumn{2}{|c|}{ CR234.0 to CR161.0 } & \multicolumn{2}{|c|}{ CR161.0 to CR113.0 } \\
\hline & Estimate & s.e. $\dagger$ & Estimate & s.e.* & Estimate & s.e. $\dagger$ & Estimate & s.e.* & Estimate & s.e.* & Estimate & s.e.* & Estimate & s.e.* \\
\hline R1_CR390 35U & 0.9793 & 0.003665 & 0.9923 & 0.002309 & --- & --- & 0.9763 & 0.004136 & 0.9853 & 0.003382 & 0.9442 & 0.006701 & 0.9631 & 0.012914 \\
\hline R2_CR346 35U & --- & --- & --- & --- & 0.9821 & 0.004222 & 0.9769 & 0.004568 & 0.9895 & 0.003287 & 0.9367 & 0.007966 & 0.9528 & 0.015054 \\
\hline R3_CR325 35U & --- & --- & --- & --- & 0.9932 & 0.003370 & 0.9663 & 0.006766 & 0.9807 & 0.005444 & 0.9495 & 0.009209 & 0.9938 & 0.020761 \\
\hline
\end{tabular}

\section{Capture Detail for Fitted Model:}

\begin{tabular}{|c|c|c|c|c|c|c|c|c|c|c|c|c|c|c|}
\hline & \multicolumn{2}{|c|}{ CR325.0 } & \multicolumn{2}{|c|}{ CR309.0 } & \multicolumn{2}{|c|}{ CR275.0 } & \multicolumn{2}{|c|}{ CR234.0 } & \multicolumn{2}{|c|}{ CR161.0 } & \multicolumn{2}{|c|}{ CR113.0 } & \multicolumn{2}{|c|}{$\begin{array}{c}\text { CR086.2 } \\
\text { Survival*Capture }\end{array}$} \\
\hline & Estimate & s.e.* & Estimate & s.e.* & Estimate & s.e.* & Estimate & s.e.* & Estimate & s.e.* & Estimate & s.e.* & Estimate & s.e.* \\
\hline $\begin{array}{l}\text { R1_CR390 } \\
35 \bar{U}\end{array}$ & 0.9821 & 0.003410 & 0.9932 & 0.002143 & 0.8911 & 0.008178 & 1.0000 & 0.000000 & 0.9255 & 0.007643 & 0.7452 & 0.015034 & 0.6474 & 0.015367 \\
\hline${ }_{35 \bar{U}}^{R 2 C R 346}$ & --- & --- & 0.9991 & 0.000874 & 0.8772 & 0.009755 & 1.0000 & 0.000000 & 0.9247 & 0.008720 & 0.7457 & 0.017146 & 0.6397 & 0.017510 \\
\hline${ }_{35 \bar{U}}^{R 3 C R 325}$ & --- & --- & 0.9987 & 0.001313 & 0.8596 & 0.012701 & 1.0000 & 0.000000 & 0.9003 & 0.012012 & 0.7275 & 0.022262 & 0.5674 & 0.021879 \\
\hline
\end{tabular}

\section{Notes:}

* Standard error is based on only the inverse Hessian.

$\uparrow$ Standard error is based on bootstrapping. 
Table F.24. John Day Dam turbine virtual release detection and survival probabilities for juvenile steelhead.

\section{Dam Survival:}

\begin{tabular}{|l|c|c|}
\hline & Estimate & s.e. $\dagger$ \\
\hline Dam Survival: & 0.7971 & 0.041790 \\
\hline
\end{tabular}

\section{Survival Summary:}

\begin{tabular}{|l|c|c|}
\hline & Estimate & s.e. $\dagger$ \\
\hline V1 & 0.7883 & 0.041118 \\
\hline R2 & 0.9821 & 0.004106 \\
\hline R3 & 0.9932 & 0.003326 \\
\hline
\end{tabular}

\section{Survival Detail for Fitted Model:}

\begin{tabular}{|c|c|c|c|c|c|c|c|c|c|c|c|c|c|c|}
\hline & \multicolumn{2}{|c|}{ CR349.0 to CR325.0 } & \multicolumn{2}{|c|}{ CR325.0 to CR309.0 } & \multicolumn{2}{|c|}{ Release to CR309.0 } & \multicolumn{2}{|c|}{ CR309.0 to CR275.0 } & \multicolumn{2}{|c|}{ CR275.0 to CR234.0 } & \multicolumn{2}{|c|}{ CR234.0 to CR161.0 } & \multicolumn{2}{|c|}{ CR161.0 to CR113.0 } \\
\hline & Estimate & s.e. $\dagger$ & Estimate & s.e.* & Estimate & s.e. $\dagger$ & Estimate & s.e.* & Estimate & s.e.* & Estimate & s.e.* & Estimate & s.e.* \\
\hline R1_CR390 35U & 0.7883 & 0.041118 & 0.9877 & 0.012751 & --- & --- & 0.9750 & 0.018429 & 0.9861 & 0.014396 & 0.9559 & 0.027176 & 0.9037 & 0.052925 \\
\hline R2_CR346 35U & --- & --- & --- & --- & 0.9821 & 0.004106 & 0.9769 & 0.004568 & 0.9895 & 0.003287 & 0.9367 & 0.007966 & 0.9528 & 0.015054 \\
\hline R3_CR325 35U & --- & --- & --- & --- & 0.9932 & 0.003326 & 0.9663 & 0.006766 & 0.9807 & 0.005444 & 0.9495 & 0.009209 & 0.9938 & 0.020761 \\
\hline
\end{tabular}

\section{Capture Detail for Fitted Model:}

\begin{tabular}{|c|c|c|c|c|c|c|c|c|c|c|c|c|c|c|}
\hline & \multicolumn{2}{|c|}{ CR325.0 } & \multicolumn{2}{|c|}{ CR309.0 } & \multicolumn{2}{|c|}{ CR275.0 } & \multicolumn{2}{|c|}{ CR234.0 } & \multicolumn{2}{|c|}{ CR161.0 } & \multicolumn{2}{|c|}{ CR113.0 } & \multicolumn{2}{|c|}{$\begin{array}{c}\text { CR086.2 } \\
\text { Survival*Capture }\end{array}$} \\
\hline & Estimate & s.e.* & Estimate & s.e.* & Estimate & s.e.* & Estimate & s.e.* & Estimate & s.e.* & Estimate & s.e.* & Estimate & s.e.* \\
\hline 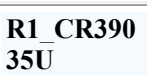 & 1.0000 & 0.000000 & 0.9867 & 0.013244 & 0.9189 & 0.031726 & 1.0000 & 0.000000 & 0.9333 & 0.032200 & 0.8140 & 0.059344 & 0.6732 & 0.065064 \\
\hline${ }_{35 \bar{U}}^{R 2 C R 346}$ & --- & --- & 0.9991 & 0.000874 & 0.8772 & 0.009755 & 1.0000 & 0.000000 & 0.9247 & 0.008720 & 0.7457 & 0.017146 & 0.6397 & 0.017510 \\
\hline $\begin{array}{l}\text { R3_CR325 } \\
\text { 35U }\end{array}$ & --- & --- & 0.9987 & 0.001313 & 0.8596 & 0.012701 & 1.0000 & 0.000000 & 0.9003 & 0.012012 & 0.7275 & 0.022262 & 0.5674 & 0.021879 \\
\hline
\end{tabular}

\section{Notes:}

* Standard error is based on only the inverse Hessian.

$\dagger$ Standard error is based on bootstrapping. 


\section{F.2.5 Dam Passage (Early Spring)}

Table F.25. John Day Dam passage virtual release detection and survival probabilities for juvenile steelhead.

Dam Survival:

\begin{tabular}{|l|c|c|}
\hline & Estimate & s.e. $\dagger$ \\
\hline Dam Survival: & 0.9856 & 0.008127 \\
\hline
\end{tabular}

\section{Survival Summary:}

\begin{tabular}{|c|c|c|}
\hline & Estimate & s.e. $\dagger$ \\
\hline V1 & 0.9701 & 0.004460 \\
\hline R2 & 0.9799 & 0.005686 \\
\hline R3 & 0.9956 & 0.003914 \\
\hline
\end{tabular}

Survival Detail for Fitted Model:

\begin{tabular}{|c|c|c|c|c|c|c|c|c|c|c|c|c|c|c|}
\hline & \multicolumn{2}{|c|}{ CR349.0 to CR325.0 } & \multicolumn{2}{|c|}{ CR325.0 to CR309.0 } & \multicolumn{2}{|c|}{ Release to CR309.0 } & \multicolumn{2}{|c|}{ CR309.0 to CR275.0 } & \multicolumn{2}{|c|}{ CR275.0 to CR234.0 } & \multicolumn{2}{|c|}{ CR234.0 to CR161.0 } & \multicolumn{2}{|c|}{ CR161.0 to CR113.0 } \\
\hline & Estimate & s.e. $\dagger$ & Estimate & s.e.* & Estimate & s.e. $\dagger$ & Estimate & s.e.* & Estimate & s.e.* & Estimate & s.e.* & Estimate & s.e.* \\
\hline R1_CR390 35U & 0.9701 & 0.004460 & 0.9949 & 0.001912 & --- & --- & 0.9736 & 0.004245 & 0.9786 & 0.003893 & 0.9582 & 0.005651 & 0.9961 & 0.008552 \\
\hline R2_CR346 35U & --- & --- & --- & --- & 0.9799 & 0.005686 & 0.9776 & 0.005660 & 0.9858 & 0.004605 & 0.9412 & 0.009385 & 0.9876 & 0.011904 \\
\hline R3_CR325 35U & --- & --- & --- & --- & 0.9956 & 0.003914 & 0.9531 & 0.010079 & 0.9745 & 0.007742 & 0.9544 & 0.010642 & 1.0035 & 0.015111 \\
\hline
\end{tabular}

Capture Detail for Fitted Model:

\begin{tabular}{|c|c|c|c|c|c|c|c|c|c|c|c|c|c|c|}
\hline & \multicolumn{2}{|c|}{ CR325.0 } & \multicolumn{2}{|c|}{ CR309.0 } & \multicolumn{2}{|c|}{ CR275.0 } & \multicolumn{2}{|c|}{ CR234.0 } & \multicolumn{2}{|c|}{ CR161.0 } & \multicolumn{2}{|c|}{ CR113.0 } & \multicolumn{2}{|c|}{$\begin{array}{c}\text { CR086.2 } \\
\text { Survival*Capture }\end{array}$} \\
\hline & Estimate & s.e.* & Estimate & s.e.* & Estimate & s.e.* & Estimate & s.e.* & Estimate & s.e.* & Estimate & s.e.* & Estimate & s.e.* \\
\hline $\begin{array}{l}\text { R1_CR390 } \\
\text { 35U }\end{array}$ & 0.9966 & 0.001515 & 0.9986 & 0.000986 & 0.9872 & 0.003007 & 1.0000 & 0.000000 & 0.9523 & 0.006055 & 0.7719 & 0.013242 & 0.7683 & 0.013291 \\
\hline $\begin{array}{l}\text { R2_CR346 } \\
35 \mathrm{U}\end{array}$ & --- & --- & 1.0000 & 0.000000 & 0.9985 & 0.001485 & 1.0000 & 0.000000 & 0.9497 & 0.008956 & 0.7746 & 0.018742 & 0.7956 & 0.018339 \\
\hline $\begin{array}{l}\text { R3_CR325 } \\
\text { 35U }\end{array}$ & --- & --- & 1.0000 & 0.000000 & 1.0000 & 0.000000 & 1.0000 & 0.000000 & 0.9598 & 0.010173 & 0.7690 & 0.024214 & 0.7691 & 0.024217 \\
\hline
\end{tabular}

Notes:

* Standard error is based on only the inverse Hessian.

$\uparrow$ Standard error is based on bootstrapping. 


\section{F.2.6 BRZ-to-BRZ (Early Spring)}

Table F.26. Forebay virtual release detection and survival probabilities for juvenile steelhead.

Dam Survival:

\begin{tabular}{|l|c|c|}
\hline \hline & Estimate & s.e. $\dagger$ \\
\hline Dam Survival: & 0.9749 & 0.0084 \\
\hline
\end{tabular}

\section{Survival Summary:}

\begin{tabular}{|l|c|c|}
\hline & Estimate & s.e.† \\
\hline V1 & 0.9596 & 0.0051 \\
\hline R2 & 0.9799 & 0.0056 \\
\hline R3 & 0.9956 & 0.0039 \\
\hline
\end{tabular}

\section{Survival Detail for Fitted Model:}

\begin{tabular}{|c|c|c|c|c|c|c|c|c|c|c|c|c|c|c|}
\hline & \multicolumn{2}{|c|}{ CR351.0 to CR325.0 } & \multicolumn{2}{|c|}{ CR325.0 to CR309.0 } & \multicolumn{2}{|c|}{ Release to CR309.0 } & \multicolumn{2}{|c|}{ CR309.0 to CR275.0 } & \multicolumn{2}{|c|}{ CR275.0 to CR234.0 } & \multicolumn{2}{|c|}{ CR234.0 to CR161.0 } & \multicolumn{2}{|c|}{ CR161.0 to CR113.0 } \\
\hline & Estimate & s.e. $\dagger$ & Estimate & s.e.* & Estimate & s.e. $\dagger$ & Estimate & s.e.* & Estimate & s.e.* & Estimate & s.e.* & Estimate & s.e.* \\
\hline R1_CR390 35U & 0.9596 & 0.0051 & 0.9949 & 0.0019 & --- & --- & 0.9736 & 0.0042 & 0.9786 & 0.0039 & 0.9583 & 0.0056 & 0.9963 & 0.0085 \\
\hline R2_CR346 35U & --- & --- & --- & --- & 0.9799 & 0.0056 & 0.9776 & 0.0057 & 0.9858 & 0.0046 & 0.9412 & 0.0094 & 0.9876 & 0.0119 \\
\hline R3_CR325 35U & --- & --- & --- & --- & 0.9956 & 0.0039 & 0.9531 & 0.0101 & 0.9745 & 0.0077 & 0.9544 & 0.0106 & 1.0035 & 0.0151 \\
\hline
\end{tabular}

\section{Capture Detail for Fitted Model:}

\begin{tabular}{|c|c|c|c|c|c|c|c|c|c|c|c|c|c|c|}
\hline & \multicolumn{2}{|c|}{ CR325.0 } & \multicolumn{2}{|c|}{ CR309.0 } & \multicolumn{2}{|c|}{ CR275.0 } & \multicolumn{2}{|c|}{ CR234.0 } & \multicolumn{2}{|c|}{ CR161.0 } & \multicolumn{2}{|c|}{ CR113.0 } & \multicolumn{2}{|c|}{ CR086.2 Survival*Capture } \\
\hline & Estimate & s.e.* & Estimate & s.e.* & Estimate & s.e.* & Estimate & s.e.* & Estimate & s.e.* & Estimate & s.e.* & Estimate & s.e.* \\
\hline R1_CR390 35U & 0.9966 & 0.0015 & 0.9986 & 0.0010 & 0.9865 & 0.0031 & 1.0000 & 0.0000 & 0.9525 & 0.0060 & 0.7716 & 0.0132 & 0.7688 & 0.0133 \\
\hline R2_CR346 35U & --- & --- & 1.0000 & 0.0000 & 0.9985 & 0.0015 & 1.0000 & 0.0000 & 0.9497 & 0.0090 & 0.7746 & 0.0187 & 0.7956 & 0.0183 \\
\hline R3_CR325 35U & --- & --- & 1.0000 & 0.0000 & 1.0000 & 0.0000 & 1.0000 & 0.0000 & 0.9598 & 0.0102 & 0.7690 & 0.0242 & 0.7691 & 0.0242 \\
\hline
\end{tabular}

Notes:

* Standard error is based on only the inverse Hessian.

$\uparrow$ Standard error is based on bootstrapping. 


\section{F.2.7 Dam Passage $30 \%$ and $40 \%$ Spill (Early Spring)}

Table F.27. John Day Dam 30\% spill virtual release detection and survival probabilities for juvenile steelhead.

Dam Survival:

\begin{tabular}{|l|c|c|}
\hline & Estimate & s.e. $\dagger$ \\
\hline Dam Survival: & 0.9836 & 0.008999 \\
\hline
\end{tabular}

\section{Survival Summary:}

\begin{tabular}{|l|c|c|}
\hline & Estimate & s.e. $\dagger$ \\
\hline V1 & 0.9682 & 0.005898 \\
\hline R2 & 0.9799 & 0.005642 \\
\hline R3 & 0.9956 & 0.003933 \\
\hline
\end{tabular}

Survival Detail for Fitted Model:

\begin{tabular}{|c|c|c|c|c|c|c|c|c|c|c|c|c|c|c|}
\hline & \multicolumn{2}{|c|}{ CR349.0 to CR325.0 } & \multicolumn{2}{|c|}{ CR325.0 to CR309.0 } & \multicolumn{2}{|c|}{ Release to CR309.0 } & \multicolumn{2}{|c|}{ CR309.0 to CR275.0 } & \multicolumn{2}{|c|}{ CR275.0 to CR234.0 } & \multicolumn{2}{|c|}{ CR234.0 to CR161.0 } & \multicolumn{2}{|c|}{ CR161.0 to CR113.0 } \\
\hline & Estimate & s.e. $\dagger$ & Estimate & s.e.* & Estimate & s.e. $\dagger$ & Estimate & s.e.* & Estimate & s.e.* & Estimate & s.e.* & Estimate & s.e.* \\
\hline R1_CR390 35U & 0.9682 & 0.005898 & 0.9957 & 0.002258 & --- & --- & 0.9749 & 0.005354 & 0.9804 & 0.004833 & 0.9635 & 0.007082 & 0.9959 & 0.013339 \\
\hline R2_CR346 35U & --- & --- & --- & --- & 0.9799 & 0.005642 & 0.9776 & 0.005660 & & 0.004605 & 0.9412 & 0.009385 & 0.9876 & 0.011904 \\
\hline R3_CR325 35U & --- & --- & --- & --- & 0.9956 & 0.003933 & 0.9531 & 0.010079 & 0.9745 & 0.007742 & 0.9544 & 0.010642 & 1.0035 & 0.015111 \\
\hline
\end{tabular}

Capture Detail for Fitted Model:

\begin{tabular}{|c|c|c|c|c|c|c|c|c|c|c|c|c|c|c|}
\hline & \multicolumn{2}{|c|}{ CR325.0 } & \multicolumn{2}{|c|}{ CR309.0 } & \multicolumn{2}{|c|}{ CR275.0 } & \multicolumn{2}{|c|}{ CR234.0 } & \multicolumn{2}{|c|}{ CR161.0 } & \multicolumn{2}{|c|}{ CR113.0 } & \multicolumn{2}{|c|}{$\begin{array}{c}\text { CR086.2 } \\
\text { Survival*Capture }\end{array}$} \\
\hline & Estimate & s.e.* & Estimate & s.e.* & Estimate & s.e.* & Estimate & s.e.* & Estimate & s.e.* & Estimate & s.e.* & Estimate & s.e.* \\
\hline $\begin{array}{l}\text { R1_CR390 } \\
\text { 35U }\end{array}$ & 0.9944 & 0.002519 & 1.0000 & 0.000000 & 0.9799 & 0.004830 & 1.0000 & 0.000000 & 0.9323 & 0.009239 & 0.7491 & 0.018157 & 0.7167 & 0.018468 \\
\hline $\begin{array}{l}\text { R2_CR346 } \\
35 \mathrm{U}\end{array}$ & --- & --- & 1.0000 & 0.000000 & 0.9985 & 0.001485 & 1.0000 & 0.000000 & 0.9497 & 0.008956 & 0.7746 & 0.018742 & 0.7956 & 0.018339 \\
\hline $\begin{array}{l}\text { R3_CR325 } \\
\text { 35U }\end{array}$ & --- & --- & 1.0000 & 0.000000 & 1.0000 & 0.000000 & 1.0000 & 0.000000 & 0.9598 & 0.010173 & 0.7690 & 0.024214 & 0.7691 & 0.024217 \\
\hline
\end{tabular}

Notes:

* Standard error is based on only the inverse Hessian.

$\uparrow$ Standard error is based on bootstrapping. 
Table F.28. John Day Dam 40\% spill virtual release detection and survival probabilities for juvenile steelhead.

\section{Dam Survival:}

\begin{tabular}{|l|c|c|}
\hline & Estimate & s.e. $\dagger$ \\
\hline Dam Survival: & 0.9897 & 0.009594 \\
\hline
\end{tabular}

\section{Survival Summary:}

\begin{tabular}{|l|c|c|}
\hline & Estimate & s.e. $\dagger$ \\
\hline V1 & 0.9742 & 0.006630 \\
\hline R2 & 0.9799 & 0.005671 \\
\hline R3 & 0.9956 & 0.003923 \\
\hline
\end{tabular}

\section{Survival Detail for Fitted Model:}

\begin{tabular}{|c|c|c|c|c|c|c|c|c|c|c|c|c|c|c|}
\hline & \multicolumn{2}{|c|}{ CR349.0 to CR325.0 } & \multicolumn{2}{|c|}{ CR325.0 to CR309.0 } & \multicolumn{2}{|c|}{ Release to CR309.0 } & \multicolumn{2}{|c|}{ CR309.0 to CR275.0 } & \multicolumn{2}{|c|}{ CR275.0 to CR234.0 } & \multicolumn{2}{|c|}{ CR234.0 to CR161.0 } & \multicolumn{2}{|c|}{ CR161.0 to CR113.0 } \\
\hline & Estimate & s.e. $\dagger$ & Estimate & s.e.* & Estimate & s.e. $\dagger$ & Estimate & s.e.* & Estimate & s.e.* & Estimate & s.e.* & Estimate & s.e.* \\
\hline R1_CR390 35U & 0.9742 & 0.006630 & 0.9934 & 0.003426 & --- & --- & 0.9728 & 0.006852 & 0.9755 & 0.006589 & 0.9525 & 0.009363 & 0.9990 & 0.009285 \\
\hline R2_CR346 35U & --- & --- & --- & --- & 0.9799 & 0.005671 & 0.9776 & 0.005660 & 0.9858 & 0.004605 & 0.9412 & 0.009385 & 0.9876 & 0.011904 \\
\hline R3_CR325 35U & --- & --- & --- & --- & 0.9956 & 0.003923 & 0.9531 & 0.010079 & 0.9745 & 0.007742 & 0.9544 & 0.010642 & 1.0035 & 0.015111 \\
\hline
\end{tabular}

\section{Capture Detail for Fitted Model:}

\begin{tabular}{|c|c|c|c|c|c|c|c|c|c|c|c|c|c|c|}
\hline & \multicolumn{2}{|c|}{ CR325.0 } & \multicolumn{2}{|c|}{ CR309.0 } & \multicolumn{2}{|c|}{ CR275.0 } & \multicolumn{2}{|c|}{ CR234.0 } & \multicolumn{2}{|c|}{ CR161.0 } & \multicolumn{2}{|c|}{ CR113.0 } & \multicolumn{2}{|c|}{$\begin{array}{c}\text { CR086.2 } \\
\text { Survival*Capture }\end{array}$} \\
\hline & Estimate & s.e.* & Estimate & s.e.* & Estimate & s.e.* & Estimate & s.e.* & Estimate & s.e.* & Estimate & s.e.* & Estimate & s.e.* \\
\hline 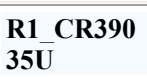 & 1.0000 & 0.000000 & 0.9964 & 0.002512 & 0.9982 & 0.001823 & 1.0000 & 0.000000 & 0.9857 & 0.005350 & 0.8051 & 0.019080 & 0.8528 & 0.017578 \\
\hline${ }_{35 \bar{U}}^{R 2 C R 346}$ & --- & --- & 1.0000 & 0.000000 & 0.9985 & 0.001485 & 1.0000 & 0.000000 & 0.9497 & 0.008956 & 0.7746 & 0.018742 & 0.7956 & 0.018339 \\
\hline $\begin{array}{l}\text { R3_CR325 } \\
\text { 35U }\end{array}$ & --- & --- & 1.0000 & 0.000000 & 1.0000 & 0.000000 & 1.0000 & 0.000000 & 0.9598 & 0.010173 & 0.7690 & 0.024214 & 0.7691 & 0.024217 \\
\hline
\end{tabular}

\section{Notes:}

* Standard error is based on only the inverse Hessian.

$\dagger$ Standard error is based on bootstrapping. 


\section{F.2.8 BRZ-to-BRZ $30 \%$ and $40 \%$ Spill (Early Spring)}

Table F.29. John Day Dam 30\% spill virtual release detection and survival probabilities for juvenile steelhead.

Dam Survival:

\begin{tabular}{|l|c|c|}
\hline & Estimate & s.e. $\dagger$ \\
\hline Dam Survival: & 0.9716 & 0.0096 \\
\hline
\end{tabular}

\section{Survival Summary:}

\begin{tabular}{|l|c|c|}
\hline & Estimate & s.e. $\dagger$ \\
\hline V1 & 0.9564 & 0.0068 \\
\hline R2 & 0.9799 & 0.0056 \\
\hline R3 & 0.9956 & 0.0039 \\
\hline
\end{tabular}

Survival Detail for Fitted Model:

\begin{tabular}{|c|c|c|c|c|c|c|c|c|c|c|c|c|c|c|}
\hline & \multicolumn{2}{|c|}{ CR351.0 to CR325.0 } & \multicolumn{2}{|c|}{ CR325.0 to CR309.0 } & \multicolumn{2}{|c|}{ Release to CR309.0 } & \multicolumn{2}{|c|}{ CR309.0 to CR275.0 } & \multicolumn{2}{|c|}{ CR275.0 to CR234.0 } & \multicolumn{2}{|c|}{ CR234.0 to CR161.0 } & \multicolumn{2}{|c|}{ CR161.0 to CR113.0 } \\
\hline & Estimate & s.e. $\dagger$ & Estimate & s.e.* & Estimate & s.e. $\dagger$ & Estimate & s.e.* & Estimate & s.e.* & Estimate & s.e.* & Estimate & s.e.* \\
\hline R1_CR390 35U & 0.9564 & 0.0068 & 0.9957 & 0.0023 & --- & --- & 0.9746 & 0.0054 & 0.9789 & 0.0050 & 0.9640 & 0.0071 & 0.9986 & 0.0132 \\
\hline R2_CR346 35U & --- & --- & --- & --- & 0.9799 & 0.0056 & 0.9776 & 0.0057 & 0.9858 & 0.0046 & 0.9412 & 0.0094 & 0.9876 & 0.0119 \\
\hline R3_CR325 35U & --- & --- & --- & --- & 0.9956 & 0.0039 & 0.9531 & 0.0101 & 0.9745 & 0.0077 & 0.9544 & 0.0106 & 1.0035 & 0.0151 \\
\hline
\end{tabular}

\section{Capture Detail for Fitted Model:}

\begin{tabular}{|c|c|c|c|c|c|c|c|c|c|c|c|c|c|c|}
\hline & \multicolumn{2}{|c|}{ CR325.0 } & \multicolumn{2}{|c|}{ CR309.0 } & \multicolumn{2}{|c|}{ CR275.0 } & \multicolumn{2}{|c|}{ CR234.0 } & \multicolumn{2}{|c|}{ CR161.0 } & \multicolumn{2}{|c|}{ CR113.0 } & \multicolumn{2}{|c|}{ CR086.2 Survival*Capture } \\
\hline & Estimate & s.e.* & Estimate & s.e.* & Estimate & s.e.* & Estimate & s.e.* & Estimate & s.e.* & Estimate & s.e.* & Estimate & s.e.* \\
\hline R1_CR390 35U & 0.9943 & 0.0025 & 1.0000 & 0.0000 & 0.9784 & 0.0050 & 1.0000 & 0.0000 & 0.9317 & 0.0093 & 0.7491 & 0.0182 & 0.7189 & 0.0185 \\
\hline R2_CR346 35U & --- & --- & 1.0000 & 0.0000 & 0.9985 & 0.0015 & 1.0000 & 0.0000 & 0.9497 & 0.0090 & 0.7746 & 0.0187 & 0.7956 & 0.0183 \\
\hline R3_CR325 35U & -- & --- & 1.0000 & 0.0000 & 1.0000 & 0.0000 & 1.0000 & 0.0000 & 0.9598 & 0.0102 & 0.7690 & 0.0242 & 0.7691 & 0.0242 \\
\hline
\end{tabular}

Notes:

* Standard error is based on only the inverse Hessian.

$\uparrow$ Standard error is based on bootstrapping. 
Table F.30. John Day Dam 40\% spill virtual release detection and survival probabilities for juvenile steelhead.

\section{Dam Survival:}

\begin{tabular}{|l|c|c|}
\hline & Estimate & s.e. $\dagger$ \\
\hline Dam Survival: & 0.9816 & 0.0102 \\
\hline
\end{tabular}

\section{Survival Summary:}

\begin{tabular}{|l|c|c|}
\hline & Estimate & s.e. $\dagger$ \\
\hline V1 & 0.9662 & 0.0075 \\
\hline R2 & 0.9799 & 0.0056 \\
\hline R3 & 0.9956 & 0.0039 \\
\hline
\end{tabular}

\section{Survival Detail for Fitted Model:}

\begin{tabular}{|c|c|c|c|c|c|c|c|c|c|c|c|c|c|c|}
\hline & \multicolumn{2}{|c|}{ CR351.0 to CR325.0 } & \multicolumn{2}{|c|}{ CR325.0 to CR309.0 } & \multicolumn{2}{|c|}{ Release to CR309.0 } & \multicolumn{2}{|c|}{ CR309.0 to CR275.0 } & \multicolumn{2}{|c|}{ CR275.0 to CR234.0 } & \multicolumn{2}{|c|}{ CR234.0 to CR161.0 } & \multicolumn{2}{|c|}{ CR161.0 to CR113.0 } \\
\hline & Estimate & s.e. $\dagger$ & Estimate & s.e.* & Estimate & s.e. $\dagger$ & Estimate & s.e.* & Estimate & s.e.* & Estimate & s.e.* & Estimate & s.e.* \\
\hline R1_CR390 35U & 0.9662 & 0.0075 & 0.9934 & 0.0034 & --- & --- & 0.9728 & 0.0069 & 0.9773 & 0.0064 & 0.9508 & 0.0095 & 0.9986 & 0.0096 \\
\hline R2_CR346 35U & --- & --- & --- & --- & 0.9799 & 0.0056 & 0.9776 & 0.0057 & 0.9858 & 0.0046 & 0.9412 & 0.0094 & 0.9876 & 0.0119 \\
\hline R3_CR325 35U & --- & --- & --- & --- & 0.9956 & 0.0039 & 0.9531 & 0.0101 & 0.9745 & 0.0077 & 0.9544 & 0.0106 & 1.0035 & 0.0151 \\
\hline
\end{tabular}

\section{Capture Detail for Fitted Model:}

\begin{tabular}{|c|c|c|c|c|c|c|c|c|c|c|c|c|c|c|}
\hline & \multicolumn{2}{|c|}{ CR325.0 } & \multicolumn{2}{|c|}{ CR309.0 } & \multicolumn{2}{|c|}{ CR275.0 } & \multicolumn{2}{|c|}{ CR234.0 } & \multicolumn{2}{|c|}{ CR161.0 } & \multicolumn{2}{|c|}{ CR113.0 } & \multicolumn{2}{|c|}{ CR086.2 Survival ${ }^{*}$ Capture } \\
\hline & Estimate & s.e.* & Estimate & s.e.* & Estimate & s.e.* & Estimate & s.e.* & Estimate & s.e.* & Estimate & s.e.* & Estimate & s.e.* \\
\hline R1_CR390 35U & 1.0000 & 0.0000 & 0.9964 & 0.0025 & 0.9982 & 0.0018 & 1.0000 & 0.0000 & 0.9837 & 0.0057 & 0.8014 & 0.0193 & 0.8471 & 0.0179 \\
\hline R2_CR346 35U & --- & --- & 1.0000 & 0.0000 & 0.9985 & 0.0015 & 1.0000 & 0.0000 & 0.9497 & 0.0090 & 0.7746 & 0.0187 & 0.7956 & 0.0183 \\
\hline R3_CR325 35U & --- & --- & 1.0000 & 0.0000 & 1.0000 & 0.0000 & 1.0000 & 0.0000 & 0.9598 & 0.0102 & 0.7690 & 0.0242 & 0.7691 & 0.0242 \\
\hline
\end{tabular}

\section{Notes:}

* Standard error is based on only the inverse Hessian.

$\dagger$ Standard error is based on bootstrapping. 


\section{Appendix G}

Juvenile Salmon Acoustic Telemetry System Hydrophone Array Performance 


\section{Appendix G}

\section{Juvenile Salmon Acoustic Telemetry System Hydrophone Array Performance}

This appendix contains data on the detection probabilities at the John Day Dam (JDA) dam-face cabled arrays and autonomous arrays used in survival estimates.

\section{G.1 Detection Probabilities at Dam-Face Arrays}

Detection probabilities for each dam-face array were greater than $99 \%$ and the combined detection probability for the two dam-face arrays used in the 2011 survival study was $100 \%$ for both yearling Chinook salmon (CH1) and juvenile steelhead (STH; Table G.1).

Table G.1. Numbers of tagged fish detected and detection probabilities for the dam-face arrays at John Day Dam $(\mathrm{N} 11=$ detected on both arrays; N10 = detected on array 1 but not array 2; N01 = detected on array 2 but not array 1).

\begin{tabular}{cccccccc}
\hline Species & $\begin{array}{c}\text { JDA Cabled } \\
\text { Array }\end{array}$ & N11 & N10 & N01 & $\begin{array}{c}\text { Detection Probability } \\
\text { at Array 1 }\end{array}$ & $\begin{array}{c}\text { Detection Probability } \\
\text { at Array 2 }\end{array}$ & $\begin{array}{c}\text { Combined Detection } \\
\text { Probability }\end{array}$ \\
\hline CH1 & 2,452 & 2,446 & 6 & 0 & 1.0000 & 0.9976 & 1.0000 \\
STH & 2,477 & 2,475 & 2 & 0 & 1.0000 & 0.9992 & 1.0000 \\
\hline
\end{tabular}

\section{G.2 Detection Probabilities at Survival Arrays}

Detection probabilities at autonomous and dam-face arrays used in estimating survival of tagged juvenile salmonids at JDA ranged from 90 to $100 \%$ and 85 to $100 \%$ for $\mathrm{CH} 1$ and STH, respectively (Table G.2). The highest detection probabilities (99\% to 100\%) occurred at The Dalles Dam (TDA) and Bonneville Dam (BON) dam-face arrays (rkm 309 and rkm 234, respectively).

Table G.2. Estimated detection probabilities used in estimating dam passage survival at John Day Dam for each species based on node arrays. Standard errors for the estimates are in parentheses.

\begin{tabular}{lcc}
\hline Release and Detection Arrays & Yearling Chinook & Steelhead \\
\hline $\mathrm{V}_{1}(\mathrm{rkm} 351)$ to $\mathrm{D}_{1}(\mathrm{rkm} 325)$ & $0.9841(0.0026)$ & $0.9845(0.0025)$ \\
$\mathrm{V}_{1}(\mathrm{rkm} 351)$ to $\mathrm{D}_{2}(\mathrm{rkm} 309)$ & $0.9911(0.0020)$ & $0.9923(0.0018)$ \\
$\mathrm{R}_{2}(\mathrm{rkm} 346)$ to $\mathrm{D}_{2}(\mathrm{rkm} 309)$ & $0.9964(0.0018)$ & $0.9991(0.0009)$ \\
$\mathrm{R}_{3}(\mathrm{rkm} 325)$ to $\mathrm{D}_{2}(\mathrm{rkm} 309)$ & $0.9907(0.0035)$ & $0.9987(0.0013)$ \\
$\mathrm{V}_{1}(\mathrm{rkm} 351)$ to $\mathrm{D}_{3}(\mathrm{rkm} 275)$ & $0.9260(0.0055)$ & $0.8822(0.0067)$ \\
$\mathrm{R}_{2}(\mathrm{rkm} 346)$ to $\mathrm{D}_{3}(\mathrm{rkm} 275)$ & $0.9015(0.0090)$ & $0.8772(0.0098)$ \\
$\mathrm{R}_{3}(\mathrm{rkm} \mathrm{325})$ to $\mathrm{D}_{3}(\mathrm{rkm} 275)$ & $0.9098(0.0105)$ & $0.8596(0.0127)$ \\
$\mathrm{V}_{1}(\mathrm{rkm} \mathrm{351})$ to $\mathrm{D}_{4}(\mathrm{rkm} 234)$ & $1.0000(0.0000)$ & $1.0000(0.0000)$ \\
$\mathrm{R}_{2}(\mathrm{rkm} 346)$ to $\mathrm{D}_{4}(\mathrm{rkm} 234)$ & $1.0000(0.0000)$ & $1.0000(0.0000)$ \\
$\mathrm{R}_{3}\left(\mathrm{rkm} \mathrm{325)}\right.$ to $\mathrm{D}_{4}(\mathrm{rkm} 234)$ & $1.0000(0.0000)$ & $1.0000(0.0000)$ \\
\hline
\end{tabular}


Appendix $\mathrm{H}$

Assessment of Survival Model Assumptions 


\section{Appendix $\mathrm{H}$}

\section{Assessment of Survival Model Assumptions}

\section{H.1 Tagger Effects}

All of the data from the seven release sites associated with the survival study were examined for tagger effects, including the three directly related to the compliance study at John Day Dam (JDA) in 2011. This was done because of the interrelationship between the multiple releases and estimation of dam passage survival at a specific location and to increase the statistical power to detect tagger effects.

To minimize any tagger effects that might go undetected, tagger effort, number of fish tagged by a tagger, should be balanced across release locations and within replicates. A total of eight taggers participated in the tagging of yearling Chinook salmon (CH1) and juvenile steelhead (STH). Tagger effort was found to be balanced across the seven release locations regardless of whether the data were pooled across species $\left(P\left(\chi_{42}^{2} \geq 27.70\right)=0.9562\right)$ or analyzed separately by CH1 $\left(P\left(\chi_{42}^{2} \geq 22.68\right)=0.9935\right)$ or STH $\left(P\left(\chi_{42}^{2} \geq 10.62\right)=1.00\right) \quad($ Table H.1).

Tagger effort was also examined by release locations within each of the 32 replicate releases conducted over the course of the season (Table H.2). Tagger effort was found to be balanced within replicates $1,2,5,6,9,10,13,14,17,18,21,22,25,26,29$, and 30 ( $P \geq 0.9982)$. To accommodate staff time off during the month-long study, tagger effort was conditionally balanced within the individual project releases (i.e., $\mathrm{R}_{1}-\mathrm{R}_{3}, \mathrm{R}_{4}-\mathrm{R}_{5}$, and $\mathrm{R}_{6}-\mathrm{R}_{7}$ ) for the remaining replicates ( $P \geq 0.7459$ ) (Table H.2). This conditional and unconditional balance within replicates is the reason for the overall balanced displayed in Table H.1. To minimize the number of contingency tables presented, results in Table H.2 are pooled across species.

To test for tagger effects, reach survival rates and cumulative survival estimates were calculated for fish tagged by different staff members on a release location (i.e., $\mathrm{R}_{1}, \ldots, \mathrm{R}_{7}$ ) and species basis (Table H.3). Of the 56 tests of homogeneous reach survival estimates, 7 were found significant at $\alpha=$ 0.10 (i.e., $12.5 \%$ ). In expectation, $10 \%$ of the 56 tests (i.e., 5.6) would be significant at $\alpha=0.10$ when no effect exists. There was no consistent pattern, with two taggers responsible for two of seven significant results each, and three taggers responsible for one significant result each. Similarly, only 2 of $54(3.7 \%)$ tests of the homogeneous cumulative survivals were found to be significant at $\alpha=0.10$. Therefore, fish tagged by all taggers were considered acceptable for the survival analyses. 
Table H.1. Numbers of $\mathrm{CH} 1$ and STH tagged by each staff member by release locations (R1, R2, .., R7). Chi-square tests of homogeneity were not significant.

a. $\mathrm{CH} 1$ and $\mathrm{STH}$ releases pooled

\begin{tabular}{ccccccccc}
\hline \multirow{2}{*}{$\begin{array}{c}\text { Release } \\
\text { Location }\end{array}$} & A & B & C & D & E & F & G & H \\
\cline { 2 - 9 } R1-CR390 & 581 & 576 & 668 & 569 & 528 & 456 & 899 & 820 \\
R2-CR346 & 279 & 254 & 302 & 263 & 293 & 227 & 388 & 383 \\
R3-CR325 & 193 & 173 & 197 & 176 & 196 & 148 & 248 & 265 \\
R4-CR307 & 195 & 176 & 197 & 168 & 200 & 150 & 249 & 264 \\
R5-CR275 & 190 & 172 & 195 & 176 & 201 & 152 & 242 & 271 \\
R6-CR233 & 189 & 179 & 190 & 179 & 196 & 150 & 246 & 261 \\
R7-CR161 & 192 & 178 & 196 & 179 & 191 & 141 & 246 & 265 \\
\hline & & & & & & & $P\left(\chi_{42}^{2} \geq 27.70\right)=0.9562$
\end{tabular}

b. $\mathrm{CH} 1$

\begin{tabular}{crrrrrrrr}
\hline \multirow{2}{*}{$\begin{array}{c}\text { Release } \\
\text { Location }\end{array}$} & \multicolumn{1}{c}{ A } & \multicolumn{1}{c}{ B } & \multicolumn{1}{c}{ C } & \multicolumn{1}{c}{ D } & E & F & \multicolumn{1}{c}{ G } & H \\
\hline R1-CR390 & 280 & 292 & 335 & 284 & 252 & 216 & 447 & 404 \\
R2-CR346 & 136 & 127 & 147 & 133 & 149 & 113 & 197 & 191 \\
R3-CR325 & 98 & 88 & 97 & 84 & 99 & 73 & 125 & 135 \\
R4-CR307 & 95 & 85 & 98 & 84 & 102 & 77 & 123 & 135 \\
R5-CR275 & 95 & 84 & 93 & 86 & 104 & 76 & 122 & 139 \\
R6-CR233 & 94 & 90 & 97 & 86 & 101 & 75 & 125 & 130 \\
R7-CR161 & 93 & 91 & 102 & 90 & 97 & 67 & 122 & 132 \\
\hline & & & & & & & $P\left(\chi_{42}^{2} \geq 22.68\right)=0.9935$
\end{tabular}

c. $\mathrm{STH}$

\begin{tabular}{crrrrrrrr}
\hline \multirow{2}{*}{$\begin{array}{c}\text { Release } \\
\text { Location }\end{array}$} & \multicolumn{1}{c}{ A } & \multicolumn{1}{c}{ B } & \multicolumn{1}{c}{ C } & \multicolumn{1}{c}{ D } & E & \multicolumn{1}{c}{ F } & \multicolumn{1}{c}{ G } & \multicolumn{1}{c}{ H } \\
\hline R1-CR390 & 301 & 284 & 333 & 285 & 276 & 240 & 452 & 416 \\
R2-CR346 & 143 & 127 & 155 & 130 & 144 & 114 & 191 & 192 \\
R3-CR325 & 95 & 85 & 100 & 92 & 97 & 75 & 123 & 130 \\
R4-CR307 & 100 & 91 & 99 & 84 & 98 & 73 & 126 & 129 \\
R5-CR275 & 95 & 88 & 102 & 90 & 97 & 76 & 120 & 132 \\
R6-CR233 & 95 & 89 & 93 & 93 & 95 & 75 & 121 & 131 \\
R7-CR161 & 99 & 87 & 94 & 89 & 94 & 74 & 124 & 133 \\
\hline & & & & & & & $P\left(\chi_{42}^{2} \geq 10.62\right) \doteq 1.00$
\end{tabular}


Table H.2. Contingency tables with number of fish tagged by each staff member per release location within a replicate release. A total of 32 replicate day or nighttime releases were performed over the course of the 2011 investigations. Results of the chi-square tests of homogeneity are presented for each table.

a. Replicate 1

\begin{tabular}{ccccc}
\hline Release & B & C & D & G \\
\hline R1-CR390 & 35 & 40 & 31 & 54 \\
R2-CR346 & 14 & 21 & 16 & 25 \\
R3-CR325 & 10 & 14 & 10 & 16 \\
R4-CR307 & 10 & 14 & 11 & 15 \\
R5-CR275 & 11 & 12 & 13 & 14 \\
R6-CR233 & 10 & 12 & 12 & 16 \\
R7-CR161 & 9 & 12 & 11 & 18 \\
\hline Chi-square $=2.7577$ & DF $=18$ & & $P$-value $=1$ \\
\hline
\end{tabular}

b. Replicate 2

\begin{tabular}{ccccc}
\hline Release & B & C & D & G \\
\hline R1-CR390 & 36 & 44 & 32 & 51 \\
R2-CR346 & 17 & 20 & 14 & 24 \\
R3-CR325 & 12 & 12 & 10 & 16 \\
R4-CR307 & 12 & 12 & 11 & 15 \\
R5-CR275 & 10 & 14 & 11 & 15 \\
R6-CR233 & 11 & 12 & 11 & 15 \\
R7-CR161 & 10 & 12 & 11 & 15 \\
\hline Chi-square $=1.2674$ & DF $=18$ & & $P$-value $=1$ \\
\hline
\end{tabular}

c. Replicate 3

\begin{tabular}{crrrrrrrrr}
\hline Release & $\mathrm{A}$ & $\mathrm{B}$ & $\mathrm{C}$ & $\mathrm{D}$ & $\mathrm{E}$ & $\mathrm{F}$ & $\mathrm{G}$ & $\mathrm{H}$ & $P$-value \\
\hline R1-CR390 & 0 & 39 & 44 & 34 & 0 & 0 & 49 & 0 & \\
R2-CR346 & 0 & 15 & 19 & 18 & 0 & 0 & 24 & 0 & 0.9677 \\
R3-CR325 & 0 & 9 & 14 & 10 & 0 & 0 & 17 & 0 & \\
R4-CR307 & 0 & 11 & 12 & 10 & 0 & 0 & 17 & 0 & 0.9948 \\
R5-CR275 & 0 & 12 & 12 & 10 & 0 & 0 & 16 & 0 & \\
R6-CR233 & 10 & 0 & 0 & 0 & 11 & 10 & 0 & 19 & 0.8460 \\
R7-CR161 & 11 & 0 & 0 & 0 & 13 & 7 & 0 & 17 & $P$-value $<0.0001$ \\
\hline
\end{tabular}

d. Replicate 4

\begin{tabular}{|c|c|c|c|c|c|c|c|c|c|}
\hline Release & $\mathrm{A}$ & $\mathrm{B}$ & $\mathrm{C}$ & $\mathrm{D}$ & $\mathrm{E}$ & $\mathrm{F}$ & $\mathrm{G}$ & $\mathrm{H}$ & $P$-value \\
\hline R1-CR390 & 0 & 34 & 42 & 37 & 0 & 0 & 49 & 0 & \multirow{3}{*}{0.9977} \\
\hline R2-CR346 & 0 & 14 & 21 & 17 & 0 & 0 & 24 & 0 & \\
\hline R3-CR325 & 0 & 10 & 12 & 11 & 0 & 0 & 17 & 0 & \\
\hline R4-CR307 & 0 & 9 & 13 & 12 & 0 & 0 & 16 & 0 & \multirow{2}{*}{0.9318} \\
\hline R5-CR275 & 0 & 11 & 11 & 11 & 0 & 0 & 17 & 0 & \\
\hline R6-CR233 & 12 & 0 & 0 & 0 & 13 & 8 & 0 & 17 & \multirow{2}{*}{0.7459} \\
\hline R7-CR161 & 12 & 0 & 0 & 0 & 9 & 11 & 0 & 18 & \\
\hline \multicolumn{4}{|c|}{ Chi-square $=495.4415$} & \multicolumn{3}{|c|}{$\mathrm{DF}=42$} & & \multicolumn{2}{|c|}{$P$-value $<0.00$} \\
\hline
\end{tabular}


Table H.2. (contd)

e. Replicate 5

\begin{tabular}{ccccc}
\hline Release & A & E & F & H \\
\hline R1-CR390 & 37 & 31 & 24 & 71 \\
R2-CR346 & 16 & 18 & 15 & 26 \\
R3-CR325 & 11 & 11 & 10 & 18 \\
R4-CR307 & 10 & 11 & 9 & 20 \\
R5-CR275 & 11 & 11 & 9 & 19 \\
R6-CR233 & 12 & 12 & 9 & 17 \\
R7-CR161 & 13 & 11 & 9 & 16 \\
\hline Chi-square $=4.8581$ & & DF $=18$ & $P$-value $=0.9991$ \\
\hline
\end{tabular}

f. Replicate 6

\begin{tabular}{cccrc}
\hline Release & A & E & F & H \\
\hline R1-CR390 & 37 & 40 & 29 & 58 \\
R2-CR346 & 17 & 17 & 14 & 28 \\
R3-CR325 & 11 & 10 & 10 & 19 \\
R4-CR307 & 12 & 11 & 9 & 18 \\
R5-CR275 & 11 & 10 & 10 & 19 \\
R6-CR233 & 11 & 13 & 9 & 17 \\
R7-CR161 & 12 & 10 & 9 & 16 \\
\hline Chi-square $=1.5118$ & DF $=18$ & & $P$-value $=1$ \\
\hline
\end{tabular}

g. Replicate 7

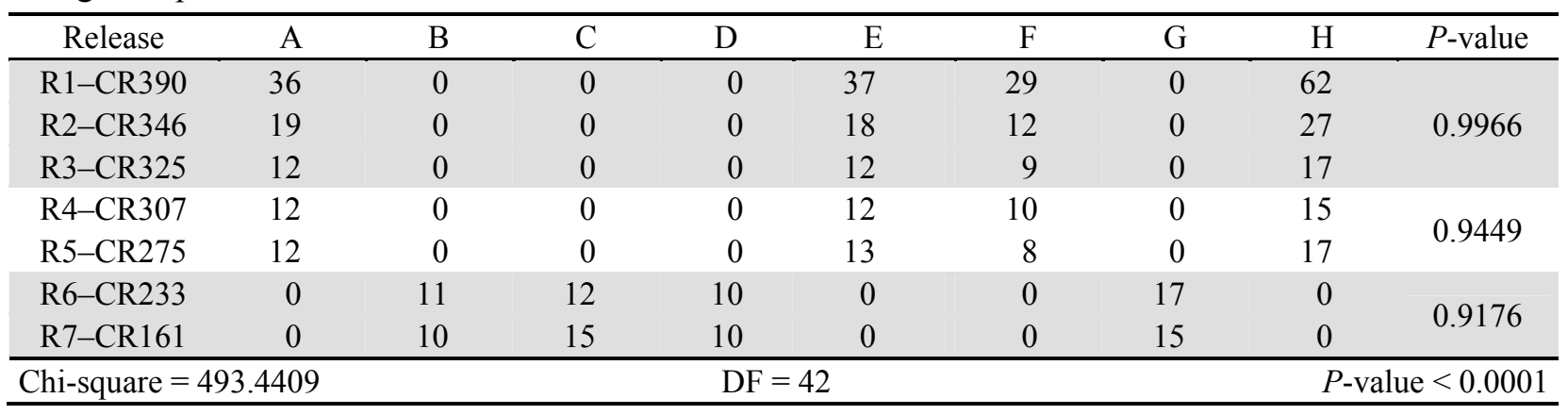

h. Replicate 8

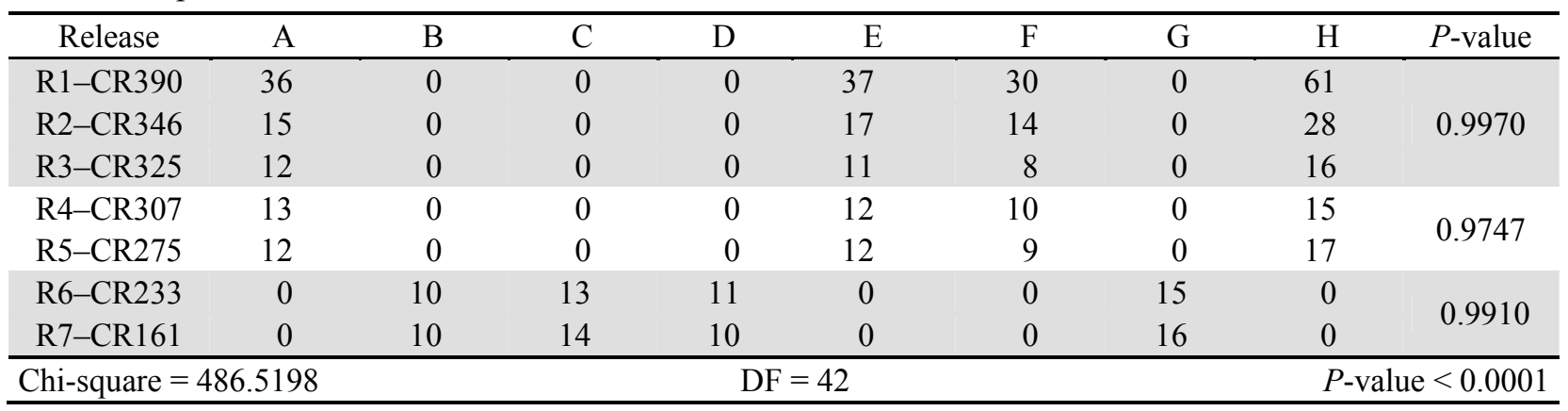


Table H.2. (contd)

i. Replicate 9

\begin{tabular}{ccccc}
\hline Release & B & C & D & G \\
\hline R1-CR390 & 35 & 43 & 38 & 48 \\
R2-CR346 & 16 & 20 & 16 & 24 \\
R3-CR325 & 10 & 13 & 11 & 16 \\
R4-CR307 & 11 & 14 & 9 & 16 \\
R5-CR275 & 11 & 13 & 10 & 16 \\
R6-CR233 & 10 & 11 & 11 & 15 \\
R7-CR161 & 11 & 12 & 11 & 16 \\
\hline Chi-square $=1.2239$ & DF $=18$ & & $P$-value $=1$ \\
\hline
\end{tabular}

j. Replicate 10

\begin{tabular}{crccc}
\hline Release & $\mathrm{B}$ & $\mathrm{C}$ & $\mathrm{D}$ & $\mathrm{G}$ \\
\hline R1-CR390 & 33 & 43 & 36 & 52 \\
R2-CR346 & 14 & 21 & 16 & 25 \\
R3-CR325 & 11 & 14 & 10 & 15 \\
R4-CR307 & 10 & 14 & 10 & 16 \\
R5-CR275 & 8 & 13 & 11 & 15 \\
R6-CR233 & 10 & 13 & 12 & 15 \\
R7-CR161 & 10 & 14 & 11 & 15 \\
\hline Chi-square $=1.0171$ & DF $=18$ & & $P$-value $=1$ \\
\hline
\end{tabular}

k. Replicate 11

\begin{tabular}{ccrrrrrrrr}
\hline Release & $\mathrm{A}$ & $\mathrm{B}$ & $\mathrm{C}$ & $\mathrm{D}$ & $\mathrm{E}$ & $\mathrm{F}$ & $\mathrm{G}$ & $\mathrm{H}$ & $P$-value \\
\hline R1-CR390 & 0 & 34 & 43 & 36 & 0 & 0 & 51 & 0 & \\
R2-CR346 & 0 & 16 & 21 & 15 & 0 & 0 & 24 & 0 & 0.9939 \\
R3-CR325 & 0 & 12 & 11 & 11 & 0 & 0 & 16 & 0 & \\
R4-CR307 & 0 & 11 & 14 & 10 & 0 & 0 & 15 & 0 & 0.9832 \\
R5-CR275 & 0 & 10 & 15 & 11 & 0 & 0 & 14 & 0 & \\
R6-CR233 & 12 & 0 & 0 & 0 & 12 & 10 & 0 & 15 & 0.9900 \\
R7-CR161 & 13 & 0 & 0 & 0 & 12 & 9 & 0 & 16 & \multicolumn{7}{c}{$P$-value $<0.0001$} \\
\hline Chi-square $=491.1992$ & & \multicolumn{7}{c}{ DF $=42$} &
\end{tabular}

1. Replicate 12

\begin{tabular}{ccrrrrrrrr}
\hline Release & $\mathrm{A}$ & $\mathrm{B}$ & $\mathrm{C}$ & $\mathrm{D}$ & $\mathrm{E}$ & $\mathrm{F}$ & $\mathrm{G}$ & $\mathrm{H}$ & $P$-value \\
\hline R1-CR390 & 0 & 34 & 46 & 36 & 0 & 0 & 48 & 0 & \\
R2-CR346 & 0 & 15 & 21 & 17 & 0 & 0 & 23 & 0 & 0.9999 \\
R3-CR325 & 0 & 11 & 13 & 11 & 0 & 0 & 15 & 0 & \\
R4-CR307 & 0 & 13 & 14 & 10 & 0 & 0 & 13 & 0 & 0.8539 \\
R5-CR275 & 0 & 12 & 11 & 13 & 0 & 0 & 13 & 0 & \\
R6-CR233 & 13 & 0 & 0 & 0 & 11 & 9 & 0 & 16 & 0.9295 \\
R7-CR161 & 12 & 0 & 0 & 0 & 12 & 7 & 0 & 18 & \multicolumn{7}{c}{$P$-value $<0.0001$} \\
\hline Chi-square $=491.908$ & \multicolumn{8}{c}{$\mathrm{DF}=42$} & \multicolumn{5}{c}{} \\
\hline
\end{tabular}


Table H.2. (contd)

m. Replicate 13

\begin{tabular}{cccccc}
\hline Release & A & E & F & G & H \\
\hline R1-CR390 & 34 & 0 & 27 & 50 & 51 \\
R2-CR346 & 19 & 17 & 16 & 0 & 24 \\
R3-CR325 & 12 & 11 & 10 & 0 & 17 \\
R4-CR307 & 12 & 12 & 9 & 0 & 17 \\
R5-CR275 & 12 & 12 & 9 & 0 & 17 \\
R6-CR233 & 13 & 13 & 7 & 0 & 17 \\
R7-CR161 & 12 & 11 & 8 & 0 & 18 \\
\hline Chi-square $=140.8547$ & \multicolumn{2}{c}{ DF $=24$} & \multicolumn{2}{c}{$P$-value $<0.0001$} \\
\hline
\end{tabular}

n. Replicate 14

\begin{tabular}{cccrcc}
\hline Release & A & E & F & G & H \\
\hline R1-CR390 & 35 & 0 & 31 & 48 & 50 \\
R2-CR346 & 18 & 19 & 14 & 0 & 23 \\
R3-CR325 & 13 & 12 & 9 & 0 & 16 \\
R4-CR307 & 13 & 13 & 10 & 0 & 14 \\
R5-CR275 & 12 & 12 & 9 & 0 & 17 \\
R6-CR233 & 12 & 11 & 10 & 0 & 17 \\
R7-CR161 & 14 & 13 & 7 & 0 & 16 \\
\hline Chi-square $=137.8706$ & DF $=24$ & \multicolumn{2}{c}{$P$-value $<0.0001$} \\
\hline
\end{tabular}

o. Replicate 15

\begin{tabular}{ccrrrrrrrr}
\hline Release & $\mathrm{A}$ & $\mathrm{B}$ & $\mathrm{C}$ & $\mathrm{D}$ & $\mathrm{E}$ & $\mathrm{F}$ & $\mathrm{G}$ & $\mathrm{H}$ & $P$-value \\
\hline R1-CR390 & 41 & 0 & 0 & 0 & 39 & 32 & 0 & 52 & \\
R2-CR346 & 20 & 0 & 0 & 0 & 20 & 13 & 0 & 23 & 0.9873 \\
R3-CR325 & 13 & 0 & 0 & 0 & 11 & 8 & 0 & 18 & \\
R4-CR307 & 13 & 0 & 0 & 0 & 12 & 8 & 0 & 17 & 0.9345 \\
R5-CR275 & 14 & 0 & 0 & 0 & 11 & 10 & 0 & 15 & \\
R6-CR233 & 0 & 13 & 11 & 10 & 0 & 0 & 16 & 0 & 0.9161 \\
R7-CR161 & 0 & 10 & 12 & 11 & 0 & 0 & 17 & 0 & \\
\hline Chi-square $=494.3843$ & & & DF $=42$ & & & & $<0.0001$ \\
\hline
\end{tabular}

p. Replicate 16

\begin{tabular}{cccccccccc}
\hline Release & $\mathrm{A}$ & $\mathrm{B}$ & $\mathrm{C}$ & $\mathrm{D}$ & $\mathrm{E}$ & $\mathrm{F}$ & $\mathrm{G}$ & $\mathrm{H}$ & $P$-value \\
\hline R1-CR390 & 40 & 0 & 0 & 0 & 39 & 32 & 0 & 52 & \\
R2-CR346 & 17 & 0 & 0 & 0 & 17 & 15 & 0 & 26 & 0.9959 \\
R3-CR325 & 13 & 0 & 0 & 0 & 12 & 8 & 0 & 17 & \\
R4-CR307 & 12 & 0 & 0 & 0 & 12 & 9 & 0 & 17 & 0.9933 \\
R5-CR275 & 12 & 0 & 0 & 0 & 12 & 8 & 0 & 18 & \\
R6-CR233 & 0 & 11 & 11 & 10 & 0 & 0 & 15 & 0 & 0.9883 \\
R7-CR161 & 0 & 12 & 10 & 11 & 0 & 0 & 15 & 0 & \\
\hline Chi-square $=484.8889$ & & & DF $=42$ & & & & $<0.0001$ \\
\hline
\end{tabular}


Table H.2. (contd)

q. Replicate 17

\begin{tabular}{ccccc}
\hline Release & B & C & D & G \\
\hline R1-CR390 & 32 & 42 & 33 & 55 \\
R2-CR346 & 15 & 17 & 18 & 23 \\
R3-CR325 & 12 & 10 & 12 & 16 \\
R4-CR307 & 11 & 11 & 11 & 17 \\
R5-CR275 & 12 & 9 & 12 & 17 \\
R6-CR233 & 11 & 12 & 10 & 16 \\
R7-CR161 & 12 & 10 & 11 & 15 \\
\hline Chi-square $=3.1892$ & DF $=18$ & & $P$-value $=1$ \\
\hline
\end{tabular}

r. Replicate 18

\begin{tabular}{ccccc}
\hline Release & B & C & D & G \\
\hline R1-CR390 & 36 & 42 & 35 & 50 \\
R2-CR346 & 17 & 16 & 16 & 26 \\
R3-CR325 & 11 & 11 & 12 & 15 \\
R4-CR307 & 12 & 11 & 9 & 18 \\
R5-CR275 & 11 & 11 & 11 & 16 \\
R6-CR233 & 12 & 11 & 13 & 14 \\
R7-CR161 & 12 & 12 & 12 & 14 \\
\hline Chi-square $=2.7843$ & DF $=18$ & & $P$-value $=1$ \\
\hline
\end{tabular}

s. Replicate 19

\begin{tabular}{ccrrrrrrrr}
\hline Release & $\mathrm{A}$ & $\mathrm{B}$ & $\mathrm{C}$ & $\mathrm{D}$ & $\mathrm{E}$ & $\mathrm{F}$ & $\mathrm{G}$ & $\mathrm{H}$ & $P$-value \\
\hline R1-CR390 & 0 & 41 & 36 & 38 & 0 & 0 & 49 & 0 & \\
R2-CR346 & 0 & 17 & 18 & 16 & 0 & 0 & 25 & 0 & 0.9882 \\
R3-CR325 & 0 & 11 & 12 & 13 & 0 & 0 & 14 & 0 & \\
R4-CR307 & 0 & 11 & 11 & 12 & 0 & 0 & 16 & 0 & 0.9352 \\
R5-CR275 & 0 & 13 & 12 & 10 & 0 & 0 & 15 & 0 & \\
R6-CR233 & 14 & 0 & 0 & 0 & 12 & 8 & 0 & 16 & 0.9704 \\
R7-CR161 & 12 & 0 & 0 & 0 & 12 & 9 & 0 & 17 & \\
\hline Chi-square $=492.9525$ & & & DF $=42$ & & & & $<0.0001$ \\
\hline
\end{tabular}

t. Replicate 20

\begin{tabular}{crrrrrrrrr}
\hline Release & A & B & C & D & E & F & G & H & $P$-value \\
\hline R1-CR390 & 0 & 39 & 37 & 36 & 0 & 0 & 52 & 0 & \\
R2-CR346 & 0 & 18 & 16 & 17 & 0 & 0 & 24 & 0 & 0.9996 \\
R3-CR325 & 0 & 11 & 12 & 12 & 0 & 0 & 15 & 0 & \\
R4-CR307 & 0 & 12 & 12 & 12 & 0 & 0 & 14 & 0 & 0.9836 \\
R5-CR275 & 0 & 11 & 13 & 11 & 0 & 0 & 15 & 0 & \\
R6-CR233 & 12 & 0 & 0 & 0 & 12 & 10 & 0 & 16 & 0.9705 \\
R7-CR161 & 12 & 0 & 0 & 0 & 12 & 8 & 0 & 17 & \\
\hline \multicolumn{7}{l}{ Chi-square $=490.2024$} & & & DF $=42$ \\
\hline
\end{tabular}


Table H.2. (contd)

u. Replicate 21

\begin{tabular}{cccrc}
\hline Release & A & E & F & H \\
\hline R1-CR390 & 41 & 41 & 29 & 53 \\
R2-CR346 & 20 & 18 & 14 & 24 \\
R3-CR325 & 12 & 13 & 9 & 16 \\
R4-CR307 & 13 & 14 & 8 & 15 \\
R5-CR275 & 11 & 15 & 8 & 16 \\
R6-CR233 & 11 & 14 & 10 & 15 \\
R7-CR161 & 11 & 12 & 8 & 17 \\
\hline Chi-square $=1.8491$ & DF $=18$ & & $P$-value $=1$ \\
\hline
\end{tabular}

v. Replicate 22

\begin{tabular}{ccccc}
\hline Release & A & E & F & H \\
\hline R1-CR390 & 39 & 40 & 32 & 48 \\
R2-CR346 & 20 & 18 & 15 & 23 \\
R3-CR325 & 10 & 15 & 10 & 15 \\
R4-CR307 & 12 & 14 & 9 & 15 \\
R5-CR275 & 12 & 14 & 8 & 16 \\
R6-CR233 & 10 & 13 & 10 & 17 \\
R7-CR161 & 12 & 11 & 10 & 17 \\
\hline Chi-square $=2.6222$ & \multicolumn{2}{c}{ DF $=18$} & $P$-value $=1$ \\
\hline
\end{tabular}

w. Replicate 23

\begin{tabular}{|c|c|c|c|c|c|c|c|c|c|}
\hline Release & $\mathrm{A}$ & $\mathrm{B}$ & $\mathrm{C}$ & $\mathrm{D}$ & $\mathrm{E}$ & $\mathrm{F}$ & $\mathrm{G}$ & $\mathrm{H}$ & $P$-value \\
\hline R1-CR390 & 41 & 0 & 0 & 0 & 41 & 30 & 0 & 52 & \multirow{3}{*}{0.9994} \\
\hline R2-CR346 & 18 & 0 & 0 & 0 & 20 & 15 & 0 & 23 & \\
\hline R3-CR325 & 12 & 0 & 0 & 0 & 14 & 9 & 0 & 15 & \\
\hline R4-CR307 & 13 & 0 & 0 & 0 & 12 & 10 & 0 & 15 & \multirow{2}{*}{0.9949} \\
\hline R5-CR275 & 12 & 0 & 0 & 0 & 12 & 10 & 0 & 16 & \\
\hline R6-CR233 & 0 & 10 & 11 & 12 & 0 & 0 & 16 & 0 & \multirow{2}{*}{0.9904} \\
\hline R7-CR161 & 0 & 11 & 11 & 11 & 0 & 0 & 17 & 0 & \\
\hline \multicolumn{3}{|c|}{ Chi-square $=490.2628$} & \multicolumn{3}{|c|}{$\mathrm{DF}=42$} & & & & $<0.0001$ \\
\hline
\end{tabular}

x. Replicate 24

\begin{tabular}{|c|c|c|c|c|c|c|c|c|c|}
\hline Release & A & B & $\mathrm{C}$ & $\mathrm{D}$ & $\mathrm{E}$ & $\mathrm{F}$ & G & $\mathrm{H}$ & $P$-value \\
\hline R1-CR390 & 40 & 0 & 0 & 0 & 45 & 27 & 0 & 52 & \multirow{3}{*}{0.9923} \\
\hline R2-CR346 & 16 & 0 & 0 & 0 & 22 & 14 & 0 & 23 & \\
\hline R3-CR325 & 12 & 0 & 0 & 0 & 12 & 9 & 0 & 17 & \\
\hline R4-CR307 & 12 & 0 & 0 & 0 & 13 & 8 & 0 & 17 & \multirow{2}{*}{0.9590} \\
\hline R5-CR275 & 11 & 0 & 0 & 0 & 12 & 10 & 0 & 17 & \\
\hline R6-CR233 & 0 & 12 & 13 & 11 & 0 & 0 & 14 & 0 & \multirow{2}{*}{0.9836} \\
\hline R7-CR161 & 0 & 11 & 12 & 12 & 0 & 0 & 15 & 0 & \\
\hline \multicolumn{3}{|c|}{ Chi-square $=491.5424$} & & $F=4$ & & & & & $<0.0001$ \\
\hline
\end{tabular}


Table H.2. (contd)

y. Replicate 25

\begin{tabular}{ccccc}
\hline Release & B & C & D & G \\
\hline R1-CR390 & 39 & 47 & 36 & 40 \\
R2-CR346 & 16 & 16 & 16 & 26 \\
R3-CR325 & 10 & 13 & 11 & 16 \\
R4-CR307 & 12 & 11 & 10 & 17 \\
R5-CR275 & 10 & 12 & 11 & 17 \\
R6-CR233 & 12 & 12 & 11 & 15 \\
R7-CR161 & 11 & 11 & 11 & 12 \\
\hline Chi-square $=5.3708$ & DF $=18$ & \multicolumn{2}{c}{$P$-value $=0.9982$} \\
\hline
\end{tabular}

z. Replicate 26

\begin{tabular}{ccccc}
\hline Release & B & C & D & G \\
\hline R1-CR390 & 36 & 38 & 37 & 53 \\
R2-CR346 & 16 & 20 & 16 & 24 \\
R3-CR325 & 11 & 13 & 11 & 15 \\
R4-CR307 & 10 & 13 & 11 & 16 \\
R5-CR275 & 11 & 13 & 11 & 15 \\
R6-CR233 & 11 & 11 & 11 & 16 \\
R7-CR161 & 10 & 10 & 8 & 12 \\
\hline Chi-square $=1.0206$ & DF $=18$ & & $P$-value $=1$ \\
\hline
\end{tabular}

aa. Replicate 27

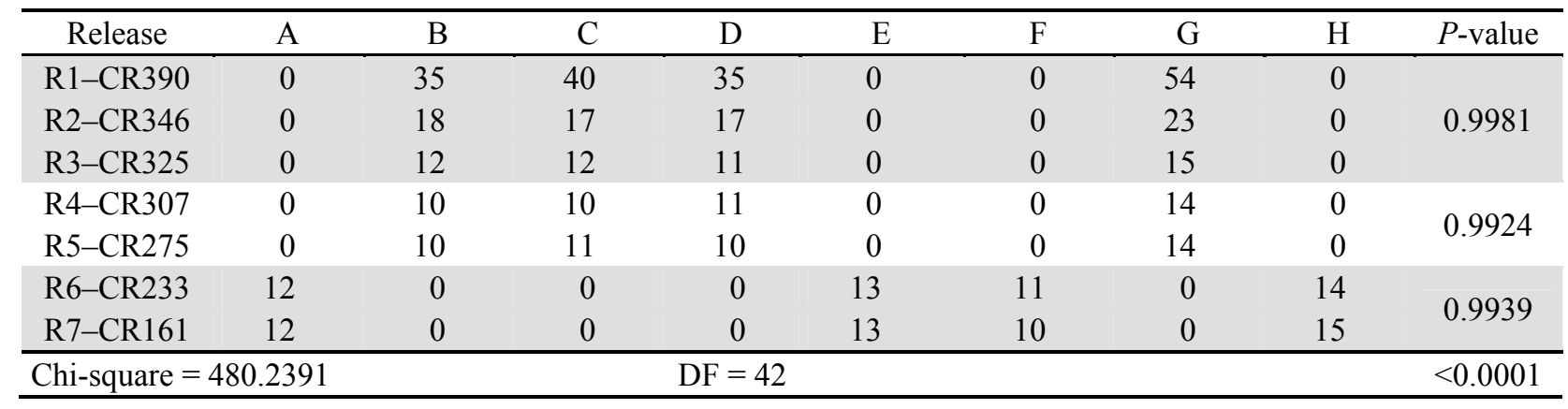

bb. Replicate 28

\begin{tabular}{crrrrrrrrr}
\hline Release & $\mathrm{A}$ & $\mathrm{B}$ & $\mathrm{C}$ & $\mathrm{D}$ & $\mathrm{E}$ & $\mathrm{F}$ & $\mathrm{G}$ & $\mathrm{H}$ & $P$-value \\
\hline R1-CR390 & 0 & 38 & 41 & 39 & 0 & 0 & 46 & 0 & \\
R2-CR346 & 0 & 16 & 18 & 18 & 0 & 0 & 24 & 0 & 0.9984 \\
R3-CR325 & 0 & 10 & 11 & 10 & 0 & 0 & 14 & 0 & \\
R4-CR307 & 0 & 11 & 11 & 9 & 0 & 0 & 14 & 0 & 0.9284 \\
R5-CR275 & 0 & 9 & 13 & 10 & 0 & 0 & 13 & 0 & \\
R6-CR233 & 12 & 0 & 0 & 0 & 12 & 9 & 0 & 16 & 0.8987 \\
R7-CR161 & 10 & 0 & 0 & 0 & 15 & 10 & 0 & 15 & \\
\hline
\end{tabular}


Table H.2. (contd)

cc. Replicate 29

\begin{tabular}{cccrc}
\hline Release & A & E & F & H \\
\hline R1-CR390 & 37 & 43 & 34 & 50 \\
R2-CR346 & 18 & 18 & 16 & 24 \\
R3-CR325 & 13 & 14 & 8 & 15 \\
R4-CR307 & 12 & 13 & 9 & 16 \\
R5-CR275 & 12 & 12 & 10 & 15 \\
R6-CR233 & 11 & 12 & 10 & 16 \\
R7-CR161 & 12 & 12 & 10 & 16 \\
\hline Chi-square $=1.2964$ & DF $=18$ & & $P$-value $=1$ \\
\hline
\end{tabular}

dd. Replicate 30

\begin{tabular}{ccccc}
\hline Release & A & E & F & H \\
\hline R1-CR390 & 21 & 21 & 16 & 24 \\
R2-CR346 & 17 & 21 & 16 & 22 \\
R3-CR325 & 12 & 13 & 10 & 15 \\
R4-CR307 & 12 & 12 & 10 & 16 \\
R5-CR275 & 11 & 14 & 10 & 15 \\
R6-CR233 & 12 & 12 & 10 & 16 \\
R7-CR161 & 12 & 13 & 9 & 16 \\
\hline Chi-square $=0.9309$ & DF $=18$ & & $P$-value $=1$ \\
\hline
\end{tabular}

ee. Replicate 31

\begin{tabular}{|c|c|c|c|c|c|c|c|c|c|}
\hline Release & $\mathrm{A}$ & $\mathrm{B}$ & $\mathrm{C}$ & $\mathrm{D}$ & $E$ & $\mathrm{~F}$ & $\mathrm{G}$ & $\mathrm{H}$ & $P$-value \\
\hline R1-CR390 & 33 & 0 & 0 & 0 & 35 & 26 & 0 & 44 & \multirow{3}{*}{1.0000} \\
\hline R2-CR346 & 14 & 0 & 0 & 0 & 16 & 11 & 0 & 19 & \\
\hline R3-CR325 & 12 & 0 & 0 & 0 & 12 & 10 & 0 & 16 & \\
\hline R4-CR307 & 12 & 0 & 0 & 0 & 13 & 11 & 0 & 19 & \multirow{2}{*}{0.9684} \\
\hline R5-CR275 & 12 & 0 & 0 & 0 & 15 & 11 & 0 & 17 & \\
\hline R6-CR233 & 0 & 13 & 13 & 13 & 0 & 0 & 16 & 0 & \multirow{2}{*}{0.9986} \\
\hline R7-CR161 & 0 & 14 & 15 & 14 & 0 & 0 & 17 & 0 & \\
\hline \multicolumn{3}{|c|}{ Chi-square $=473.8784$} & & $\overline{\mathrm{DF}}=$ & & & & & $<0.0001$ \\
\hline
\end{tabular}

ff. Replicate 32

\begin{tabular}{|c|c|c|c|c|c|c|c|c|c|}
\hline Release & A & $\mathrm{B}$ & $\mathrm{C}$ & $\mathrm{D}$ & $\mathrm{E}$ & $\mathrm{F}$ & $\mathrm{G}$ & $\mathrm{H}$ & $P$-value \\
\hline R1-CR390 & 33 & 0 & 0 & 0 & 39 & 28 & 0 & 40 & \multirow{3}{*}{0.9976} \\
\hline R2-CR346 & 15 & 0 & 0 & 0 & 17 & 13 & 0 & 20 & \\
\hline R3-CR325 & 13 & 0 & 0 & 0 & 13 & 11 & 0 & 18 & \\
\hline R4-CR307 & 12 & 0 & 0 & 0 & 14 & 11 & 0 & 18 & \multirow{2}{*}{0.9925} \\
\hline R5-CR275 & 13 & 0 & 0 & 0 & 14 & 13 & 0 & 20 & \\
\hline R6-CR233 & 0 & 12 & 12 & 11 & 0 & 0 & 15 & 0 & \multirow{2}{*}{0.9958} \\
\hline R7-CR161 & 0 & 15 & 14 & 14 & 0 & 0 & 17 & 0 & \\
\hline Chi-sq & $\overline{=48}$ & & & $\overline{\mathrm{DF}}=4$ & & & & & $<0.0001$ \\
\hline
\end{tabular}


Table H.3. Estimates of reach survival and cumulative survival for a) $\mathrm{CH} 1$ and b) STH, along with $P$-values associated with the $F$-tests of homogeneous survival across fish tagged by different staff members.

a. $\mathrm{CH} 1$

1) Release 1 - Reach survival

\begin{tabular}{|c|c|c|c|c|c|c|c|c|c|c|c|c|c|c|}
\hline & \multicolumn{2}{|c|}{ Release to CR349 } & \multicolumn{2}{|c|}{ CR349 to CR325 } & \multicolumn{2}{|c|}{ CR325 to CR309 } & \multicolumn{2}{|c|}{ CR309 to CR275 } & \multicolumn{2}{|c|}{ CR275 to CR234 } & \multicolumn{2}{|c|}{ CR234 to CR161 } & \multicolumn{2}{|c|}{ CR161 to CR113 } \\
\hline & $\hat{S}$ & SE & $\hat{S}$ & SE & $\hat{S}$ & $\mathrm{SE}$ & $\hat{S}$ & $\mathrm{SE}$ & $\hat{S}$ & $\mathrm{SE}$ & $\hat{S}$ & $\mathrm{SE}$ & $\hat{S}$ & $\mathrm{SE}$ \\
\hline A & 0.9823 & 0.0079 & 0.9636 & 0.0113 & 0.9968 & 0.0039 & 0.9579 & 0.0125 & 0.9958 & 0.0042 & 0.9908 & 0.0132 & 0.9345 & 0.0297 \\
\hline B & 0.9795 & 0.0083 & 0.9613 & 0.0115 & 0.9965 & 0.0037 & 0.9561 & 0.0125 & 0.9958 & 0.0042 & 0.9874 & 0.0123 & 0.9435 & 0.0255 \\
\hline $\mathrm{C}$ & 0.9731 & 0.0088 & 0.9601 & 0.0109 & 0.9935 & 0.0046 & 0.9493 & 0.0126 & 0.9888 & 0.0064 & 0.9399 & 0.0162 & 0.9447 & 0.0278 \\
\hline D & 0.9824 & 0.0078 & 0.9501 & 0.0131 & 0.9731 & 0.0101 & 0.9688 & 0.0109 & 1.0000 & 0.0000 & 0.9502 & 0.0154 & 0.9874 & 0.0248 \\
\hline E & 0.9643 & 0.0117 & 0.9628 & 0.0122 & 1.0011 & 0.0006 & 0.9650 & 0.0123 & 0.9951 & 0.0049 & 0.9379 & 0.0194 & 0.9355 & 0.0343 \\
\hline $\mathrm{H}$ & 0.9802 & 0.0069 & 0.9622 & 0.0096 & 0.9951 & 0.0038 & 0.9602 & 0.0101 & 0.9970 & 0.0030 & 0.9455 & 0.0139 & 0.9529 & 0.0228 \\
\hline$P$-value & \multicolumn{2}{|c|}{0.8084} & \multicolumn{2}{|c|}{0.9719} & \multicolumn{2}{|c|}{0.0087} & \multicolumn{2}{|c|}{0.6973} & \multicolumn{2}{|c|}{0.7485} & \multicolumn{2}{|c|}{0.0858} & \multicolumn{2}{|c|}{0.5196} \\
\hline
\end{tabular}

2) Release 1 - Cumulative survival

\begin{tabular}{|c|c|c|c|c|c|c|c|c|c|c|c|c|c|c|}
\hline & \multicolumn{2}{|c|}{ Release to CR349 } & \multicolumn{2}{|c|}{ Release to CR325 } & \multicolumn{2}{|c|}{ Release to CR309 } & \multicolumn{2}{|c|}{ Release to CR275 } & \multicolumn{2}{|c|}{ Release to CR234 } & \multicolumn{2}{|c|}{ Release to CR161 } & \multicolumn{2}{|c|}{ Release to CR113 } \\
\hline & $\hat{S}$ & SE & $\hat{S}$ & SE & $\hat{S}$ & SE & $\hat{S}$ & SE & $\hat{S}$ & SE & $\hat{S}$ & SE & $\hat{S}$ & SE \\
\hline A & 0.9823 & 0.0079 & 0.9465 & 0.0135 & 0.9435 & 0.0139 & 0.9038 & 0.0176 & 0.9000 & 0.0179 & 0.8917 & 0.0213 & 0.8332 & 0.0301 \\
\hline B & 0.9795 & 0.0083 & 0.9416 & 0.0138 & 0.9382 & 0.0141 & 0.8970 & 0.0179 & 0.8932 & 0.0181 & 0.8820 & 0.0210 & 0.8321 & 0.0275 \\
\hline $\mathrm{C}$ & 0.9731 & 0.0088 & 0.9343 & 0.0136 & 0.9282 & 0.0141 & 0.8812 & 0.0178 & 0.8713 & 0.0183 & 0.8190 & 0.0223 & 0.7737 & 0.0296 \\
\hline $\mathrm{D}$ & 0.9824 & 0.0078 & 0.9334 & 0.0149 & 0.9083 & 0.0172 & 0.8799 & 0.0193 & 0.8799 & 0.0193 & 0.8361 & 0.0228 & 0.8255 & 0.0296 \\
\hline $\mathrm{E}$ & 0.9643 & 0.0117 & 0.9284 & 0.0163 & 0.9294 & 0.0163 & 0.8969 & 0.0192 & 0.8926 & 0.0195 & 0.8371 & 0.0252 & 0.7831 & 0.0351 \\
\hline $\mathrm{F}$ & 0.9815 & 0.0092 & 0.9395 & 0.0163 & 0.9353 & 0.0169 & 0.8983 & 0.0208 & 0.8880 & 0.0215 & 0.8433 & 0.0276 & 0.7802 & 0.0374 \\
\hline G & 0.9799 & 0.0066 & 0.9508 & 0.0102 & 0.9395 & 0.0113 & 0.9218 & 0.0127 & 0.9171 & 0.0131 & 0.8658 & 0.0170 & 0.8652 & 0.0223 \\
\hline $\mathrm{H}$ & 0.9802 & 0.0069 & 0.9431 & 0.0115 & 0.9385 & 0.0120 & 0.9012 & 0.0149 & 0.8985 & 0.0150 & 0.8496 & 0.0189 & 0.8096 & 0.0251 \\
\hline$P$-value & \multicolumn{2}{|c|}{0.8084} & \multicolumn{2}{|c|}{0.9613} & \multicolumn{2}{|c|}{0.7767} & \multicolumn{2}{|c|}{0.7912} & \multicolumn{2}{|c|}{0.7700} & \multicolumn{2}{|c|}{0.2749} & \multicolumn{2}{|c|}{0.3320} \\
\hline
\end{tabular}


Table H.3. (contd)

3) Release 2 - Reach survival

\begin{tabular}{|c|c|c|c|c|c|c|c|c|c|c|c|c|}
\hline & \multicolumn{2}{|c|}{ Release to CR325 } & \multicolumn{2}{|c|}{ CR325 to CR309 } & \multicolumn{2}{|c|}{ CR309 to CR275 } & \multicolumn{2}{|c|}{ CR275 to CR234 } & \multicolumn{2}{|c|}{ CR234 to CR161 } & \multicolumn{2}{|c|}{ CR161 to CR113 } \\
\hline & $\hat{S}$ & SE & $\hat{S}$ & SE & $\hat{S}$ & SE & $\hat{S}$ & $\mathrm{SE}$ & $\hat{S}$ & SE & $\hat{S}$ & $\mathrm{SE}$ \\
\hline A & 1.0005 & 0.0004 & 0.9853 & 0.0106 & 0.9474 & 0.0194 & 1.0000 & 0.0000 & 0.9568 & 0.0211 & 0.9785 & 0.0364 \\
\hline B & 1.0000 & 0.0000 & 1.0000 & 0.0000 & 0.9616 & 0.0173 & 0.9908 & 0.0091 & 0.9540 & 0.0243 & 0.9583 & 0.0450 \\
\hline $\mathrm{C}$ & 1.0001 & 0.0001 & 0.9931 & 0.0069 & 0.9046 & 0.0244 & 0.9919 & 0.0080 & 0.9154 & 0.0274 & 0.9372 & 0.0382 \\
\hline $\mathrm{D}$ & 0.9932 & 0.0075 & 0.9690 & 0.0153 & 0.9459 & 0.0201 & 0.9911 & 0.0089 & 0.9676 & 0.0191 & 1.0046 & 0.0362 \\
\hline $\mathrm{E}$ & 0.9879 & 0.0095 & 0.9783 & 0.0124 & 0.9731 & 0.0137 & 0.9919 & 0.0080 & 0.9643 & 0.0219 & 0.9551 & 0.0370 \\
\hline $\mathrm{F}$ & 0.9827 & 0.0124 & 0.9908 & 0.0094 & 0.9725 & 0.0157 & 1.0000 & 0.0000 & 0.9351 & 0.0285 & 0.9268 & 0.0414 \\
\hline G & 0.9746 & 0.0112 & 1.0002 & 0.0002 & 0.9690 & 0.0126 & 0.9942 & 0.0058 & 0.9585 & 0.0174 & 0.9448 & 0.0325 \\
\hline $\mathrm{H}$ & 0.9898 & 0.0074 & 0.9895 & 0.0076 & 0.9523 & 0.0158 & 0.9937 & 0.0063 & 0.9546 & 0.0219 & 0.9101 & 0.0350 \\
\hline$P$-value & \multicolumn{2}{|c|}{0.2701} & \multicolumn{2}{|c|}{0.3361} & \multicolumn{2}{|c|}{0.1281} & \multicolumn{2}{|c|}{0.9480} & \multicolumn{2}{|c|}{0.7861} & \multicolumn{2}{|c|}{0.7442} \\
\hline
\end{tabular}

4) Release 2-Cumulative survival

\begin{tabular}{|c|c|c|c|c|c|c|c|c|c|c|c|c|}
\hline & \multicolumn{2}{|c|}{ Release to CR325 } & \multicolumn{2}{|c|}{ Release to CR309 } & \multicolumn{2}{|c|}{ Release to CR275 } & \multicolumn{2}{|c|}{ Release to CR234 } & \multicolumn{2}{|c|}{ Release to CR161 } & \multicolumn{2}{|c|}{ Release to CR113 } \\
\hline & $\hat{S}$ & SE & $\hat{S}$ & SE & $\hat{S}$ & SE & $\hat{S}$ & SE & $\hat{S}$ & SE & $\hat{S}$ & SE \\
\hline A & 1.0005 & 0.0004 & 0.9857 & 0.0103 & 0.9338 & 0.0213 & 0.9338 & 0.0213 & 0.8935 & 0.0284 & 0.8743 & 0.0403 \\
\hline B & 1.0000 & 0.0000 & 1.0000 & 0.0000 & 0.9616 & 0.0173 & 0.9528 & 0.0188 & 0.9089 & 0.0293 & 0.8710 & 0.0457 \\
\hline $\mathrm{C}$ & 1.0001 & 0.0001 & 0.9932 & 0.0068 & 0.8984 & 0.0250 & 0.8912 & 0.0257 & 0.8158 & 0.0339 & 0.7646 & 0.0420 \\
\hline D & 0.9932 & 0.0075 & 0.9624 & 0.0165 & 0.9104 & 0.0249 & 0.9023 & 0.0258 & 0.8730 & 0.0303 & 0.8770 & 0.0419 \\
\hline E & 0.9879 & 0.0095 & 0.9664 & 0.0148 & 0.9405 & 0.0196 & 0.9329 & 0.0205 & 0.8996 & 0.0284 & 0.8592 & 0.0384 \\
\hline $\mathrm{F}$ & 0.9827 & 0.0124 & 0.9737 & 0.0151 & 0.9469 & 0.0211 & 0.9469 & 0.0211 & 0.8854 & 0.0334 & 0.8206 & 0.0439 \\
\hline G & 0.9746 & 0.0112 & 0.9748 & 0.0112 & 0.9445 & 0.0164 & 0.9391 & 0.0170 & 0.9001 & 0.0231 & 0.8504 & 0.0345 \\
\hline $\mathrm{H}$ & 0.9898 & 0.0074 & 0.9793 & 0.0104 & 0.9326 & 0.0182 & 0.9267 & 0.0189 & 0.8846 & 0.0271 & 0.8050 & 0.0352 \\
\hline$P$-value & \multicolumn{2}{|c|}{0.2701} & \multicolumn{2}{|c|}{0.3867} & \multicolumn{2}{|c|}{0.4513} & \multicolumn{2}{|c|}{0.4331} & \multicolumn{2}{|c|}{0.4395} & \multicolumn{2}{|c|}{0.4395} \\
\hline
\end{tabular}


Table H.3. (contd)

5) Release 3 - Reach survival

\begin{tabular}{|c|c|c|c|c|c|c|c|c|c|c|}
\hline & \multicolumn{2}{|c|}{ Release to CR309 } & \multicolumn{2}{|c|}{ CR309 to CR275 } & \multicolumn{2}{|c|}{ CR275 to CR234 } & \multicolumn{2}{|c|}{ CR234 to CR161 } & \multicolumn{2}{|c|}{ CR161 to CR113 } \\
\hline & $\hat{S}$ & SE & $\hat{S}$ & SE & $\hat{S}$ & SE & $\hat{S}$ & SE & $\hat{S}$ & SE \\
\hline $\mathrm{A}$ & 0.9803 & 0.0143 & 0.9375 & 0.0250 & 0.9882 & 0.0117 & 0.9612 & 0.0261 & 0.9579 & 0.0593 \\
\hline B & 0.9886 & 0.0113 & 0.9791 & 0.0162 & 0.9744 & 0.0179 & 0.9209 & 0.0308 & 1.0148 & 0.0412 \\
\hline $\mathrm{C}$ & 1.0000 & 0.0000 & 0.9592 & 0.0202 & 0.9888 & 0.0112 & 0.9506 & 0.0240 & 1.0080 & 0.0294 \\
\hline $\mathrm{D}$ & 1.0000 & 0.0000 & 0.9413 & 0.0259 & 0.9865 & 0.0134 & 0.8863 & 0.0363 & 1.0341 & 0.0272 \\
\hline $\mathrm{E}$ & 0.9899 & 0.0101 & 0.9796 & 0.0143 & 1.0000 & 0.0000 & 0.9901 & 0.0156 & 0.9946 & 0.0488 \\
\hline $\mathrm{F}$ & 0.9738 & 0.0192 & 0.9565 & 0.0246 & 1.0000 & 0.0000 & 0.9418 & 0.0333 & 1.0445 & 0.0708 \\
\hline G & 0.9763 & 0.0137 & 0.9597 & 0.0181 & 0.9904 & 0.0096 & 0.9298 & 0.0273 & 0.9241 & 0.0363 \\
\hline $\mathrm{H}$ & 0.9798 & 0.0128 & 0.9147 & 0.0246 & 1.0000 & 0.0000 & 0.9734 & 0.0219 & 0.9332 & 0.0431 \\
\hline$P$-value & \multicolumn{2}{|c|}{0.7449} & \multicolumn{2}{|c|}{0.4098} & \multicolumn{2}{|c|}{0.7639} & \multicolumn{2}{|c|}{0.2063} & \multicolumn{2}{|c|}{0.4650} \\
\hline
\end{tabular}

6) Release 3 -Cumulative survival

\begin{tabular}{|c|c|c|c|c|c|c|c|c|c|c|}
\hline & \multicolumn{2}{|c|}{ Release to CR309 } & \multicolumn{2}{|c|}{ Release to CR275 } & \multicolumn{2}{|c|}{ Release to CR234 } & \multicolumn{2}{|c|}{ Release to CR161 } & \multicolumn{2}{|c|}{ Release to CR113 } \\
\hline & $\hat{S}$ & SE & $\hat{S}$ & SE & $\hat{S}$ & SE & $\hat{S}$ & SE & $\hat{S}$ & SE \\
\hline A & 0.9803 & 0.0143 & 0.9190 & 0.0277 & 0.9082 & 0.0292 & 0.8729 & 0.0367 & 0.8362 & 0.0593 \\
\hline $\mathrm{B}$ & 0.9886 & 0.0113 & 0.9680 & 0.0195 & 0.9432 & 0.0247 & 0.8685 & 0.0369 & 0.8814 & 0.0505 \\
\hline $\mathrm{C}$ & 1.0000 & 0.0000 & 0.9592 & 0.0202 & 0.9485 & 0.0225 & 0.9016 & 0.0312 & 0.9087 & 0.0397 \\
\hline $\mathrm{D}$ & 1.0000 & 0.0000 & 0.9413 & 0.0259 & 0.9286 & 0.0281 & 0.8230 & 0.0419 & 0.8511 & 0.0483 \\
\hline $\mathrm{E}$ & 0.9899 & 0.0101 & 0.9697 & 0.0172 & 0.9697 & 0.0172 & 0.9601 & 0.0228 & 0.9549 & 0.0494 \\
\hline $\mathrm{F}$ & 0.9738 & 0.0192 & 0.9315 & 0.0296 & 0.9315 & 0.0296 & 0.8773 & 0.0417 & 0.9163 & 0.0720 \\
\hline G & 0.9763 & 0.0137 & 0.9370 & 0.0219 & 0.9280 & 0.0231 & 0.8628 & 0.0332 & 0.7973 & 0.0406 \\
\hline $\mathrm{H}$ & 0.9798 & 0.0128 & 0.8963 & 0.0262 & 0.8963 & 0.0262 & 0.8725 & 0.0322 & 0.8142 & 0.0441 \\
\hline$P$-value & \multicolumn{2}{|c|}{0.7449} & \multicolumn{2}{|c|}{0.3474} & \multicolumn{2}{|c|}{0.5715} & \multicolumn{2}{|c|}{0.2765} & \multicolumn{2}{|c|}{0.3432} \\
\hline
\end{tabular}


Table H.3. (contd)

7) Release 4-Reach survival

\begin{tabular}{|c|c|c|c|c|c|c|c|c|}
\hline & \multicolumn{2}{|c|}{ Release to CR275 } & \multicolumn{2}{|c|}{ CR275 to CR234 } & \multicolumn{2}{|c|}{ CR234 to CR161 } & \multicolumn{2}{|c|}{ CR161 to CR113 } \\
\hline & $\hat{S}$ & $\mathrm{SE}$ & $\hat{S}$ & SE & $\hat{S}$ & SE & $\hat{S}$ & $\mathrm{SE}$ \\
\hline A & 1.0015 & 0.0016 & 0.9880 & 0.0120 & 0.9347 & 0.0336 & 0.8793 & 0.0537 \\
\hline B & 0.9765 & 0.0164 & 1.0000 & 0.0000 & 0.9878 & 0.0181 & 0.9584 & 0.0470 \\
\hline $\mathrm{C}$ & 1.0016 & 0.0013 & 0.9780 & 0.0154 & 0.9818 & 0.0193 & 0.9711 & 0.0369 \\
\hline D & 0.9881 & 0.0118 & 1.0000 & 0.0000 & 0.9252 & 0.0312 & 0.9399 & 0.0418 \\
\hline E & 1.0011 & 0.0011 & 0.9891 & 0.0108 & 0.9273 & 0.0324 & 0.8360 & 0.0514 \\
\hline $\mathrm{F}$ & 0.9870 & 0.0129 & 1.0000 & 0.0000 & 0.9554 & 0.0263 & 1.0181 & 0.0456 \\
\hline G & 0.9924 & 0.0081 & 0.9912 & 0.0087 & 0.9448 & 0.0233 & 0.9949 & 0.0436 \\
\hline $\mathrm{H}$ & 0.9711 & 0.0146 & 0.9917 & 0.0083 & 0.9704 & 0.0197 & 0.9724 & 0.0419 \\
\hline$P$-value & \multicolumn{2}{|c|}{0.2677} & \multicolumn{2}{|c|}{0.7656} & \multicolumn{2}{|c|}{0.5274} & \multicolumn{2}{|c|}{0.0888} \\
\hline
\end{tabular}

8) Release 4-Cumulative survival

\begin{tabular}{|c|c|c|c|c|c|c|c|c|}
\hline & \multicolumn{2}{|c|}{ Release to CR275 } & \multicolumn{2}{|c|}{ Release to CR234 } & \multicolumn{2}{|c|}{ Release to CR161 } & \multicolumn{2}{|c|}{ Release to CR113 } \\
\hline & $\hat{S}$ & $\mathrm{SE}$ & $\hat{S}$ & $\mathrm{SE}$ & $\hat{S}$ & SE & $\hat{S}$ & $\mathrm{SE}$ \\
\hline A & 1.0015 & 0.0016 & 0.9895 & 0.0105 & 0.9249 & 0.0347 & 0.8133 & 0.0517 \\
\hline B & 0.9765 & 0.0164 & 0.9765 & 0.0164 & 0.9645 & 0.0240 & 0.9244 & 0.0476 \\
\hline $\mathrm{C}$ & 1.0016 & 0.0013 & 0.9796 & 0.0143 & 0.9617 & 0.0235 & 0.9340 & 0.0381 \\
\hline D & 0.9881 & 0.0118 & 0.9881 & 0.0118 & 0.9142 & 0.0328 & 0.8593 & 0.0465 \\
\hline E & 1.0011 & 0.0011 & 0.9902 & 0.0098 & 0.9182 & 0.0333 & 0.7676 & 0.0498 \\
\hline $\mathrm{F}$ & 0.9870 & 0.0129 & 0.9870 & 0.0129 & 0.9430 & 0.0287 & 0.9600 & 0.0494 \\
\hline G & 0.9924 & 0.0081 & 0.9837 & 0.0114 & 0.9294 & 0.0254 & 0.9247 & 0.0454 \\
\hline $\mathrm{H}$ & 0.9711 & 0.0146 & 0.9630 & 0.0163 & 0.9344 & 0.0247 & 0.9086 & 0.0426 \\
\hline$P$-value & \multicolumn{2}{|c|}{0.2677} & \multicolumn{2}{|c|}{0.8464} & \multicolumn{2}{|c|}{0.8839} & \multicolumn{2}{|c|}{0.0441} \\
\hline
\end{tabular}


Table H.3. (contd)

9) Release 5-Reach survival

\begin{tabular}{|c|c|c|c|c|c|c|}
\hline & \multicolumn{2}{|c|}{ Release to CR234 } & \multicolumn{2}{|c|}{ CR234 to CR161 } & \multicolumn{2}{|c|}{ CR161 to CR113 } \\
\hline & $\hat{S}$ & SE & $\hat{S}$ & SE & $\hat{S}$ & $\mathrm{SE}$ \\
\hline A & 0.9895 & 0.0105 & 0.9439 & 0.0356 & 0.8632 & 0.0641 \\
\hline B & 0.9881 & 0.0118 & 0.9482 & 0.0268 & 0.9876 & 0.0405 \\
\hline $\mathrm{C}$ & 0.9892 & 0.0107 & 0.9293 & 0.0283 & 1.0372 & 0.0474 \\
\hline D & 0.9884 & 0.0116 & 0.9513 & 0.0263 & 0.9501 & 0.0414 \\
\hline E & 0.9808 & 0.0135 & 0.9799 & 0.0211 & 0.9605 & 0.0530 \\
\hline $\mathrm{F}$ & 0.9737 & 0.0184 & 0.9749 & 0.0246 & 0.9679 & 0.0542 \\
\hline G & 0.9836 & 0.0115 & 0.9358 & 0.0250 & 0.9707 & 0.0456 \\
\hline $\mathrm{H}$ & 0.9712 & 0.0142 & 0.9235 & 0.0307 & 0.9268 & 0.0492 \\
\hline$P$-value & \multicolumn{2}{|c|}{0.9496} & \multicolumn{2}{|c|}{0.8070} & \multicolumn{2}{|c|}{0.4299} \\
\hline
\end{tabular}

10) Release 5 -Cumulative survival

\begin{tabular}{|c|c|c|c|c|c|c|}
\hline & \multicolumn{2}{|c|}{ Release to CR234 } & \multicolumn{2}{|c|}{ Release to CR161 } & \multicolumn{2}{|c|}{ Release to CR113 } \\
\hline & $\hat{S}$ & $\mathrm{SE}$ & $\hat{S}$ & $\mathrm{SE}$ & $\hat{S}$ & $\mathrm{SE}$ \\
\hline A & 0.9895 & 0.0105 & 0.9340 & 0.0366 & 0.8062 & 0.0597 \\
\hline B & 0.9881 & 0.0118 & 0.9369 & 0.0287 & 0.9253 & 0.0448 \\
\hline $\mathrm{C}$ & 0.9892 & 0.0107 & 0.9193 & 0.0297 & 0.9535 & 0.0518 \\
\hline D & 0.9884 & 0.0116 & 0.9403 & 0.0283 & 0.8933 & 0.0444 \\
\hline E & 0.9808 & 0.0135 & 0.9610 & 0.0246 & 0.9231 & 0.0520 \\
\hline $\mathrm{F}$ & 0.9737 & 0.0184 & 0.9493 & 0.0299 & 0.9188 & 0.0547 \\
\hline G & 0.9836 & 0.0115 & 0.9205 & 0.0269 & 0.8935 & 0.0471 \\
\hline $\mathrm{H}$ & 0.9712 & 0.0142 & 0.8969 & 0.0326 & 0.8313 & 0.0468 \\
\hline$P$-value & \multicolumn{2}{|c|}{0.9496} & \multicolumn{2}{|c|}{0.8755} & \multicolumn{2}{|c|}{0.4359} \\
\hline
\end{tabular}


Table H.3. (contd)

11) Release 6 - Reach survival

\begin{tabular}{|c|c|c|c|c|}
\hline & \multicolumn{2}{|c|}{ Release to CR161 } & \multicolumn{2}{|c|}{ CR161 to CR113 } \\
\hline & $\hat{S}$ & $\mathrm{SE}$ & $\hat{S}$ & SE \\
\hline A & 0.9735 & 0.0224 & 0.9394 & 0.0400 \\
\hline B & 1.0350 & 0.0142 & 0.9185 & 0.0467 \\
\hline $\mathrm{C}$ & 0.9569 & 0.0232 & 0.9860 & 0.0300 \\
\hline D & 0.9648 & 0.0237 & 0.9481 & 0.0440 \\
\hline $\mathrm{E}$ & 0.9798 & 0.0177 & 0.9094 & 0.0373 \\
\hline F & 0.9528 & 0.0264 & 1.0702 & 0.0530 \\
\hline G & 0.9919 & 0.0152 & 0.9680 & 0.0400 \\
\hline $\mathrm{H}$ & 1.0044 & 0.0132 & 0.9561 & 0.0404 \\
\hline$P$-value & \multicolumn{2}{|c|}{0.0697} & \multicolumn{2}{|c|}{0.1837} \\
\hline
\end{tabular}

12) Release 6 -Cumulative survival

\begin{tabular}{|c|c|c|c|c|}
\hline & \multicolumn{2}{|c|}{ Release to CR161 } & \multicolumn{2}{|c|}{ Release to CR113 } \\
\hline & $\hat{S}$ & $\mathrm{SE}$ & $\hat{S}$ & $\mathrm{SE}$ \\
\hline A & 0.9735 & 0.0224 & 0.9145 & 0.0395 \\
\hline B & 1.0350 & 0.0142 & 0.9507 & 0.0385 \\
\hline $\mathrm{C}$ & 0.9569 & 0.0232 & 0.9436 & 0.0336 \\
\hline $\mathrm{D}$ & 0.9648 & 0.0237 & 0.9147 & 0.0448 \\
\hline $\mathrm{E}$ & 0.9798 & 0.0177 & 0.8911 & 0.0374 \\
\hline $\mathrm{F}$ & 0.9528 & 0.0264 & 1.0196 & 0.0559 \\
\hline G & 0.9919 & 0.0152 & 0.9601 & 0.0385 \\
\hline $\mathrm{H}$ & 1.0044 & 0.0132 & 0.9603 & 0.0378 \\
\hline -value & \multicolumn{2}{|c|}{0.0697} & \multicolumn{2}{|c|}{0.4992} \\
\hline
\end{tabular}

$P$-value 
Table H.3. (contd)

13) Release 7 - Reach survival

\begin{tabular}{|c|c|c|}
\hline & \multicolumn{2}{|c|}{ Release to CR113 } \\
\hline & $\hat{S}$ & $\mathrm{SE}$ \\
\hline A & 0.9238 & 0.0481 \\
\hline B & 0.9590 & 0.0466 \\
\hline $\mathrm{C}$ & 0.9316 & 0.0382 \\
\hline $\mathrm{D}$ & 0.9757 & 0.0473 \\
\hline E & 0.9770 & 0.0328 \\
\hline $\mathrm{F}$ & 0.9454 & 0.0397 \\
\hline G & 0.9465 & 0.0321 \\
\hline $\mathrm{H}$ & 0.9221 & 0.0366 \\
\hline$P$-value & \multicolumn{2}{|c|}{0.9611} \\
\hline
\end{tabular}


Table H.3. (contd)

b. STH

14) Release 1 - Reach survival

\begin{tabular}{|c|c|c|c|c|c|c|c|c|c|c|c|c|c|c|}
\hline & \multicolumn{2}{|c|}{ Release to CR349 } & \multicolumn{2}{|c|}{ CR349 to CR325 } & \multicolumn{2}{|c|}{ CR325 to CR309 } & \multicolumn{2}{|c|}{ CR309 to CR275 } & \multicolumn{2}{|c|}{ CR275 to CR234 } & \multicolumn{2}{|c|}{ CR234 to CR161 } & \multicolumn{2}{|c|}{ CR161 to CR113 } \\
\hline & $\hat{S}$ & SE & $\hat{S}$ & SE & $\hat{S}$ & SE & $\hat{S}$ & $\mathrm{SE}$ & $\hat{S}$ & $\mathrm{SE}$ & $\hat{S}$ & $\mathrm{SE}$ & $\hat{S}$ & $\mathrm{SE}$ \\
\hline A & 0.9601 & 0.0113 & 0.9860 & 0.0070 & 0.9934 & 0.0051 & 0.9768 & 0.0098 & 0.9826 & 0.0086 & 0.9573 & 0.0150 & 0.8991 & 0.0293 \\
\hline B & 0.9508 & 0.0128 & 0.9814 & 0.0083 & 0.9962 & 0.0039 & 0.9849 & 0.0086 & 0.9651 & 0.0121 & 0.9382 & 0.0159 & 1.0187 & 0.0308 \\
\hline $\mathrm{C}$ & 0.9369 & 0.0133 & 0.9873 & 0.0064 & 0.9901 & 0.0057 & 0.9683 & 0.0102 & 0.9887 & 0.0065 & 0.9645 & 0.0129 & 1.0048 & 0.0323 \\
\hline D & 0.9686 & 0.0104 & 0.9601 & 0.0118 & 0.9886 & 0.0065 & 0.9781 & 0.0093 & 0.9872 & 0.0073 & 0.9612 & 0.0140 & 0.9568 & 0.0304 \\
\hline $\mathrm{E}$ & 0.9783 & 0.0088 & 0.9634 & 0.0115 & 0.9882 & 0.0069 & 0.9829 & 0.0088 & 0.9817 & 0.0091 & 0.9491 & 0.0178 & 0.9302 & 0.0380 \\
\hline $\mathrm{F}$ & 0.9584 & 0.0129 & 0.9739 & 0.0106 & 0.9955 & 0.0046 & 0.9972 & 0.0047 & 0.9892 & 0.0076 & 0.9270 & 0.0190 & 0.9763 & 0.0341 \\
\hline G & 0.9515 & 0.0101 & 0.9696 & 0.0083 & 0.9952 & 0.0034 & 0.9819 & 0.0068 & 0.9840 & 0.0065 & 0.9368 & 0.0129 & 1.0022 & 0.0231 \\
\hline $\mathrm{H}$ & 0.9736 & 0.0079 & 0.9778 & 0.0073 & 0.9954 & 0.0036 & 0.9688 & 0.0092 & 0.9818 & 0.0074 & 0.9495 & 0.0131 & 0.9490 & 0.0285 \\
\hline$P$-value & \multicolumn{2}{|c|}{0.1645} & \multicolumn{2}{|c|}{0.2884} & \multicolumn{2}{|c|}{0.8869} & \multicolumn{2}{|c|}{0.3137} & \multicolumn{2}{|c|}{0.5454} & \multicolumn{2}{|c|}{0.6392} & \multicolumn{2}{|c|}{0.0930} \\
\hline
\end{tabular}

15) Release 1 - Cumulative survival

\begin{tabular}{|c|c|c|c|c|c|c|c|c|c|c|c|c|c|c|}
\hline & \multicolumn{2}{|c|}{ Release to CR349 } & \multicolumn{2}{|c|}{ Release to CR325 } & \multicolumn{2}{|c|}{ Release to CR309 } & \multicolumn{2}{|c|}{ Release to CR275 } & \multicolumn{2}{|c|}{ Release to CR234 } & \multicolumn{2}{|c|}{ Release to CR161 } & \multicolumn{2}{|c|}{ Release to CR113 } \\
\hline & $\hat{S}$ & SE & $\hat{S}$ & SE & $\hat{S}$ & SE & $\hat{S}$ & SE & $\hat{S}$ & SE & $\hat{S}$ & SE & $\hat{S}$ & SE \\
\hline A & 0.9601 & 0.0113 & 0.9467 & 0.0130 & 0.9405 & 0.0138 & 0.9186 & 0.0161 & 0.9027 & 0.0172 & 0.8641 & 0.0213 & 0.7769 & 0.0302 \\
\hline $\mathrm{B}$ & 0.9508 & 0.0128 & 0.9331 & 0.0148 & 0.9296 & 0.0152 & 0.9155 & 0.0170 & 0.8836 & 0.0191 & 0.8289 & 0.0227 & 0.8444 & 0.0341 \\
\hline $\mathrm{C}$ & 0.9369 & 0.0133 & 0.9251 & 0.0144 & 0.9159 & 0.0152 & 0.8869 & 0.0175 & 0.8769 & 0.0180 & 0.8458 & 0.0207 & 0.8499 & 0.0333 \\
\hline $\mathrm{D}$ & 0.9686 & 0.0104 & 0.9299 & 0.0151 & 0.9193 & 0.0161 & 0.8992 & 0.0179 & 0.8877 & 0.0187 & 0.8533 & 0.0218 & 0.8164 & 0.0323 \\
\hline $\mathrm{E}$ & 0.9783 & 0.0088 & 0.9424 & 0.0141 & 0.9313 & 0.0152 & 0.9153 & 0.0170 & 0.8986 & 0.0182 & 0.8528 & 0.0235 & 0.7933 & 0.0369 \\
\hline $\mathrm{F}$ & 0.9584 & 0.0129 & 0.9334 & 0.0161 & 0.9292 & 0.0166 & 0.9266 & 0.0171 & 0.9167 & 0.0178 & 0.8497 & 0.0240 & 0.8296 & 0.0362 \\
\hline G & 0.9515 & 0.0101 & 0.9225 & 0.0126 & 0.9181 & 0.0129 & 0.9015 & 0.0141 & 0.8870 & 0.0149 & 0.8310 & 0.0181 & 0.8328 & 0.0259 \\
\hline $\mathrm{H}$ & 0.9736 & 0.0079 & 0.9519 & 0.0105 & 0.9476 & 0.0110 & 0.9180 & 0.0137 & 0.9013 & 0.0146 & 0.8557 & 0.0183 & 0.8121 & 0.0289 \\
\hline$P$-value & \multicolumn{2}{|c|}{0.1645} & \multicolumn{2}{|c|}{0.7891} & \multicolumn{2}{|c|}{0.7715} & \multicolumn{2}{|c|}{0.7262} & \multicolumn{2}{|c|}{0.8003} & \multicolumn{2}{|c|}{0.9448} & \multicolumn{2}{|c|}{0.7588} \\
\hline
\end{tabular}


Table H.3. (contd)

16) Release 2 - Reach survival

\begin{tabular}{|c|c|c|c|c|c|c|c|c|c|c|c|c|}
\hline & \multicolumn{2}{|c|}{ Release to CR325 } & \multicolumn{2}{|c|}{ CR325 to CR309 } & \multicolumn{2}{|c|}{ CR309 to CR275 } & \multicolumn{2}{|c|}{ CR275 to CR234 } & \multicolumn{2}{|c|}{ CR234 to CR161 } & \multicolumn{2}{|c|}{ CR161 to CR113 } \\
\hline & $\hat{S}$ & SE & $\hat{S}$ & SE & $\hat{S}$ & SE & $\hat{S}$ & $\mathrm{SE}$ & $\hat{S}$ & SE & $\hat{S}$ & SE \\
\hline A & 1.0003 & 0.0003 & 0.9930 & 0.0072 & 0.9726 & 0.0140 & 0.9918 & 0.0082 & 0.9640 & 0.0180 & 0.9567 & 0.0359 \\
\hline B & 1.0003 & 0.0003 & 0.9840 & 0.0112 & 0.9780 & 0.0138 & 0.9735 & 0.0151 & 0.9147 & 0.0270 & 0.9356 & 0.0464 \\
\hline $\mathrm{C}$ & 0.9940 & 0.0064 & 0.9671 & 0.0145 & 0.9814 & 0.0116 & 0.9847 & 0.0107 & 0.9642 & 0.0170 & 1.0251 & 0.0483 \\
\hline $\mathrm{D}$ & 0.9927 & 0.0077 & 0.9841 & 0.0111 & 0.9868 & 0.0112 & 0.9735 & 0.0151 & 0.9184 & 0.0283 & 0.8859 & 0.0446 \\
\hline $\mathrm{E}$ & 1.0001 & 0.0001 & 0.9860 & 0.0098 & 0.9718 & 0.0139 & 1.0000 & 0.0000 & 0.9377 & 0.0227 & 0.9253 & 0.0386 \\
\hline $\mathrm{F}$ & 0.9916 & 0.0087 & 0.9908 & 0.0091 & 0.9732 & 0.0153 & 1.0000 & 0.0000 & 0.9456 & 0.0245 & 0.9540 & 0.0556 \\
\hline G & 0.9897 & 0.0074 & 0.9892 & 0.0076 & 0.9951 & 0.0054 & 0.9942 & 0.0058 & 0.9082 & 0.0220 & 0.9816 & 0.0336 \\
\hline $\mathrm{H}$ & 0.9952 & 0.0052 & 0.9839 & 0.0092 & 0.9532 & 0.0156 & 0.9933 & 0.0066 & 0.9433 & 0.0206 & 0.9399 & 0.0453 \\
\hline$P$-value & \multicolumn{2}{|c|}{0.7902} & \multicolumn{2}{|c|}{0.7547} & \multicolumn{2}{|c|}{0.4981} & \multicolumn{2}{|c|}{0.4474} & \multicolumn{2}{|c|}{0.5105} & \multicolumn{2}{|c|}{0.5348} \\
\hline
\end{tabular}

$\underset{\sigma}{\square} \quad$ 17) Release 2 - Cumulative survival

\begin{tabular}{|c|c|c|c|c|c|c|c|c|c|c|c|c|}
\hline & \multicolumn{2}{|c|}{ Release to CR325 } & \multicolumn{2}{|c|}{ Release to CR309 } & \multicolumn{2}{|c|}{ Release to CR275 } & \multicolumn{2}{|c|}{ Release to CR234 } & \multicolumn{2}{|c|}{ Release to CR161 } & \multicolumn{2}{|c|}{ Release to CR113 } \\
\hline & $\hat{S}$ & $\mathrm{SE}$ & $\hat{S}$ & $\mathrm{SE}$ & $\hat{S}$ & SE & $\hat{S}$ & SE & $\hat{S}$ & $\mathrm{SE}$ & $\hat{S}$ & $\mathrm{SE}$ \\
\hline A & 1.0003 & 0.0003 & 0.9932 & 0.0070 & 0.9660 & 0.0154 & 0.9580 & 0.0168 & 0.9236 & 0.0236 & 0.8836 & 0.0386 \\
\hline $\mathrm{B}$ & 1.0003 & 0.0003 & 0.9843 & 0.0110 & 0.9626 & 0.0173 & 0.9370 & 0.0216 & 0.8571 & 0.0321 & 0.8019 & 0.0487 \\
\hline $\mathrm{C}$ & 0.9940 & 0.0064 & 0.9613 & 0.0155 & 0.9434 & 0.0188 & 0.9290 & 0.0206 & 0.8957 & 0.0254 & 0.9182 & 0.0496 \\
\hline $\mathrm{D}$ & 0.9927 & 0.0077 & 0.9769 & 0.0132 & 0.9641 & 0.0170 & 0.9385 & 0.0211 & 0.8619 & 0.0329 & 0.7635 & 0.0455 \\
\hline $\mathrm{E}$ & 1.0001 & 0.0001 & 0.9861 & 0.0098 & 0.9583 & 0.0167 & 0.9583 & 0.0167 & 0.8986 & 0.0268 & 0.8315 & 0.0409 \\
\hline $\mathrm{F}$ & 0.9916 & 0.0087 & 0.9825 & 0.0123 & 0.9561 & 0.0192 & 0.9561 & 0.0192 & 0.9041 & 0.0296 & 0.8625 & 0.0559 \\
\hline G & 0.9897 & 0.0074 & 0.9791 & 0.0104 & 0.9743 & 0.0116 & 0.9686 & 0.0126 & 0.8797 & 0.0242 & 0.8634 & 0.0371 \\
\hline $\mathrm{H}$ & 0.9952 & 0.0052 & 0.9792 & 0.0103 & 0.9333 & 0.0182 & 0.9271 & 0.0188 & 0.8745 & 0.0260 & 0.8220 & 0.0445 \\
\hline$P$-value & \multicolumn{2}{|c|}{0.7902} & \multicolumn{2}{|c|}{0.7126} & \multicolumn{2}{|c|}{0.7533} & \multicolumn{2}{|c|}{0.6753} & \multicolumn{2}{|c|}{0.7042} & \multicolumn{2}{|c|}{0.3265} \\
\hline
\end{tabular}


Table H.3. (contd)

18) Release 3 - Reach survival

\begin{tabular}{|c|c|c|c|c|c|c|c|c|c|c|}
\hline & \multicolumn{2}{|c|}{ Release to CR309 } & \multicolumn{2}{|c|}{ CR309 to CR275 } & \multicolumn{2}{|c|}{ CR275 to CR234 } & \multicolumn{2}{|c|}{ CR234 to CR161 } & \multicolumn{2}{|c|}{ CR161 to CR113 } \\
\hline & $\hat{S}$ & SE & $\hat{S}$ & SE & $\hat{S}$ & SE & $\hat{S}$ & SE & $\hat{S}$ & SE \\
\hline A & 0.9895 & 0.0105 & 0.9727 & 0.0186 & 0.9733 & 0.0186 & 0.9683 & 0.0232 & 1.0272 & 0.0569 \\
\hline $\mathrm{B}$ & 1.0000 & 0.0000 & 0.9431 & 0.0256 & 0.9730 & 0.0189 & 0.9396 & 0.0280 & 1.0006 & 0.0656 \\
\hline $\mathrm{C}$ & 1.0000 & 0.0000 & 0.9943 & 0.0104 & 0.9655 & 0.0196 & 0.9375 & 0.0273 & 1.0068 & 0.0559 \\
\hline $\mathrm{D}$ & 0.9891 & 0.0108 & 0.9231 & 0.0279 & 1.0000 & 0.0000 & 0.9773 & 0.0215 & 0.9583 & 0.0563 \\
\hline E & 1.0003 & 0.0004 & 0.9728 & 0.0181 & 0.9747 & 0.0177 & 0.8820 & 0.0361 & 1.0958 & 0.0930 \\
\hline $\mathrm{F}$ & 0.9733 & 0.0186 & 0.9589 & 0.0232 & 1.0000 & 0.0000 & 0.9720 & 0.0258 & 0.9622 & 0.0677 \\
\hline G & 0.9919 & 0.0081 & 0.9773 & 0.0141 & 0.9813 & 0.0131 & 0.9592 & 0.0211 & 0.9937 & 0.0471 \\
\hline $\mathrm{H}$ & 0.9846 & 0.0108 & 0.9720 & 0.0156 & 0.9806 & 0.0136 & 0.9542 & 0.0219 & 0.9348 & 0.0474 \\
\hline$P$-value & \multicolumn{2}{|c|}{0.6295} & \multicolumn{2}{|c|}{0.2810} & \multicolumn{2}{|c|}{0.7382} & \multicolumn{2}{|c|}{0.2099} & \multicolumn{2}{|c|}{0.7317} \\
\hline
\end{tabular}

19) Release 3 - Cumulative survival

\begin{tabular}{|c|c|c|c|c|c|c|c|c|c|c|}
\hline & \multicolumn{2}{|c|}{ Release to CR309 } & \multicolumn{2}{|c|}{ Release to CR275 } & \multicolumn{2}{|c|}{ Release to CR234 } & \multicolumn{2}{|c|}{ Release to CR161 } & \multicolumn{2}{|c|}{ Release to CR113 } \\
\hline & $\hat{S}$ & SE & $\hat{S}$ & SE & $\hat{S}$ & SE & $\hat{S}$ & SE & $\hat{S}$ & SE \\
\hline A & 0.9895 & 0.0105 & 0.9625 & 0.0210 & 0.9368 & 0.0250 & 0.9072 & 0.0325 & 0.9319 & 0.0585 \\
\hline $\mathrm{B}$ & 1.0000 & 0.0000 & 0.9431 & 0.0256 & 0.9176 & 0.0298 & 0.8622 & 0.0380 & 0.8627 & 0.0675 \\
\hline $\mathrm{C}$ & 1.0000 & 0.0000 & 0.9943 & 0.0104 & 0.9600 & 0.0196 & 0.9000 & 0.0320 & 0.9062 & 0.0576 \\
\hline $\mathrm{D}$ & 0.9891 & 0.0108 & 0.9130 & 0.0294 & 0.9130 & 0.0294 & 0.8923 & 0.0348 & 0.8551 & 0.0577 \\
\hline $\mathrm{E}$ & 1.0003 & 0.0004 & 0.9731 & 0.0179 & 0.9485 & 0.0225 & 0.8365 & 0.0396 & 0.9167 & 0.0870 \\
\hline $\mathrm{F}$ & 0.9733 & 0.0186 & 0.9333 & 0.0288 & 0.9333 & 0.0288 & 0.9072 & 0.0369 & 0.8729 & 0.0677 \\
\hline $\mathrm{G}$ & 0.9919 & 0.0081 & 0.9693 & 0.0161 & 0.9512 & 0.0194 & 0.9124 & 0.0274 & 0.9067 & 0.0489 \\
\hline $\mathrm{H}$ & 0.9846 & 0.0108 & 0.9570 & 0.0186 & 0.9385 & 0.0211 & 0.8954 & 0.0288 & 0.8370 & 0.0484 \\
\hline$P$-value & \multicolumn{2}{|c|}{0.6295} & \multicolumn{2}{|c|}{0.2229} & \multicolumn{2}{|c|}{0.8869} & \multicolumn{2}{|c|}{0.7561} & \multicolumn{2}{|c|}{0.9586} \\
\hline
\end{tabular}


Table H.3. (contd)

20) Release 4 - Reach survival

\begin{tabular}{|c|c|c|c|c|c|c|c|c|}
\hline & \multicolumn{2}{|c|}{ Release to CR275 } & \multicolumn{2}{|c|}{ CR275 to CR234 } & \multicolumn{2}{|c|}{ CR234 to CR161 } & \multicolumn{2}{|c|}{ CR161 to CR113 } \\
\hline & $\hat{S}$ & SE & $\hat{S}$ & SE & $\hat{S}$ & SE & $\hat{S}$ & SE \\
\hline A & 0.9800 & 0.0140 & 1.0000 & 0.0000 & 0.9111 & 0.0317 & 0.8392 & 0.0507 \\
\hline $\mathrm{B}$ & 0.9915 & 0.0111 & 0.9753 & 0.0172 & 0.8974 & 0.0347 & 0.9228 & 0.0503 \\
\hline $\mathrm{C}$ & 1.0016 & 0.0013 & 0.9783 & 0.0152 & 0.9455 & 0.0250 & 0.9886 & 0.0495 \\
\hline $\mathrm{D}$ & 0.9903 & 0.0121 & 0.9857 & 0.0142 & 0.9226 & 0.0315 & 0.9437 & 0.0558 \\
\hline $\mathrm{E}$ & 0.9917 & 0.0104 & 0.9878 & 0.0121 & 0.9592 & 0.0236 & 0.9492 & 0.0574 \\
\hline $\mathrm{F}$ & 1.0033 & 0.0034 & 0.9831 & 0.0168 & 0.9613 & 0.0288 & 0.9322 & 0.0600 \\
\hline G & 0.9694 & 0.0157 & 0.9825 & 0.0123 & 0.9466 & 0.0237 & 0.9462 & 0.0459 \\
\hline $\mathrm{H}$ & 0.9678 & 0.0175 & 0.9612 & 0.0190 & 0.9630 & 0.0209 & 0.9974 & 0.0569 \\
\hline$P$-value & \multicolumn{2}{|c|}{0.2631} & \multicolumn{2}{|c|}{0.7965} & \multicolumn{2}{|c|}{0.5862} & \multicolumn{2}{|c|}{0.5751} \\
\hline
\end{tabular}

21) Release 4 - Cumulative survival

\begin{tabular}{|c|c|c|c|c|c|c|c|c|}
\hline & \multicolumn{2}{|c|}{ Release to CR275 } & \multicolumn{2}{|c|}{ Release to CR234 } & \multicolumn{2}{|c|}{ Release to CR161 } & \multicolumn{2}{|c|}{ Release to CR113 } \\
\hline & $\hat{S}$ & SE & $\hat{S}$ & SE & $\hat{S}$ & SE & $\hat{S}$ & SE \\
\hline A & 0.9800 & 0.0140 & 0.9800 & 0.0140 & 0.8929 & 0.0336 & 0.7493 & 0.0510 \\
\hline B & 0.9915 & 0.0111 & 0.9670 & 0.0187 & 0.8678 & 0.0375 & 0.8008 & 0.0534 \\
\hline $\mathrm{C}$ & 1.0016 & 0.0013 & 0.9798 & 0.0141 & 0.9264 & 0.0279 & 0.9158 & 0.0518 \\
\hline $\mathrm{D}$ & 0.9903 & 0.0121 & 0.9762 & 0.0166 & 0.9007 & 0.0344 & 0.8500 & 0.0580 \\
\hline $\mathrm{E}$ & 0.9917 & 0.0104 & 0.9796 & 0.0143 & 0.9396 & 0.0269 & 0.8919 & 0.0574 \\
\hline $\mathrm{F}$ & 1.0033 & 0.0034 & 0.9863 & 0.0136 & 0.9481 & 0.0313 & 0.8838 & 0.0597 \\
\hline G & 0.9694 & 0.0157 & 0.9524 & 0.0190 & 0.9015 & 0.0289 & 0.8530 & 0.0472 \\
\hline $\mathrm{H}$ & 0.9678 & 0.0175 & 0.9302 & 0.0224 & 0.8958 & 0.0290 & 0.8935 & 0.0565 \\
\hline$P$-value & \multicolumn{2}{|c|}{0.2631} & \multicolumn{2}{|c|}{0.2717} & \multicolumn{2}{|c|}{0.6473} & \multicolumn{2}{|c|}{0.4050} \\
\hline
\end{tabular}


Table H.3. (contd)

22) Release 5 - Reach survival

\begin{tabular}{|c|c|c|c|c|c|c|}
\hline & \multicolumn{2}{|c|}{ Release to CR234 } & \multicolumn{2}{|c|}{ CR234 to CR161 } & \multicolumn{2}{|c|}{ CR161 to CR113 } \\
\hline & $\hat{S}$ & SE & $\hat{S}$ & SE & $\hat{S}$ & SE \\
\hline A & 0.9895 & 0.0105 & 0.9602 & 0.0243 & 0.9177 & 0.0466 \\
\hline $\mathrm{B}$ & 0.9659 & 0.0193 & 0.9664 & 0.0243 & 0.9081 & 0.0536 \\
\hline $\mathrm{C}$ & 0.9804 & 0.0137 & 0.8727 & 0.0358 & 0.8720 & 0.0495 \\
\hline $\mathrm{D}$ & 1.0000 & 0.0000 & 0.9673 & 0.0228 & 0.9061 & 0.0480 \\
\hline $\mathrm{E}$ & 0.9897 & 0.0103 & 0.9436 & 0.0251 & 0.9521 & 0.0499 \\
\hline $\mathrm{F}$ & 0.9868 & 0.0131 & 0.8860 & 0.0380 & 0.9851 & 0.0484 \\
\hline G & 0.9917 & 0.0083 & 0.9342 & 0.0249 & 0.9445 & 0.0533 \\
\hline $\mathrm{H}$ & 0.9773 & 0.0130 & 0.9559 & 0.0206 & 1.0495 & 0.0510 \\
\hline$P$-value & \multicolumn{2}{|c|}{0.6971} & \multicolumn{2}{|c|}{0.0880} & \multicolumn{2}{|c|}{0.2866} \\
\hline
\end{tabular}

23) Release 5 - Cumulative survival

\begin{tabular}{|c|c|c|c|c|c|c|}
\hline & \multicolumn{2}{|c|}{ Release to CR234 } & \multicolumn{2}{|c|}{ Release to CR161 } & \multicolumn{2}{|c|}{ Release to CR113 } \\
\hline & $\hat{S}$ & SE & $\hat{S}$ & $\mathrm{SE}$ & $\hat{S}$ & SE \\
\hline A & 0.9895 & 0.0105 & 0.9501 & 0.0261 & 0.8719 & 0.0472 \\
\hline $\mathrm{B}$ & 0.9659 & 0.0193 & 0.9334 & 0.0300 & 0.8477 & 0.0541 \\
\hline $\mathrm{C}$ & 0.9804 & 0.0137 & 0.8556 & 0.0371 & 0.7461 & 0.0509 \\
\hline $\mathrm{D}$ & 1.0000 & 0.0000 & 0.9673 & 0.0228 & 0.8765 & 0.0481 \\
\hline $\mathrm{E}$ & 0.9897 & 0.0103 & 0.9339 & 0.0267 & 0.8892 & 0.0517 \\
\hline $\mathrm{F}$ & 0.9868 & 0.0131 & 0.8743 & 0.0392 & 0.8612 & 0.0557 \\
\hline G & 0.9917 & 0.0083 & 0.9264 & 0.0259 & 0.8750 & 0.0534 \\
\hline $\mathrm{H}$ & 0.9773 & 0.0130 & 0.9342 & 0.0237 & 0.9804 & 0.0518 \\
\hline$P$-value & \multicolumn{2}{|c|}{0.6971} & \multicolumn{2}{|c|}{0.1194} & \multicolumn{2}{|c|}{0.1531} \\
\hline
\end{tabular}


Table H.3. (contd)

24) Release 6 - Reach survival

\begin{tabular}{|c|c|c|c|c|c|}
\hline & & \multicolumn{2}{|c|}{ Release to CR161 } & \multicolumn{2}{|c|}{ CR161 to CR113 } \\
\hline & & $\hat{S}$ & SE & $\hat{S}$ & SE \\
\hline A & & 0.9728 & 0.0222 & 0.7971 & 0.0469 \\
\hline B & & 1.0103 & 0.0053 & 0.9490 & 0.0501 \\
\hline $\mathrm{C}$ & & 0.9562 & 0.0242 & 0.9724 & 0.0563 \\
\hline $\mathrm{D}$ & & 0.9438 & 0.0261 & 1.0223 & 0.0562 \\
\hline E & & 0.9529 & 0.0264 & 0.9205 & 0.0541 \\
\hline $\mathrm{F}$ & & 0.9518 & 0.0308 & 0.9206 & 0.0700 \\
\hline G & & 0.9458 & 0.0235 & 1.0321 & 0.0462 \\
\hline $\mathrm{H}$ & & 0.9668 & 0.0193 & 0.9900 & 0.0343 \\
\hline \multicolumn{2}{|l|}{$P$-value } & \multicolumn{2}{|c|}{0.5359} & \multicolumn{2}{|c|}{0.0487} \\
\hline \multicolumn{6}{|c|}{ 25) Release 6 - Cumulative survival } \\
\hline & & \multicolumn{2}{|c|}{ Release to CR161 } & \multicolumn{2}{|c|}{ Release to CR113 } \\
\hline & & $\hat{S}$ & SE & $\hat{S}$ & SE \\
\hline A & & 0.9728 & 0.0222 & 0.7754 & 0.0460 \\
\hline B & & 1.0103 & 0.0053 & 0.9588 & 0.0482 \\
\hline $\mathrm{C}$ & & 0.9562 & 0.0242 & 0.9298 & 0.0565 \\
\hline $\mathrm{D}$ & & 0.9438 & 0.0261 & 0.9649 & 0.0574 \\
\hline $\mathrm{E}$ & & 0.9529 & 0.0264 & 0.8772 & 0.0536 \\
\hline $\mathrm{F}$ & & 0.9518 & 0.0308 & 0.8762 & 0.0683 \\
\hline G & & 0.9458 & 0.0235 & 0.9762 & 0.0472 \\
\hline $\mathrm{H}$ & & 0.9668 & 0.0193 & 0.9571 & 0.0348 \\
\hline$P$-value & & \multicolumn{2}{|c|}{0.5359} & \multicolumn{2}{|c|}{0.1042} \\
\hline
\end{tabular}


Table H.3. (contd)

26) Release 7 - Reach survival

\begin{tabular}{|c|c|c|}
\hline & \multicolumn{2}{|c|}{ Release to CR113 } \\
\hline & $\hat{S}$ & $\mathrm{SE}$ \\
\hline $\mathrm{A}$ & 0.8905 & 0.0440 \\
\hline B & 0.9473 & 0.0501 \\
\hline $\mathrm{C}$ & 0.9415 & 0.0479 \\
\hline $\mathrm{D}$ & 0.9668 & 0.0443 \\
\hline E & 0.9002 & 0.0464 \\
\hline $\mathrm{F}$ & 0.9230 & 0.0578 \\
\hline G & 0.9080 & 0.0468 \\
\hline $\mathrm{H}$ & 0.8905 & 0.0440 \\
\hline$P$-value & \multicolumn{2}{|c|}{0.9540} \\
\hline
\end{tabular}




\section{H.2 Examination of Tag-Lot Effects}

Three different tag lots were used in the tagging of the $\mathrm{CH} 1$ and STH. Overall, the tag lots were not evenly distributed among the seven release locations for the three-dam survival study; including the three release sites specific to the compliance study at JDA (Table H.4). However, closer examination found the below-dam release pairs (i.e., $R_{2}-R_{3}, R_{4}-R_{5}$, and $R_{6}-R_{7}$ ) to be homogeneous with regard to tag-lot allocation $(P \geq 0.9415)$. This pairwise homogeneity is particularly important in the virtual/paired-release design where the downstream pair is used to estimate the extra-reach mortality needed to adjust the survival estimate from the virtual forebay release.

Tests of homogeneous reach survivals across tag lots by release locations were performed (Table H.5). These tests looked for any tag-lot effects not accounted for by tag-lot-specific tag-life corrections. Of the 56 tests of homogeneous reach survivals across tag lots, 11 were significant at $P \leq 0.10$ (i.e., 19\%). However, there was no particular pattern to the lot-specific reach survivals. Lot 1 had the lowest survival in 3 of the 11 significant tests; lot 2 had the lower survival in 3 tests, and lots 3 through 5 had the lowest survival in 5 tests.

Tests of homogeneous cumulative survival were also performed. In the 54 tests of homogeneous cumulative survival, 9 were significant at $P \leq 0.10$ (i.e., 16.7\%). However, the tests of cumulative survival are not independent within an analysis of a release group. For example, seven of the nine significant results all occurred within the $R_{1}$ release of STH. In the same case, tag-lot 1 had the lowest survivals in two of the seven instances, while tag-lot 2 had the lowest survival in five instances.

Based on the homogeneity tests, it was concluded that tag lots corrected for tag life had no significant effect on observed juvenile salmonid survivals; therefore, fish tagged from all tag lots were used in the analyses. 
Table H.4. Numbers of tags used per tag lot at each release location for a) $\mathrm{CH} 1$ and b) STH in the 2011 juvenile salmon acoustic telemetry system survival study. Chi-square tests of homogeneity performed for the overall table and pairwise comparisons of the below-dam release pairs.

a. $\mathrm{CH} 1$

\begin{tabular}{ccccc}
\hline & \multicolumn{3}{c}{ Tag Lot } & \\
\cline { 2 - 4 } Release Location & 1 & 2 & $3,4,5$ & $P$-value \\
\hline R1-CR390 & 706 & 501 & 1303 & \\
R2-CR346 & 226 & 302 & 665 & 0.9801 \\
R3-CR325 & 150 & 200 & 449 & \\
R4-CR307 & 150 & 149 & 500 & 0.9805 \\
R5-CR275 & 150 & 146 & 503 & \\
R6-CR233 & 100 & 150 & 548 & 0.9323 \\
R7-CR161 & 96 & 146 & 552 & \\
\hline Chi-square $=211.77$ & \multicolumn{5}{c}{ DF $=12$} & & $<0.0001$ \\
\hline
\end{tabular}

b. STH

\begin{tabular}{crrrr}
\hline & \multicolumn{3}{c}{ Tag Lot } & \\
\cline { 2 - 4 } Release Location & 1 & 2 & $3,4,5$ & $P$-value \\
\hline R1-CR390 & 698 & 498 & 1391 & \\
R2-CR346 & 228 & 302 & 666 & 0.9415 \\
R3-CR325 & 150 & 197 & 450 & \\
R4-CR307 & 150 & 150 & 500 & 1.0000 \\
R5-CR275 & 150 & 150 & 500 & \\
R6-CR233 & 99 & 146 & 547 & 0.9681 \\
R7-CR161 & 100 & 150 & 544 & \\
\hline Chi-square $=178.67$ & \multicolumn{5}{c}{ DF $=12$} & & $<0.0001$ \\
\hline
\end{tabular}


Table H.5. Estimates of reach survival and cumulative survival for a) $\mathrm{CH} 1$ and b) STH, along with $P$-values associated with the $F$-tests of homogeneous survival across tag lots.

a. $\mathrm{CH} 1$

1) Release 1 - Reach survival

\begin{tabular}{|c|c|c|c|c|c|c|c|c|c|c|c|c|c|c|}
\hline & \multicolumn{2}{|c|}{$\begin{array}{c}\text { Release to } \\
\text { CR349 }\end{array}$} & \multicolumn{2}{|c|}{$\begin{array}{l}\text { CR349 to } \\
\text { CR325 }\end{array}$} & \multicolumn{2}{|c|}{$\begin{array}{c}\text { CR325 to } \\
\text { CR309 }\end{array}$} & \multicolumn{2}{|c|}{$\begin{array}{l}\text { CR309 to } \\
\text { CR275 }\end{array}$} & \multicolumn{2}{|c|}{$\begin{array}{l}\text { CR275 to } \\
\text { CR234 }\end{array}$} & \multicolumn{2}{|c|}{$\begin{array}{c}\text { CR234 to } \\
\text { CR161 }\end{array}$} & \multicolumn{2}{|c|}{$\begin{array}{l}\text { CR161 to } \\
\text { CR113 }\end{array}$} \\
\hline & $\hat{S}$ & & SE & $\mathrm{SI}$ & $\hat{S}$ & SE & $\hat{S}$ & SE & $\hat{S}$ & SE & $\hat{S}$ & SE & $\hat{S}$ & SE \\
\hline Lot 1 & 0.98 & $\begin{array}{ll}802 & 0.0\end{array}$ & $052 \quad 0.95$ & $\begin{array}{ll}578 & 0.00\end{array}$ & $\begin{array}{ll}77 & 0.99\end{array}$ & 9240.003 & 340.9664 & $4 \quad 0.0071$ & $\begin{array}{ll}1 & 0.9937\end{array}$ & 0.0032 & 0.9587 & 0.0081 & 1.0025 & 0.0041 \\
\hline Lot 2 & 0.98 & $801 \quad 0.0$ & $0 \begin{array}{ll}063 & 0.95\end{array}$ & $\begin{array}{ll}528 & 0.00\end{array}$ & 0.99 & $914 \quad 0.004$ & 430.9501 & 10.0101 & 10.9954 & +0.0032 & 0.9570 & 0.0107 & 0.9839 & 0.0124 \\
\hline Lot 3, & $4, \quad 0.97$ & 7620.0 & $042 \quad 0.96$ & 6720.00 & $\begin{array}{ll}50 & 0.99\end{array}$ & 9220.002 & 270.9665 & $5 \quad 0.0053$ & 30.9951 & 0.0022 & 0.9719 & 0.0095 & 0.9512 & 0.0226 \\
\hline \multicolumn{2}{|c|}{$P$-value } & 0.8312 & \multicolumn{2}{|r|}{0.4029} & \multicolumn{2}{|r|}{0.9774} & \multicolumn{2}{|c|}{0.2268} & \multicolumn{2}{|c|}{0.9067} & \multicolumn{2}{|c|}{0.4775} & \multicolumn{2}{|c|}{0.0520} \\
\hline \multirow[t]{3}{*}{ 2) } & \multicolumn{14}{|c|}{ Release 1 - Cumulative survival } \\
\hline & \multicolumn{2}{|c|}{$\begin{array}{c}\text { Release to } \\
\text { CR349 }\end{array}$} & \multicolumn{2}{|c|}{$\begin{array}{l}\text { Release to } \\
\text { CR325 }\end{array}$} & \multicolumn{2}{|c|}{$\begin{array}{l}\text { Release to } \\
\text { CR309 }\end{array}$} & \multicolumn{2}{|c|}{$\begin{array}{l}\text { Release to } \\
\text { CR275 }\end{array}$} & \multicolumn{2}{|c|}{$\begin{array}{c}\text { Release to } \\
\text { CR234 }\end{array}$} & \multicolumn{2}{|c|}{$\begin{array}{l}\text { Release to } \\
\text { CR161 }\end{array}$} & \multicolumn{2}{|c|}{$\begin{array}{l}\text { Release to } \\
\text { CR113 }\end{array}$} \\
\hline & $\hat{S}$ & SE & $\hat{S}$ & SE & $\hat{S}$ & SE & $\hat{S}$ & SE & $\hat{S}$ & SE & $\hat{S}$ & SE & $\hat{S}$ & SE \\
\hline Lot & 0.9802 & 0.0052 & 0.9389 & 0.0090 & 0.9317 & 0.0095 & 0.9004 & 0.0113 & 0.8947 & 0.0116 & 0.8577 & 0.0133 & 0.8598 & 0.0138 \\
\hline $2^{\text {Lot }}$ & 0.9801 & 0.0063 & 0.9338 & 0.0111 & 0.9258 & 0.0117 & 0.8796 & 0.0146 & 0.8756 & 0.0148 & 0.8380 & 0.0170 & 0.8245 & 0.0191 \\
\hline $\begin{array}{r}\text { Lot } \\
3,4,5\end{array}$ & 0.9762 & 0.0042 & 0.9442 & 0.0064 & 0.9368 & 0.0068 & 0.9054 & 0.0081 & 0.9009 & 0.0083 & 0.8756 & 0.0117 & 0.8329 & 0.0205 \\
\hline $\begin{array}{c}P \text { - } \\
\text { value }\end{array}$ & 0.8 & 312 & & 7192 & & 7177 & 0.25 & 511 & 0.28 & 898 & & 713 & & 508 \\
\hline
\end{tabular}

3) Release 2 - Reach survival

\begin{tabular}{|c|c|c|c|c|c|c|c|c|c|c|c|c|}
\hline & \multicolumn{2}{|c|}{$\begin{array}{l}\text { CR349 to } \\
\text { CR325 }\end{array}$} & \multicolumn{2}{|c|}{$\begin{array}{c}\text { CR325 to } \\
\text { CR309 }\end{array}$} & \multicolumn{2}{|c|}{$\begin{array}{l}\text { CR309 to } \\
\text { CR275 }\end{array}$} & \multicolumn{2}{|c|}{$\begin{array}{c}\text { CR275 to } \\
\text { CR234 }\end{array}$} & \multicolumn{2}{|c|}{$\begin{array}{c}\text { CR234 to } \\
\text { CR161 }\end{array}$} & \multicolumn{2}{|c|}{$\begin{array}{l}\text { CR161 to } \\
\text { CR113 }\end{array}$} \\
\hline & $\hat{S}$ & SE & $\hat{S}$ & SE & $\hat{S}$ & SE & $\hat{S}$ & SE & $\hat{S}$ & SE & $\hat{S}$ & SE \\
\hline Lot 1 & 0.9912 & 0.0062 & 0.9869 & 0.0077 & 0.9409 & 0.0159 & 0.9952 & 0.0048 & 0.9662 & 0.0127 & 0.9762 & 0.0127 \\
\hline Lot 2 & 0.9868 & 0.0066 & 0.9799 & 0.0081 & 0.9623 & 0.0111 & 0.9893 & 0.0061 & 0.9498 & 0.0132 & 1.0133 & 0.0066 \\
\hline${ }_{5}^{\text {Lot } 3,4,}$ & 0.9913 & 0.0037 & 0.9939 & 0.0032 & 0.9531 & 0.0084 & 0.9961 & 0.0027 & 0.9688 & 0.0139 & 0.9316 & 0.0296 \\
\hline$P$-value & \multicolumn{2}{|c|}{0.8128} & \multicolumn{2}{|c|}{0.3376} & \multicolumn{2}{|c|}{0.4611} & \multicolumn{2}{|c|}{0.5483} & \multicolumn{2}{|c|}{0.5465} & \multicolumn{2}{|c|}{0.0096} \\
\hline
\end{tabular}


Table H.5. (contd)

4) Release 2 - Cumulative survival

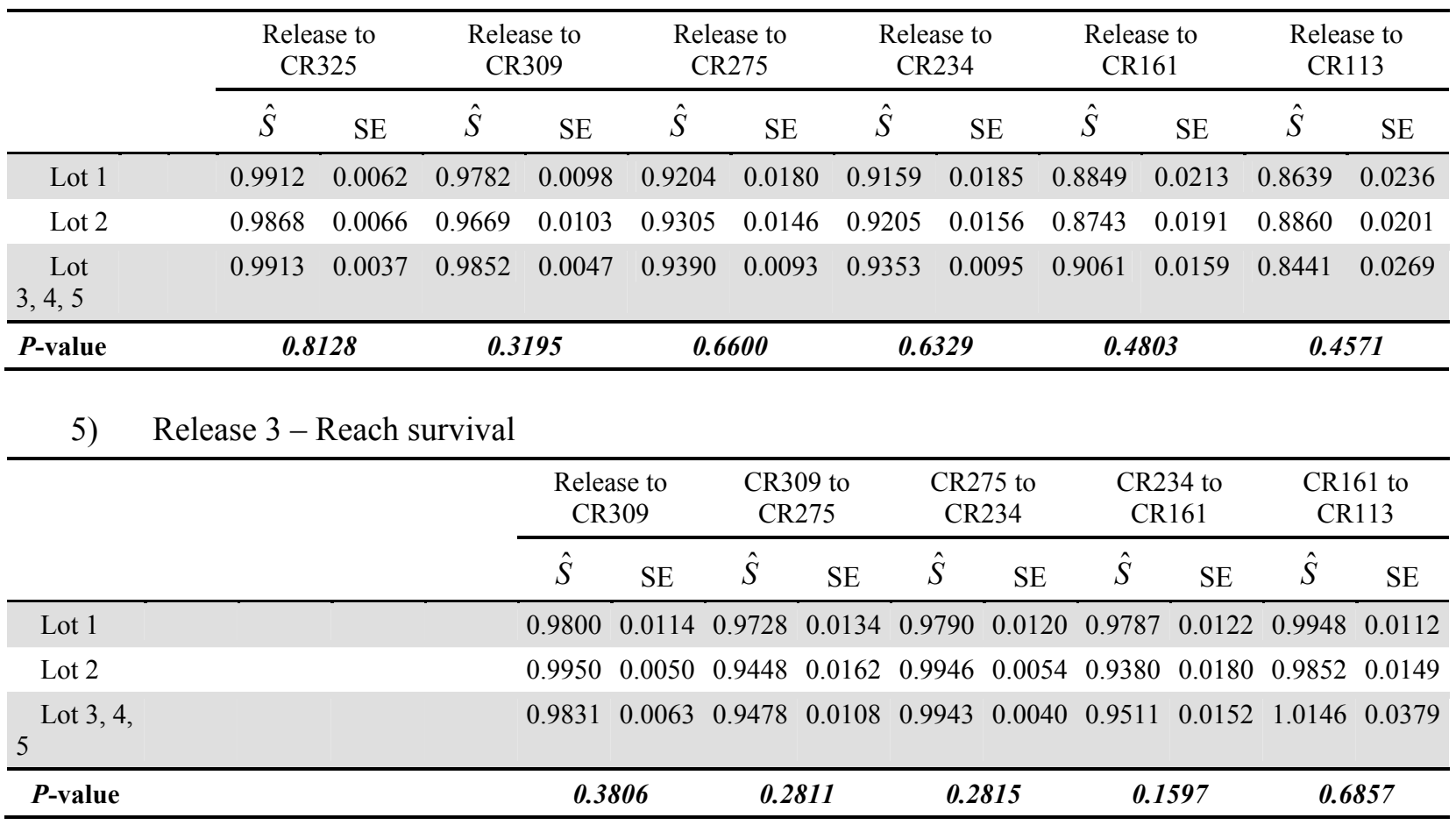

6) Release 3 - Cumulative survival

\begin{tabular}{|c|c|c|c|c|c|c|c|c|c|c|}
\hline & \multicolumn{2}{|c|}{$\begin{array}{c}\text { Release to } \\
\text { CR309 }\end{array}$} & \multicolumn{2}{|c|}{$\begin{array}{l}\text { Release to } \\
\text { CR275 }\end{array}$} & \multicolumn{2}{|c|}{$\begin{array}{l}\text { Release to } \\
\text { CR234 }\end{array}$} & \multicolumn{2}{|c|}{$\begin{array}{c}\text { Release to } \\
\text { CR161 }\end{array}$} & \multicolumn{2}{|c|}{$\begin{array}{c}\text { Release to } \\
\text { CR113 }\end{array}$} \\
\hline & $\hat{S}$ & $\mathrm{SE}$ & $\hat{S}$ & SE & $\hat{S}$ & $\mathrm{SE}$ & $\hat{S}$ & $\mathrm{SE}$ & $\hat{S}$ & SE \\
\hline Lot 1 & 0.9800 & 0.0114 & 0.9533 & 0.0172 & 0.9333 & 0.0204 & 0.9134 & 0.0230 & 0.9086 & 0.0250 \\
\hline Lot 2 & 0.9950 & 0.0050 & 0.9401 & 0.0168 & 0.9350 & 0.0174 & 0.8771 & 0.0235 & 0.8641 & 0.0261 \\
\hline $4,5^{\operatorname{Lot} 3,}$ & 0.9831 & 0.0063 & 0.9318 & 0.0120 & 0.9265 & 0.0123 & 0.8812 & 0.0183 & 0.8941 & 0.0354 \\
\hline$P$-value & \multicolumn{2}{|c|}{0.3806} & \multicolumn{2}{|c|}{0.6137} & \multicolumn{2}{|c|}{0.9326} & \multicolumn{2}{|c|}{0.4326} & \multicolumn{2}{|c|}{0.5469} \\
\hline
\end{tabular}

7) Release 4 - Reach survival

\begin{tabular}{|c|c|c|c|c|c|c|c|c|}
\hline & \multicolumn{2}{|c|}{$\begin{array}{l}\text { Release to } \\
\text { CR275 }\end{array}$} & \multicolumn{2}{|c|}{$\begin{array}{c}\text { CR275 to } \\
\text { CR234 }\end{array}$} & \multicolumn{2}{|c|}{$\begin{array}{c}\text { CR234 to } \\
\text { CR161 }\end{array}$} & \multicolumn{2}{|c|}{$\begin{array}{l}\text { CR161 to } \\
\text { CR113 }\end{array}$} \\
\hline & $\hat{S}$ & SE & $\hat{S}$ & SE & $\hat{S}$ & SE & $\hat{S}$ & SE \\
\hline Lot 1 & 0.9867 & 0.0094 & 0.9932 & 0.0067 & 0.9663 & 0.0150 & 0.9913 & 0.0106 \\
\hline Lot 2 & 0.9799 & 0.0115 & 0.9795 & 0.0117 & 0.9648 & 0.0155 & 1.0147 & 0.0060 \\
\hline${ }_{5}^{\text {Lot } 3,4,}$ & 0.9926 & 0.0040 & 0.9954 & 0.0033 & 0.9655 & 0.0146 & 0.9260 & 0.0318 \\
\hline$P$-value & \multicolumn{2}{|c|}{0.5987} & \multicolumn{2}{|c|}{0.3169} & \multicolumn{2}{|c|}{0.9975} & \multicolumn{2}{|c|}{0.0043} \\
\hline
\end{tabular}


Table H.5. (contd)

8) Release 4-Cumulative survival

\begin{tabular}{|c|c|c|c|c|c|c|c|c|c|c|}
\hline & & \multicolumn{2}{|c|}{ Release to CR275 } & \multicolumn{2}{|c|}{ Release to CR234 } & \multicolumn{3}{|c|}{ Release to CR161 I } & \multicolumn{2}{|c|}{ Release to CR113 } \\
\hline & & $\hat{S}$ & SE & $\hat{S}$ & SE & $\hat{S}$ & & $\mathrm{E}$ & $\hat{S}$ & SE \\
\hline Lot 1 & & 0.9867 & 0.0094 & 0.9800 & 0.0114 & $4 \quad 0.94$ & $\begin{array}{ll}70 & 0.0\end{array}$ & 1840 & 0.9388 & 0.0207 \\
\hline Lot 2 & & 0.9799 & 0.0115 & 0.9597 & 0.0161 & $1 \quad 0.92$ & $59 \quad 0.02$ & $215 \quad 0$ & 0.9396 & 0.0225 \\
\hline $4,5^{\text {Lot } 3,}$ & & 0.9926 & 0.0040 & 0.9880 & 0.0049 & $9 \quad 0.95$ & $\begin{array}{ll}39 & 0.0\end{array}$ & 152 & 0.8833 & 0.0296 \\
\hline \multicolumn{2}{|l|}{$P$-value } & \multicolumn{2}{|c|}{0.5987} & \multicolumn{2}{|c|}{0.2137} & \multicolumn{3}{|c|}{0.5377} & \multicolumn{2}{|c|}{0.1777} \\
\hline \multicolumn{11}{|c|}{ 9) Release 5 - Reach survival } \\
\hline & & & & & \multicolumn{2}{|c|}{$\begin{array}{l}\text { Release to } \\
\text { CR234 }\end{array}$} & \multicolumn{2}{|c|}{$\begin{array}{l}\text { CR234 to } \\
\text { CR161 }\end{array}$} & \multicolumn{2}{|c|}{$\begin{array}{l}\text { CR161 to } \\
\text { CR113 }\end{array}$} \\
\hline & & & & & $\hat{S}$ & SE & $\hat{S}$ & SE & $\hat{S}$ & SE \\
\hline Lot 1 & & & & & 0.9733 & 0.0132 & 0.9381 & 0.0200 & $0 \quad 0.9890$ & 0.0165 \\
\hline Lot 2 & & & & & 1.0000 & 0.0000 & 0.9656 & 0.0153 & $\begin{array}{ll}30.9896\end{array}$ & 0.0136 \\
\hline${ }_{5}$ Lot 3,4, & & & & & 0.9801 & 0.0062 & 0.9592 & 0.0154 & 40.9686 & 0.0362 \\
\hline$P$-value & & & & \multicolumn{3}{|c|}{0.1775} & 0.48 & 899 & & 7849 \\
\hline
\end{tabular}

10) Release 5 - Cumulative survival

\begin{tabular}{cccccccc}
\hline & \multicolumn{2}{c}{ Release to CR234 } & \multicolumn{2}{c}{ Release to CR161 } & \multicolumn{2}{c}{ Release to CR113 } \\
\cline { 2 - 8 } & $\hat{S}$ & SE & $\hat{S}$ & SE & & $\hat{S}$ & SE \\
\hline Lot 1 & 0.9733 & 0.0132 & 0.9131 & 0.0231 & 0.9031 & 0.0273 \\
Lot 2 & 1.0000 & 0.0000 & 0.9656 & 0.0153 & 0.9556 & 0.0199 \\
Lot 3, & 0.9801 & 0.0062 & 0.9401 & 0.0162 & 0.9106 & 0.0335 \\
4,5 & & & & & & & \\
\hline $\boldsymbol{P}$-value & & $\mathbf{0 . 1 7 7 5}$ & & $\mathbf{0 . 1 3 3 8}$ & & $\mathbf{0 . 3 4 4 0}$ \\
\hline
\end{tabular}

11) Release 6 - Reach survival

\begin{tabular}{|c|c|c|c|c|}
\hline & \multicolumn{2}{|c|}{$\begin{array}{c}\text { Release to } \\
\text { CR161 }\end{array}$} & \multicolumn{2}{|c|}{$\begin{array}{c}\text { CR161 to } \\
\text { CR113 }\end{array}$} \\
\hline & $\hat{S}$ & SE & $\hat{S}$ & SE \\
\hline Lot 1 & 0.9802 & 0.0140 & 0.9897 & 0.0155 \\
\hline Lot 2 & 0.9934 & 0.0066 & 1.0023 & 0.0079 \\
\hline 5 Lot 3,4 & 0.9951 & 0.0104 & 0.9472 & 0.0243 \\
\hline$P$-value & \multicolumn{2}{|c|}{0.5635} & \multicolumn{2}{|c|}{0.0608} \\
\hline
\end{tabular}


Table H.5. (contd)

12) Release 6 - Cumulative survival

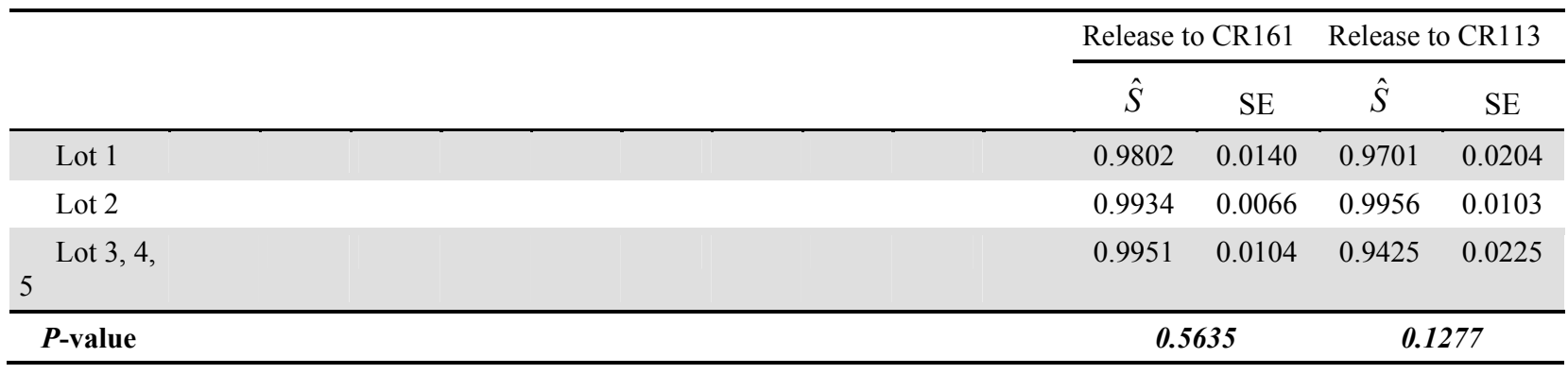

13) Release 7 - Reach survival

\begin{tabular}{lcc}
\hline & \multicolumn{2}{c}{$\begin{array}{c}\text { Release to } \\
\text { CR113 }\end{array}$} \\
\cline { 2 - 3 } & $\hat{S}$ & SE \\
\hline Lot 1 & 0.9874 & 0.0156 \\
Lot $2^{2}$ & 0.9790 & 0.0139 \\
$5^{\text {Lot } 3,4,}$ & 0.9552 & 0.0229 \\
\hline $\boldsymbol{P}$-value & & \\
\hline
\end{tabular}

b. STH

14) Release 1 - Reach survival

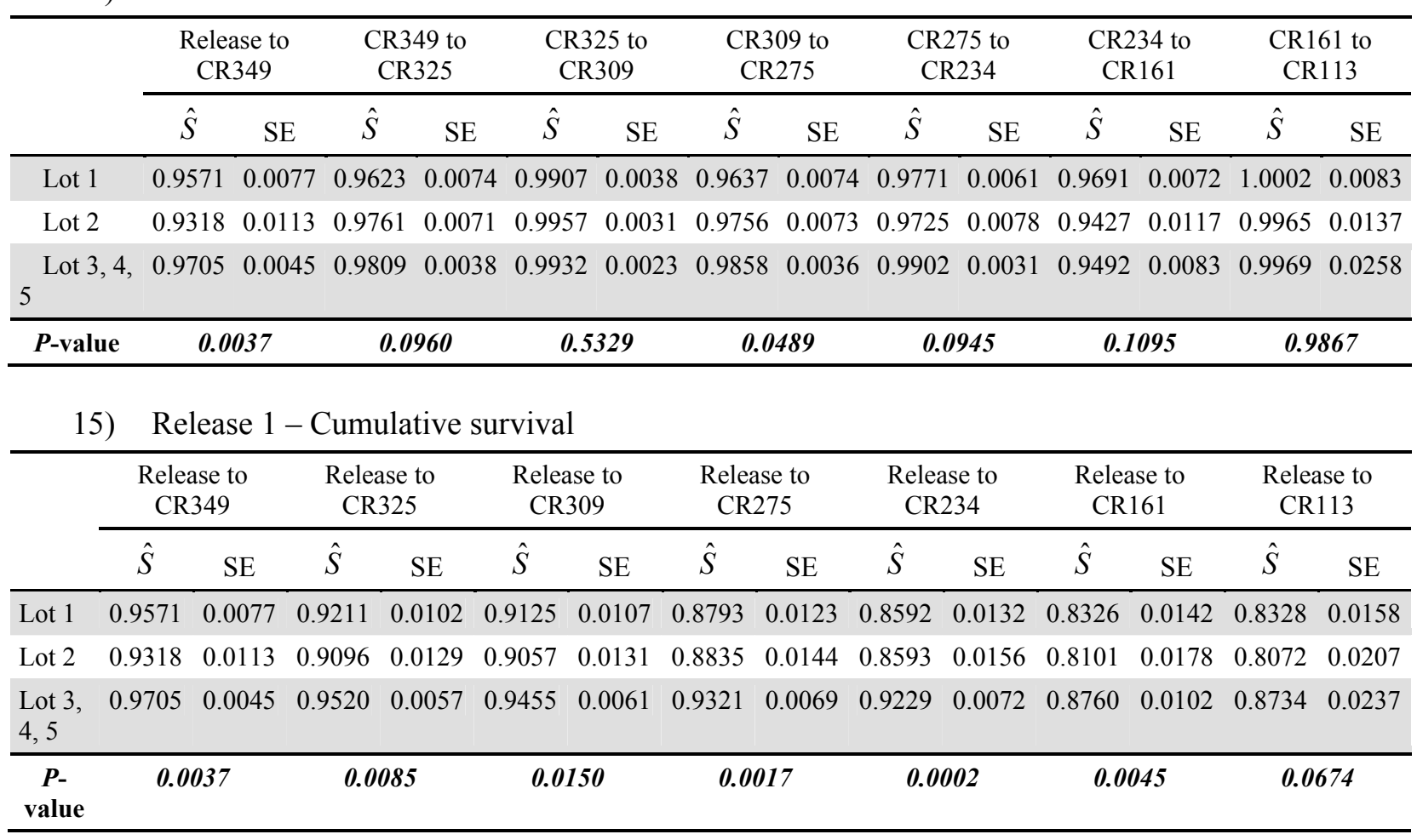


Table H.5. (contd)

16) Release 2 - Reach survival

\begin{tabular}{|c|c|c|c|c|c|c|c|c|c|c|c|c|}
\hline & \multicolumn{2}{|c|}{$\begin{array}{l}\text { CR349 to } \\
\text { CR325 }\end{array}$} & \multicolumn{2}{|c|}{$\begin{array}{c}\text { CR325 to } \\
\text { CR309 }\end{array}$} & \multicolumn{2}{|c|}{$\begin{array}{l}\text { CR309 to } \\
\text { CR275 }\end{array}$} & \multicolumn{2}{|c|}{$\begin{array}{c}\text { CR275 to } \\
\text { CR234 }\end{array}$} & \multicolumn{2}{|c|}{$\begin{array}{c}\text { CR234 to } \\
\text { CR161 }\end{array}$} & \multicolumn{2}{|c|}{$\begin{array}{l}\text { CR161 to } \\
\text { CR113 }\end{array}$} \\
\hline & $\hat{S}$ & SE & $\hat{S}$ & SE & $\hat{S}$ & SE & $\hat{S}$ & SE & $\hat{S}$ & SE & $\hat{S}$ & SE \\
\hline Lot 1 & 1.0000 & 0.0000 & 0.9868 & 0.0075 & 0.9733 & 0.0107 & 0.9909 & 0.0064 & 0.9449 & 0.0155 & 1.0030 & 0.0135 \\
\hline Lot 2 & 0.9834 & 0.0073 & 0.9899 & 0.0058 & 0.9864 & 0.0068 & 0.9897 & 0.0059 & 0.9416 & 0.0140 & 0.9960 & 0.0136 \\
\hline${ }_{5}$ Lot 3,4, & 0.9992 & 0.0015 & 0.9813 & 0.0054 & 0.9735 & 0.0067 & 0.9879 & 0.0049 & 0.9425 & 0.0124 & 0.9594 & 0.0360 \\
\hline$P$-value & \multicolumn{2}{|c|}{0.0775} & \multicolumn{2}{|c|}{0.6208} & \multicolumn{2}{|c|}{0.4398} & \multicolumn{2}{|c|}{0.9344} & \multicolumn{2}{|c|}{0.9853} & \multicolumn{2}{|c|}{0.3713} \\
\hline
\end{tabular}

17) Release 2 - Cumulative survival

\begin{tabular}{|c|c|c|c|c|c|c|c|c|c|c|c|c|}
\hline & \multicolumn{2}{|c|}{$\begin{array}{l}\text { Release to } \\
\text { CR325 }\end{array}$} & \multicolumn{2}{|c|}{$\begin{array}{l}\text { Release to } \\
\text { CR309 }\end{array}$} & \multicolumn{2}{|c|}{$\begin{array}{l}\text { Release to } \\
\text { CR275 }\end{array}$} & \multicolumn{2}{|c|}{$\begin{array}{l}\text { Release to } \\
\text { CR234 }\end{array}$} & \multicolumn{2}{|c|}{$\begin{array}{l}\text { Release to } \\
\text { CR161 }\end{array}$} & \multicolumn{2}{|c|}{$\begin{array}{l}\text { Release to } \\
\text { CR113 }\end{array}$} \\
\hline & $\hat{S}$ & $\mathrm{SE}$ & $\hat{S}$ & SE & $\hat{S}$ & SE & $\hat{S}$ & SE & $\hat{S}$ & SE & $\hat{S}$ & SE \\
\hline Lot 1 & 1.0000 & 0.0000 & 0.9868 & 0.0075 & 0.9605 & 0.0129 & 0.9518 & 0.0142 & 0.8993 & 0.0200 & 0.9021 & 0.0234 \\
\hline Lot 2 & 0.9834 & 0.0073 & 0.9735 & 0.0092 & 0.9603 & 0.0112 & 0.9503 & 0.0125 & 0.8949 & 0.0177 & 0.8913 & 0.0213 \\
\hline $\begin{array}{r}\text { Lot } \\
3,4,5\end{array}$ & 0.9992 & 0.0015 & 0.9805 & 0.0054 & 0.9545 & 0.0084 & 0.9429 & 0.0090 & 0.8887 & 0.0145 & 0.8526 & 0.0332 \\
\hline$P$-value & \multicolumn{2}{|c|}{0.0775} & \multicolumn{2}{|c|}{0.4602} & \multicolumn{2}{|c|}{0.9084} & \multicolumn{2}{|c|}{0.8561} & \multicolumn{2}{|c|}{0.9118} & \multicolumn{2}{|c|}{0.3803} \\
\hline
\end{tabular}

18) Release 3 - Reach survival

\begin{tabular}{|c|c|c|c|c|c|c|c|c|c|c|}
\hline & \multicolumn{2}{|c|}{$\begin{array}{c}\text { Release to } \\
\text { CR309 }\end{array}$} & \multicolumn{2}{|c|}{$\begin{array}{l}\text { CR309 to } \\
\text { CR275 }\end{array}$} & \multicolumn{2}{|c|}{$\begin{array}{c}\text { CR275 to } \\
\text { CR234 }\end{array}$} & \multicolumn{2}{|c|}{$\begin{array}{c}\text { CR234 to } \\
\text { CR161 }\end{array}$} & \multicolumn{2}{|c|}{$\begin{array}{l}\text { CR161 to } \\
\text { CR113 }\end{array}$} \\
\hline & $\hat{S}$ & SE & $\hat{S}$ & SE & $\hat{S}$ & SE & $\hat{S}$ & SE & $\hat{S}$ & SE \\
\hline Lot 1 & 0.9933 & 0.0066 & 0.9866 & 0.0094 & 0.9796 & 0.0117 & 0.9376 & 0.0202 & 1.0246 & 0.0164 \\
\hline Lot 2 & 0.9898 & 0.0071 & 0.9282 & 0.0185 & 0.9669 & 0.0133 & 0.9675 & 0.0138 & 0.9913 & 0.0193 \\
\hline${ }_{5}$ Lot 3,4 , & 0.9912 & 0.0044 & 0.9737 & 0.0081 & 0.9878 & 0.0061 & 0.9577 & 0.0144 & 1.0688 & 0.0563 \\
\hline$P$-value & \multicolumn{2}{|c|}{0.9221} & \multicolumn{2}{|c|}{0.0034} & \multicolumn{2}{|c|}{0.3863} & \multicolumn{2}{|c|}{0.4209} & \multicolumn{2}{|c|}{0.3039} \\
\hline
\end{tabular}

19) Release 3 - Cumulative survival

\begin{tabular}{|c|c|c|c|c|c|c|c|c|c|c|}
\hline & \multicolumn{2}{|c|}{$\begin{array}{c}\text { Release to } \\
\text { CR309 }\end{array}$} & \multicolumn{2}{|c|}{$\begin{array}{l}\text { Release to } \\
\text { CR275 }\end{array}$} & \multicolumn{2}{|c|}{$\begin{array}{c}\text { Release to } \\
\text { CR234 }\end{array}$} & \multicolumn{2}{|c|}{$\begin{array}{c}\text { Release to } \\
\text { CR161 }\end{array}$} & \multicolumn{2}{|c|}{$\begin{array}{l}\text { Release to } \\
\text { CR113 }\end{array}$} \\
\hline & $\hat{S}$ & SE & $\hat{S}$ & SE & $\hat{S}$ & SE & $\hat{S}$ & SE & $\hat{S}$ & SE \\
\hline Lot 1 & 0.9933 & 0.0066 & 0.9800 & 0.0114 & 0.9600 & 0.0160 & 0.9001 & 0.0245 & 0.9222 & 0.0291 \\
\hline Lot 2 & 0.9898 & 0.0071 & 0.9188 & 0.0195 & 0.8883 & 0.0224 & 0.8595 & 0.0249 & 0.8520 & 0.0295 \\
\hline $\begin{array}{r}\text { Lot } 3, \\
4,5\end{array}$ & 0.9912 & 0.0044 & 0.9651 & 0.0091 & 0.9533 & 0.0099 & 0.9130 & 0.0167 & 0.9758 & 0.0522 \\
\hline$P$-value & \multicolumn{2}{|c|}{0.9221} & \multicolumn{2}{|c|}{0.0058} & \multicolumn{2}{|c|}{0.0042} & \multicolumn{2}{|c|}{0.2107} & \multicolumn{2}{|c|}{0.0739} \\
\hline
\end{tabular}


Table H.5. (contd)

20) Release 4 - Reach survival

\begin{tabular}{|c|c|c|c|c|c|c|c|c|}
\hline & \multicolumn{2}{|c|}{$\begin{array}{l}\text { Release to } \\
\text { CR275 }\end{array}$} & \multicolumn{2}{|c|}{$\begin{array}{l}\text { CR275 to } \\
\text { CR234 }\end{array}$} & \multicolumn{2}{|c|}{$\begin{array}{l}\text { CR234 to } \\
\text { CR161 }\end{array}$} & \multicolumn{2}{|c|}{$\begin{array}{l}\text { CR161 to } \\
\text { CR113 }\end{array}$} \\
\hline & $\hat{S}$ & SE & $\hat{S}$ & SE & $\hat{S}$ & SE & $\hat{S}$ & SE \\
\hline Lot 1 & 0.9933 & 0.0066 & 0.9463 & 0.0185 & 0.9362 & 0.0206 & 1.0211 & 0.0192 \\
\hline Lot 2 & 0.9800 & 0.0114 & 0.9932 & 0.0068 & 0.9522 & 0.0177 & 0.9952 & 0.0142 \\
\hline${ }_{5} \operatorname{Lot} 3,4$, & 0.9821 & 0.0064 & 0.9897 & 0.0051 & 0.9501 & 0.0141 & 0.9230 & 0.0360 \\
\hline$P$-value & \multicolumn{2}{|c|}{0.4905} & \multicolumn{2}{|c|}{0.0070} & \multicolumn{2}{|c|}{0.7848} & \multicolumn{2}{|c|}{0.0157} \\
\hline
\end{tabular}

21) Release 4 - Cumulative survival

\begin{tabular}{|c|c|c|c|c|c|c|c|c|c|c|}
\hline & & \multicolumn{2}{|c|}{ Release to CR275 } & \multicolumn{2}{|c|}{ Release to CR234 } & \multicolumn{3}{|c|}{ Release to CR161 } & \multicolumn{2}{|c|}{ Release to CR113 } \\
\hline & & $\hat{S}$ & SE & $\hat{S}$ & SE & $\hat{S}$ & S & $E$ & $\hat{S}$ & SE \\
\hline Lot 1 & & 0.9933 & 0.0066 & 0.9400 & 0.0194 & 0.880 & 0.0 & 265 & 0.8986 & 0.0319 \\
\hline Lot 2 & & 0.9800 & 0.0114 & 0.9733 & 0.0132 & 0.926 & 0.0 & 213 & 0.9224 & 0.0249 \\
\hline 4,5 & & 0.9821 & 0.0064 & 0.9720 & 0.0074 & 0.923 & 0.0 & 154 & 0.8524 & 0.0338 \\
\hline$P$-value & & \multicolumn{2}{|c|}{0.4905} & \multicolumn{2}{|c|}{0.1706} & \multicolumn{3}{|c|}{0.2305} & \multicolumn{2}{|c|}{0.2554} \\
\hline \multirow[t]{3}{*}{ 22) } & Release 5 - Reach survival & & & & & & & & & \\
\hline & & & & & \multicolumn{2}{|c|}{$\begin{array}{c}\text { Release to } \\
\text { CR234 }\end{array}$} & \multicolumn{2}{|c|}{$\begin{array}{c}\text { CR234 to } \\
\text { CR161 }\end{array}$} & \multicolumn{2}{|c|}{$\begin{array}{l}\text { CR161 to } \\
\text { CR113 }\end{array}$} \\
\hline & & & & & $\hat{S}$ & SE & $\hat{S}$ & SE & $\hat{S}$ & SE \\
\hline Lot 1 & & & & & 0.9867 & 0.0094 & 0.9259 & 0.0216 & $6 \quad 1.0030$ & 0.0124 \\
\hline Lot 2 & & & & & 0.9867 & 0.0094 & 0.9601 & 0.0162 & 20.9755 & 0.0187 \\
\hline 5 Lot 3,4, & & & & & 0.9840 & 0.0056 & 0.9436 & 0.0137 & 70.9586 & 0.0378 \\
\hline$P$-value & & & & & \multicolumn{2}{|c|}{0.9654} & \multicolumn{2}{|c|}{0.3840} & \multicolumn{2}{|c|}{0.4582} \\
\hline
\end{tabular}

23) Release 5 - Cumulative survival

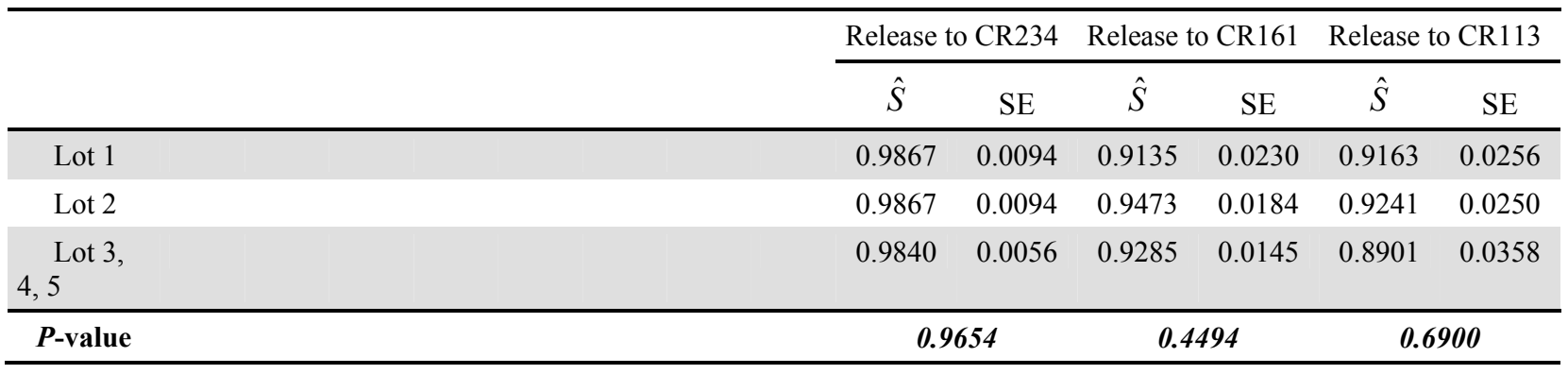


Table H.5. ( contd)

24) Release 6-Reach survival

\begin{tabular}{|c|c|c|c|c|}
\hline & \multicolumn{2}{|c|}{$\begin{array}{l}\text { Release to } \\
\text { CR161 }\end{array}$} & \multicolumn{2}{|c|}{$\begin{array}{l}\text { CR161 to } \\
\text { CR113 }\end{array}$} \\
\hline & $\hat{S}$ & SE & $\hat{S}$ & SE \\
\hline Lot 1 & 0.9802 & 0.0142 & 0.9934 & 0.0163 \\
\hline Lot 2 & 0.9659 & 0.0151 & 0.9911 & 0.0136 \\
\hline${ }_{5} \operatorname{Lot} 3,4$, & 0.9705 & 0.0117 & 0.9449 & 0.0301 \\
\hline$P$-value & \multicolumn{2}{|c|}{0.7527} & \multicolumn{2}{|c|}{0.1916} \\
\hline
\end{tabular}

25) Release 6 - Cumulative survival

\begin{tabular}{|c|c|c|c|c|}
\hline & \multicolumn{2}{|c|}{ Release to CR161 } & \multicolumn{2}{|c|}{ Release to CR113 } \\
\hline & $\hat{S}$ & $\mathrm{SE}$ & $\hat{S}$ & SE \\
\hline Lot 1 & 0.9802 & 0.0142 & 0.9738 & 0.0211 \\
\hline Lot 2 & 0.9659 & 0.0151 & 0.9573 & 0.0198 \\
\hline${ }_{5} \quad$ Lot 3,4, & 0.9705 & 0.0117 & 0.9170 & 0.0288 \\
\hline$P$-value & \multicolumn{2}{|c|}{0.7527} & \multicolumn{2}{|c|}{0.2147} \\
\hline
\end{tabular}

26) Release 7 - Reach survival

\begin{tabular}{|c|c|c|}
\hline & \multicolumn{2}{|c|}{$\begin{array}{l}\text { Release to } \\
\text { CR113 }\end{array}$} \\
\hline & $\hat{S}$ & SE \\
\hline Lot 1 & 0.9714 & 0.0240 \\
\hline Lot 2 & 0.9835 & 0.0160 \\
\hline 5 Lot 3,4 , & 0.9297 & 0.0282 \\
\hline$P$-value & \multicolumn{2}{|c|}{0.2303} \\
\hline
\end{tabular}




\section{H.3 Examination of Delayed Handling Effects}

The purpose of these tests was to assess whether downstream reach survivals were affected by how far upstream juvenile salmonids were released. The results of these tests were used to determine which release groups were included in the sample population of the downstream virtual-release group. Data were pooled across taggers and tag lots during these analyses because previous tests of tag-lot and tagger effects were not significant.

There were 10 reach comparisons, one of which was significant at $\alpha=0.10$. In the 10 cases, the survival estimates typically differed by less than 0.01 , and reach survival for the uppermost release group was often higher than that of the downriver release groups (Table H.6). Comparison of cumulative survivals in reaches common to multiple release groups found 4 of 30 (i.e., 13.3\%) tests to be significant at $\alpha=0.10$ (Table H.7). In all cases, the upper release group $\left(R_{1}\right)$ had higher survival than a group released further downriver. These observations are not consistent with evidence of time-dependent tag effects.

Based on these findings, there is no evidence of a delayed handling/tag effect influencing the survival studies. For this reason, all available upriver releases were used in the construction of virtual-release groups at the face of John Day, The Dalles, and Bonneville dams. 
Table H.6. Comparison of reach survivals between tag releases from different upstream locations for a) $\mathrm{CH} 1$ and b) STH during the 2011 Juvenile Salmon Acoustic Telemetry System (JSATS) survival study. Darkened reach survivals were not included in the $F$-tests of homogeneous survival because they represent new releases. Newly released fish and previously released fish were not compared within a reach.

a. $\mathrm{CH} 1$

\begin{tabular}{|c|c|c|c|c|c|c|c|c|c|c|c|c|c|c|c|}
\hline \multirow[b]{2}{*}{ Reach } & \multicolumn{2}{|c|}{ CR390 } & \multicolumn{2}{|c|}{ CR346 } & \multicolumn{2}{|c|}{ CR325 } & \multicolumn{2}{|c|}{ CR307 } & \multicolumn{2}{|c|}{ CR275 } & \multicolumn{2}{|c|}{ CR233 } & \multicolumn{2}{|c|}{ CR161 } & \multirow{2}{*}{$\begin{array}{c}P \\
(F \text {-test })\end{array}$} \\
\hline & $\hat{S}$ & SE & $\hat{S}$ & SE & $\hat{S}$ & SE & $\hat{S}$ & SE & $\hat{S}$ & SE & $\hat{S}$ & $\mathrm{SE}$ & $\hat{S}$ & SE & \\
\hline $\begin{array}{l}\text { Release to } \\
\text { CR349 }\end{array}$ & $\begin{array}{c}0.98 \\
10\end{array}$ & $\begin{array}{c}0.00 \\
29\end{array}$ & & & & & & & & & & & & & \\
\hline $\begin{array}{l}\text { CR349 to } \\
\text { CR325 }\end{array}$ & $\begin{array}{c}0.96 \\
20\end{array}$ & $\begin{array}{c}0.00 \\
39\end{array}$ & $\begin{array}{c}0.99 \\
23\end{array}$ & $\begin{array}{c}0.00 \\
29\end{array}$ & & & & & & & & & & & \\
\hline $\begin{array}{l}\text { CR325 to } \\
\text { CR309 }\end{array}$ & $\begin{array}{c}0.99 \\
24\end{array}$ & $\begin{array}{c}0.00 \\
19\end{array}$ & $\begin{array}{c}0.98 \\
92\end{array}$ & $\begin{array}{c}0.00 \\
31\end{array}$ & $\begin{array}{c}0.98 \\
74\end{array}$ & $\begin{array}{c}0.00 \\
43\end{array}$ & & & & & & & & & 0.3788 \\
\hline $\begin{array}{l}\text { CR309 to } \\
\text { CR275 }\end{array}$ & $\begin{array}{c}0.96 \\
36\end{array}$ & $\begin{array}{c}0.00 \\
39\end{array}$ & $\begin{array}{c}0.95 \\
38\end{array}$ & $\begin{array}{c}0.00 \\
62\end{array}$ & $\begin{array}{l}0.95 \\
25\end{array}$ & $\begin{array}{c}0.00 \\
77\end{array}$ & $\begin{array}{c}0.99 \\
15\end{array}$ & $\begin{array}{c}0.00 \\
38\end{array}$ & & & & & & & 0.3760 \\
\hline $\begin{array}{l}\text { CR275 to } \\
\text { CR234 }\end{array}$ & $\begin{array}{c}0.99 \\
54\end{array}$ & $\begin{array}{c}0.00 \\
16\end{array}$ & $\begin{array}{c}0.99 \\
47\end{array}$ & $\begin{array}{c}0.00 \\
24\end{array}$ & $\begin{array}{c}0.99 \\
19\end{array}$ & $\begin{array}{c}0.00 \\
36\end{array}$ & $\begin{array}{c}0.99 \\
24\end{array}$ & $\begin{array}{c}0.00 \\
34\end{array}$ & $\begin{array}{c}0.98 \\
51\end{array}$ & $\begin{array}{c}0.00 \\
47\end{array}$ & & & & & 0.7845 \\
\hline $\begin{array}{l}\text { CR234 to } \\
\text { CR161 }\end{array}$ & $\begin{array}{c}0.95 \\
51\end{array}$ & $\begin{array}{c}0.00 \\
54\end{array}$ & $\begin{array}{c}0.95 \\
18\end{array}$ & $\begin{array}{c}0.00 \\
80\end{array}$ & $\begin{array}{c}0.94 \\
64\end{array}$ & $\begin{array}{c}0.00 \\
95\end{array}$ & $\begin{array}{c}0.95 \\
41\end{array}$ & $\begin{array}{c}0.00 \\
92\end{array}$ & $\begin{array}{c}0.94 \\
51\end{array}$ & $\begin{array}{c}0.00 \\
99\end{array}$ & $\begin{array}{c}0.98 \\
63\end{array}$ & $\begin{array}{c}0.00 \\
67\end{array}$ & & & 0.8916 \\
\hline $\begin{array}{l}\text { CR161 to } \\
\text { CR113 }\end{array}$ & $\begin{array}{c}0.95 \\
77\end{array}$ & $\begin{array}{c}0.00 \\
94\end{array}$ & $\begin{array}{c}0.95 \\
15\end{array}$ & $\begin{array}{c}0.01 \\
33\end{array}$ & $\begin{array}{c}0.97 \\
99\end{array}$ & $\begin{array}{c}0.01 \\
55\end{array}$ & $\begin{array}{c}0.94 \\
67\end{array}$ & $\begin{array}{c}0.01 \\
61\end{array}$ & $\begin{array}{c}0.95 \\
71\end{array}$ & $\begin{array}{c}0.01 \\
76\end{array}$ & $\begin{array}{c}0.95 \\
86\end{array}$ & $\begin{array}{c}0.01 \\
44\end{array}$ & $\begin{array}{c}0.94 \\
79\end{array}$ & $\begin{array}{c}0.01 \\
41\end{array}$ & 0.6943 \\
\hline
\end{tabular}

b. STH

\begin{tabular}{|c|c|c|c|c|c|c|c|c|c|c|c|c|c|c|c|}
\hline \multirow[b]{2}{*}{ Reach } & \multicolumn{2}{|c|}{ CR390 } & \multicolumn{2}{|c|}{ CR346 } & \multicolumn{2}{|c|}{ CR325 } & \multicolumn{2}{|c|}{ CR307 } & \multicolumn{2}{|c|}{ CR275 } & \multicolumn{2}{|c|}{ CR233 } & \multicolumn{2}{|c|}{ CR161 } & \multirow{2}{*}{$\begin{array}{c}P \\
(F \text {-test }) \\
\end{array}$} \\
\hline & $\hat{S}$ & SE & $\hat{S}$ & SE & $\hat{S}$ & SE & $\hat{S}$ & $\mathrm{SE}$ & $\hat{S}$ & $\mathrm{SE}$ & $\hat{S}$ & SE & $\hat{S}$ & $\mathrm{SE}$ & \\
\hline $\begin{array}{c}\text { Release to } \\
\text { CR349 }\end{array}$ & $\begin{array}{c}0.96 \\
23\end{array}$ & $\begin{array}{c}0.00 \\
39\end{array}$ & & & & & & & & & & & & & \\
\hline $\begin{array}{l}\text { CR349 to } \\
\text { CR325 }\end{array}$ & $\begin{array}{c}0.97 \\
57\end{array}$ & $\begin{array}{c}0.00 \\
32\end{array}$ & $\begin{array}{c}0.99 \\
75\end{array}$ & $\begin{array}{c}0.00 \\
20\end{array}$ & & & & & & & & & & & \\
\hline $\begin{array}{l}\text { CR325 to } \\
\text { CR309 }\end{array}$ & $\begin{array}{c}0.99 \\
32\end{array}$ & $\begin{array}{c}0.00 \\
17\end{array}$ & $\begin{array}{c}0.98 \\
47\end{array}$ & $\begin{array}{c}0.00 \\
36\end{array}$ & $\begin{array}{c}0.99 \\
32\end{array}$ & $\begin{array}{c}0.00 \\
33\end{array}$ & & & & & & & & & 0.0328 \\
\hline $\begin{array}{l}\text { CR309 to } \\
\text { CR275 }\end{array}$ & $\begin{array}{c}0.97 \\
95\end{array}$ & $\begin{array}{c}0.00 \\
31\end{array}$ & $\begin{array}{c}0.97 \\
69\end{array}$ & $\begin{array}{c}0.00 \\
46\end{array}$ & $\begin{array}{c}0.96 \\
63\end{array}$ & $\begin{array}{c}0.00 \\
68\end{array}$ & $\begin{array}{c}0.98 \\
67\end{array}$ & $\begin{array}{c}0.00 \\
47\end{array}$ & & & & & & & 0.1489 \\
\hline $\begin{array}{l}\text { CR275 to } \\
\text { CR234 }\end{array}$ & $\begin{array}{c}0.98 \\
31\end{array}$ & $\begin{array}{c}0.00 \\
29\end{array}$ & $\begin{array}{l}0.98 \\
95\end{array}$ & $\begin{array}{c}0.00 \\
33\end{array}$ & $\begin{array}{c}0.98 \\
07\end{array}$ & $\begin{array}{c}0.00 \\
54\end{array}$ & $\begin{array}{c}0.98 \\
16\end{array}$ & $\begin{array}{c}0.00 \\
52\end{array}$ & $\begin{array}{c}0.98 \\
74\end{array}$ & $\begin{array}{c}0.00 \\
43\end{array}$ & & & & & 0.4732 \\
\hline $\begin{array}{l}\text { CR234 to } \\
\text { CR161 }\end{array}$ & $\begin{array}{c}0.94 \\
80\end{array}$ & $\begin{array}{c}0.00 \\
52\end{array}$ & $\begin{array}{c}0.93 \\
67\end{array}$ & $\begin{array}{c}0.00 \\
80\end{array}$ & $\begin{array}{c}0.94 \\
95\end{array}$ & $\begin{array}{c}0.00 \\
92\end{array}$ & $\begin{array}{c}0.94 \\
01\end{array}$ & $\begin{array}{c}0.00 \\
97\end{array}$ & $\begin{array}{c}0.93 \\
79\end{array}$ & $\begin{array}{c}0.00 \\
96\end{array}$ & $\begin{array}{c}0.96 \\
59\end{array}$ & $\begin{array}{c}0.00 \\
82\end{array}$ & & & 0.7484 \\
\hline $\begin{array}{l}\text { CR161 to } \\
\text { CR113 }\end{array}$ & $\begin{array}{c}0.96 \\
91\end{array}$ & $\begin{array}{c}0.01 \\
07\end{array}$ & $\begin{array}{c}0.95 \\
28\end{array}$ & $\begin{array}{c}0.01 \\
51\end{array}$ & $\begin{array}{c}0.99 \\
38\end{array}$ & $\begin{array}{c}0.02 \\
08\end{array}$ & $\begin{array}{c}0.94 \\
51\end{array}$ & $\begin{array}{c}0.01 \\
89\end{array}$ & $\begin{array}{c}0.94 \\
45\end{array}$ & $\begin{array}{c}0.01 \\
78\end{array}$ & $\begin{array}{c}0.95 \\
01\end{array}$ & $\begin{array}{c}0.01 \\
75\end{array}$ & $\begin{array}{c}0.92 \\
58\end{array}$ & $\begin{array}{c}0.01 \\
67\end{array}$ & 0.2810 \\
\hline
\end{tabular}


Table H.7. Comparison of cumulative survivals between different upstream tag-release locations for a) $\mathrm{CH} 1$ and b) STH during the 2011 JSATS survival study. $P$-values associated with $F$-tests of homogeneous survival.

a. $\mathrm{CH} 1$

\begin{tabular}{cccccc}
\hline & \multicolumn{2}{c}{ CR390 } & \multicolumn{2}{c}{ CR346 } & \\
\cline { 2 - 5 } Reach & $\hat{S}$ & SE & $\hat{S}$ & SE & $P(F$-test $)$ \\
\hline CR325 to CR309 & 0.9924 & 0.001879 & 0.9955 & 0.0035 & 0.4352 \\
CR325 to CR275 & 0.9565 & 0.004293 & 0.9542 & 0.010577 & 0.8403 \\
CR325 to CR234 & 0.9524 & 0.004486 & 0.9515 & 0.010804 & 0.9387 \\
\hline CR325 to CR161 & 0.9097 & 0.006679 & 0.9178 & 0.020062 & 0.7017 \\
CR325 to CR113 & 0.873 & 0.009901 & 0.8403 & 0.035585 & 0.3760 \\
\hline
\end{tabular}

\begin{tabular}{cccccccc}
\hline & \multicolumn{2}{c}{ CR390 } & \multicolumn{2}{c}{ CR346 } & \multicolumn{2}{c}{ CR325 } & \\
\cline { 2 - 7 } Reach & $\hat{S}$ & SE & $\hat{S}$ & SE & $\hat{S}$ & SE & $P(F$-test $)$ \\
\hline CR309 to CR275 & 0.9636 & 0.003938 & 0.9538 & 0.00623 & 0.9525 & 0.007725 & 0.3794 \\
CR309 to CR234 & 0.9591 & 0.00417 & 0.9487 & 0.006539 & 0.9447 & 0.00827 & 0.2754 \\
CR309 to CR161 & 0.9173 & 0.006508 & 0.9035 & 0.009765 & 0.8932 & 0.01192 & 0.2085 \\
CR309 to CR113 & 0.8778 & 0.009878 & 0.8603 & 0.013978 & 0.8763 & 0.017157 & 0.6184 \\
\hline
\end{tabular}

\begin{tabular}{|c|c|c|c|c|c|c|c|c|c|}
\hline \multirow[b]{2}{*}{ Reach } & \multicolumn{2}{|c|}{ CR390 } & \multicolumn{2}{|c|}{ CR346 } & \multicolumn{2}{|c|}{ CR325 } & \multicolumn{2}{|c|}{ CR307 } & \multirow{2}{*}{$\begin{array}{c}P(F- \\
\text { test })\end{array}$} \\
\hline & $\hat{S}$ & SE & $\hat{S}$ & SE & $\hat{S}$ & SE & $\hat{S}$ & SE & \\
\hline $\begin{array}{c}\text { CR275 to } \\
\text { CR234 }\end{array}$ & $\begin{array}{c}0.995 \\
3\end{array}$ & 0.00159 & $\begin{array}{c}0.994 \\
7\end{array}$ & $\begin{array}{c}0.00243 \\
4\end{array}$ & $\begin{array}{c}0.991 \\
9\end{array}$ & $\begin{array}{c}0.00357 \\
8\end{array}$ & $\begin{array}{c}0.992 \\
4\end{array}$ & $\begin{array}{c}0.00335 \\
3\end{array}$ & 0.7922 \\
\hline $\begin{array}{c}\text { CR275 to } \\
\text { CR161 }\end{array}$ & $\begin{array}{c}0.948 \\
4\end{array}$ & $\begin{array}{c}0.00570 \\
4\end{array}$ & $\begin{array}{c}0.945 \\
9\end{array}$ & $\begin{array}{c}0.00837 \\
3\end{array}$ & $\begin{array}{c}0.940 \\
0\end{array}$ & $\begin{array}{c}0.01020 \\
8\end{array}$ & $\begin{array}{c}0.945 \\
3\end{array}$ & $\begin{array}{c}0.00976 \\
5\end{array}$ & 0.9199 \\
\hline $\begin{array}{c}\text { CR275 to } \\
\text { CR113 }\end{array}$ & $\begin{array}{c}0.917 \\
5\end{array}$ & $\begin{array}{c}0.00944 \\
6\end{array}$ & 0.908 & $\begin{array}{c}0.01308 \\
9\end{array}$ & $\begin{array}{c}0.916 \\
8\end{array}$ & $\begin{array}{c}0.01629 \\
2\end{array}$ & $\begin{array}{c}0.905 \\
7\end{array}$ & $\begin{array}{c}0.01612 \\
1\end{array}$ & 0.9067 \\
\hline
\end{tabular}

\begin{tabular}{|c|c|c|c|c|c|c|c|c|c|c|c|}
\hline \multirow[b]{2}{*}{ Reach } & \multicolumn{2}{|c|}{ CR390 } & \multicolumn{2}{|c|}{ CR346 } & \multicolumn{2}{|c|}{ CR325 } & \multicolumn{2}{|c|}{ CR307 } & \multicolumn{2}{|c|}{ CR275 } & \multirow{2}{*}{$\begin{array}{l}P(F- \\
\text { test })\end{array}$} \\
\hline & $\hat{S}$ & SE & $\hat{S}$ & SE & $\hat{S}$ & SE & $\hat{S}$ & SE & $\hat{S}$ & SE & \\
\hline $\begin{array}{c}\text { CR234 to } \\
\text { CR161 }\end{array}$ & $\begin{array}{c}0.95 \\
52\end{array}$ & $\begin{array}{c}0.005 \\
388\end{array}$ & $\begin{array}{c}0.95 \\
19\end{array}$ & $\begin{array}{c}0.007 \\
953\end{array}$ & 0.9465 & $\begin{array}{c}0.009 \\
451\end{array}$ & 0.9542 & $\begin{array}{c}0.009 \\
151\end{array}$ & 0.9452 & $\begin{array}{c}0.0098 \\
56\end{array}$ & $\begin{array}{c}0.889 \\
8\end{array}$ \\
\hline $\begin{array}{c}\text { CR234 to } \\
\text { CR113 }\end{array}$ & $\begin{array}{c}0.91 \\
48\end{array}$ & $\begin{array}{c}0.009 \\
493\end{array}$ & $\begin{array}{c}0.90 \\
57\end{array}$ & $\begin{array}{c}0.013 \\
356\end{array}$ & 0.9275 & $\begin{array}{c}0.016 \\
155\end{array}$ & 0.9033 & $\begin{array}{c}0.016 \\
241\end{array}$ & 0.9047 & $\begin{array}{c}0.0176 \\
62\end{array}$ & $\begin{array}{c}0.759 \\
5\end{array}$ \\
\hline
\end{tabular}

\begin{tabular}{|c|c|c|c|c|c|c|c|c|c|c|c|c|c|}
\hline \multirow[b]{2}{*}{ Reach } & \multicolumn{2}{|c|}{ CR390 } & \multicolumn{2}{|c|}{ CR346 } & \multicolumn{2}{|c|}{ CR325 } & \multicolumn{2}{|c|}{ CR307 } & \multicolumn{2}{|c|}{ CR275 } & \multicolumn{2}{|c|}{ CR233 } & \multirow{2}{*}{$\begin{array}{c}P(F- \\
\text { test })\end{array}$} \\
\hline & $\hat{S}$ & SE & $\hat{S}$ & SE & $\hat{S}$ & SE & $\hat{S}$ & SE & $\hat{S}$ & SE & $\hat{S}$ & SE & \\
\hline $\begin{array}{c}\text { CR161 to } \\
\text { CR113 }\end{array}$ & $\begin{array}{c}0.95 \\
08\end{array}$ & $\begin{array}{c}0.009 \\
279\end{array}$ & $\begin{array}{c}0.94 \\
67\end{array}$ & $\begin{array}{c}0.013 \\
29\end{array}$ & 0.9683 & $\begin{array}{c}0.014 \\
953\end{array}$ & 0.9425 & $\begin{array}{c}0.016 \\
114\end{array}$ & 0.9475 & $\begin{array}{c}0.0173 \\
17\end{array}$ & 0.951 & $\begin{array}{c}0.0142 \\
48\end{array}$ & 0.8584 \\
\hline
\end{tabular}


Table H.7. (contd)

b. STH

\begin{tabular}{cccccc}
\hline & \multicolumn{2}{c}{ CR390 } & \multicolumn{2}{c}{ CR346 } & \multirow{2}{*}{$\begin{array}{c}P(F- \\
\text { test })\end{array}$} \\
\cline { 2 - 5 } Reach & $\hat{S}$ & $\mathrm{SE}$ & $\hat{S}$ & $\mathrm{SE}$ & 0.0339 \\
CR325 to & 0.993 & 0.00173 & 0.984 & 0.00361 & 0.0339 \\
CR309 & 2 & 2 & 7 & 4 & \\
CR325 to & 0.973 & 0.00350 & 0.962 & 0.00573 & 0.1045 \\
CR275 & 2 & 1 & 3 & & \\
CR325 to & 0.956 & 0.00424 & 0.952 & 0.00632 & 0.5548 \\
CR234 & 6 & 6 & 1 & 7 & \\
CR325 to & 0.907 & 0.00643 & 0.893 & 0.00962 & 0.2366 \\
CR161 & 5 & 6 & 8 & 2 & \\
CR325 to & 0.879 & 0.01110 & 0.852 & 0.01572 & 0.1593 \\
CR113 & 8 & 3 & 7 & 9 & \\
\hline
\end{tabular}

\begin{tabular}{ccccccccc}
\hline & \multicolumn{2}{c}{ CR390 } & \multicolumn{2}{c}{ CR346 } & \multicolumn{2}{c}{ CR325 } & \multirow{2}{*}{$\begin{array}{c}P(F- \\
\text { test })\end{array}$} \\
\cline { 2 - 7 } Reach & $\hat{S}$ & SE & $\hat{S}$ & SE & $\hat{S}$ & SE & (n) \\
\hline CR309 to & 0.979 & 0.00311 & 0.977 & 0.00456 & 0.9663 & 0.00676 & 0.1449 \\
CR275 & 5 & 4 & 0 & 8 & & 7 & \\
CR309 to & 0.962 & 0.00394 & 0.966 & 0.00531 & 0.9476 & 0.00799 & 0.0587 \\
CR234 & 8 & 2 & 7 & 3 & & 9 & \\
CR309 to & 0.913 & 0.00625 & 0.905 & 0.00917 & 0.8998 & 0.01157 & 0.5660 \\
CR161 & 7 & 4 & 5 & 5 & & 9 & \\
CR309 to & 0.886 & 0.01109 & 0.862 & 0.01565 & 0.8932 & 0.02107 & 0.3864 \\
CR113 & 9 & 5 & 8 & 3 & & 6 & \\
\hline
\end{tabular}

\begin{tabular}{|c|c|c|c|c|c|c|c|c|c|}
\hline \multirow[b]{2}{*}{ Reach } & \multicolumn{2}{|c|}{ CR390 } & \multicolumn{2}{|c|}{ CR346 } & \multicolumn{2}{|c|}{ CR325 } & \multicolumn{2}{|c|}{ CR307 } & \multirow{2}{*}{$\begin{array}{c}P(F- \\
\text { test })\end{array}$} \\
\hline & $\hat{S}$ & SE & $\hat{S}$ & SE & $\hat{S}$ & SE & $\hat{S}$ & SE & \\
\hline $\begin{array}{c}\text { CR275 to } \\
\text { CR234 }\end{array}$ & $\begin{array}{c}0.983 \\
2\end{array}$ & $\begin{array}{c}0.00287 \\
8\end{array}$ & $\begin{array}{c}0.989 \\
5\end{array}$ & $\begin{array}{c}0.00328 \\
7\end{array}$ & 0.9807 & $\begin{array}{c}0.00544 \\
4\end{array}$ & 0.9816 & $\begin{array}{c}0.00521 \\
6\end{array}$ & 0.4769 \\
\hline $\begin{array}{c}\text { CR275 to } \\
\text { CR161 }\end{array}$ & $\begin{array}{c}0.934 \\
6\end{array}$ & $\begin{array}{c}0.00595 \\
9\end{array}$ & $\begin{array}{c}0.925 \\
1\end{array}$ & $\begin{array}{c}0.00892 \\
2\end{array}$ & 0.9334 & $\begin{array}{c}0.01045 \\
1\end{array}$ & 0.9199 & $\begin{array}{c}0.01122 \\
7\end{array}$ & 0.6431 \\
\hline $\begin{array}{l}\text { CR275 to } \\
\text { CR113 }\end{array}$ & $\begin{array}{c}0.904 \\
9\end{array}$ & $\begin{array}{c}0.01087 \\
7\end{array}$ & $\begin{array}{c}0.888 \\
7\end{array}$ & $\begin{array}{c}0.01546 \\
3\end{array}$ & 0.9408 & $\begin{array}{c}0.02074 \\
1\end{array}$ & 0.8824 & $\begin{array}{c}0.01940 \\
3\end{array}$ & 0.0699 \\
\hline
\end{tabular}


Table H.7. (contd)

\begin{tabular}{|c|c|c|c|c|c|c|c|c|c|c|c|c|c|}
\hline \multirow[b]{2}{*}{ Reach } & \multicolumn{2}{|c|}{ CR390 } & \multicolumn{2}{|c|}{ CR346 } & \multicolumn{3}{|c|}{ CR325 } & \multicolumn{3}{|c|}{ CR307 } & \multicolumn{2}{|c|}{ CR275 } & \multirow[b]{2}{*}{$P(F$-test $)$} \\
\hline & $\hat{S}$ & SE & $\hat{S}$ & SE & & $\hat{S}$ & SE & $\hat{S}$ & SH & & $\hat{S}$ & $\mathrm{SE}$ & \\
\hline $\begin{array}{l}\text { CR234 to } \\
\text { CR161 }\end{array}$ & $\begin{array}{c}0.948 \\
1\end{array}$ & $\begin{array}{c}0.00523 \\
7\end{array}$ & $\begin{array}{c}0.93 \\
8\end{array}$ & $\begin{array}{c}0.007 \\
7\end{array}$ & & $0.9496 \quad 0$ & 0.00921 & 0.9402 & $\begin{array}{r}0.00 \\
5\end{array}$ & 9660. & $0.938^{0}$ & $\begin{array}{l}.0096 \\
01\end{array}$ & 0.7478 \\
\hline \multirow[t]{2}{*}{$\begin{array}{l}\text { CR234 to } \\
\text { CR113 }\end{array}$} & $\begin{array}{c}0.919 \\
2\end{array}$ & $\begin{array}{c}0.01090 \\
7\end{array}$ & $\begin{array}{c}0.892 \\
5\end{array}$ & $\begin{array}{c}0.015 \\
7\end{array}$ & $\begin{array}{ll}40 \\
\end{array}$ & 0.94370 & $\begin{array}{c}0.02081 \\
4\end{array}$ & 0.8886 & $\begin{array}{r}0.01 \\
7\end{array}$ & $906 \quad 0.8$ & $.8859^{0}$ & $\begin{array}{l}.0181 \\
82\end{array}$ & 0.0788 \\
\hline & \multicolumn{2}{|c|}{ CR390 } & \multicolumn{2}{|c|}{ CR346 } & \multicolumn{2}{|c|}{ CR325 } & \multicolumn{2}{|c|}{ CR307 } & \multicolumn{2}{|c|}{ CR275 } & \multicolumn{2}{|c|}{ CR233 } & \\
\hline Reach & $\hat{S}$ & SE & $\hat{S}$ & SE & $\hat{S}$ & SE & $\hat{S}$ & SE & $\hat{S}$ & SE & $\hat{S}$ & SE & test) \\
\hline $\begin{array}{l}\text { CR161 to } \\
\text { CR113 }\end{array}$ & $\begin{array}{c}0.965 \\
1\end{array}$ & $\begin{array}{c}0.0106 \\
7\end{array}$ & $\begin{array}{l}0.945 \\
9\end{array}$ & $\begin{array}{c}0.0148 \\
03\end{array}$ & $\begin{array}{c}0.982 \\
8\end{array}$ & $\begin{array}{cc}2 & 0.0202 \\
& 28\end{array}$ & $\begin{array}{c}20.938 \\
5\end{array}$ & $\begin{array}{c}0.0185 \\
89\end{array}$ & $\begin{array}{c}0.9 \\
4\end{array}$ & $\begin{array}{c}0.0176 \\
74\end{array}$ & $\begin{array}{c}50.940 \\
3\end{array}$ & $\begin{array}{c}0.0171 \\
19\end{array}$ & 0.3321 \\
\hline
\end{tabular}




\section{H.4 Handling Mortality and Tag Shedding}

Fish were held for 18 to $36 \mathrm{~h}$ prior to release. The overall post-tagging mortality in spring 2011 was $0.19 \%$ of all fish tagged and released for the survival study. Specifically, mortality was $0.31 \%(\mathrm{n}=24)$ for $\mathrm{CH} 1$ and $0.08 \%(\mathrm{n}=6)$ for STH. No tags were shed during the 24 -h holding period.

\section{H.5 Detection of Dead Fish on Downstream Arrays}

None of the dead fish with active acoustic transmitters intentionally released in the JDA spillway were detected at the first downstream detection site used for estimating survival (i.e., rkm 325). This indicates that the detection site was located sufficiently far enough below JDA to avoid detection of tagged fish that may have died during dam passage.

\section{H.6 Examination of Tailrace Release Location Effects on Survival}

The distribution of weighted detections of dam-passed fish ( $V_{1}-$ Figure H.1) on tailrace autonomous nodes relative to the distribution of reference releases among five locations in the tailrace was examined along with the effect of tailrace release location on single-release survival rates to The Dalles Dam (Figure H.1). The percent of fish detected on four autonomous nodes in the JDA tailrace was weighted in an effort to equalize sampling effort and detectability among node locations. Sampling execution varied because some nodes stopped sampling prematurely due to damage or loss. Detectability varied as it was inversely related to water velocities, which were highest on the Washington side of the channel and positively correlated with depth, which was greatest on the Oregon side of the channel. On each node, the percent of all $\mathrm{CH} 1$ detection events with only the minimum number of tag-code receptions (4) was used to index detectability loss, which was, from Washington to Oregon side of river, $25 \%$ at Location $1 ; 10 \%$ at Location 2; 5\% at Location 3; and 1\% at Location 4. Detectability loss percentages for juvenile STH were $25 \%$ at Location $1 ; 10 \%$ at Location $2 ; 5 \%$ at Location 3; and 5\% at Location 4.

The uniform distribution of fish releases among five locations in the tailrace appeared to be reasonable given the observed weighted distribution of detections of dam-passed fish ( $V_{1}-$ Figure H.1). Fish that passed the dam were detected at only a slightly higher percentage on the Oregon side of the channel than they were on the Washington side. Survival rates by release location varied from 0.971 to 0.993 for $\mathrm{CH} 1$, and from 0.963 to 0.994 for juvenile STH. Wide and overlapping $95 \%$ confidence intervals suggest that point estimates of survival rates did not differ significantly among release locations. Low precision is expected given sample sizes that ranged from 208 to 260 fish. 


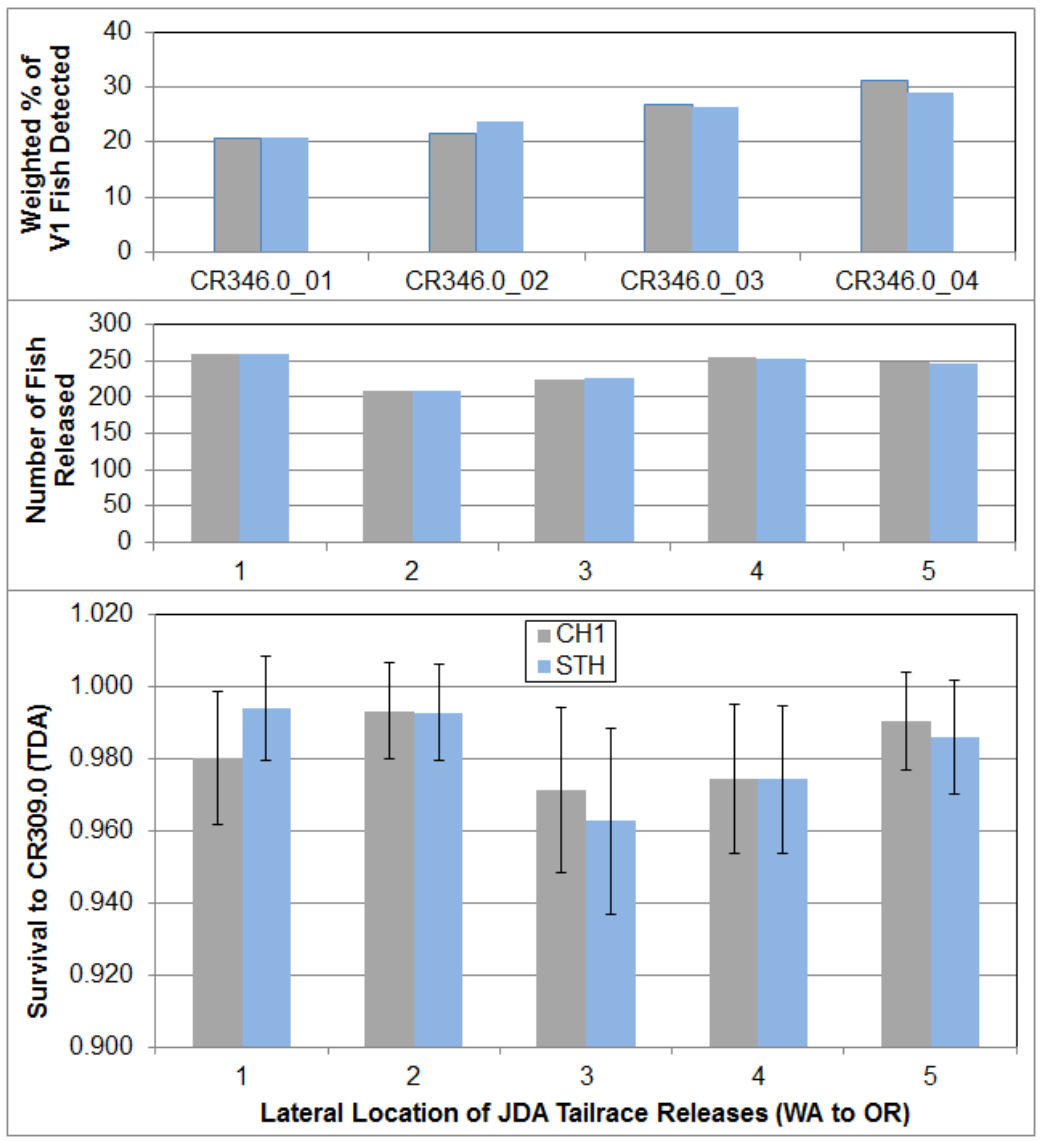

Figure H.1. Distributions of tailrace detections of $V_{1}$ fish on autonomous nodes (top), numbers of fish released in the tailrace at five locations (middle), and survival rates by tailrace release location (bottom). Gray bars are for $\mathrm{CH} 1$; blue bars are for STH; vertical bars are $95 \%$ confidence intervals on survival estimates.

\section{H.7 Examination of Time In-River on Survivals of Different Release Groups}

The virtual-release group formed from the detections of upriver releases at the face of the dam could result in biased survival estimates if fish from varying upriver release locations had different downriver survival rates. For this reason, reach survival rates and cumulative survival rates were compared across fish from different upriver release locations, including release groups downstream of JDA used to estimate survival for The Dalles and Bonneville Dam studies. There was no consistent or reproducible evidence to suggest that the amount of time (i.e., distance) in-river had a subsequent effect on downriver juvenile salmonid survival for either $\mathrm{CH} 1$ or STH. Therefore, in constructing the virtual releases at the face of the dam, fish from all available upriver release locations were used in subsequent survival and other parameter estimation. Nevertheless, in the case of the JDA compliance studies, only one upstream release location was available in forming the virtual-release group at the face of the dam (Figure 3.2). 


\section{H.8 Run Timing}

The run timings of downstream migrating $\mathrm{CH} 1$ and $\mathrm{STH}$ as indicated by the smolt passage index from the JDA Smolt Monitoring Program (SMP), were compared with the numbers of fish tagged at the JDA Smolt Monitoring Facility in 2011. The fish release periods for spring were from April 27 to May 29.

Study objectives included tagging the middle $80 \%$ of the run (10th to 90 th percentile) for each species. During the spring, 27 out of the possible 34 tagging days were conducted during the middle $80 \%$ of the run for CH1 (Table H.8). For STH, all 34 of the STH tagging days were within the middle $80 \%$ of the run (Table H.9).

Table H.8. Ten-year average yearling Chinook salmon run-timing showing the percent passage at the John Day Dam Smolt Monitoring Facility.

\begin{tabular}{|c|c|c|c|c|c|c|c|c|c|}
\hline Year & First & $1 \%$ & $5 \%$ & $10 \%$ & $50 \%$ & $90 \%$ & $95 \%$ & Last & Middle $80 \%$ Days \\
\hline 1999 & 1-Apr & 10-Apr & 18-Apr & 22-Apr & 13-May & 31-May & 5-Jun & 30-Aug & 40 \\
\hline 2000 & 4-Apr & 10-Apr & 16-Apr & 21-Apr & 9-May & 28-May & 5-Jun & 1-Aug & 38 \\
\hline 2001 & 30-Mar & 21-Apr & 1-May & 6-May & 27-May & 20-Jun & 27-Jun & 17-Sep & 46 \\
\hline 2002 & 19-Mar & 18-Apr & 25-Apr & 1-May & 17-May & 1-Jun & 5-Jun & 30-Aug & 32 \\
\hline 2003 & 1-Apr & 14-Apr & 27-Apr & 3-May & 19-May & 2-Jun & 4-Jun & 30-Aug & 31 \\
\hline 2004 & 2-Apr & 9-Apr & 20-Apr & 28-Apr & 16-May & 30-May & 6-Jun & 17-Aug & 33 \\
\hline 2005 & 2-Apr & 5-Apr & 18-Apr & 25-Apr & 12-May & 22-May & 30-May & 28-Aug & 28 \\
\hline 2006 & 4-Apr & 14-Apr & 22-Apr & 25-Apr & 11-May & 24-May & 27-May & 19-Jul & 30 \\
\hline 2007 & 3-Apr & 16-Apr & 26-Apr & 2-May & 13-May & 25-May & 30-May & 17-Aug & 24 \\
\hline 2008 & 2-Apr & 12-Apr & 26-Apr & 4-May & 22-May & 1-Jun & 6-Jun & $15-\mathrm{Sep}$ & 29 \\
\hline 2009 & 1-Apr & 16-Apr & 24-Apr & 27-Apr & 17-May & 1-Jun & 7-Jun & 11-Aug & 36 \\
\hline 2010 & 1-Apr & 24-Apr & 28-Apr & 1-May & 18-May & 6-Jun & 9-Jun & 9-Jul & 37 \\
\hline $10-y r$ avg & 31-Mar & 14-Apr & 23-Apr & 29-Apr & 16-May & 31-May & 5-Jun & 17-Aug & 33 \\
\hline 2011 & 1-Apr & 15-Apr & 27-Apr & 2-May & 17-May & 28-May & 31-May & 18-Jul & 27 \\
\hline
\end{tabular}

Table H.9. Ten-year average STH run-timing showing the percent passage at the John Day Dam Smolt Monitoring Facility.

\begin{tabular}{|c|c|c|c|c|c|c|c|c|c|}
\hline Year & First & $1 \%$ & $5 \%$ & $10 \%$ & $50 \%$ & $90 \%$ & $95 \%$ & Last & Middle $80 \%$ Days \\
\hline 1999 & 1-Apr & 2-Apr & 22-Apr & 28-Apr & 26-May & 6-Jun & 11-Jun & 9-Sep & 40 \\
\hline 2000 & 4-Apr & 12-Apr & 15-Apr & 16-Apr & 4-May & 26-May & 2-Jun & 18-Sep & 41 \\
\hline 2001 & 30-Mar & 16-Apr & 25-Apr & 30-Apr & 12-May & 2-Jun & 20-Jun & 17-Sep & 34 \\
\hline 2002 & 20-Mar & 14-Apr & 19-Apr & 22-Apr & 16-May & 7-Jun & 12-Jun & 9-Aug & 47 \\
\hline 2003 & 1-Apr & 11-Apr & 26-Apr & 2-May & 29-May & 4-Jun & 6-Jun & 4-Sep & 34 \\
\hline 2004 & 2-Apr & 12-Apr & 25-Apr & 3-May & 21-May & 31-May & 5-Jun & 13-Sep & 29 \\
\hline 2005 & 2-Apr & 17-Apr & 30-Apr & 2-May & 18-May & 25-May & 28-May & 15-Sep & 24 \\
\hline 2006 & 4-Apr & 17-Apr & 24-Apr & 27-Apr & 11-May & 29-May & 1-Jun & 12-Sep & 33 \\
\hline 2007 & 3-Apr & 17-Apr & 1-May & 4-May & 12-May & 26-May & 2-Jun & 7-Sep & 23 \\
\hline 2008 & 2-Apr & 25-Apr & 4-May & 7-May & 18-May & 31-May & 4-Jun & 13-Aug & 25 \\
\hline 2009 & 1-Apr & 22-Apr & 27-Apr & 28-Apr & 10-May & 28-May & 7-Jun & 21-Aug & 31 \\
\hline 2010 & 1-Apr & 24-Apr & 27-Apr & 1-May & 12-May & 9-Jun & 12-Jun & 20-Aug & 40 \\
\hline $10-y r$ avg & 31-Mar & 17-Apr & 25-Apr & 29-Apr & 14-May & 31-May & 6-Jun & 2-Sep & 33 \\
\hline 2011 & 1-Apr & 10-Apr & 14-Apr & 21-Apr & 19-May & 30-May & 4-Jun & 10-Aug & 40 \\
\hline
\end{tabular}




\section{H.9 Fish Size Distributions}

Comparison of JSATS-tagged fish used for survival estimates with run-of-river (ROR) fish sampled at JDA through the SMP shows that the length frequency distributions were generally well matched for $\mathrm{CH} 1$ (Figure H.2) and STH (Figure H.3). The length distributions for the three CH1 releases and the three STH releases were quite similar. Mean lengths for the $\mathrm{CH} 1$ tagged with acoustic micro-transmitters (AMTs) were $148.6 \mathrm{~mm}$ and for the steelhead, $203.8 \mathrm{~mm}$. Mean lengths for CH1 and STH sampled at the JDA Smolt Monitoring Facility were $151.4 \mathrm{~mm}$ and $199.1 \mathrm{~mm}$, respectively. Changes in the length of fish tagged with AMTs changed minimally over the course of the study (Figure H.4). 
a. John Day Dam (release $V_{2}$ )

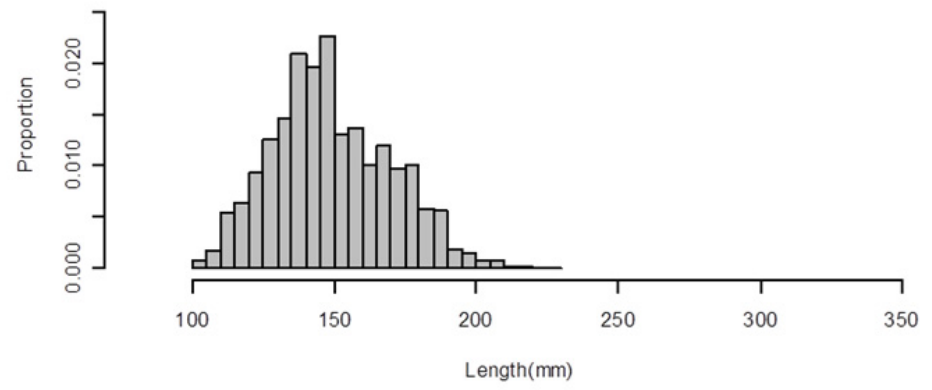

b. John Day Tailrace (release $R_{2}$ )

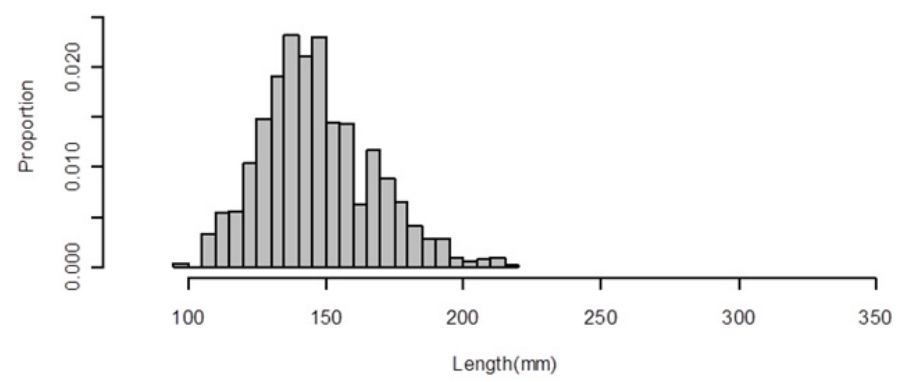

c. Mid-Reservoir (release $R_{3}$ )

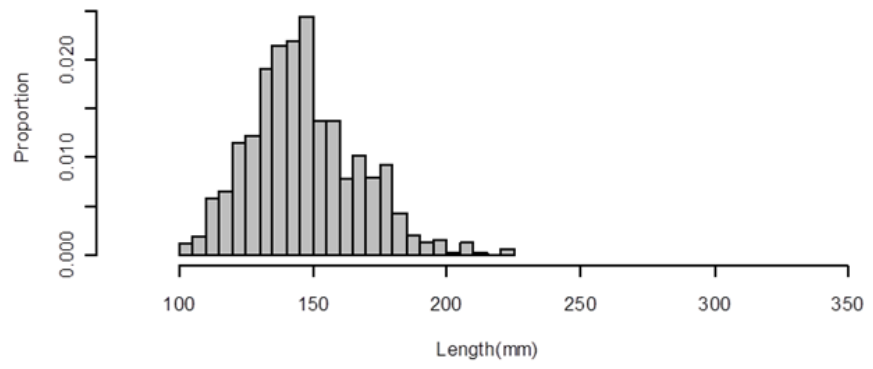

d. ROR CH1 at John Day Dam

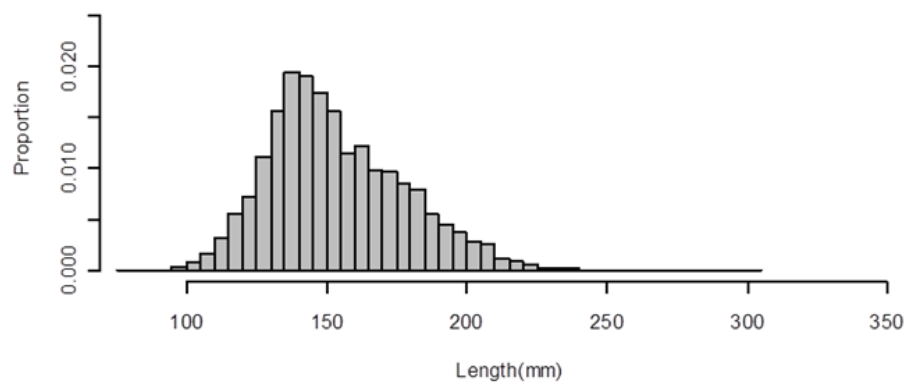

Figure H.2. Relative frequency distributions for fish lengths (mm) of CH1 used in a) release $V_{2}$, b) release $R_{2}$, c) release $R_{3}$, and d) run-of-river (ROR) fish sampled at John Day Dam by the Fish Passage Center. 
a. John Day Dam (release $V_{2}$ )

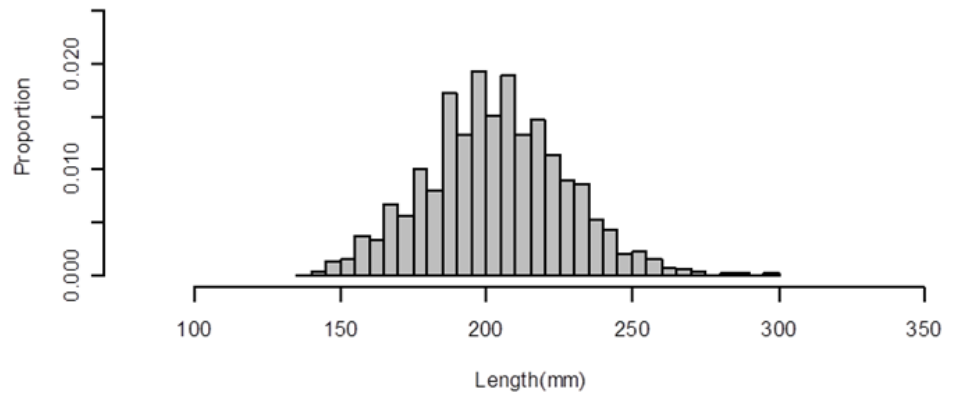

b. John Day Tailrace (release $R_{2}$ )
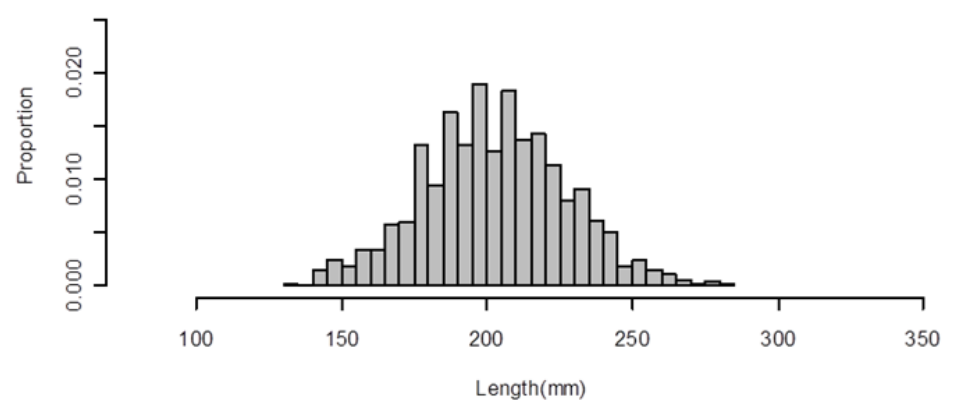

c. Mid-Reservoir (release $R_{3}$ )

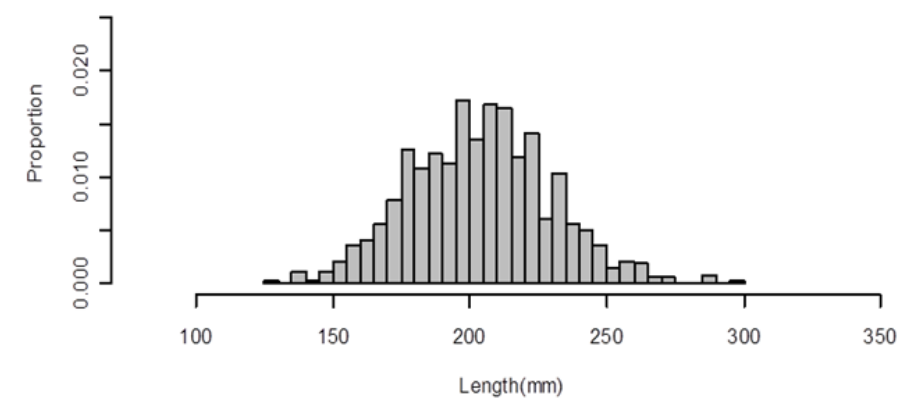

d. ROR STH at John Day Dam

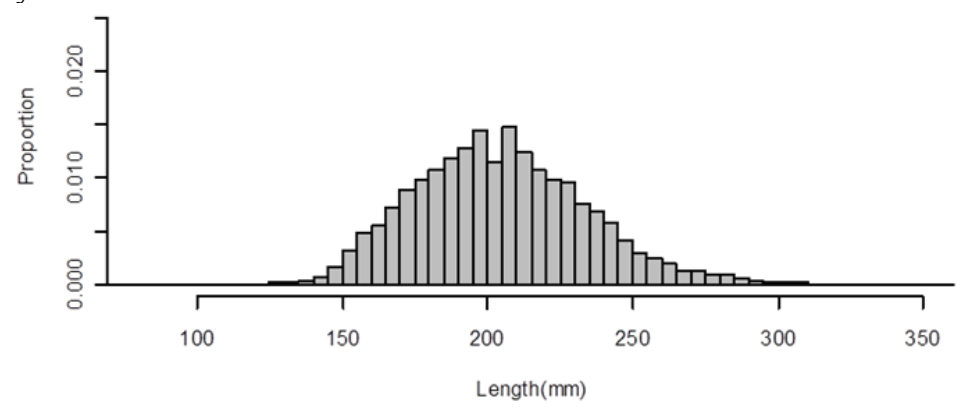

Figure H.3. Relative frequency distributions for fish lengths (mm) of STH used in a) release $V_{2}$, b) release $R_{2}, \mathrm{c}$ ) release $R_{3}$, and d) ROR fish sampled at John Day Dam by the Fish Passage Center. 
a. $\mathrm{CH} 1$

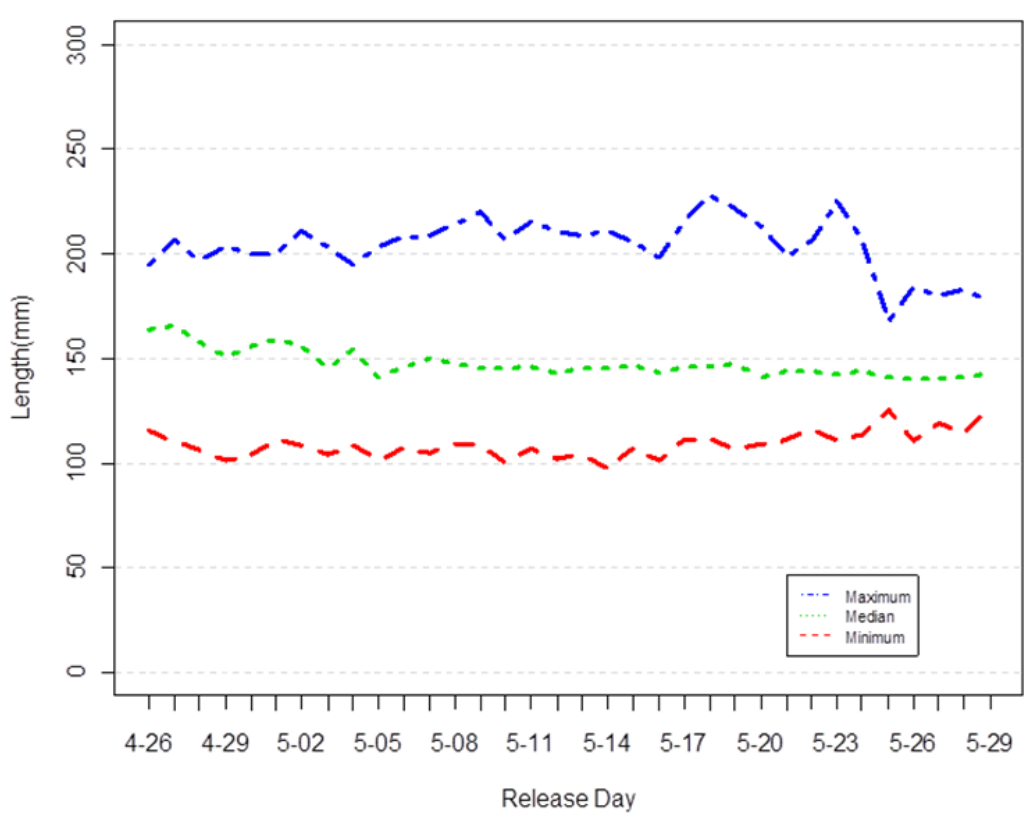

b. STH

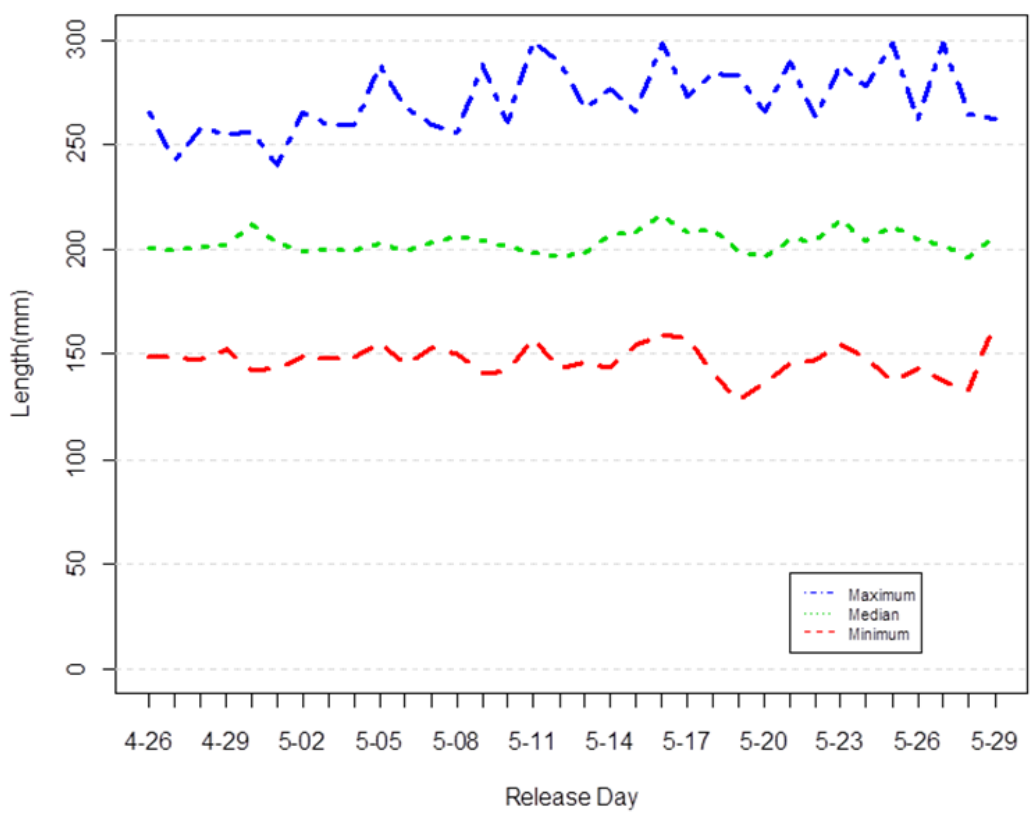

Figure H.4. Range and median lengths of a) CH1 and b) STH tagged with AMTs used in the 2011 survival studies. Releases were made daily from 27 April through 29 May at three release locations: $\mathrm{rkm} 390, \mathrm{rkm} 346$, and rkm 325. 


\section{H.10 Tag-Life Corrections}

During the 2011 spring study, five different manufacturing lots of JSATS tags were used in tagging the $\mathrm{CH} 1$ and STH. Lot 1 was manufactured distinctly from lot 2, which was manufactured distinctly from lots 3 through 5. Fifty to 59 tags were systematically sampled from each of these three tag-lot groupings for independent tag-life studies done for a total of 159 tags. Vitality curves devised by Li and Anderson (2009) were fit independently to each of the lots 1,2, and 3 through 5 (Figure H.5). Mantel and Haenszel (1959) tests of homogeneous tag-life distributions found lot 1 was significantly different from lot $2(P=$ $0.0005)$ and lots 3 through $5(P=0.0023)$, but lots 2 and lots 3 through 5 were not significantly different $(P=0.5698)$ (Figure H.5). Average tag lives were 31.74, 30.32, and 30.52 days for lots 1,2 , and 3 through 5, respectively. Minimal tag-life corrections were needed in calculating survival estimates.

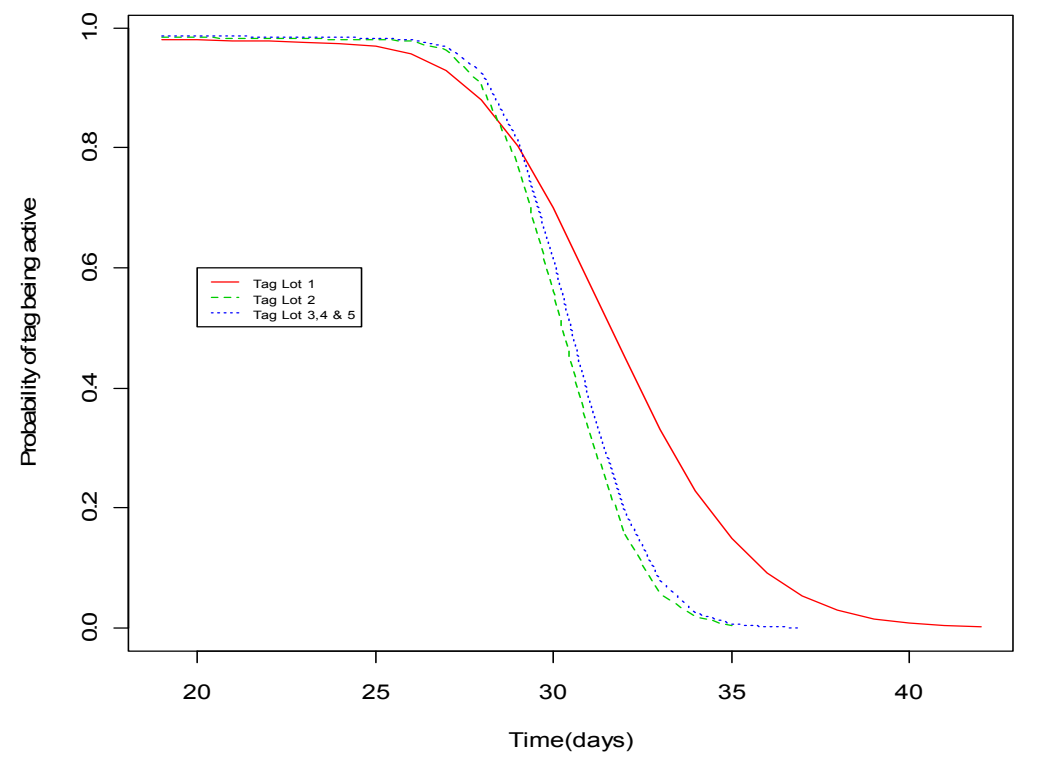

Figure H.5. Comparison of fitted survivorship curves using the Li and Anderson (2009) vitality model for JSATS tag-lots 1, 2, and 3 through 5 used in the 2011 compliance studies.

\section{H.11 Arrival Distributions}

The estimated probability that an AMT was active when fish arrived at a downstream detection array depends on the tag-life curve and the distribution of observed travel times (Figure H.5). Examination of the fish arrival distributions to the last detection array used in the survival analyses indicated all fish that arrived had passed through the study area before tag failure became influential. These probabilities were calculated by integrating the tag survivorship curve (Figure H.5) over the observed distribution of fish arrival times (i.e., time from tag activation to arrival). The three separate tag-life survivorship models for tag-lots 1,2, and 3 through 5 were used to estimate the probabilities of tag failure and provide tag-lifeadjusted estimates of juvenile salmonid survival. The probability of a JSATS tag being active at a downstream detection site was specific to release location, tag lot, and species. In all cases, the probability a tag was active at a downstream detection site as far as rkm 113 for $\mathrm{CH} 1$ was $\geq 0.9929$ and for STH it was $\geq 0.9937$ (Table H.10). 
Table H.10. Estimated probabilities $(L)$ of an acoustic micro-transmitter being active at a downstream detection site for a) $\mathrm{CH} 1$ and b) STH by tag lot and release group. (Standard errors are in parentheses.)

\begin{tabular}{|c|c|c|c|c|c|c|c|}
\hline \multirow{2}{*}{$\begin{array}{l}\text { Release } \\
\text { Group }\end{array}$} & \multirow{2}{*}{$\begin{array}{l}\text { Tag } \\
\text { Lot }\end{array}$} & \multicolumn{6}{|c|}{ Detection Site } \\
\hline & & rkm 325 & rkm 309 & rkm 275 & rkm 234 & rkm 161 & rkm 113 \\
\hline \multicolumn{8}{|l|}{ a. $\mathrm{CH} 1$} \\
\hline \multirow[t]{3}{*}{$\begin{array}{l}V_{2} \\
(\text { rkm 349) (a) }\end{array}$} & 1 & $\begin{array}{c}0.9994 \\
(0.0004)\end{array}$ & $\begin{array}{c}0.9990 \\
(0.0007)\end{array}$ & $\begin{array}{c}0.9984 \\
(0.0012)\end{array}$ & $\begin{array}{c}0.9975 \\
(0.0017)\end{array}$ & $\begin{array}{c}0.9960 \\
(0.0027)\end{array}$ & $\begin{array}{c}0.9953 \\
(0.0032)\end{array}$ \\
\hline & 2 & $\begin{array}{c}0.9996 \\
(0.0003)\end{array}$ & $\begin{array}{c}0.9993 \\
(0.0005)\end{array}$ & $\begin{array}{c}0.9988 \\
(0.0008)\end{array}$ & $\begin{array}{c}0.9982 \\
(0.0012)\end{array}$ & $\begin{array}{c}0.9974 \\
(0.0018)\end{array}$ & $\begin{array}{c}0.9969 \\
(0.0021)\end{array}$ \\
\hline & $3-5$ & $\begin{array}{c}0.9998 \\
(0.0006)\end{array}$ & $\begin{array}{c}0.9996 \\
(0.0010)\end{array}$ & $\begin{array}{c}0.9993 \\
(0.0020)\end{array}$ & $\begin{array}{c}0.9989 \\
(0.0032)\end{array}$ & $\begin{array}{c}0.9985 \\
(0.0049)\end{array}$ & $\begin{array}{c}0.9981 \\
(0.0060)\end{array}$ \\
\hline \multirow[t]{3}{*}{$\begin{array}{l}R_{2} \\
(\mathrm{rkm} 346)\end{array}$} & 1 & -- & $\begin{array}{c}0.9967 \\
(0.0024)\end{array}$ & $\begin{array}{c}0.9960 \\
(0.0029)\end{array}$ & $\begin{array}{c}0.9951 \\
(0.0035)\end{array}$ & $\begin{array}{c}0.9934 \\
(0.0047)\end{array}$ & $\begin{array}{c}0.9929 \\
(0.0053)\end{array}$ \\
\hline & 2 & -- & $\begin{array}{c}0.9974 \\
(0.0017)\end{array}$ & $\begin{array}{c}0.9969 \\
(0.0021)\end{array}$ & $\begin{array}{c}0.9962 \\
(0.0025)\end{array}$ & $\begin{array}{c}0.9953 \\
(0.0031)\end{array}$ & $\begin{array}{c}0.9948 \\
(0.0035)\end{array}$ \\
\hline & $3-5$ & -- & $\begin{array}{c}0.9981 \\
(0.0054)\end{array}$ & $\begin{array}{c}0.9978 \\
(0.0066)\end{array}$ & $\begin{array}{c}0.9972 \\
(0.0079)\end{array}$ & $\begin{array}{c}0.9968 \\
(0.0096)\end{array}$ & $\begin{array}{c}0.9965 \\
(0.0107)\end{array}$ \\
\hline \multirow[t]{3}{*}{$\begin{array}{l}R_{3} \\
(\mathrm{rkm} 325)\end{array}$} & 1 & -- & $\begin{array}{c}0.9972 \\
(0.0020)\end{array}$ & $\begin{array}{c}0.9964 \\
(0.0026)\end{array}$ & $\begin{array}{c}0.9955 \\
(0.0032)\end{array}$ & $\begin{array}{c}0.9942 \\
(0.0042)\end{array}$ & $\begin{array}{c}0.9935 \\
(0.0048)\end{array}$ \\
\hline & 2 & -- & $\begin{array}{c}0.9978 \\
(0.0014)\end{array}$ & $\begin{array}{c}0.9972 \\
(0.0018)\end{array}$ & $\begin{array}{c}0.9966 \\
(0.0022)\end{array}$ & $\begin{array}{c}0.9956 \\
(0.0029)\end{array}$ & $\begin{array}{c}0.9952 \\
(0.0033)\end{array}$ \\
\hline & $3-5$ & -- & $\begin{array}{c}0.9983 \\
(0.0048)\end{array}$ & $\begin{array}{c}0.9980 \\
(0.0060)\end{array}$ & $\begin{array}{c}0.9974 \\
(0.0072)\end{array}$ & $\begin{array}{c}0.9971 \\
(0.0088)\end{array}$ & $\begin{array}{c}0.9968 \\
(0.0099)\end{array}$ \\
\hline \multicolumn{8}{|l|}{ b. STH } \\
\hline \multirow[t]{3}{*}{$\begin{array}{l}V_{2} \\
(\mathrm{rkm} 349)^{(\mathrm{a})}\end{array}$} & 1 & $\begin{array}{c}0.9988 \\
(0.0009)\end{array}$ & $\begin{array}{c}0.9986 \\
(0.0012)\end{array}$ & $\begin{array}{c}0.9980 \\
(0.0016)\end{array}$ & $\begin{array}{c}0.9973 \\
(0.0022)\end{array}$ & $\begin{array}{c}0.9961 \\
(0.0032)\end{array}$ & $\begin{array}{c}0.9959 \\
(0.0035)\end{array}$ \\
\hline & 2 & $\begin{array}{c}0.9994 \\
(0.0006)\end{array}$ & $\begin{array}{c}0.9992 \\
(0.0008)\end{array}$ & $\begin{array}{c}0.9987 \\
(0.0012)\end{array}$ & $\begin{array}{c}0.9983 \\
(0.0016)\end{array}$ & $\begin{array}{c}0.9975 \\
(0.0024)\end{array}$ & $\begin{array}{c}0.9971 \\
(0.0029)\end{array}$ \\
\hline & $3-5$ & $\begin{array}{c}0.9997 \\
(0.0011)\end{array}$ & $\begin{array}{c}0.9996 \\
(0.0015)\end{array}$ & $\begin{array}{c}0.9988 \\
(0.0026)\end{array}$ & $\begin{array}{c}0.9984 \\
(0.0038)\end{array}$ & $\begin{array}{c}0.9978 \\
(0.0053)\end{array}$ & $\begin{array}{c}0.9981 \\
(0.0063) \\
\end{array}$ \\
\hline \multirow[t]{3}{*}{$\begin{array}{l}R_{2} \\
\text { (rkm 346) }\end{array}$} & 1 & -- & $\begin{array}{c}0.9970 \\
(0.0026)\end{array}$ & $\begin{array}{c}0.9963 \\
(0.0032)\end{array}$ & $\begin{array}{c}0.9957 \\
(0.0037)\end{array}$ & $\begin{array}{c}0.9943 \\
(0.0049)\end{array}$ & $\begin{array}{c}0.9937 \\
(0.0054)\end{array}$ \\
\hline & 2 & -- & $\begin{array}{c}0.9976 \\
(0.0023)\end{array}$ & $\begin{array}{c}0.9970 \\
(0.0029)\end{array}$ & $\begin{array}{c}0.9965 \\
(0.0033)\end{array}$ & $\begin{array}{c}0.9957 \\
(0.0041)\end{array}$ & $\begin{array}{c}0.9953 \\
(0.0047)\end{array}$ \\
\hline & $3-5$ & -- & $\begin{array}{c}0.9981 \\
(0.0064)\end{array}$ & $\begin{array}{c}0.9979 \\
(0.0073)\end{array}$ & $\begin{array}{c}0.9974 \\
(0.0089)\end{array}$ & $\begin{array}{c}0.9970 \\
(0.0100)\end{array}$ & $\begin{array}{c}0.9967 \\
(0.0111)\end{array}$ \\
\hline \multirow[t]{3}{*}{$\begin{array}{l}R_{3} \\
\text { (rkm 325) }\end{array}$} & 1 & -- & $\begin{array}{c}0.9974 \\
(0.0023)\end{array}$ & $\begin{array}{c}0.9967 \\
(0.0028)\end{array}$ & $\begin{array}{c}0.9961 \\
(0.0034)\end{array}$ & $\begin{array}{c}0.9947 \\
(0.0045)\end{array}$ & $\begin{array}{c}0.9942 \\
(0.0051)\end{array}$ \\
\hline & 2 & -- & $\begin{array}{c}0.9979 \\
(0.0021)\end{array}$ & $\begin{array}{c}0.9974 \\
(0.0025)\end{array}$ & $\begin{array}{c}0.9969 \\
(0.0030)\end{array}$ & $\begin{array}{c}0.9959 \\
(0.0040)\end{array}$ & $\begin{array}{c}0.9954 \\
(0.0045)\end{array}$ \\
\hline & $3-5$ & -- & $\begin{array}{c}0.9983 \\
(0.0058)\end{array}$ & $\begin{array}{c}0.9980 \\
(0.0067)\end{array}$ & $\begin{array}{c}0.9976 \\
(0.0081)\end{array}$ & $\begin{array}{c}0.9971 \\
(0.0097)\end{array}$ & $\begin{array}{c}0.9969 \\
(0.0105)\end{array}$ \\
\hline
\end{tabular}

(a) Conditional probabilities of a tag being active, given they were active when a fish first arrived at the dam face. 


\section{H.12 Downstream Mixing}

To help induce downstream mixing of the release groups, the $R_{1}$ release was $39 \mathrm{~h}$ before the $R_{2}$ release which, in turn, occurred $9 \mathrm{~h}$ before the $R_{3}$ release. The release schedule was used for both the $\mathrm{CH} 1$ and STH. Plots of the arrival timing of the various release groups at downstream detection sites indicate reasonable mixing for both $\mathrm{CH} 1$ (Figure H.6) and STH (Figure H.7). The arrival modes for releases $R_{2}$ and $R_{3}$ were nearly synchronous. The modes for $R_{2}$ and $R_{3}$ were slightly later than the arrival mode for $V_{2}$ but during the majority of the distribution of arrival times for $V_{2}$ (Figure H.8; Figure H.9).

a. $\mathrm{CH} 1$

Tag lot 1

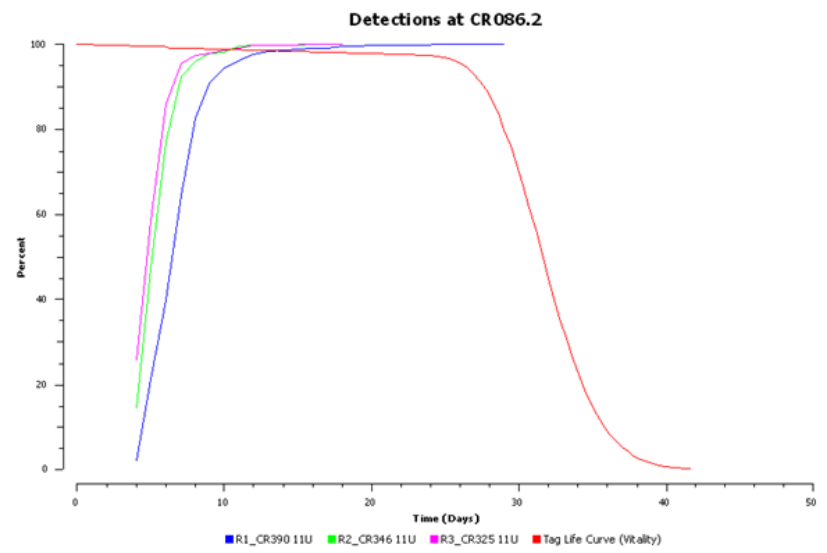

Tag lot 2

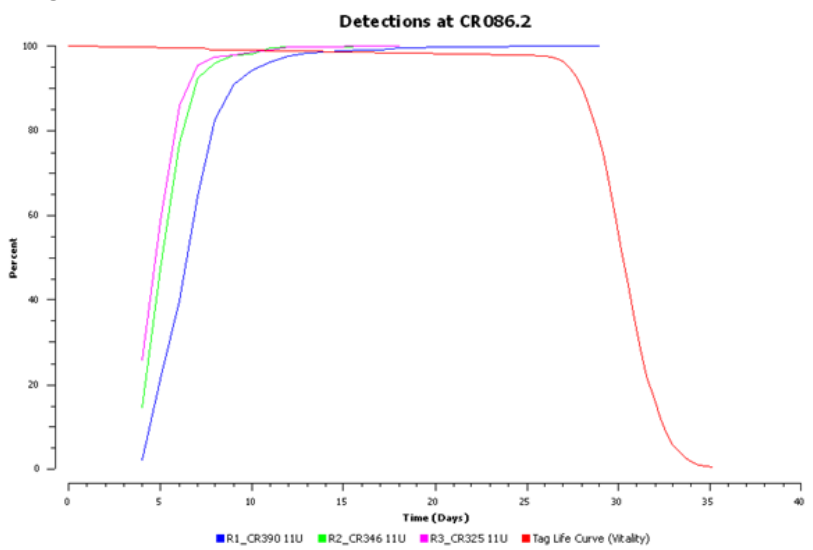

Tag lot 3 through 5

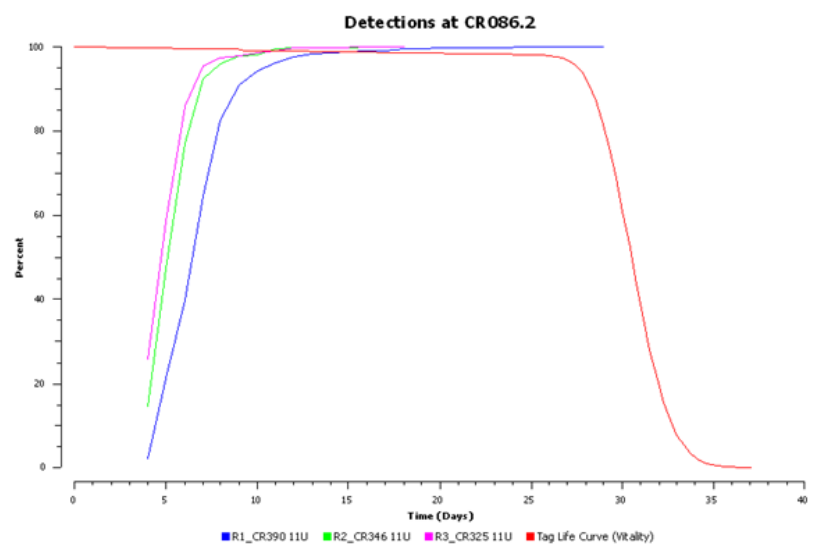

Figure H.6. Plots of the fitted tag-life survivorship curve and the arrival-time distributions of $\mathrm{CH} 1$ for releases $V_{2}, R_{2}$, and $R_{3}$ at the acoustic-detection array located at rkm 86.0 (Figure 3.2). 
b. STH

Tag lot 1

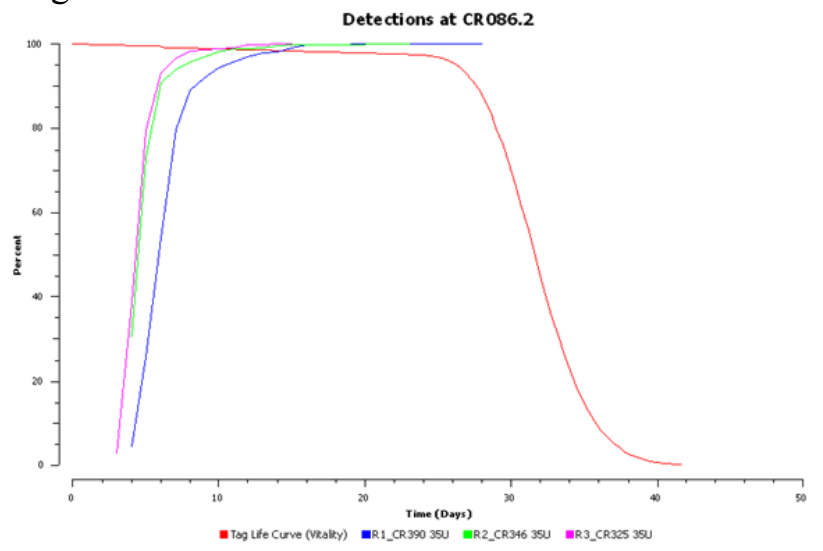

Tag lot 2

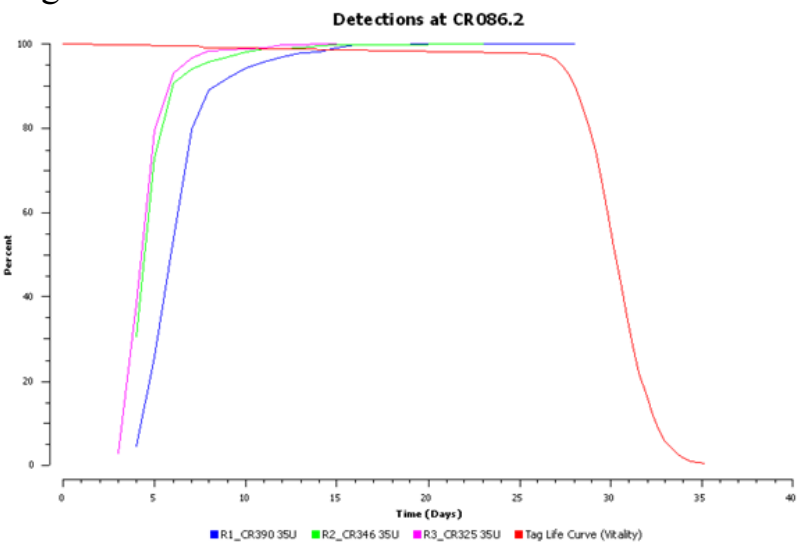

Tag lot 3 through 5

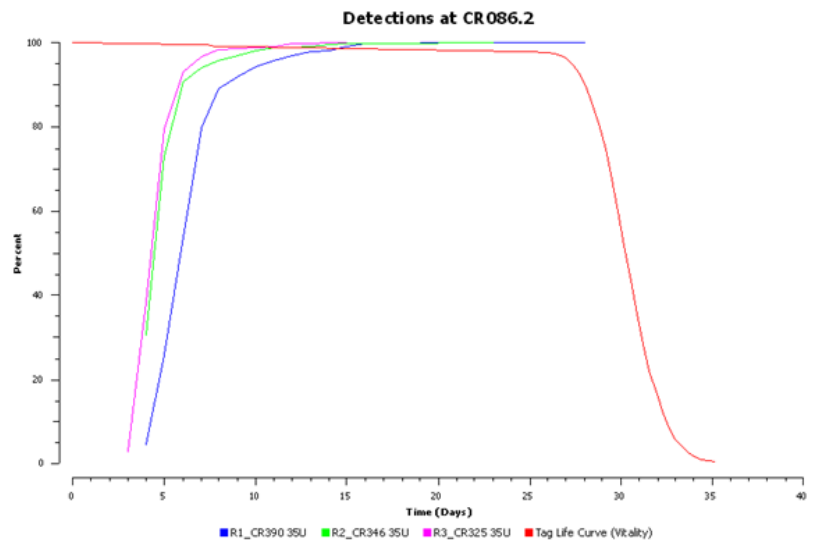

Figure H.7. Plots of the fitted tag-life survivorship curve and the arrival-time distributions of STH for releases $V_{2}, R_{2}$, and $R_{3}$ at the acoustic-detection array located at rkm 86.0 (Figure 3.2) 
a. $\quad$ rkm 309

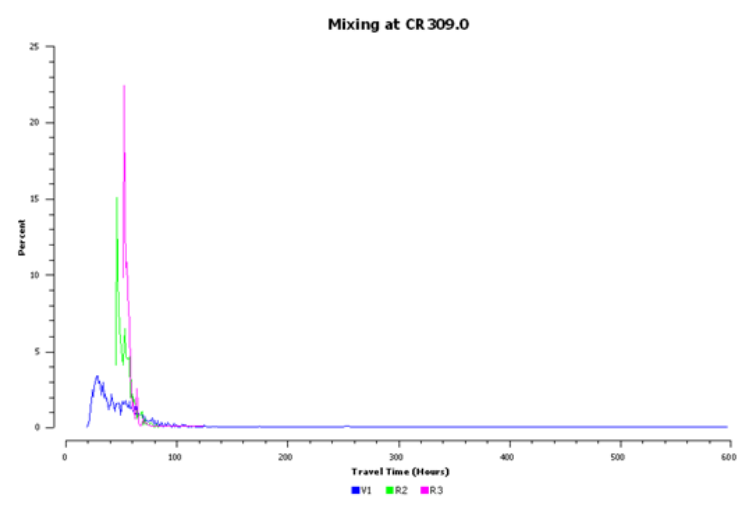

c. $\quad$ rkm 234

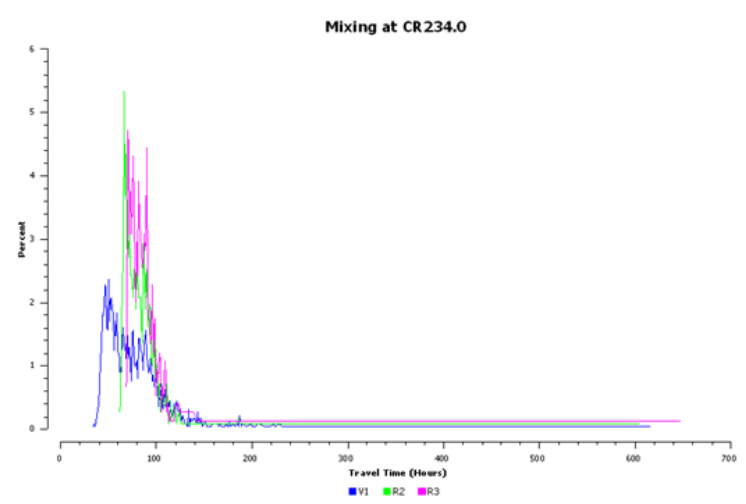

e. $\quad$ kkm 113

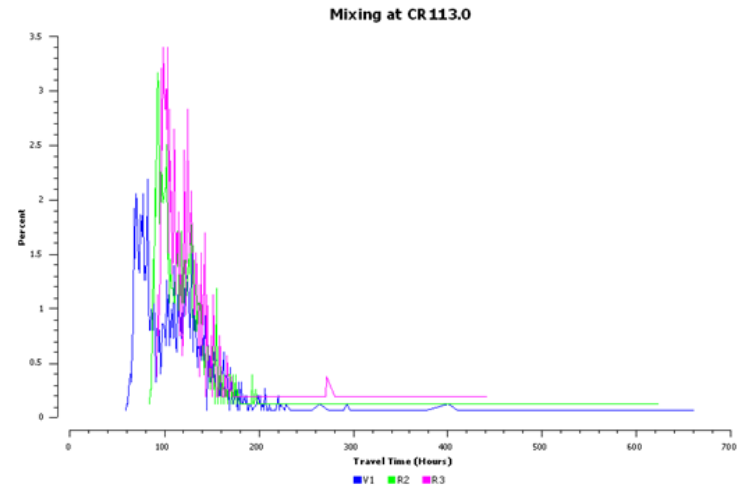

b. $\quad \operatorname{rkm} 275$

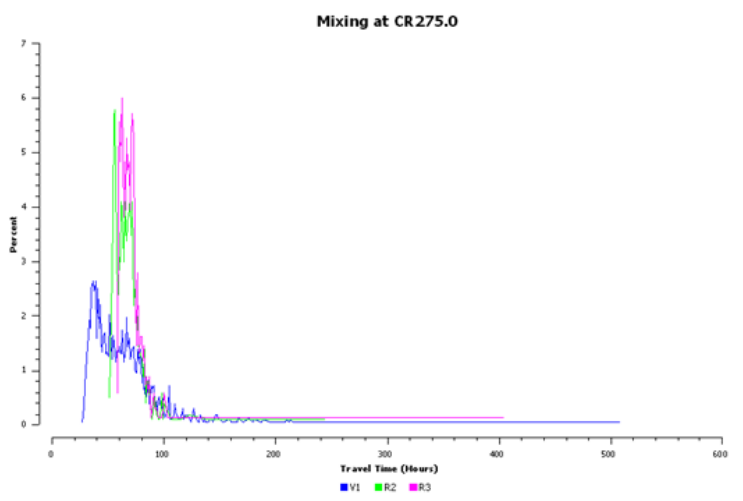

d. $\quad$ rkm 161

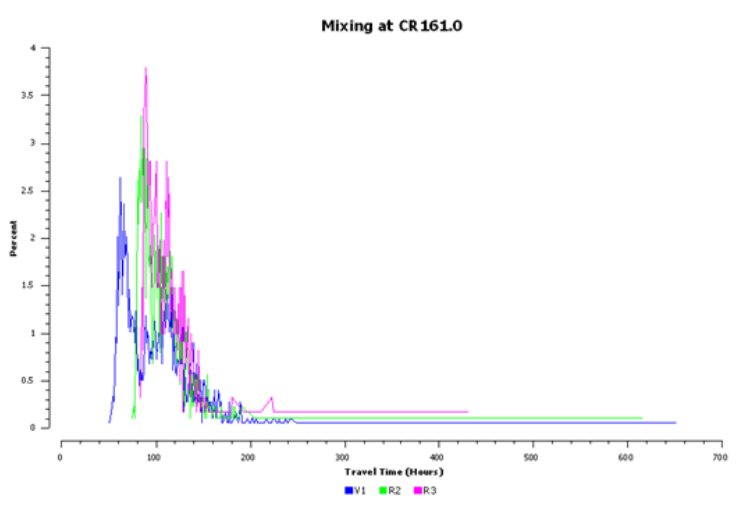

f. $\quad \mathrm{rkm} 86$

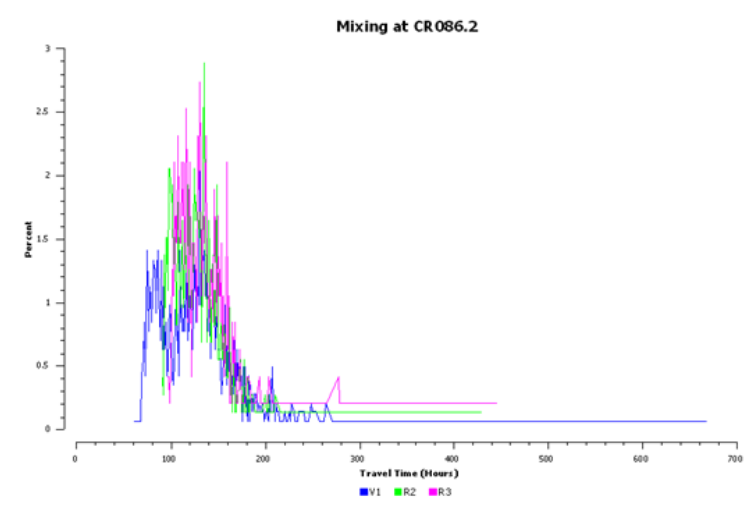

Figure H.8. Frequency distribution plots of downstream arrival timing (expressed as percentages) for $\mathrm{CH} 1$ releases $V_{2}, R_{2}$, and $R_{3}$ at detection arrays located at a) rkm 309, b) rkm 275,

c) rkm 234 , d) rkm 161, e) rkm 113, and f) rkm 86. All times adjusted relative to the release time of $V_{2}$. 
a. $\quad$ rkm 309

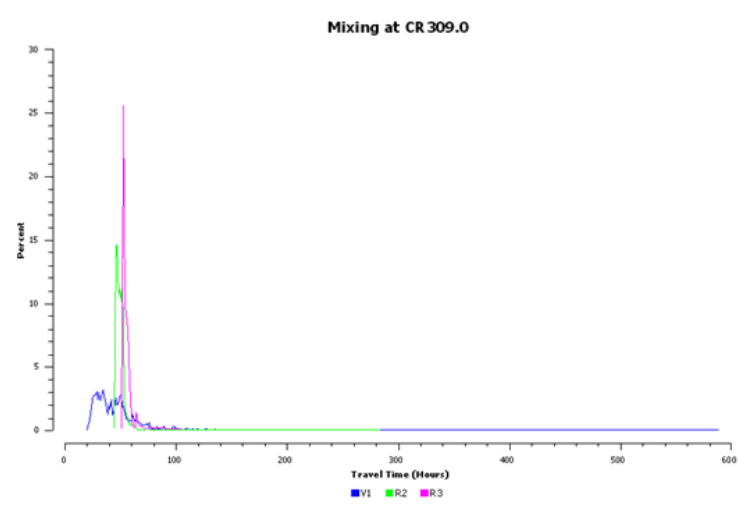

c. $\quad$ rkm 234

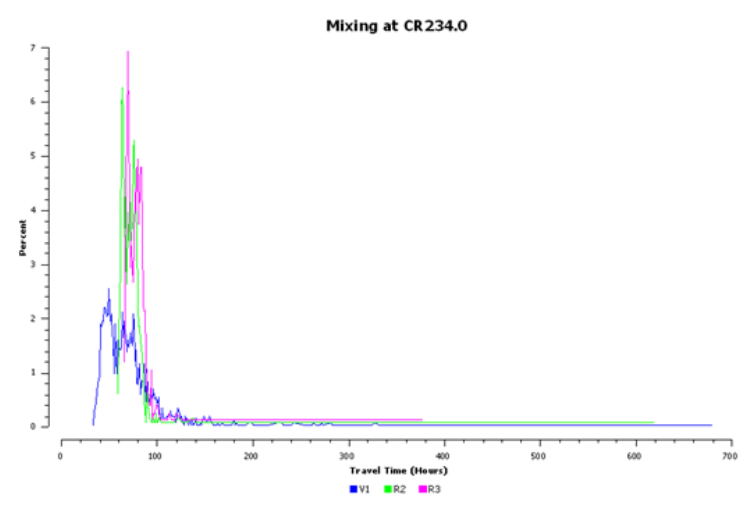

e. $\quad$ rkm 113

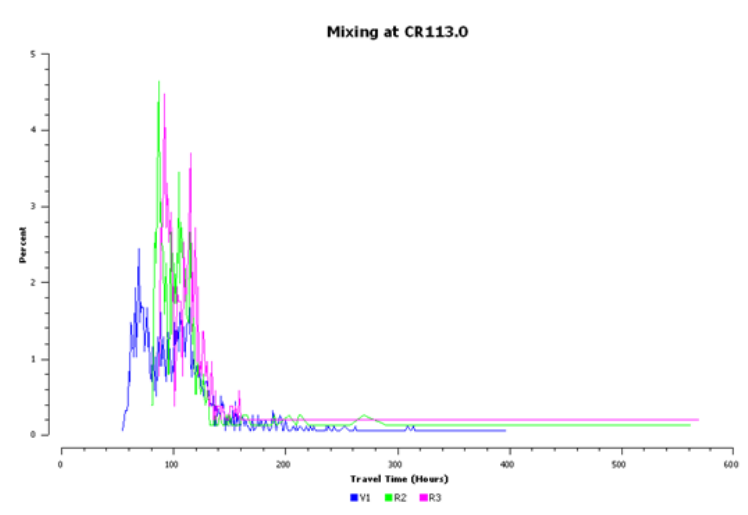

b. $\quad$ rkm 275

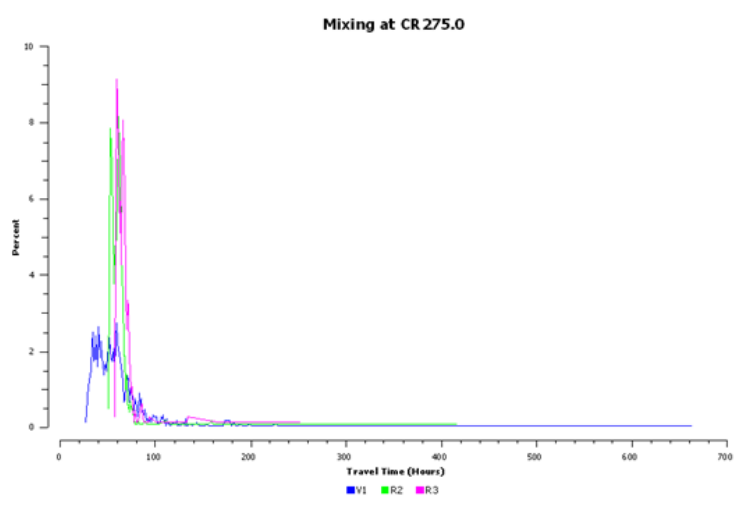

d. $\quad$ rkm 161

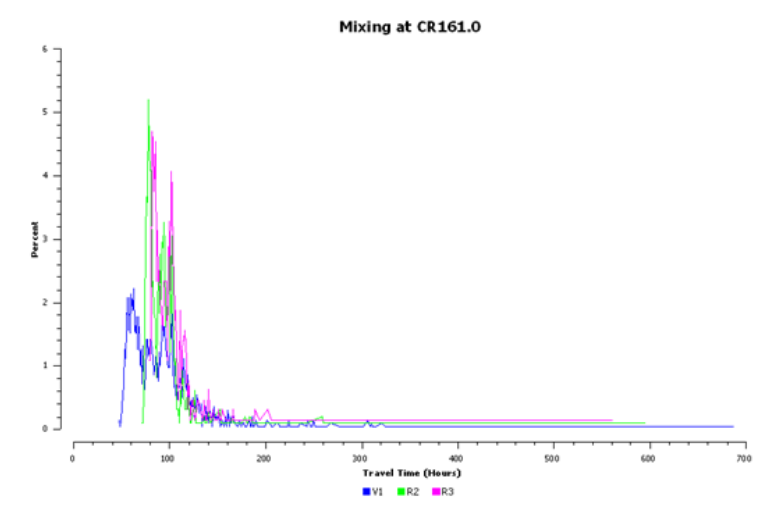

f. $\quad \mathrm{rkm} 86$

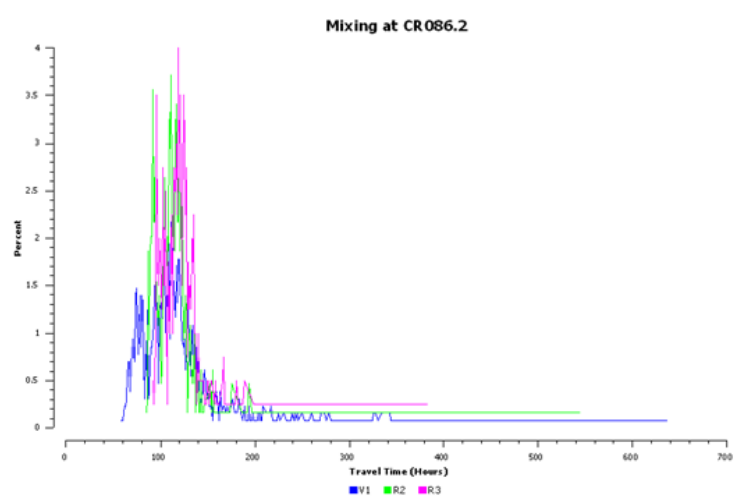

Figure H.9. Frequency distribution plots of downstream arrival timing (expressed as percentages) for STH releases $V_{2}, R_{2}$, and $R_{3}$ at detection arrays located at a) rkm 309, b) rkm 275, c) rkm 234 , d) rkm 161, e) rkm 113, and f) rkm 86 . All times adjusted relative to the release time of $V_{2}$.) 


\section{H.13 References}

Li T and JJ Anderson. 2009. "The vitality model: A way to understand population survival and demographic heterogeneity." Theoretical Population Biology 76(2):118-131.

Mantel N and W Haenszel. 1959. Statistical aspects of the analysis of data from retrospective studies of disease. Journal of the National Cancer Institute 22:719-748. 


\section{Distribution}

No. of

Copies

OFFSITE

Paper copy and PDF

Brad Eppard

USACE District, Portland

CENWP-PM-E

333 SW 1st Avenue (R. Duncan Plaza)

Portland, OR 97204-3495

20 Paper copies and PDF

Mark Weiland

390 Evergreen Drive

P.O. Box 241

North Bonneville, WA 98639
No. of

Copies

\section{ONSITE}

3 Pacific Northwest National Laboratory

DR Geist (Paper and PDF)

K6-85

KD Ham (Paper and PDF)

K6-85

S Schlahta (PDF)

K6-83

PNNL Library (Paper and PDF)

Distr.1 


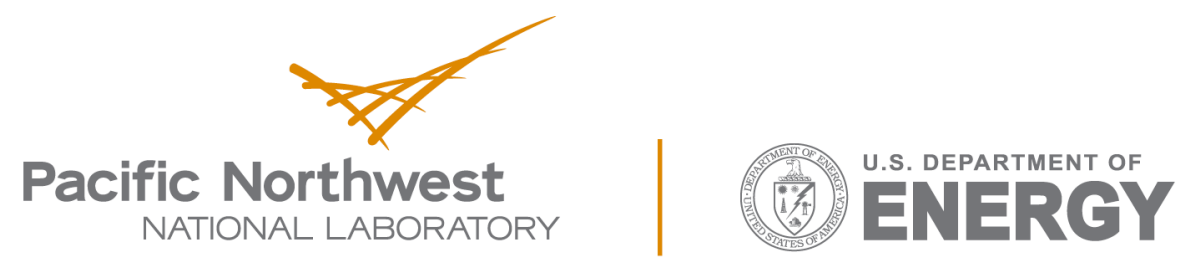

Proudly Operated by Battelle Since 1965

902 Battelle Boulevard

P.O. Box 999

Richland, WA 99352

1-888-375-PNNL (7665)

www.pnnl.gov 